\title{
Project W-551 Interim Pretreatment System Preconceptual Candidate Technology Descriptions
}

\author{
TH May \\ CH2M HILL Hanford Group, Inc. \\ Richland, WA 99352 \\ U.S. Department of Energy Contract DE-AC27-99RL14047
EDT/ECN: N/A UC:
Cost Center: $\quad$ Charge Code: 503145
B\&R Code: $\quad$ Total Pages: 254

Key Words: Interim Pretreatment, Project W-551,

Abstract: The Office of River Protection (ORP) has authorized a study to recommend and select options for interim pretreatment of tank waste and support Waste Treatment Plant (WTP) low activity waste (LAW) operations prior to startup of all the WTP facilities. The Interim Pretreatment System (IPS) is to be a moderately sized system which separates entrained solids and $137 \mathrm{Cs}$ from tank waste for an interim time period while WTP high level waste vitrification and pretreatment facilities are completed. This study's objective is to prepare pre-conceptual technology descriptions that expand the technical detail for selected solid and cesium separation technologies. This revision includes information on additional feed tanks.

TRADEMARK DISCLAIMER. Reference herein to any specific commercial product, process, or service by trade name, trademark, manufacturer, or otherwise, does not necessarily constitute or imply its endorsement, recommendation, or favoring by the United States Government or any agency thereof or its contractors or subcontractors.

Printed in the United States of America. To obtain copies of this document, contact: Document Control Services, P.O. Box 950, Mailstop H6-08, Richland WA 99352, Phone (509) 372-2420; Fax (509) 376-4989.
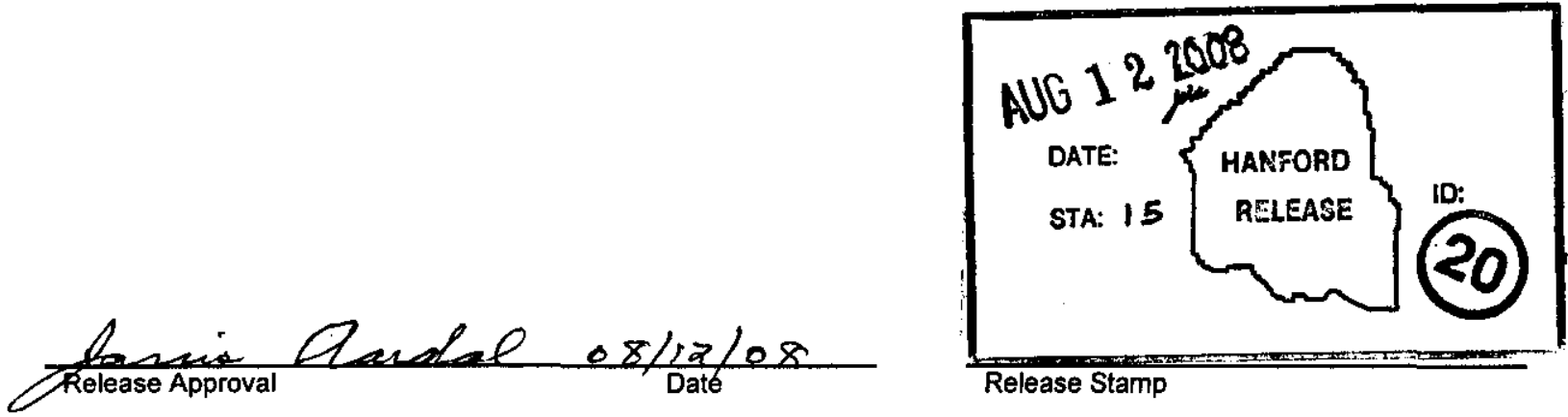

Release Stamp 


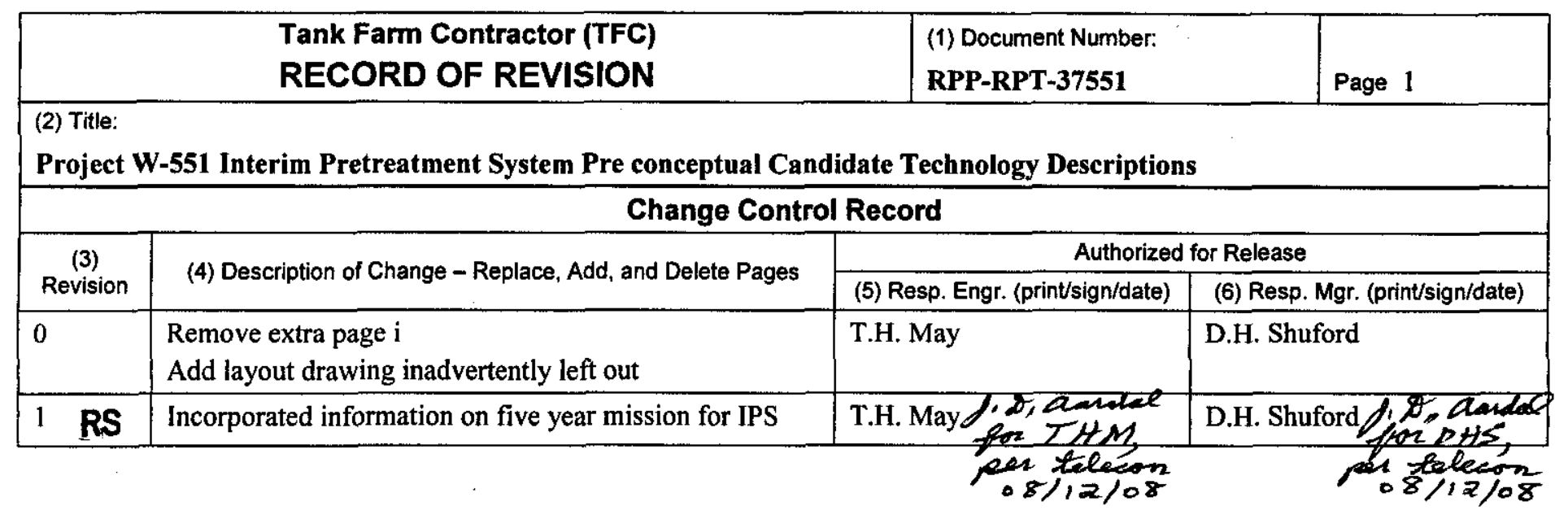




\title{
Project W-551 Interim Pretreatment System Pre-conceptual Candidate Technology Descriptions
}

TH May

CH2M HILL Hanford Group, Inc.

\author{
A Pajunen \\ J Baker \\ M Himes \\ G Stegen \\ AEM Consulting, LLC. \\ Date Published \\ September 2008
}

Prepared for the U.S. Department of Energy

Assistant Secretary for Environmental Management

Contractor for the U.S. Department of Energy

Office of River Protection under Contract DE-AC27-99RL14047

\section{CH2MHILL}

Hanford Group, Inc.

P.O. Box 1500

Richland, Washington 


\section{EXECUTIVE SUMMARY}

The Office of River Protection (ORP) has authorized a study to recommend and select options for interim pretreatment of tank waste and support Waste Treatment Plant (WTP) low-activity waste (LAW) operations prior to startup of all the WTP facilities. The Interim Pretreatment System (IPS) is to be a moderately sized system which separates entrained solids and ${ }^{137} \mathrm{Cs}$ from tank waste for an interim time period while WTP high-level waste vitrification and pretreatment facilities are completed. This study's objective is to prepare pre-conceptual technology descriptions that expand the technical detail for selected solid and cesium separation technologies identified in RPP-RPT-30160, Supporting Information for the Evaluation of Waste Treatment and Immobilization Plant (WTP) Low Activity Waste (LAW) Startup First Scenarios.

The technologies selected for further development are:

- Entrained Solids Separation

- Rotary Microfiltration, and

- Crossflow Filtration

- Cesium Separation

- Fractional Crystallization (FC),

- Caustic-Side Solvent Extraction (CSSX), and

- Ion Exchange using spherical resorcinol-formaldehyde as the ion exchange media (sR-F)

The pre-conceptual technology descriptions will be used to support selection of the preferred entrained solids and cesium separation technologies that are recommended to ORP for inclusion in an IPS. No conclusions or recommendations as to the preferred separation technologies are included in this document because the actual technology selection will be performed by a separate activity.

The overall IPS capacity used as a basis for this study produces LAW at a rate equivalent to $1175 \mathrm{MT} \mathrm{Na} / \mathrm{yr}$ that is transferred from the IPS to LAW immobilization systems. The LAW includes sodium originating in Double Shell Tank waste feed and "cold sodium" additions required for IPS operation. Applying a 70\% availability results in an instantaneous design rate of 4.6 MT Na per operating day, or $192 \mathrm{~kg} \mathrm{Na}$ per operating hr. The instantaneous design rate is equivalent to a volumetric flow rate of $6.1 \mathrm{gpm}$ at 6 molar sodium.

All candidate technologies meet the requirements for solids removal and for ${ }^{137} \mathrm{Cs}$ separation. All candidate technologies satisfy the WTP feed specification for radionuclide content. CSSX and IX selectively remove the ${ }^{137} \mathrm{Cs}$. FC removes ${ }^{137} \mathrm{Cs}$ along with other radionuclides such as ${ }^{99} \mathrm{Tc}$ and ${ }^{129} \mathrm{I}$, thereby reducing the concentration of radionuclides in the early-LAW secondary liquid waste streams.

Revision 0 of this document compared the cesium removal technologies on the basis of 8 feed tanks. Because this basis did not provide sufficient feed for Fractional Crystallization, a subsequent study compared the cesium removal technologies on the basis of 5 years operation. Revision 1 of this document provides this comparison. 
Solids Separation - Candidate Technology Comparison

Published results of simulant and actual waste testing, and actual deployment at ORNL, suggest both technologies will meet performance requirements for waste feed delivery to the downstream cesium separation process. However, DOE/ORP-2007-01, Technology Readiness Assessment for the Supplemental Treatment Program judged both rotary microfiltration and crossflow filtration technologies to be immature (e.g., Technology Readiness Level 3) given the limited testing completed on simulated and actual Hanford Site tank waste, and very minimal design concepts development and definition of project requirements for implementation. Nevertheless, the consensus of DOE/ORP-2007-01 was that either technology can be readily matured through additional testing and concept development.

\section{Cesium Separation - Candidate Technology Comparison}

Table ES-1 presents the overall sodium balance for the candidate cesium separation technologies. The difference in Na processed in waste feed and Na generated in the LAW and Cs products is the result of chemical additions necessary for the separation process operation. For solvent extraction and ion exchange the Na sent to the WTP is about $45 \%$ greater than the Na content of waste feed processed. Given that fractional crystallization does not add $\mathrm{Na}$ during processing, the combined $\mathrm{Na}$ output to vitrification and $\mathrm{Cs}$ product returned to Double Shell Tanks equals the $\mathrm{Na}$ input from waste feed.

Although fractional crystallization returns a substantial quantity of $\mathrm{Na}$ to tank farms with the Cs product, it produces a LAW product with a lower content of ${ }^{99} \mathrm{Tc}$ and ${ }^{129} \mathrm{I}$. Both solvent extraction and ion exchange essentially remove only cesium from the waste feed. However, for the waste batches evaluated in this study, all the candidate separation technologies can satisfy the WTP acceptance specification for radionuclide content.

The solvent extraction technology generates a relatively large volume, dilute solution that is returned to Double Shell Tanks, with cesium concentration ranging from 0.19 to $1.62 \mathrm{Ci}^{137} \mathrm{Cs} / \mathrm{L}$. This volume could be substantially reduced by processing the material through the $242-\mathrm{A}$ Evaporator.

The fractional crystallization technology produces a lower volume of LAW product in comparison to the other technologies. This is partly attributable to the inability of the fractional crystallization technology to partition the bulk of waste feed $\mathrm{Na}$ into the LAW product. Fractional crystallization also produces a highly concentrated LAW product that must be diluted with water prior to transfer to the WTP (material balances based on dilution to $9 \mathrm{M} \mathrm{Na}$ ). The solvent extraction and ion exchange technologies dilute waste feed to $6 \mathrm{M}$ Na prior to processing the waste feed material and, consequently, send more dilute LAW to the WTP.

One secondary waste stream (excluding failed equipment and personnel protection equipment) is routinely generated by each of the candidate technologies that must be addressed by interfaces external to the tank farm system. The secondary waste streams are summarized as follows:

- Ion Exchange - Resin in the ion exchange columns slowly degrades with reuse and must be replaced when cesium removal becomes inefficient. Spent resin is periodically disposed as a solid waste. 
- Fractional Crystallization - Process condensate is continuously generated by the crystallizer condensers and steam jets. Excess condensate, not reused for crystallized solids washing or dissolution, is transferred to the Effluent Treatment Facility

- Solvent Extraction - Solvent in the extraction system slowly degrades with reuse and must be replaced when cesium removal becomes inefficient. The solvent inventory is periodically replaced, mixed with an adsorbent, and disposed as solid waste.

All three cesium separation processes are based on fundamentally mature technologies. Examples can also be cited where each technology is being or has been used in the DOE complex (e.g., cesium recovery in B Plant for ion exchange, 242-A Evaporator for fractional crystallization, and the MCU for solvent extraction). However, each technology would benefit from additional development testing.

Ion exchange testing with sR-F is limited to a laboratory-scale for actual waste. While actual and simulant data obtained to date produce consistent results, there is a risk that a new process issue could be identified during operation at full-scale with actual waste that was not identified during simulant testing. The fractional crystallization pilot-scale testing underway at SRS is focused on different objectives, requirements, and target tank wastes than those identified for IPS demonstration scenarios. In addition, an optimization study would be necessary to address several issues (e.g., pretreatment to increase $\mathrm{Na}$ yields). Although solvent extraction has been demonstrated from laboratory-scale through to a full-scale commissioned facility, only recently has testing been initiated on Hanford tank waste stimulants. Also, the throughput issue at the MCU facility has yet to be resolved. 
RPP-RPT-37551, Rev. 1

Table E-1 Sodium Balance Comparison Case 2 (5 Year Basis)

\begin{tabular}{|c|c|c|c|c|c|c|c|c|c|c|}
\hline \multirow[b]{2}{*}{$\begin{array}{c}\text { Waste } \\
\text { Feed Batch }\end{array}$} & \multirow[b]{2}{*}{$\begin{array}{l}\text { Sodium in } \\
\text { Waste } \\
\text { Feed } \\
\text { Processed } \\
\text { (MT Na) }\end{array}$} & \multicolumn{3}{|c|}{ Caustic-Side Solvent Extraction } & \multicolumn{3}{|c|}{ Ion Exchange } & \multicolumn{3}{|c|}{ Fractional Crystallization $^{2}$} \\
\hline & & $\begin{array}{l}\text { Hours of } \\
\text { Operation }^{1}\end{array}$ & $\begin{array}{c}\text { Sodium in } \\
\text { LAW } \\
\text { Product } \\
\text { Produced } \\
\text { (MT Na) }\end{array}$ & $\begin{array}{l}\text { Sodium in } \\
\text { Cesium } \\
\text { Product } \\
\text { Produced } \\
\text { (MT Na) }\end{array}$ & $\begin{array}{l}\text { Hours of } \\
\text { Operation }\end{array}$ & $\begin{array}{c}\text { Sodium in } \\
\text { LAW } \\
\text { Product } \\
\text { Produced } \\
\text { (MT Na) }\end{array}$ & $\begin{array}{l}\text { Sodium in } \\
\text { Cesium } \\
\text { Product } \\
\text { Produced } \\
\text { (MT Na) }\end{array}$ & $\begin{array}{l}\text { Hours of } \\
\text { Operation }\end{array}$ & $\begin{array}{c}\text { Sodium in } \\
\text { LAW } \\
\text { Product } \\
\text { Produced } \\
\text { (MT Na) }\end{array}$ & $\begin{array}{c}\text { Sodium in } \\
\text { Cesium } \\
\text { Product } \\
\text { Produced } \\
\text { (MT Na) }\end{array}$ \\
\hline AP-104 & 734 & 5,414 & 1,037 & 4 & 5,360 & 1,027 & 16 & 1,929 & 370 & 364 \\
\hline AP-102 & 740 & 6,060 & 1,161 & 4 & 5,999 & 1,150 & 18 & 1,636 & 313 & 427 \\
\hline AP-101 & 827 & 5,511 & 1,056 & 4 & 5,438 & 1,042 & 23 & 2,693 & 516 & 310 \\
\hline AP-103 & 827 & 6,833 & 1,309 & 4 & 6,768 & 1,297 & 19 & 2,155 & 413 & 414 \\
\hline AP-105 & 807 & 5,877 & 1,126 & 3 & 5,959 & 1,142 & 18 & 1,927 & 369 & 437 \\
\hline AP-108 & 899 & & & & 175 & 34 & 1 & 2,127 & 408 & 491 \\
\hline AP-107 & 780 & & & & & & & 2,518 & 482 & 297 \\
\hline AN-104 & 763 & & & & & & & 1,411 & 270 & 493 \\
\hline AN-105 & 826 & & & & & & & 1,646 & 315 & 511 \\
\hline AN-103 & 1065 & & & & & & & 1,661 & 318 & 747 \\
\hline AW-101 & 1,015 & & & & & & & 1,888 & 362 & 653 \\
\hline AW-104 & 777 & & & & & & & 1,767 & 339 & 438 \\
\hline AP-106 & 445 & & & & & & & 1,140 & 218 & 227 \\
\hline SY-101 & 181 & & & & & & & 445 & 85 & 96 \\
\hline S-109 & 760 & & & & & & & 3,337 & 639 & 121 \\
\hline $\mathrm{S}-109 \mathrm{Eq}^{3}$ & 137 & & & & & & & 1,415 & 137 & 224 \\
\hline Total & 11,941 & 29,696 & 5690 & 19 & 29,696 & 5,690 & 95 & 29,694 & 5,690 & 6,251 \\
\hline
\end{tabular}

1. Operating hours are equivalent to $100 \%$ total operating efficiency

2. Assuming $100 \%$ of high sulfate stream sent to tank farms

3. S-109 Eq represents a generic SST with composition the same as S-109 


\section{TABLE OF CONTENTS}

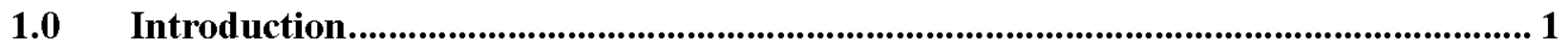

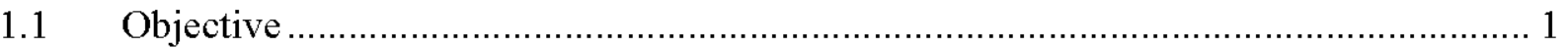

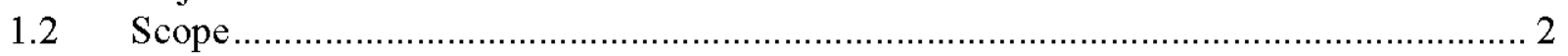



3.0 Requirements.................................................................................................................. 11

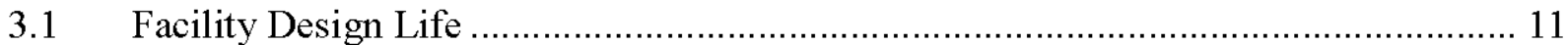

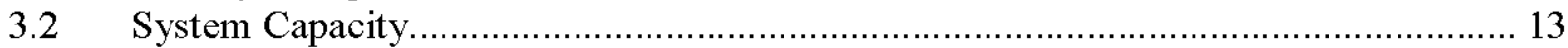

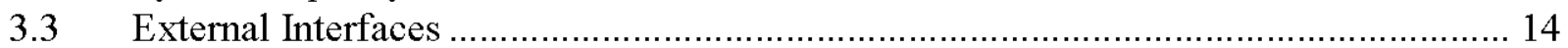

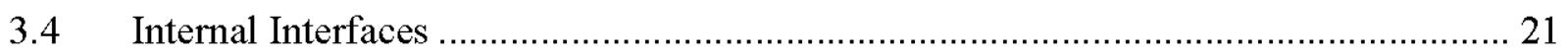

4.0 Computer Models........................................................................................................ 22

$5.0 \quad$ Solids Separation Technology Alternatives................................................................. 22

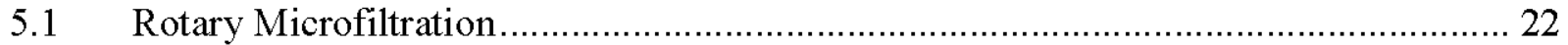

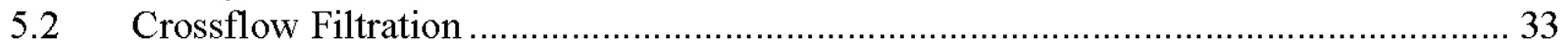

$5.3 \quad$ Filtration Alternatives Comparison...................................................................... 44

6.0 Cesium Separation Technology Alternatives ……..................................................... 45

6.1 Ion Exchange using Spherical Resorcinol-Formaldehyde ........................................ 45

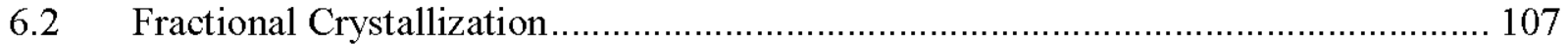

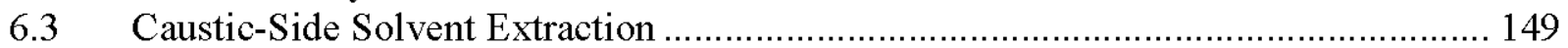

6.4 Cesium Separation Alternatives Comparison ...................................................... 180

6.5 Cesium Separation 5 year baseline ………….............................................. 189

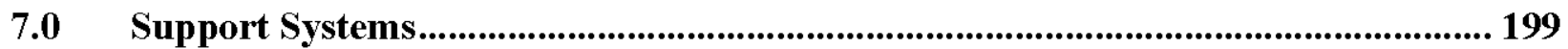

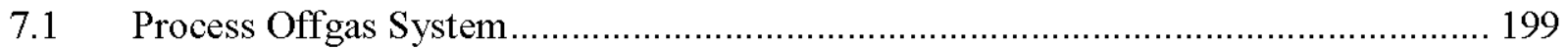

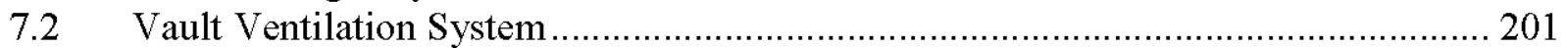

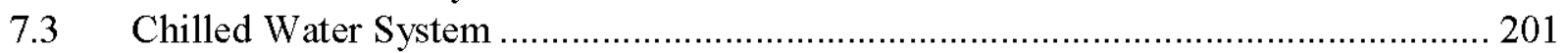

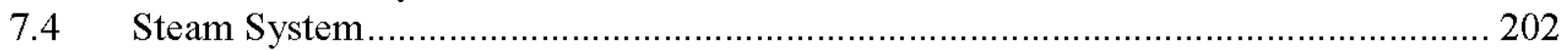

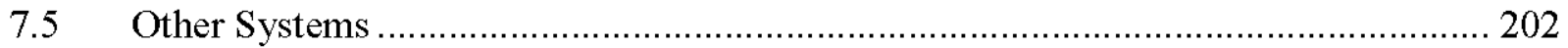



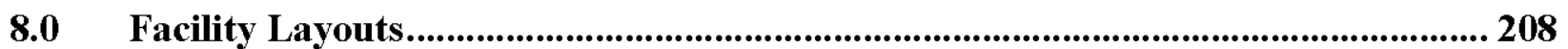

$8.1 \quad$ Rotary Microfilter Solids Separation ……………............................................... 208

8.2 Crossflow Filter Solids Separation ………………........................................ 209

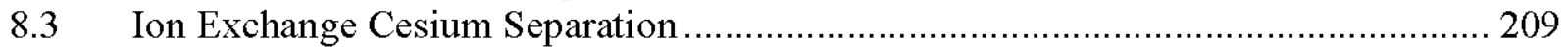

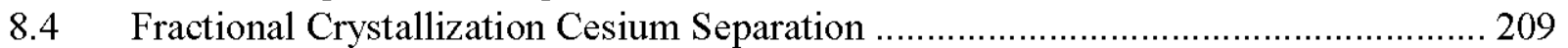

8.5 Solvent Extraction Cesium Separation ……………...................................... 210

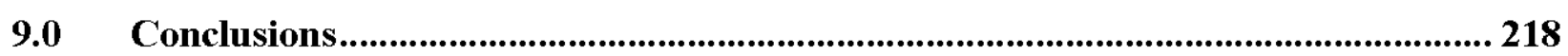

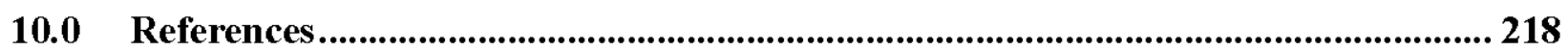

APPENDIX A - Referenced E-Mails.........................................................

APPENDIX B - SVF-1513 output... ....................................................... 


\section{LIST OF FIGURES}

Figure 1-1

Figure 3-1

Figure 5-1

Figure 5-2

Figure 5-3

Figure 6-1

Figure 6-2

Figure 6-3

Figure 6-4

Figure 6-5

Figure 6-6

Figure 6-7

Figure 6-8

Figure 6-9

Figure 6-10

Figure 6-11

Figure 6-12

Figure 6-13

Figure 6-14

Figure 6-15

Figure 6-16

Figure 6-17

Figure 6-18

Figure 6-19

Figure 6-20

Figure 6-21

Figure 6-22

Figure 6-23

Figure 6-24

Figure 6-25

Figure 6-26

Figure 6-27
Summary of Interim Pretreatment System Alternatives Evaluated 3

Interim Pretreatment System Interfaces. 12 Conceptual Drawing of Rotary Microfilter Module for In-tank Riser Installation

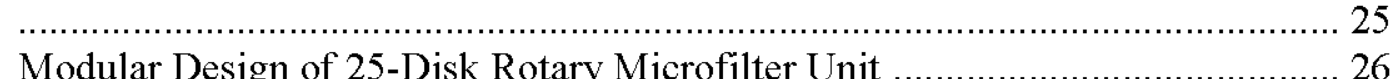

Crossflow Filtration Process Flow Diagram................................................... 36

Ion Exchange System Process Flow Diagram ............................................... 48

Resin Replacement Process Flow Diagram ....................................................... 51

Ion Exchange System Chemical Addition System ...................................... 53

Example Waste Dilution Operating Diagram for Waste from Tank AP-104...... 56

Variation of Fluidized Bed Height with Superficial Velocity for Upflow of $0.5 \mathrm{M}$

$\mathrm{NaOH}$.

58

Variation of Fluidized Bed Height with Superficial Velocity for Upflow of Waste

Simulant 58

Column Sizing Estimate for Steady State Material Balances .......................... 61

Resin Bed Porosity at Spent Resin Removal Conditions.................................. 63

Diagram Indicating Lead Column Operating Cycle Liquid Phase Volumes and

Characteristic Composition... 71

Diagram Indicating Polishing Column Operating Cycle Liquid Phase Volumes

and Characteristic Composition.... 73

Description of Ion Transfer between Liquid Phase and Resin during an Ion

Exchange Operating Cycle 76

Fractional Crystallization First Stage Process Flow Diagram ......................... 114

Fractional Crystallization Second Stage Process Flow Diagram....................... 115

Caustic-Side Solvent Extraction Process Flow Diagram................................. 152

Centrifugal Contactor Schematic ......................................................... 154

Prototypical 2-Stage Contactor Unit ....................................................... 154

Staged Equilibrium Extraction Section....................................................... 159

Example Extraction McCabe-Thiele Diagram............................................. 160

Staged Equilibrium Stripping Section .................................................... 161

Example Stripping McCabe-Thiele Diagram ............................................ 162

Centrifugal Contactor Specification ............................................................ 172

Waste Batches Processed over Initial 5 yr IPS Operating Period - Ion Exchange

and Solvent Extraction Cesium Separation Technologies ................................ 190

Waste Sodium and Total Sodium in LAW Transferred to Vitrification - Ion

Exchange Cesium Separation Technology ...................................................... 190

Waste Sodium and Total Sodium in LAW Transferred to Vitrification - Solvent

Extraction Cesium Separation Technology

Waste Batches Processed over Initial 5 yr IPS Operating Period - Fractional

Crystallization Cesium Separation Technology

DST Waste Volume Removed and Returned by IPS Operation - Ion Exchange

Cesium Separation Technology .

Net Change in Available Double-Shell Tank Waste Storage Space - Ion

Exchange Cesium Separation Technology 
Figure 6-28 Waste Volume Removed and Returned by IPS Operation - Solvent Extraction Cesium Separation Technology ............................................................... 195

Figure 6-29 Net Change in Available Double-Shell Tank Waste Storage Space - Solvent Extraction Cesium Separation Technology ................................................. 196

Figure 6-30 Waste Volume Removed and Returned by IPS Operation - Fractional Crystallization Cesium Separation Technology.....

Figure 6-31 Net Change in Available Double-Shell Tank Waste Storage Space - Fractional Crystallization Cesium Separation Technology............................................ 197

Figure 6-32 Comparison of Net Change in Available Waste Storage Space for Alternative Cesium Separation Technologies ................................................................... 198

Figure 7-1 Ion Exchange Process Offgas System......................................................... 199

Figure 7-2 Fractional Crystallization Process Offgas System ......................................... 200

Figure 7-3 Solvent Extraction Process Offgas System................................................ 200

Figure 7-4 Vault Ventilation System and Process Offgas Treatment............................... 203

Figure 8-1 Ion Exchange with Crossflow Filtration Facility Layout .................................. 211

Figure 8-2 Ion Exchange with Rotary Microfiltration Facility Layout ............................ 212

Figure 8-3 Fractional Crystallization with Crossflow Filtration Facility Layout................ 213

Figure 8-4 Fractional Crystallization with Rotary Microfilter Facility Layout.................. 214

Figure 8-5 Fractional Crystallization Facility Elevation ............................................ 215

Figure 8-6 Caustic Side Solvent Extraction with Crossflow Filtration Facility Layout....... 216

Figure 8-7 Caustic Side Solvent Extraction with Rotary Microfiltration Facility Layout ... 217

\section{LIST OF TABLES}

Table 2-1 Case 1 Interim Pretreatment System Waste Feed Batch Volume and Liquid Phase Composition .......................................................................................... 5

Table 2-2 Case 1 Interim Pretreatment System Waste Feed Batch Liquid Phase Curie

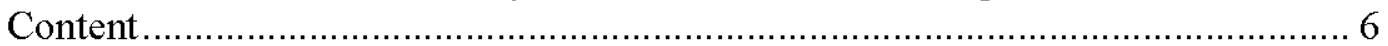

Table 2-3 Case 2 Interim Pretreatment System Waste Feed Batch Volume and Liquid Phase

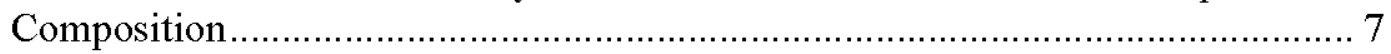

Table 2-4 Case 2 Interim Pretreatment System Waste Feed Batch Liquid Phase Curie

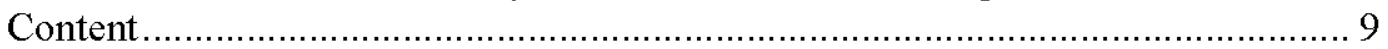

Table 2-5 Case 1 Interim Pretreatment System Waste Feed Batch Sources ....................... 10

Table 3-1 Design Basis Chemical Compositions for Alternative Vitrification Systems ...... 15

Table 3-2 Process and Physical Limits on Treated LAW ............................................. 15

Table 3-3 Radionuclide Concentration Limits for Treated Low Activity Waste from the Interim Pretreatment System......................................................... 16

Table 3-4 Evaluation of Waste Transfer Compatibility Program for Comparison Study

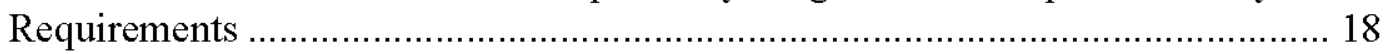

Table 3-5 Double-Shell Tanks Waste Chemistry Limits ............................................... 19

Table 5-1 Rotary Microfilter Literature Survey Summary ............................................ 23

Table 5-2 Rotary Microfiltration Sizing Summary ….................................................... 27

Table 5-3 Rotary Microfilter Equipment List ......................................................... 30

Table 5-4 Process Consumables Summary for Rotary Microfiltration ............................... 32

Table 5-5 Crossflow Filtration Literature Survey Summary........................................ 35

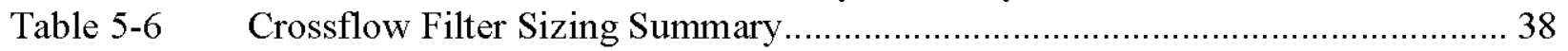

Table 5-7 Crossflow Filter Equipment List.............................................................. 41 
Table 5-8

Table 6-1

Table 6-2

Table 6-3

Table 6-4

Table 6-5

Table 6-6

Table 6-7

Table 6-8

Table 6-9

Table 6-10

Table 6-11

Table 6-12

Table 6-13

Table 6-14

Table 6-15

Table 6-16

Table 6-17

Table 6-18

Table 6-19

Table 6-20

Table 6-21

Table 6-22

Table 6-23

Table 6-24

Table 6-25

Table 6-26

Table 6-27

Table 6-28

Table 6-29

Table 6-30

Table 6-31

Table 6-32
Process Consumables Summary for Crossflow Filtration 43

User Supplied Input Data for Ion Exchange Mass Balance Calculations............. 54

Variation of Dilution Caustic Composition with Waste Feed Composition......... 56

Variation of Minimum Column Dimensions to Support the Design Waste

Processing Rate assuming a Fresh Resin Bed.

Cycle Volumes and Flow Rates Supporting Ion Exchange Column Operation ... 62

Average Ion Exchange Column Performance Inputs to Steady State Material

Balance.

Comparison of Ion Exchange Loading Cycle Volume Predictions by Alternate

Calculations.

Summary of Resin Physical Properties used as Inputs to Material Balances ...... 68

Volume and Characteristic Composition of Lead Column Effluents over an Ion

Exchange Column Operating Cycle. 72

Volume and Characteristic Composition of Polishing Column Effluents over an

Ion Exchange Column Operating Cycle 74

Lead Column Liquid Phase Component Balances for Operating Cycles ............. 80

Polishing Column Liquid Phase Component Balances for Operating Cycles ...... 81

Steady State Material Balance Stream Flows and Component Concentrations ... 82

Mass Balance Summary for Generic Filter with Ion Exchange Cesium Separation

- Waste Feed Batch \#1, AP-104

Mass Balance Summary for Generic Filter with Ion Exchange Cesium Separation

- Waste Feed Batch \#2, AP-102. 88

Mass Balance Summary for Generic Filter with Ion Exchange Cesium Separation

- Waste Feed Batch \#3, AP-101 89

Mass Balance Summary for Generic Filter with Ion Exchange Cesium Separation

- Waste Feed Batch \#4, AP-103 90

Mass Balance Summary for Generic Filter with Ion Exchange Cesium Separation

- Waste Feed Batch \#5, AP-105. 91

Mass Balance Summary for Generic Filter with Ion Exchange Cesium Separation

- Waste Feed Batch \#6, AP-108. 92

Mass Balance Summary for Generic Filter with Ion Exchange Cesium Separation

- Waste Feed Batch \#7, AP-107. 93

Mass Balance Summary for Generic Filter with Ion Exchange Cesium Separation

- Waste Feed Batch $\# 8$, AN-104 94

Summary of Spent Resin Metals and Radionuclide Concentrations after

Processing a Sequence of Actual Waste Samples in Column Tests .................... 95

Ion Exchange Equipment List..................................................................... 99

Bulk Caustic and Water Usage for Ion Exchange .......................................... 105

Mass Balance Input Parameters, Constant for All Waste Feed Batches............. 119

Theoretical Yield Input Data ................................................................ 120

Fractional Crystallization Mass Balance Summary ...................................... 127

Fractional Crystallization Equipment List .................................................... 136

Predicted Cesium Distribution Coefficients for Extraction .............................. 155

User-Supplied Input Parameters Common to all Feed Batches........................ 156

Feed-Specific User-Supplied Input Parameters ............................................... 158

Caustic-Side Solvent Extraction Mass Balance Summary for 241-AN-104 ...... 164

Caustic-Side Solvent Extraction Mass Balance Summary for 241-AP-101 ....... 165 
Table 6-33 Caustic-Side Solvent Extraction Mass Balance Summary for 241-AP-102 ...... 166

Table 6-34 Caustic-Side Solvent Extraction Mass Balance Summary for 241-AP-103 ...... 167

Table 6-35 Caustic-Side Solvent Extraction Mass Balance Summary for 241-AP-104 ...... 168

Table 6-36 Caustic-Side Solvent Extraction Mass Balance Summary for 241-AP-105 ...... 169

Table 6-37 Caustic-Side Solvent Extraction Mass Balance Summary for 241-AP-107 ...... 170

Table 6-38 Caustic-Side Solvent Extraction Mass Balance Summary for 241-AP-107 ...... 171

Table 6-39 Caustic Side Solvent Extraction Equipment List........................................ 173

Table 6-40 Peak Chemical Usage for Caustic-Side Solvent Extraction ............................ 179

Table 6-41 Sodium Balance Comparison Case 1 (8 Tank Basis) ..................................... 182

Table 6-42 Sodium Balance Comparison Case 2 (5 Year Basis) ..................................... 183

Table 6-43 Low-Activity Waste Radionuclide Content Comparison ............................... 185

Table 6-44 Cesium Product Radionuclide Content Comparison ${ }^{1}$..................................... 186

Table 6-45 Volume Comparison ...................................................................... 187

Table 6-46 Consumable Usage Comparison ............................................................... 188

Table 6-47 Process Vault plus Process Building Footprint Comparison ........................... 188

Table 6-48 Waste Group Assignments Estimating Fractional Crystallization Component



Table 7-1 Common Equipment List ..................................................................... 204 


\section{LIST OF TERMS}

$\begin{array}{ll}\text { AHU } & \text { Air Handling Unit } \\ \text { ASME } & \text { American Society of Mechanical Engineers } \\ \text { BV } & \text { Bed Volume } \\ \text { CEMS } & \text { Continuous Effluent Monitoring System } \\ \text { CSSX } & \text { Caustic Side Solvent Extraction } \\ \text { CV } & \text { Column Volume } \\ \text { D\&D } & \text { Decontamination and Decommissioning } \\ \text { DF } & \text { Decontamination Factor } \\ \text { DOE } & \text { U.S. Department of Energy } \\ \text { DST } & \text { Double Shell Tank } \\ \text { ESP } & \text { Environmental Simulation Program } \\ \text { ETF } & \text { Effluent Treatment Facility } \\ \text { FC } & \text { Fractional Crystallization } \\ \text { FD } & \text { Feed Displacement } \\ \text { HEPA } & \text { High-Efficiency Particulate Air } \\ \text { HLW } & \text { High Level Waste } \\ \text { IPS } & \text { Interim Pretreatment System } \\ \text { IX } & \text { Ion Exchange } \\ \text { LAW } & \text { Low Activity Waste } \\ \text { LC } & \text { Lead Column } \\ \text { L/D } & \text { Length to Diameter ratio } \\ \text { LH } & \text { Liquid Holdup } \\ \text { MCU } & \text { Modular CSSX Unit } \\ \text { MOV } & \text { Motor-Operated Valve } \\ \text { MT } & \text { Metric Ton } \\ \text { O/A } & \text { Organic to aqueous } \\ \text { ORNL } & \text { Oak Ridge National Laboratory } \\ \text { ORP } & \text { U.S. Department of Energy, Office of River Protection } \\ \text { PC } & \text { Polishing Column } \\ \text { PRV } & \text { Pressure Relief Valve } \\ \text { RD } & \text { Regenerant Displacement } \\ \text { RMF } & \text { Rotary Microfilter } \\ \text { sR-F } & \text { spherical resorcinol-formaldehyde } \\ \text { SRNL } & \text { Savannah River National Laboratory } \\ \text { SRS } & \text { Savannah River Site } \\ \text { SST } & \text { Single Shell Tank } \\ \text { SS } & \text { Stainless Steel } \\ \text { TDS } & \text { Total Dissolved Solids } \\ \text { TRU } & \text { Trans-Uranic } \\ \text { ULD } & \text { Unit Liter Dose } \\ \text { USOF } & \text { Vnit Sum-of-Fraction } \\ \text { VFD } & \end{array}$


VOC Volatile Organic Compound

WAC Waste Acceptance Criteria

WTP Waste Treatment Plant

WVDP West Valley Demonstration Project 


\section{I.0 INTRODUCTION}

The U.S. Department of Energy, Office of River Protection (ORP) has authorized a study to recommend and select options for interim pretreatment of Hanford tank waste that supports lowactivity waste (LAW) vitrification operations in the WTP prior to full startup of all the WTP facilities. The Interim Pretreatment System (IPS) is to be a moderately sized system that separates entrained solids and cesium from the LAW for an interim time period while WTP highlevel waste (HLW) vitrification and pretreatment facilities are completed. RPP-RPT-30160, Supporting Information for the Evaluation of Waste Treatment and Immobilization Plant (WTP) Low Activity Waste (LAW) Startup First Scenarios, developed information on a broad range of concepts for performing entrained solids and ${ }^{137} \mathrm{Cs}$ separation from tank waste using either existing or new tank farm facilities for the IPS. Modifications to the WTP project to allow operation of the LAW vitrification facility, independent of the pretreatment facility are also discussed in RPP-RPT-30160 and integrated scenarios constructed to describe potential systems that could be operated to produce immobilized LAW for an interim time period. RPP-29981, Evaluation of Starting the Waste Treatment and Immobilization Plant (WTP) Low Activity Waste Facility First, evaluates and contrasts the integrated scenarios with the RPP mission baseline.

\subsection{OBJECTIVE}

The objective of this study is to prepare pre-conceptual technology descriptions that expand the detail of technical information for selected solid and cesium separation technologies identified in RPP-RPT-30160. The technologies selected for detail expansion are:

- Entrained Solids Separation

- Rotary Microfiltration, and

- Crossflow Filtration

- Cesium Separation

- Fractional Crystallization (FC),

- Caustic Side Solvent Extraction (CSSX), and

- Ion Exchange (IX) using spherical resorcinol-formaldehyde (sR-F) as the ion exchange media

The pre-conceptual technology descriptions will be used as input into comparison activities that culminate with workshops/meetings to select preferred entrained solids and cesium separation technologies recommended to ORP for inclusion in an IPS. 


\subsection{SCOPE}

The process scope of this study is described in general terms by Figure 1-1. This report compares the alternatives for two cases: 1) on a basis of feed from eight Double-Shell Tanks (DST); and 2) on a basis of a 5 year mission. The first case provides sufficient feed for CSSX and IX but not for FC. The second case provides sufficient feed for all three technologies. Consistent with RPP-RPT-30160, 241-AP-104 (AP-104) is assumed to be the feed tank, while 241-AP-102 (AP-102) acts as a staging tank for waste sampling and characterization prior to performing entrained solids and cesium separations.

Treated LAW is transferred from the IPS to immobilization systems that consist of the WTP LAW vitrification system and/or a future vitrification system. Solids and cesium separated by the IPS are returned to DSTs for storage until construction of the WTP pretreatment and HLW vitrification facilities is completed and the facilities are operational. Estimates of waste volumes returned to tank farms are included for each alternative. However, activities required to manage waste volumes returned to tank farms from the IPS is outside the study scope.

The focus of this study is development of data that allows comparison of the technology alternatives. Reduced emphasis is placed on system characteristics that can be justified as not discriminating between alternatives. Data prepared as pre-conceptual technology descriptions for each entrained solids and cesium separation technology includes:

- Process flow diagram, including mass and energy balance, and secondary waste stream estimates,

- Brief process description,

- Site/facility layout, in sufficient detail to support an order-of-magnitude project cost estimate,

- A list of process components, including size and availability, in sufficient detail to support an order-of-magnitude project cost estimate, and

- A list of process consumables in sufficient detail to support an order-of-magnitude project cost estimate 


\section{Figure 1-1 Summary of Interim Pretreatment System Alternatives Evaluated}

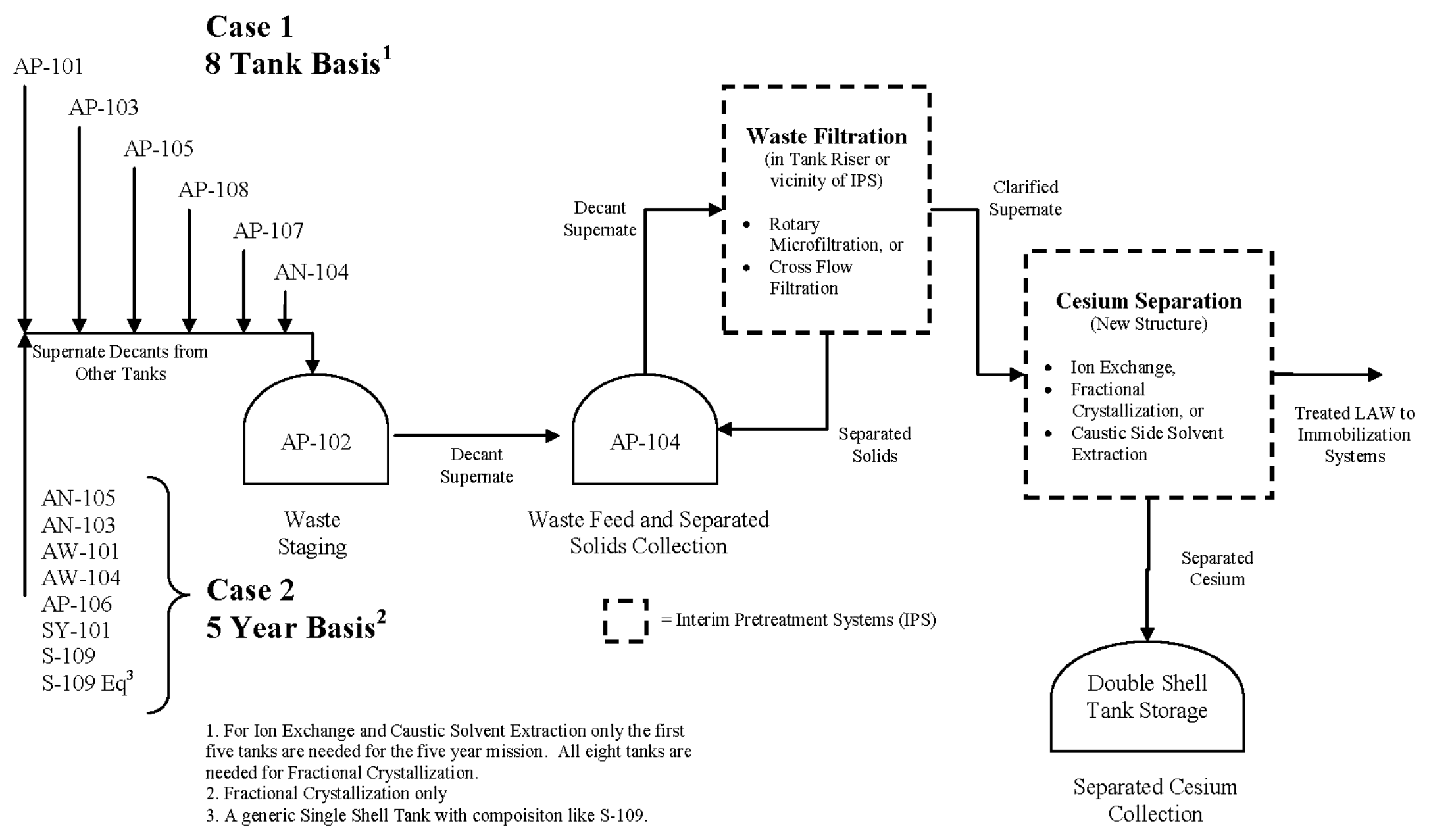




\subsection{INITIAL WASTE INVENTORY}

For development of the IPS pre-conceptual candidate technology descriptions, it is assumed that all waste feeds to the IPS are transferred from tank AP-104. Each time waste in AP-104 is drawn down to near the minimum heel level a new batch is transferred in to fill the tank. Batches of waste are pre-blended and staged prior to delivery to AP-104. This is consistent with assumptions in RPP-RPT-30160. The specific AP tank selected as the IPS feed interface does not appear important to comparison of the technology alternatives, provided the number of large risers (two) available for installation of rotary microfilters remains the same as assumed for the current study.

Liquid phase compositions and quantities for the assumed feed batches are given in Table 2-1 and Table 2-2 for Case 1. Tables 2-3 and 2-4 provide the same data for all of the additional tanks in Case 2. Table 2-5 summarizes the main source tanks for each of the pre-staged waste batches. The composition and volume of waste feed batches were calculated in spreadsheet SVF-1493, "Interim Pretreatment System Adjusted Feed DST Feed Composition Calculation;" which is in turn based on input data provided by CH2M HILL Hanford Group, Inc. in spreadsheet SVF-1484, "Interim Pretreatment System DST Feed Calculation." The Single Shell Tank (SST) identified as "S-109 eq" in Table 2-4 represents a generic SST with a composition equivalent to $\mathrm{S}-109$.

To calculate liquid phase compositions in SVF-1493, waste batch inventory values from SVF1484 were first converted to moles per liter. The charge balance between cationic and anionic species was checked and determined to be out of balance for all waste batches. To achieve charge balance, the concentration of anionic species $\left(\mathrm{Al}(\mathrm{OH})_{4}, \mathrm{CrO}_{2}, \mathrm{~F}, \mathrm{NO}_{2}, \mathrm{NO}_{3}\right.$, oxalate, $\mathrm{PO}_{4}$, $\mathrm{SO}_{4}, \mathrm{CO}_{3}$, and $\mathrm{OH}$ ) was then increased or decreased by a uniform factor to achieve zero net charge in solution.

Curies per liter values in Table 2-4 were converted from total curies per batch, but were not otherwise adjusted. Isotope values in Table 2-4 are based on decay through January 1, 2004. Additional decay through the projected waste processing dates is not expected to materially affect technology comparisons and was not included in the mass balance calculations for the current study.

Spreadsheet SVF-1484 assumes some intentional blending of tank supernatants and salt cake to provide a suitable feed for the WTP. There will be additional incidental blending as each batch is transferred into the IPS feed tank due to the heel material left in the tank prior to batch transfer. However, composition changes are expected to be small if the feed tank is drawn down to the minimum heel before refilling with the next batch. Composition adjustment for this additional incidental blending does not appear important for down selection of the treatment process and is therefore not considered in the current study.

Study calculations assume the waste feed supernatants have a suspended solids concentration of $0.5 \mathrm{wt} \%$, based on data discussed in RPP-RPT-30160, Section A.1.1. 
Table 2-1 Case 1 Interim Pretreatment System Waste Feed Batch Volume and Liquid Phase Composition

\begin{tabular}{|c|c|c|c|c|c|c|c|c|}
\hline Feed Batch Order & 1 & 2 & 3 & 4 & 5 & 6 & 7 & 8 \\
\hline Prestaged Location & 241-AP-104 & 241-AP-102 & 241-AP-101 & 241-AP-103 & 241-AP-105 & 241-AP-108 & 241-AP-107 & 241-AN-104 \\
\hline Volume (kL) & $3.787 \mathrm{E}+03$ & $4.004 \mathrm{E}+03$ & $4.126 \mathrm{E}+03$ & $4.245 \mathrm{E}+03$ & $3.944 \mathrm{E}+03$ & $4.337 \mathrm{E}+03$ & $4.318 \mathrm{E}+03$ & $5.528 \mathrm{E}+03$ \\
\hline \multicolumn{9}{|c|}{ Composition, gmol/L } \\
\hline $\mathrm{Al}$ as $\mathrm{Al}(\mathrm{OH})_{4}{ }^{-}$ & $6.037 \mathrm{E}-01$ & $8.508 \mathrm{E}-01$ & $4.347 \mathrm{E}-01$ & $7.918 \mathrm{E}-01$ & $6.995 \mathrm{E}-01$ & $8.793 \mathrm{E}-01$ & $4.115 \mathrm{E}-01$ & $6.479 \mathrm{E}-01$ \\
\hline $\mathrm{Bi}$ & $9.500 \mathrm{E}-05$ & $1.084 \mathrm{E}-04$ & $1.505 \mathrm{E}-04$ & $1.296 \mathrm{E}-04$ & $1.215 \mathrm{E}-04$ & $8.385 \mathrm{E}-05$ & $8.198 \mathrm{E}-05$ & $1.162 \mathrm{E}-05$ \\
\hline $\mathrm{Ca}$ & $1.451 \mathrm{E}-03$ & $6.481 \mathrm{E}-04$ & $1.148 \mathrm{E}-03$ & $1.752 \mathrm{E}-03$ & $2.151 \mathrm{E}-03$ & $5.741 \mathrm{E}-04$ & $5.484 \mathrm{E}-04$ & $5.641 \mathrm{E}-05$ \\
\hline $\mathrm{Cl}$ & $1.343 \mathrm{E}-01$ & $1.463 \mathrm{E}-01$ & $8.065 \mathrm{E}-02$ & $1.587 \mathrm{E}-01$ & $2.141 \mathrm{E}-01$ & $1.439 \mathrm{E}-01$ & $7.828 \mathrm{E}-02$ & $1.017 \mathrm{E}-01$ \\
\hline $\mathrm{Cr}$ & $1.319 \mathrm{E}-02$ & $1.139 \mathrm{E}-02$ & $1.786 \mathrm{E}-02$ & $1.345 \mathrm{E}-02$ & $7.234 \mathrm{E}-03$ & $1.570 \mathrm{E}-02$ & $2.040 \mathrm{E}-02$ & $3.762 \mathrm{E}-03$ \\
\hline $\mathrm{Cs}$ & $8.260 \mathrm{E}-05$ & $1.036 \mathrm{E}-04$ & $1.333 \mathrm{E}-04$ & $1.035 \mathrm{E}-04$ & $1.174 \mathrm{E}-04$ & $8.931 \mathrm{E}-05$ & $2.714 \mathrm{E}-04$ & $8.140 \mathrm{E}-05$ \\
\hline $\mathrm{F}$ & $3.393 \mathrm{E}-02$ & $2.157 \mathrm{E}-03$ & $4.515 \mathrm{E}-02$ & $3.821 \mathrm{E}-02$ & $8.243 \mathrm{E}-03$ & $1.961 \mathrm{E}-02$ & $3.879 \mathrm{E}-02$ & $1.343 \mathrm{E}-02$ \\
\hline $\mathrm{Fe}$ & $1.530 \mathrm{E}-04$ & $9.002 \mathrm{E}-05$ & $1.590 \mathrm{E}-04$ & $2.887 \mathrm{E}-04$ & $2.694 \mathrm{E}-04$ & $1.517 \mathrm{E}-04$ & $8.039 \mathrm{E}-05$ & $1.966 \mathrm{E}-05$ \\
\hline $\mathrm{Hg}$ & $1.082 \mathrm{E}-07$ & $1.581 \mathrm{E}-11$ & $7.592 \mathrm{E}-08$ & $1.621 \mathrm{E}-07$ & $1.129 \mathrm{E}-08$ & $3.150 \mathrm{E}-09$ & $3.225 \mathrm{E}-07$ & $0.000 \mathrm{E}+00$ \\
\hline $\mathrm{K}$ & $1.643 \mathrm{E}-01$ & $1.169 \mathrm{E}-01$ & $2.141 \mathrm{E}-01$ & $1.338 \mathrm{E}-01$ & $1.009 \mathrm{E}-01$ & $2.618 \mathrm{E}-01$ & $9.804 \mathrm{E}-02$ & $5.343 \mathrm{E}-02$ \\
\hline $\mathrm{La}$ & $1.382 \mathrm{E}-05$ & $1.906 \mathrm{E}-05$ & $2.068 \mathrm{E}-05$ & $2.747 \mathrm{E}-05$ & $1.476 \mathrm{E}-05$ & $1.540 \mathrm{E}-05$ & $7.911 \mathrm{E}-06$ & $3.157 \mathrm{E}-16$ \\
\hline $\mathrm{Mn}$ & $6.741 \mathrm{E}-05$ & $4.196 \mathrm{E}-05$ & $8.690 \mathrm{E}-05$ & $5.720 \mathrm{E}-05$ & $2.743 \mathrm{E}-05$ & $3.256 \mathrm{E}-05$ & $4.161 \mathrm{E}-05$ & $5.559 \mathrm{E}-06$ \\
\hline $\mathrm{Na}$ & $8.428 \mathrm{E}+00$ & $8.039 \mathrm{E}+00$ & $8.715 \mathrm{E}+00$ & $8.474 \mathrm{E}+00$ & $8.896 \mathrm{E}+00$ & $9.016 \mathrm{E}+00$ & $7.856 \mathrm{E}+00$ & $6.003 \mathrm{E}+00$ \\
\hline $\mathrm{Ni}$ & $6.876 \mathrm{E}-04$ & $1.476 \mathrm{E}-04$ & $2.939 \mathrm{E}-04$ & $1.059 \mathrm{E}-03$ & $1.584 \mathrm{E}-03$ & $4.948 \mathrm{E}-04$ & $2.317 \mathrm{E}-04$ & $8.309 \mathrm{E}-06$ \\
\hline $\mathrm{NO} 2$ & $1.375 \mathrm{E}+00$ & $1.972 \mathrm{E}+00$ & $1.005 \mathrm{E}+00$ & $1.970 \mathrm{E}+00$ & $2.369 \mathrm{E}+00$ & $1.784 \mathrm{E}+00$ & $1.217 \mathrm{E}+00$ & $1.159 \mathrm{E}+00$ \\
\hline $\mathrm{NO} 3$ & $3.405 \mathrm{E}+00$ & $2.556 \mathrm{E}+00$ & $4.142 \mathrm{E}+00$ & $2.569 \mathrm{E}+00$ & $2.638 \mathrm{E}+00$ & $2.900 \mathrm{E}+00$ & $3.091 \mathrm{E}+00$ & $1.461 \mathrm{E}+00$ \\
\hline Oxalate & $2.830 \mathrm{E}-02$ & $3.740 \mathrm{E}-03$ & $2.624 \mathrm{E}-02$ & $4.150 \mathrm{E}-02$ & $5.899 \mathrm{E}-03$ & $7.788 \mathrm{E}-03$ & $3.046 \mathrm{E}-02$ & 7.337E-04 \\
\hline $\mathrm{Pb}$ & $1.244 \mathrm{E}-04$ & $3.279 \mathrm{E}-04$ & $1.490 \mathrm{E}-04$ & $1.694 \mathrm{E}-04$ & $1.300 \mathrm{E}-04$ & $1.436 \mathrm{E}-04$ & $1.083 \mathrm{E}-04$ & $3.299 \mathrm{E}-05$ \\
\hline $\mathrm{PO} 4$ & $6.795 \mathrm{E}-02$ & $2.919 \mathrm{E}-02$ & $6.354 \mathrm{E}-02$ & $5.900 \mathrm{E}-02$ & $4.470 \mathrm{E}-02$ & $2.051 \mathrm{E}-02$ & $5.215 \mathrm{E}-02$ & $1.946 \mathrm{E}-02$ \\
\hline $\mathrm{Si}$ & $2.444 \mathrm{E}-03$ & $1.712 \mathrm{E}-03$ & $4.047 \mathrm{E}-03$ & $3.053 \mathrm{E}-03$ & $1.912 \mathrm{E}-03$ & $3.514 \mathrm{E}-03$ & $1.487 \mathrm{E}-03$ & $2.214 \mathrm{E}-03$ \\
\hline $\mathrm{SO} 4$ & $6.254 \mathrm{E}-02$ & $2.738 \mathrm{E}-02$ & $1.096 \mathrm{E}-01$ & $5.884 \mathrm{E}-02$ & $6.366 \mathrm{E}-02$ & $4.915 \mathrm{E}-02$ & $1.572 \mathrm{E}-01$ & $4.607 \mathrm{E}-02$ \\
\hline $\mathrm{Sr}$ & $1.213 \mathrm{E}-05$ & $1.328 \mathrm{E}-05$ & $1.639 \mathrm{E}-05$ & $1.925 \mathrm{E}-05$ & $7.024 \mathrm{E}-06$ & $6.816 \mathrm{E}-06$ & $2.908 \mathrm{E}-06$ & $4.306 \mathrm{E}-06$ \\
\hline TIC as $\mathrm{CO}_{3}^{-}$ & $5.160 \mathrm{E}-01$ & $2.736 \mathrm{E}-01$ & $5.960 \mathrm{E}-01$ & $6.373 \mathrm{E}-01$ & $4.378 \mathrm{E}-01$ & $5.614 \mathrm{E}-01$ & $6.380 \mathrm{E}-01$ & $3.759 \mathrm{E}-01$ \\
\hline TOC & $3.601 \mathrm{E}-01$ & $1.980 \mathrm{E}-01$ & $2.161 \mathrm{E}-01$ & $5.904 \mathrm{E}-01$ & $4.312 \mathrm{E}-01$ & $2.918 \mathrm{E}-01$ & $2.134 \mathrm{E}-01$ & 1.119E-01 \\
\hline UTOTAL & $1.287 \mathrm{E}-04$ & $5.593 \mathrm{E}-05$ & $1.231 \mathrm{E}-04$ & $1.356 \mathrm{E}-04$ & $2.105 \mathrm{E}-05$ & $1.046 \mathrm{E}-04$ & $1.293 \mathrm{E}-04$ & $3.514 \mathrm{E}-05$ \\
\hline $\mathrm{Zr}$ & $2.120 \mathrm{E}-05$ & $2.294 \mathrm{E}-05$ & $3.130 \mathrm{E}-05$ & $3.202 \mathrm{E}-05$ & $1.562 \mathrm{E}-05$ & $3.564 \mathrm{E}-05$ & $2.782 \mathrm{E}-05$ & $1.135 \mathrm{E}-05$ \\
\hline Free $\mathrm{OH}$ & $1.598 \mathrm{E}+00$ & $1.908 \mathrm{E}+00$ & $1.528 \mathrm{E}+00$ & $1.402 \mathrm{E}+00$ & $1.910 \mathrm{E}+00$ & $2.218 \mathrm{E}+00$ & $1.268 \mathrm{E}+00$ & $1.757 \mathrm{E}+00$ \\
\hline
\end{tabular}

Reference: SVF-1493 rev. 1 
Table 2-2 Case 1 Interim Pretreatment System Waste Feed Batch Liquid Phase Curie Content

\begin{tabular}{|c|c|c|c|c|c|c|c|c|}
\hline Feed Batch Order & 1 & 2 & 3 & 4 & 5 & 6 & 7 & 8 \\
\hline Prestaged Location & 241-AP-104 & 241-AP-102 & 241-AP-101 & 241-AP-103 & 241-AP-105 & 241-AP-108 & 241-AP-107 & 241-AN-104 \\
\hline & \multicolumn{8}{|c|}{ Curies Per Batch } \\
\hline $106 \mathrm{Ru}$ & $2.162 \mathrm{E}-05$ & $2.162 \mathrm{E}-05$ & $2.162 \mathrm{E}-05$ & $2.162 \mathrm{E}-05$ & $2.162 \mathrm{E}-05$ & $2.162 \mathrm{E}-05$ & $2.162 \mathrm{E}-05$ & $2.162 \mathrm{E}-05$ \\
\hline $113 \mathrm{mCd}$ & $1.169 \mathrm{E}+02$ & $1.169 \mathrm{E}+02$ & $1.169 \mathrm{E}+02$ & $1.169 \mathrm{E}+02$ & $1.169 \mathrm{E}+02$ & $1.169 \mathrm{E}+02$ & $1.169 \mathrm{E}+02$ & $1.169 \mathrm{E}+02$ \\
\hline $125 \mathrm{Sb}$ & $2.970 \mathrm{E}+01$ & $2.970 \mathrm{E}+01$ & $2.970 \mathrm{E}+01$ & $2.970 \mathrm{E}+01$ & $2.970 \mathrm{E}+01$ & $2.970 \mathrm{E}+01$ & $2.970 \mathrm{E}+01$ & $2.970 \mathrm{E}+01$ \\
\hline $126 \mathrm{Sn}$ & $5.399 \mathrm{E}+00$ & $5.399 \mathrm{E}+00$ & $5.399 \mathrm{E}+00$ & $5.399 \mathrm{E}+00$ & $5.399 \mathrm{E}+00$ & $5.399 \mathrm{E}+00$ & $5.399 \mathrm{E}+00$ & $5.399 \mathrm{E}+00$ \\
\hline $129 \mathrm{I}$ & $6.763 \mathrm{E}-01$ & $6.763 \mathrm{E}-01$ & $6.763 \mathrm{E}-01$ & $6.763 \mathrm{E}-01$ & $6.763 \mathrm{E}-01$ & $6.763 \mathrm{E}-01$ & $6.763 \mathrm{E}-01$ & $6.763 \mathrm{E}-01$ \\
\hline $134 \mathrm{Cs}$ & $8.154 \mathrm{E}+00$ & $8.154 \mathrm{E}+00$ & $8.154 \mathrm{E}+00$ & $8.154 \mathrm{E}+00$ & $8.154 \mathrm{E}+00$ & $8.154 \mathrm{E}+00$ & $8.154 \mathrm{E}+00$ & $8.154 \mathrm{E}+00$ \\
\hline $137 \mathrm{Cs}$ & $7.260 \mathrm{E}+05$ & $7.260 \mathrm{E}+05$ & $7.260 \mathrm{E}+05$ & $7.260 \mathrm{E}+05$ & $7.260 \mathrm{E}+05$ & $7.260 \mathrm{E}+05$ & $7.260 \mathrm{E}+05$ & $7.260 \mathrm{E}+05$ \\
\hline $137 \mathrm{mBa}$ & $6.847 \mathrm{E}+05$ & $6.847 \mathrm{E}+05$ & $6.847 \mathrm{E}+05$ & $6.847 \mathrm{E}+05$ & $6.847 \mathrm{E}+05$ & $6.847 \mathrm{E}+05$ & $6.847 \mathrm{E}+05$ & $6.847 \mathrm{E}+05$ \\
\hline $14 \mathrm{C}$ & $5.340 \mathrm{E}+00$ & $5.340 \mathrm{E}+00$ & $5.340 \mathrm{E}+00$ & $5.340 \mathrm{E}+00$ & $5.340 \mathrm{E}+00$ & $5.340 \mathrm{E}+00$ & $5.340 \mathrm{E}+00$ & $5.340 \mathrm{E}+00$ \\
\hline $151 \mathrm{Sm}$ & $2.578 \mathrm{E}+04$ & $2.578 \mathrm{E}+04$ & $2.578 \mathrm{E}+04$ & $2.578 \mathrm{E}+04$ & $2.578 \mathrm{E}+04$ & $2.578 \mathrm{E}+04$ & $2.578 \mathrm{E}+04$ & $2.578 \mathrm{E}+04$ \\
\hline $152 \mathrm{Eu}$ & $5.722 \mathrm{E}+00$ & $5.722 \mathrm{E}+00$ & $5.722 \mathrm{E}+00$ & $5.722 \mathrm{E}+00$ & $5.722 \mathrm{E}+00$ & $5.722 \mathrm{E}+00$ & $5.722 \mathrm{E}+00$ & $5.722 \mathrm{E}+00$ \\
\hline $154 \mathrm{Eu}$ & $3.027 \mathrm{E}+01$ & $3.027 \mathrm{E}+01$ & $3.027 \mathrm{E}+01$ & $3.027 \mathrm{E}+01$ & $3.027 \mathrm{E}+01$ & $3.027 \mathrm{E}+01$ & $3.027 \mathrm{E}+01$ & $3.027 \mathrm{E}+01$ \\
\hline $155 \mathrm{Eu}$ & $7.560 \mathrm{E}+01$ & $7.560 \mathrm{E}+01$ & $7.560 \mathrm{E}+01$ & $7.560 \mathrm{E}+01$ & $7.560 \mathrm{E}+01$ & $7.560 \mathrm{E}+01$ & $7.560 \mathrm{E}+01$ & $7.560 \mathrm{E}+01$ \\
\hline $226 \mathrm{Ra}$ & $3.363 \mathrm{E}-04$ & $3.363 \mathrm{E}-04$ & $3.363 \mathrm{E}-04$ & $3.363 \mathrm{E}-04$ & $3.363 \mathrm{E}-04$ & $3.363 \mathrm{E}-04$ & $3.363 \mathrm{E}-04$ & $3.363 \mathrm{E}-04$ \\
\hline $227 \mathrm{Ac}$ & $5.377 \mathrm{E}-03$ & $5.377 \mathrm{E}-03$ & $5.377 \mathrm{E}-03$ & $5.377 \mathrm{E}-03$ & $5.377 \mathrm{E}-03$ & $5.377 \mathrm{E}-03$ & $5.377 \mathrm{E}-03$ & $5.377 \mathrm{E}-03$ \\
\hline $228 \mathrm{Ra}$ & $7.082 \mathrm{E}-02$ & $7.082 \mathrm{E}-02$ & $7.082 \mathrm{E}-02$ & $7.082 \mathrm{E}-02$ & $7.082 \mathrm{E}-02$ & $7.082 \mathrm{E}-02$ & $7.082 \mathrm{E}-02$ & $7.082 \mathrm{E}-02$ \\
\hline $229 \mathrm{Th}$ & $4.602 \mathrm{E}-03$ & $4.602 \mathrm{E}-03$ & $4.602 \mathrm{E}-03$ & $4.602 \mathrm{E}-03$ & $4.602 \mathrm{E}-03$ & $4.602 \mathrm{E}-03$ & $4.602 \mathrm{E}-03$ & $4.602 \mathrm{E}-03$ \\
\hline $231 \mathrm{~Pa}$ & $2.610 \mathrm{E}-02$ & $2.610 \mathrm{E}-02$ & $2.610 \mathrm{E}-02$ & $2.610 \mathrm{E}-02$ & $2.610 \mathrm{E}-02$ & $2.610 \mathrm{E}-02$ & $2.610 \mathrm{E}-02$ & $2.610 \mathrm{E}-02$ \\
\hline $232 \mathrm{Th}$ & $2.952 \mathrm{E}-03$ & $2.952 \mathrm{E}-03$ & $2.952 \mathrm{E}-03$ & $2.952 \mathrm{E}-03$ & $2.952 \mathrm{E}-03$ & $2.952 \mathrm{E}-03$ & $2.952 \mathrm{E}-03$ & $2.952 \mathrm{E}-03$ \\
\hline $232 \mathrm{U}$ & $1.213 \mathrm{E}-02$ & $1.213 \mathrm{E}-02$ & $1.213 \mathrm{E}-02$ & $1.213 \mathrm{E}-02$ & $1.213 \mathrm{E}-02$ & $1.213 \mathrm{E}-02$ & $1.213 \mathrm{E}-02$ & $1.213 \mathrm{E}-02$ \\
\hline $233 \mathrm{U}$ & $8.449 \mathrm{E}-02$ & $8.449 \mathrm{E}-02$ & $8.449 \mathrm{E}-02$ & $8.449 \mathrm{E}-02$ & $8.449 \mathrm{E}-02$ & $8.449 \mathrm{E}-02$ & $8.449 \mathrm{E}-02$ & $8.449 \mathrm{E}-02$ \\
\hline $234 \mathrm{U}$ & $4.574 \mathrm{E}-02$ & $4.574 \mathrm{E}-02$ & $4.574 \mathrm{E}-02$ & $4.574 \mathrm{E}-02$ & $4.574 \mathrm{E}-02$ & $4.574 \mathrm{E}-02$ & $4.574 \mathrm{E}-02$ & $4.574 \mathrm{E}-02$ \\
\hline $235 \mathrm{U}$ & $1.764 \mathrm{E}-03$ & $1.764 \mathrm{E}-03$ & $1.764 \mathrm{E}-03$ & $1.764 \mathrm{E}-03$ & $1.764 \mathrm{E}-03$ & $1.764 \mathrm{E}-03$ & $1.764 \mathrm{E}-03$ & $1.764 \mathrm{E}-03$ \\
\hline $236 \mathrm{U}$ & $2.077 \mathrm{E}-03$ & $2.077 \mathrm{E}-03$ & $2.077 \mathrm{E}-03$ & $2.077 \mathrm{E}-03$ & $2.077 \mathrm{E}-03$ & $2.077 \mathrm{E}-03$ & $2.077 \mathrm{E}-03$ & $2.077 \mathrm{E}-03$ \\
\hline $237 \mathrm{~Np}$ & $1.937 \mathrm{E}-01$ & $1.937 \mathrm{E}-01$ & $1.937 \mathrm{E}-01$ & $1.937 \mathrm{E}-01$ & $1.937 \mathrm{E}-01$ & $1.937 \mathrm{E}-01$ & $1.937 \mathrm{E}-01$ & $1.937 \mathrm{E}-01$ \\
\hline $238 \mathrm{Pu}$ & 4.771E-01 & $4.771 \mathrm{E}-01$ & $4.771 \mathrm{E}-01$ & $4.771 \mathrm{E}-01$ & $4.771 \mathrm{E}-01$ & 4.771E-01 & 4.771E-01 & 4.771E-01 \\
\hline $238 \mathrm{U}$ & $3.866 \mathrm{E}-02$ & $3.866 \mathrm{E}-02$ & $3.866 \mathrm{E}-02$ & $3.866 \mathrm{E}-02$ & $3.866 \mathrm{E}-02$ & $3.866 \mathrm{E}-02$ & $3.866 \mathrm{E}-02$ & $3.866 \mathrm{E}-02$ \\
\hline $239 \mathrm{Pu}$ & $2.497 \mathrm{E}+00$ & $2.497 \mathrm{E}+00$ & $2.497 \mathrm{E}+00$ & $2.497 \mathrm{E}+00$ & $2.497 \mathrm{E}+00$ & $2.497 \mathrm{E}+00$ & $2.497 \mathrm{E}+00$ & $2.497 \mathrm{E}+00$ \\
\hline $240 \mathrm{Pu}$ & $4.239 \mathrm{E}-01$ & $4.239 \mathrm{E}-01$ & $4.239 \mathrm{E}-01$ & $4.239 \mathrm{E}-01$ & $4.239 \mathrm{E}-01$ & $4.239 \mathrm{E}-01$ & $4.239 \mathrm{E}-01$ & $4.239 \mathrm{E}-01$ \\
\hline $241 \mathrm{Am}$ & $7.690 \mathrm{E}+00$ & $7.690 \mathrm{E}+00$ & $7.690 \mathrm{E}+00$ & $7.690 \mathrm{E}+00$ & $7.690 \mathrm{E}+00$ & $7.690 \mathrm{E}+00$ & $7.690 \mathrm{E}+00$ & $7.690 \mathrm{E}+00$ \\
\hline $241 \mathrm{Pu}$ & $2.883 \mathrm{E}+00$ & $2.883 \mathrm{E}+00$ & $2.883 \mathrm{E}+00$ & $2.883 \mathrm{E}+00$ & $2.883 \mathrm{E}+00$ & $2.883 \mathrm{E}+00$ & $2.883 \mathrm{E}+00$ & $2.883 \mathrm{E}+00$ \\
\hline $242 \mathrm{Cm}$ & $2.812 \mathrm{E}-02$ & $2.812 \mathrm{E}-02$ & $2.812 \mathrm{E}-02$ & $2.812 \mathrm{E}-02$ & $2.812 \mathrm{E}-02$ & $2.812 \mathrm{E}-02$ & $2.812 \mathrm{E}-02$ & $2.812 \mathrm{E}-02$ \\
\hline
\end{tabular}


Table 2-2 Case 1 Interim Pretreatment System Waste Feed Batch Liquid Phase Curie Content

\begin{tabular}{|c|c|c|c|c|c|c|c|c|}
\hline Feed Batch Order & 1 & 2 & 3 & 4 & 5 & 6 & 7 & 8 \\
\hline Prestaged Location & 241-AP-104 & 241-AP-102 & 241-AP-101 & 241-AP-103 & 241-AP-105 & $241-\mathrm{AP}-108$ & $241-\mathrm{AP}-107$ & 241-AN-104 \\
\hline \multicolumn{9}{|c|}{ Curies Per Batch } \\
\hline $242 \mathrm{Pu}$ & $2.462 \mathrm{E}-05$ & $2.462 \mathrm{E}-05$ & $2.462 \mathrm{E}-05$ & $2.462 \mathrm{E}-05$ & $2.462 \mathrm{E}-05$ & $2.462 \mathrm{E}-05$ & $2.462 \mathrm{E}-05$ & $2.462 \mathrm{E}-05$ \\
\hline $243 \mathrm{Am}$ & $3.182 \mathrm{E}-04$ & $3.182 \mathrm{E}-04$ & $3.182 \mathrm{E}-04$ & $3.182 \mathrm{E}-04$ & $3.182 \mathrm{E}-04$ & $3.182 \mathrm{E}-04$ & $3.182 \mathrm{E}-04$ & $3.182 \mathrm{E}-04$ \\
\hline $243 \mathrm{Cm}$ & $9.142 \mathrm{E}-02$ & $9.142 \mathrm{E}-02$ & $9.142 \mathrm{E}-02$ & $9.142 \mathrm{E}-02$ & $9.142 \mathrm{E}-02$ & $9.142 \mathrm{E}-02$ & $9.142 \mathrm{E}-02$ & $9.142 \mathrm{E}-02$ \\
\hline $244 \mathrm{Cm}$ & $2.139 \mathrm{E}+00$ & $2.139 \mathrm{E}+00$ & $2.139 \mathrm{E}+00$ & $2.139 \mathrm{E}+00$ & $2.139 \mathrm{E}+00$ & $2.139 \mathrm{E}+00$ & $2.139 \mathrm{E}+00$ & $2.139 \mathrm{E}+00$ \\
\hline $3 \mathrm{H}$ & $5.417 \mathrm{E}+00$ & $5.417 \mathrm{E}+00$ & $5.417 \mathrm{E}+00$ & $5.417 \mathrm{E}+00$ & $5.417 \mathrm{E}+00$ & $5.417 \mathrm{E}+00$ & $5.417 \mathrm{E}+00$ & $5.417 \mathrm{E}+00$ \\
\hline $59 \mathrm{Ni}$ & $4.278 \mathrm{E}+00$ & $4.278 \mathrm{E}+00$ & $4.278 \mathrm{E}+00$ & $4.278 \mathrm{E}+00$ & $4.278 \mathrm{E}+00$ & $4.278 \mathrm{E}+00$ & $4.278 \mathrm{E}+00$ & $4.278 \mathrm{E}+00$ \\
\hline $60 \mathrm{Co}$ & $2.511 \mathrm{E}+01$ & $2.511 \mathrm{E}+01$ & $2.511 \mathrm{E}+01$ & $2.511 \mathrm{E}+01$ & $2.511 \mathrm{E}+01$ & $2.511 \mathrm{E}+01$ & $2.511 \mathrm{E}+01$ & $2.511 \mathrm{E}+01$ \\
\hline $63 \mathrm{Ni}$ & $3.931 \mathrm{E}+02$ & $3.931 \mathrm{E}+02$ & $3.931 \mathrm{E}+02$ & $3.931 \mathrm{E}+02$ & $3.931 \mathrm{E}+02$ & $3.931 \mathrm{E}+02$ & $3.931 \mathrm{E}+02$ & $3.931 \mathrm{E}+02$ \\
\hline $79 \mathrm{Se}$ & $2.677 \mathrm{E}+00$ & $2.677 \mathrm{E}+00$ & $2.677 \mathrm{E}+00$ & $2.677 \mathrm{E}+00$ & $2.677 \mathrm{E}+00$ & $2.677 \mathrm{E}+00$ & $2.677 \mathrm{E}+00$ & $2.677 \mathrm{E}+00$ \\
\hline $90 \mathrm{Sr}$ & $5.273 \mathrm{E}+03$ & $5.273 \mathrm{E}+03$ & $5.273 \mathrm{E}+03$ & $5.273 \mathrm{E}+03$ & $5.273 \mathrm{E}+03$ & $5.273 \mathrm{E}+03$ & $5.273 \mathrm{E}+03$ & $5.273 \mathrm{E}+03$ \\
\hline $90 \mathrm{Y}$ & $5.273 \mathrm{E}+03$ & $5.273 \mathrm{E}+03$ & $5.273 \mathrm{E}+03$ & $5.273 \mathrm{E}+03$ & $5.273 \mathrm{E}+03$ & $5.273 \mathrm{E}+03$ & $5.273 \mathrm{E}+03$ & $5.273 \mathrm{E}+03$ \\
\hline $93 \mathrm{mNb}$ & $3.683 \mathrm{E}+01$ & $3.683 \mathrm{E}+01$ & $3.683 \mathrm{E}+01$ & $3.683 \mathrm{E}+01$ & $3.683 \mathrm{E}+01$ & $3.683 \mathrm{E}+01$ & $3.683 \mathrm{E}+01$ & $3.683 \mathrm{E}+01$ \\
\hline $93 \mathrm{Zr}$ & $4.404 \mathrm{E}+01$ & $4.404 \mathrm{E}+01$ & $4.404 \mathrm{E}+01$ & $4.404 \mathrm{E}+01$ & $4.404 \mathrm{E}+01$ & $4.404 \mathrm{E}+01$ & $4.404 \mathrm{E}+01$ & $4.404 \mathrm{E}+01$ \\
\hline \multirow[t]{2}{*}{$99 \mathrm{Tc}$} & $6.294 \mathrm{E}+02$ & $6.294 \mathrm{E}+02$ & $6.294 \mathrm{E}+02$ & $6.294 \mathrm{E}+02$ & $6.294 \mathrm{E}+02$ & $6.294 \mathrm{E}+02$ & $6.294 \mathrm{E}+02$ & $6.294 \mathrm{E}+02$ \\
\hline & \multicolumn{8}{|c|}{ Concentration Curies per Liter } \\
\hline $137 \mathrm{Cs}$ & 0.192 & 0.241 & 0.309 & 0.240 & 0.273 & 0.207 & 0.630 & 0.189 \\
\hline $90 \mathrm{Sr}$ & 0.00139 & 0.00039 & 0.00091 & 0.00216 & 0.00182 & 0.00102 & 0.00175 & 0.001 \\
\hline
\end{tabular}

Reference: SVF-1493 Rev. 1

Table 2-3 Case 2 Interim Pretreatment System Waste Feed Batch Volume and Liquid Phase Composition

\begin{tabular}{|l|c|c|c|c|c|c|c|c|}
\hline Feed Batch Order & 1 & 2 & 3 & 4 & 5 & 7 \\
\hline Prestaged Location & $241-\mathrm{AN}-105$ & $241-\mathrm{AN}-103$ & $241-\mathrm{AW}-101$ & $241-\mathrm{AW}-104$ & $241-\mathrm{AP}-106$ & $241 \mathrm{SY}-101$ & $241-\mathrm{S}-109$ & $241-\mathrm{S}-109 \mathrm{Eq}$ \\
\hline Volume (kL) & $5.983 \mathrm{E}+03$ & $7.714 \mathrm{E}+03$ & $7.354 \mathrm{E}+03$ & $5.631 \mathrm{E}+03$ & $4.301 \mathrm{E}+03$ & $3.23 \mathrm{E}+03$ & $5.51 \mathrm{E}+03$ & $3.58 \mathrm{E}+03$ \\
\hline \multicolumn{7}{|l|}{ Composition, gmol/L } \\
\hline $\mathrm{Al}$ as Al(OH) ${ }_{4}^{-}$ & $7.130 \mathrm{E}-01$ & $1.121 \mathrm{E}+00$ & $4.711 \mathrm{E}-01$ & $6.648 \mathrm{E}-01$ & $5.094 \mathrm{E}-01$ & $1.282 \mathrm{E}-01$ & $1.626 \mathrm{E}-01$ & $1.63 \mathrm{E}-01$ \\
\hline $\mathrm{Bi}$ & $2.367 \mathrm{E}-05$ & $4.883 \mathrm{E}-06$ & $4.236 \mathrm{E}-06$ & $8.079 \mathrm{E}-06$ & $1.246 \mathrm{E}-05$ & $6.395 \mathrm{E}-05$ & $1.199 \mathrm{E}-07$ & $1.20 \mathrm{E}-07$ \\
\hline $\mathrm{Ca}$ & $4.545 \mathrm{E}-04$ & $4.722 \mathrm{E}-05$ & $9.127 \mathrm{E}-05$ & $8.109 \mathrm{E}-04$ & $9.688 \mathrm{E}-04$ & $5.129 \mathrm{E}-04$ & $3.301 \mathrm{E}-04$ & $3.30 \mathrm{E}-04$ \\
\hline $\mathrm{Cl}$ & $1.291 \mathrm{E}-01$ & $1.071 \mathrm{E}-01$ & $8.381 \mathrm{E}-02$ & $1.104 \mathrm{E}-01$ & $8.141 \mathrm{E}-02$ & $2.079 \mathrm{E}-02$ & $1.067 \mathrm{E}-02$ & $1.07 \mathrm{E}-02$ \\
\hline $\mathrm{Cr}$ & $4.517 \mathrm{E}-03$ & $1.803 \mathrm{E}-03$ & $1.034 \mathrm{E}-03$ & $3.743 \mathrm{E}-03$ & $1.370 \mathrm{E}-02$ & $1.870 \mathrm{E}-03$ & $3.971 \mathrm{E}-03$ & $3.97 \mathrm{E}-03$ \\
\hline $\mathrm{Cs}$ & $7.967 \mathrm{E}-05$ & $9.131 \mathrm{E}-05$ & $8.565 \mathrm{E}-05$ & $7.101 \mathrm{E}-05$ & $7.554 \mathrm{E}-05$ & $1.104 \mathrm{E}-05$ & $3.109 \mathrm{E}-06$ & $3.11 \mathrm{E}-06$ \\
\hline $\mathrm{F}$ & $3.898 \mathrm{E}-02$ & $2.395 \mathrm{E}-02$ & $5.457 \mathrm{E}-02$ & $3.452 \mathrm{E}-01$ & $6.774 \mathrm{E}-03$ & $2.522 \mathrm{E}-02$ & $7.415 \mathrm{E}-03$ & $7.41 \mathrm{E}-03$ \\
\hline
\end{tabular}


Table 2-3 Case 2 Interim Pretreatment System Waste Feed Batch Volume and Liquid Phase Composition

\begin{tabular}{|c|c|c|c|c|c|c|c|c|}
\hline Feed Batch Order & 1 & 2 & 3 & 4 & 5 & 6 & 7 & 8 \\
\hline Prestaged Location & $241-A N-105$ & $241-\mathrm{AN}-103$ & 241-AW-101 & 241-AW-104 & $241-\mathrm{AP}-106$ & $241 \mathrm{SY}-101$ & 241-S-109 & $241-\mathrm{S}-109 \mathrm{Eq}$ \\
\hline Volume (kL) & $5.983 \mathrm{E}+03$ & $7.714 \mathrm{E}+03$ & $7.354 \mathrm{E}+03$ & $5.631 \mathrm{E}+03$ & $4.301 \mathrm{E}+03$ & $3.23 \mathrm{E}+03$ & $5.51 \mathrm{E}+03$ & $3.58 \mathrm{E}+03$ \\
\hline \multicolumn{9}{|c|}{ Composition, gmol/L } \\
\hline $\mathrm{Fe}$ & $1.298 \mathrm{E}-05$ & $2.747 \mathrm{E}-07$ & $1.722 \mathrm{E}-06$ & $9.476 \mathrm{E}-06$ & $8.213 \mathrm{E}-05$ & $2.755 \mathrm{E}-05$ & $6.546 \mathrm{E}-04$ & $6.55 \mathrm{E}-04$ \\
\hline $\mathrm{Hg}$ & $9.307 \mathrm{E}-07$ & $3.007 \mathrm{E}-07$ & $3.430 \mathrm{E}-07$ & $1.027 \mathrm{E}-07$ & $0.000 \mathrm{E}+00$ & $1.043 \mathrm{E}-08$ & $1.680 \mathrm{E}-06$ & $1.68 \mathrm{E}-06$ \\
\hline $\mathrm{K}$ & $6.944 \mathrm{E}-02$ & $1.403 \mathrm{E}-01$ & $5.186 \mathrm{E}-01$ & $1.156 \mathrm{E}-01$ & $3.610 \mathrm{E}-02$ & $6.876 \mathrm{E}-03$ & $5.407 \mathrm{E}-03$ & $5.41 \mathrm{E}-03$ \\
\hline La & $3.146 \mathrm{E}-16$ & $1.762 \mathrm{E}-15$ & $5.602 \mathrm{E}-12$ & $3.279 \mathrm{E}-11$ & $1.408 \mathrm{E}-05$ & $1.580 \mathrm{E}-05$ & $8.737 \mathrm{E}-09$ & $8.74 \mathrm{E}-09$ \\
\hline $\mathrm{Mn}$ & $7.146 \mathrm{E}-06$ & $2.266 \mathrm{E}-07$ & $4.820 \mathrm{E}-06$ & $1.925 \mathrm{E}-05$ & $3.716 \mathrm{E}-05$ & $1.868 \mathrm{E}-05$ & $0.000 \mathrm{E}+00$ & $0.00 \mathrm{E}+00$ \\
\hline $\mathrm{Na}$ & $6.003 \mathrm{E}+00$ & $6.003 \mathrm{E}+00$ & $6.003 \mathrm{E}+00$ & $6.003 \mathrm{E}+00$ & $4.500 \mathrm{E}+00$ & $2.441 \mathrm{E}+00$ & $6.000 \mathrm{E}+00$ & $6.00 \mathrm{E}+00$ \\
\hline $\mathrm{Ni}$ & $5.598 \mathrm{E}-05$ & $1.085 \mathrm{E}-06$ & $2.359 \mathrm{E}-06$ & $6.019 \mathrm{E}-06$ & $5.069 \mathrm{E}-04$ & $7.500 \mathrm{E}-05$ & $3.496 \mathrm{E}-05$ & $3.50 \mathrm{E}-05$ \\
\hline $\mathrm{NO} 2$ & $1.223 \mathrm{E}+00$ & $1.262 \mathrm{E}+00$ & $1.089 \mathrm{E}+00$ & $1.381 \mathrm{E}+00$ & $9.153 \mathrm{E}-01$ & $1.849 \mathrm{E}-01$ & $9.493 \mathrm{E}-02$ & $9.49 \mathrm{E}-02$ \\
\hline $\mathrm{NO} 3$ & $1.369 \mathrm{E}+00$ & $1.453 \mathrm{E}+00$ & $1.567 \mathrm{E}+00$ & $1.540 \mathrm{E}+00$ & $1.160 \mathrm{E}+00$ & $8.505 \mathrm{E}-01$ & $5.342 \mathrm{E}+00$ & $5.34 \mathrm{E}+00$ \\
\hline Oxalate & $1.524 \mathrm{E}-03$ & $5.799 \mathrm{E}-04$ & $2.727 \mathrm{E}-04$ & $2.143 \mathrm{E}-04$ & $7.873 \mathrm{E}-03$ & $2.222 \mathrm{E}-02$ & $1.780 \mathrm{E}-02$ & $1.78 \mathrm{E}-02$ \\
\hline $\mathrm{Pb}$ & $4.607 \mathrm{E}-05$ & $1.173 \mathrm{E}-06$ & $1.993 \mathrm{E}-06$ & $9.015 \mathrm{E}-07$ & $1.952 \mathrm{E}-05$ & $5.298 \mathrm{E}-05$ & $2.936 \mathrm{E}-06$ & $2.94 \mathrm{E}-06$ \\
\hline PO4 & $2.773 \mathrm{E}-02$ & $1.191 \mathrm{E}-02$ & $6.803 \mathrm{E}-03$ & $1.128 \mathrm{E}-02$ & $8.220 \mathrm{E}-02$ & $1.012 \mathrm{E}-01$ & $6.688 \mathrm{E}-02$ & $6.69 \mathrm{E}-02$ \\
\hline $\mathrm{Si}$ & $9.294 \mathrm{E}-04$ & $5.558 \mathrm{E}-03$ & $2.605 \mathrm{E}-03$ & $6.085 \mathrm{E}-03$ & $1.019 \mathrm{E}-03$ & $3.029 \mathrm{E}-03$ & $5.201 \mathrm{E}-03$ & $5.20 \mathrm{E}-03$ \\
\hline SO4 & $3.638 \mathrm{E}-02$ & $1.616 \mathrm{E}-02$ & $1.522 \mathrm{E}-02$ & $5.682 \mathrm{E}-02$ & $3.891 \mathrm{E}-02$ & $2.105 \mathrm{E}-02$ & $4.966 \mathrm{E}-02$ & $4.97 \mathrm{E}-02$ \\
\hline $\mathrm{Sr}$ & $1.082 \mathrm{E}-05$ & $1.634 \mathrm{E}-07$ & $5.685 \mathrm{E}-05$ & $4.847 \mathrm{E}-07$ & $3.264 \mathrm{E}-06$ & $1.256 \mathrm{E}-05$ & $0.00 \mathrm{E}+00^{1}$ & $0.00 \mathrm{E}+00^{1}$ \\
\hline TIC as $\mathrm{CO}_{3}^{-}$ & $4.736 \mathrm{E}-01$ & $1.934 \mathrm{E}-01$ & $2.256 \mathrm{E}-01$ & $4.072 \mathrm{E}-01$ & $5.283 \mathrm{E}-01$ & $1.210 \mathrm{E}-01$ & $1.709 \mathrm{E}-02$ & $1.71 \mathrm{E}-02$ \\
\hline TOC & $1.194 \mathrm{E}-01$ & $4.362 \mathrm{E}-02$ & $8.890 \mathrm{E}-02$ & $1.281 \mathrm{E}-01$ & $2.884 \mathrm{E}-01$ & $8.261 \mathrm{E}-02$ & $1.343 \mathrm{E}-02$ & $1.34 \mathrm{E}-02$ \\
\hline UTOTAL & $1.627 \mathrm{E}-06$ & $4.535 \mathrm{E}-06$ & $9.997 \mathrm{E}-05$ & $4.757 \mathrm{E}-04$ & $2.032 \mathrm{E}-05$ & $9.211 \mathrm{E}-05$ & $9.792 \mathrm{E}-06$ & $9.79 \mathrm{E}-06$ \\
\hline $\mathrm{Zr}$ & $7.704 \mathrm{E}-06$ & $7.710 \mathrm{E}-06$ & $5.008 \mathrm{E}-05$ & $7.914 \mathrm{E}-04$ & $2.200 \mathrm{E}-05$ & $1.207 \mathrm{E}-05$ & $8.918 \mathrm{E}-06$ & $8.92 \mathrm{E}-06$ \\
\hline Free $\mathrm{OH}$ & $1.483 \mathrm{E}+00$ & $1.705 \mathrm{E}+00$ & $2.746 \mathrm{E}+00$ & $1.100 \mathrm{E}+00$ & $4.410 \mathrm{E}-01$ & $5.985 \mathrm{E}-01$ & $2.271 \mathrm{E}-03$ & $2.27 \mathrm{E}-03$ \\
\hline
\end{tabular}


Table 2-4 Case 2 Interim Pretreatment System Waste Feed Batch Liquid Phase Curie Content

\begin{tabular}{|c|c|c|c|c|c|c|c|c|}
\hline Feed Batch Order & 1 & 2 & 3 & 4 & 5 & 6 & 7 & 8 \\
\hline Prestaged Location & 241-AN-105 & 241-AN-103 & 241-AW-101 & 241-AW-104 & 241-AP-106 & 241SY-101 & 241-S-109 & $241-\mathrm{S}-109 \mathrm{Eq}$ \\
\hline & \multicolumn{8}{|c|}{ Curies Per Batch } \\
\hline $106 \mathrm{Ru}$ & $1.136 \mathrm{E}-06$ & $3.574 \mathrm{E}-05$ & $2.438 \mathrm{E}-05$ & $1.738 \mathrm{E}-05$ & $1.870 \mathrm{E}-05$ & $7.69 \mathrm{E}-06$ & $2.27 \mathrm{E}-07$ & $2.27 \mathrm{E}-07$ \\
\hline $113 \mathrm{mCd}$ & $1.217 \mathrm{E}+01$ & $0.000 \mathrm{E}+00$ & $0.000 \mathrm{E}+00$ & $0.000 \mathrm{E}+00$ & $1.230 \mathrm{E}+02$ & $3.03 \mathrm{E}+01$ & $3.29 \mathrm{E}+01$ & $3.29 \mathrm{E}+01$ \\
\hline $125 \mathrm{Sb}$ & $3.790 \mathrm{E}+00$ & $3.887 \mathrm{E}+00$ & $3.739 \mathrm{E}+00$ & $4.296 \mathrm{E}+00$ & $7.820 \mathrm{E}+01$ & $6.70 \mathrm{E}+00$ & $1.08 \mathrm{E}+00$ & $1.08 \mathrm{E}+00$ \\
\hline $126 \mathrm{Sn}$ & $2.059 \mathrm{E}+00$ & $9.558 \mathrm{E}-02$ & $1.172 \mathrm{E}-01$ & $2.524 \mathrm{E}-02$ & $5.110 \mathrm{E}+00$ & $1.87 \mathrm{E}+00$ & $8.69 \mathrm{E}-02$ & $8.69 \mathrm{E}-02$ \\
\hline $129 \mathrm{I}$ & $5.837 \mathrm{E}-01$ & $1.210 \mathrm{E}+00$ & $6.670 \mathrm{E}-01$ & $8.620 \mathrm{E}-01$ & $3.300 \mathrm{E}-01$ & $1.54 \mathrm{E}-01$ & $3.97 \mathrm{E}-01$ & $3.97 \mathrm{E}-01$ \\
\hline $134 \mathrm{Cs}$ & $8.631 \mathrm{E}+00$ & $1.019 \mathrm{E}+01$ & $5.077 \mathrm{E}+01$ & $2.895 \mathrm{E}+00$ & $7.020 \mathrm{E}-01$ & $5.13 \mathrm{E}-02$ & $5.28 \mathrm{E}-02$ & $5.28 \mathrm{E}-02$ \\
\hline $137 \mathrm{Cs}$ & $1.106 \mathrm{E}+06$ & $1.635 \mathrm{E}+06$ & $1.462 \mathrm{E}+06$ & $9.280 \mathrm{E}+05$ & $7.540 \mathrm{E}+05$ & $8.26 \mathrm{E}+04$ & $3.98 \mathrm{E}+04$ & $3.98 \mathrm{E}+04$ \\
\hline $137 \mathrm{mBa}$ & $1.044 \mathrm{E}+06$ & $1.539 \mathrm{E}+06$ & $1.385 \mathrm{E}+06$ & $8.761 \mathrm{E}+05$ & $7.110 \mathrm{E}+05$ & $7.80 \mathrm{E}+04$ & $3.76 \mathrm{E}+04$ & $3.76 \mathrm{E}+04$ \\
\hline $14 \mathrm{C}$ & $1.388 \mathrm{E}+01$ & $1.499 \mathrm{E}+01$ & $1.070 \mathrm{E}+01$ & $4.838 \mathrm{E}+00$ & $4.240 \mathrm{E}+00$ & $7.57 \mathrm{E}+00$ & $1.23 \mathrm{E}+01$ & $1.23 \mathrm{E}+01$ \\
\hline $151 \mathrm{Sm}$ & $6.431 \mathrm{E}-03$ & $1.632 \mathrm{E}-01$ & $1.494 \mathrm{E}-01$ & $1.128 \mathrm{E}-01$ & $2.500 \mathrm{E}+04$ & $9.52 \mathrm{E}+03$ & $1.65 \mathrm{E}-08$ & $1.65 \mathrm{E}-08$ \\
\hline $152 \mathrm{Eu}$ & $4.384 \mathrm{E}-07$ & $1.798 \mathrm{E}-05$ & $1.625 \mathrm{E}-05$ & $2.104 \mathrm{E}-05$ & $5.740 \mathrm{E}+00$ & $2.51 \mathrm{E}+00$ & $5.97 \mathrm{E}-13$ & $5.97 \mathrm{E}-13$ \\
\hline $154 \mathrm{Eu}$ & $2.874 \mathrm{E}-05$ & $9.741 \mathrm{E}-04$ & $1.026 \mathrm{E}-03$ & $5.995 \mathrm{E}-04$ & $6.200 \mathrm{E}+02$ & $3.40 \mathrm{E}+00$ & $2.38 \mathrm{E}-11$ & $2.38 \mathrm{E}-11$ \\
\hline $155 \mathrm{Eu}$ & $1.166 \mathrm{E}-05$ & $4.778 \mathrm{E}-04$ & $4.329 \mathrm{E}-04$ & $3.355 \mathrm{E}-04$ & $1.290 \mathrm{E}+02$ & $4.70 \mathrm{E}+01$ & $1.02 \mathrm{E}-11$ & $1.02 \mathrm{E}-11$ \\
\hline $226 \mathrm{Ra}$ & $2.307 \mathrm{E}-05$ & $6.560 \mathrm{E}-06$ & $7.872 \mathrm{E}-06$ & $9.816 \mathrm{E}-06$ & $3.100 \mathrm{E}-04$ & $6.93 \mathrm{E}-05$ & $3.66 \mathrm{E}-05$ & $3.66 \mathrm{E}-05$ \\
\hline $227 \mathrm{Ac}$ & $3.826 \mathrm{E}-09$ & $8.575 \mathrm{E}-08$ & $1.022 \mathrm{E}-07$ & $2.947 \mathrm{E}-08$ & $2.680 \mathrm{E}-03$ & $1.37 \mathrm{E}-03$ & $1.73 \mathrm{E}-15$ & $1.73 \mathrm{E}-15$ \\
\hline $228 \mathrm{Ra}$ & $6.558 \mathrm{E}-03$ & $1.871 \mathrm{E}-03$ & $2.235 \mathrm{E}-03$ & $6.074 \mathrm{E}-03$ & $3.310 \mathrm{E}-01$ & $7.03 \mathrm{E}-03$ & $2.08 \mathrm{E}-03$ & $2.08 \mathrm{E}-03$ \\
\hline $229 \mathrm{Th}$ & $3.495 \mathrm{E}-07$ & $1.360 \mathrm{E}-05$ & $1.626 \mathrm{E}-05$ & $1.064 \mathrm{E}-03$ & $1.310 \mathrm{E}-02$ & $3.67 \mathrm{E}-04$ & $2.23 \mathrm{E}-06$ & $2.23 \mathrm{E}-06$ \\
\hline $231 \mathrm{~Pa}$ & $4.996 \mathrm{E}-02$ & $4.076 \mathrm{E}-02$ & $4.868 \mathrm{E}-02$ & $7.826 \mathrm{E}-03$ & $9.060 \mathrm{E}-03$ & $8.85 \mathrm{E}-03$ & $2.43 \mathrm{E}-03$ & $2.43 \mathrm{E}-03$ \\
\hline $232 \mathrm{Th}$ & $9.734 \mathrm{E}-07$ & 4.913E-05 & $2.599 \mathrm{E}-05$ & $4.426 \mathrm{E}-03$ & $9.450 \mathrm{E}-03$ & $2.43 \mathrm{E}-04$ & $7.68 \mathrm{E}-06$ & $7.68 \mathrm{E}-06$ \\
\hline $232 \mathrm{U}$ & $2.265 \mathrm{E}-05$ & $8.130 \mathrm{E}-05$ & $1.717 \mathrm{E}-03$ & $8.391 \mathrm{E}-04$ & $7.930 \mathrm{E}-03$ & $1.21 \mathrm{E}-03$ & $3.45 \mathrm{E}-05$ & $3.45 \mathrm{E}-05$ \\
\hline $233 \mathrm{U}$ & $1.393 \mathrm{E}-03$ & $5.008 \mathrm{E}-03$ & $1.054 \mathrm{E}-01$ & $1.841 \mathrm{E}-02$ & $3.360 \mathrm{E}-02$ & $4.49 \mathrm{E}-02$ & $2.20 \mathrm{E}-03$ & $2.20 \mathrm{E}-03$ \\
\hline $234 \mathrm{U}$ & $9.831 \mathrm{E}-04$ & $3.545 \mathrm{E}-03$ & $7.480 \mathrm{E}-02$ & $3.070 \mathrm{E}-01$ & $7.810 \mathrm{E}-03$ & $2.52 \mathrm{E}-02$ & $4.30 \mathrm{E}-03$ & $4.30 \mathrm{E}-03$ \\
\hline $235 \mathrm{U}$ & $3.898 \mathrm{E}-05$ & $1.398 \mathrm{E}-04$ & $2.946 \mathrm{E}-03$ & $1.171 \mathrm{E}-02$ & $3.110 \mathrm{E}-04$ & $1.05 \mathrm{E}-03$ & $1.83 \mathrm{E}-04$ & $1.83 \mathrm{E}-04$ \\
\hline $236 \mathrm{U}$ & $6.668 \mathrm{E}-05$ & $2.400 \mathrm{E}-04$ & $5.047 \mathrm{E}-03$ & $2.914 \mathrm{E}-02$ & $2.690 \mathrm{E}-04$ & $6.22 \mathrm{E}-04$ & $9.46 \mathrm{E}-05$ & $9.46 \mathrm{E}-05$ \\
\hline $237 \mathrm{~Np}$ & $3.966 \mathrm{E}-03$ & $9.505 \mathrm{E}-02$ & $6.079 \mathrm{E}-02$ & $1.413 \mathrm{E}-01$ & $1.490 \mathrm{E}+00$ & $7.21 \mathrm{E}-01$ & $5.91 \mathrm{E}-01$ & $5.91 \mathrm{E}-01$ \\
\hline $238 \mathrm{Pu}$ & $1.979 \mathrm{E}-02$ & $4.833 \mathrm{E}-03$ & $1.119 \mathrm{E}-01$ & $1.062 \mathrm{E}+00$ & $8.930 \mathrm{E}-03$ & $7.71 \mathrm{E}-03$ & $3.24 \mathrm{E}-02$ & $3.24 \mathrm{E}-02$ \\
\hline $238 \mathrm{U}$ & 7.719E-04 & $2.777 \mathrm{E}-03$ & $5.841 \mathrm{E}-02$ & $2.120 \mathrm{E}-01$ & $6.950 \mathrm{E}-03$ & $2.36 \mathrm{E}-02$ & $4.28 \mathrm{E}-03$ & $4.28 \mathrm{E}-03$ \\
\hline $239 \mathrm{Pu}$ & $2.732 \mathrm{E}-01$ & $6.659 \mathrm{E}-02$ & $1.534 \mathrm{E}+00$ & $1.062 \mathrm{E}+01$ & $3.180 \mathrm{E}-01$ & $9.87 \mathrm{E}-02$ & $1.65 \mathrm{E}+00$ & $1.65 \mathrm{E}+00$ \\
\hline $240 \mathrm{Pu}$ & $7.123 \mathrm{E}-02$ & $1.734 \mathrm{E}-02$ & $4.005 \mathrm{E}-01$ & $2.992 \mathrm{E}+00$ & $5.470 \mathrm{E}-02$ & $2.15 \mathrm{E}-02$ & $3.23 \mathrm{E}-01$ & $3.23 \mathrm{E}-01$ \\
\hline $241 \mathrm{Am}$ & $1.425 \mathrm{E}+00$ & $2.519 \mathrm{E}-01$ & $1.278 \mathrm{E}+00$ & $8.994 \mathrm{E}-01$ & $2.610 \mathrm{E}+00$ & $1.34 \mathrm{E}-01$ & $4.28 \mathrm{E}-01$ & $4.28 \mathrm{E}-01$ \\
\hline $241 \mathrm{Pu}$ & $1.247 \mathrm{E}+00$ & $3.038 \mathrm{E}-01$ & $7.043 \mathrm{E}+00$ & $7.564 \mathrm{E}+01$ & $4.160 \mathrm{E}-01$ & $1.14 \mathrm{E}-01$ & $9.10 \mathrm{E}-01$ & $9.10 \mathrm{E}-01$ \\
\hline $242 \mathrm{Cm}$ & $1.055 \mathrm{E}-02$ & $1.202 \mathrm{E}-02$ & $1.395 \mathrm{E}-02$ & $2.277 \mathrm{E}-02$ & $5.590 \mathrm{E}-03$ & $1.99 \mathrm{E}-04$ & $1.12 \mathrm{E}-02$ & $1.12 \mathrm{E}-02$ \\
\hline
\end{tabular}


Table 2-4 Case 2 Interim Pretreatment System Waste Feed Batch Liquid Phase Curie Content

\begin{tabular}{|c|c|c|c|c|c|c|c|c|}
\hline Feed Batch Order & 1 & 2 & 3 & 4 & 5 & 6 & 7 & 8 \\
\hline Prestaged Location & 241-AN-105 & $241-\mathrm{AN}-103$ & 241-AW-101 & 241-AW-104 & $241-\mathrm{AP}-106$ & 241SY-101 & 241-S-109 & 241-S-109 Eq \\
\hline \multicolumn{9}{|c|}{ Curies Per Batch } \\
\hline $242 \mathrm{Pu}$ & $7.528 \mathrm{E}-06$ & $1.826 \mathrm{E}-06$ & $4.250 \mathrm{E}-05$ & $3.744 \mathrm{E}-04$ & $3.650 \mathrm{E}-06$ & $1.08 \mathrm{E}-06$ & $1.10 \mathrm{E}-05$ & $1.10 \mathrm{E}-05$ \\
\hline $243 \mathrm{Am}$ & $9.429 \mathrm{E}-04$ & $1.655 \mathrm{E}-04$ & $8.227 \mathrm{E}-04$ & $3.530 \mathrm{E}-04$ & $9.830 \mathrm{E}-05$ & $5.13 \mathrm{E}-05$ & $2.00 \mathrm{E}-04$ & $2.00 \mathrm{E}-04$ \\
\hline $243 \mathrm{Cm}$ & 5.823E-04 & $6.644 \mathrm{E}-04$ & $3.586 \mathrm{E}-02$ & $3.525 \mathrm{E}-03$ & $1.590 \mathrm{E}-03$ & $6.99 \mathrm{E}-06$ & $3.37 \mathrm{E}-04$ & $3.37 \mathrm{E}-04$ \\
\hline $244 \mathrm{Cm}$ & $1.377 \mathrm{E}-02$ & $1.567 \mathrm{E}-02$ & $8.014 \mathrm{E}-01$ & $7.101 \mathrm{E}-02$ & $2.880 \mathrm{E}-02$ & $1.64 \mathrm{E}-04$ & $7.42 \mathrm{E}-03$ & $7.42 \mathrm{E}-03$ \\
\hline $3 \mathrm{H}$ & $4.200 \mathrm{E}+00$ & $7.270 \mathrm{E}+00$ & $2.880 \mathrm{E}+01$ & $5.860 \mathrm{E}+00$ & $6.710 \mathrm{E}+01$ & $1.34 \mathrm{E}+01$ & $3.78 \mathrm{E}+01$ & $3.78 \mathrm{E}+01$ \\
\hline $59 \mathrm{Ni}$ & $1.731 \mathrm{E}+00$ & $1.283 \mathrm{E}-01$ & $9.157 \mathrm{E}-02$ & $3.810 \mathrm{E}-02$ & $4.300 \mathrm{E}+00$ & $3.23 \mathrm{E}+00$ & $3.31 \mathrm{E}+00$ & $3.31 \mathrm{E}+00$ \\
\hline $60 \mathrm{Co}$ & $3.180 \mathrm{E}+00$ & $2.535 \mathrm{E}-02$ & $3.341 \mathrm{E}-02$ & $2.042 \mathrm{E}-02$ & $1.280 \mathrm{E}+01$ & $1.27 \mathrm{E}+00$ & $7.17 \mathrm{E}-02$ & $7.17 \mathrm{E}-02$ \\
\hline $63 \mathrm{Ni}$ & $1.620 \mathrm{E}+02$ & $1.198 \mathrm{E}+01$ & $8.553 \mathrm{E}+00$ & $3.574 \mathrm{E}+00$ & $3.950 \mathrm{E}+02$ & $2.98 \mathrm{E}+02$ & $3.00 \mathrm{E}+02$ & $3.00 \mathrm{E}+02$ \\
\hline $79 \mathrm{Se}$ & $3.180 \mathrm{E}+00$ & $2.735 \mathrm{E}+00$ & $1.111 \mathrm{E}+00$ & $5.843 \mathrm{E}+00$ & $2.770 \mathrm{E}-01$ & $6.19 \mathrm{E}-01$ & $2.79 \mathrm{E}+00$ & $2.79 \mathrm{E}+00$ \\
\hline $90 \mathrm{Sr}$ & $4.425 \mathrm{E}+03$ & $4.523 \mathrm{E}+03$ & $4.859 \mathrm{E}+03$ & $4.313 \mathrm{E}+03$ & $5.120 \mathrm{E}+03$ & $7.60 \mathrm{E}+01$ & $0.00 \mathrm{E}+00^{1}$ & $0.00 \mathrm{E}+00^{1}$ \\
\hline $90 \mathrm{Y}$ & $4.425 \mathrm{E}+03$ & $4.523 \mathrm{E}+03$ & $4.859 \mathrm{E}+03$ & $4.313 \mathrm{E}+03$ & $5.120 \mathrm{E}+03$ & $7.60 \mathrm{E}+01$ & $2.44 \mathrm{E}+02$ & $2.44 \mathrm{E}+02$ \\
\hline $93 \mathrm{mNb}$ & $1.337 \mathrm{E}+01$ & $1.326 \mathrm{E}+01$ & $1.586 \mathrm{E}+01$ & $5.621 \mathrm{E}+00$ & $2.770 \mathrm{E}+01$ & $1.78 \mathrm{E}+01$ & $6.74 \mathrm{E}+00$ & $6.74 \mathrm{E}+00$ \\
\hline $93 \mathrm{Zr}$ & $9.245 \mathrm{E}+00$ & $1.581 \mathrm{E}+01$ & $1.898 \mathrm{E}+01$ & $5.627 \mathrm{E}+00$ & $3.730 \mathrm{E}+01$ & $2.14 \mathrm{E}+01$ & $1.24 \mathrm{E}+01$ & $1.24 \mathrm{E}+01$ \\
\hline \multirow[t]{2}{*}{$99 \mathrm{Tc}$} & $9.744 \mathrm{E}+02$ & $2.247 \mathrm{E}+02$ & $6.217 \mathrm{E}+02$ & $6.603 \mathrm{E}+02$ & $3.680 \mathrm{E}+02$ & $4.05 \mathrm{E}+01$ & $3.97 \mathrm{E}+02$ & $3.97 \mathrm{E}+02$ \\
\hline & \multicolumn{8}{|c|}{ Concentration Curies per Liter } \\
\hline $137 \mathrm{Cs}$ & 0.185 & 0.212 & 0.199 & 0.165 & 0.175 & 0.026 & 0.007 & 0.007 \\
\hline $90 \mathrm{Sr}$ & 0.00074 & 0.00059 & 0.00066 & 0.00077 & 0.00119 & 0.00002 & 0.00000 & 0.00000 \\
\hline
\end{tabular}

Reference: SVF-1493 Rev. 1

1. BBI wash factors for strontium are not defined. Strontium is slightly soluble so the concentration will be greater than 0.0 . Should FC be considered for IPS application at a later date, these values will be refined.

Table 2-5 Case 1 Interim Pretreatment System Waste Feed Batch Sources

\begin{tabular}{|c|c|c|c|c|c|c|c|c|}
\hline Feed Batch Order & 1 & 2 & 3 & 4 & 5 & 6 & 7 & 8 \\
\hline Prestaging Location & $241-\mathrm{AP}-104$ & $241-\mathrm{AP}-102$ & 241-AP-101 & $241-\mathrm{AP}-103$ & $241-\mathrm{AP}-105$ & 241-AP-108 & 241-AP-107 & 241-AN-104 \\
\hline $\begin{array}{l}\text { Primary Waste } \\
\text { Sources }\end{array}$ & $\begin{array}{c}241-\mathrm{AP}-104 \\
\text { plus } 1 / 2 \\
\text { contents of } \\
241-\mathrm{AP}-105\end{array}$ & 241-AP-102 & $\begin{array}{c}241-\mathrm{AP}-101 \\
\text { plus } 1 / 2 \\
\text { contents of } \\
241-\mathrm{AP}-105\end{array}$ & 241-AP-103 & 241-AN-101 & 241-AP-108 & $\begin{array}{l}\text { AP- } 107 \text { plus } \\
1 / 3 \text { contents } \\
\text { of } \mathrm{AZ}-102\end{array}$ & 241-AN-104 \\
\hline
\end{tabular}




\subsection{REQUIREMENTS}

Interfaces with external Hanford waste systems identified for the IPS alternative technologies generally consist of:

- Waste feed from AP-104,

- Treated LAW transferred to the LAW vitrification system,

- Separated liquid waste returned to the tank farm DSTs,

- Secondary liquid waste transferred to the Effluent Treatment Facility,

- Secondary solid waste transferred to the Hanford Solid Waste Management System,

- Gaseous effluents to the atmosphere, and

- Utilities.

Figure 3-1 provides a sketch describing the interfaces with Hanford systems external to the IPS. Section 3.3 describes requirements imposed on the IPS by these external interfaces for the purpose of evaluating the technology alternatives. Quantified criteria have not been imposed on the process design for selected external interfaces where simplifying assumptions can be justified to approximate the process design. These simplifications should not be interpreted as implying the criteria for these external interfaces are unimportant, rather that the criteria were not considered likely to differentiate between the alternate technologies under consideration.

Interfaces between process elements within the IPS are also indicated on Figure 3-1. The internal interfaces consist of:

- The waste transfer between the entrained solids separation and cesium separation systems, and

- The transfer of cold chemicals into the process

Requirements for internal interfaces are currently limited to identification of lag storage hold up times between the source and receiver process system within the IPS (primarily sizing storage vessels between waste solids and cesium separation systems and storage for addition of process solutions).

\subsection{FACILITY DESIGN LIFE}

The IPS is not intended to replace the WTP Pretreatment Facility. RPP-RPT-37644, Interim Pretreatment System Mission Scoping Report indicates that the IPS will be scoped to support both an early LAW treatment and backup supplemental risk reduction capability for the purpose 


\section{Figure 3-1 Interim Pretreatment System Interfaces}




of pre-conceptual alternative evaluation and cost estimating. The scoping basis equates to a 5year operating period for the early LAW treatment mission, a 20-year backup capability mission, and a 15 year contingent operating availability. To maintain the process operating efficiency, structures supporting a rapid replacement of failed equipment (e.g., dedicated crane within a process enclosure) become more important as the operating duration is extended. Definition of support systems required to maintain the process design throughput for an operating time period between 5 and 20 years is difficult to develop at the pre-conceptual design stage. Therefore, facility layouts have focused on an estimate of the structure required to contain process equipment in this study. It is anticipated that systems supporting increased replacement frequencies, as equipment ages beyond 5-years, are similar for each technology and will be revisited as part of the conceptual design effort.

\subsection{SYSTEM CAPACITY}

The overall IPS capacity used as a basis for process design in this study produces treated LAW at a rate equivalent to $1175 \mathrm{MT} \mathrm{Na} / \mathrm{yr}$ that is transferred from the IPS to the LAW immobilization systems, consistent with RPP-RPT-37644. The sodium mass basis is independent of the original source of sodium ion in the treated LAW produced by the IPS, combining sodium originating in DSTs with cold sodium additions required to operate the IPS processes.

Process systems are assumed to be operated on a continuous basis ( 365 calendar days per year) at an overall availability of $70 \%$ (RPP-RPT-37644). The assumed availability results in an operating basis of 255 operating days per calendar year. Applying the availability results in an instantaneous design rate of 4.6 MT Na per operating day, or $192 \mathrm{~kg} \mathrm{Na} /$ Operating hr (see Equation 3.2-1). The instantaneous design rate is equivalent to producing $6.1 \mathrm{gpm}$ of LAW at a sodium concentration of $6 \mathrm{gmol} \mathrm{Na} / \mathrm{L}$.

\section{Equation 3.2-1}

$$
\begin{aligned}
\text { Instantaneous Design Rate } & =\frac{\left(1175 \frac{\mathrm{MTNa}}{\text { CalendarYear }}\right)}{\left(255 \frac{\text { OperatingDays }}{\text { Calen darYear }}\right)}=4.6 \frac{\mathrm{MT} \mathrm{Na}}{\text { Operating Day }} \\
& =0.192 \frac{\mathrm{MT} \mathrm{Na}}{\text { Operating }} \\
& =192 \frac{\mathrm{kg} \mathrm{Na}}{\text { Operatinghr }}
\end{aligned}
$$

The instantaneous design rate describes the quantity of sodium ion in treated LAW that must be produced by the alternative cesium separation technologies when operating on a continuous basis. 


\subsection{EXTERNAL INTERFACES}

The following sections describe external interfaces with the IPS.

\subsubsection{Waste Feed from AP-104}

For the purpose of technology comparisons, the waste composition of eight feed batches listed in Section 2.0 are assumed to be provided via AP-102 and AP-104 to the IPS without mixing or blending of heels. Double-shell tank AP-104 provides the primary lag storage capacity between the remaining DSTs and the IPS. Any composition modifications during waste transfers between the originating tank and AP-104 are assumed to be incorporated in the composition listed in Section 2.0. In addition, waste transfers between DSTs are assumed to be performed in a timely manner such that feed is available in AP-104 to support the IPS, independent of the separation technologies selected.

\subsubsection{Low-Activity Waste Requirements}

Treated LAW produced by the IPS will be immobilized in glass by either the WTP Vitrification Facility or some future LAW immobilization facility. Chemical, physical, and radionuclide criteria imposed on the LAW by the design bases for LAW vitrification facilities are described below based on existing WTP Vitrification Facility requirements.

3.3.2.1 Chemical Composition and Solution Physical Characteristics. Table 3-1 provides a summary of chemical analyte compositions, referenced to the molar quantity of sodium ion, used as a requirements basis for this comparison study. Chemical composition criteria for the WTP LAW Vitrification Facility are based on 155889, "Early LAW Waste Receipt Criteria Revision." A future supplemental LAW immobilization system is assumed to be designed to accommodate waste chemical concentrations similar to the WTP LAW Vitrification Facility.

Table 3 of 155889 indicates that the sodium ion concentration of LAW transferred to the WTP will be limited to a concentration range of 5 to $6 \mathrm{gmol} \mathrm{Na} / \mathrm{L}$. However, the WTP LAW facility is designed to receive waste at higher sodium concentrations. While the waste feed must be adjusted to a sodium ion concentration of $6 \mathrm{gmol} \mathrm{Na} / \mathrm{L}$ for the ion exchange and solvent extraction technologies, the fractional crystallization technology can produce a more concentrated product without additional process steps. Therefore, this study selected an LAW composition of $9 \mathrm{gmol} \mathrm{Na} / \mathrm{L}$ as a more likely description of implementing fractional crystallization in an IPS. Additional physical property limits are identified in Table 3 of 155889 as criteria for transfer of LAW to the WTP LAW Vitrification facility. These requirements are summarized in Table 3-2. 
Table 3-1 Design Basis Chemical Compositions for Alternative Vitrification Systems

\begin{tabular}{|c|c|c|}
\hline \multirow[t]{2}{*}{$\begin{array}{l}\text { Chemical } \\
\text { Analyte }\end{array}$} & \multicolumn{2}{|c|}{$\begin{array}{c}\text { Maximum Chemical Concentration in Treated LAW to WTP Vitrification Facility for Early LAW } \\
\text { Alternatives, gmol analyte/gmol sodium }\end{array}$} \\
\hline & $\begin{array}{ll}\text { Envelope A } \\
\end{array}$ & Envelope B \\
\hline $\mathrm{Al}$ & $2.5 \mathrm{E}-01$ & $2.5 \mathrm{E}-01$ \\
\hline $\mathrm{Ba}$ & $1.0 \mathrm{E}-04$ & $1.0 \mathrm{E}-04$ \\
\hline $\mathrm{Ca}$ & $4.0 \mathrm{E}-02$ & $4.0 \mathrm{E}-02$ \\
\hline $\mathrm{Cd}$ & $4.0 \mathrm{E}-03$ & $4.0 \mathrm{E}-03$ \\
\hline $\mathrm{Cl}$ & $3.7 \mathrm{E}-02$ & $8.9 \mathrm{E}-02$ \\
\hline $\mathrm{Cr}$ & $6.9 \mathrm{E}-03$ & $2.0 \mathrm{E}-02$ \\
\hline $\mathrm{F}$ & $9.1 \mathrm{E}-02$ & $2.0 \mathrm{E}-01$ \\
\hline $\mathrm{Fe}$ & $1.0 \mathrm{E}-02$ & $1.0 \mathrm{E}-02$ \\
\hline $\mathrm{Hg}$ & $1.4 \mathrm{E}-05$ & $1.4 \mathrm{E}-05$ \\
\hline $\mathrm{K}$ & $1.8 \mathrm{E}-01$ & $1.8 \mathrm{E}-01$ \\
\hline $\mathrm{La}$ & $8.3 \mathrm{E}-05$ & $8.3 \mathrm{E}-05$ \\
\hline $\mathrm{Mn}$ & \multicolumn{2}{|c|}{ Not specified in source } \\
\hline $\mathrm{Ni}$ & $3.0 \mathrm{E}-03$ & $3.0 \mathrm{E}-03$ \\
\hline $\mathrm{NO}_{2}$ & $3.8 \mathrm{E}-01$ & $3.8 \mathrm{E}-01$ \\
\hline $\mathrm{NO}_{3}$ & $8.0 \mathrm{E}-01$ & $8.0 \mathrm{E}-01$ \\
\hline $\mathrm{Pb}$ & $6.8 \mathrm{E}-04$ & $6.8 \mathrm{E}-04$ \\
\hline $\mathrm{PO}_{4}$ & $3.8 \mathrm{E}-04$ & $1.3 \mathrm{E}-01$ \\
\hline $\mathrm{SO}_{4}$ & $1.0 \mathrm{E}-02$ & $7.0 \mathrm{E}-02$ \\
\hline $\mathrm{Si}$ & \multicolumn{2}{|c|}{ Not specified in source } \\
\hline $\mathrm{Sr}$ & \multicolumn{2}{|c|}{ Not specified in source } \\
\hline $\mathrm{TIC}^{1}$ & $3.0 \mathrm{E}-01$ & $3.0 \mathrm{E}-01$ \\
\hline $\mathrm{TOC}^{2,3}$ & $5.0 \mathrm{E}-01$ & $5.0 \mathrm{E}-01$ \\
\hline $\mathrm{U}$ & $1.2 \mathrm{E}-03$ & $1.2 \mathrm{E}-03$ \\
\hline
\end{tabular}

Notes:

1. Mole of inorganic carbon atoms / mole of sodium

2. Mole of organic carbon atoms / mole of sodium

3. The LAW feed shall not contain a visible separate organic phase

4. From Memorandum 155889, "Early LAW Waste Receipt Criteria Revision", Table 1

Table 3-2 Process and Physical Limits on Treated LAW

\begin{tabular}{|l|c|}
\hline Characteristic $^{(\mathbf{1})}$ & Limit $^{(\mathbf{( 1 )}}$ \\
\hline Sodium Ion Concentration & Fluid Properties \\
\hline Maximum Fluid Temperature & $6 \mathrm{gmol} \mathrm{Na} / \mathrm{L}^{(\mathbf{2})}$ \\
\hline Maximum Specific Gravity of Slurries & $140^{\circ} \mathrm{F}$ \\
\hline Maximum Viscosity & 1.46 \\
\hline Maximum Solid Particle Size & $15 \mathrm{cP}$ \\
\hline Specific Gravity of Solids & $31.1 \mathrm{microns}$ \\
\hline Maximum Solids Loading & 2.5 \\
\hline \multicolumn{2}{|c|}{ Design Requirements } \\
\hline Pump Discharge Pressure & $3.8 \mathrm{wt} \%$ \\
\hline Design Flow Rate & $150 \mathrm{psig}$ \\
\hline Fill Cycle Time for Alternate Receiver Vessels & $88 \mathrm{gpm}$ \\
\hline Transfer Batch Size, including line flush & $32 \mathrm{hr}$ \\
\hline
\end{tabular}

Notes:

1. From 155889 , "Early LAW Waste Receipt Criteria Revision", Table 3

2. Reference identifies a range of 5 to $6 \mathrm{gmol} \mathrm{Na} / \mathrm{L}$, but notes that the WTP LAW facility is designed to receive waste at higher sodium concentrations. 
3.3.2.2 Radionuclide Composition. Table 3-3 provides a summary of radionuclides, referenced to the molar quantity of sodium ion, used as a requirements basis for this comparison study. Radionuclide criteria for the WTP LAW Vitrification Facility are based on 155889. Radionuclide criteria for a future supplemental LAW immobilization system are assumed to be similar to the WTP LAW Vitrification Facility criteria, with the exception that higher isotope concentrations contributing to package dose could be accepted if a bulk vitrification supplemental system were implemented due to the inherent shielding in the waste package.

Table 3-3 Radionuclide Concentration Limits for Treated Low Activity Waste from the Interim Pretreatment System

\begin{tabular}{|c|c|}
\hline Radionuclide & $\begin{array}{c}\text { Maximum Radionuclide Concentration in Treated LAW to WTP Vitrification Facility for } \\
\text { Early LAW Alternatives, Ci/gmol Na } \mathbf{~}^{\mathbf{1}}\end{array}$ \\
\hline${ }^{137} \mathrm{Cs}$ & $1.68 \mathrm{E}-05$ \\
\hline${ }^{154} \mathrm{Eu}$ & $1.62 \mathrm{E}-05$ \\
\hline${ }^{60} \mathrm{Co}$ & $1.65 \mathrm{E}-06$ \\
\hline${ }^{90} \mathrm{Sr}$ & $1.12 \mathrm{E}-03$ \\
\hline${ }^{99} \mathrm{Tc}$ & $1.68 \mathrm{E}-04$ \\
\hline${ }^{129} \mathrm{I}$ & Not specified in source \\
\hline${ }^{233} \mathrm{U}$ & $1.30 \mathrm{E}-08$ \\
\hline${ }^{235} \mathrm{U}$ & $6.00 \mathrm{E}-11$ \\
\hline${ }^{239} \mathrm{Pu}$ & $6.10 \mathrm{E}-07$ \\
\hline $\mathrm{TRU}^{2}$ & $1.30 \mathrm{E}-05$ \\
\hline
\end{tabular}

Notes

1. From 155889, "Early LAW Waste Receipt Criteria Revision", Table 2

2. Transuranic (TRU) is defined as: Alpha-emitting radionuclides with an atomic number greater than 92 with half-life greater than 20 years in HNF-EP-0063, Hanford Site Solid Waste Acceptance Criteria, which has been adopted for this study

3.3.2.3 Lag Storage. Lag storage for LAW is based on a vessel maximum fill at $80 \%$ of tank capacity. The interface of LAW from the IPS to the vitrification facility is common to all alternatives. Waste characterization sampling and analyses to support glass formulation activities is assumed to be completed in the DST used for waste staging (AP-102). These sample results are expected to be available to confirm the chemical and radionuclide composition of LAW will comply with vitrification facility acceptance criteria if the IPS is operated properly. Since the IPS functions are limited to separation of solids and cesium, the focus of sampling at this interface is assumed limited to confirmation that LAW complies with the TRU, 90Sr, and $137 \mathrm{Cs}$ criteria (requires sodium ion analysis to compare results to criteria). Four days of lag storage has been allowed to support sampling and analysis.

General lag storage requirements at this interface are summarized as follows:

- 2 vessels in parallel

- Each vessel sized to contain 4 days at the design basis instantaneous throughput 


\subsubsection{Criteria for Waste Returned to Tank Farms}

3.3.3.1 Waste Transfer Criteria. HNF-SD-WM-OCD-015, Tank Farms Waste Transfer Compatibility Program, was reviewed to identify requirements associated with the return of waste from the IPS to tank farms. The review is summarized in Table 3-4. A number of compatibility requirements were considered beyond the scope of this comparison study or would not be expected to differentiate between the IPS alternatives under consideration. Requirements identified from the compatibility program review, including both process design criteria and comparison study methods of addressing requirements are summarized below.

- Waste composition adjustments must be performed to waste streams returned to tank farms that exceed unit liter dose (ULD) and toxilogical unit sum-of-fractions (USOF) identified in HNF-IP-1266, Section 5.9

- Waste returned to tank farms at phosphate ion concentrations that exceed $0.1 \mathrm{M}$ will be identified as a risk that requires further evaluation

- Waste transfers shall not exceed 25 vol\% solids

- Composition adjustments shall be made to waste returned to tank farms to comply with composition limits listed in Table 3-5.

- Equipment will be included to minimize the potential for observing separable organics in waste returned to tank farms

- The maximum Pu equivalents in waste transfer to tank farms for comparison with the maximum $\mathrm{Pu}$ equivalent concentration listed in Table 3-5 of HNF-SD-WM-OCD-015

- Use of chemicals that are new to the Hanford tanks waste constituents shall be identified as a risk that requires further evaluation

- Wastes returned to tank farms containing a settled solids loading $>5 \%$ by volume and specific gravity $>1.35$, or aluminum ion concentration $>0.5 \mathrm{M}$ shall be identified as a risk to transfer line plugging that requires further evaluation 
Table 3-4 Evaluation of Waste Transfer Compatibility Program for Comparison Study Requirements

\begin{tabular}{|c|c|}
\hline Compatibility Program Section & Evaluation $^{(1)}$ \\
\hline 1.0 Introduction/Scope & $\begin{array}{l}\text { Interpreted as indicating decision rules apply to all waste } \\
\text { streams returned to tank farms from the IPS since additions are } \\
\text { not included in current Exemption List }\end{array}$ \\
\hline 2.0 Requirements & $\begin{array}{l}\text { Interpreted that documentation requirements, data } \\
\text { requirements, and assessment requirements would be common } \\
\text { to all alternatives. Not considered by this comparison study. }\end{array}$ \\
\hline \multicolumn{2}{|l|}{ 3.0 Decision Rules } \\
\hline \multicolumn{2}{|l|}{ 3.1 Tank Farm Administrative Controls } \\
\hline \multicolumn{2}{|l|}{ 3.1.1 Source Term Controls } \\
\hline 3.1.1.1 Evaluation of Waste Transfer & $\begin{array}{l}\text { Waste transfers returned to tank farms must comply with Unit } \\
\text { Liter Dose (ULD) and Toxilogical Unit Sum-of-Fraction } \\
\text { (USOF) in HNF-IP-1266, Section 5.9. }\end{array}$ \\
\hline 3.1.1.2 WASTE (L) Criteria & Defer comparison to WASTE (L) criteria to later studies. \\
\hline \multicolumn{2}{|l|}{ 3.1.2 Flammable Gas Controls } \\
\hline 3.1 .2 .1 to 3.1 .2 .7 & $\begin{array}{l}\text { Not evaluated as part of comparison studies since managing } \\
\text { waste within the tank farm system is outside this study scope. }\end{array}$ \\
\hline 3.1.2.8 Waste Gel Prevention & $\begin{array}{l}\text { Limit consideration to identifying if waste }\left[\mathrm{PO}_{4}{ }^{-}\right] \text {exceeds } \\
0.1 \mathrm{M} \text { and further evaluation is required. }\end{array}$ \\
\hline \multicolumn{2}{|l|}{ 3.1.3 Transfer Controls } \\
\hline 3.1.3.1 Insoluble Solids Content & Limit waste transfers to $\leq 25 \mathrm{vol} \%$ solids \\
\hline 3.1.3.2 Tank Bump Controls & $\begin{array}{l}\text { Not evaluated as part of comparison studies since managing } \\
\text { waste within the tank farm system is outside this study scope. }\end{array}$ \\
\hline 3.1.4 Corrosion Mitigation Controls & $\begin{array}{l}\text { Composition adjustments are required to control DST Waste } \\
\text { Chemistry }\end{array}$ \\
\hline 3.2 242-A Administrative Control Decision Rules & $\begin{array}{l}\text { Waste transfer returned to tank farms shall contain no } \\
\text { separable organics to allow the option of processing waste in } \\
\text { the } 242 \text {-A Evaporator }(3.2 .3)\end{array}$ \\
\hline \multicolumn{2}{|l|}{ 3.3 Safety Decision Rules } \\
\hline 3.3.1 Criticality Safety Control & $\begin{array}{l}\text { Limit to identification of Pu equivalents in each waste transfer } \\
\text { stream. Further evaluation is outside the alternatives } \\
\text { comparison study scope }\end{array}$ \\
\hline 3.4 Regulatory Decision Rules & $\begin{array}{l}\text { Limit to identification of chemicals that are new to the } \\
\text { Hanford tank waste constituents }\end{array}$ \\
\hline 3.5 Programmatic Decision Rules & $\begin{array}{l}\text { Not evaluated as part of comparison studies since managing } \\
\text { waste within the tank farm system is outside this study scope. }\end{array}$ \\
\hline 3.6 Operating Decision Rules & $\begin{array}{l}\text { Identify if waste requires additional evaluation to investigate } \\
\text { the potential for transfer line plugging }\end{array}$ \\
\hline
\end{tabular}


RPP-RPT-37551, Rev. 1

Table 3-5 Double-Shell Tanks Waste Chemistry Limits

\begin{tabular}{|c|c|c|c|c|}
\hline \multirow[b]{2}{*}{$\mathrm{FOR}_{\text {[NO }}$ ] RANGE } & \multirow[b]{2}{*}{ VARIABLE } & \multicolumn{3}{|c|}{ FOR WASTE TEMPERATURE (T) RANGE } \\
\hline & & $T<167^{\circ} \mathrm{F}$ & $167^{\circ} \mathrm{F} \leq \mathrm{T} \leq 212^{\circ} \mathrm{F}$ & $\mathrm{T}>212 \circ \mathrm{F}$ \\
\hline \multirow{3}{*}{$\left\lfloor\mathrm{NU}_{3}{ }^{-}\right\rfloor \leq 1.0 \mathrm{M}$} & [OIJ] & $0.010 \mathrm{M} \leq[0 \mathrm{H}] \leq 8.0 \mathrm{M}$ & $0.010 \mathrm{M} \leq[0 \mathrm{H}]=5.0 \mathrm{M}$ & $0.010 \mathrm{M} \leq[\mathrm{OH}]<4.0 \mathrm{M}$ \\
\hline & $\left\lfloor\mathrm{NU}_{2}\right\rfloor$ & $0.011 \mathrm{M} \leq\left[\mathrm{NO}_{2}\right] \leq 5.5 \mathrm{M}$ & $0.011 \mathrm{M} \leq\left[\mathrm{NO}_{2}\right] \leq 5.5 \mathrm{M}$ & $0.011 \mathrm{M} \leq\left[\mathrm{NO}_{2}\right] \leq 5.5 \mathrm{M}$ \\
\hline & {$\left[\mathrm{NO}_{3}\right] /\left([\mathrm{OH}]+\left[\mathrm{NO}_{2}\right]\right)$} & $<2.5$ & $<2.5$ & $<2.5$ \\
\hline \multirow{2}{*}{$1.0 \mathrm{M}<\left\lceil\mathrm{NO}_{3}\right] \leq 3.0 \mathrm{M}$} & {$[\mathrm{OH}]$} & $0.1\left(\left[\mathrm{NO}_{3}\right]\right) \leq\left[\mathrm{OH}^{-}\right]<10 \mathrm{M}$ & $0.1\left(\left[\mathrm{NO}_{3}\right]\right) \leq[\mathrm{OH}]<10 \mathrm{M}$ & $0.1\left(\left[\mathrm{NO}_{3}{ }^{\circ}\right]\right) \leq[\mathrm{OII}]<4.0 \mathrm{M}$ \\
\hline & {$\left[\mathrm{OH}^{*}\right],\left[\mathrm{NO}_{2}\right]$} & $\geq 0.4\left(\left[\mathrm{NO}_{3}{ }^{\circ}\right]\right)$ & $\geq 0.4\left(\left[\mathrm{NO}_{-}^{-}\right]\right)$ & $\geq 0.4\left(\left[\mathrm{NU}_{3}\right]\right)$ \\
\hline \multirow{3}{*}[\mathrm{NO}_{3}]{$>3.0 \mathrm{M}$} & [OIJ] & $0.3 \mathrm{M} \leq[\mathrm{OH}]<10 \mathrm{M}$ & $0.3 \mathrm{M} \leq[\mathrm{OH} ;<10 \mathrm{M}$ & $0.3 \mathrm{M} \leq\left[\mathrm{OH}^{\prime}\right]<4.0 \mathrm{M}$ \\
\hline & {$\left[\mathrm{OH}^{-}\right]+\left[\mathrm{NO}_{2}\right]$} & $\geq 1.2 \mathrm{M}$ & $\geq 1.2 \mathrm{MI}$ & $\geq 1.2 \mathrm{M}$ \\
\hline & {$\left[\mathrm{NO}_{3}{ }^{-}\right]$} & $\leq 5.5 \mathrm{M}$ & $\leq 5.5 \mathrm{M}$ & $\leq 5.5 \mathrm{M}$ \\
\hline
\end{tabular}

Source: HNF-SD-WM-OCD-015, Tank F arms Waste Transfer Compatibility Program, Table 3-2. 
3.3.3.2 Lag Storage Requirements. Lag storage requirements for solutions containing separated Cs returned to tank farms vary with the cesium separation alternative under consideration. All alternatives assume no constraint on timing for use of the transfer route to the destination DST. The lag storage requirements used as a basis for this study are summarized below.

Cs Ion Exchange:

- One vessel (supports chemical adjustment, periodic inputs from process every 64 to 135 hrs, assume no sample results delay - 1 vessel considered justified since periodic additions provide window for sampling, if required)

- Sample analyses assumed limited to confirmation of hydroxide ion, nitrite ion, and nitrate ion concentration after neutralization, plus ${ }^{137} \mathrm{Cs}$ content.

- It is assumed that sample turn around times will be designed to support return of results in approximately $60 \mathrm{hr}$; otherwise a second lag storage vessel would be required.

- Sized to contain input from two elution/rinse cycles, plus additions to comply with tank farm corrosion criteria

Fractional Crystallization:

- One vessel (functions as pump tank only since waste originated in DST, only concentrated waste with no additions)

- Sized to contain one day of input from worst case throughput at the design basis instantaneous throughput

Solvent Extraction

- Two vessels to receive continuous stream (two vessels considered justified since solutions returned to DSTs are generated continuously by the process, one vessel for composition adjustment, and one vessel for transfer)

- Sample analyses assumed limited to confirmation of hydroxide ion, nitrite ion, and nitrate ion concentration after neutralization, plus ${ }^{137} \mathrm{Cs}$ content. Also requires confirmation of no separable organic.

- It is assumed that sample turn around times will be designed to support return of results in approximately $24 \mathrm{hr}$; otherwise the capacity of lag storage vessels would be increased.

- Sized to contain 1.5 days of input from worst case throughput at the design basis instantaneous throughput

\subsubsection{Secondary Liquid Waste Criteria}

Secondary liquid waste is assumed transferred to the 200 Area Liquid Effluent Retention Facility/Effluent Treatment Facility. Wastewater acceptance criteria are described in HNF-3172, Liquid Waste Processing Facilities Waste Acceptance Criteria for the Hanford site. Process definition in this study focused on identifying process equipment requirements that support compliance with radionuclide acceptance criteria. 


\subsubsection{Secondary Solid Waste Criteria}

Solid waste acceptance criteria are described in HNF-EP-0063, Hanford Site Solid Waste Acceptance Criteria for the Hanford site. Process definition in this study focused on addressing the requirement that solid waste packages are limited to a maximum of one volume percent free liquid.

\subsubsection{Gaseous Emissions}

A detailed evaluation of gaseous emissions has not been addressed by this study. No chemical reactions are required as part of the process basis for solids separation of cesium separation processes. Therefore, it was assumed that gaseous emission treatment can be generally approximated by filtration. All vessels containing radioactive solutions are assumed to be ventilated by a process ventilation system to control the potential evolution of hydrogen gas from radiolysis. The solvent extraction cesium separation technology represents an exception to this generality and an organic adsorption unit operation is assumed to be required as part of the solvent extraction process off-gas treatment system.

\subsubsection{Utilities}

Definition of utility interfaces was limited in this study to estimates of process demands for electricity, steam, water, and process air.

\subsection{INTERNAL INTERFACES}

\subsubsection{Solids Separation/Cesium Separation Interface}

Lag storage between the solids separation and cesium separation system is included as a buffer to maintain throughput during short term outages which may occur in either system. Lag storage at this interface uses a common basis for cesium separation system and is based on containing one day of feed to at the maximum instantaneous flow rate determined for the alternative feed compositions. 


\subsubsection{Cold chemical additions}

The bases for lag storage requirements within the IPS are specific to the cesium separation technology under consideration and are described in the tank sizing calculation basis.

\subsection{COMPUTER MODELS}

Mass balance models were developed using Excel ${ }^{\text {TM }}$ 2003. Supporting calculations were generated using either Excel ${ }^{\mathrm{TM}} 2003$ or MathCad ${ }^{\mathrm{TM}} 13$.

\subsection{SOLIDS SEPARATION TECHNOLOGY ALTERNATIVES}

\subsection{ROTARY MICROFILTRATION}

Rotary microfiltration consists of a filter disk assembly rotating within a pressurized housing. Differential pressure drives filtrate through the filter membrane on the disk. Filtrate travels to the central shaft to be removed and concentrate leaves the housing to be returned to the feed tank. The rotation of the filter disks creates a shear force at the membrane surface which minimizes filter fouling mechanisms.

\subsubsection{Literature Survey}

The SRNL received funding from DOE, Office of Cleanup Technologies, to develop the rotary microfilter for high-level radioactive service. The work focused on evaluating alternative rotary microfilter vendors, redesigning the equipment for radioactive service, engineering studies to evaluate the risks, determining downstream impacts, assessing costs and benefits of deploying this technology, performing actual waste and pilot-scale testing of the technology, and evaluating alternative filter media. This work has culminated in the decision to design, fabricate and perform testing on a full-scale rotary microfilter for potential SRS tank farm applications (WSRC-STI-2008-00050).

Initial testing began in 2001 with bench-scale testing of an off-the-shelf, single-disk, rotary microfilter, which led to additional pilot-scale testing in the following years. Both actual waste and simulant testing was performed as well as materials irradiation testing and evaluations. This testing showed good performance with generally higher flux rates than cross flow filtration. 
Bench-scale testing demonstrated flux rates of 2 to 10 times that of crossflow filtration and pilotscale testing demonstrated flux rates of 1.5 to 2.8 times. A detailed summary of the testing up to 2005 is given in WSRC-MS-2004-00646, Development of a Rotary Microfilter for Savannah River Site High-Level Waste Applications.

Table 5-1 Rotary Microfilter Literature Survey Summary

\begin{tabular}{|c|c|}
\hline Document Number & Title \\
\hline DE-FC21-94MC31388-30 & EM Task9-Centrifugal Membrane Filtration \\
\hline DOE/ORP-2007-01 & $\begin{array}{l}\text { Technology Readiness Assessment for the Supplemental Treatment } \\
\text { Program }\end{array}$ \\
\hline WSRC-TR-2001-00214 & $\begin{array}{l}\text { Filtration Systems, Inc., Report for WSRC SpinTek Rotary Microfilter } \\
\text { Testing }\end{array}$ \\
\hline WSRC-TR-2003-00030 & $\begin{array}{l}\text { Testing of the SpinTek Rotary Microfilter Using } \\
\text { Actual Waste }\end{array}$ \\
\hline WSRC-TR-2003-00071 & $\begin{array}{l}\text { Pilot-Scale Testing of a SpinTek Rotary Microfilter with SRS Simulated } \\
\text { High Level Waste }\end{array}$ \\
\hline WSRC-RP-2003-00605 & $\begin{array}{l}\text { Recommendations for Additional Design Development of Components } \\
\text { for the SpinTek Rotary Microfilter Prior to Radioactive Service }\end{array}$ \\
\hline WSRC-TR-2004-00047 & $\begin{array}{l}\text { Pilot-Scale Testing of a Rotary Microfilter with Irradiated Filter Disks } \\
\text { and Simulated SRS Waste }\end{array}$ \\
\hline WSRC-MS-2004-00194 & $\begin{array}{l}\text { Pilot-Scale Testing of a Rotary Microfilter with Irradiated Filter Disks } \\
\text { and Simulated SRS Waste }\end{array}$ \\
\hline WSRC-TR-2004-00213 & $\begin{array}{l}\text { Pilot-Scale Testing of a SpinTek Rotary Microfilter with Welded Disks } \\
\text { and Simulated Savannah River Site High Level Waste }\end{array}$ \\
\hline WSRC-RP-2004-00234 & $\begin{array}{l}\text { Impact of a Rotary Microfilter on the Savannah River Site High Level } \\
\text { Waste System }\end{array}$ \\
\hline WSRC-MS-2004-00646 & $\begin{array}{l}\text { Development of a Rotary Microfilter for Savannah River Site High- } \\
\text { Level Waste Applications }\end{array}$ \\
\hline WSRC-TR-2005-00205 & Rotary Microfilter Media Evaluation \\
\hline WSRC-STI-2006-00073 & $\begin{array}{l}\text { Testing and Evaluation of the Modified Design of the } 25 \text { Disk Rotary } \\
\text { Microfilter }\end{array}$ \\
\hline WSRC-STI-2008-00050 & Development of a Rotary Microfilter for Radioactive Waste Applications \\
\hline WSRC-STI-2008-DRAFT & Testing of a Rotary Microfilter to Support Hanford Applications \\
\hline
\end{tabular}

The success of this development testing encouraged progression of the design. SRS has developed and tested a full scale radiation hardened SpinTek rotary microfilter unit (WSRC-STI2006-00073) and has designed a system to be deployed in the SRS underground storage tank. Testing of the unit demonstrated continued ability to meet filtrate quality objectives and suggested further design improvements. Flux rates of 0.12 to $0.29 \mathrm{gpm} / \mathrm{ft}^{2}$ were observed at a variety of solids concentrations. This performance is up to $6.5 \mathrm{X}$ that of comparable test data from crossflow filtration (WSRC-TR-2003-00071, Pilot-Scale Testing of a SpinTek Rotary Microfilter with SRS Simulated High Level Waste and WSRC-STI-2006-00073, Testing and Evaluation of the Modified Design of the 25 Disk Rotary Microfilter). Capability to dewater solids up to $20 \mathrm{wt} \%$ has also been demonstrated with no operational problems (WSRC-STI2006-00073).

The full-scale SpinTek unit used for testing by SRS has been tested using a Hanford waste simulant (AN-105), but final test results are not available at the time of this report. Follow-on 
testing is planned at the bench-scale using actual waste to validate the simulant used in the fullscale testing.

The SRS design modifies the standard SpinTek ST-II, 25-disk model for use in a radiation environment. Modifications include use of more radiation tolerant materials; use of a modular design that contains the filter stack, all seals and rotary unions within a removable unit; and seal and bushing modifications to mitigate areas of high wear experienced during testing.

\subsubsection{Process Description}

The proposed rotary microfilter process uses multiple $0.1-\mu \mathrm{m}$ sintered metal welded disks. The disks are hollow with the submicron membrane on each disk surface. The disks are spaced along a hollow central shaft that spins inside a pressurized housing and the differential pressure between the housing and the inside of the disks drives filtrate across the membrane. An external motor rotates the central shaft and disk assembly. The speed of the disk rotation can be adjusted to increase the shear forces at the surface of the disks. The shear force disrupts particulate deposition mechanisms and aids in minimizing the thickness of the particulate layer that builds up on the membrane, thus enhancing the filtrate flux rate. The efficiency of this fluid shear, or "sweeping action" increases with the velocity of the fluid. Stationary spoke turbulence promoters are positioned above and below each disk, which also increases the shear rate at the surface of the membrane by minimizing the boundary layer.

The rotary microfilter unit uses sintered metal disks available in $0.1-\mu \mathrm{m}$ or larger pore sizes. The pore size of $0.1-\mu \mathrm{m}$ is chosen because it has demonstrated higher flux rates than the $0.5-\mu \mathrm{m}$ filter in crossflow filter testing. This is likely due to the smaller particle sizes in Hanford waste and simulant, which tend to more readily clog the pores of the $0.5-\mu \mathrm{m}$ filter.

The feed slurry is pumped into the filter housing and flows across the external surface of the rotating filter disks. A transmembrane pressure gradient drives the supernate through the filter membrane and into the center of the hollow disks. A valve on the concentrate exit automatically controls the pressure inside the filter housing. This pressure provides the transmembrane pressure required to force filtrate through the filter membranes. The filtrate moves to the center of the disk and collects in the shaft holding the disks. The filtrate is discharged from the central shaft to the cesium removal process. Concentrated feed slurry exits the filter housing to be returned to the DST.

The rotary microfilter unit with feed pumps is housed in a module that is inserted through an existing riser on an existing DST (Figure 5-1). The feed solution contained within the DST is transferred through the rotary microfilter unit. The clarified supernatant is transferred to the cesium separation process while the solid concentrate is discharged back into the DST. Periodic cleaning of the rotary microfilter elements should be conducted with water, sodium hydroxide and/or nitric acid to minimize solids accumulation and fouling of filter membrane. Because the cleaning requirement is unknown without further evaluation, this study conservatively assumes that a $2.0 \mathrm{M}$ nitric acid cleaning is required. 
Figure 5-1 Conceptual Drawing of Rotary Microfilter Module for In-tank Riser

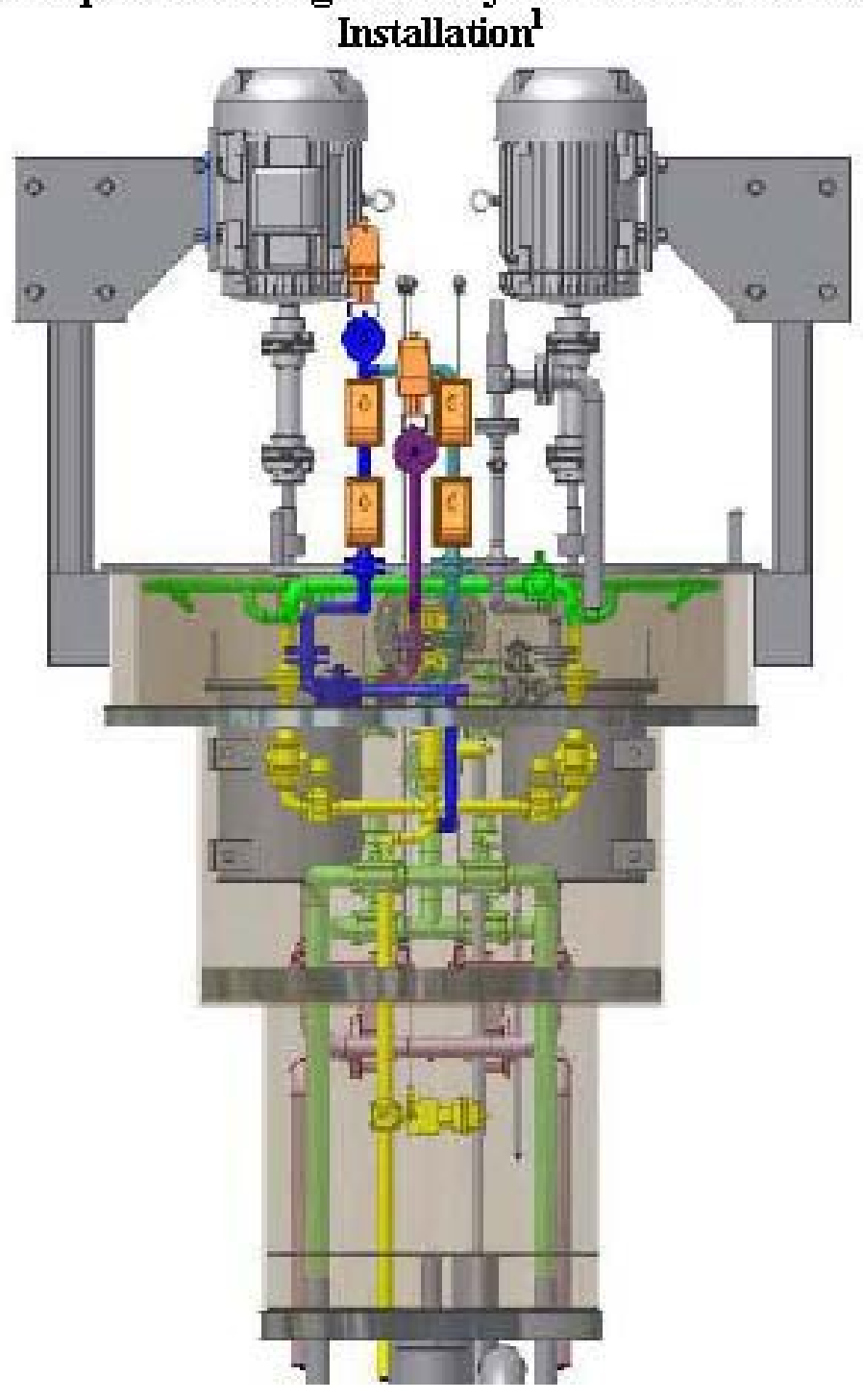

Two risers are available on the feed DST, Tank AP-104, for installation of the rotary microfilter modules. Two 25-disk units are contained in each module for a maximum total of four units that can be installed in DST risers, with the filter modules operated in parallel (Figure 5-2). The fractional crystallization altemative for osium separation, however, requires up to 12 units because the waste feed rate is much higher than that of the other two cesium separation altematives. Therefore, the rotary microfiltration option, if selected with the fractional crystallization alternative, would need to be housed in a separate structure, collocated with the cesium extraction process.

\footnotetext{
' Excerpt from WSRC-STI-2008-00050.
} 


\section{Figure 5-2 Modular Design of 25-Disk Rotary Microfilter Unit ${ }^{2}$}

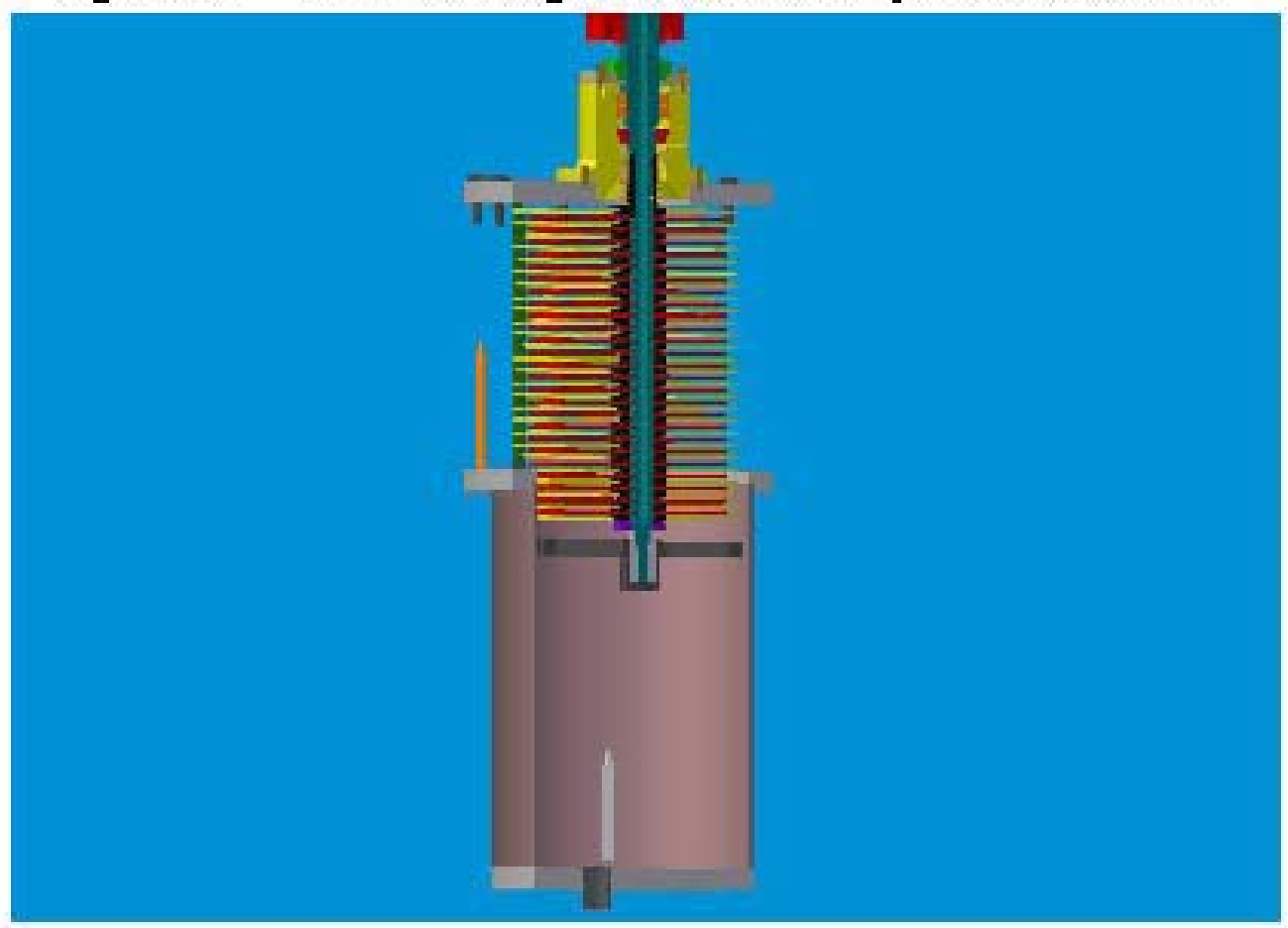

No test data is available to date that provides a sound basis for rotary microfilter flux rates with the IPS feed stream Rotary microfilter flux is, therefore, based on the most applicable existing documented test data for radicactive waste applications. The typical methodology, when evaluating these data, is to compare the results to crossflow filter test data with similar, but not identical, test parameters to derive a flux rate multiplier. This flux rate multiplier methodology is also used in this report. When tests results that are more relevant to the IPS feed stream become available, the flux rate estimate shoul d be revisited.

The baseline flux rate multiplier is assumed to be $4 \mathrm{X}$ the crossflow filter flux rate used in this study. This flux rate multiplier is supported by test data from SRS testing (refer to Section 5.1.9 for a discussion of the risk associated with this flux rate estimate). Filter fluxes for the rotary microfilter showed no significant decline at higher solids concentrations(WSRC-MS-200400646). Dewatering of the slurry to up to $20 \mathrm{w} \%$ solids has been achieved in testing with no operational problems with the filter unit (WSRC-STI-2006-00073). The vendor recommended feed flow rate is 1 to 2 gpmper disk, so the 25 -disk unit should operate with a feed rate between 25 and $50 \mathrm{gpm}$.

Test data for filter removal efficiencies are not available, however test measurements of filtrate quality are typically less than 5 NTU or non-detectable. Based on this, it is assumed that the filter removal efficiency is $99.99 \%$.

\footnotetext{
${ }^{2}$ Excerpt from WSRC-STI-2008-000S0.
} 
5.1.2.1 Process Sizing. The rotary microfilter consists of filter modules installed in DST risers that are based on the design developed by SRS. Each module consists of two 25-disk filter units operated in series with a $25 \mathrm{gpm}$ feed pump. Nominal pore size for the membranes should be $0.1 \mu \mathrm{m}$. Table 5-2 summarizes the required filtrate flow for each cesium separation alternative and the number of units required to achieve that flow. The fractional crystallization alternative requires more units than can be installed in available DST risers, so these units would need to be installed in a separate structure, collocated with the cesium separation process. These filter units would be operated in series and a $50 \mathrm{gpm}$ pump would supply waste feed and concentrate recirculation back to the DST.

Table 5-2 Rotary Microfiltration Sizing Summary

\begin{tabular}{|c|c|c|c|}
\hline $\begin{array}{l}\text { Cesium Separation } \\
\text { Alternative }\end{array}$ & $\begin{array}{l}\text { Filtrate Flow Required } \\
\text { (gpm) }\end{array}$ & Number of Units ${ }^{2}$ & $\begin{array}{l}\text { Predicted Filtrate Flow }{ }^{3} \\
\text { (gpm) }\end{array}$ \\
\hline Ion Exchange & 4.1 & 4 & 5.8 \\
\hline $\begin{array}{l}\text { Fractional } \\
\text { Crystallization }\end{array}$ & 17.3 & 12 & 17.3 \\
\hline Solvent Extraction & 4.0 & 4 & 5.8 \\
\hline \multicolumn{4}{|l|}{ Notes: } \\
\hline \multicolumn{4}{|c|}{$\begin{array}{l}\text { 1. Based on the highest filtrate flow to meet plant throughput requirements, determined by mass balance, } \\
\text { RPP-CALC-37594 (AEM-CHG-2008-CN-015, -023, and -038). }\end{array}$} \\
\hline $\begin{array}{l}\text { 2. Based on a } t \\
\text { 3. Based on rot }\end{array}$ & $\begin{array}{l}0.06 \mathrm{gpm} / \mathrm{ft}^{2} \text {. } \\
\text { lter sizing calculation, }\end{array}$ & LC-37594 (AEM- & 008-CN-007). \\
\hline
\end{tabular}

5.1.2.2 Maintenance. The rotating parts of the SpinTek filter pack are inherently more susceptible to failure than a passive filter system. The feed pumps included in the filter module would pose similar maintenance challenges. The modular design of the rotary microfilter unit that has been developed for the SRS for installation in a tank riser has all components with potential for failure in a removable filter pack. This includes the filter disks, bearings, seals and rotary joints. This design facilitates semi-remote removal and replacement of the filter pack or feed pumps and this replacement would be similar to equipment replacement practices and radiological control procedures already in use at tank farms.

Chemical cleaning of the filter disks may be periodically required. Although the high shear forces at the membrane surface results in less filter cake buildup and depth fouling than crossflow filters, chemical cleaning capability should be included in the baseline. The baseline cleaning of the crossflow filters at the WTP is primarily with a $0.1 \underline{\mathrm{M} \mathrm{NaOH}}$ solution once per batch; although a less frequent $2 \underline{\mathrm{M}}$ nitric acid cleaning is expected (24590-WTP-RPT-PT-02005, Flowsheet Bases, Assumptions, and Requirements). The capability of both a caustic and acid cleaning should be provided for the rotary microfilter as well, but the frequency of cleaning is likely to be much less than that of the crossflow filters. This study assumes that an acid cleaning only is required from a consumables standpoint. An evaluation performed for the SRS concluded that chemical cleaning can be conservatively assumed to be required once per year (WSRC-RP-2004-00234, Impact of a Rotary Microfilter on the Savannah River Site High Level 
Waste System). The volume for chemical cleaning of the rotary microfilter is equal to the volume of the filter pack, estimated to be approximately 10 gal per filter unit.

5.1.2.3 Service Life. An evaluation performed for SRS in 2004 concluded that a service life of 5 years could be assumed based on operating experience in a radiological environment in Russia and based on the radiation hardening design improvements developed by SRS (WSRC-RP-200400234). Subsequent testing of the SRS design resulted in high wear in the seal and lower shaft support bushing resulting in an estimation of service life of one year (WSRC-STI-2008-00050, Development of a Rotary Microfilter for Radioactive Waste Applications). The seal manufacturer (John Crane) proposed an expected seal life of one year based on the demonstrated wear, but suggested that replacement with an air cooled seal should extend the life to up to five years. The seal on the SRS test unit has been replaced with the recommended air cooled seal and testing is ongoing. Seal performance has been satisfactory, but inspection for wear has not been performed at the time of this report since more operating hours are required to provide meaningful results. The baseline assumption of expected lifetime for this study is conservatively selected as three years.

\subsubsection{Input Data}

The radiation hardened rotary microfiltration unit developed by SRS consists of a 25 -disk filter pack with filter surface area of $0.96 \mathrm{ft}^{2}$ per disk.

The highest filtrate flow rate requirement, determined in the material balance for each cesium separation alternative, is used for filter sizing; $4.1 \mathrm{gpm}$ for ion exchange, $17.3 \mathrm{gpm}$ for fractional crystallization, and 4.0 gpm for solvent extraction.

\subsubsection{Assumptions}

Filter flux test data is assumed to be relative between SRS and Hanford waste simulants and between crossflow and rotary filters to derive a multiplier of $4 \mathrm{X}$ the crossflow filter flux rate of $0.015 \mathrm{gpm} / \mathrm{ft}^{2}$. This assumption should be verified through technology development activities. Evaluation of existing test data shows that direct scaling of bench scale testing to prototypic and full scale typically does not provide accurate results (WSRC-MS-2006-0115, Cross-Flow Ultrafiltration Scaling Considerations).

Rotary microfilter efficiency is assumed to be $99.99 \%$. Quantitative removal efficiencies are not available, but testing typically resulted in turbidity less than 5 NTU.

A concentration of insoluble solids is not provided in the feed stream definition. It is assumed to be $0.5 \mathrm{wt} \%$. The DST supernate is assumed to be concentrated to $20 \mathrm{wt} \%$ by the rotary microfilters. 
Chemical cleaning is assumed to require either a caustic or an acid cleaning once per year. Capability for both should be provided. The volume of cleaning agent is assumed to be that required to fill each 25-disk filter pack.

The SRS SpinTek rotary microfilter unit is designed to fit within a 48-inch diameter riser on a SRS underground storage tank. The SpinTek rotary micro filter would need to be re-designed to fit within a 42-inch diameter riser on a Hanford DST and the pump suction legs would need to be extended. These modifications appear to be feasible.

\subsubsection{Flowsheet Methodology}

The design production rate $(192 \mathrm{~kg} \mathrm{Na} / \mathrm{hr})$ and Treated LAW sodium concentration are used to determine the required waste feed rate and, therefore, the filtrate flow rate to each cesium separation process. The filtration process is modeled simply as a feed stream that is separated into a filtrate stream and a concentrate stream with a solids removal efficiency of $99.99 \%$. The feed stream is assumed to begin with a solids concentration of $0.5 \mathrm{wt} \%$ and is dewatered to a final solids concentration of $20 \mathrm{wt} \%$.

\subsubsection{Mass and Energy Balances}

Refer to the material balance results for each of the cesium separation alternatives. A generic filter material balance is included at the front end of the process for each solids separation alternative. The filter is modeled as a once through flow process and is not representative of the instantaneous flow rates of the constant DST feed recirculation loop process.

Waste feed temperature will be that of the DST. Some heat is added due to work from the feed pump and from the disk rotation, but this is not quantified. It is assumed that the bulk temperature of the DST will not increase significantly due to this added heat. A small heat exchanger may be required if this heat addition is shown to be significant.

The feed pump(s) must generate a transmembrane pressure of $40 \mathrm{psi}$ and overcome piping pressure losses.

\subsubsection{Equipment List and Sizing}

Table 5-3 provides a summary of major equipment required for the rotary microfilter alternative. 
RPP-RPT-37551, Rev. 1

\begin{tabular}{|c|c|c|c|c|c|}
\hline \multicolumn{3}{|r|}{ Table 5-3 } & \multicolumn{3}{|c|}{$\begin{array}{l}\text { Rotary Microfilter Equipment List } \\
\text { (2 sheets) }\end{array}$} \\
\hline Qty & Component & Process Sizing & Physical Dimensions & Features & Comments \\
\hline \multicolumn{6}{|c|}{ Rotary Microfilter, IX and CSSX alternatives } \\
\hline 4 & 25-Disk Filter Units & $\begin{array}{l}0.1 \mu \mathrm{m} \text { pore disks } \\
0.06 \mathrm{gpm} / \mathrm{ft}^{2} \text { flux } \\
25 \mathrm{disk} \\
24.1 \mathrm{sq} \text { feet }\end{array}$ & $\begin{array}{l}\text { One module (two filter } \\
\text { units) Installed in 42-in } \\
\text { DST riser. }\end{array}$ & $\begin{array}{l}\text { Consists of two modules, each with } \\
\text { two } 25 \text {-disk filter units and a feed } \\
\text { pump } \\
\text { Each filter unit driven by } 25 \mathrm{hp} \\
\text { motor } \\
\text { I\&C: Back pressure control } \\
\quad \text { (2) Pressure } \\
\quad \text { (1) Coriolis flow meters } \\
\end{array}$ & $\begin{array}{l}\text { Sized to provide maximum feed } \\
\text { flow rate required for each } \\
\text { cesium separation alternative. } \\
\text { Flux based on multiplier relative } \\
\text { to crossflow filter flux rate. }\end{array}$ \\
\hline \multirow[t]{2}{*}{2} & Feed Pumps & $25 \mathrm{gpm}$ & & Installed with filter modules. & \\
\hline & PUREX type jumpers & & & $\begin{array}{l}\text { (4) Process } \\
\text { (8) Electrical power } \\
\text { (6) Instrument } \\
\end{array}$ & \\
\hline \multicolumn{6}{|c|}{ Structures } \\
\hline 1 & Pump pit & & $16^{\prime} \mathrm{L} \times 10^{\prime} \mathrm{W} \times 6^{\prime}-6^{\prime \prime} \mathrm{H}$ & $\begin{array}{l}\text { Additional pump pit added to tank } \\
\text { riser similar in construction to } \mathrm{H}-2- \\
90447\end{array}$ & \\
\hline \multicolumn{6}{|c|}{ Rotary Microfilter, FC alternative } \\
\hline 12 & 25-Disk Filter Units & $\begin{array}{l}0.1 \mu \mathrm{m} \text { pore disks } \\
0.06 \mathrm{gpm} / \mathrm{ft} 2 \mathrm{flux} \\
25 \mathrm{disk} \\
24.1 \mathrm{sq} \text { feet }\end{array}$ & $3.5-\mathrm{ft} \times 3.5-\mathrm{ft}$ & $\begin{array}{l}\text { Installed in series in a vault } \\
\text { collocated with FC equipment } \\
\text { Each filter unit driven by } 25 \mathrm{hp} \\
\text { motor } \\
\text { I\&C: Back pressure control } \\
\text { (2) Pressure } \\
\quad \text { (1) Coriolis flow meters }\end{array}$ & $\begin{array}{l}\text { Sized to provide maximum feed } \\
\text { flow rate required for each } \\
\text { cesium separation alternative. } \\
\text { Flux based on multiplier relative } \\
\text { to crossflow filter flux rate. }\end{array}$ \\
\hline \multirow[t]{2}{*}{1} & Feed Pump & $50 \mathrm{gpm}$ & & Installed in DST feed tank. & \\
\hline & PUREX type jumpers & & & $\begin{array}{l}\text { (4) Process } \\
\text { (16) Electrical power } \\
\text { (14) Instrument }\end{array}$ & \\
\hline
\end{tabular}


RPP-RPT-37551, Rev. 1

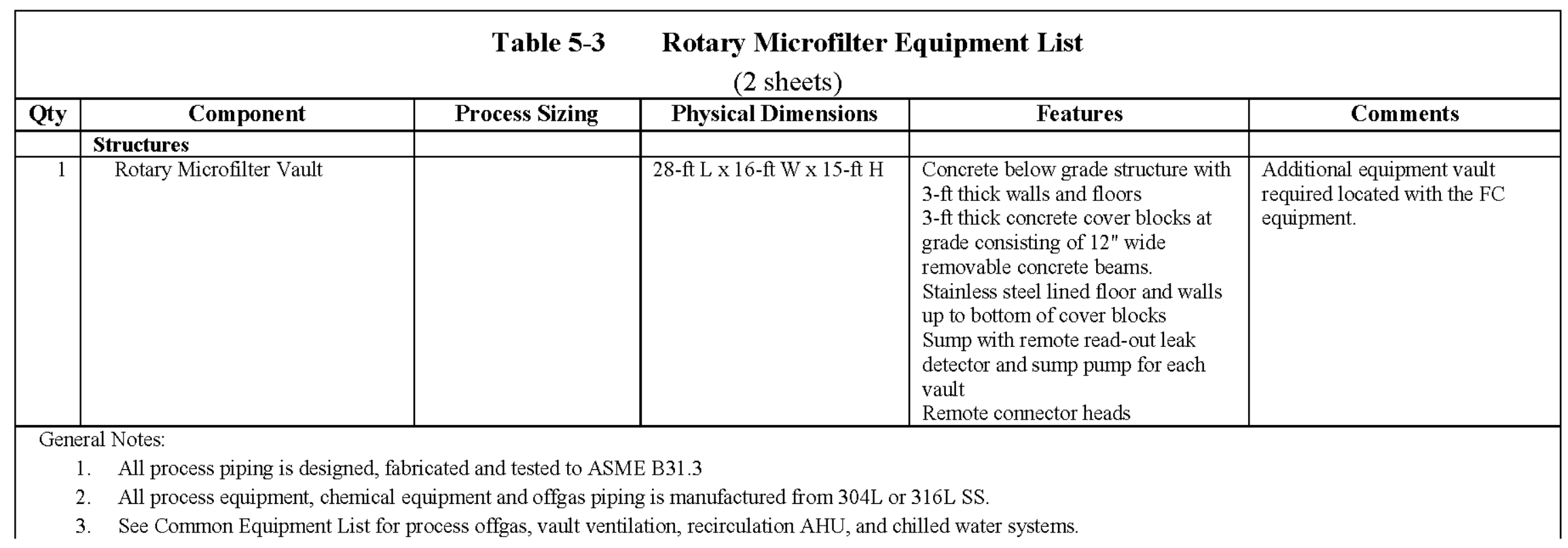




\subsubsection{Process Consumables}

Table 5-4 provides estimates of annual chemical cleaning reagent usage for the rotary microfilter system. Electrical power consumption is also estimated, which varies with the cesium separation technology implemented.

Table 5-4 Process Consumables Summary for Rotary Microfiltration

\begin{tabular}{|c|c|c|c|c|}
\hline Consumable & $\begin{array}{c}\text { Cs Separation } \\
\text { Alternative } \\
\end{array}$ & Quantity & Frequency & Annual Amount \\
\hline \multirow{3}{*}{$\begin{array}{c}\text { Chemical Cleaning } \\
\text { Agent } \\
\left(2 \mathrm{M} \mathrm{HNO}_{3}\right)\end{array}$} & IX & $40 \mathrm{gal}$ & Annually & $40 \mathrm{gal}$ \\
\hline & $\mathrm{FC}$ & $120 \mathrm{gal}$ & Annually & $120 \mathrm{gal}$ \\
\hline & CSSX & $40 \mathrm{gal}$ & Annually & $40 \mathrm{gal}$ \\
\hline \multirow{3}{*}{ Electrical Power } & IX & $\begin{array}{l}4 \times 25 \text { hp rotor } \\
2 \times 3 \text { hp pump }\end{array}$ & Continuous & $82 \mathrm{~kW}$ \\
\hline & $\mathrm{FC}$ & $\begin{array}{l}12 \times 25 \text { hp rotor } \\
1 \times 5 \text { hp pump }\end{array}$ & Continuous & $305 \mathrm{~kW}$ \\
\hline & CSSX & $\begin{array}{l}4 \times 25 \text { hp rotor } \\
2 \times 3 \text { hp pump }\end{array}$ & Continuous & $82 \mathrm{~kW}$ \\
\hline
\end{tabular}

\subsubsection{Risk/Issue Identification}

The rotary microfilter flux rate used for sizing is based on SRS test data that is compared to similar crossflow filtration test data. The relative flux rates for rotary microfiltration range from $1.5 \mathrm{X}$ to $10 \mathrm{X}$ the crossflow filter flux rates for all published test data and $1.5 \mathrm{X}$ to $6 \mathrm{X}$ for pilot scale to full scale test data (WSRC-TR-2003-00071 and WSRC-STI-2006-00073). A flux rate of $4 \mathrm{X}$ the crossflow filter flux rate is chosen for rotary microfilter sizing in this report.

Review of the existing test data for both rotary microfiltration and crossflow filtration indicates that the flux rate can depend on a number of test variables including membrane pore size, transmembrane pressure, scale of test apparatus, crossflow velocity, simulant formulation, etc. Unfortunately, the comparative flux rates cited above are not always based on tests that have maintained all these variables constant. Also, the test data used as the basis for rotary microfilter performance is not wholly relevant to the IPS feed stream and process conditions.

The risk is that a significantly lower actual flux rate than that predicted using the $4 \mathrm{X}$ multiplier could either reduce plant throughput for some or all batches or make impractical the installation of the rotary microfilter system in the DST feed tank risers. The risk is also exacerbated by the risk associated with the crossflow filter flux rate discussed in Section 5.2.9.

A draft test report (WSRC-STI-2008-DRAFT) of recent testing of the 25-disk Spin-Tek rotary microfilter unit using a simulant of AN-105 supernate waste shows rotary microfiltration flux rates from 0.10 to $0.29 \mathrm{gpm} / \mathrm{ft}^{2}$ at solids concentrations from $0.06 \mathrm{wt} \%$ to $1.29 \mathrm{wt} \%$.

Comparisons with crossflow filter data (BNF-003-98-0221, Final Report: Pilot-scale Cross-flow 
Ultrafiltration Test Using a Hanford Site Tank 241-AN-105 Waste Simulant-Envelope A + Entrained Solids) are discussed in the draft test report with the measured rotary microfiltration flux rates between 0.7X and 3.0X the crossflow filter flux rates. This is less than the $4 \mathrm{X}$ multiplier used as the basis in this study. However, the test data comparison is not completely valid because several test variables are different between the two tests.

The crossflow filter test (BNF-003-98-0221) used $0.1 \mu \mathrm{m}$ pore filter tubes in a prototype scale test apparatus, while the rotary microfiltration test used $0.5 \mu \mathrm{m}$ pore filter disks in a full scale test unit. The particle size distribution was different with more small particles in the rotary microfiltration simulant. Since smaller particles tend to penetrate and clog the filter media, the combination of larger filter pore size and smaller particle size in the rotary microfiltration testing would tend to lower the flux rates. Also, increased filter fouling due to the startup/shutdown procedure used may also have contributed to lower rotary microfiltration flux rates.

This is an example of the risk associated with comparing test data to derive a flux rate multiplier for rotary microfilter sizing. The $4 \mathrm{X}$ multiplier used in this report is somewhat arbitrary, but is generally supported by the existing test data and the multiplier methodology is consistent with the available test data. This is the best basis available until more targeted testing with IPS relevant simulants and operating conditions is completed.

The amount of operating experience with the rotary microfilter is generally less than that of the crossflow filter for this type of application. This technology has never been deployed in radioactive waste service. This presents a risk of unforeseen issues with operability and maintainability.

Modification of the SRS modular design to fit in the Hanford tank risers appears to be possible, but presents a risk until detailed design can be completed.

\subsection{CROSSFLOW FILTRATION}

Crossflow filtration consists of a series of sintered metal tubes installed in a housing. The waste feed is pumped through the inside of the tubes at a high axial velocity. Differential pressure drives filtrate through the porous tubes to be collected in the housing and transferred to downstream process equipment. Concentrate exits the downstream end of the tubes to be recirculated back through the filter.

\subsubsection{Literature Survey}

Crossflow filtration has been used successfully in radioactive service at multiple DOE sites including West Valley Demonstration Project (WVDP), the SRS and Oak Ridge National Laboratory (ORNL). 
The crossflow filter unit used at ORNL was part of the Wastewater Triad Project, which included a cesium removal system (ion exchange columns) and an out-of-tank evaporator system. The crossflow filter consists of two Mott HyPulse LSX Filter modules connected in series, each consisting of a $5 \mathrm{ft}$-long-bundle of 31 elements with a 0.75 -in. outside diameter and a $0.5 \mu \mathrm{m}$ pore size.

The MVST feed to the crossflow filter unit contained up to $22 \mathrm{wt} \%$ solids. The filtrate flux rate for the ORNL crossflow filter was 0.012 to $0.16 \mathrm{gpm} / \mathrm{ft}^{2}$. The alpha concentration (primarily associated with the solids) in the MVST feed to the crossflow filter was reduced by $>99.9 \%$ and solids content of the filtrate was $\sim 0.02 \mathrm{wt} \%$ during initial testing in 1999 .

The ORNL hot operations in 1999 processed a total volume of waste during two campaigns of about 45,000 gal. Filtrate flux rates were dependant on solids concentration with reduced flux rates at higher undissolved solids concentrations. Filter performance correlated well with design filtrate production rates. The quality of the filtrate consistently met the requirements for feed to the downstream ion-exchange and evaporation processes. The modular system, including pumps, valves, instrumentation, shielding, and containment, experienced a high degree of reliability and operability.

The ORNL success demonstrates the suitability of this technology for radioactive waste applications. However, filtration performance is very much waste-specific and targeted testing is required to validate filter performance for the waste stream to be processed by the IPS. Testing specific to Hanford waste types began in the mid-1990's with bench scale testing of actual sludge and supernate (PNNL-11376). This testing provided initial data for filtrate quality, flux rates, effect of TMP and axial velocity, and pore size recommendations.

Crossflow filtration has been selected for solid-liquid separation at the WTP Pretreatment facility after evaluating candidate technologies. The WTP uses $0.1-\mu \mathrm{m}$ filter elements to achieve $99.99 \%$ solids removal. Bench scale and pilot scale testing has since been performed to further develop the technology for application to Hanford waste. Further testing to support technology development for WTP has progressed through pilot scale testing using simulants and is expected to support evaluation of technology readiness for the IPS.

Pilot-scale testing using simulants of AN-105 (Envelope A) and AN-107 (Envelope C) wastes was performed early in the WTP design phase by BNFL (BNF-003-98-0221 and BNF-003-980226). Flux rates ranged from 0.10 to $0.16 \mathrm{gpm} / \mathrm{ft}^{2}$ at solids concentrations of 0.5 to $16 \mathrm{wt} \%$. These tests demonstrated the flux rate dependence on axial velocity and recommended a velocity of $12 \mathrm{ft} / \mathrm{sec}$ with a transmembrane pressure of 40 to $55 \mathrm{psid}$ for best filter performance. The effectiveness of frequent backpulse for maintaining flux rates was also demonstrated.

Excluding Sr/TRU precipitation and filtration tests, only two crossflow filtration tests have been conducted with actual LAW solutions from tanks AW-101 and AN-104 (WSRC-TR-2002-00530 and WSRC-RT-2003-00295). These tests produced average filter fluxes of between 0.050 and $0.085 \mathrm{gpm} / \mathrm{ft}^{2}$ at low solids concentrations $(<1 \mathrm{wt} \%)$, with axial velocities of approximately 11 $\mathrm{ft} / \mathrm{sec}$ and transmembrane pressures from $40 \mathrm{psi}$ to $60 \mathrm{psi}$. 
Table 5-5 Crossflow Filtration Literature Survey Summary

\begin{tabular}{|l|l|}
\hline \multicolumn{1}{|c|}{ Document Number } & \multicolumn{1}{c|}{ Title } \\
\hline DOE/ORP-2007-01 & $\begin{array}{l}\text { Technology Readiness Assessment for the Supplemental Treatment } \\
\text { Program }\end{array}$ \\
\hline BNF-003-98-0221 & $\begin{array}{l}\text { FinalReport: Pilot-scale Cross-flow Ultrafiltration Test Using a Hanford } \\
\text { Site Tank 241-AN-105 Waste Simulant - Envelope A + Entrained Solids }\end{array}$ \\
\hline BNF-003-98-0226 & $\begin{array}{l}\text { Final Report: PiIot-scale Cross-flow Ultrafiltration Test Using a Hanford } \\
\text { Site Tank 24I-AN-107 Waste Simulant -Envelope C + Entrained Solids }+ \\
\text { Strontium-Transuranic Precipitation }\end{array}$ \\
\hline ORNL/TM-2000/27 & $\begin{array}{l}\text { Development and Deployment of a Full-Scale Cross-Flow Filtration } \\
\text { System for Treatment of Liquid Low-Level Waste at Oak Ridge National } \\
\text { Laboratory }\end{array}$ \\
\hline PNNL-11376 & $\begin{array}{l}\text { Bench-Scale Cross Flow Filtration of Tank S-107 Sludge Slurries and } \\
\text { Tank C-107 Supernatant }\end{array}$ \\
\hline WSRC-TR-2000-00506 & $\begin{array}{l}\text { Strontium-Transuranic Precipitation and Crossflow Filtration of 241-AN- } \\
\text { 102 Large C }\end{array}$ \\
\hline WSRC-TR-2002-00526 & $\begin{array}{l}\text { Investigation of Alternative Approaches for Cleaning Mott Porous Metals } \\
\text { Filters }\end{array}$ \\
\hline WSRC-TR-2002-00530 & Filtration of a Hanford AW-101 Waste Sample (U) \\
\hline WSRC-TR-2003-00204 & $\begin{array}{l}\text { FinalReport: Pilot-Scale Cross-Flow Ultrafiltration Test Using a Hanford } \\
\text { Site Tank 241-AN-102 Waste Simulant (U) }\end{array}$ \\
\hline WSRC-TR-2003-00295 & Filtration of a Hanford AN-104 Sample (U) \\
\hline WSRC-TR-2003-00469 & $\begin{array}{l}\text { Pilot-Scale Testing of a O.1 Micron Filter with SRS } \\
\text { Simulated High Level Waste }\end{array}$ \\
\hline WSRC-TR-2003-00756 & $\begin{array}{l}\text { Filtration of a Hanford Site Tank 241-AN-102 Waste Sample with } \\
\text { Alternate Sr/TRU Precipitation Conditions at Bench and Pilot Scales }\end{array}$ \\
\hline WSRC-MS-2006-0115 & Cross-Flow Ultrafiltration Scaling Considerations \\
\hline
\end{tabular}

\subsubsection{Process Description}

The proposed crossflow filter process uses multiple $0.1-\mu \mathrm{m}$ sintered metal tubes enclosed within a shell. Waste flows axially through the tube (parallel to the filter media) and filtrate passes radially through the tube wall driven by a differential pressure between the inside of the tubes and the shell. High-flow velocity through the tubes produces a shear at the inside tube wall that reduces the build up of a particulate layer. Some build up of solids is expected; however, so periodic back-pulse of the filter and chemical cleaning is required to remove these solids and to maintain the filter flux rate.

The pore size of $0.1-\mu \mathrm{m}$ is chosen because it has demonstrated higher flux rates than the $0.5-\mu \mathrm{m}$ filter in crossflow filter testing. This is likely due to the smaller particle sizes in Hanford waste and simulant, which tend to more readily clog the pores of the $0.5-\mu \mathrm{m}$ filter.

Figure 5-3 is the proposed process flow diagram for the crossflow filter alternative. A high capacity pump circulates waste supernate from the filter feed tank through the crossflow filter unit. The circulating pump should be of the "low- shear" type to avoid reducing the size of particles in the suspended solids. Suspended solids with small particle size tend to plug the pores of the cross-flow filters, resulting in a decrease in filtrate production. The filtrate passes through 
Figure 5-3 Crossflow Filtration Process Flow Diagram

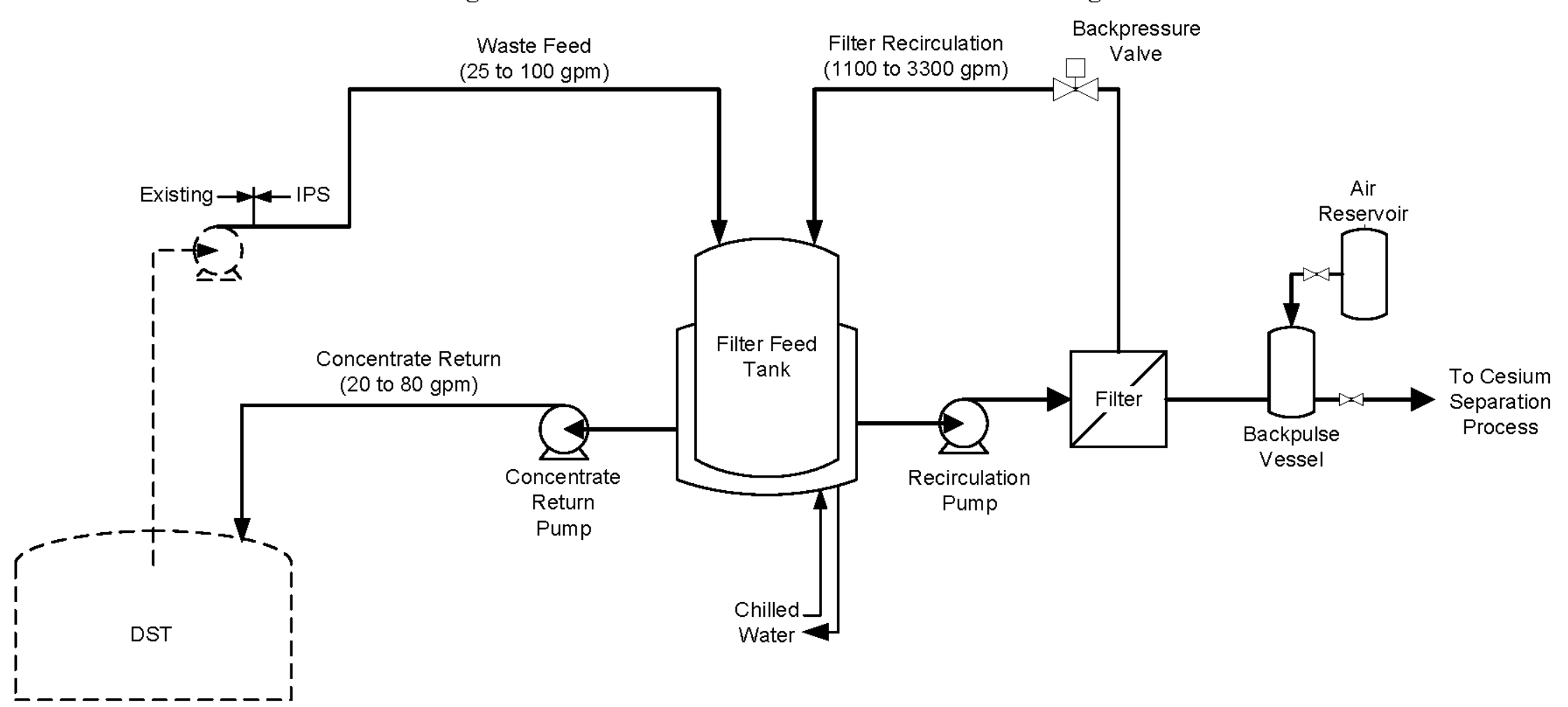


the filter elements to the shell side of the filters and is delivered to the cesium removal process. The concentrate passes through a regulating valve (used to control differential pressure across the filter elements) and is returned to the crossflow filter feed tank. A pressurized back-pulse vessel is used to periodically clean the crossflow filter elements with filtrate to minimize solids accumulation and fouling of filter membrane. Chemical cleaning of the filter with sodium hydroxide may also be used to remove deep fouling from the filter tubes. The cleaning fluids are collected in the filter feed tank.

The crossflow filter unit is housed in a shielded module collocated with the cesium removal process. LAW feed solution contained within the DST is transferred through a hard-piped, shielded, above ground transfer pipeline to the crossflow filter feed tank at a flow rate between 25 and $100 \mathrm{gpm}$ depending on required feed rate to the cesium separation process. The filter feed tank provides: (1) a suction volume for the high flow recirculation pump, (2) continuous recirculation back to the DST to minimize the solids concentration in the filter loop, thus increasing the average filter flux rate, and (3) a cooling jacket to remove heat from the filter recirculation loop caused by pump work.

Filtrate quality and removal efficiency has not been quantitatively determined. In some testing, the solids content in the filtrate was below the resolution of the measurement instrument. The solids removal efficiency is assumed to be $99.99 \%$ in the material balance, which is consistent with the basis used for the WTP.

Testing has been conducted on both actual and simulated Hanford waste to determine crossflow filter flux rates. However, it has been shown that bench scale performance data typically overestimate the filtrate flux rate at larger scale, so test data cannot be directly applied to design (WSRC-MS-2006-00115). The WTP flowsheet contains a variable flux rate depending on wt $\%$ solids and sodium molarity that is based on an evaluation of test data. It is assumed that the crossflow filters remove $99.99 \%$ of solids and the feed stream is concentrated to $20 \mathrm{wt} \%$ solids (24590-WTP-RPT-PT-02-005).

This study uses the WTP variable flux rate equation for non-Envelope C waste from 24590 WTP-RPT-PT-02-005, 2005, Flowsheet Bases, Assumptions, and Requirements, as the best available estimate of crossflow filter performance with Hanford waste (Equation 5.2-1). The average flux rate over the range of solids concentrations and sodium molarity expected in the IPS feed stream is used for filter sizing. This average flux rate is determined to be $0.015 \mathrm{gpm} / \mathrm{ft}^{2}$ (RPP-CALC-37594, Project $W$-551 Supporting Calculations for Interim Pretreatment System Pre-Conceptual Candidate Technology Descriptions [AEM-CHG-2008-CN-006]) ${ }^{3}$.

\footnotetext{
${ }^{3}$ This flux rate is lower than the WTP design basis flux rate of approximately $0.03 \mathrm{gpm} / \mathrm{ft}^{2}$ due to the high sodium concentration in the feed stream to the IPS, which averages approximately $8.2 \mathrm{MNa}$. A sodium concentration of 4 $\mathrm{MNa}$ would give an estimated average flux of approximately $0.03 \mathrm{gpm} / \mathrm{ft}^{2}$ using the variable flux equation.
} 


\section{Equation 5.2-1}

$$
y=(0.011 \times \ln (x)+0.050\} 4.45 / M_{-}^{-}
$$

where:

$$
\begin{aligned}
& \mathrm{y}=\text { filter flux }\left(\mathrm{gpm} / \mathrm{ft}^{2}\right) \\
& \mathrm{x}=\text { weight percent solids } \\
& \mathrm{M}=\text { sodium molarity }(\mathrm{mol} / \mathrm{L})
\end{aligned}
$$

5.2.2.1 Process Sizing. The crossflow filter will consist of 0.75 -in diameter sintered metal tube with nominal pore size of $0.1 \mu \mathrm{m}$. Table 5-6 summarizes the required filtrate flow for each

\begin{tabular}{|c|c|c|c|c|}
\hline $\begin{array}{l}\text { Cs Separation } \\
\text { Alternative }\end{array}$ & $\begin{array}{c}\text { Filtrate Flow } \\
\text { Required }^{1} \\
\text { (gpm) }\end{array}$ & $\begin{array}{c}\text { Total Actual } \\
\text { Filter Area }{ }^{2} \\
\qquad\left(\mathbf{f t}^{2}\right) \\
\end{array}$ & $\begin{array}{c}\text { Predicted } \\
\text { Filtrate Flow } \\
\text { (gpm) }\end{array}$ & Filter Size \\
\hline Ion Exchange & 4.1 & 275 & 4.1 & $\begin{array}{l}2 \text { Filters } \\
70 \% / 4 " \text { Tubes/Bundle } \\
10 \mathrm{ft} \text { long }\end{array}$ \\
\hline $\begin{array}{l}\text { Fractional } \\
\text { Crystallization }\end{array}$ & 17.3 & 1278 & 19.2 & $\begin{array}{l}3 \text { Filters } \\
2173 / 4 " \text { Tubes/Bundle } \\
10 \mathrm{ft} \text { long }\end{array}$ \\
\hline $\begin{array}{l}\text { Solvent } \\
\text { Extraction }\end{array}$ & 4.0 & 275 & 4.1 & $\begin{array}{l}2 \text { Filters } \\
70^{3 / 4 "} \text { Tubes/Bundle } \\
10 \mathrm{ft} \text { long }\end{array}$ \\
\hline
\end{tabular}
cesium separation alternative and the filter sizing required to achieve that flow. Support equipment sizing can be found in the equipment list (Section 5.2.7).

\section{Table 5-6 Crossflow Filter Sizing Summary}

Notes:

1. Based on the highest filtrate flow to meet plant throughput requirements, determined by mass balance, RPP-CALC-37594 (AEM-CHG-2008-CN-015, -023, and -038).

2. Based on a flux rate of $0.015 \mathrm{gpm} / \mathrm{ft}^{2}$. For comparison, the WTP crossflow filter area is approximately $1162 \mathrm{ft}^{2}$ per filter train.

3. Based on crossflow filter sizing calculation, RPP-CALC-37594 (AEM-CHG-2008-CN-006).

5.2.2.2 Maintenance. The recirculation pump may have routine maintenance requirements and moderate probability of failure depending on pump type selected and seal type. Pump installation should be designed for semi-remote removal and replacement. The pump should be located in the valve vault, shielded from the main dose contribution from the process vessels to reduce the dose consequences for maintenance activities.

The crossflow filter units are passive and unlikely to fail during the project lifetime. A periodic back pulse and chemical cleaning regime should maintain filter performance. In the unlikely event of failure or operational upset condition that requires filter replacement, the filters should be designed for semi-remote removal and replacement. 
Online back pulse capability will be provided, which should be operated at a frequency of approximately once every one to two hours. Pilot-scale testing recommends a backpulse volume of $0.036 \mathrm{gal} / \mathrm{ft}^{2}$ (BNF-003-98-0221). Chemical cleaning of the crossflow filters will also be required periodically. The baseline cleaning of the crossflow filters at the WTP is primarily with a $0.1 \underline{\mathrm{M}} \mathrm{NaOH}$ solution once per batch; although a less frequent $2 \underline{\mathrm{M}}$ nitric acid cleaning is expected (24590-WTP-RPT-PT-02-005). Nitric acid has been shown to be effective for cleaning crossflow filter elements during bench scale, actual waste testing (WSRC-TR-2000-00506). This capability for both a caustic and acid cleaning should be provided for the IPS crossflow filters. Volume for one chemical cleaning includes the volume of the entire recirculation loop including filter, piping and pump.

5.2.2.3 Service Life. Service life is expected to exceed the project lifetime of 5 years.

\subsubsection{Input Data}

The variable flux equation that is used in the WTP flowsheet for crossflow filters is used to estimate the flux rate for the non-Envelope $\mathrm{C}$ waste to be processed by the IPS. The average flux over the range of sodium molarity and solids concentrations in the feed stream is used for crossflow filter sizing. This is an extrapolation since the sodium concentration in the IPS feed stream is higher than the data used as the basis for the variable flux equation.

The highest filtrate flow rate requirement, determined in the material balance for each cesium separation alternative, is used for crossflow filter sizing; $4.1 \mathrm{gpm}$ for ion exchange, $17.3 \mathrm{gpm}$ for fractional crystallization, and $4.0 \mathrm{gpm}$ for solvent extraction.

For crossflow filter physical sizing, porous sintered metal tube media is available in effective lengths of either 8 feet or 10 feet. The estimated number of tubes per tube bundle and the tube bundle size are based on a triangular pitch of $1.25 \mathrm{x}$ tube OD. Tube ID is 0.75 inch with a wall thickness of $1 / 16$ inch.

\subsubsection{Assumptions}

Crossflow filter efficiency is assumed to be $99.99 \%$. Quantitative removal efficiencies are not available, but testing typically resulted in either turbidity less than 5 NTU or non-detectable quantities of solids in the filtrate.

A concentration of insoluble solids is not provided in the feed stream definition. It is assumed to be $0.5 \mathrm{wt} \%$. The DST supernate is assumed to be concentrated to $20 \mathrm{wt} \%$ by the crossflow filters. 
The chemical cleaning requirement is assumed to match the protocol established for WTP. This includes a $0.1 \mathrm{M} \mathrm{NaOH}$ solution and a less frequent 2M nitric acid cleaning (24590-WTP-RPTPT-02-005). The used cleaning agent is assumed to either be returned to the DST or added to the product waste stream and does not result in a secondary waste stream. The volume of cleaning agent is assumed to be that required to fill the crossflow filter, recirculation loop piping and pump.

\subsubsection{Flowsheet Methodology}

The design production rate $(192 \mathrm{~kg} \mathrm{Na} / \mathrm{hr})$ and Treated LAW sodium concentration are used to determine the required waste feed rate and, therefore, the filtrate flow rate to each cesium separation process. The filtration process is modeled simply as a feed stream that is separated into a filtrate stream and a concentrate stream with a solids removal efficiency of $99.99 \%$. The feed stream is assumed to begin with a solids concentration of $0.5 \mathrm{wt} \%$ and is dewatered to a final solids concentration of $20 \mathrm{wt} \%$.

\subsubsection{Material and Energy Balances}

Refer to the material balance results for each of the cesium separation alternatives. A generic filter material balance is included at the front end of the process for each solids separation alternative. The filter is modeled as a once through flow process and is not representative of the instantaneous flow rates of the constant DST feed recirculation loop process.

The crossflow filter recirculation pump adds a significant amount of heat in the form of pump work to the loop. A jacketed filter feed tank, cooled with chilled water, is sized to provide enough heat transfer area to remove this heat. The maximum temperature in the recirculation loop is $140^{\circ} \mathrm{F}$, which is the maximum waste feed temperature for the fractional crystallization alternative.

The minimum recirculation pump pressure is calculated to be between 61 and $66 \mathrm{psig}$ in order to maintain a transmembrane pressure of $40 \mathrm{psi}$ and to account for estimated piping pressure losses. The backpulse vessel should provide a minimum of $30 \mathrm{psi}$ back pressure with the recirculation pump in operation. Backpulse pressure should therefore be approximately $85 \mathrm{psi}$ (the sum of the $30 \mathrm{psi}$ backpressure, plus the $40 \mathrm{psi}$ transmembrane pressure, and plus approximately $13 \mathrm{psi}$ overall pressure loss in the filter tubes).

\subsubsection{Equipment List and Sizing}

Table 5-7 provides a summary of major equipment required for the crossflow filter alternative. 


\section{Table 5-7 Crossflow Filter Equipment List}

\begin{tabular}{|c|c|c|c|c|c|}
\hline Qty & Component & Process Sizing & Physical Dimensions & Features & Comments \\
\hline $2 / 3 / 2 *$ & Crossflow Filter & $\begin{array}{l}0.1 \mu \mathrm{m} \text { pore tubes } \\
0.015 \mathrm{gpm} / \mathrm{ft}^{2} \text { flux } \\
70 / 217 / 70^{*} 0.75 \text {-in } \mathrm{D} \mathrm{x} \\
10 \text {-ft L tubes }\end{array}$ & $\begin{array}{l}14 / 22 / 14^{*} \text {-in D x } \\
12 \text {-ft L per filter }\end{array}$ & $\begin{array}{c}\text { I\&C: Back pressure control } \\
\text { Differential Pressure }\end{array}$ & $\begin{array}{l}\text { Sized based on worst case } \\
\text { filtrate feed requirement for } \\
\text { each cesium separation } \\
\text { alternative. Flux based on } \\
\text { WTP variable flux equation. }\end{array}$ \\
\hline 1 & Recirculation Pump & $\begin{array}{l}1100 / 3300 / 1100^{*} \mathrm{gpm} \\
60 / 65 / 60^{*} \mathrm{psid} \\
100 / 300 / 100^{*} \mathrm{Hp}\end{array}$ & & $\begin{array}{l}\text { Low shear type pump } \\
\text { I\&C: Suction pressure } \\
\text { Discharge pressure } \\
\text { Flow control } \\
\text { VFD } \\
\end{array}$ & $\begin{array}{l}\text { Sized to provide } 11 \mathrm{ft} / \mathrm{s} \\
\text { crossflow velocity and } 40 \mathrm{psid} \\
\text { transmembrane pressure. }\end{array}$ \\
\hline 1 & Filter Feed Tank & $\begin{array}{l}700 / 3500 / 700^{*} \text { gal total } \\
\text { capacity }\end{array}$ & $\begin{array}{l}\text { 3.9-ft D x 7.8-ft H (IX) } \\
6.7 \text {-ft D x 13.4-ft H (FC) } \\
3.9 \text {-ft D x 7.8-ft H (CSSX) }\end{array}$ & $\begin{array}{l}\text { Jacketed, cooled by chilled water } \\
\text { Nozzles: (4) process piping } \\
\text { (1) off gas } \\
\text { (1) pump } \\
\text { (3) instrumentation } \\
\text { (1) PRV } \\
\text { I\&C: Level } \\
\text { Temperature } \\
\text { Pressure control (offgas) }\end{array}$ & $\begin{array}{l}\text { Sized to provide jacketed heat } \\
\text { transfer surface area to remove } \\
\text { heat due to pump work. }\end{array}$ \\
\hline 1 & Concentrate Return Pump & $20 / 80 / 20^{*} \mathrm{gpm}$ & & $\begin{array}{l}\text { I\&C: Discharge pressure } \\
\text { Flow } \\
\text { VFD }\end{array}$ & $\begin{array}{l}\text { Flow to provide turnover in } \\
\text { filter feed tank of } 5 \text { times the } \\
\text { filtrate flow rate. }\end{array}$ \\
\hline 1 & Backpulse vessel & $100 \mathrm{gal}$ & & $\begin{array}{l}\text { I\&C: Level } \\
\text { Pressure } \\
\text { Backpulse control } \\
\end{array}$ & $\begin{array}{l}\text { Provide } 0.036 \mathrm{gal} \text { of backpulse } \\
\text { per foot of filter area. }\end{array}$ \\
\hline \multirow[t]{3}{*}{$\overline{1}$} & Compressed air system & $\begin{array}{l}10 \mathrm{scfm} \\
100 \mathrm{psig} \\
100 \mathrm{gal}\end{array}$ & & $\begin{array}{l}\text { Compressor, dryer, reservoir } \\
\text { I\&C: Pressure }\end{array}$ & \\
\hline & \multicolumn{5}{|l|}{ PUREX type jumpers } \\
\hline & Crossflow Filter Vault & & & $\begin{array}{l}\text { (9) Process ( } 11 \text { for FC) } \\
\text { (1) Electrical power } \\
\text { (4) Instrument }\end{array}$ & $\begin{array}{l}\text { Filter modules (3) } \\
\text { Backpulse MOV's (3) } \\
\text { Concentrate return pump (1) } \\
\text { Assume two MOV's per process } \\
\text { line (2) }\end{array}$ \\
\hline & Valve Vault & & & $\begin{array}{l}\text { (2) Process } \\
\text { (1) Electrical power } \\
\text { (2) Instrument }\end{array}$ & Recirculation pump \\
\hline
\end{tabular}


RPP-RPT-37551, Rev. 1

Table 5-7 Crossflow Filter Equipment List

(2 sheets)

\begin{tabular}{|c|c|c|c|c|c|}
\hline Qty & Component & Process Sizing & Physical Dimensions & Features & Comments \\
\hline \multicolumn{6}{|c|}{ Structures, Crossflow Filter } \\
\hline 1 & $\begin{array}{l}\text { Filter Feed Tank and Filter } \\
\text { vault }\end{array}$ & & 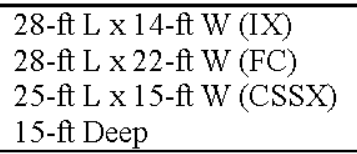 & $\begin{array}{l}\text { Adjacent to Cs equipment tank vault } \\
\text { with similar construction. }\end{array}$ & $\begin{array}{l}\text { Refer to facility layouts in } \\
\text { Section } 8 .\end{array}$ \\
\hline \multicolumn{6}{|c|}{ General Notes: } \\
\hline 1. & \multicolumn{5}{|c|}{ All tanks are designed, fabricated and tested to ASME Section VIII } \\
\hline 2. & \multicolumn{5}{|c|}{ All process piping is designed, fabricated and tested to ASME B31.3 } \\
\hline 3. & \multicolumn{5}{|c|}{ All process equipment, chemical equipment and offgas piping is manufactured from $304 \mathrm{~L}$ or $316 \mathrm{~L} \mathrm{SS}$. } \\
\hline 4. & \multicolumn{5}{|c|}{ See Common Equipment List for process offgas, vault ventilation, recirculation AHU, and chilled water systems. } \\
\hline 5. & \multicolumn{5}{|c|}{ Tanks are sized assuming a working volume equal to $80 \%$ of the total capacity. } \\
\hline
\end{tabular}




\subsubsection{Process Consumables}

Table 5-8 provides estimates of annual chemical cleaning reagent usage for the rotary microfilter system. Electrical power consumption is also estimated, which varies with the cesium separation technology implemented.

Table 5-8 Process Consumables Summary for Crossflow Filtration

\begin{tabular}{|c|c|c|c|c|}
\hline $\begin{array}{c}\text { Cs Separation } \\
\text { Alternative }\end{array}$ & Consumable * & Quantity & Frequency & Annual Amount \\
\hline \multirow{4}{*}{ IX } & $0.1 \mathrm{M} \mathrm{NaOH}$ & $250 \mathrm{gal}$ & Monthly & 3000 gal \\
\hline & $2 \mathrm{M} \mathrm{HNO}_{3}$ & $250 \mathrm{gal}$ & Semi-Annually & 500 gal \\
\hline & $19 \mathrm{MNaOH}$ & & & $50 \mathrm{gal}$ \\
\hline & $4 \mathrm{MNaNO}_{2}$ & & & $38 \mathrm{gal}$ \\
\hline \multirow{4}{*}{$\mathrm{FC}$} & $0.1 \mathrm{M} \mathrm{NaOH}$ & 750 gal & Monthly & 9000 gal \\
\hline & $2 \mathrm{M} \mathrm{HNO}_{3}$ & $750 \mathrm{gal}$ & Semi-Annually & $1500 \mathrm{gal}$ \\
\hline & $19 \mathrm{MNaOH}$ & & & 150 gal \\
\hline & $4 \mathrm{MNaNO}_{2}$ & & & $113 \mathrm{gal}$ \\
\hline \multirow{4}{*}{ CSSX } & $0.1 \mathrm{M} \mathrm{NaOH}$ & $250 \mathrm{gal}$ & Monthly & 3000 gal \\
\hline & $2 \mathrm{M} \mathrm{HNO}_{3}$ & $250 \mathrm{gal}$ & Semi-Annually & 500 gal \\
\hline & $19 \mathrm{MNaOH}$ & & & $50 \mathrm{gal}$ \\
\hline & $4 \mathrm{MNaNO}_{2}$ & & & 38 gal \\
\hline IX & Electrical Power & $\begin{array}{c}100 \text { hp recirc pump } \\
2 \times 5 \text { hp pump }\end{array}$ & Continuous & $82 \mathrm{~kW}$ \\
\hline $\mathrm{FC}$ & Electrical Power & $\begin{array}{c}300 \text { hp recirc pump } \\
2 \times 10 \text { hp pump }\end{array}$ & Continuous & $239 \mathrm{~kW}$ \\
\hline CSSX & Electrical Power & $\begin{array}{l}100 \text { hp recirc pump } \\
2 \times 5 \text { hp pump }\end{array}$ & Continuous & $82 \mathrm{~kW}$ \\
\hline
\end{tabular}

* $0.1 \mathrm{M} \mathrm{NaOH}$ and $2 \mathrm{M} \mathrm{HNO} 3$ are used for chemical cleaning of filter and $19 \mathrm{M} \mathrm{NaOH}$ and $4 \mathrm{M} \mathrm{NaNO} 2$ are used for neutralization of cleaning chemicals to meet DST waste chemistry limits in accordance with Table 3-5.

\subsubsection{Preliminary Risk/Issue Identification}

The use of the WTP variable flux equation for the IPS feed stream is essentially an extrapolation of the test data used as a basis for the equation. The equation is based on test data for solids concentrations from approximately 7 to $23 \mathrm{wt} \%$ and sodium concentrations from approximately 1 to $4.5 \mathrm{M} \mathrm{Na}$ (24590-WTP-RPT-PT-02-005). The IPS feed stream is assumed to range from 0.5 to $20 \mathrm{wt} \%$ solids and has a sodium concentration from approximately 6 to $9 \mathrm{M} \mathrm{Na}$. Therefore there is some risk associated with the $0.015 \mathrm{gpm} / \mathrm{ft}^{2}$ flux rate used to size the filters. More filter surface area would be required if this estimated flux rate is overly optimistic. This risk is lessened, however, by averaging the flux rate over the range of suspended solids. More realistically, the filters would operate much longer in the lower solids loading range and would, therefore, realize a higher flux rate. Also, the assumption of $0.5 \mathrm{wt} \%$ solids in the feed stream is likely to be conservative.

The proposed configuration includes a filter feed tank which is in continuous recirculation with the feed DST at a flow rate of approximately 25 to $100 \mathrm{gpm}$. This allows more dilute feed to the 
crossflow filters, which typically have higher flux rates at lower solids concentrations. The filter recirculation pump then takes a suction off this filter feed tank at approximately 1100 to 3300 gpm. This configuration requires an additional concentrate return transfer line back to the DST.

An alternative solution that would eliminate the need for this additional transfer line would be to have a larger filter feed tank and operate the crossflow filters batch wise. In this case, the filter feed tank would be filled with DST feed and then concentrated down to $20 \mathrm{wt} \%$ with the crossflow filters, providing filtrate to the cesium separation process. The filtration process would then be stopped and the concentrate returned to the DST using the feed transfer line. The trade offs between the proposed option with the required additional transfer line and the alternative option with the required larger feed tank, impact on downstream processing of batch operations, and potentially lower filtrate rate would need to be evaluated.

\subsection{FILTRATION ALTERNATIVES COMPARISON}

Both technologies meet waste clarity requirements for solids content for delivery to downstream cesium separation processes in all testing with simulant and actual waste, and in actual deployment at ORNL. Removal efficiencies of $99.99 \%$ can be expected.

Filtrate flow rates can be achieved by both technologies by providing sufficient filter surface area for a given flux rate. The significantly higher shear force at the membrane surface of the rotary microfilter limits filter fouling mechanisms and will theoretically reduce filter cake buildup and depth fouling. A slightly higher risk of flux rate performance degradation therefore exists with crossflow filtration due to a higher potential for depth fouling, but this is not quantified and should be mitigated by the more frequent chemical cleaning protocol. Also, crossflow filter flux rates tend to decrease with increased solids loading, while some (but not all) test data indicates that rotary microfilter flux rates do not decrease significantly. The crossflow filter flux rate is affected by axial velocity, which is coupled to recirculation pumping flow rate. The rotary microfilter disk surface cross flow velocity, however, is controlled through disk rotational speed, independent of feed flow rate.

Existing work for both technologies supports a high probability that both will work for the application and can be developed further. Both rotary microfiltration and crossflow filtration were found by DOE/ORP-2007-01, Technology Readiness Assessment for the Supplemental Treatment Program to generally support multiple pretreatment missions in Tank Farms, including interim pretreatment for early feed to LAW. However, the technologies were determined to be immature (e.g. Technical Readiness Level 3) due to the limited testing completed on simulated and actual Hanford Site LAW tank waste and very limited development of the design concepts and project requirements for implementation of these technologies. Based on previous testing of these technologies, the assessment team deemed that either technology can be readily matured through testing and concept development to support future design implementation.

The crossflow filter alternative requires more frequent chemical cleaning with a higher volume of solution as shown in the process consumables section of each alternative. 


\subsection{CESIUM SEPARATION TECHNOLOGY ALTERNATIVES}

Three cesium separation technologies are described below: 1) Ion Exchange, 2) Fractional Crystallization, and 3) Caustic Side Solvent Extraction. Initially, the baseline for the technologies was the 8 feed tanks identified in Figure 1-1. This did not provide 5 years of operation for Fractional Crystallization, so an additional study was performed to place all of the technologies on a 5 year operating baseline. The additional study is described in section 6.5.

All candidate technologies meet the requirements for solids removal and for ${ }^{137} \mathrm{Cs}$ separation. All candidate technologies satisfy the WTP feed specification for radionuclide content. CSSX and IX selectively remove the ${ }^{137} \mathrm{Cs}$. FC removes ${ }^{137} \mathrm{Cs}$ along with other radionuclides such as ${ }^{99} \mathrm{Tc}$ and ${ }^{129} \mathrm{I}$, thereby reducing the concentration of radionuclides in the early-LAW secondary liquid waste streams.

\subsection{ION EXCHANGE USING SPHERICAL RESORCINOL-FORMALDEHYDE}

\subsubsection{Literature Survey}

Ion exchange material balance inputs are primarily based on 24590-WTP-RPT-RT-07-005, Implementation Recommendations for WTP Use of Spherical Resorcinol Formaldehyde Resin as the Primary Cesium Ion Exchange Resin. This document provides a summary of test data that have been accumulated through 2007 to investigate implementation of Spherical ResorcinolFormaldehyde as the cesium removal resin in WTP Pretreatment Facility ion exchange columns. The data summarized include:

- Hydraulic performance test results,

- Batch equilibrium test data to identify the variation of cesium loading with waste composition,

- Column cesium removal performance test data,

- Resin degradation test results,

- Studies performed to characterize radionuclides and trace metals in spent resin, and

- Resin stability in potential off-normal chemical and operating conditions

Recommendations for implementation of Spherical Resorcinol-Formaldehyde resin in the WTP Pretreatment Facility provided in 14590-WTP-RPT-RT-07-005 were generally adopted as the material balance basis for ion exchange in this study.

Laboratory-scale column testing $(\sim 1.5 \mathrm{~cm}$ diameter columns $)$ has been performed using actual waste from two different waste tanks. The remainder of the Spherical Resorcinol-Formaldehyde test experience has been obtained using waste simulants. 
Hydraulic performance test experience was obtained using bench-scale and pilot-scale equipment with column diameters of 3 -inches and 24 -inches, respectively. The pilot-scale equipment approaches the column size projected to be required for the IPS implementation of ion exchange technology ( $\sim 34$-inch diameter column).

Data to support prediction of cesium removal performance by ion exchange columns are obtained from laboratory-scale testing ( 1.5 to $2 \mathrm{~cm}$ diameter columns). Cesium removal performance tests were completed using the pilot-scale equipment. However, the pilot-scale tests using feed materials spiked with cesium were limited by the quantity of chemicals that could be handled in the test facility. Cesium in the column effluent was at the detection limit of analytical techniques throughout the loading cycle. Therefore, a cesium breakthrough curve could not be constructed based on data obtained from the larger scale equipment.

Hydraulic testing on a pilot-scale cycled a resin bed through 17 load, rinse, elution, and regeneration cycles to investigate the impact of chemical degradation on resin bed performance. The impact of chemical degradation on cesium removal performance was evaluated by comparing cesium breakthrough curves developed using resin samples of the pilot-scale resin bed after cycling in a laboratory-scale column with fresh resin test results. Radiation degradation was evaluated by comparing the equilibrium batch distribution data of resin samples irradiated up to $100 \mathrm{Mrad}$ with similar data for unirradiated resin. Actual data investigating the combined effects of chemical and radiation degradation are not available. Resin degradation effects must be extrapolated from these test data to approximate the column performance after reuse of resin beds for 30 loading cycles.

\subsubsection{Process Description}

The cesium ion exchange process contains multiple operating phases. Figure 6-1 describes the primary process flow diagram from the Cesium Ion Exchange process. Figure 6-1 represents the dominant operating configuration used for waste processing by ion exchange. Filtrate obtained from the selected solids separation system becomes feed to the ion exchange system.

Ion exchange operating conditions of $6 \mathrm{M}$ sodium ion and $25^{\circ} \mathrm{C}$ were selected for the material balance. Limiting the waste sodium ion concentration approximates a limitation of the waste viscosity passing through an ion exchange resin bed to range that has been demonstrated to produce acceptable pressure drops through resin beds at the selected design superficial velocity. In addition, the $6 \mathrm{M}$ sodium ion concentration is within the range of sodium concentrations where ion exchange equilibrium data are available to describe cesium removal performance. An operating temperature of $25^{\circ} \mathrm{C}$ was selected as the basis for material balance preparation. This operating temperature is consistent with the base operating temperature selected for ion exchange implementation in the WTP. Loading cycle volumes decrease as temperature is increased which increases the number of rinse, elution, and regeneration cycles that must be performed to process a unit volume of waste. In addition, resin degradation can increase significantly in the nitric acid eluant at temperatures above $45^{\circ} \mathrm{C}$. Therefore, operating at a constant temperature of $25^{\circ} \mathrm{C}$ minimizes the potential for excessive resin degradation. 
Supernate is diluted with caustic to $6 \mathrm{M} \mathrm{Na}$ such that aluminum solids are not precipitated when cooled to $25^{\circ} \mathrm{C}$, prior to storage in the ion exchange column feed tank. The dilution supports the selected operating conditions while preventing formation of solids that may foul resin bed during waste processing. 
Figure 6-1 Ion Exchange System Process Flow Diagram

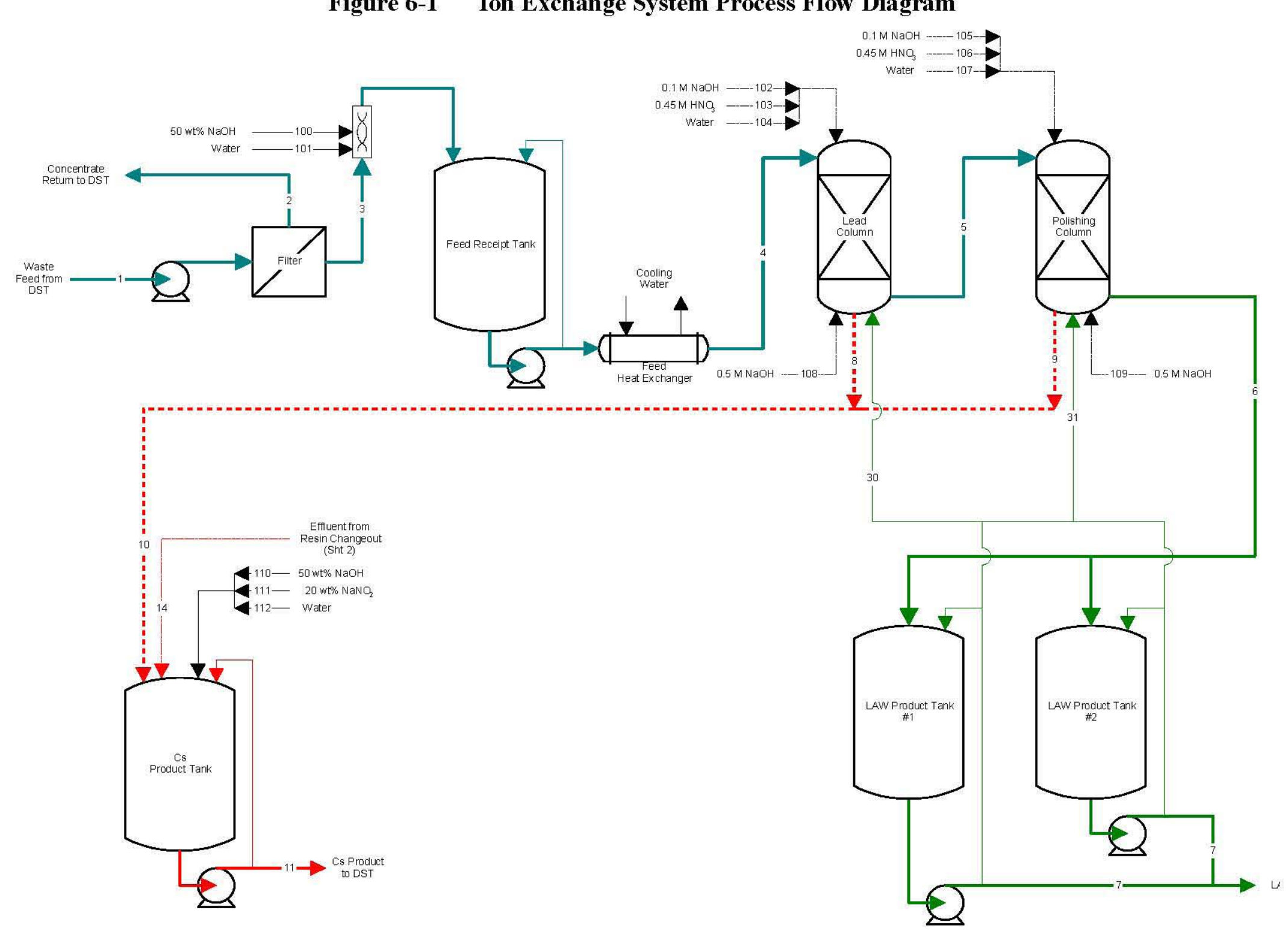


The ion exchange column feed is accumulated in a lag storage vessel that is used as a pump tank. This provides hold up between the solids separation and ion exchange systems so that filtered LAW can continue to be generated when the ion exchange column is not operating for short time periods (e.g., during period rinse, elution, and regeneration cycles).

Material balance calculations are based on use of the spherical form of Resorcinol-Formaldehyde as the resin bed. Two columns in series are included for processing waste during the cesium loading cycle, a lead and polishing column. The two column system allows process monitoring of the LAW between the two columns to determine when the columns should be eluted to ensure adequate cesium removal is obtained. The waste feed is processed through the two ion exchange columns to remove $\mathrm{Cs}$ during the loading cycle. After passing through the two columns, the LAW is collected in one of two tanks prior to transfer out of the IPS and to the LAW Vitrification facility.

The two column ion exchange system operates in a semi-continuous operating mode. Most of the operating time is spent in the loading cycle, where cesium in waste supernate passing through the resin bed is adsorbed by the resin. The volume of waste processed by a loading cycle is determined by the concentration of cesium observed in the Treated LAW product. Frequently, the loading cycle is stopped when the observed cesium concentration leaving the lead column is one-half the cesium concentration in feed to the lead column (a short hand notation for this is $\mathrm{C} / \mathrm{C}_{0}=0.5$, where $\mathrm{C}$ is the cesium molar concentration in the column effluent and $\mathrm{C}_{0}$ is the cesium molar concentration in the column feed). For this study, the loading cycle duration has been defined as the volume of waste processed when the time averaged concentration of waste leaving the Polishing column is equivalent to $1.68 \times 10^{-5} \mathrm{Ci}^{137} \mathrm{Cs} / \mathrm{gmol} \mathrm{Na}$ to produce a LAW product that is comparable to the other separation alternatives.

When process monitoring indicates that the end of the loading cycle has been reached, waste feed to the ion exchange columns is stopped. Both lead and polishing columns are then rinsed, eluted to remove cesium from the resin, and regenerated, allowing the ion exchange columns to be reused to treat additional waste. The rinse, elution, and regeneration activities are composed of a series of operating cycles summarized as follows:

- Feed Displacement Cycle - Displace waste from the column liquid hold up using a solution of $0.1 \mathrm{M} \mathrm{NaOH}$ (dilute caustic is used for displacement to avoid precipitating aluminum solids in the column)

- Pre-Elution Rinse Cycle - Displaces residual caustic from the column liquid hold up using water (minimizes acid-base neutralization heat generated when acid added to column during elution)

- Elution Cycle - Elutes cesium from the resin bed using a solution of $0.45 \mathrm{M} \mathrm{HNO}_{3}$

- Post-Elution Rinse Cycle - Displaces residual acid from the column liquid hold up using water (minimizes acid-base neutralization heat generated when caustic added to the column during regeneration)

- Regeneration Cycle - Converts resin from the H-form to the Na-form prior to introducing waste into the column. Resin beads also expand when converted to the Na-form. Therefore, regeneration is performed upflow, under bed fluidizing conditions, to 
minimize the potential for generating stresses in the resin bed that reduce permeability and increase bed pressure drop

- Regenerant Displacement Cycle - Displaces spent regeneration solution from the column using a small volume of Treated LAW that was produced during the loading cycle. Regenerant displacement is also performed upflow, under fluidizing conditions, to complete the resin bead expansion at waste solution ionic strength and displace the low density regenerant with an upflow of high density waste such that the resin bed is not disturbed by waste addition at the start of the loading cycle

Upon completion of the regeneration cycle, the two ion exchange columns are ready to resume operation in the loading cycle configuration and remove cesium from additional waste supernate. Column effluents, including rinse, eluate, and regenerant, from both ion exchange columns are directed to a Cs Product Tank where the solutions are chemically adjusted to conform with tank farm corrosion criteria and returned to the DSTs for storage.

The resin used for treating waste supernate slowly degrades as solutions are passed through the columns. Chemical and radiolytic degradation has been observed during laboratory testing. Chemical oxidation occurs due to the presence of dissolved oxygen in waste, rinse, elution, and regeneration solutions that pass through the resin bed. Radiolytic degradation is assumed to occur primarily during the loading cycle, as ${ }^{137} \mathrm{Cs}$ accumulates in the columns.

Resin degradation reduces the capacity of resin to adsorb cesium from the waste, resulting in a shortened loading cycle as resin is reused. At some point, the loading cycle duration becomes short compared to the rinse, elution, and regeneration cycle duration and the resin bed replaced in order to maintain the design throughput rate. Figure 6-2 indicates the process flow diagram for replacing resin. Resin is removed from each column using a fluidizing flow of water with the resultant resin/fluid slurry transferred to spent resin accumulation tank.

The resin replacement cycles are projected to be performed two to three times per year of operation. Prior to performing the resin replacement cycle, fresh resin is prepared in a make up tank. Resin is received in 55-gal drums in the H-form. The resin is converted to the Na-form prior to addition to a column by transferring fresh resin from the drums into a solution of $\mathrm{NaOH}$ to produce slurry containing $28 \mathrm{vol} \%$ resin. Two resin makeup tanks have been included in the ion exchange system configuration (one for each column) to minimize down time spent for resin bed replacement and control the volume of resin added to an individual column. After spent resin has been removed from a column, the fresh resin slurry is transferred by gravity draining from the makeup tank to the column.

Liquid holdup in the empty column is displaced to the spent resin accumulation tank during fresh resin addition to the column. Once the fresh resin has been added to both columns, treated LAW is used to displace the transfer solution and the columns are ready to resume waste processing. 
RPP-RPT-37551, Rev. 1

Figure 6-2 Resin Replacement Process Flow Diagram

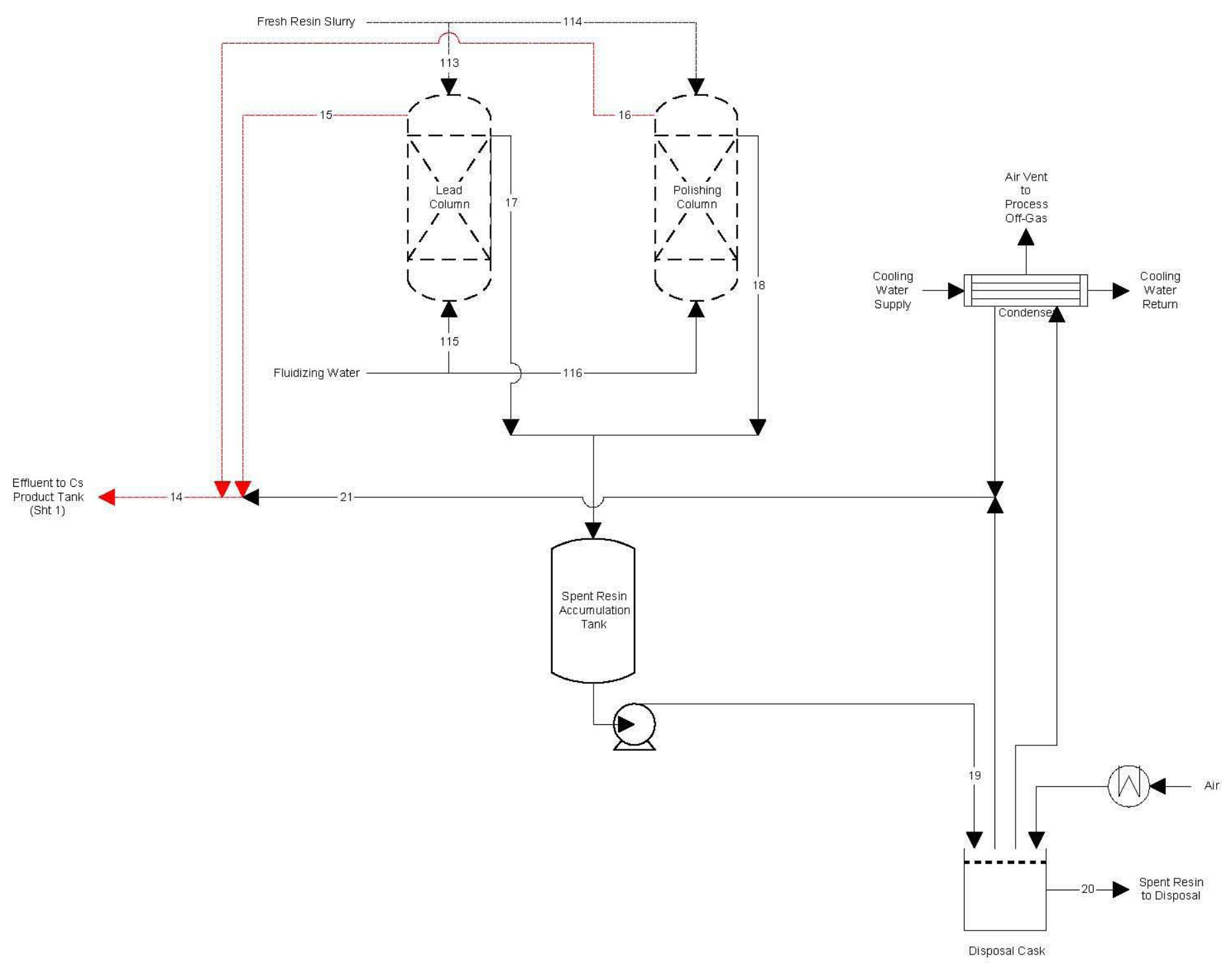


Spent resin is removed from the system as a solid waste. The approach selected for preparing spent resin for solid waste load out is similar to the approach developed for the WTP Pretreatment facility. The accumulated spent resin slurry is transferred from the spent resin tank into a cask that contains an internal screen. The cask is sized to contain resin from two columns. The internal screen confines resin within the cask as the slurry passes through the cask, with the transfer liquid combined with other process effluents in the Cs Product tank that are returned to DSTs.

After completion of the slurry transfer, emptying the spent resin accumulation tank, the disposal cask contains a combination of resin solids and transfer liquid holdup (primarily water). Free liquid remaining in the cask must be removed to satisfy solid waste disposal criteria. Dewatering is accomplished by bubbling heated air through the disposal cask using the same input leg as used for introducing the spent resin slurry. It is estimated that an air stream of $100 \mathrm{SCFM}$, heated to $75^{\circ} \mathrm{C}$, will complete spent resin dewatering in approximately 7 days. After dewatering, the cask penetrations are sealed and the cask transferred out of the ion exchange facility for disposal.

Cold chemical additions for the ion exchange process are projected to include the following:

- Sodium hydroxide solution $(\mathrm{NaOH})$

- Nitric acid solution $\left(\mathrm{HNO}_{3}\right)$

- Sodium nitrite solution

- Water

- Fresh resin

Figure 6-3 provides a sketch of the cold chemical additions system. It is assumed that sodium hydroxide will be received as a $50 \mathrm{wt} \% \mathrm{NaOH}$ solution $(19 \mathrm{M})$ in 5,000 gal tank truck trailers. Nitric acid is also assumed to be received in 5,000 gal tank truck trailers as a $60 \mathrm{wt} \% \mathrm{HNO}_{3}$ solution $(12.2 \mathrm{M})$. Water is added to these bulk chemicals to produce the process input concentrations required to support ion exchange operation. Small quantities of sodium nitrite and fresh resin are required to support the process operation and these makeup materials are assumed to be received in 55 -gal drums for input into the process. 


\section{Figure 6-3 Ion Exchange System Chemical Addition System}

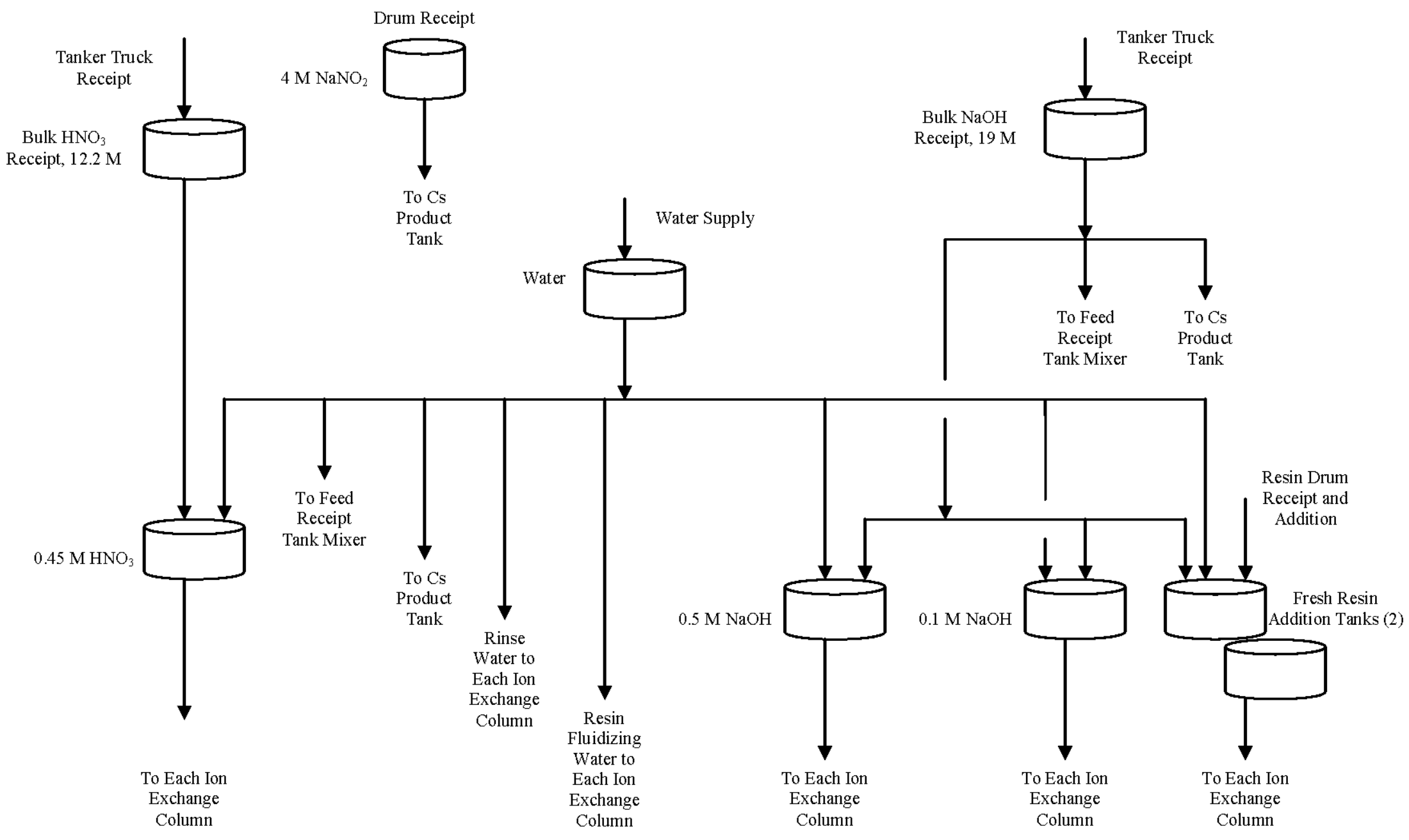




\subsubsection{Input Data and Assumptions}

6.1.3.1 Input Data for Spreadsheet Calculations. The IPS ion exchange mass balance calculations are performed spreadsheet SVF-1499, IPS Ion Exchange Mass Balance Model. Feed composition input data is discussed in Section 2.0 and other interface requirements are discussed in Section 3.0. Additional key user inputs to the spreadsheet model are summarized in Table 6-1.

\section{Table 6-1 User Supplied Input Data for Ion Exchange Mass Balance Calculations}

\begin{tabular}{|c|c|c|}
\hline \multicolumn{3}{|c|}{ (2 sheets) } \\
\hline Parameter & Value & Basis \\
\hline \multicolumn{3}{|l|}{ Waste Feed } \\
\hline Total Suspended Solids (TSS) $=$ & $0.005 \mathrm{wt}$ fraction & Study basis \\
\hline \multicolumn{3}{|l|}{ Filtration } \\
\hline Solids Removal Efficiency = & 0.9999 & Study basis \\
\hline Solids in Concentrate $=$ & 0.2 wt fraction & Study basis \\
\hline \multicolumn{3}{|l|}{ Feed Preparation } \\
\hline Target Feed $\mathrm{Na}$ Concentration $=$ & $6 \mathrm{~mol} / \mathrm{L}$ & Study basis \\
\hline $\mathrm{NaOH}$ Dilution Concentration $=$ & 0.5 wt fraction & Engineering judgment \\
\hline $\mathrm{NaOH}$ Solution Density $=$ & $1.5253 \mathrm{~kg} / \mathrm{L}$ & $\begin{array}{l}\text { Perry \& Chilton, Chemical Engineering } \\
\text { Handbook, 5th ed. }\end{array}$ \\
\hline Caustic Addition per Batch $=$ & See Table $6-2$ & $\begin{array}{l}\text { RPP-CALC-37594 (AEM-CHG-2008- } \\
\text { CN-002) }\end{array}$ \\
\hline Caustic Addition Wt Fraction $=$ & See Table $6-2$ & $\begin{array}{l}\text { RPP-CALC-37594 (AEM-CHG-2008- } \\
\text { CN-002) }\end{array}$ \\
\hline \multicolumn{3}{|l|}{ IX Column } \\
\hline Bed Volume $($ Vbed $)=$ & $614 \mathrm{~L}$ & $\begin{array}{l}\text { RPP-CALC-37594 (AEM-CHG-2008- } \\
\text { CN-005) }\end{array}$ \\
\hline Column Volume $(\mathrm{Vcol})=$ & $1023 \mathrm{~L}$ & $\begin{array}{l}\text { RPP-CALC-37594 (AEM-CHG-2008- } \\
\text { CN-005) }\end{array}$ \\
\hline Bed Void Fraction $=$ & 0.42 & $\begin{array}{l}\text { RPP-CALC-37594 (AEM-CHG-2008- } \\
\text { CN-005) }\end{array}$ \\
\hline Loading Cycle Volume (Vload) $=$ & See Table $6-5$ & $\begin{array}{l}\text { RPP-CALC-37594 (AEM-CHG-2008- } \\
\text { CN-005) }\end{array}$ \\
\hline Total Ion Capacity $=$ & $1.69 \mathrm{~g}-\mathrm{mol} / \mathrm{L}$ resin bed & 24590-WTP-RPT-RT-07-0005, Fig. 11 \\
\hline $\begin{array}{l}\text { Cs Fraction Recovered during Load } \\
\text { Cycle }(\Phi)=\end{array}$ & See Table $6-5$ & $\begin{array}{l}\text { RPP-CALC-37594 (AEM-CHG-2008- } \\
\text { CN-005) }\end{array}$ \\
\hline $0.1 \mathrm{M} \mathrm{NaOH}$ Solution Density = & $1 \mathrm{~kg} / \mathrm{L}$ & $\begin{array}{l}\text { Perry \& Chilton, Chemical Engineering } \\
\text { Handbook, 5th ed. }\end{array}$ \\
\hline $0.45 \mathrm{M} \mathrm{HNO}_{3}$ Solution Density $=$ & $1.01318 \mathrm{~kg} / \mathrm{L}$ & $\begin{array}{l}\text { Perry \& Chilton, Chemical Engineering } \\
\text { Handbook, 5th ed. }\end{array}$ \\
\hline Rinse Water Density $=$ & $1 \mathrm{~kg} / \mathrm{L}$ & Engineering judgment \\
\hline $0.5 \mathrm{M} \mathrm{NaOH}$ Solution Density = & $1.0217 \mathrm{~kg} / \mathrm{L}$ & $\begin{array}{l}\text { Perry \& Chilton, Chemical Engineering } \\
\text { Handbook, 5th ed. }\end{array}$ \\
\hline
\end{tabular}


Table 6-1 User Supplied Input Data for Ion Exchange Mass Balance Calculations

\begin{tabular}{|c|c|c|}
\hline \multicolumn{3}{|c|}{ (2 sheets) } \\
\hline Parameter & Value & Basis \\
\hline Target $\mathrm{OH}$ Conc $=$ & $0.01 \mathrm{~mol} / \mathrm{L}$ & HNF-SD-WM-OCD-015 \\
\hline Target $\mathrm{NO}_{2}$ Conc $=$ & $0.011 \mathrm{~mol} / \mathrm{L}$ & $\begin{array}{l}\text { HNF-SD-WM-OCD-015 } \\
\end{array}$ \\
\hline Target $\mathrm{NO}_{3} /\left(\mathrm{OH}+\mathrm{NO}_{2}\right)$ Ratio $<=$ & $2.5 \mathrm{~mol} / \mathrm{mol}$ & HNF-SD-WM-OCD-015 \\
\hline $\mathrm{NaOH}$ Adjustment Concentration $=$ & $0.5 \mathrm{Wt}$ fraction & Engineering judgment \\
\hline $\mathrm{NaOH}$ Solution Density $=$ & $1.5253 \mathrm{Kg} / \mathrm{L}$ & $\begin{array}{l}\text { Perry \& Chilton, Chemical Engineering } \\
\text { Handbook, 5th ed. }\end{array}$ \\
\hline $\mathrm{NaNO}_{2}$ Adjustment Concentration $=$ & $0.2 \mathrm{Wt}$ fraction & Engineering judgment \\
\hline $\mathrm{NaNO}_{2}$ Solution Density $=$ & $1.1394 \mathrm{Kg} / \mathrm{L}$ & $\begin{array}{l}\text { Perry \& Chilton, Chemical Engineering } \\
\text { Handbook, 5th ed. }\end{array}$ \\
\hline Water Addition Rate $=$ & $0 \mathrm{~L} / \mathrm{hr}$ & \\
\hline \multicolumn{3}{|l|}{ LAW Product } \\
\hline Target ${ }^{137} \mathrm{Cs} / \mathrm{Na}$ Ratio $=$ & $1.68 \mathrm{E}-05 \mathrm{Ci} / \mathrm{mol}$ & Study constraint \\
\hline Production Rate $=$ & $1175 \mathrm{MT} / \mathrm{yr} \mathrm{Na}$ & Study constraint \\
\hline Total Operating Efficiency $=$ & $70 \%$ & Study constraint \\
\hline \multicolumn{3}{|l|}{ Bed Change Out } \\
\hline Bead Void Fraction $=$ & 0.61 & $\begin{array}{l}\text { 24590-WTP-RPT-RT-07-005, Rev. 0, } \\
\text { Fig. } 13\end{array}$ \\
\hline Water Density $=$ & $1 \mathrm{Kg} / \mathrm{L}$ & Engineering judgment \\
\hline Resin Density $=$ & $0.3 \mathrm{Kg} / \mathrm{L}$ (dry $\mathrm{H}+$ form $)$ & $\begin{array}{l}\text { RPP-CALC-37594 (AEM-CHG-2008- } \\
\text { CN-005) }\end{array}$ \\
\hline
\end{tabular}

6.1.3.2 Waste Supernate Dilution. Operating conditions selected for the ion exchange system are based on controlling the waste feed temperature to $25^{\circ} \mathrm{C}$ and the waste feed sodium ion concentration at $6 \mathrm{gmol} \mathrm{Na} / \mathrm{L}$. Supernate from the solids separation system must be diluted to produce the desired sodium ion concentration. Aluminum solids precipitation in ion exchange column feed solutions have the potential to foul resin beds. Therefore, the hydroxide ion concentration after dilution must be controlled to prevent aluminum solids from precipitating when the waste feed solution is cooled to $25^{\circ} \mathrm{C}$.

A caustic solution is used to dilute waste supernate. An operating diagram approach is described in RPP-CALC-37594 (AEM-CHG-2008-CN-002) to calculate the total mass of caustic solution and weight fraction of $\mathrm{NaOH}$ in the caustic solution that produces ion exchange feed at 6 gmol $\mathrm{Na} / \mathrm{L}$ and a hydroxide ion concentration that precludes exceeding the solubility limit of aluminate ion when the ion exchange feed is cooled to $25^{\circ} \mathrm{C}$. Figure 6-4 provides an example of the dilution operating diagram for waste from Tank AP-104. The caustic solution for diluting waste is dependent on the aluminate and hydroxide ion concentration of waste in the originating tank. Therefore, the total mass and weight fraction $\mathrm{NaOH}$ in caustic dilution solutions is specific to the waste feed batch processed. Table 6-2 provides a summary of the caustic dilution solution characteristics for each waste feed batch used as inputs to the ion exchange material balance. Estimates of the sodium, hydroxide, potassium, and cesium molar concentrations in the ion exchange column feed solution after dilution are also shown in Table 6-2. 


\section{Figure 6-4 Example Waste Dilution Operating Diagram for Waste from Tank AP-104}

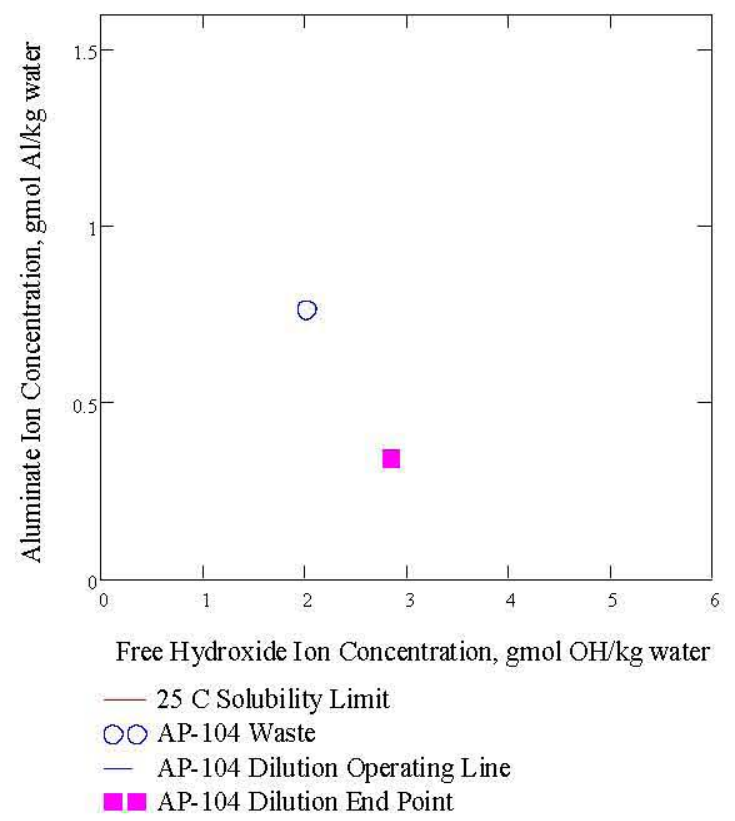

Source: RPP-CALC-37594 (AEM-CHG-2008-CN-002)

Table 6-2 Variation of Dilution Caustic Composition with Waste Feed Composition

\begin{tabular}{|l|c|c|c|c|c|c|c|c|}
\hline Feed Batch & $\mathbf{1}$ & $\mathbf{2}$ & $\mathbf{3}$ & $\mathbf{4}$ & $\mathbf{5}$ & $\mathbf{6}$ & $\mathbf{7}$ & $\mathbf{8}$ \\
\hline $\begin{array}{l}\text { Originating } \\
\text { Tank }\end{array}$ & AP-104 & AP-102 & AP-101 & AP-103 & AP-105 & AP-108 & AP-107 & AN-104 \\
\hline $\begin{array}{l}\text { Total Caustic } \\
\text { Solution } \\
\text { Addition, kg }\end{array}$ & $4.26 \mathrm{E}+06$ & $5.09 \mathrm{E}+06$ & $4.00 \mathrm{E}+06$ & $6.04 \mathrm{E}+06$ & $5.04 \mathrm{E}+06$ & $6.29 \mathrm{E}+06$ & $3.53 \mathrm{E}+06$ & $3.38 \mathrm{E}+06$ \\
\hline $\begin{array}{l}\text { NaOH in } \\
\text { Caustic Solution } \\
\begin{array}{l}\text { Addition, } \\
\text { weight } \\
\text { fraction }\end{array}\end{array}$ & 0.124 & 0.144 & 0.100 & 0.139 & 0.120 & 0.127 & 0.120 & 0.202 \\
\hline $\begin{array}{l}\text { Column Feed Waste Composition after Dilution to } 6 \mathrm{MNa}, \text { gmol/L } \\
\text { [Na] }\end{array}$ & 6 & 6 & 6 & 6 & 6 & 6 & 6 & 6 \\
[OH] & 2.86 & 3.40 & 2.42 & 3.13 & 3.02 & 3.34 & 2.43 & 3.47 \\
[K] & 0.083 & 0.056 & 0.115 & 0.060 & 0.048 & 0.115 & 0.057 & 0.035 \\
[Cs] & $4.16 \mathrm{E}-05$ & $4.93 \mathrm{E}-05$ & $7.18 \mathrm{E}-05$ & $4.63 \mathrm{E}-05$ & $5.54 \mathrm{E}-05$ & $3.94 \mathrm{E}-05$ & $1.58 \mathrm{E}-04$ & $5.38 \mathrm{E}-05$ \\
\hline
\end{tabular}

Notes:

1. Calculated based on the total waste inventory in each waste feed batch in RPP-CALC-37594 (AEM-CHG-2008-CN002)

2. Lead column feed compositions from RPP-CALC-37594 (AEM-CHG-2008-CN-002) 
6.1.3.3 Ion Exchange Column Sizing. Ion exchange columns can be configured as a carousel with appropriate valves and supporting piping. The carousel configuration was selected for implementation in the WTP Pretreatment Facility and has the advantage of providing continuous production of Treated LAW, minimizing the size of ion exchange columns. However, the carousel configuration requires more complex valve and piping configurations. A simple two column system was selected for the ion exchange system considered by this study, where the same column always acts as the lead column while the other column always acts as the polishing column. For this type of configuration, LAW production from the ion exchange columns is suspended while the columns go through the rinse, elution, and regeneration cycles. Operating time used for rinse, elution, and regeneration cycles is balanced by increasing the column size such that the overall design waste processing throughput can be achieved. Since some process additions are dependent on the column size, material balances are dependent on the column sizing calculation. Therefore, calculations to size the column have been performed as part of the material balance inputs.

6.1.3.3.1 Basis for Resin Bed Length to Diameter Ratio. The resin bed experiences significant volume changes as solution compositions are changed during loading, rinse, elution and regeneration cycles. Tests with ground gel type resins have found that bed volume expansion during resin regeneration can produces stresses within the bed due to friction forces at the column wall. These forces result in deformation of the resin particles, decreasing resin permeability and the liquid flow rate that can pass through the bed. Increasing the length to diameter ratio (L/D) of a resin bed increases the impact of volume expansion on the observed bed permeability. Much of the poor column hydraulics experience with ground gel resin forms has been mitigated by the spherical resin form. However, past experience indicates that caution should be used in the selection of resin bed geometry when dealing with a compressible bed material.

Test experience with spherical RF hydraulics is reported for a 24-in pilot scale system in WSRCTR-2005-00570, Pilot-Scale Hydraulic Testing of Resorcinol Formaldehyde Ion Exchange Resin. Hydraulics were successfully tested on this scale at $\mathrm{L} / \mathrm{D}=1.2$, as long as the resin bed was regenerated using an upflow of the $0.5 \mathrm{M} \mathrm{NaOH}$ regenerant. Higher L/D is likely a feasible geometry as long as bed fluidization is performed during resin bed swelling that primarily occurs in the regeneration cycle and when waste replaces the regenerant caustic. However, testing would be required to be demonstrated adequate hydraulic performance at the higher $\mathrm{L} / \mathrm{D}$ geometries. Therefore, this study limited the resin bed geometry to an $\mathrm{L} / \mathrm{D}=1.2$.

6.1.3.3.2 Basis for Column Length to Diameter Ratio. Based on the experience with column hydraulics, regeneration of the resin bed and displacement of the spent regenerant solution is performed under fluidizing conditions that produce an expanded bed equivalent to $140 \%$ of static resin bed volume (24590-WTP-RPT-RT-07-005, Basis of Recommendation for Use of Spherical Resorcinol Formaldehyde Resin as the Primary Cesium Ion Exchange Resin in the WTP). The column must be sized to accommodate this bed expansion as part of the routine operating conditions. Figure 6-5 and Figure 6-6 indicates the fluid superficial velocities required to 
produce the fluidizing conditions by up flow of $0.5 \mathrm{M} \mathrm{NaOH}$ and waste stimulant, respectively. Allow ing for expansion to $140 \%$ of the static bed volume requires a minimum column $\mathrm{L} / \mathrm{D}$ of $1.2 \times 1.4=1.7$. Column design for the WTP column allows space for screens and other internal structure which increased the WTP column height to an $L / D$ of $\sim 2$. Therefore, a column $L / D=2$ has been used as a basis for column sizing in this study.

Figure 6-5 Variation of Fluidized Bed Height with Superficial Velocity for Upflow of $0.5 \mathrm{M} \mathrm{NaOH}$



Source: 24590-WTP-RPT-RT-07-005, Figure 14

Figure 6-6 Variation of Fluidized Bed Height with Superficial Velocity for Upflow of Waste Simulant

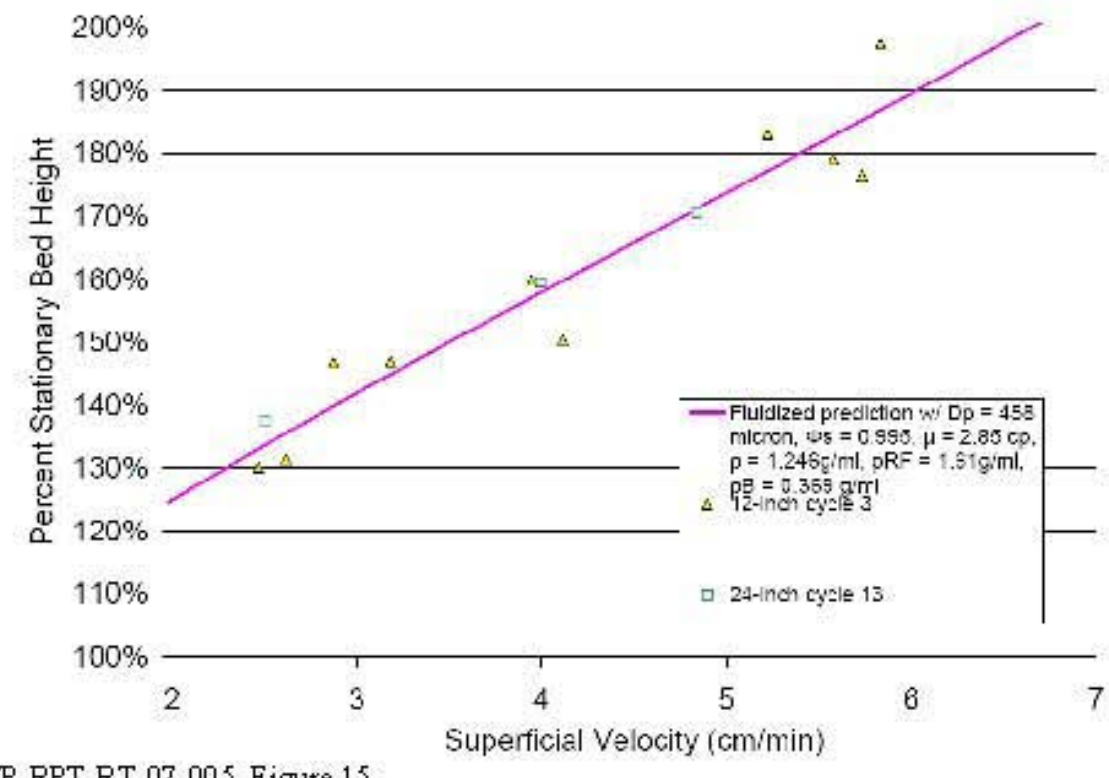

Source: 24590-WTP-RPT-RT-07-005, Figure 15 
6.1.3.3.3 Calculated Column Dimensions. Resin cesium capacity varies with the concentration of sodium, hydroxide, potassium, and cesium ion in waste being processed during the loading cycle. Therefore, a determination of the ion exchange column sizing began by determining the column diameter required to support the required steady state waste processing rate of $192 \mathrm{~kg}$ $\mathrm{Na} / \mathrm{hr}$ for the different waste compositions. Table 6-3 summarizes the results of these preliminary calculations. 24590-WTP-RPT-RT-07-005 describes an analytical equation that produces a simplified approximation of the cesium breakthrough curve for an ion exchange column. The loading cycle volume is defined as the waste volume that can be processed through the lead/polishing column configuration where the integrated quantity of cesium in the polishing column effluent is equivalent to $1.68 \mathrm{E}-05 \mathrm{Ci}^{137} \mathrm{Cs} / \mathrm{gmol} \mathrm{Na}$.

Table 6-3 Variation of Minimum Column Dimensions to Support the Design Waste Processing Rate assuming a Fresh Resin Bed

\begin{tabular}{|c|c|c|c|c|c|c|c|c|}
\hline Feed Batch & 1 & 2 & 3 & 4 & 5 & 6 & 7 & 8 \\
\hline Originating Tank & AP-104 & AP-102 & AP-101 & AP-103 & AP-105 & AP-108 & AP-107 & AN-104 \\
\hline \multicolumn{9}{|c|}{ Column Feed Waste Composition after Dilution to $6 \mathrm{M} \mathrm{Na}, \mathrm{gmol} / \mathrm{L}^{(1)}$} \\
\hline$[\mathrm{Na}]$ & 6 & 6 & 6 & 6 & 6 & 6 & 6 & 6 \\
\hline$[\mathrm{OH}]$ & 2.86 & 3.40 & 2.42 & 3.13 & 3.02 & 3.34 & 2.43 & 3.47 \\
\hline$[\mathrm{K}]$ & 0.083 & 0.056 & 0.115 & 0.060 & 0.048 & 0.115 & 0.057 & 0.035 \\
\hline [Cs] & $4.16 \mathrm{E}-05$ & 4.93E-05 & $7.18 \mathrm{E}-05$ & 4.63E-05 & $5.54 \mathrm{E}-05$ & $3.94 \mathrm{E}-05$ & $1.58 \mathrm{E}-04$ & $5.38 \mathrm{E}-05$ \\
\hline Bed Volume, $\mathrm{m}^{3}$ & 0.518 & 0.520 & 0.541 & 0.518 & 0.522 & 0.520 & 0.571 & 0.520 \\
\hline $\begin{array}{l}\text { Column Diameter, } \\
\mathrm{m}^{(2)}\end{array}$ & 0.819 & 0.820 & 0.831 & 0.819 & 0.821 & 0.820 & 0.846 & 0.820 \\
\hline $\begin{array}{l}\text { Column Height, } \\
\mathrm{m}^{(2)}\end{array}$ & 1.639 & 1.640 & 1.662 & 1.639 & 1.643 & 1.641 & 1.693 & 1.640 \\
\hline $\begin{array}{l}\text { Loading Cycle } \\
\text { Volume, } \mathrm{m}^{3}\end{array}$ & 216 & 211 & 159 & 215 & 201 & 210 & 120 & 210 \\
\hline $\begin{array}{l}\text { Loading Cycle } \\
\text { Duration, hr }\end{array}$ & 139 & 135 & 98 & 138 & 128 & 134 & 70 & 135 \\
\hline
\end{tabular}

Notes:

1. Lead column feed compositions from RPP-CALC-37594 (AEM-CHG-2008-CN-002)

2. Column dimensions to support a processing rate equivalent to $192 \mathrm{~kg} \mathrm{Na} / \mathrm{hr}$ on a continuous operating basis determined in RPP-CALC-37594 (AEM-CHG-2008-CN-003)

The analytical equation has been used to estimate the variation of loading cycle volume for different waste feed compositions. As the calculated loading cycle volume decreases, the resin beds must be eluted more frequently. More frequent elution results in a larger fraction of the operating time to be consumed by operations that do not produce treated LAW for transfer to the Vitrification facility. Therefore, the resin bed size must be increased to support higher waste feed rates during the loading cycle to compensate for operating time lost to the rinse, elution, and regeneration cycles. Table 6-3 indicates that the composition of waste originating in Tank AP107 (Feed batch 7) produces the largest column dimensions and the AP-107 waste composition is used as the basis for sizing the ion exchange columns.

The preliminary calculations summarized in Table 6-3 do not include the impact of resin degradation on ion exchange resin performance. Test data discussed in 24590-WTP-RPT-RT- 
07-005 indicate that the resin effective cesium capacity is reduced by exposure to dissolved oxygen in column addition streams (chemical oxidation) and radiation exposure. The loading cycle volume is reduced as the resin degrades. Therefore, resin degradation also results in more frequent elution cycles, increasing the resin bed volume required to support a specified average waste processing rate.

Test data described in 24590-WTP-RPT-RT-07-005 indicate that resin chemical oxidation effects can be described by a cesium capacity reduction of $25 \%$ per $\left(\mathrm{gmol} \mathrm{O}_{2} / \mathrm{kg}\right.$ resin). Chemical oxidation occurs when feed streams containing dissolved oxygen (waste and all make up streams are assumed to be saturated with oxygen) are passed through the resin beds. Radiation effects can be described by a cesium capacity reduction of $15 \%$ per $100 \mathrm{Mrad}$ of exposure to gamma irradiation from ${ }^{137} \mathrm{Cs}$, however, estimates reported in 24590-RPT-RT-07005 indicate that radiation degradation represents approximately $12 \%$ of the combined chemical and radiation degradation. Therefore, radiation degradation has been neglected for the column sizing calculations used as a basis for this study to simplify the calculations.

Ion exchange sizing calculations are performed in RPP-CALC-37594 (AEM-CHG-2008-CN003). The sizing calculation is based on processing waste at a composition that represents supernate originating in Tank AP-107, after dilution to $6 \mathrm{M} \mathrm{Na}$. Resin beds are assumed to be reused 30 times prior to replacement. Therefore, the column sizing calculation assumes that the resin must be capable of supporting an average waste processing rate equivalent to $192 \mathrm{~kg} \mathrm{Na} / \mathrm{hr}$ after degrading the resin over 30 loading, rinse, elution, and regeneration cycles. Based on the sizing calculation, a resin bed volume of $0.614 \mathrm{~m}^{3}(162 \mathrm{gal})$ is required. The resin bed volume results in a column diameter of $0.867 \mathrm{~m}(\sim 34$-inches $)$ and column height of $1.734 \mathrm{~m}(\sim 68$ inches). Figure 6-7 provides a sketch describing the ion exchange column sizing calculation results. Both lead and polishing columns must be the same size for the sizing calculation basis to be applicable. 


\section{Figure 6-7 Column Sizing Estimate for Steady State Material Balances}



6.1.3.4 Process Additions. The following sections describe the basis for fresh chemical additions to ion exchange columns during the rinse/elution/regeneration cycles and resin bed replacement.

6.1.3.4.1 Ion Exchange Column Cycle Additions. Ion exchange cycle volumetric flow rates and total addition solution volumes are based on recommendations from 242590-WTP-RPT-RT07-005 and summarized in Table 6-4. The recommended inputs are provided in the reference as generalized parameters based on the resin bed and column volumes. These generalized parameters are converted dimensioned flow rates and total volumes based on the resin bed and column volume selected for the IPS ion exchange technology alternative shown on Figure 6-7. The loading cycle volume is shown as being dependent on the waste composition. Loading cycle volumes for a time averaged performance of the ion exchange columns are summarized for each waste feed batch in Table 6-5. Since the column sizing is based on the worst case feed composition and resin degradation after the maximum number of cycles prior to resin bed replacement, column resin beds are greater than or equal to the resin bed needed to produce the time averaged design basis throughput of $192 \mathrm{~kg} \mathrm{Na} / \mathrm{hr}$. Therefore, the time averaged loading cycle feed rate will always be less than or equal to the flow rate shown in Table 6-4. 
RPP-RPT-37551, Rev. 1

Table 6-4 Cycle Volumes and Flow Rates Supporting Ion Exchange Column Operation

\begin{tabular}{|c|c|c|c|c|c|}
\hline \multirow{2}{*}{$\begin{array}{l}\text { Cycle } \\
\text { (Feed Composition) }\end{array}$} & \multicolumn{2}{|c|}{ Generalized Parameters $^{(1)}$} & \multicolumn{2}{|c|}{$\begin{array}{c}\text { Dimensioned Parameters Based on Column } \\
\text { and Bed Volume }{ }^{(3)}\end{array}$} & \multirow[t]{2}{*}{ Cycle Time } \\
\hline & Flow or Velocity & Total Volume & Flow, L/min & Total Volume, $\mathrm{L}$ & \\
\hline $\begin{array}{l}\text { Loading } \\
\text { (Waste) }\end{array}$ & Maximum of $3 \mathrm{BV} / \mathrm{hr}^{(5)}$ & $\begin{array}{l}\text { Depends on waste } \\
\text { composition }\end{array}$ & Maximum of $30.7^{(5)}$ & $\begin{array}{c}\text { Depends on waste } \\
\text { composition }\end{array}$ & $\begin{array}{c}\text { Depends on waste } \\
\text { composition }\end{array}$ \\
\hline $\begin{array}{l}\text { LAW Displacement } \\
(0.1 \mathrm{M} \mathrm{NaOH})\end{array}$ & $3 \mathrm{BV} / \mathrm{hr}$ & $1.5 \mathrm{CV}$ & 30.7 & 1560 & $0.83 \mathrm{hr}$ \\
\hline $\begin{array}{l}\text { Pre-Elution Rinse } \\
\text { (Demineralized Water) }\end{array}$ & $3 \mathrm{BV} / \mathrm{hr}$ & $1 \mathrm{CV}$ & 30.7 & 1040 & $0.56 \mathrm{hr}$ \\
\hline $\begin{array}{l}\text { Elution } \\
\left(0.45 \mathrm{M} \mathrm{HNO}_{3}\right)\end{array}$ & $1.5 \mathrm{BV} / \mathrm{hr}^{(2)}$ & $15 \mathrm{BV}$ & 15.3 & 9210 & $10.00 \mathrm{hr}$ \\
\hline $\begin{array}{l}\text { Post-Elution Rinse } \\
\text { (Demineralized Water) }\end{array}$ & $3 \mathrm{BV} / \mathrm{hr}^{(2)}$ & $1.3 \mathrm{CV}$ & 30.7 & 1352 & $0.72 \mathrm{hr}$ \\
\hline $\begin{array}{l}\text { Regeneration } \\
(0.5 \mathrm{M} \mathrm{NaOH})\end{array}$ & $\begin{array}{c}12.5 \mathrm{~cm} / \mathrm{min} \\
\text { No flow for } 10 \mathrm{~min} \\
2 \mathrm{~cm} / \mathrm{min}\end{array}$ & $\begin{array}{c}3 \mathrm{BV} \\
- \\
0.3 \mathrm{BV}\end{array}$ & $\begin{array}{c}73.8 \\
- \\
11.8 \\
\end{array}$ & 2026 & Allow $1.5 \mathrm{hr}^{(4)}$ \\
\hline $\begin{array}{l}\text { Regenerant Displacement } \\
\text { (Decontaminated Waste) }\end{array}$ & $\begin{array}{c}2.5 \mathrm{~cm} / \mathrm{min} \\
4 \mathrm{~cm} / \mathrm{min} \\
\text { No flow for } 30 \mathrm{~min}\end{array}$ & $\begin{array}{c}0.9 \mathrm{CV} \\
0.13 \mathrm{CV} \\
- \\
\end{array}$ & $\begin{array}{c}14.8 \\
23.6 \\
- \\
\end{array}$ & 1071 & Allow $2.6 \mathrm{hr}^{(4)}$ \\
\hline \multicolumn{5}{|c|}{ Total Resin Regeneration Cycle Time } & $16.2 \mathrm{hr}$ \\
\hline
\end{tabular}

Notes:

1. 24590-WTP-RPT-RT-07-005, 2008, Implementation Recommendations for WTP Use of Spherical Resorcinol Formaldehyde Resin as the Primary Cesium Ion Exchange Resin, Figure 11

2. Figure 11 of the source reference indicates flow rates of $1 \mathrm{BV} / \mathrm{hr}$ for the elution and post-elution rinse cycles. These flow rates are limited by the eluate concentrator in the WTP process design, which is not included in the IPS system. Table 8 of the source reference indicates that actual elution test was performed at flow rates of 1.4 to 1.6 BV/hr. Therefore, higher flow rates were adopted for elution and post-elution rinse in the IPS design basis.

3. Based on bed volume of $0.614 \mathrm{~m}^{3}$ (162 gal), column volume of $1.04 \mathrm{~m}^{3}$ ( 275 gal), column diameter of $0.867 \mathrm{~m}$ ( 34 -inch), and column height of $1.734 \mathrm{~m}$ ( 68 -inches) selected for the bounding waste composition as the equipment sizing basis described in Section 6.1.3.3.3.

4. Time allowance assuming the time to perform process steps will be the same as indicated on Figure 11 of 24590-WTP-RPT-RT-07-005.

5. Column sizing is based on producing $192 \mathrm{~kg} \mathrm{Na} / \mathrm{hr}$ at $3 \mathrm{BV} / \mathrm{hr}$ with the waste composition that produces the smallest loading cycle volume after resin degradation reusing resin bed 30 times. The analytical model of cesium breakthrough for ion exchange columns was calibrated to test data performed at a waste feed rate of $3.13 \mathrm{BV} / \mathrm{hr}$. Therefore, a maximum feed rate of $3 \mathrm{BV} / \mathrm{hr}$ was assumed as the demonstrated applicability of the column sizing basis calculation.

$\mathrm{L}_{\text {resin }}=$ Resin Bed Length

$\mathrm{D}_{\text {column }}=$ Ion Exchange Column Diameter

$\mathrm{L}_{\text {column }}=$ Ion Exchange Column Length

$\mathrm{BV}=$ Resin Bed Volume, Basis $\mathrm{L}_{\text {resin }} / \mathrm{D}_{\text {column }}=1.2$

$\mathrm{CV}=$ Column Volume, Basis $\mathrm{L}_{\text {column }} / \mathrm{D}_{\text {colum }}=2$

$1 \mathrm{CV}=1.67 \mathrm{BV}$ 


\section{RPP-RPT-37551, Rev. 1}

6.1.3.4.2 Resin Bed Replacement. Column sizing is based on resin degradation estimates assuming a resin bed is reused for 30 loading cycles. The resin bed replacement is a relatively infrequent operation occurring on the order of two to three times per year based on operating durations shown for each waste feed batch composition shown in Table 6-5.

The resin bed replacement cycles begin after both columns have been eluted and the post-elution rinse cycle has been performed. Resin is removed from both columns using a fluidizing flow of water introduced into the bottom of the column. Section 8.6 of 24590-WTP-RPT-RT-07-005 indicates that a total transfer fluid volume of 2.6 resin bed volumes will remove $994 \%$ of a resin bed. The fluidizing water flow rate, consistent with this resin removal performance, is obtained from Figure 6-8 and requires a superficial velocity of the liquid phase of $37.2 \mathrm{~cm} / \mathrm{min}$. Therefore, material balance calculations are based on using a water volume equal to 2.6 resin bed volumes for resin removal resin removal from each ion exchange column. For the column sizing basis, this results in the use of $1596 \mathrm{~L}(\sim 420 \mathrm{gal})$ of water to remove resin from each column. The resin removal requirements are time averaged for the steady state material balances based on performing the resin removal every 30 loading cycles.

\section{Figure 6-8 Resin Bed Porosity at Spent Resin Removal Conditions}

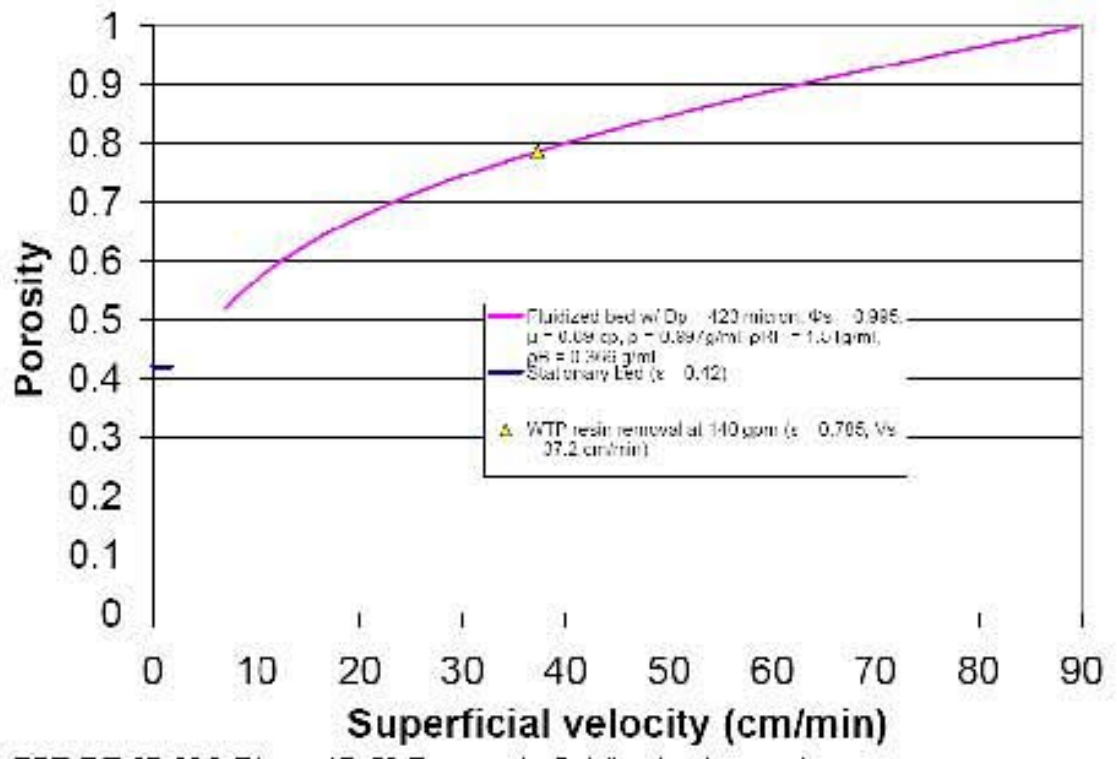

Souxce: 24590-WTP-RPT-RT-07-005, Figure 17 (H-Form resinfludization in water)

Pump sizing for the resin removal fluidizing water is based on producing a superficial velocity of $37.2 \mathrm{~cm} / \mathrm{min}$ in the column. The cross-section area of the $86.7 \mathrm{~cm}$ diameter column is approximately $5904 \mathrm{~cm}^{2}$. Therefore, a volumetric flow rate of water equivalent to $\sim 220 \mathrm{~L} / \mathrm{min}$ $(\sim 58 \mathrm{gpm})$ is required to support the resin removal activities.

Fresh resin is assumed to be received in the hydrogen form that must be converted into the sodium form resin prior to introduction into a column to form a replacement resin bed. For material balance purposes, the fresh resin preparation was simplified to the equivalent of adding resin to a caustic solution in the fresh resin makeup tank to produce slurry that is contains $28 \mathrm{vol} \%$ resin beads. The slurry resin loading is consistent with the 30 vol $\%$ slurry used to 
demonstrate the resin bed addition sequence during 24-inch diameter pilot-scale testing reported in Section 4.11.2 of WSRC-TR-2005-00570, Pilot-Scale Hydraulic Testing of Resorcinol Formaldehyde Ion Exchange Resin and defines the total liquid phase volume associated with adding new resin to an ion exchange column.

The quantity of caustic added to convert fresh H-form resin to the Na-form is based on stoichiometric addition of sodium based on a resin sodium capacity of $1.69 \mathrm{gmol} \mathrm{NaOH} / \mathrm{L}$ wet Na-form resin bed (Figure 11 of 24590-WTP-RPT-RT-07-005). A stoichiometric addition was assumed to simplify the material balance calculations for a stream that is used infrequently. In actual practice, excess caustic is expected to be used as part of the fresh resin treatment steps.

6.1.3.5 Average Ion Exchange System Performance Estimates. The column sizing calculation was performed using worst case conditions, where resin was assumed to be degraded by reuse for 30 loading cycles using the most conservative waste feed composition. These conditions produce the smallest loading cycle volume for the ion exchange system. Loading cycle volume is a key parameter for estimating the ion exchange system material balance since chemical additions for rinse, elution, and regeneration are constant each time a loading cycle is completed. Therefore, chemical additions, per unit volume of waste processed, increase as the loading cycle volume decreases.

Average column performance for each waste feed batch composition was estimated as input to the material balance in AEM-CHG-2008-CN-005. For these estimates, the resin bed and column volume was held constant at the values shown in Figure 6-7. Average performance was determined over the resin life assuming resin degradation is characterized by the resin degradation that occurs from resin reuse for 15 loading cycles and the loading cycle feed rate adjusted to produce a time averaged waste processing throughput equivalent to $192 \mathrm{~kg} \mathrm{Na} / \mathrm{hr}$. Loading cycle volumes and the cesium removal efficiency of both columns for the various waste feed batch compositions are summarized in Table 6-5 and represent inputs to material balances describing the ion exchange technology.

Table 6-5 also provides an estimate of the average loading cycle duration for each waste feed batch composition, ranging from 64 to $138 \mathrm{hr}$. The frequency of resin bed replacement is also indicated based on performing 30 average loading cycles prior to changing a resin bed. The estimate indicates that resin beds will be replaced after 100 to 193 operating days, depending on the waste being processed. In actual practice, loading cycles can be longer when resin has been degraded for less than 15 loading cycles and shorter when resin has been degraded for more than 15 loading cycles. 
RPP-RPT-37551, Rev. 1

Table 6-5 Average Ion Exchange Column Performance Inputs to Steady State Material Balance

\begin{tabular}{|c|c|c|c|c|c|c|c|c|}
\hline Feed Batch & 1 & 2 & 3 & 4 & 5 & 6 & 7 & 8 \\
\hline Originating Tank & AP-104 & AP-102 & AP-101 & AP-103 & AP-105 & AP-108 & AP-107 & AN-104 \\
\hline \multicolumn{9}{|c|}{ Column Feed Waste Composition ${ }^{(1)}, \mathrm{gmol}^{\prime} \mathrm{L}$} \\
\hline$[\mathrm{Na}]$ & 6 & 6 & 6 & 6 & 6 & 6 & 6 & 6 \\
\hline$[\mathrm{OH}]$ & 2.86 & 3.40 & 2.42 & 3.13 & 3.02 & 3.34 & 2.43 & 3.47 \\
\hline$[\mathrm{K}]$ & 0.083 & 0.056 & 0.115 & 0.060 & 0.048 & 0.115 & 0.057 & 0.035 \\
\hline$[\mathrm{Cs}]$ & $4.16 \mathrm{E}-05$ & 4.93E-05 & $7.18 \mathrm{E}-05$ & 4.63E-05 & $5.54 \mathrm{E}-05$ & $3.94 \mathrm{E}-05$ & $1.58 \mathrm{E}-04$ & $5.38 \mathrm{E}-05$ \\
\hline Loading Cycle Volume ${ }^{(2)}, \mathrm{m}^{3}$ & 208.6 & 204.9 & 154.5 & 208.4 & 196.4 & 203.4 & 111.7 & 204.4 \\
\hline \multicolumn{9}{|c|}{ Fraction of Cs in column feed recovered during Loading $\mathrm{Cycle}^{(3)}$} \\
\hline Lead Column & 0.808197 & 0.82004 & 0.852135 & 0.815467 & 0.828838 & 0.804971 & 0.908056 & 0.826027 \\
\hline Polishing Column & 0.994555 & 0.995103 & 0.995906 & 0.994917 & 0.995416 & 0.994346 & 0.997009 & 0.995355 \\
\hline Overall & 0.998956 & 0.999119 & 0.999395 & 0.99062 & 0.999215 & 0.998897 & 0.999725 & 0.999192 \\
\hline $\begin{array}{l}\text { Overall Cesium Decontamination } \\
\text { Factor }^{(4)}\end{array}$ & 958 & 1135 & 1652 & 1066 & 1274 & 907 & 3636 & 1238 \\
\hline Loading Cycle Duration $^{(5)}, \mathrm{hr}$ & 134 & 131 & 95 & 134 & 125 & 130 & 64 & 131 \\
\hline $\begin{array}{l}\text { Fraction of Operating Time used for } \\
\text { Elution/ Regeneration Cycles }\end{array}$ & 0.108 & 0.110 & 0.146 & 0.108 & 0.115 & 0.111 & 0.202 & 0.11 \\
\hline $\begin{array}{l}\text { Operating Time between Resin Bed } \\
\text { Replacement }^{(7)} \text {, Operating Days }\end{array}$ & 187 & 184 & 139 & 187 & 176 & 183 & 100 & 183 \\
\hline
\end{tabular}

Notes:

1. Estimate of waste feed during loading cycle after dilution to avoid aluminate ion precipitation at $25^{\circ} \mathrm{C}$ calculated in RPP-CALC-37594 (AEM-CHG-2008-CN-002). Used only for estimating ion exchange column performance and may not be exactly the same as determined by steady state material balance.

2. Calculated for selected resin bed dimensions at an average Treated LAW production rate of $192 \mathrm{~kg} \mathrm{Na} / \mathrm{hr}$ assuming resin capacity after degradation for 15 cycles represents average over reusing resin for 30 cycles calculated in RPP-CALC-37594 (AEM-CHG-2008-CN-005). Loading cycle endpoint produces a composite cesium concentration equivalent to $1.68 \mathrm{E}-05 \mathrm{Ci}^{137} \mathrm{Cs} / \mathrm{gmol} \mathrm{Na}$.

3. Fraction of cesium entering a column that is recovered by resin during a loading cycle calculated in RPP-CALC-37594 (AEM-CHG-2008-CN-005)

4. Overall two column cesium decontamination factor (concentration Cs in feed/concentration Cs in LAW) calculated in RPP-CALC-37594 (AEM-CHG-2008-CN-005)

5. Operating time for loading cycle at waste feed flow rate producing Treated LAW at an average rate of $192 \mathrm{~kg} \mathrm{Na} / \mathrm{hr}$ calculated in RPP-CALC-37594 (AEM-CHG-2008-CN-005)

6. Fraction of total ion exchange cycle operating time used to perform elution/regeneration cycles calculated in RPP-CALC-37594 (AEM-CHG-2008-CN-005)

7. Operating time between resin bed replacements assuming resin is reused for 30 ion exchange loading cycles calculated in RPP-CALC-37594 (AEM-CHG-2008-CN-005,) 
6.1.3.6 Comparison of Material Balance Inputs to Alternate Estimates. The ion exchange column system is described (performance and equipment size) based on simplified calculations that were considered suitable for pre-conceptual estimates. WSRC-STI-2008-00232, Modeling of Ion-Exchange for Cesium Removal from Hanford Interim Pretreatment System Feeds has developed estimates of the ion exchange system performance using a more sophisticated approach based on ion exchange column computer modeling. The two calculations were performed in parallel due to the compressed schedule available for developing technology descriptions. The following discussion provides a comparison of the ion exchange performance estimated in this study with estimates from WSRC-STI-2008-00232.

The two performance estimates were determined using similar, but different bases. Therefore, it should be expected that different results were obtained independent of the calculation sophistication.

Column sizing influences the size of a number of support vessels in the ion exchange columns (for example, fresh resin addition vessels and the spent resin accumulation vessel). Therefore, column sizing influences the layout presented to describe the ion exchange technology alternative.

Both calculations use a two column ion exchange system, with the columns operating in series during the waste loading cycle. The resin bed volume was provided as input to the WSRC-STI2008-00232 calculation at 340 gal resin per column, operating at a nominal flow rate of 2 Bed Volumes (BV) per hour during the loading cycle. Therefore, waste is processed through the ion exchange system at $11.3 \mathrm{gpm}$, which is produces a treated LAW sodium throughput of $\sim 355 \mathrm{~kg}$ $\mathrm{Na} / \mathrm{hr}$ for waste a $6 \mathrm{M} \mathrm{Na}$. Assuming rinse, elution, and regeneration cycles consume 10 to $20 \%$ of the total operating time, the time averaged sodium throughput rate for the WSRC-STI-200800232 is 280 to $320 \mathrm{~kg} \mathrm{Na} / \mathrm{hr}$.

The ion exchange column size for this study is based on a time averaged sodium throughput rate of $192 \mathrm{~kg} \mathrm{Na} / \mathrm{hr}$ and resulted in an estimate of $\sim 160$ gal resin per column. Therefore, the resin bed volume is approximately $50 \%$ of that used in the WSRC-STI-2008-00232 calculation, while the time averaged throughput is 60 to $70 \%$ of the WSRC-STI-2008-00232 sodium throughput.

Column sizing in this study was also based on a nominal flow rate of $3 \mathrm{BV} / \mathrm{hr}$ during the loading cycle, compared to $2 \mathrm{BV} / \mathrm{hr}$ in WSRC-STI-2008-00232. WSRC-STI-2008-00232 also considered a loading flow rate of $3 \mathrm{BV} / \mathrm{hr}$ in sensitivity studies and noted that $3 \mathrm{BV} / \mathrm{hr}$ loading decreases the loading cycle volume processed by about $11 \%$ and decreased the loading cycle duration by $40 \%$. The difference in loading flow rates produces a net gain in the rate that waste can be processed by a unit volume of resin bed and required column size is reduced by approximately $20 \%$ to achieve a specified waste throughput. It appears that sodium throughput and loading cycle flow rate basis differences account for column sizing variations for the two calculations.

The waste loading cycle volume is an important input to describing overall material balances for the ion exchange technology alternative. Smaller loading cycle volumes result in a larger 
volume of waste returned to DSTs since the rinse, elution, and regeneration cycles must be performed more frequently.

Waste composition influences the loading cycle volume. Waste feed compositions originate from the same source and both calculations assume waste is diluted to $6 \mathrm{M} \mathrm{Na}$ prior to feeding waste to the ion exchange columns. However, the waste dilution calculation in this study apparently uses a more conservative aluminum solubility curve for defining caustic additions to dilute waste to $6 \mathrm{M} \mathrm{Na}$. Therefore, $\mathrm{Cs}$ and $\mathrm{K}$ concentrations in the ion exchange waste feed are reduced by $\sim 20 \%$ compared to the feed composition used for WSRC-STI-2008-00232. Reduced $\mathrm{Cs}$ and $\mathrm{K}$ concentrations would be expected to produce larger loading cycle volume predictions.

Calculations in WSRC-STI-2008-00232 are based on fresh resin, while resin is assumed to be reused for 30 loading cycles in this study. Resin degradation reduces the apparent resin cesium capacity, independent of the column feed composition. Reduced cesium resin capacity would be expected to produce smaller loading cycle volume predictions.

Loading cycle volume can be considered in terms of bed volumes for comparison of different sized resin beds. Loading cycle volumes predicted for each waste composition are compared in Table 6-6. In each case, the simplified calculation in this study produces smaller loading cycle volumes compared to those estimated by WSRC-STI-2008-00232. Therefore, the overall material balance estimates in this study will be conservative compared to material balances based on WSRC-STI-2008-00232.

Table 6-6 Comparison of Ion Exchange Loading Cycle Volume Predictions by Alternate Calculations

\begin{tabular}{|c|c|c|}
\hline \multirow{2}{*}{ Feed } & \multicolumn{2}{|c|}{ Loading Cycle Volume, Bed Volumes } \\
\cline { 2 - 3 } & $\begin{array}{c}\text { WSRC-STI-2008-00232, Based } \\
\text { on Table 9-4 }\end{array}$ & $\begin{array}{c}\text { This study, } \\
\text { Based on Table 6-5 }\end{array}$ \\
\hline AP-104 & 452 & 340 \\
\hline AP-102 & 566 & 334 \\
\hline AP-101 & 368 & 252 \\
\hline AP-103 & 482 & 350 \\
\hline AP-105 & 634 & 320 \\
\hline AP-108 & 420 & 331 \\
\hline AP-107 & 504 & 182 \\
\hline AN-104 & 864 & 333 \\
\hline
\end{tabular}

The basis for defining the end of a loading cycle is not the same for the two calculations. The ion exchange loading cycle endpoint was defined in this study as the waste volume processed where the time averaged cesium concentration leaving the polishing column reaches the criteria cesium concentration in treated LAW sent to Vitrification without contingency. This approach was selected to produce results that were comparable to the other cesium separation technologies, rather than a model of how the operation might be designed if the technology is selected for implementation. 
The loading cycle endpoint was defined in WSRC-STI-2008-00232 as the waste volume processed where the instantaneous cesium concentration leaving the polishing column reaches $\sim 80 \%$ of the criteria cesium concentration in treated LAW. Both the contingency on the criteria and application to an instantaneous cesium concentration, rather than time averaging, decrease the loading cycle volume calculated by WSRC-STI-2008-00232. The effect of the loading cycle endpoint basis is shown in Table 9-5 of WSRC-STI-2008-00232 which indicates the cesium decontamination factor is approximately 30 to 100 times higher than needed to achieve the treated LAW cesium concentration criteria. The difference in loading cycle endpoint definition increases the apparent conservatism of loading cycle volumes calculated in this study compared to that calculated by WSRC-STI-2008-00232.

Based on the comparisons:

- Waste throughput and loading cycle flow rate describe the difference in column sizes that appear in the ion exchange column calculations for waste processed by the IPS

- Qualitatively, it appears that differences in waste loading cycle estimates can partially be attributed to waste composition differences and incorporation of resin degradation factors. However, the smaller loading cycle volumes estimated in this study produce conservative overall material balances and a quantitative description of the reason for loading cycle volume differences was not considered necessary to support the current pre-conceptual technology description effort.

6.1.3.7 General Resin Physical Properties. Table 6-7 provides a summary of the source for selected resin physical properties used as inputs to the material balances.

Table 6-7 Summary of Resin Physical Properties used as Inputs to Material Balances

\begin{tabular}{|l|c|l|}
\hline Property & Value & Source \\
\hline $\begin{array}{l}\text { Resin Bed Density, kg dry H-form Resin per } \\
\text { Liter wet Na-form Resin }\end{array}$ & $\rho_{\text {resin }}=0.3$ & $24590-$ WTP-RPT-RT-07-005, Table 6 \\
\hline Resin Bed Void Fraction, dimensionless & $\varepsilon_{\text {bed }}=0.42$ & $24590-W T P-R P T-R T-07-005$, Figure 13 \\
\hline Resin Bead Void Fraction, dimensionless & $\varepsilon_{\text {bead }}=0.61$ & $24590-W T P-R P T-R T-07-005$, Figure 13 \\
\hline $\begin{array}{l}\text { Resin Total Ion Capacity, equivalents per } \\
\text { Liter wet Na-form Resin }\end{array}$ & Qresin $=1.69$ & $24590-W T P-R P T-R T-07-005$, Figure 11 \\
\hline
\end{tabular}

\subsubsection{Assumptions}

Summary of ion exchange system assumptions:

- Availability incorporated into the process design capacity is typically reserved as an allocation for unplanned downtime that occurs during operation. The ion exchange process contains intermittent interruptions to treated LAW production (to perform column elution) as part of the process design. Therefore, the ion exchange system waste processing rate during the loading cycle was increased to produce a time averaged throughput rate of $192 \mathrm{~kg} \mathrm{Na} / \mathrm{hr}$ over a complete ion exchange operating cycle that 
includes the routine rinse, elution, and regeneration activities. Resin bed replacement is an infrequent operation and is neglected as a factor in determining the system waste processing throughput.

- Neglect resin bed volume expansion and contraction as it is converted between the Hydrogen-form (H-form) resin and Sodium-form (Na-form) resin during rinse, elution, and regeneration cycles

- Resin beds are assumed to be reused for 30 loading cycles prior to replacement. Resin bed performance after reuse for 15 loading cycles is assumed to approximate the time averaged material flows when resin beds are reused for a total of 30 loading cycles.

- Time cycles for resin bed sizing and performance estimates assume the lead and polish columns are processed simultaneously through the rinse, elution, and regeneration cycles. If simultaneous operation of the cycles is considered impractical, the resin bed volume is expected to increase by $20 \%{ }^{4}$.

\subsubsection{Flowsheet Methodology}

The ion exchange process is described as a batch process; while material balances prepared for comparisons with other technologies represent the equivalent of a continuous process. The loading cycle volume for each waste feed batch composition and design production rate of Treated LAW are used as the basis for converting the ion exchange inputs into an equivalent continuous process material balance. The design production rate $(192 \mathrm{~kg} \mathrm{Na} / \mathrm{hr})$ and Treated LAW sodium concentration are used to determine the loading cycle volumetric flow rate ( $\mathrm{v}_{\text {rate }}$ ). Chemical additions are defined relative to the loading cycle volume to determine effective continuous volumetric flow rates for these streams. The following discussion describes how the batch process inputs were converted to a time-averaged, steady-state material balance which was subsequently implemented in the calculations performed by SVF-1499.

6.1.5.1 Characteristic Column Effluent Volume and Composition. Liquid holdup in the ion exchange columns complicates the evaluation of liquid effluent compositions for each ion exchange cycle (see definition on Figure 6-7). Liquid holdup results in solution from the end of one cycle to be discharged in the column effluent at the start of the next cycle, influencing the liquid phase composition of column effluents. The issue for material balance calculations was simplified for the IPS process flow diagram by recognizing that all column effluent streams during rinse, elution, and regeneration cycles are combined in the Cs Product Tank. Therefore, a continuous steady state material balance can address the column liquid phase effluent as a single composite concentration.

The column effluent composition calculation began by identifying characteristic volumes and compositions for streams during each cycle assuming liquid is displaced as plug flow. Figure 6-9 indicates the characteristic volume and composition of lead column effluents which was

\footnotetext{
${ }^{4}$ Informal estimate based on repeating calculation in RPP-CALC-37594 (AEM-CHG-2008-004) with Total Resin Regeneration Time listed in Table 6-4 increased by a factor of 2 .
} 
determined by the evaluation summarized in Table 6-8. The evaluation result indicates that the composition of lead column effluent transferred to the Cs Product Tank is characterized by:

- 1 liquid holdup of waste with cesium concentration equal waste leaving the lead column during the loading cycle,

- 1.5 column volumes of $0.1 \mathrm{M} \mathrm{NaOH}$,

- 2.3 column volumes of water,

- 15 bed volumes of $0.45 \mathrm{M}$ nitric acid,

- 3.3 bed volumes of spent $0.5 \mathrm{M} \mathrm{NaOH}$, and

- (1.03 column volumes - 1 liquid holdup) of LAW

Figure 6-10 and Table 6-9 provide a similar description of the basis for estimating the characteristic composition of polishing column effluent transferred to the Cs Product Tank. 


\section{Figure 6-9 Diagram Indicating Lead Column Operating Cycle Liquid Phase Volumes and Characteristic Composition}

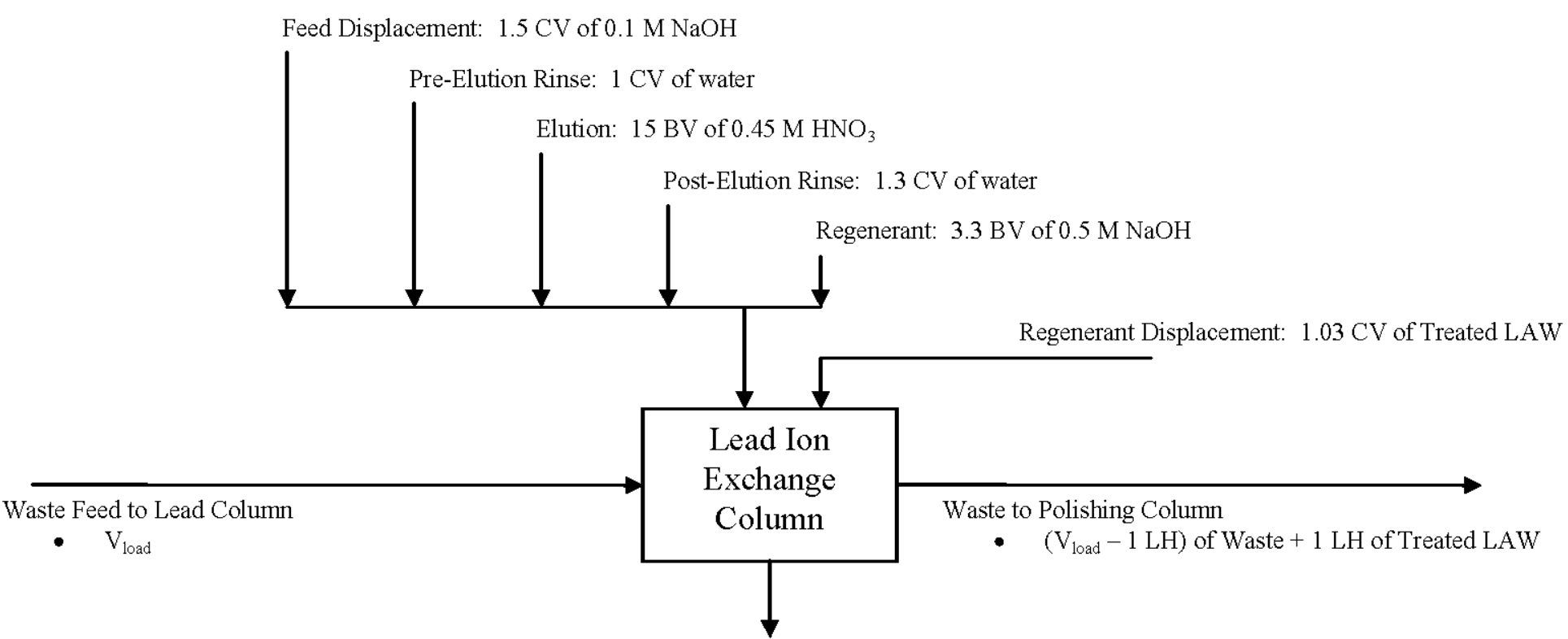

$\mathrm{BV}=$ Resin Bed Volume

Column Effluent to Cs Product Tank:

- 1 LH Waste

- $1.5 \mathrm{CV} 0.1 \mathrm{M} \mathrm{NaOH}$

- $1 \mathrm{CV}$ water

- $15 \mathrm{BV} 0.45 \mathrm{HNO}_{3}$

- $1.3 \mathrm{CV}$ water

- $\quad 3.3 \mathrm{BV}$ Spent $0.5 \mathrm{M} \mathrm{NaOH}$

$\mathrm{CV}=$ Column Volume

- $(1.03 \mathrm{CV}-1 \mathrm{LH})$ Treated LAW

$\mathrm{LH}=$ Liquid Holdup of Column with Resin Bed

$1 \mathrm{CV}=1.67 \mathrm{BV}$ 
RPP-RPT-37551, Rev. 1

Table 6-8 Volume and Characteristic Composition of Lead Column Effluents over an Ion Exchange Column Operating Cycle

\begin{tabular}{|c|c|c|c|c|c|c|c|}
\hline \multirow[b]{2}{*}{$\begin{array}{l}\text { Ion Exchange } \\
\text { Cycle }\end{array}$} & \multicolumn{7}{|c|}{ Column Effluent Volume and Characteristic Composition ${ }^{(1)}$} \\
\hline & $\begin{array}{l}\text { Waste at Feed } \\
\text { Composition }\end{array}$ & $0.1 \mathrm{M} \mathrm{NaOH}$ & Water & $\begin{array}{c}\text { Spent } 0.45 \mathrm{M} \\
\mathrm{HNO}_{3} \\
\end{array}$ & Water & $\begin{array}{c}\text { Spent } \\
\text { Regenerant }\end{array}$ & LAW \\
\hline Loading $^{(2)}$ & $\mathrm{V}_{\text {load }}-1 \mathrm{LH}$ & & & & & & $1 \mathrm{LH}$ \\
\hline $\begin{array}{l}\text { Feed } \\
\text { Displacement }\end{array}$ & $1 \mathrm{LH}$ & $1.5 \mathrm{CV}-1 \mathrm{LH}$ & & & & & \\
\hline Pre-Elution Rinse & & $1 \mathrm{LH}$ & $1 \mathrm{CV}-1 \mathrm{LH}$ & & & & \\
\hline Elution & & & $1 \mathrm{LH}$ & $15 \mathrm{BV}-1 \mathrm{LH}$ & & & \\
\hline $\begin{array}{l}\text { Post-Elution } \\
\text { Rinse }\end{array}$ & & & & $1 \mathrm{LH}$ & $1.3 \mathrm{CV}-1 \mathrm{LH}$ & & \\
\hline Regeneration & & & & & $1 \mathrm{LH}$ & $3.3 \mathrm{BV}-1 \mathrm{LH}$ & \\
\hline $\begin{array}{l}\text { Regenerant } \\
\text { Displacement }^{(2)}\end{array}$ & & & & & & $1 \mathrm{LH}$ & $1.03 \mathrm{CV}-1 \mathrm{LH}$ \\
\hline \multirow{2}{*}{$\begin{array}{l}\text { Total Output to } \\
\text { Polishing } \\
\text { Column }\end{array}$} & $\mathrm{V}_{\text {load }}-1 \mathrm{LH}$ & & & & & & $1 \mathrm{LH}$ \\
\hline & \multicolumn{7}{|c|}{$\mathrm{V}_{\text {load }}-1 \mathrm{LH}+1 \mathrm{LH}=\mathrm{V}_{\text {load }}$} \\
\hline \multirow{2}{*}{$\begin{array}{l}\text { Total Output to } \\
\text { Cs Product } \\
\text { Tank }^{(4)}\end{array}$} & $1 \mathrm{LH}$ & $1.5 \mathrm{CV}$ & $1 \mathrm{CV}$ & $15 \mathrm{BV}$ & $1.3 \mathrm{BV}$ & $3.3 \mathrm{BV}$ & $1.03 \mathrm{CV}-1 \mathrm{LH}$ \\
\hline & \multicolumn{7}{|c|}{$1 \mathrm{LH}+1.5 \mathrm{CV}+1 \mathrm{CV}+15 \mathrm{BV}+1.3 \mathrm{BV}+3.3 \mathrm{BV}+1.03 \mathrm{CV}-1 \mathrm{LH}=1.5 \mathrm{CV}+1 \mathrm{CV}+15 \mathrm{BV}+1.3 \mathrm{BV}+3.3 \mathrm{BV}+1.03 \mathrm{CV}$} \\
\hline $\begin{array}{l}\text { Total of All } \\
\text { Outputs from } \\
\text { Lead Column }\end{array}$ & \multicolumn{7}{|c|}{$\mathrm{V}_{\text {load }}+1.5 \mathrm{CV}+1 \mathrm{CV}+15 \mathrm{BV}+1.3 \mathrm{BV}+3.3 \mathrm{BV}+1.03 \mathrm{CV}$} \\
\hline
\end{tabular}

1. Assumes plug flow of liquids through column to simplify estimates. Some mixing will occur in column regions with no resin which is neglected by this estimate. Considered justified since affected streams are combined in the Cs Product Tank. Column volumes fed to column in each cycle are based on Table 6-4.

2. Column liquid hold up assumed to be composed of LAW at the start of loading cycle (equivalent to end of Regenerant Displacement).

3. Total volume to polishing column $=\mathrm{V}_{\text {load. }}$. Composition characterized by volume of $\left(\mathrm{V}_{\text {load }}-1 \mathrm{LH}\right)$ at lead column loading cycle effluent composition and $1 \mathrm{LH}$ at $\mathrm{LAW}$ composition.

4. Total volume to $\mathrm{Cs}$ Product Tank $=1.5 \mathrm{CV}+1 \mathrm{CV}+15 \mathrm{BV}+1.3 \mathrm{BV}+3.3 \mathrm{BV}+1.03 \mathrm{CV}$. Composition characterized by volume of $1 \mathrm{LH}$ at lead column loading cycle effluent composition, 1.5 CV 0.1 M NaOH, $1 \mathrm{CV}$ water, 15 BV 0.45 M HNO3, 1.3 BV water, 3.3 BV Spent Regenerant, and (1.03 CV - $1 \mathrm{LH}) \mathrm{LAW}$.

$\mathrm{V}_{\text {load }}=$ Loading cycle volume; $\mathrm{LH}=$ Liquid holdup in ion exchange column; $\mathrm{CV}=$ Column volume; $\mathrm{BV}=\mathrm{Bed}$ volume 
Figure 6-10 Diagram Indicating Polishing Column Operating Cycle Liquid Phase Volumes and Characteristic Composition

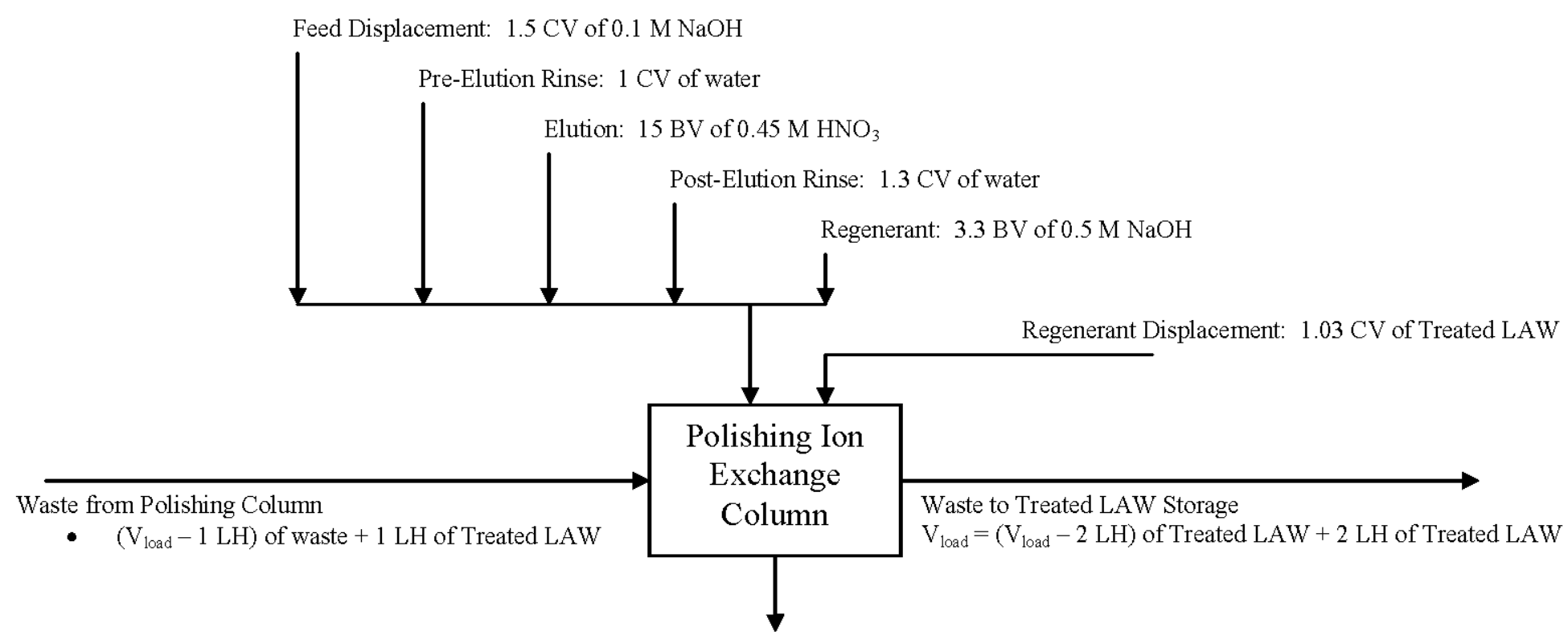

$\mathrm{BV}=$ Resin Bed Volume

Down-flow Column Effluent:

- 1 LH Treated LAW

- $\quad 1.5 \mathrm{CV} 0.1 \mathrm{M} \mathrm{NaOH}$

- $1 \mathrm{CV}$ water

- $15 \mathrm{BV} 0.45 \mathrm{HNO}_{3}$

- $1.3 \mathrm{CV}$ water

- $\quad 3.3 \mathrm{BV}$ Spent $0.5 \mathrm{M} \mathrm{NaOH}$

$\mathrm{CV}=$ Column Volum

- $(1.03 \mathrm{CV}-1 \mathrm{LH})$ Treated LAW

LH = Liquid Holdup of Column with Resin Bed

$! \mathrm{CV}=1.67 \mathrm{BV}$ 
Table 6-9 Volume and Characteristic Composition of Polishing Column Effluents over an Ion Exchange Column Operating Cycle

\begin{tabular}{|c|c|c|c|c|c|c|c|}
\hline \multirow{2}{*}{$\begin{array}{l}\text { Ion Exchange } \\
\text { Cycle }\end{array}$} & \multicolumn{7}{|c|}{ Column Effluent Volume and Characteristic Composition ${ }^{(1)}$} \\
\hline & $\begin{array}{l}\text { Waste at Feed } \\
\text { Composition }\end{array}$ & $0.1 \mathrm{M} \mathrm{NaOH}$ & Water & $\begin{array}{l}\text { Spent } 0.45 \mathrm{M} \\
\mathrm{HNO}_{3}\end{array}$ & Water & $\begin{array}{c}\text { Spent } \\
\text { Regenerant }\end{array}$ & LAW \\
\hline Loading $^{(2)}$ & $\mathrm{V}_{\text {load }}-2 \mathrm{LH}$ & & & & & & $2 \mathrm{LH}$ \\
\hline $\begin{array}{l}\text { Feed } \\
\text { Displacement }\end{array}$ & $1 \mathrm{LH}$ & $1.5 \mathrm{CV}-1 \mathrm{LH}$ & & & & & \\
\hline Pre-Elution Rinse & & $1 \mathrm{LH}$ & $1 \mathrm{CV}-1 \mathrm{LH}$ & & & & \\
\hline Elution & & & $1 \mathrm{LH}$ & $15 \mathrm{BV}-1 \mathrm{LH}$ & & & \\
\hline $\begin{array}{l}\text { Post-Elution } \\
\text { Rinse }\end{array}$ & & & & $1 \mathrm{LH}$ & $1.3 \mathrm{CV}-1 \mathrm{LH}$ & & \\
\hline Regeneration & & & & & $1 \mathrm{LH}$ & $3.3 \mathrm{BV}-1 \mathrm{LH}$ & \\
\hline $\begin{array}{l}\text { Regenerant } \\
\text { Displacement }^{(2)} \\
\end{array}$ & & & & & & $1 \mathrm{LH}$ & $1.03 \mathrm{CV}-1 \mathrm{LH}$ \\
\hline \multirow{2}{*}{$\begin{array}{l}\text { Total Output to } \\
\text { Treated LAW } \\
\text { Storage }^{(3)}\end{array}$} & $\mathrm{V}_{\text {load }}-2 \mathrm{LH}$ & & & & & & $2 \mathrm{LH}$ \\
\hline & \multicolumn{7}{|c|}{$\mathrm{V}_{\text {load }}-2 \mathrm{LH}+2 \mathrm{LH}=\mathrm{V}_{\text {load }}$} \\
\hline \multirow{2}{*}{$\begin{array}{l}\text { Total Output to } \\
\text { Cs Product } \\
\text { Tank }^{(4)}\end{array}$} & $1 \mathrm{LH}$ & $1.5 \mathrm{CV}$ & $1 \mathrm{CV}$ & $15 \mathrm{BV}$ & $1.3 \mathrm{BV}$ & $3.3 \mathrm{BV}$ & $1.03 \mathrm{CV}-1 \mathrm{LH}$ \\
\hline & \multicolumn{7}{|c|}{$1 \mathrm{LH}+1.5 \mathrm{CV}+1 \mathrm{CV}+15 \mathrm{BV}+1.3 \mathrm{BV}+3.3 \mathrm{BV}+1.03 \mathrm{CV}-1 \mathrm{LH}=1.5 \mathrm{CV}+1 \mathrm{CV}+15 \mathrm{BV}+1.3 \mathrm{BV}+3.3 \mathrm{BV}+1.03 \mathrm{CV}$} \\
\hline $\begin{array}{l}\text { Total of All } \\
\text { Outputs from } \\
\text { Lead Column } \\
\end{array}$ & \multicolumn{7}{|c|}{$\mathrm{V}_{\text {load }}+1.5 \mathrm{CV}+1 \mathrm{CV}+15 \mathrm{BV}+1.3 \mathrm{BV}+3.3 \mathrm{BV}+1.03 \mathrm{CV}$} \\
\hline
\end{tabular}

Notes:

1. Assumes plug flow of liquids through column to simplify estimates. Some mixing will occur in column regions with no resin which is neglected by this estimate. Considered justified since affected streams are combined in the Cs Product Tank. Column volumes fed to column in each cycle are based on Table 6-4.

2. Column liquid hold up assumed to be composed of LAW at the start of loading cycle (equivalent to end of Regenerant Displacement).

3. Total volume to Treated LAW Storage $=\mathrm{V}_{\text {load. }}$ Composition characterized by volume of $\mathrm{V}_{\text {load }}$ at $\mathrm{LAW}$ composition.

4. Total volume to Cs Product Tank $=1.5 \mathrm{CV}+1 \mathrm{CV}+15 \mathrm{BV}+1.3 \mathrm{BV}+3.3 \mathrm{BV}+1.03 \mathrm{CV}$. Composition characterized by volume of $1 \mathrm{LH}$ at LAW, $1.5 \mathrm{CV} 0.1 \mathrm{M}$ $\mathrm{NaOH}, 1 \mathrm{CV}$ water, $15 \mathrm{BV} 0.45 \mathrm{M}$ HNO3, 1.3 BV water, 3.3 BV Spent Regenerant, and (1.03 CV - 1 LH) LAW.

$\mathrm{V}_{\text {load }}=$ Loading cycle volume; $\mathrm{LH}=$ Liquid holdup in ion exchange column; $\mathrm{CV}=$ Column volume; $\mathrm{BV}=\mathrm{Bed}$ volume 
6.1.5.2 Continuous Material Balance Component Balances. The evaluation of characteristic volume and composition is combined with estimates of resin ion inventories to produce component balances describing the equivalent steady material flows for the ion exchange system.

6.1.5.2.1 Ion Transfer between Resin and Liquid Phase. The ion exchange resin adsorbs additional ions beyond cesium from waste that are subsequently eluted from the columns. For the IPS ion exchange configuration, these ions end up in process streams that are ultimately returned to DSTs for storage. Sodium, potassium, and cesium represent the dominant ion transferred from waste to the eluate by the ion exchange system. Figure 6-11 describes the ion transfer between the resin and liquid phase used as a basis for the material balance calculation. The ion transfers are summarized as follows:

- At the start of a loading cycle, resin loading of sodium and potassium ion is in equilibrium with the waste composition due to displacement of spent regenerant with LAW

- During the loading cycle, cesium ion is adsorbed by the resin, transferring an equi-molar quantity of sodium ion to the liquid phase

- No significant ion transfer between the resin and liquid phase is assumed to occur during the feed displacement and pre-elution rinse cycles

- During the elution cycle, cesium, sodium, and potassium ions are transferred to the liquid phase and replaced by hydrogen ion on the active resin sites

- No significant ion transfer between the resin and liquid phase is assumed to occur during the post-elution rinse cycle

- During the regeneration cycle, sodium ion is transferred from the liquid phase to the active resin sites, replacing hydrogen ion on the resin

- During the regenerant displacement cycle, potassium ion replaces some of the sodium ions on the active resin sites. In actual practice, additional hydrogen ion is displaced from resin sites during the initial contact of resin with waste due to the higher $\mathrm{pH}$ of waste solutions compared to the regeneration solution. This has been neglected for the material balance calculations. 
Figure 6-11 Description of Ion Transfer between Liquid Phase and Resin during an Ion Exchange Operating Cycle

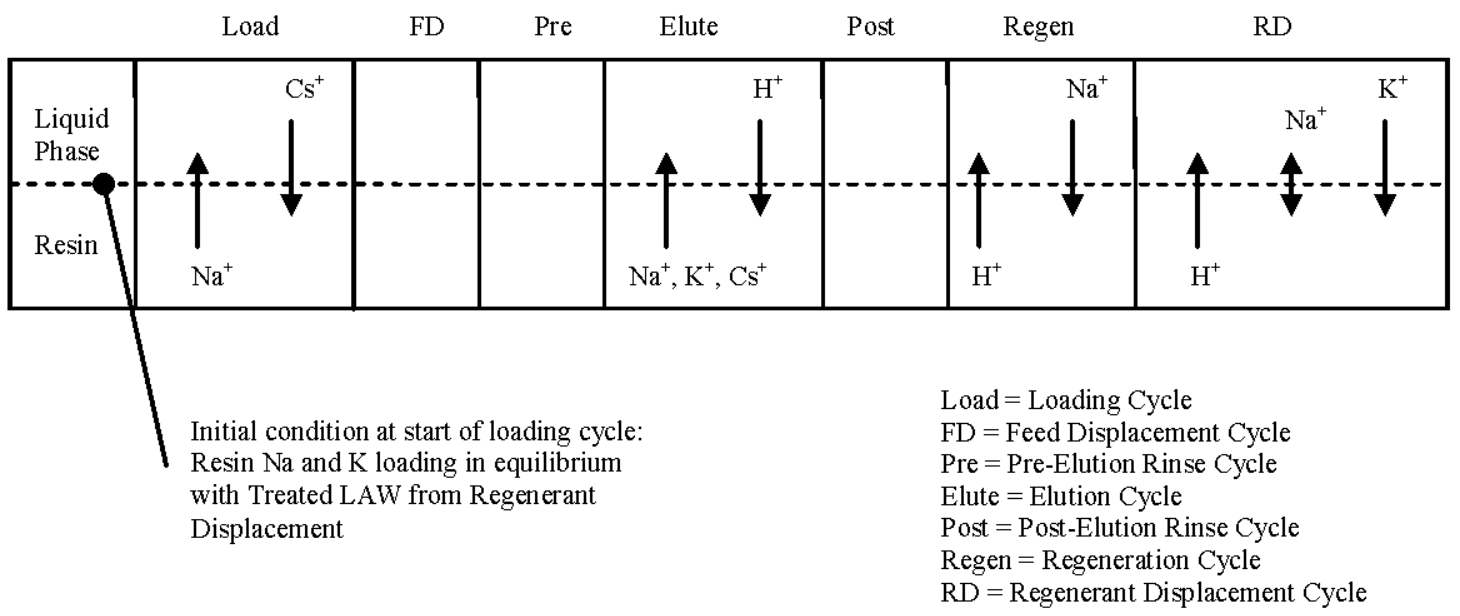

6.1.5.2.2 Ions Captured on Resin. The total resin capacity is a constant per unit mass of dry Hform resin in a column bed. Cations occupying resin sites are dominated by $\mathrm{H}^{+}, \mathrm{Na}^{+}, \mathrm{K}^{+}$, and $\mathrm{Cs}^{+}$. The fraction of total resin sites occupied by the different cations varies with liquid phase composition and ion mass transfer rates between the liquid phase and resin. For example, at the end of the loading cycle, the resin sites are occupied by a combination of $\mathrm{Na}^{+}, \mathrm{K}^{+}$, and $\mathrm{Cs}^{+}$, while the resin sites are occupied by $\mathrm{H}^{+}$at the end of the elution cycle. For the steady state material balance, the loading cycle volume and fractional recovery of cesium are provided as input for each material balance as described in Section 6.1.3.5 based on the waste composition for each IPS feed batch. These inputs allow calculation of the resin loading at the end of the loading cycle in each column.

Table 6-7 indicates that the total ion loading of a resin bed in waste solution is approximately:

TotalIon Capacity $=Q_{\text {resin }}=1.69 \frac{\text { gmol(orequivalent) }}{\text { L resin bed }}$

Therefore, for a single IPS resin bed in either the lead or polish position, the total ion loading is determined by Equation 6.1-1.

\section{Equation 6.1-1}

$$
\left.\mathrm{Q}_{\mathrm{tot}}=\mathbf{( 6 9 \frac { \mathrm { gmol } } { \mathrm { L } \text { resinbed } }} \zeta 14 \mathrm{~L}\right) 1037.7 \mathrm{gmol}
$$

The loading of $\mathrm{Na}, \mathrm{K}$, and $\mathrm{Cs}$ at the end of the loading cycle are defined to support the steady state material balance inputs. 
Let :

$\mathrm{C}_{\mathrm{Cs}, 4}=\mathrm{Cs}$ concentration in waste entering thelead column, gmol $\mathrm{Cs} / \mathrm{L}$

$\mathrm{E}_{1, \mathrm{k}}=\mathrm{Cs}$ loading on resin bed at theend of loading cycle, gmol

$\mathrm{E}_{2, \mathrm{k}}=\mathrm{Na}$ loading on resin bed at theend of loading cycle, gmol

$\mathrm{E}_{3, \mathrm{k}}=\mathrm{K}$ loading on resin bed at theend of loading cycle, gmol

$\varphi_{\mathrm{L}}=$ Fraction of Cesium entering thelead column that is captured on theresin bed

$\varphi_{\mathrm{P}}=$ Fraction of Cesium entering the polishing column that is captured on theresin bed where $\mathrm{k}=\mathrm{L}$ or $\mathrm{P}$ for theLead or Polishing column, respectively

The lead column resin cesium loading at the end of the loading cycle is determined by Equation 6.1-2.

\section{Equation 6.1-2}

$$
\mathrm{E}_{1, \mathrm{~L}}=\mathrm{V}_{\text {load }} \varphi_{\mathrm{L}} \mathrm{C}_{\mathrm{Cs}, 4}
$$

The polishing column resin cesium loading at the end of the loading cycle is determined by Equation 6.1-3.

\section{Equation 6.1-3}

$$
\mathrm{E}_{1, \mathrm{P}}=\mathrm{V}_{\text {load }} \varphi_{\mathrm{P}} \mathrm{C}_{\mathrm{Cs}, 5}=\mathrm{V}_{\text {load }} \varphi_{\mathrm{P}}<-\varphi_{\mathrm{L}} \zeta_{\mathrm{Cs}, 4}
$$

Potassium loaded on resin relative to the sodium loading has been correlated to the waste feed composition based on column test observations of eluate composition shown on Figure 23 of 24590-WTP-RPT-RT-07-005 by assuming potassium and sodium ion observed in eluate during column tests describes the resin loading of these ions. The correlation is shown as Equation 6.1-4.

\section{Equation 6.1-4}

$$
\left[\frac{\mathrm{K}}{\mathrm{Na}}\right]_{\mathrm{resin}}=\left\{5.887 \mathrm{e}^{-9.84\left[\frac{\mathrm{K}}{\mathrm{Na}}\right]_{\mathrm{Feed}}}+1\right\}\left[\frac{\mathrm{K}}{\mathrm{Na}}\right]_{\mathrm{Feed}}
$$

Equation 6.1-4 is used to estimate the resin loading of $\mathrm{Na}$ and $\mathrm{K}$ based on Equation 6.1-5. 


\section{Equation 6.1-5}

$$
\begin{aligned}
\mathrm{Q}_{\text {tot }}-\mathrm{E}_{1, \mathrm{k}} & =\mathrm{E}_{2, \mathrm{k}}+\mathrm{E}_{3, \mathrm{k}} \\
& =\left(1+\frac{\mathrm{E}_{3, \mathrm{k}}}{\mathrm{E}_{2, \mathrm{k}}}\right) \mathrm{E}_{2, \mathrm{k}} \\
& =\left(1+\left[\frac{\mathrm{K}}{\mathrm{Na}}\right]_{\mathrm{resin}}\right) \mathrm{E}_{2, \mathrm{k}}
\end{aligned}
$$

or

$$
E_{2, \mathrm{k}}=\frac{\mathrm{Q}_{\mathrm{tot}}-\mathrm{E}_{1, \mathrm{k}}}{\left(1+\left[\frac{\mathrm{K}}{\mathrm{Na}}\right]_{\text {resin }}\right)}
$$

and

$$
\mathrm{E}_{3, \mathrm{k}}=\left[\frac{\mathrm{K}}{\mathrm{Na}}\right]_{\text {resin }} \mathrm{E}_{2, \mathrm{k}}
$$

where $\mathrm{k}=\mathrm{L}$ or $\mathrm{P}$ for theLead or Polishing Column, respectively

6.1.5.2.3 Component Balances. Liquid phase component balances for each ion exchange cycle are developed on a batch basis and shown on Table 6-10 and Table 6-11 for the lead and polishing column, respectively. The liquid phase component balances include the influence of the change in liquid holdup composition and resin ion loading that occurs during completion of the ion exchange cycle. Table 6-12 indicates the basis for determining the equivalent steady state stream flow rate and compositions based on Table 6-8, Table 6-9, Table 6-10, and Table 6-11.

Actual calculations focus on determining the change in component concentrations in waste over the loading cycle. The change in cesium concentration across the polishing column during the loading cycle is determined based on Equation 6.1-6.

\section{Equation 6.1-6}

$$
\begin{aligned}
& \mathrm{C}_{\mathrm{Cs}, 7}=\mathrm{C}_{\mathrm{Cs}, 6}=\frac{\mathrm{N}_{\mathrm{Cs}, 6}}{\mathrm{~V}_{\text {load }}} \\
& \mathrm{C}_{\mathrm{Cs}, 7} \mathrm{~V}_{\text {load }}=\mathrm{N}_{\mathrm{Cs}, 6}=\mathrm{N}_{\mathrm{Cs}, 5}-\mathrm{I}_{\mathrm{LH}} \mathrm{C}_{\mathrm{Cs}, 5}\left(-\varphi_{\mathrm{P}} \succ \mathrm{V}_{\mathrm{LH}} \mathrm{C}_{\mathrm{Cs}, 7}\right] \mathbf{E}_{1, \mathrm{P}}-0_{-}^{-} \\
& \mathrm{C}_{\mathrm{Cs}, 7} \mathrm{~V}_{\text {load }}=\mathrm{V}_{\text {load }} \mathrm{C}_{\mathrm{Cs}, 5}-\mathrm{V}_{\mathrm{LH}} \mathrm{C}_{\mathrm{Cs}, 5}\left(-\varphi_{\mathrm{P}}\right) \mathrm{V}_{\mathrm{LH}} \mathrm{C}_{\mathrm{Cs}, 7}-\mathrm{E}_{1, \mathrm{P}} \\
& \boldsymbol{V}_{\text {load }}-\mathrm{V}_{\mathrm{LH}} \zeta_{\mathrm{Cs}, 7}=\mathrm{V}_{\text {load }} \mathrm{C}_{\mathrm{Cs}, 5}-\mathrm{V}_{\mathrm{LH}} \mathrm{C}_{\mathrm{Cs}, 5}\left(-\varphi_{\mathrm{P}}\right) \mathrm{V}_{\text {load }} \varphi_{\mathrm{P}} \mathrm{C}_{\mathrm{Cs}, 5} \\
& \mathbb{V}_{\text {load }}-\mathrm{V}_{\mathrm{LH}} \mathcal{S}_{\mathrm{Cs}, 7}=\mathrm{V}_{\text {load }} \mathrm{C}_{\mathrm{Cs}, 5}\left(-\varphi_{\mathrm{P}}\right)-\mathrm{V}_{\mathrm{LH}} \mathrm{C}_{\mathrm{Cs}, 5}\left(-\varphi_{\mathrm{P}}\right) \\
& \mathbb{V}_{\text {load }}-V_{\mathrm{LH}} \zeta_{\mathrm{Cs}, 7}=\mathbf{V}_{\text {load }}-\mathrm{V}_{\mathrm{LH}} \boldsymbol{\zeta}-\varphi_{\mathrm{P}} \zeta_{\mathrm{Cs}, 5} \\
& \mathrm{C}_{\mathrm{Cs}, 7}=\left(-\varphi_{\mathrm{P}} \boldsymbol{S}_{\mathrm{Cs}, 5}\right.
\end{aligned}
$$


Where:

$\mathrm{N}_{\mathrm{i}, \mathrm{j}}=$ gmol of component $\mathrm{i}$ in stream $\mathrm{j}$,

$\mathrm{C}_{\mathrm{i}, \mathrm{j}}=$ concentration of component $\mathrm{i}$ in stream $\mathrm{j}$, gmol/L,

$\mathrm{V}_{\text {load }}=$ loading cycle volume, $\mathrm{L}$,

$\mathrm{V}_{\mathrm{LH}}=$ column liquid holdup volume, $\mathrm{L}$,

$\mathrm{E}_{1, \mathrm{~L}}, \mathrm{E}_{2, \mathrm{~L}}$, and $\mathrm{E}_{3, \mathrm{~L}}=$ cesium, sodium, and potassium ion adsorbed on lead column resin bed, respectively, gmol ion, and

Stream numbers are defined on Figure 6-1 
Table 6-10 Lead Column Liquid Phase Component Balances for Operating Cycles

\begin{tabular}{|c|c|c|c|c|c|c|}
\hline \multirow{2}{*}{ Cycle } & \multirow{2}{*}{ Components } & \multicolumn{2}{|c|}{ Liquid Holdup, gmol } & \multicolumn{2}{|c|}{ Resin Ion Inventory, gmol } & \multirow{2}{*}{ Liquid Phase Balance } \\
\hline & & Start $\left(\mathrm{LH}_{\mathrm{S}}\right)$ & End $\left(\mathrm{LH}_{\mathrm{E}}\right)$ & $\operatorname{Start}\left(R_{S}\right)$ & $\operatorname{End}\left(R_{E}\right)$ & \\
\hline \multirow{4}{*}{ Loading } & $\mathrm{Cs}$ & $\mathrm{V}_{\mathrm{LH}} \mathrm{C}_{\mathrm{Cs}, 7}$ & $\mathrm{~V}_{\mathrm{LH}} \mathrm{C}_{\mathrm{Cs}, 4}\left(1-\varphi_{\mathrm{L}}\right)$ & 0 & $\mathrm{E}_{1, \mathrm{~L}}$ & \multirow{4}{*}{$\begin{array}{l}\text { Entering Column: } \\
\mathrm{N}_{\mathrm{i}, 4}=\mathrm{V}_{\text {load }} \mathrm{C}_{\mathrm{i}, 4} \\
\text { Column Effluent: } \\
\mathrm{N}_{\mathrm{i}, 5}=\mathrm{N}_{\mathrm{i}, 4}-\left(\mathrm{LH}_{\mathrm{E}, \mathrm{i}}-\mathrm{LH}_{\mathrm{S}, \mathrm{i}}\right)-\left(\mathrm{R}_{\mathrm{E}, \mathrm{i}}-\mathrm{R}_{\mathrm{S}, \mathrm{i}}\right)\end{array}$} \\
\hline & $\mathrm{Na}$ & $\mathrm{V}_{\mathrm{LH}} \mathrm{C}_{\mathrm{Na}, 7}$ & $\mathrm{~V}_{\mathrm{LH}} \mathrm{C}_{\mathrm{Na}, 4}$ & $E_{1, \mathrm{~L}}+E_{2, \mathrm{~L}}$ & $\mathrm{E}_{2, \mathrm{~L}}$ & \\
\hline & $\mathrm{K}$ & $\mathrm{V}_{\mathrm{LH}} \mathrm{C}_{\mathrm{K}, 7}$ & $\mathrm{~V}_{\mathrm{LH}} \mathrm{C}_{\mathrm{K}, 4}$ & $\mathrm{E}_{3, \mathrm{~L}}$ & $\mathrm{E}_{3, \mathrm{~L}}$ & \\
\hline & Other Ions & $\mathrm{V}_{\mathrm{LH}} \mathrm{C}_{\mathrm{i}, 7}$ & $\mathrm{~V}_{\mathrm{LH}} \mathrm{C}_{\mathrm{i}, 4}$ & - & - & \\
\hline \multirow{4}{*}{$\begin{array}{l}\text { Feed } \\
\text { Displacement }\end{array}$} & Cs & $\mathrm{V}_{\mathrm{LH}} \mathrm{C}_{\mathrm{Cs}, 4} \varphi_{\mathrm{L}}$ & $\mathrm{V}_{\mathrm{LH}} \mathrm{C}_{\mathrm{i}, 102}$ & $\mathrm{E}_{1, \mathrm{~L}}$ & $\mathrm{E}_{1, \mathrm{~L}}$ & \multirow{4}{*}{$\begin{array}{l}\text { Entering Column: } \\
\mathrm{N}_{\mathrm{i}, 102}=1.5(\mathrm{CV}) \mathrm{C}_{\mathrm{i}, 102} \\
\text { Column Effluent: } \\
\mathrm{N}_{\mathrm{i}, 8 \mathrm{a}}=\mathrm{N}_{\mathrm{i}, 102}-\left(\mathrm{LH}_{\mathrm{E}, \mathrm{i}}-\mathrm{LH}_{\mathrm{S}, \mathrm{i}}\right)-\left(\mathrm{R}_{\mathrm{E}, \mathrm{i}}-\mathrm{R}_{\mathrm{S}, \mathrm{i}}\right)\end{array}$} \\
\hline & $\mathrm{Na}$ & $\mathrm{V}_{\mathrm{LH}} \mathrm{C}_{\mathrm{Na}, 4}$ & $\mathrm{~V}_{\mathrm{LH}} \mathrm{C}_{\mathrm{i}, 102}$ & $\mathrm{E}_{2, \mathrm{~L}}$ & $\mathrm{E}_{2, \mathrm{~L}}$ & \\
\hline & $\mathrm{K}$ & $\mathrm{V}_{\mathrm{LH}} \mathrm{C}_{\mathrm{K}, 4}$ & $\mathrm{~V}_{\mathrm{LH}} \mathrm{C}_{\mathrm{i}, 102}$ & $\mathrm{E}_{3, \mathrm{~L}}$ & $\mathrm{E}_{3, \mathrm{~L}}$ & \\
\hline & Other Ions & $\mathrm{V}_{\mathrm{LH}} \mathrm{C}_{\mathrm{i}, 4}$ & $\mathrm{~V}_{\mathrm{LH}} \mathrm{C}_{\mathrm{i}, 102}$ & - & - & \\
\hline \multirow{4}{*}{$\begin{array}{l}\text { Pre-Elution } \\
\text { Rinse }\end{array}$} & $\mathrm{Cs}$ & \multirow{4}{*}{$\mathrm{V}_{\mathrm{LH}} \mathrm{C}_{\mathrm{i}, 102}$} & \multirow{4}{*}{$\mathrm{V}_{\mathrm{LH}} \mathrm{C}_{\mathrm{i}, 104}$} & $\mathrm{E}_{1, \mathrm{~L}}$ & $\mathrm{E}_{1, \mathrm{~L}}$ & \multirow{4}{*}{$\begin{array}{l}\text { Entering Column: } \\
\mathrm{N}_{\mathrm{i}, 104 \mathrm{a}}=1(\mathrm{CV}) \mathrm{C}_{\mathrm{i}, 104} \\
\text { Column Effluent: } \\
\mathrm{N}_{\mathrm{i}, 8 \mathrm{~b}}=\mathrm{N}_{\mathrm{i}, 104 \mathrm{a}}-\left(\mathrm{LH}_{\mathrm{E}, \mathrm{i}}-\mathrm{LH}_{\mathrm{S}, \mathrm{i}}\right)-\left(\mathrm{R}_{\mathrm{E}, \mathrm{i}}-\mathrm{R}_{\mathrm{S}, \mathrm{i}}\right)\end{array}$} \\
\hline & $\mathrm{Na}$ & & & $\mathrm{E}_{2, \mathrm{~L}}$ & $\mathrm{E}_{2, \mathrm{~L}}$ & \\
\hline & $\mathrm{K}$ & & & $E_{3, L}$ & $\mathrm{E}_{3, \mathrm{~L}}$ & \\
\hline & Other Ions & & & - & - & \\
\hline \multirow{4}{*}{ Elution } & $\mathrm{Cs}$ & \multirow{4}{*}{$\mathrm{V}_{\mathrm{LH}} \mathrm{C}_{\mathrm{i}, 104}$} & \multirow{4}{*}{$\mathrm{V}_{\mathrm{LH}} \mathrm{C}_{\mathrm{i}, 103}$} & $\mathrm{E}_{1, \mathrm{~L}}$ & 0 & \multirow{4}{*}{$\begin{array}{l}\text { Entering Column: } \\
\mathrm{N}_{\mathrm{i}, 103}=15(\mathrm{BV}) \mathrm{C}_{\mathrm{i}, 103} \\
\text { Column Effluent: } \\
\mathrm{N}_{\mathrm{i}, 8 \mathrm{c}}=\mathrm{N}_{\mathrm{i}, 103}-\left(\mathrm{LH}_{\mathrm{E}, \mathrm{i}}-\mathrm{LH}_{\mathrm{S}, \mathrm{i}}\right)-\left(\mathrm{R}_{\mathrm{E}, \mathrm{i}}-\mathrm{R}_{\mathrm{S}, \mathrm{i}}\right)\end{array}$} \\
\hline & $\mathrm{Na}$ & & & $\mathrm{E}_{2, \mathrm{~L}}$ & 0 & \\
\hline & $\mathrm{K}$ & & & $E_{3, L}$ & 0 & \\
\hline & Other Ions & & & - & - & \\
\hline \multirow{4}{*}{$\begin{array}{l}\text { Post-Elution } \\
\text { Rinse }\end{array}$} & $\mathrm{Cs}$ & \multirow{4}{*}{$\mathrm{V}_{\mathrm{LH}} \mathrm{C}_{\mathrm{i}, 103}$} & \multirow{4}{*}{$\mathrm{V}_{\mathrm{LH}} \mathrm{C}_{\mathrm{i}, 104}$} & 0 & 0 & \multirow{4}{*}{$\begin{array}{l}\text { Entering Column: } \\
\mathrm{N}_{\mathrm{i}, 104 \mathrm{~b}}=1.3(\mathrm{CV}) \mathrm{C}_{\mathrm{i}, 104} \\
\text { Column Effluent: } \\
\mathrm{N}_{\mathrm{i}, 8 \mathrm{~d}}=\mathrm{N}_{\mathrm{i}, 104 \mathrm{~b}}-\left(\mathrm{LH}_{\mathrm{E}, \mathrm{i}}-\mathrm{LH}_{\mathrm{S}, \mathrm{i}}\right)-\left(\mathrm{R}_{\mathrm{E}, \mathrm{i}}-\mathrm{R}_{\mathrm{S}, \mathrm{i}}\right)\end{array}$} \\
\hline & $\mathrm{Na}$ & & & 0 & 0 & \\
\hline & $\mathrm{K}$ & & & 0 & 0 & \\
\hline & Other Ions & & & - & - & \\
\hline \multirow{4}{*}{ Regeneration } & Cs & \multirow{4}{*}{$\mathrm{V}_{\mathrm{LH}} \mathrm{C}_{\mathrm{i}, 104}$} & \multirow{4}{*}{$\mathrm{V}_{\mathrm{LH}} \mathrm{C}_{\mathrm{i}, 108}$} & 0 & 0 & \multirow{4}{*}{$\begin{array}{l}\text { Entering Column: } \\
\mathrm{N}_{\mathrm{i}, 108}=3.3 \text { (BV) } \mathrm{C}_{\mathrm{i}, 108} \\
\text { Column Effluent: } \\
\mathrm{N}_{\mathrm{i}, \mathrm{ee}}=\mathrm{N}_{\mathrm{i}, 108}-\left(\mathrm{LH}_{\mathrm{E}, \mathrm{i}}-\mathrm{LH}_{\mathrm{S}, \mathrm{i}}\right)-\left(\mathrm{R}_{\mathrm{E}, \mathrm{i}}-\mathrm{R}_{\mathrm{S}, \mathrm{i}}\right)\end{array}$} \\
\hline & $\mathrm{Na}$ & & & 0 & $E_{1, L}+E_{2, L}+E_{3, L}$ & \\
\hline & $\mathrm{K}$ & & & 0 & 0 & \\
\hline & Other Ions & & & - & - & \\
\hline \multirow{4}{*}{$\begin{array}{l}\text { Regenerant } \\
\text { Displacement }\end{array}$} & $\mathrm{Cs}$ & $\mathrm{V}_{\mathrm{LH}} \mathrm{C}_{\mathrm{Cs}, 108}$ & $\mathrm{~V}_{\mathrm{LH}} \mathrm{C}_{\mathrm{Cs}, 7}$ & 0 & 0 & \multirow{4}{*}{$\begin{array}{l}\text { Entering Column: } \\
\mathrm{N}_{\mathrm{i}, 30}=1.03(\mathrm{CV}) \mathrm{C}_{\mathrm{i}, 7} \\
\text { Column Effluent: } \\
\mathrm{N}_{\mathrm{i}, 8 \mathrm{f}}=\mathrm{N}_{\mathrm{i}, 30}-\left(\mathrm{LH}_{\mathrm{E}, \mathrm{i}}-\mathrm{LH}_{\mathrm{S}, \mathrm{i}}\right)-\left(\mathrm{R}_{\mathrm{E}, \mathrm{i}}-\mathrm{R}_{\mathrm{S}, \mathrm{i}}\right)\end{array}$} \\
\hline & $\mathrm{Na}$ & $\mathrm{V}_{\mathrm{LH}} \mathrm{C}_{\mathrm{Na}, 108}$ & $\mathrm{~V}_{\mathrm{LH}} \mathrm{C}_{\mathrm{Na}, 7}$ & $\mathrm{E}_{1, \mathrm{~L}}+\mathrm{E}_{2, \mathrm{~L}}+\mathrm{E}_{3, \mathrm{~L}}$ & $E_{1, L}+E_{2, L}$ & \\
\hline & $\mathrm{K}$ & $\mathrm{V}_{\mathrm{LH}} \mathrm{C}_{\mathrm{K}, 108}$ & $\mathrm{~V}_{\mathrm{LH}} \mathrm{C}_{\mathrm{K}, 7}$ & 0 & $E_{3, \mathrm{~L}}$ & \\
\hline & Other Ions & $\mathrm{V}_{\mathrm{LH}} \mathrm{C}_{\mathrm{i}, 108}$ & $\mathrm{~V}_{\mathrm{LH}} \mathrm{C}_{\mathrm{i}, 7}$ & - & - & \\
\hline
\end{tabular}

Notes:

1. $\mathrm{N}_{\mathrm{i}, \mathrm{j}}=$ gmol of component $\mathrm{i}$ in stream $\mathrm{j} . \mathrm{C}_{\mathrm{i}, \mathrm{j}}=$ concentration of component $\mathrm{i}$ in stream $\mathrm{j}$, gmol/L. $\mathrm{V}_{\text {load }}=$ loading cycle volume, $\mathrm{L}$. $\mathrm{V}_{\mathrm{LH}}=$ column liquid holdup volume, $\mathrm{L} . \mathrm{E}_{1, \mathrm{~L}}, \mathrm{E}_{2, \mathrm{~L}}$, and $\mathrm{E}_{3, \mathrm{~L}}=$ cesium, sodium, and potassium ion adsorbed on lead column resin bed, respectively, gmol ion

2. Stream numbers are defined on Figure 6-1 
Table 6-11 Polishing Column Liquid Phase Component Balances for Operating Cycles

\begin{tabular}{|c|c|c|c|c|c|c|}
\hline \multirow{2}{*}{ Cycle } & \multirow{2}{*}{ Components } & \multicolumn{2}{|c|}{ Liquid Holdup, gmol } & \multicolumn{2}{|c|}{ Resin Ion Inventory, gmol } & \multirow{2}{*}{ Liquid Phase Balance } \\
\hline & & $\operatorname{Start}\left(\mathrm{LH}_{\mathrm{S}}\right)$ & End $\left(\mathrm{LH}_{\mathrm{E}}\right)$ & $\operatorname{Start}\left(R_{\mathrm{S}}\right)$ & End $\left(R_{E}\right)$ & \\
\hline \multirow{4}{*}{ Loading } & $\mathrm{Cs}$ & $\mathrm{V}_{\mathrm{LH}} \mathrm{C}_{\mathrm{Cs}, 7}$ & $\mathrm{~V}_{\mathrm{LH}} \mathrm{C}_{\mathrm{Cs}, 5}\left(1-\varphi_{\mathrm{P}}\right)$ & 0 & $\mathrm{E}_{1, \mathrm{P}}$ & \multirow{4}{*}{$\begin{array}{l}\text { Entering Column: } \\
\mathrm{N}_{\mathrm{i}, 5}=\mathrm{V}_{\text {load }} \mathrm{C}_{\mathrm{i}, 5} \\
\text { Column Effluent: } \\
\mathrm{N}_{\mathrm{i}, 6}=\mathrm{N}_{\mathrm{i}, 5}-\left(\mathrm{LH}_{\mathrm{E}, \mathrm{i}}-\mathrm{LH}_{\mathrm{S}, \mathrm{i}}\right)-\left(\mathrm{R}_{\mathrm{E}, \mathrm{i}}-\mathrm{R}_{\mathrm{S}, \mathrm{i}}\right) \\
\end{array}$} \\
\hline & $\mathrm{Na}$ & $\mathrm{V}_{\mathrm{LH}} \mathrm{C}_{\mathrm{Na}, 7}$ & $\mathrm{~V}_{\mathrm{LH}} \mathrm{C}_{\mathrm{Na}, 5}$ & $\mathrm{E}_{1, \mathrm{P}}+\mathrm{E}_{2, \mathrm{P}}$ & $E_{2, P}$ & \\
\hline & $\mathrm{K}$ & $\mathrm{V}_{\mathrm{LH}} \mathrm{C}_{\mathrm{K}, 7}$ & $\mathrm{~V}_{\mathrm{LH}} \mathrm{C}_{\mathrm{K}, 5}$ & $\mathrm{E}_{3, \mathrm{P}}$ & $E_{3, P}$ & \\
\hline & Other Ions & $\mathrm{V}_{\mathrm{LH}} \mathrm{C}_{\mathrm{i}, 7}$ & $\mathrm{~V}_{\mathrm{LH}} \mathrm{C}_{\mathrm{i}, 5}$ & - & - & \\
\hline \multirow{4}{*}{$\begin{array}{l}\text { Feed } \\
\text { Displacement }\end{array}$} & $\mathrm{Cs}$ & $\mathrm{V}_{\mathrm{LH}} \mathrm{C}_{\mathrm{Cs}, 5} \varphi_{\mathrm{P}}$ & $\mathrm{V}_{\mathrm{LH}} \mathrm{C}_{\mathrm{i}, 105}$ & $\mathrm{E}_{1, \mathrm{P}}$ & $\mathrm{E}_{1, \mathrm{P}}$ & \multirow{4}{*}{$\begin{array}{l}\text { Entering Column: } \\
\mathrm{N}_{\mathrm{i}, 105}=1.5(\mathrm{CV}) \mathrm{C}_{\mathrm{i}, 105} \\
\text { Column Effluent: } \\
\mathrm{N}_{\mathrm{i}, 9 \mathrm{a}}=\mathrm{N}_{\mathrm{i}, 105}-\left(\mathrm{LH}_{\mathrm{E}, \mathrm{i}}-\mathrm{LH}_{\mathrm{S}, \mathrm{i}}\right)-\left(\mathrm{R}_{\mathrm{E}, \mathrm{i}}-\mathrm{R}_{\mathrm{S}, \mathrm{i}}\right)\end{array}$} \\
\hline & $\mathrm{Na}$ & $\mathrm{V}_{\mathrm{LH}} \mathrm{C}_{\mathrm{Na}, 5}$ & $\mathrm{~V}_{\mathrm{LH}} \mathrm{C}_{\mathrm{i}, 105}$ & $\mathrm{E}_{2, \mathrm{P}}$ & $\mathrm{E}_{2, \mathrm{P}}$ & \\
\hline & $\mathrm{K}$ & $\mathrm{V}_{\mathrm{LH}} \mathrm{C}_{\mathrm{K}, 5}$ & $\mathrm{~V}_{\mathrm{LH}} \mathrm{C}_{\mathrm{i}, 105}$ & $E_{3, P}$ & $\mathrm{E}_{3, \mathrm{P}}$ & \\
\hline & Other Ions & $\mathrm{V}_{\mathrm{LH}} \mathrm{C}_{\mathrm{i}, 5}$ & $\mathrm{~V}_{\mathrm{LH}} \mathrm{C}_{\mathrm{i}, 105}$ & - & - & \\
\hline \multirow{4}{*}{$\begin{array}{l}\text { Pre-Elution } \\
\text { Rinse }\end{array}$} & $\mathrm{Cs}$ & \multirow{4}{*}{$\mathrm{V}_{\mathrm{LH}} \mathrm{C}_{\mathrm{i}, 105}$} & \multirow{4}{*}{$\mathrm{V}_{\mathrm{LH}} \mathrm{C}_{\mathrm{i}, 107}$} & $\mathrm{E}_{1, \mathrm{P}}$ & $\mathrm{E}_{1, \mathrm{P}}$ & \multirow{4}{*}{$\begin{array}{l}\text { Entering Column: } \\
\mathrm{N}_{\mathrm{i}, 107 \mathrm{a}}=1(\mathrm{CV}) \mathrm{C}_{\mathrm{i}, 107} \\
\text { Column Effluent: } \\
\mathrm{N}_{\mathrm{i}, \mathrm{b}}=\mathrm{N}_{\mathrm{i}, 107 \mathrm{a}}-\left(\mathrm{LH}_{\mathrm{E}, \mathrm{i}}-\mathrm{LH}_{\mathrm{S}, \mathrm{i}}\right)-\left(\mathrm{R}_{\mathrm{E}, \mathrm{i}}-\mathrm{R}_{\mathrm{S}, \mathrm{i}}\right)\end{array}$} \\
\hline & $\mathrm{Na}$ & & & $E_{2, P}$ & $E_{2, P}$ & \\
\hline & $\mathrm{K}$ & & & $\mathrm{E}_{3, \mathrm{P}}$ & $\mathrm{E}_{3, \mathrm{P}}$ & \\
\hline & Other Ions & & & - & - & \\
\hline \multirow{4}{*}{ Elution } & $\mathrm{Cs}$ & \multirow{4}{*}{$\mathrm{V}_{\mathrm{LH}} \mathrm{C}_{\mathrm{i}, 107}$} & \multirow{4}{*}{$\mathrm{V}_{\mathrm{LH}} \mathrm{C}_{\mathrm{i}, 106}$} & $\mathrm{E}_{1, \mathrm{P}}$ & 0 & \multirow{4}{*}{$\begin{array}{l}\text { Entering Column: } \\
\mathrm{N}_{\mathrm{i}, 106}=15 \text { (BV) } \mathrm{C}_{\mathrm{i}, 106} \\
\text { Column Effluent: } \\
\mathrm{N}_{\mathrm{i}, 9_{\mathrm{c}}}=\mathrm{N}_{\mathrm{i}, 103}-\left(\mathrm{LH}_{\mathrm{E}, \mathrm{i}}-\mathrm{LH}_{\mathrm{S}, \mathrm{i}}\right)-\left(\mathrm{R}_{\mathrm{E}, \mathrm{i}}-\mathrm{R}_{\mathrm{S}, \mathrm{i}}\right)\end{array}$} \\
\hline & $\mathrm{Na}$ & & & $E_{2, P}$ & 0 & \\
\hline & $\mathrm{K}$ & & & $E_{3, P}$ & 0 & \\
\hline & Other Ions & & & - & - & \\
\hline \multirow{4}{*}{$\begin{array}{l}\text { Post-Elution } \\
\text { Rinse }\end{array}$} & $\mathrm{Cs}$ & \multirow{4}{*}{$\mathrm{V}_{\mathrm{LH}} \mathrm{C}_{\mathrm{i}, 106}$} & \multirow{4}{*}{$\mathrm{V}_{\mathrm{LH}} \mathrm{C}_{\mathrm{i}, 107}$} & 0 & 0 & \multirow{4}{*}{$\begin{array}{l}\text { Entering Column: } \\
\mathrm{N}_{\mathrm{i}, 107 \mathrm{~b}}=1.3(\mathrm{CV}) \mathrm{C}_{\mathrm{i}, 107} \\
\text { Column Effluent: } \\
\mathrm{N}_{\mathrm{i}, \mathrm{d}}=\mathrm{N}_{\mathrm{i}, 107 \mathrm{~b}}-\left(\mathrm{LH}_{\mathrm{E}, \mathrm{i}}-\mathrm{LH}_{\mathrm{S}, \mathrm{i}}\right)-\left(\mathrm{R}_{\mathrm{E}, \mathrm{i}}-\mathrm{R}_{\mathrm{S}, \mathrm{i}}\right)\end{array}$} \\
\hline & $\mathrm{Na}$ & & & 0 & 0 & \\
\hline & $\mathrm{K}$ & & & 0 & 0 & \\
\hline & Other Ions & & & - & - & \\
\hline \multirow{4}{*}{ Regeneration } & $\mathrm{Cs}$ & \multirow{4}{*}{$\mathrm{V}_{\mathrm{LH}} \mathrm{C}_{\mathrm{i}, 107}$} & \multirow{4}{*}{$\mathrm{V}_{\mathrm{LH}} \mathrm{C}_{\mathrm{i}, 109}$} & 0 & 0 & \multirow{4}{*}{$\begin{array}{l}\text { Entering Column: } \\
\mathrm{N}_{\mathrm{i}, 109}=3.3 \text { (BV) } \mathrm{C}_{\mathrm{i}, 109} \\
\text { Column Effluent: } \\
\mathrm{N}_{\mathrm{i}, \mathrm{e}}=\mathrm{N}_{\mathrm{i}, 109}-\left(\mathrm{LH}_{\mathrm{E}, \mathrm{i}}-\mathrm{LH}_{\mathrm{S}, \mathrm{i}}\right)-\left(\mathrm{R}_{\mathrm{E}, \mathrm{i}}-\mathrm{R}_{\mathrm{S}, \mathrm{i}}\right)\end{array}$} \\
\hline & $\mathrm{Na}$ & & & 0 & $\mathrm{E}_{1, \mathrm{P}}+\mathrm{E}_{2, \mathrm{P}}+\mathrm{E}_{3, \mathrm{P}}$ & \\
\hline & $\mathrm{K}$ & & & 0 & 0 & \\
\hline & Other Ions & & & - & - & \\
\hline \multirow{4}{*}{$\begin{array}{l}\text { Regenerant } \\
\text { Displacement }\end{array}$} & $\mathrm{Cs}$ & $\mathrm{V}_{\mathrm{LH}} \mathrm{C}_{\mathrm{Cs}, 109}$ & $\mathrm{~V}_{\mathrm{LH}} \mathrm{C}_{\mathrm{Cs}, 7}$ & 0 & 0 & \multirow{4}{*}{$\begin{array}{l}\text { Entering Column: } \\
\mathrm{N}_{\mathrm{i}, 31}=1.03(\mathrm{CV}) \mathrm{C}_{\mathrm{i}, 7} \\
\text { Column Effluent: } \\
\mathrm{N}_{\mathrm{i}, \mathrm{f}}=\mathrm{N}_{\mathrm{i}, 31}-\left(\mathrm{LH}_{\mathrm{E}, \mathrm{i}}-\mathrm{LH}_{\mathrm{S}, \mathrm{i}}\right)-\left(\mathrm{R}_{\mathrm{E}, \mathrm{i}}-\mathrm{R}_{\mathrm{S}, \mathrm{i}}\right)\end{array}$} \\
\hline & $\mathrm{Na}$ & $\mathrm{V}_{\mathrm{LH}} \mathrm{C}_{\mathrm{Na}, 109}$ & $\mathrm{~V}_{\mathrm{LH}} \mathrm{C}_{\mathrm{Na}, 7}$ & $\mathrm{E}_{1, \mathrm{P}}+\mathrm{E}_{2, \mathrm{P}}+\mathrm{E}_{3, \mathrm{P}}$ & $\mathrm{E}_{1, \mathrm{P}}+\mathrm{E}_{2, \mathrm{P}}$ & \\
\hline & $\mathrm{K}$ & $\mathrm{V}_{\mathrm{LH}} \mathrm{C}_{\mathrm{K}, 109}$ & $\mathrm{~V}_{\mathrm{LH}} \mathrm{C}_{\mathrm{K}, 7}$ & 0 & $E_{3, P}$ & \\
\hline & Other Ions & $\mathrm{V}_{\mathrm{LH}} \mathrm{C}_{\mathrm{i}, 109}$ & $\mathrm{~V}_{\mathrm{LH}} \mathrm{C}_{\mathrm{i}, 7}$ & - & - & \\
\hline
\end{tabular}

Notes:

1. $\mathrm{N}_{\mathrm{i}, \mathrm{j}}=$ gmol of component $\mathrm{i}$ in stream $\mathrm{j} . \mathrm{C}_{\mathrm{i}, \mathrm{j}}=$ concentration of component $\mathrm{i}$ in stream $\mathrm{j}$, gmol/L. $\mathrm{V}_{\text {load }}=$ loading cycle volume, $\mathrm{L}$. $\mathrm{V}_{\mathrm{LH}}=$ column liquid holdup volume, $\mathrm{L} . \mathrm{E}_{1, \mathrm{P}}, \mathrm{E}_{2, \mathrm{P}}$, and $\mathrm{E}_{3, \mathrm{P}}=$ cesium, sodium, and potassium ion adsorbed on polishing column resin bed, respectively, gmol ion.

2. Stream numbers are defined on Figure 6-1 
Table 6-12 Steady State Material Balance Stream Flows and Component Concentrations

\begin{tabular}{|c|c|c|}
\hline Stream Number & Volumetric Flow Rate & Component Concentrations \\
\hline \multicolumn{3}{|l|}{ Lead Column } \\
\hline 5 & $\mathrm{~V}_{\text {rate }}$ & $\mathrm{N}_{\mathrm{i}, 5} / \mathrm{V}_{\text {load }}$ \\
\hline 8 & $\begin{array}{l}(1.5 \times \mathrm{CV}+1 \times \mathrm{CV}+15 \times \mathrm{BV}+1.3 \times \mathrm{CV}+3.3 \times \mathrm{BV}+1.03 \times \mathrm{CV}) \times \\
\left(\mathrm{V}_{\text {rate }} / \mathrm{V}_{\text {load }}\right)\end{array}$ & $\begin{array}{l}\left(\mathrm{N}_{\mathrm{i}, 8 \mathrm{a}}+\mathrm{N}_{\mathrm{i}, 8 \mathrm{~b}}+\mathrm{N}_{\mathrm{i}, 8 \mathrm{e}}+\mathrm{N}_{\mathrm{i}, 8 \mathrm{~d}}+\mathrm{N}_{\mathrm{i}, 8 \mathrm{e}}+\mathrm{N}_{\mathrm{i}, 8 \mathrm{f}}\right) / \\
(1.5 \times \mathrm{CV}+1 \times \mathrm{CV}+15 \times \mathrm{BV}+1.3 \times \mathrm{CV}+3.3 \times \mathrm{BV}+1.03 \times \mathrm{CV}) \\
\end{array}$ \\
\hline 30 & $(1.03 \times \mathrm{CV})\left(\mathrm{v}_{\mathrm{rate}} / \mathrm{V}_{\text {load }}\right)$ & ( \\
\hline 102 & $(1.5 \times \mathrm{CV})\left(\mathrm{v}_{\mathrm{rate}} / \mathrm{V}_{\text {load }}\right)$ & $\mathrm{C}_{\mathrm{i}, 102}$ \\
\hline 103 & $(15 \times \mathrm{BV})\left(\mathrm{v}_{\text {rate }} / \mathrm{V}_{\text {load }}\right)$ & $\mathrm{C}_{\mathrm{i}, 103}$ \\
\hline 104 & $(1 \times \mathrm{CV}+1.3 \times \mathrm{CV})\left(\mathrm{v}_{\text {rate }} / \mathrm{V}_{\text {load }}\right)$ & $\mathrm{C}_{\mathrm{i}, 104}$ \\
\hline 108 & $(3.3 \times \mathrm{BV})\left(\mathrm{v}_{\mathrm{rate}} / \mathrm{V}_{\text {load }}\right)$ & $\mathrm{C}_{\mathrm{i}, 108}$ \\
\hline \multicolumn{3}{|l|}{ Polishing Column } \\
\hline 6 & $\mathrm{~V}_{\text {rate }}$ & $\mathrm{N}_{\mathrm{i}, 6} / \mathrm{V}_{\text {load }}$ \\
\hline 9 & $\begin{array}{l}(1.5 \times \mathrm{CV}+1 \times \mathrm{CV}+15 \times \mathrm{BV}+1.3 \times \mathrm{CV}+3.3 \times \mathrm{BV}+1.03 \times \mathrm{CV}) \times \\
\left(\mathrm{V}_{\text {rate }} / \mathrm{V}_{\text {load }}\right)\end{array}$ & $\begin{array}{l}\left(\mathrm{N}_{\mathrm{i}, 9 \mathrm{a}}+\mathrm{N}_{\mathrm{i}, 9 \mathrm{~b}}+\mathrm{N}_{\mathrm{i}, 9 \mathrm{c}}+\mathrm{N}_{\mathrm{i}, 9 \mathrm{~d}}+\mathrm{N}_{\mathrm{i}, 9 \mathrm{e}}+\mathrm{N}_{\mathrm{i}, 9 \mathrm{f}}\right) / \\
(1.5 \times \mathrm{CV}+1 \times \mathrm{CV}+15 \times \mathrm{BV}+1.3 \times \mathrm{CV}+3.3 \times \mathrm{BV}+1.03 \times \mathrm{CV})\end{array}$ \\
\hline 31 & $(1.03 \times \mathrm{CV})\left(\mathrm{v}_{\text {rate }} / \mathrm{V}_{\text {load }}\right)$ & $\mathrm{C}_{\mathrm{i}, 7}$ \\
\hline 105 & $(1.5 \times \mathrm{CV})\left(\mathrm{V}_{\text {rate }} / \mathrm{V}_{\text {load }}\right)$ & $\mathrm{C}_{\mathrm{i}, 105}$ \\
\hline 106 & $(15 \times \mathrm{BV})\left(\mathrm{v}_{\text {rate }} / \mathrm{V}_{\text {load }}\right)$ & $\mathrm{C}_{\mathrm{i}, 106}$ \\
\hline 107 & $(1 \times \mathrm{CV}+1.3 \times \mathrm{CV})\left(\mathrm{v}_{\text {rate }} / \mathrm{V}_{\text {load }}\right)$ & $\mathrm{C}_{\mathrm{i}, 107}$ \\
\hline 109 & $(3.3 \times \mathrm{BV})\left(\mathrm{v}_{\mathrm{rate}} / \mathrm{V}_{\text {load }}\right)$ & $\mathrm{C}_{\mathrm{i}, 109}$ \\
\hline
\end{tabular}

1. $\mathrm{V}_{\text {rate }}=$ steady state volumetric flow rate of waste feed to ion exchange system in Stream 4. Stream numbers are identified on Figure 6-1

2. $\mathrm{N}_{\mathrm{i}, \mathrm{j}}=$ gmol of component $\mathrm{i}$ in stream $\mathrm{j}$ and are defined in Table 6-9 and Table 6-10.

3. $\mathrm{C}_{\mathrm{i}, \mathrm{j}}=$ concentration of component $\mathrm{i}$ in stream $\mathrm{j}$, gmol $/ \mathrm{L} . \mathrm{V}_{\text {load }}=$ loading cycle volume, $\mathrm{L}$.

4. $\mathrm{CV}=$ column volume, $\mathrm{L} . \mathrm{BV}=$ resin bed volume, $\mathrm{L}$. 
The change in cesium concentration across the lead column during the loading cycle is determined by Equation 6.1-7.

Equation 6.1-7

$$
\begin{aligned}
& \left.\mathrm{V}_{\text {load }} \mathrm{C}_{\mathrm{Cs}, 5}=\mathrm{N}_{\mathrm{Cs}, 5}=\mathrm{N}_{\mathrm{Cs}, 4}-\mathbf{V}_{\mathrm{LH}} \mathrm{C}_{\mathrm{Cs}, 4}\left(1-\varphi_{\mathrm{L}}\right)-\mathrm{V}_{\mathrm{LH}} \mathrm{C}_{\mathrm{Cs}, 7} \neq \mathbf{E}_{1, \mathrm{~L}}-0\right\rfloor \\
& \mathrm{V}_{\text {lo ad }} \mathrm{C}_{\mathrm{Cs}, 5}=\mathrm{V}_{\text {load }} \mathrm{C}_{\mathrm{Cs}, 4}-\mathrm{V}_{\mathrm{LH}} \mathrm{C}_{\mathrm{Cs}, 4}\left(1-\varphi_{\mathrm{L}}\right)+\mathrm{V}_{\mathrm{LH}} \mathrm{C}_{\mathrm{Cs}, 7}-\mathrm{V}_{\text {load }} \varphi_{\mathrm{L}} \mathrm{Cs}_{\mathrm{Cs}, 4} \\
& \mathrm{~V}_{\text {load }} \mathrm{C}_{\mathrm{Cs}, 5}=\mathrm{V}_{\text {load }} \mathrm{C}_{\mathrm{Cs}, 4}-\mathrm{V}_{\mathrm{LH}} \mathrm{C}_{\mathrm{Cs}, 4}\left(1-\varphi_{\mathrm{L}}\right)+\mathrm{V}_{\mathrm{LH}}\left(-\varphi_{\mathrm{P}} \mathcal{C}_{\mathrm{Cs}, 5}-\mathrm{V}_{\text {load }} \varphi_{\mathrm{L}} \mathrm{Cs}_{\mathrm{Cs}, 4}\right. \\
& \mathbf{V}_{\text {load }}-\mathrm{V}_{\mathrm{LH}}\left(-\varphi_{\mathrm{P}} \mathcal{f}_{\mathrm{Cs}, 5}=\mathrm{V}_{\text {load }} \mathrm{C}_{\mathrm{Cs}, 4}-\mathrm{V}_{\mathrm{LH}} \mathrm{C}_{\mathrm{Cs}, 4}\left(1-\varphi_{\mathrm{L}}\right)-\mathrm{V}_{\text {load }} \varphi_{\mathrm{L}} \mathrm{Cs}_{\mathrm{Cs}, 4}\right. \\
& \mathrm{V}_{\text {load }}-\mathrm{V}_{\mathrm{LH}}\left(-\varphi_{\mathrm{P}} \mathcal{G}_{\mathrm{Cs}, 5}=\mathrm{V}_{\text {load }}\left(-\varphi_{\mathrm{L}} \mathcal{C}_{\mathrm{Cs}, 4}-\mathrm{V}_{\mathrm{LH}} \mathrm{C}_{\mathrm{Cs}, 4}\left(1-\varphi_{\mathrm{L}}\right)\right.\right. \\
& \mathrm{V}_{\text {load }}-\mathrm{V}_{\mathrm{LH}}<-\varphi_{\mathrm{P}} \mathrm{f}_{\mathrm{Cs}, 5}=\nabla_{\text {load }}-\mathrm{V}_{\mathrm{LH}} \boldsymbol{\gamma}-\varphi_{\mathrm{L}} \zeta_{\mathrm{Cs}, 4} \\
& \mathrm{C}_{\mathrm{Cs}, 5}=\frac{\mathbf{Q}_{\text {load }}-\mathrm{V}_{\mathrm{LH}} \boldsymbol{\mathbf { C }}-\varphi_{\mathrm{L}} \mathrm{C}_{\mathrm{Cs}, 4}}{\mathbf{V}_{\text {load }}-\mathrm{V}_{\mathrm{LH}}\left(-\varphi_{\mathrm{P}}\right)}
\end{aligned}
$$

The change in sodium concentration across the polishing column during the loading cycle is determined by Equation 6.1-8.

\section{Equation 6.1-8}

$$
\begin{aligned}
& \mathrm{C}_{\mathrm{Na}, 7}=\mathrm{C}_{\mathrm{Na}, 6}=\frac{\mathrm{N}_{\mathrm{Na}, 6}}{\mathrm{~V}_{\text {load }}} \\
& \mathrm{C}_{\mathrm{Na}, 7} \mathrm{~V}_{\text {load }}=\mathrm{N}_{\mathrm{Na}, 6}=\mathrm{N}_{\mathrm{Na}, 5}-\mathrm{V}_{\mathrm{LH}} \mathrm{C}_{\mathrm{Na}, 5}-\mathrm{V}_{\mathrm{LH}} \mathrm{C}_{\mathrm{Na}, 7}-\mathbf{E}_{2, \mathrm{P}}-\boldsymbol{\epsilon}_{1, \mathrm{P}}+\mathrm{E}_{2, \mathrm{P}} \\
& \mathrm{C}_{\mathrm{Na}, 7} \mathrm{~V}_{\text {load }}=\mathrm{V}_{\text {load }} \mathrm{C}_{\mathrm{Na}, 5}-\mathrm{V}_{\mathrm{LH}} \mathrm{C}_{\mathrm{Na}, 5}+\mathrm{V}_{\mathrm{LH}} \mathrm{C}_{\mathrm{Na}, 7}+\mathrm{E}_{1, \mathrm{P}} \\
& \mho_{\text {load }}-\mathrm{V}_{\mathrm{LH}} \zeta_{\mathrm{Na}, 7}=\boldsymbol{\nabla}_{\text {load }}-\mathrm{V}_{\mathrm{LH}} \zeta_{\mathrm{Na}, 5}+\mathrm{E}_{1, \mathrm{P}} \\
& \mathrm{C}_{\mathrm{Na}, 7}=\mathrm{C}_{\mathrm{Na}, 5}+\frac{\mathrm{E}_{1, \mathrm{P}}}{\mathrm{V}_{\text {load }}-\mathrm{V}_{\mathrm{LH}}}
\end{aligned}
$$

The change in sodium concentration across the lead column during the loading cycle is determined by Equation 6.1-9. 
Equation 6.1-9

$$
\begin{aligned}
& \mathrm{V}_{\text {load }} \mathrm{C}_{\mathrm{Na}, 5}=\mathrm{N}_{\mathrm{Na}, 5}=\mathrm{N}_{\mathrm{Na}, 4}-\mathrm{V}_{\mathrm{LH}} \mathrm{C}_{\mathrm{Na}, 4}-\mathrm{V}_{\mathrm{LH}} \mathrm{C}_{\mathrm{Na}, 7}+\mathbf{l}_{2, \mathrm{~L}}-\mathbf{C}_{1, \mathrm{~L}}+\mathrm{E}_{2, \mathrm{~L}} \lambda \\
& \mathrm{C}_{\mathrm{Na}, 5} \mathrm{~V}_{\text {load }}=\mathrm{V}_{\text {load }} \mathrm{C}_{\mathrm{Na}, 4}-\mathrm{V}_{\mathrm{LH}} \mathrm{C}_{\mathrm{Na}, 4}+\mathrm{V}_{\mathrm{LH}} \mathrm{C}_{\mathrm{Na}, 7}+\mathrm{E}_{1, \mathrm{~L}}
\end{aligned}
$$

During theloading cycle, $\mathrm{C}_{\mathrm{Na}, 5} \approx \mathrm{C}_{\mathrm{Na}, 6}=\mathrm{C}_{\mathrm{Na}, 7}$

$$
\begin{aligned}
& \mho_{\text {load }}-V_{\mathrm{LH}} \zeta_{\mathrm{Na}, 7}=\mho_{\text {load }}-\mathrm{V}_{\mathrm{LH}} \zeta_{\mathrm{Na}, 4}+\mathrm{E}_{1, \mathrm{~L}} \\
& \mathrm{C}_{\mathrm{Na}, 7}=\mathrm{C}_{\mathrm{Na}, 4}+\frac{\mathrm{E}_{1, \mathrm{~L}}}{\mathrm{~V}_{\text {load }}-\mathrm{V}_{\mathrm{LH}}} \\
& \mathrm{C}_{\mathrm{Na}, 5}+\frac{\mathrm{E}_{1, \mathrm{P}}}{\mathbb{V}_{\text {load }}-\mathrm{V}_{\mathrm{LH}}}=\mathrm{C}_{\mathrm{Na}, 4}+\frac{\mathrm{E}_{1, \mathrm{~L}}}{\mathbb{V}_{\text {load }}-\mathrm{V}_{\mathrm{LH}}} \\
& \mathrm{C}_{\mathrm{Na}, 5}=\mathrm{C}_{\mathrm{Na}, 4}+\frac{\mathrm{E}_{1, \mathrm{~L}}-\mathrm{E}_{1, \mathrm{P}}}{\mathrm{Q}_{\text {load }}-\mathrm{V}_{\mathrm{LH}}}
\end{aligned}
$$

The potassium concentration remains constant in column effluents throughout the loading cycle as shown by Equation 6.1-10 and Equation 6.1-11. Similarly, Equation 6.1-12 and Equation 6.1-13 indicates that the concentration of other components remain constant in column effluents throughout the loading cycle.

\section{Equation 6.1-10}

$$
\begin{aligned}
& \mathrm{C}_{\mathrm{K}, 7}=\mathrm{C}_{\mathrm{K}, 6}=\frac{\mathrm{N}_{\mathrm{K}, 6}}{\mathrm{~V}_{\text {load }}} \\
& \mathrm{C}_{\mathrm{K}, 7} \mathrm{~V}_{\text {load }}=\mathrm{N}_{\mathrm{K}, 6}=\mathrm{N}_{\mathrm{K}, 5}-\mathrm{V}_{\mathrm{LH}} \mathrm{C}_{\mathrm{K}, 5}-\mathrm{V}_{\mathrm{LH}} \mathrm{C}_{\mathrm{K}, 7}=\mathbf{E}_{3, \mathrm{P}}-\mathrm{E}_{3, \mathrm{P}}- \\
& \mathrm{C}_{\mathrm{K}, 7} \mathrm{~V}_{\text {load }}=\mathrm{V}_{\text {load }} \mathrm{C}_{\mathrm{K}, 5}-\mathrm{V}_{\mathrm{LH}} \mathrm{C}_{\mathrm{K}, 5}+\mathrm{V}_{\mathrm{LH}} \mathrm{C}_{\mathrm{K}, 7}-0 \\
& \mathrm{~V}_{\text {load }}-\mathrm{V}_{\mathrm{LH}} \mathrm{S}_{\mathrm{K}, 7}=\mathbb{V}_{\text {load }}-\mathrm{V}_{\mathrm{LH}} \mathrm{S}_{\mathrm{K}, 5} \\
& \mathrm{C}_{\mathrm{K}, 7}=\mathrm{C}_{\mathrm{K}, 5}
\end{aligned}
$$

\section{Equation 6.1-11}

$$
\begin{aligned}
& \mathrm{V}_{\text {load }} \mathrm{C}_{\mathrm{K}, 5}=\mathrm{N}_{\mathrm{K}, 5}=\mathrm{N}_{\mathrm{K}, 4}-\mathbf{V}_{\mathrm{LH}} \mathrm{C}_{\mathrm{K}, 4}-\mathrm{V}_{\mathrm{LH}} \mathrm{C}_{\mathrm{K}, 7} \neq \mathbf{V}_{3, \mathrm{~L}}-\mathrm{E}_{3, \mathrm{~L}}- \\
& \mathrm{C}_{\mathrm{K}, 5} \mathrm{~V}_{\text {lo ad }}=\mathrm{V}_{\text {lo ad }} \mathrm{C}_{\mathrm{K}, 4}-\mathrm{V}_{\mathrm{LH}} \mathrm{C}_{\mathrm{K}, 4}+\mathrm{V}_{\mathrm{LH}} \mathrm{C}_{\mathrm{K}, 7}-0 \\
& \mathbb{V}_{\text {load }}-\mathrm{V}_{\mathrm{LH}} \mathrm{S}_{\mathrm{K}, 7}=\mathbb{V}_{\text {lo ad }}-\mathrm{V}_{\mathrm{LH}} \mathrm{C}_{\mathrm{K}, 4} \\
& \mathrm{C}_{\mathrm{K}, 7}=\mathrm{C}_{\mathrm{K}, 5}=\mathrm{C}_{\mathrm{K}, 4}
\end{aligned}
$$


Equation 6.1-12

$$
\begin{aligned}
& \mathrm{C}_{\mathrm{i}, 7}=\mathrm{C}_{\mathrm{i}, 6}=\frac{\mathrm{N}_{\mathrm{i}, 6}}{\mathrm{~V}_{\text {load }}} \\
& \mathrm{C}_{\mathrm{i}, 7} \mathrm{~V}_{\text {load }}=\mathrm{N}_{\mathrm{i}, 6}=\mathrm{N}_{\mathrm{i}, 5}-\mathbf{V}_{\mathrm{LH}} \mathrm{C}_{\mathrm{i}, 5}-\mathrm{V}_{\mathrm{LH}} \mathrm{C}_{\mathrm{i}, 7-}- \\
& \mathrm{C}_{\mathrm{i}, 7} \mathrm{~V}_{\text {load }}=\mathrm{V}_{\text {load }} \mathrm{C}_{\mathrm{i}, 5}-\mathrm{V}_{\mathrm{LH}} \mathrm{C}_{\mathrm{i}, 5}+\mathrm{V}_{\mathrm{LH}} \mathrm{C}_{\mathrm{i}, 7} \\
& \mathbb{}_{\text {load }}-\mathrm{V}_{\mathrm{LH}} \mathrm{C}_{\mathrm{i}, 7}=\mathrm{V}_{\text {load }}-\mathrm{V}_{\mathrm{LH}} \mathrm{S}_{\mathrm{i}, 5} \\
& \mathrm{C}_{\mathrm{i}, 7}=\mathrm{C}_{\mathrm{i}, 5}
\end{aligned}
$$

Equation 6.1-13

$$
\begin{aligned}
& \mathrm{V}_{\text {load }} \mathrm{C}_{\mathrm{i}, 5}=\mathrm{N}_{\mathrm{i}, 5}=\mathrm{N}_{\mathrm{i}, 4}-\mathbf{V}_{\mathrm{LH}} \mathrm{C}_{\mathrm{i}, 4}-\mathrm{V}_{\mathrm{LH}} \mathrm{C}_{\mathrm{i}, 7} \\
& \mathrm{C}_{\mathrm{i}, 5} \mathrm{~V}_{\text {load }}=\mathrm{V}_{\text {load }} \mathrm{C}_{\mathrm{i}, 4}-\mathrm{V}_{\mathrm{LH}} \mathrm{C}_{\mathrm{i}, 4}+\mathrm{V}_{\mathrm{LH}} \mathrm{C}_{\mathrm{i}, 7} \\
& \mathbf{V}_{\text {load }}-\mathrm{V}_{\mathrm{LH}} \mathrm{S}_{\mathrm{i}, 7}=\mathbf{V}_{\text {load }}-\mathrm{V}_{\mathrm{LH}} \mathrm{S}_{\mathrm{i}, 4} \\
& \mathrm{C}_{\mathrm{i}, 7}=\mathrm{C}_{\mathrm{i}, 5}=\mathrm{C}_{\mathrm{i}, 4}
\end{aligned}
$$

Total flow rates and compositions entering the columns are input values. Therefore, the composition column effluent to the Cs Product Tank can be calculated by difference between the sum of the inputs and the composition change of waste during the loading cycle. The component balances indicate that the loading cycle column effluent concentrations are reduced by the quantity of cesium removed from the waste, which results in an equi-molar increase in the sodium ion concentration. All other ion concentrations remain approximately constant. Note that the composite column effluent to the Cs Product Tank includes one liquid holdup volume of waste from each column transferred out of the column during the feed displacement cycle. Simplifications to the component balance result in the quantity of potassium transferred to the $\mathrm{Cs}$ Product Tank via the column eluant being approximately equal to the potassium in these waste liquid holdup volumes. This simplification can underestimate the potassium ion in waste returned to DSTs by a few gmol per loading cycle volume.

Resin slurry density estimates, converting mass rates to volumetric flow, represent a simplified approximation of the material balances in this study. The density estimates were simplified since resin bead volume changes were neglected. This required estimating the resin skeletal density at $1.33 \mathrm{~kg} \mathrm{solid} / \mathrm{L}$ to maintain consistency between the resin mass in an ion exchange column and the resin bed volume. The actual skeletal density is estimated at $\sim 1.6 \mathrm{~kg}$ solid $/ \mathrm{L}$ if volume changes between the H-form and $\mathrm{Na}$-form resin are considered.

For a slurry, the void volume containing the liquid phase is described by Equation 6.1-14.

\section{Equation 6.1-14}

$$
\varepsilon_{\text {total }}=1-\left(1-\varepsilon_{\text {bead }}\right)\left(1-\varepsilon_{\text {sluny }}\right)
$$

where:

$\varepsilon_{\text {total }}$ is the total fraction of a unit slurry volume occupied by the liquid phase 
$\varepsilon_{\text {bead }}$ is the fraction resin bead volume occupied by the liquid phase

$\varepsilon_{\text {slurry }}$ is the fraction of a unit slurry volume occupied by resin beads

The density of a resin slurry is estimated by Equation $6.1-15$, where the liquid density ( $\rho_{\text {liquid }}$ ) is in $\mathrm{kg} / \mathrm{L}$.

\section{Equation 6.1-15}

$$
\rho_{\text {slury }}=\varepsilon_{\text {total }} \rho_{\text {liquid }}+\left(1-\varepsilon_{\text {total }}\right) 1.33 \quad \frac{\mathrm{kg}}{\mathrm{L}}
$$

In Equation 6.1-14, (1- $\left.\varepsilon_{\text {slurry }}\right)$ represents the volume fraction of resin beads in a slurry transfer and the void fraction of a resin bead is 0.61 based on Table 6-7.

\subsubsection{Mass and Energy Balances}

6.1.6.1 Material Balance Results. Table 6-13 through Table 6-20 present summary mass balance results. These results were generated by entering the input data into SVF-1499. More detailed results are available in RPP-CALC-37594 (AEM-CHG-2008-CN-015 through CN-022). 
Table 6-13 Mass Balance Summary for Generic Filter with Ion Exchange Cesium Separation - Waste Feed Batch \#1, AP-104

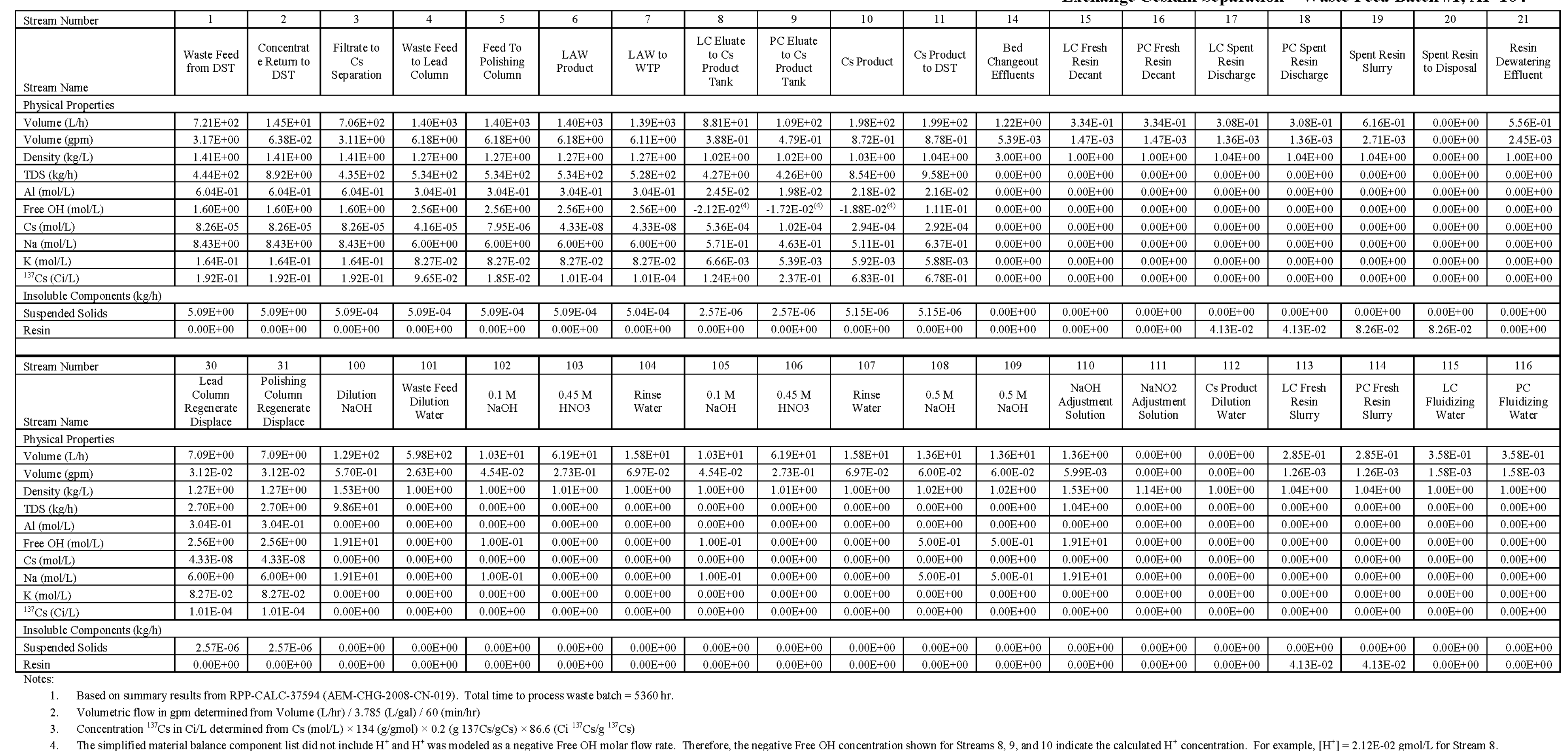


Table 6-14 Mass Balance Summary for Generic Filter with Ion

Exchange Cesium Separation - Waste Feed Batch \#2, AP-102

\begin{tabular}{|c|c|c|c|c|c|c|c|c|c|c|c|c|c|c|c|c|c|c|c|}
\hline Stream Number & 1 & 2 & 3 & 4 & 5 & 6 & 7 & 8 & 9 & 10 & 11 & 14 & 15 & 16 & 17 & 18 & 19 & 20 & 21 \\
\hline Stream Name & $\begin{array}{l}\text { Waste Feed } \\
\text { from DST }\end{array}$ & $\begin{array}{l}\text { Concentrat } \\
\text { e Return to } \\
\text { DST }\end{array}$ & $\begin{array}{l}\text { Filtrate to } \\
C \mathrm{C} \\
\text { Separation }\end{array}$ & $\begin{array}{c}\text { Waste Feed } \\
\text { to Lead } \\
\text { Column }\end{array}$ & $\begin{array}{l}\text { Feed To } \\
\text { Polishing } \\
\text { Column }\end{array}$ & $\begin{array}{l}\text { LAW } \\
\text { Product }\end{array}$ & $\begin{array}{l}\text { LAW to } \\
\text { WTP }\end{array}$ & $\begin{array}{l}\text { LC Eluate } \\
\text { to CS } \\
\text { Product } \\
\text { Tank }\end{array}$ & $\begin{array}{l}\text { PC Eluate } \\
\text { to CS } \\
\text { Product } \\
\text { Tank }\end{array}$ & Cs Product & $\begin{array}{l}\text { Cs Product } \\
\text { to DST }\end{array}$ & $\begin{array}{c}\text { Bed } \\
\text { Changeout } \\
\text { Effluents }\end{array}$ & $\begin{array}{l}\text { LC Fresh } \\
\text { Resin } \\
\text { Decant }\end{array}$ & $\begin{array}{l}\text { PC Fresh } \\
\text { Resin } \\
\text { Decant }\end{array}$ & $\begin{array}{c}\text { LC Spent } \\
\text { Resin } \\
\text { Discharge }\end{array}$ & $\begin{array}{l}\text { PC Spent } \\
\text { Resin } \\
\text { Discharge }\end{array}$ & $\begin{array}{c}\text { Spent Resin } \\
\text { Slurry }\end{array}$ & \begin{tabular}{|c|}
$\begin{array}{l}\text { Spent Resin } \\
\text { to Disposal }\end{array}$ \\
\end{tabular} & $\begin{array}{c}\text { Resin } \\
\text { Dewatering } \\
\text { Effluent }\end{array}$ \\
\hline \multicolumn{20}{|l|}{ Physical Properties } \\
\hline Volume $(\mathrm{L} / \mathrm{h})$ & $6.81 \mathrm{E}+02$ & $1.37 \mathrm{E}+01$ & $6.67 \mathrm{E}+02$ & $1.40 \mathrm{E}+03$ & $1.40 \mathrm{E}+03$ & $1.40 \mathrm{E}+03$ & $1.39 \mathrm{E}+03$ & $8.97 \mathrm{E}+01$ & $1.11 \mathrm{E}+02$ & $2.02 \mathrm{E}+02$ & $2.03 \mathrm{E}+02$ & $1.25 \mathrm{E}+00$ & $3.40 \mathrm{E}-01$ & $3.40 \mathrm{E}-01$ & $3.14 \mathrm{E}-01$ & $3.14 \mathrm{E}-01$ & $6.28 \mathrm{E}-01$ & $0.00 \mathrm{E}+00$ & $5.66 \mathrm{E}-01$ \\
\hline Volume (gpm) & \begin{tabular}{ll|}
$3.00 \mathrm{E}+00$ \\
\end{tabular} & $6.03 \mathrm{E}-02$ & $2.94 \mathrm{E}+00$ & \begin{tabular}{ll|}
$6.18 \mathrm{E}+00$ \\
6
\end{tabular} & $6.18 \mathrm{E}+00$ & $6.18 \mathrm{E}+00$ & $6.12 \mathrm{E}+00$ & $3.95 \mathrm{E}-01$ & $4.88 \mathrm{E}-01$ & $8.88 \mathrm{E}-01$ & $8.94 \mathrm{E}-01$ & $5.49 \mathrm{E}-03$ & $1.50 \mathrm{E}-03$ & $1.50 \mathrm{E}-03$ & $1.38 \mathrm{E}-03$ & $1.38 \mathrm{E}-03$ & $2.76 \mathrm{E}-03$ & $0.00 \mathrm{E}+00$ & $2.49 \mathrm{E}-03$ \\
\hline Density $(\mathrm{kg} / \mathrm{L})$ & $1.39 \mathrm{E}+00$ & $1.39 \mathrm{E}+00$ & $1.39 \mathrm{E}+00$ & $1.27 \mathrm{E}+00$ & $1.27 \mathrm{E}+00$ & $1.27 \mathrm{E}+00$ & $1.27 \mathrm{E}+00$ & $1.02 \mathrm{E}+00$ & $1.02 \mathrm{E}+00$ & $1.03 \mathrm{E}+00$ & $1.04 \mathrm{E}+00$ & $3.00 \mathrm{E}+00$ & $1.00 \mathrm{E}+00$ & $1.00 \mathrm{E}+00$ & $1.04 \mathrm{E}+00$ & $1.04 \mathrm{E}+00$ & $1.04 \mathrm{E}+00$ & $0.00 \mathrm{E}+00$ & $1.00 \mathrm{E}+00$ \\
\hline $\operatorname{TDS}(\mathrm{kg} / \mathrm{h})$ & $\begin{array}{ll}3.97 \mathrm{E}+02 \\
\end{array}$ & $7.97 \mathrm{E}+00$ & $3.89 \mathrm{E}+02$ & $\begin{array}{ll}5.11 \mathrm{E}+02 \\
\end{array}$ & $5.11 \mathrm{E}+02$ & $5.11 \mathrm{E}+02$ & $5.06 \mathrm{E}+02$ & $4.23 \mathrm{E}+00$ & $4.23 \mathrm{E}+00$ & $8.47 \mathrm{E}+00$ & $9.50 \mathrm{E}+00$ & $0.00 \mathrm{E}+00$ & $0.00 \mathrm{E}+00$ & $0.00 \mathrm{E}+00$ & $0.00 \mathrm{E}+00$ & $0.00 \mathrm{E}+00$ & $0.00 \mathrm{E}+00$ & $0.00 \mathrm{E}+00$ & $0.00 \mathrm{E}+00$ \\
\hline $\mathrm{Al}(\mathrm{mol} / \mathrm{L})$ & $8.51 \mathrm{E}-01$ & $8.51 \mathrm{E}-01$ & $8.51 \mathrm{E}-01$ & $4.05 \mathrm{E}-01$ & $4.05 \mathrm{E}-01$ & $4.05 \mathrm{E}-01$ & $4.05 \mathrm{E}-01$ & $3.26 \mathrm{E}-02$ & $2.64 \mathrm{E}-02$ & $2.89 \mathrm{E}-02$ & $2.88 \mathrm{E}-02$ & $0.00 \mathrm{E}+00$ & $0.00 \mathrm{E}+00$ & $0.00 \mathrm{E}+00$ & $0.00 \mathrm{E}+00$ & $0.00 \mathrm{E}+00$ & $0.00 \mathrm{E}+00$ & $0.00 \mathrm{E}+00$ & $0.00 \mathrm{E}+00$ \\
\hline Free $\mathrm{OH}(\mathrm{mol} / \mathrm{L})$ & $1.91 \mathrm{E}+00$ & $1.91 \mathrm{E}+00$ & $1.91 \mathrm{E}+00$ & $3.09 \mathrm{E}+00$ & $3.09 \mathrm{E}+00$ & $3.09 \mathrm{E}+00$ & $3.09 \mathrm{E}+00$ & $2.08 \mathrm{E}-02$ & $1.69 \mathrm{E}-02$ & $1.85 \mathrm{E}-02$ & $1.46 \mathrm{E}-01$ & $0.00 \mathrm{E}+00$ & $0.00 \mathrm{E}+00$ & $0.00 \mathrm{E}+00$ & $0.00 \mathrm{E}+00$ & $0.00 \mathrm{E}+00$ & $0.00 \mathrm{E}+00$ & $0.00 \mathrm{E}+00$ & $0.00 \mathrm{E}+00$ \\
\hline $\mathrm{Cs}(\mathrm{mol} / \mathrm{L})$ & $1.04 \mathrm{E}-04$ & $1.04 \mathrm{E}-04$ & $1.04 \mathrm{E}-04$ & $4.93 \mathrm{E}-05$ & $8.84 \mathrm{E}-06$ & $4.33 \mathrm{E}-08$ & $4.33 \mathrm{E}-08$ & $6.33 \mathrm{E}-04$ & $1.11 \mathrm{E}-04$ & $3.43 \mathrm{E}-04$ & $3.40 \mathrm{E}-04$ & $0.00 \mathrm{E}+00$ & $0.00 \mathrm{E}+00$ & $0.00 \mathrm{E}+00$ & $0.00 \mathrm{E}+00$ & $0.00 \mathrm{E}+00$ & $0.00 \mathrm{E}+00$ & $0.00 \mathrm{E}+00$ & $0.00 \mathrm{E}+00$ \\
\hline $\mathrm{Na}(\mathrm{mol} / \mathrm{L})$ & $8.04 \mathrm{E}+00$ & $8.04 \mathrm{E}+00$ & $8.04 \mathrm{E}+00$ & $6.00 \mathrm{E}+00$ & $6.00 \mathrm{E}+00$ & $6.00 \mathrm{E}+00$ & $6.00 \mathrm{E}+00$ & $5.71 \mathrm{E}-01$ & $4.63 \mathrm{E}-01$ & $5.11 \mathrm{E}-01$ & $6.35 \mathrm{E}-01$ & $0.00 \mathrm{E}+00$ & $0.00 \mathrm{E}+00$ & $0.00 \mathrm{E}+00$ & $0.00 \mathrm{E}+00$ & $0.00 \mathrm{E}+00$ & $0.00 \mathrm{E}+00$ & $0.00 \mathrm{E}+00$ & $0.00 \mathrm{E}+00$ \\
\hline $\mathrm{K}(\mathrm{mol} / \mathrm{L})$ & $1.17 \mathrm{E}-01$ & $1.17 \mathrm{E}-01$ & $1.17 \mathrm{E}-01$ & $5.56 \mathrm{E}-02$ & $5.56 \mathrm{E}-02$ & $5.56 \mathrm{E}-02$ & $5.56 \mathrm{E}-02$ & $4.47 \mathrm{E}-03$ & $3.62 \mathrm{E}-03$ & $3.98 \mathrm{E}-03$ & $3.95 \mathrm{E}-03$ & $0.00 \mathrm{E}+00$ & $0.00 \mathrm{E}+00$ & $0.00 \mathrm{E}+00$ & $0.00 \mathrm{E}+00$ & $0.00 \mathrm{E}+00$ & $0.00 \mathrm{E}+00$ & $0.00 \mathrm{E}+00$ & $0.00 \mathrm{E}+00$ \\
\hline${ }^{137} \mathrm{Cs}(\mathrm{C} / \mathrm{L})$ & $2.41 \mathrm{E}-01$ & $2.41 \mathrm{E}-01$ & $2.41 \mathrm{E}-01$ & $1.14 \mathrm{E}-01$ & $2.05 \mathrm{E}-02$ & $1.00 \mathrm{E}-04$ & $1.00 \mathrm{E}-04$ & $1.47 \mathrm{E}+00$ & $2.59 \mathrm{E}-01$ & $7.95 \mathrm{E}-01$ & $7.90 \mathrm{E}-01$ & $0.00 \mathrm{E}+00$ & $0.00 \mathrm{E}+00$ & $0.00 \mathrm{E}+00$ & $0.00 \mathrm{E}+00$ & $0.00 \mathrm{E}+00$ & $0.00 \mathrm{E}+00$ & $0.00 \mathrm{E}+00$ & $0.00 \mathrm{E}+00$ \\
\hline \multicolumn{20}{|c|}{ Insoluble Components (kgh) } \\
\hline Suspended Solids & $4.75 \mathrm{E}+00$ & $4.75 \mathrm{E}+00$ & $4.75 \mathrm{E}-04$ & $4.75 \mathrm{E}-04$ & $4.75 \mathrm{E}-04$ & $4.75 \mathrm{E}-04$ & $4.70 \mathrm{E}-04$ & $2.44 \mathrm{E}-06$ & $2.44 \mathrm{E}-06$ & $\begin{array}{ll}4.89 \mathrm{E}-06 \\
\end{array}$ & $4.89 \mathrm{E}-06$ & $0.00 \mathrm{E}+00$ & $0.00 \mathrm{E}+00$ & $0.00 \mathrm{E}+00$ & $0.00 \mathrm{E}+00$ & $0.00 \mathrm{E}+00$ & $0.00 \mathrm{E}+00$ & $0.00 \mathrm{E}+00$ & $0.00 \mathrm{E}+00$ \\
\hline Resin & $0.00 \mathrm{E}+00$ & $0.00 \mathrm{E}+00$ & $0.00 \mathrm{E}+00$ & $0.00 \mathrm{E}+00$ & $0.00 \mathrm{E}+00$ & $0.00 \mathrm{E}+00$ & $0.00 \mathrm{E}+00$ & $0.00 \mathrm{E}+00$ & $0.00 \mathrm{E}+00$ & $0.00 \mathrm{E}+00$ & $0.00 \mathrm{E}+00$ & $0.00 \mathrm{E}+00$ & $0.00 \mathrm{E}+00$ & $0.00 \mathrm{E}+00$ & $4.20 \mathrm{E}-02$ & $4.20 \mathrm{E}-02$ & $8.41 \mathrm{E}-02$ & $8.41 \mathrm{E}-02$ & $0.00 \mathrm{E}+00$ \\
\hline & & & & & & & & & & & & & & & & & & & \\
\hline Stream Number & 30 & 31 & 100 & 101 & 102 & 103 & 104 & 105 & 106 & 107 & 108 & 109 & 110 & 111 & 112 & 113 & 114 & 115 & 116 \\
\hline Stream Name & $\begin{array}{c}\text { Lead } \\
\text { Column } \\
\text { Regenerate } \\
\text { Displace } \\
\end{array}$ & $\begin{array}{c}\text { Polishing } \\
\text { Column } \\
\text { Regenerate } \\
\text { Displace } \\
\end{array}$ & $\begin{array}{l}\text { Dilution } \\
\text { NaOH }\end{array}$ & $\begin{array}{c}\text { Waste Feed } \\
\text { Dilution } \\
\text { Water } \\
\end{array}$ & $\begin{array}{l}0.1 \mathrm{M} \\
\mathrm{NaOH}\end{array}$ & $\begin{array}{l}0.45 \mathrm{M} \\
\mathrm{HNO} 3\end{array}$ & $\begin{array}{l}\text { Rinse } \\
\text { Water }\end{array}$ & $\begin{array}{l}0.1 \mathrm{M} \\
\mathrm{NaOH}\end{array}$ & $\begin{array}{l}0.45 \mathrm{M} \\
\mathrm{HNO}\end{array}$ & $\begin{array}{l}\text { Rinse } \\
\text { Water }\end{array}$ & $\begin{array}{l}0.5 \mathrm{M} \\
\mathrm{NaOH}\end{array}$ & $\begin{array}{l}0.5 \mathrm{M} \\
\mathrm{NaOH}\end{array}$ & $\begin{array}{c}\mathrm{NaOH} \\
\text { Adjustment } \\
\text { Solution } \\
\end{array}$ & $\begin{array}{c}\text { NaNO2 } \\
\text { Adjustment } \\
\text { Solution } \\
\end{array}$ & $\begin{array}{c}\text { Cs Product } \\
\text { Dilution } \\
\text { Water } \\
\end{array}$ & $\begin{array}{l}\text { LC Fresh } \\
\text { Resin } \\
\text { Slurry } \\
\end{array}$ & $\begin{array}{l}\text { PC Fresh } \\
\text { Resin } \\
\text { Slurry } \\
\end{array}$ & $\begin{array}{c}\text { LC } \\
\text { Fluidizing } \\
\text { Water }\end{array}$ & $\begin{array}{c}\text { PC } \\
\text { Fluidizing } \\
\text { Water } \\
\end{array}$ \\
\hline \multicolumn{20}{|l|}{ Physical Properties } \\
\hline Volume (L/h) & $7.22 \mathrm{E}+00$ & $7.22 \mathrm{E}+00$ & $1.60 \mathrm{E}+02$ & $6.04 \mathrm{E}+02$ & $1.05 \mathrm{E}+01$ & $6.31 \mathrm{E}+01$ & $1.61 \mathrm{E}+01$ & $1.05 \mathrm{E}+01$ & $6.31 \mathrm{E}+01$ & $1.61 \mathrm{E}+01$ & $1.39 \mathrm{E}+01$ & $1.39 \mathrm{E}+01$ & $1.36 \mathrm{E}+00$ & $0.00 \mathrm{E}+00$ & $0.00 \mathrm{E}+00$ & $2.90 \mathrm{E}-01$ & $2.90 \mathrm{E}-01$ & $3.64 \mathrm{E}-01$ & $3.64 \mathrm{E}-01$ \\
\hline Volume (gpm) & $3.18 \mathrm{E}-02$ & $3.18 \mathrm{E}-02$ & $7.06 \mathrm{E}-01$ & $2.66 \mathrm{E}+00$ & $4.63 \mathrm{E}-02$ & $2.78 \mathrm{E}-01$ & $7.10 \mathrm{E}-02$ & $4.63 \mathrm{E}-02$ & $2.78 \mathrm{E}-01$ & $7.10 \mathrm{E}-02$ & $6.11 \mathrm{E}-02$ & $6.11 \mathrm{E}-02$ & $5.99 \mathrm{E}-03$ & $0.00 \mathrm{E}+00$ & $0.00 \mathrm{E}+00$ & $1.28 \mathrm{E}-03$ & $1.28 \mathrm{E}-03$ & $1.60 \mathrm{E}-03$ & $1.60 \mathrm{E}-03$ \\
\hline Density $(\mathrm{kg} / \mathrm{L})$ & $1.27 \mathrm{E}+00$ & $1.27 \mathrm{E}+00$ & $1.53 \mathrm{E}+00$ & $1.00 \mathrm{E}+00$ & $1.00 \mathrm{E}+00$ & $1.01 \mathrm{E}+00$ & $1.00 \mathrm{E}+00$ & $1.00 \mathrm{E}+00$ & $1.01 \mathrm{E}+00$ & $1.00 \mathrm{E}+00$ & $1.02 \mathrm{E}+00$ & $1.02 \mathrm{E}+00$ & $1.53 \mathrm{E}+00$ & $1.14 \mathrm{E}+00$ & $1.00 \mathrm{E}+00$ & $1.04 \mathrm{E}+00$ & $1.04 \mathrm{E}+00$ & $1.00 \mathrm{E}+00$ & $1.00 \mathrm{E}+00$ \\
\hline TDS (kgh) & $2.63 \mathrm{E}+00$ & $2.63 \mathrm{E}+00$ & $1.22 \mathrm{E}+02$ & $0.00 \mathrm{E}+00$ & $0.00 \mathrm{E}+00$ & $0.00 \mathrm{E}+00$ & $0.00 \mathrm{E}+00$ & $0.00 \mathrm{E}+00$ & $0.00 \mathrm{E}+00$ & $0.00 \mathrm{E}+00$ & $0.00 \mathrm{E}+00$ & $0.00 \mathrm{E}+00$ & $1.04 \mathrm{E}+00$ & $0.00 \mathrm{E}+00$ & $0.00 \mathrm{E}+00$ & $0.00 \mathrm{E}+00$ & $0.00 \mathrm{E}+00$ & $0.00 \mathrm{E}+00$ & $0.00 \mathrm{E}+00$ \\
\hline $\mathrm{Al}(\mathrm{mol} / \mathrm{L})$ & $4.05 \mathrm{E}-01$ & $4.05 \mathrm{E}-01$ & $0.00 \mathrm{E}+00$ & $0.00 \mathrm{E}+00$ & $0.00 \mathrm{E}+00$ & $0.00 \mathrm{E}+00$ & $0.00 \mathrm{E}+00$ & $0.00 \mathrm{E}+00$ & $0.00 \mathrm{E}+00$ & $0.00 \mathrm{E}+00$ & $0.00 \mathrm{E}+00$ & $0.00 \mathrm{E}+00$ & $0.00 \mathrm{E}+00$ & $0.00 \mathrm{E}+00$ & $0.00 \mathrm{E}+00$ & $0.00 \mathrm{E}+00$ & $0.00 \mathrm{E}+00$ & $0.00 \mathrm{E}+00$ & $0.00 \mathrm{E}+00$ \\
\hline Free $\mathrm{OH}(\mathrm{mol} / \mathrm{L})$ & $3.09 \mathrm{E}+00$ & $3.09 \mathrm{E}+00$ & $1.91 \mathrm{E}+01$ & \begin{tabular}{ll|l}
$0.00 \mathrm{E}+00$ \\
\end{tabular} & $1.00 \mathrm{E}-01$ & $0.00 \mathrm{E}+00$ & $0.00 \mathrm{E}+00$ & $1.00 \mathrm{E}-01$ & $0.00 \mathrm{E}+00$ & $0.00 \mathrm{E}+00$ & $5.00 \mathrm{E}-01$ & $5.00 \mathrm{E}-01$ & $1.91 \mathrm{E}+01$ & $0.00 \mathrm{E}+00$ & $0.00 \mathrm{E}+00$ & $0.00 \mathrm{E}+00$ & $0.00 \mathrm{E}+00$ & $0.00 \mathrm{E}+00$ & $0.00 \mathrm{E}+00$ \\
\hline $\mathrm{Cs}(\mathrm{mo} / \mathrm{L})$ & $4.33 \mathrm{E}-08$ & $4.33 \mathrm{E}-08$ & $0.00 \mathrm{E}+00$ & $0.00 \mathrm{E}+00$ & $0.00 \mathrm{E}+00$ & $0.00 \mathrm{E}+00$ & $0.00 \mathrm{E}+00$ & $0.00 \mathrm{E}+00$ & $0.00 \mathrm{E}+00$ & $0.00 \mathrm{E}+00$ & $0.00 \mathrm{E}+00$ & $0.00 \mathrm{E}+00$ & $0.00 \mathrm{E}+00$ & $0.00 \mathrm{E}+00$ & $0.00 \mathrm{E}+00$ & $0.00 \mathrm{E}+00$ & $0.00 \mathrm{E}+00$ & $0.00 \mathrm{E}+00$ & $0.00 \mathrm{E}+00$ \\
\hline $\mathrm{Na}(\mathrm{mol} / \mathrm{L})$ & $6.00 \mathrm{E}+00$ & $6.00 \mathrm{E}+00$ & $1.91 \mathrm{E}+01$ & $0.00 \mathrm{E}+00$ & $1.00 \mathrm{E}-01$ & $0.00 \mathrm{E}+00$ & $0.00 \mathrm{E}+00$ & $1.00 \mathrm{E}-01$ & $0.00 \mathrm{E}+00$ & $0.00 \mathrm{E}+00$ & $5.00 \mathrm{E}-01$ & $5.00 \mathrm{E}-01$ & $1.91 \mathrm{E}+01$ & $0.00 \mathrm{E}+00$ & $0.00 \mathrm{E}+00$ & $0.00 \mathrm{E}+00$ & $0.00 \mathrm{E}+00$ & $0.00 \mathrm{E}+00$ & $0.00 \mathrm{E}+00$ \\
\hline $\mathrm{K}(\mathrm{mol} / \mathrm{L})$ & $5.56 \mathrm{E}-02$ & $5.56 \mathrm{E}-02$ & $0.00 \mathrm{E}+00$ & $0.00 \mathrm{E}+00$ & $0.00 \mathrm{E}+00$ & $0.00 \mathrm{E}+00$ & $0.00 \mathrm{E}+00$ & $0.00 \mathrm{E}+00$ & $0.00 \mathrm{E}+00$ & $0.00 \mathrm{E}+00$ & $0.00 \mathrm{E}+00$ & $0.00 \mathrm{E}+00$ & $0.00 \mathrm{E}+00$ & $0.00 \mathrm{E}+00$ & $0.00 \mathrm{E}+00$ & $0.00 \mathrm{E}+00$ & $0.00 \mathrm{E}+00$ & $0.00 \mathrm{E}+00$ & $0.00 \mathrm{E}+00$ \\
\hline $1{ }^{137} \mathrm{Cs}(\mathrm{Ci} / \mathrm{L})$ & $1.00 \mathrm{E}-04$ & $1.00 \mathrm{E}-04$ & $0.00 \mathrm{E}+00$ & $0.00 \mathrm{E}+00$ & $0.00 \mathrm{E}+00$ & $0.00 \mathrm{E}+00$ & $0.00 \mathrm{E}+00$ & $0.00 \mathrm{E}+00$ & $0.00 \mathrm{E}+00$ & $0.00 \mathrm{E}+00$ & $0.00 \mathrm{E}+00$ & $0.00 \mathrm{E}+00$ & $0.00 \mathrm{E}+00$ & $0.00 \mathrm{E}+00$ & $0.00 \mathrm{E}+00$ & $0.00 \mathrm{E}+00$ & $0.00 \mathrm{E}+00$ & $0.00 \mathrm{E}+00$ & $0.00 \mathrm{E}+00$ \\
\hline \multicolumn{20}{|l|}{ Insoluble Componen } \\
\hline Suspended Solids & $2.44 \mathrm{E}-06$ & $2.44 \mathrm{E}-06$ & $0.00 \mathrm{E}+00$ & $0.00 \mathrm{E}+00$ & $0.00 \mathrm{E}+00$ & $0.00 \mathrm{E}+00$ & $0.00 \mathrm{E}+00$ & $0.00 \mathrm{E}+00$ & $0.00 \mathrm{E}+00$ & $0.00 \mathrm{E}+00$ & $0.00 \mathrm{E}+00$ & $0.00 \mathrm{E}+00$ & $0.00 \mathrm{E}+00$ & \begin{tabular}{l|l|}
$0.00 \mathrm{E}+00$ \\
\end{tabular} & $0.00 \mathrm{E}+00$ & $0.00 \mathrm{E}+00$ & $0.00 \mathrm{E}+00$ & $0.00 \mathrm{E}+00$ & $0.00 \mathrm{E}+00$ \\
\hline Resin & $0.00 \mathrm{E}+00$ & $0.00 \mathrm{E}+00$ & \begin{tabular}{l|l}
$0.00 \mathrm{E}+00$ \\
\end{tabular} & $0.00 \mathrm{E}+00$ & $0.00 \mathrm{E}+00$ & $0.00 \mathrm{E}+00$ & $0.00 \mathrm{E}+00$ & \begin{tabular}{ll|}
$0.00 \mathrm{E}+00$ \\
\end{tabular} & $0.00 \mathrm{E}+00$ & $0.00 \mathrm{E}+00$ & $0.00 \mathrm{E}+00$ & $0.00 \mathrm{E}+00$ & $0.00 \mathrm{E}+00$ & \begin{tabular}{ll|}
$0.00 \mathrm{E}+00$ \\
\end{tabular} & $0.00 \mathrm{E}+00$ & $4.20 \mathrm{E}-02$ & $4.20 \mathrm{E}-02$ & $0.00 \mathrm{E}+00$ & $0.00 \mathrm{E}+00$ \\
\hline \multicolumn{20}{|c|}{$0.00 \mathrm{C} T 00$} \\
\hline
\end{tabular}


Table 6-15 Mass Balance Summary for Generic Filter with Ion

Exchange Cesium Separation - Waste Feed Batch \#3, AP-101

\begin{tabular}{|c|c|c|c|c|c|c|c|c|c|c|c|c|c|c|c|c|c|c|c|}
\hline Stream Number & 1 & 2 & 3 & 4 & 5 & 6 & 7 & 8 & 0 & 10 & 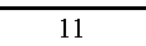 & 11 & 15 & 16 & 17 & 18 & 19 & 20 & 21 \\
\hline Stream Name & $\begin{array}{l}\text { Waste Feed } \\
\text { from DST }\end{array}$ & $\begin{array}{l}\text { Concentrat } \\
\text { e Return to } \\
\text { DST }\end{array}$ & $\begin{array}{l}\text { Filtrate to } \\
\text { Cs } \\
\text { Separation }\end{array}$ & $\begin{array}{l}\text { Waste Feed } \\
\text { to Lead } \\
\text { Column }\end{array}$ & $\begin{array}{l}\text { Feed To } \\
\text { Polishing } \\
\text { Column }\end{array}$ & $\begin{array}{l}\text { LAW } \\
\text { Product }\end{array}$ & $\begin{array}{l}\text { LAW to } \\
\text { WTP }\end{array}$ & $\begin{array}{l}\text { LC Eluate } \\
\text { to Cs } \\
\text { Product } \\
\text { Tank }\end{array}$ & $\begin{array}{c}\text { PC Eluate } \\
\text { to Cs } \\
\text { Product } \\
\text { Tank }\end{array}$ & Cs Product & $\begin{array}{l}\text { Cs Product } \\
\text { to DST }\end{array}$ & $\begin{array}{l}\text { Bed } \\
\text { Changeout } \\
\text { Effluents }\end{array}$ & $\begin{array}{l}\text { LC Fresh } \\
\text { Resin } \\
\text { Decant }\end{array}$ & $\begin{array}{l}\text { PC Fresh } \\
\text { Resin } \\
\text { Decant }\end{array}$ & $\begin{array}{l}\text { LC Spent } \\
\text { Resin } \\
\text { Discharge }\end{array}$ & $\begin{array}{l}\text { PC Spent } \\
\text { Resin } \\
\text { Discharge }\end{array}$ & $\begin{array}{l}\text { Spent Resin } \\
\text { Slurry }\end{array}$ & $\begin{array}{l}\text { Spent Resin } \\
\text { to Disposal }\end{array}$ & $\begin{array}{c}\text { Resin } \\
\text { Dewatering } \\
\text { Effluent }\end{array}$ \\
\hline \multicolumn{20}{|l|}{ Physical Properties } \\
\hline Volume $(\mathrm{L} / \mathrm{h})$ & $7.74 \mathrm{E}+02$ & $1.56 \mathrm{E}+01$ & $7.59 \mathrm{E}+02$ & $1.41 \mathrm{E}+03$ & $1.41 \mathrm{E}+03$ & $1.41 \mathrm{E}+03$ & $1.39 \mathrm{E}+03$ & $1.20 \mathrm{E}+02$ & $1.48 \mathrm{E}+02$ & $2.69 \mathrm{E}+02$ & $2.71 \mathrm{E}+02$ & $1.66 \mathrm{E}+00$ & $4.53 \mathrm{E}-01$ & $4.53 \mathrm{E}-01$ & $4.18 \mathrm{E}-01$ & $4.18 \mathrm{E}-01$ & $8.37 \mathrm{E}-01$ & $0.00 \mathrm{E}+00$ & $7.55 \mathrm{E}-01$ \\
\hline Volume (gpm) & $3.41 \mathrm{E}+00$ & $6.85 \mathrm{E}-02$ & $3.34 \mathrm{E}+00$ & $6.21 \mathrm{E}+00$ & $6.21 \mathrm{E}+00$ & $6.21 \mathrm{E}+00$ & $6.12 \mathrm{E}+00$ & $5.26 \mathrm{E}-01$ & $6.50 \mathrm{E}-01$ & $1.18 \mathrm{E}+00$ & $1.20 \mathrm{E}+00$ & 7.31E- 03 & $2.00 \mathrm{E}-03$ & $2.00 \mathrm{E}-03$ & $1.84 \mathrm{E}-03$ & $1.84 \mathrm{E}-03$ & 3.68E-03 & $0.00 \mathrm{E}+00$ & $3.32 \mathrm{E}-03$ \\
\hline Density $(\mathrm{kg} / \mathrm{L})$ & $1.42 \mathrm{E}+00$ & $1.42 \mathrm{E}+00$ & $1.42 \mathrm{E}+00$ & $1.29 \mathrm{E}+00$ & $1.29 \mathrm{E}+00$ & $1.29 \mathrm{E}+00$ & $1.29 \mathrm{E}+00$ & $1.02 \mathrm{E}+00$ & $1.02 \mathrm{E}+00$ & $1.03 \mathrm{E}+00$ & $1.04 \mathrm{E}+00$ & $3.00 \mathrm{E}+00$ & $1.00 \mathrm{E}+00$ & $1.00 \mathrm{E}+00$ & $1.04 \mathrm{E}+00$ & $1.04 \mathrm{E}+00$ & $1.04 \mathrm{E}+00$ & $0.00 \mathrm{E}+00$ & $1.00 \mathrm{E}+00$ \\
\hline $\operatorname{TDS}(\mathrm{kg} / \mathrm{h})$ & $4.97 \mathrm{E}+02$ & $9.98 \mathrm{E}+00$ & $4.87 \mathrm{E}+02$ & $5.60 \mathrm{E}+02$ & $5.60 \mathrm{E}+02$ & $5.60 \mathrm{E}+02$ & $5.52 \mathrm{E}+02$ & $5.96 \mathrm{E}+00$ & $5.95 \mathrm{E}+00$ & $1.19 \mathrm{E}+01$ & $1.39 \mathrm{E}+01$ & $0.00 \mathrm{E}+00$ & $0.00 \mathrm{E}+00$ & $0.00 \mathrm{E}+00$ & $0.00 \mathrm{E}+00$ & $0.00 \mathrm{E}+00$ & $0.00 \mathrm{E}+00$ & $0.00 \mathrm{E}+00$ & $0.00 \mathrm{E}+00$ \\
\hline $\mathrm{Al}(\mathrm{mol} / \mathrm{L})$ & $4.35 \mathrm{E}-01$ & $4.35 \mathrm{E}-01$ & $4.35 \mathrm{E}-01$ & $2.34 \mathrm{E}-01$ & $2.34 \mathrm{E}-01$ & $2.34 \mathrm{E}-01$ & $2.34 \mathrm{E}-01$ & $1.88 \mathrm{E}-02$ & $1.52 \mathrm{E}-02$ & $1.67 \mathrm{E}-02$ & $1.66 \mathrm{E}-02$ & $0.00 \mathrm{E}+00$ & $0.00 \mathrm{E}+00$ & $0.00 \mathrm{E}+00$ & $0.00 \mathrm{E}+00$ & $0.00 \mathrm{E}+00$ & $0.00 \mathrm{E}+00$ & $0.00 \mathrm{E}+00$ & $0.00 \mathrm{E}+00$ \\
\hline Free $\mathrm{OH}(\mathrm{m}$ & $1.53 \mathrm{E}+00$ & $1.53 \mathrm{E}+00$ & $1.53 \mathrm{E}+00$ & 00 & $13 \mathrm{E}+00$ & $2.13 \mathrm{E}+00$ & $2.13 \mathrm{E}+00$ & $-5.63 \mathrm{E}-02^{(4)}$ & $-4.56 \mathrm{E}-02^{(4)}$ & $-5.01 \mathrm{E}-02^{(4)}$ & $1.36 \mathrm{E}-01$ & $0.00 \mathrm{E}+00$ & $0.00 \mathrm{E}+00$ & $0.00 \mathrm{E}+00$ & $0.00 \mathrm{E}+00$ & $0.00 \mathrm{E}+00$ & $0.00 \mathrm{E}+00$ & $0.00 \mathrm{E}+00$ & $0.00 \mathrm{E}+00$ \\
\hline $\mathrm{Cs}(\mathrm{mol} / \mathrm{L})$ & $1.33 \mathrm{E}-04$ & $1.33 \mathrm{E}-04$ & $1.33 \mathrm{E}-04$ & $7.17 \mathrm{E}-05$ & $1.06 \mathrm{E}-05$ & $4.32 \mathrm{E}-08$ & $4.32 \mathrm{E}-08$ & $7.21 \mathrm{E}-04$ & $1.00 \mathrm{E}-04$ & $3.76 \mathrm{E}-04$ & $3.72 \mathrm{E}-04$ & $0.00 \mathrm{E}+00$ & $0.00 \mathrm{E}+00$ & $0.00 \mathrm{E}+00$ & $0.00 \mathrm{E}+00$ & $0.00 \mathrm{E}+00$ & $0.00 \mathrm{E}+00$ & $0.00 \mathrm{E}+00$ & $0.00 \mathrm{E}+00$ \\
\hline $\mathrm{Na}(\mathrm{mol} / \mathrm{L})$ & $8.71 \mathrm{E}+00$ & $8.71 \mathrm{E}+00$ & $8.71 \mathrm{E}+00$ & $6.00 \mathrm{E}+00$ & $6.00 \mathrm{E}+00$ & $6.00 \mathrm{E}+00$ & $6.00 \mathrm{E}+00$ & $5.71 \mathrm{E}-01$ & $4.63 \mathrm{E}-01$ & $5.10 \mathrm{E}-01$ & $6.91 \mathrm{E}-01$ & $0.00 \mathrm{E}+00$ & $0.00 \mathrm{E}+00$ & $0.00 \mathrm{E}+00$ & $0.00 \mathrm{E}+00$ & $0.00 \mathrm{E}+00$ & $0.00 \mathrm{E}+00$ & $0.00 \mathrm{E}+00$ & $0.00 \mathrm{E}+00$ \\
\hline $\mathrm{K}(\mathrm{mol} / \mathrm{L})$ & $2.14 \mathrm{E}-01$ & $2.14 \mathrm{E}-01$ & $2.14 \mathrm{E}-01$ & $1.15 \mathrm{E}-01$ & $1.15 \mathrm{E}-01$ & $1.15 \mathrm{E}-01$ & $1.15 \mathrm{E}-01$ & $9.27 \mathrm{E}-03$ & $7.51 \mathrm{E}-03$ & $8.25 \mathrm{E}-03$ & $8.17 \mathrm{E}-03$ & $0.00 \mathrm{E}+00$ & $0.00 \mathrm{E}+00$ & $0.00 \mathrm{E}+00$ & $0.00 \mathrm{E}+00$ & $0.00 \mathrm{E}+00$ & $0.00 \mathrm{E}+00$ & $0.00 \mathrm{E}+00$ & $0.00 \mathrm{E}+00$ \\
\hline${ }^{137} \mathrm{Cs}(\mathrm{C} / \mathrm{L} / \mathrm{L})$ & $3.09 \mathrm{E}-01$ & $3.09 \mathrm{E}-01$ & $3.09 \mathrm{E}-01$ & $1.67 \mathrm{E}-01$ & $2.45 \mathrm{E}-02$ & $1.00 \mathrm{E}-04$ & $1.00 \mathrm{E}-04$ & $1.67 \mathrm{E}+00$ & $2.33 \mathrm{E}-01$ & $8.73 \mathrm{E}-01$ & $8.64 \mathrm{E}-01$ & $0.00 \mathrm{E}+00$ & $0.00 \mathrm{E}+00$ & $0.00 \mathrm{E}+00$ & $0.00 \mathrm{E}+00$ & $0.00 \mathrm{E}+00$ & $0.00 \mathrm{E}+00$ & $0.00 \mathrm{E}+00$ & $0.00 \mathrm{E}+00$ \\
\hline \multicolumn{20}{|c|}{ Insoluble Components $\mathrm{kgg}$} \\
\hline Suspended Solids & $5.52 \mathrm{E}+00$ & $5.52 \mathrm{E}+00$ & $5.52 \mathrm{E}-04$ & $5.52 \mathrm{E}-04$ & $5.52 \mathrm{E}-04$ & $5.52 \mathrm{E}-04$ & $5.44 \mathrm{E}-04$ & $3.77 \mathrm{E}-06$ & $3.77 \mathrm{E}-06$ & $7.53 \mathrm{E}-06$ & $7.53 \mathrm{E}-06$ & $0.00 \mathrm{E}+00$ & $0.00 \mathrm{E}+00$ & $0.00 \mathrm{E}+00$ & $0.00 \mathrm{E}+00$ & $0.00 \mathrm{E}+00$ & $0.00 \mathrm{E}+00$ & $0.00 \mathrm{E}+00$ & $0.00 \mathrm{E}+00$ \\
\hline Resin & $0.00 \mathrm{E}+00$ & $0.00 \mathrm{E}+00$ & $0.00 \mathrm{E}+00$ & $0.00 \mathrm{E}+00$ & $0.00 \mathrm{E}+00$ & $0.00 \mathrm{E}+00$ & $0.00 \mathrm{E}+00$ & $0.00 \mathrm{E}+00$ & $0.00 \mathrm{E}+00$ & $0.00 \mathrm{E}+00$ & $0.00 \mathrm{E}+00$ & $0.00 \mathrm{E}+00$ & $0.00 \mathrm{E}+00$ & $0.00 \mathrm{E}+00$ & $5.60 \mathrm{E}-02$ & $5.60 \mathrm{E}-02$ & $1.12 \mathrm{E}-01$ & $1.12 \mathrm{E}-01$ & $0.00 \mathrm{E}+00$ \\
\hline TStream Number & 30 & & 100 & 101 & 102 & 10 & 104 & 105 & 106 & 107 & 108 & 109 & 110 & 111 & 112 & 113 & 114 & 115 & 116 \\
\hline Stream Name & $\begin{array}{c}\text { Lead } \\
\text { Column } \\
\text { Regenerate } \\
\text { Displace }\end{array}$ & $\begin{array}{l}\text { Polishing } \\
\text { Column } \\
\text { Regenerate } \\
\text { Displace }\end{array}$ & $\begin{array}{l}\text { Dilution } \\
\mathrm{NaOH}\end{array}$ & $\begin{array}{l}\text { Waste Feed } \\
\text { Dilution } \\
\text { Water }\end{array}$ & $\begin{array}{l}0.1 \mathrm{M} \\
\mathrm{NaOH}\end{array}$ & $\begin{array}{l}0.45 \mathrm{M} \\
\text { HNO3 }\end{array}$ & $\begin{array}{l}\text { Rinse } \\
\text { Water }\end{array}$ & $\begin{array}{l}0.1 \mathrm{M} \\
\mathrm{NaOH}\end{array}$ & $\begin{array}{l}0.45 \mathrm{M} \\
\text { HNO3 }\end{array}$ & $\begin{array}{l}\text { Rinse } \\
\text { Water }\end{array}$ & $\begin{array}{l}0.5 \mathrm{M} \\
\mathrm{NaOH}\end{array}$ & $\begin{array}{l}0.5 \mathrm{M} \\
\mathrm{NaOH}\end{array}$ & $\begin{array}{c}\text { NaOH } \\
\text { Adjustment } \\
\text { Solution }\end{array}$ & $\begin{array}{c}\text { NaNO2 } \\
\text { Adjustment } \\
\text { Solution }\end{array}$ & $\begin{array}{l}\text { Cs Product } \\
\text { Dilution } \\
\text { Water }\end{array}$ & $\begin{array}{l}\text { LC Fresh } \\
\text { Resin } \\
\text { Slurry }\end{array}$ & $\begin{array}{c}\text { PC Fresh } \\
\text { Resin } \\
\text { Slurry }\end{array}$ & $\begin{array}{c}\text { LC } \\
\text { Fluidizing } \\
\text { Water }\end{array}$ & $\begin{array}{c}\text { PC } \\
\text { Fluidizing } \\
\text { Water }\end{array}$ \\
\hline
\end{tabular}

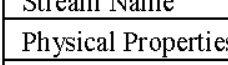
\begin{tabular}{ccc} 
Regenerate & $\begin{array}{c}\text { Regenerat } \\
\text { Displace } \\
\text { Displace }\end{array}$ \\
\hline
\end{tabular}

Water

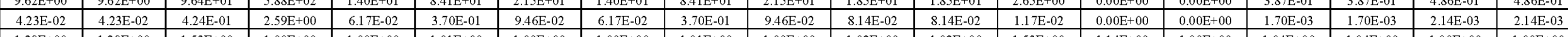

Volume (opm

Density (ko/L) \begin{tabular}{llllllllllllll|l|l|l|l|l|l|l|l}
$1.29 \mathrm{E}+00$ & $1.29 \mathrm{E}+00$ & $1.53 \mathrm{E}+00$ & $1.00 \mathrm{E}+00$ & $1.00 \mathrm{E}+00$ & $1.01 \mathrm{E}+00$ & $1.00 \mathrm{E}+00$ & $1.00 \mathrm{E}+00$ & $1.01 \mathrm{E}+00$ & $1.00 \mathrm{E}+00$ & $1.02 \mathrm{E}+00$ & $1.02 \mathrm{E}+00$ & $1.53 \mathrm{E}+00$ & $1.14 \mathrm{E}+00$ & $1.00 \mathrm{E}+00$ & $1.04 \mathrm{E}+00$ & $1.04 \mathrm{E}+00$ & $1.00 \mathrm{E}+00$ & $1.00 \mathrm{E}+00$ \\
\hline
\end{tabular}

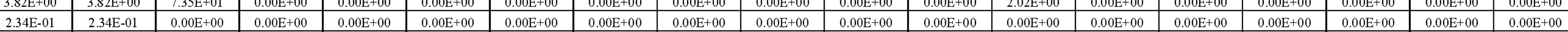

$(\mathrm{mol} / \mathrm{L})$

Free $\mathrm{OH}(\mathrm{mol} / \mathrm{L}$

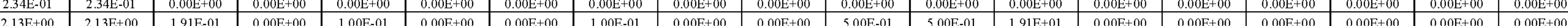

Cs (mol/L)

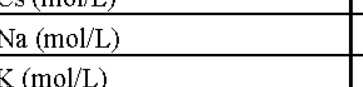

\begin{tabular}{|c|c|c|c|c|c|c|c|c|c|c|c|c|c|c|c|c|c|c|c|c|c|c|}
\hline & $0.00 \mathrm{E}+00$ & $0.00 \mathrm{E}+00$ & $0.00 \mathrm{E}+00$ & $0.00 \mathrm{E}+00$ & $0.00 \mathrm{E}+00$ & $0.00 \mathrm{E}+00$ & $0.00 \mathrm{E}+00$ & $0.00 \mathrm{E}+00$ & $0.00 \mathrm{E}+00$ & $0.00 \mathrm{E}+00$ & $0.00 \mathrm{E}+00$ & $0.00 \mathrm{E}+00$ \\
\hline
\end{tabular}

$\frac{\mathrm{K}(\mathrm{mol} / \mathrm{L})}{{ }^{13} \mathrm{Cs}(\mathrm{C} / \mathrm{L})}$

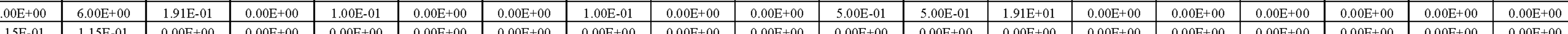
\begin{tabular}{lllllllllllllllllllll}
$1.00 \mathrm{E}-04$ & $1.00 \mathrm{E}-04$ & $0.00 \mathrm{E}+00$ & $0.00 \mathrm{E}+00$ & $0.00 \mathrm{E}+00$ & $0.00 \mathrm{E}+00$ & $0.00 \mathrm{E}+00$ & $0.00 \mathrm{E}+00$ & $0.00 \mathrm{E}+00$ & $0.00 \mathrm{E}+00$ & $0.00 \mathrm{E}+00$ & $0.00 \mathrm{E}+00$ & $0.00 \mathrm{E}+00$ & $0.00 \mathrm{E}+00$ & $0.00 \mathrm{E}+00$ & $0.00 \mathrm{E}+00$ & $0.00 \mathrm{E}+00$ & $0.00 \mathrm{E}+00$ & $0.00 \mathrm{E}+00$ \\
\hline
\end{tabular} Suspended Solids

\begin{tabular}{ll}
\hline Resin \\
Notes:
\end{tabular} \begin{tabular}{|c|c|c|c|c|c|c|c|c|c|c|c|c|c|c|c|c|c|c|c|c|c|c|}
\hline $3.77 \mathrm{E}-06$ & $3.77 \mathrm{E}-06$ & $0.00 \mathrm{E}+00$ & $0.00 \mathrm{E}+00$ & $0.00 \mathrm{E}+00$ & $0.00 \mathrm{E}+00$ & $0.00 \mathrm{E}+00$ & $0.00 \mathrm{E}+00$ & $0.00 \mathrm{E}+00$ & $0.00 \mathrm{E}+00$ & $0.00 \mathrm{E}+00$ & $0.00 \mathrm{E}+00$ & $0.00 \mathrm{E}+00$ & $0.00 \mathrm{E}+00$ & $0.00 \mathrm{E}+00$ & $0.00 \mathrm{E}+00$ & $0.00 \mathrm{E}+00$ & $0.00 \mathrm{E}+00$ & $0.00 \mathrm{E}+00$ \\
\hline
\end{tabular}

Based on summary results from RPP-CALC-37594 (AEM-CHG-2008-CN-016). Total time to process waste batch $=5438$

Volumetric flow in gpm determined from Volume (L/hr) $/ 3.785$ (L/gal) / 60 (minh/r)

The simplified material 
Table 6-16 Mass Balance Summary for Generic Filter with Ion

Exchange Cesium Separation - Waste Feed Batch \#4, AP-103

\begin{tabular}{|c|c|c|c|c|c|c|c|c|c|c|c|c|c|c|c|c|c|c|c|}
\hline Stream Number & 1 & 2 & 3 & 4 & 5 & 6 & 7 & 8 & 9 & 10 & 11 & 14 & 15 & 16 & 17 & 18 & 19 & 20 & 21 \\
\hline Stream Name & $\begin{array}{l}\text { Waste Feed } \\
\text { from DST }\end{array}$ & $\begin{array}{l}\text { Concentrat } \\
\text { e Return to } \\
\text { DST }\end{array}$ & $\begin{array}{c}\text { Filtrate to } \\
\quad \mathrm{Cs} \\
\text { Separation }\end{array}$ & $\begin{array}{c}\text { Waste Feed } \\
\text { to Lead } \\
\text { Column }\end{array}$ & $\begin{array}{l}\text { Feed do } \\
\text { Polishing } \\
\text { Column }\end{array}$ & $\begin{array}{l}\text { LAW } \\
\text { Product }\end{array}$ & $\begin{array}{l}\text { LAW to } \\
\text { WTP }\end{array}$ & $\begin{array}{c}\text { LC Eluate } \\
\text { to CS } \\
\text { Product } \\
\text { Tank } \\
\end{array}$ & $\begin{array}{c}\text { PC Eluate } \\
\text { to Cs } \\
\text { Product } \\
\text { Tank } \\
\end{array}$ & Cs Product & $\begin{array}{l}\text { Cs Product } \\
\text { to DST }\end{array}$ & $\begin{array}{c}\text { Bed } \\
\text { Changeout } \\
\text { Effluents }\end{array}$ & $\begin{array}{l}\text { LC Fresh } \\
\text { Resin } \\
\text { Decant }\end{array}$ & $\begin{array}{l}\text { PC Fresh } \\
\text { Resin } \\
\text { Decant }\end{array}$ & $\begin{array}{c}\text { LC Spent } \\
\text { Resin } \\
\text { Discharge }\end{array}$ & $\begin{array}{l}\text { PC Spent } \\
\text { Resin } \\
\text { Discharge }\end{array}$ & $\begin{array}{c}\text { Spent Resin } \\
\text { Slurry }\end{array}$ & \begin{tabular}{l|} 
Spent Resin \\
to Disposal
\end{tabular} & $\begin{array}{l}\text { Resin } \\
\text { Dewatering } \\
\text { Effluent }\end{array}$ \\
\hline \multicolumn{20}{|l|}{ Physical Properties } \\
\hline Volume $(\mathrm{L} / \mathrm{h})$ & $6.40 \mathrm{E}+02$ & $1.29 \mathrm{E}+01$ & $6.27 \mathrm{E}+02$ & $1.40 \mathrm{E}+03$ & $1.40 \mathrm{E}+03$ & $1.40 \mathrm{E}+03$ & $1.39 \mathrm{E}+03$ & $8.82 \mathrm{E}+01$ & $1.09 \mathrm{E}+02$ & $1.98 \mathrm{E}+02$ & $1.98 \mathrm{E}+02$ & $1.23 \mathrm{E}+00$ & $3.34 \mathrm{E}-01$ & $3.34 \mathrm{E}-01$ & $3.09 \mathrm{E}-01$ & $3.09 \mathrm{E}-01$ & $6.17 \mathrm{E}-01$ & $0.00 \mathrm{E}+00$ & $5.57 \mathrm{E}-01$ \\
\hline Volume (gpm) & $2.82 \mathrm{E}+00$ & $5.67 \mathrm{E}-02$ & $2.76 \mathrm{E}+00$ & $6.18 \mathrm{E}+00$ & $6.18 \mathrm{E}+00$ & $6.18 \mathrm{E}+00$ & $6.12 \mathrm{E}+00$ & $3.88 \mathrm{E}-01$ & $4.80 \mathrm{E}-01$ & $8.73 \mathrm{E}-01$ & $8.74 \mathrm{E}-01$ & $5.40 \mathrm{E}-03$ & $1.47 \mathrm{E}-03$ & $1.47 \mathrm{E}-03$ & $1.36 \mathrm{E}-03$ & $1.36 \mathrm{E}-03$ & $2.72 \mathrm{E}-03$ & $0.00 \mathrm{E}+00$ & $2.45 \mathrm{E}-03$ \\
\hline Density $(\mathrm{kg} / \mathrm{L})$ & $1.41 \mathrm{E}+00$ & $1.41 \mathrm{E}+00$ & $1.41 \mathrm{E}+00$ & $1.27 \mathrm{E}+00$ & $1.27 \mathrm{E}+00$ & $1.27 \mathrm{E}+00$ & $1.27 \mathrm{E}+00$ & $1.02 \mathrm{E}+00$ & $1.02 \mathrm{E}+00$ & $1.03 \mathrm{E}+00$ & $1.03 \mathrm{E}+00$ & $3.00 \mathrm{E}+00$ & $1.00 \mathrm{E}+00$ & $1.00 \mathrm{E}+00$ & $1.04 \mathrm{E}+00$ & $1.04 \mathrm{E}+00$ & $1.04 \mathrm{E}+00$ & $0.00 \mathrm{E}+00$ & $1.00 \mathrm{E}+00$ \\
\hline $\operatorname{TDS}(\mathrm{kg} / \mathrm{h})$ & $3.95 \mathrm{E}+02$ & $7.94 \mathrm{E}+00$ & $3.87 \mathrm{E}+02$ & $5.11 \mathrm{E}+02$ & $5.11 \mathrm{E}+02$ & $5.11 \mathrm{E}+02$ & $5.06 \mathrm{E}+02$ & $4.16 \mathrm{E}+00$ & $4.15 \mathrm{E}+00$ & $8.33 \mathrm{E}+00$ & $8.40 \mathrm{E}+00$ & $0.00 \mathrm{E}+00$ & $0.00 \mathrm{E}+00$ & $0.00 \mathrm{E}+00$ & $0.00 \mathrm{E}+00$ & $0.00 \mathrm{E}+00$ & $0.00 \mathrm{E}+00$ & $0.00 \mathrm{E}+00$ & $0.00 \mathrm{E}+00$ \\
\hline $\mathrm{Al}(\mathrm{mol} / \mathrm{L})$ & $7.92 \mathrm{E}-01$ & $7.92 \mathrm{E}-01$ & $7.92 \mathrm{E}-01$ & $3.54 \mathrm{E}-01$ & $3.54 \mathrm{E}-01$ & $3.54 \mathrm{E}-01$ & $3.54 \mathrm{E}-01$ & $2.85 \mathrm{E}-02$ & $2.31 \mathrm{E}-02$ & $2.53 \mathrm{E}-02$ & $2.53 \mathrm{E}-02$ & $0.00 \mathrm{E}+00$ & $0.00 \mathrm{E}+00$ & $0.00 \mathrm{E}+00$ & $0.00 \mathrm{E}+00$ & $0.00 \mathrm{E}+00$ & $0.00 \mathrm{E}+00$ & $0.00 \mathrm{E}+00$ & $0.00 \mathrm{E}+00$ \\
\hline Free $\mathrm{OH}(\mathrm{mol} / \mathrm{L})$ & $1.40 \mathrm{E}+00$ & $1.40 \mathrm{E}+00$ & $1.40 \mathrm{E}+00$ & $2.84 \mathrm{E}+00$ & $2.84 \mathrm{E}+00$ & $2.84 \mathrm{E}+00$ & $2.84 \mathrm{E}+00$ & $1.01 \mathrm{E}-03$ & $8.14 \mathrm{E}-04$ & $8.94 \mathrm{E}-04$ & $9.88 \mathrm{E}-03$ & $0.00 \mathrm{E}+00$ & $0.00 \mathrm{E}+00$ & $0.00 \mathrm{E}+00$ & $0.00 \mathrm{E}+00$ & $0.00 \mathrm{E}+00$ & $0.00 \mathrm{E}+00$ & $0.00 \mathrm{E}+00$ & $0.00 \mathrm{E}+00$ \\
\hline $\mathrm{Cs}(\mathrm{mol} / \mathrm{L})$ & $1.04 \mathrm{E}-04$ & $1.04 \mathrm{E}-04$ & $1.04 \mathrm{E}-04$ & $4.63 \mathrm{E}-05$ & $8.52 \mathrm{E}-06$ & $4.33 \mathrm{E}-08$ & $4.33 \mathrm{E}-08$ & $6.01 \mathrm{E}-04$ & $1.09 \mathrm{E}-04$ & $3.27 \mathrm{E}-04$ & $3.27 \mathrm{E}-04$ & $0.00 \mathrm{E}+00$ & $0.00 \mathrm{E}+00$ & $0.00 \mathrm{E}+00$ & $0.00 \mathrm{E}+00$ & $0.00 \mathrm{E}+00$ & $0.00 \mathrm{E}+00$ & $0.00 \mathrm{E}+00$ & $0.00 \mathrm{E}+00$ \\
\hline $\mathrm{Na}(\mathrm{mol} / \mathrm{L})$ & $8.47 \mathrm{E}+00$ & $8.47 \mathrm{E}+00$ & $8.47 \mathrm{E}+00$ & $6.00 \mathrm{E}+00$ & $6.00 \mathrm{E}+00$ & $6.00 \mathrm{E}+00$ & $6.00 \mathrm{E}+00$ & $5.71 \mathrm{E}-01$ & $4.63 \mathrm{E}-01$ & $5.11 \mathrm{E}-01$ & $5.19 \mathrm{E}-01$ & $0.00 \mathrm{E}+00$ & $0.00 \mathrm{E}+00$ & $0.00 \mathrm{E}+00$ & $0.00 \mathrm{E}+00$ & $0.00 \mathrm{E}+00$ & $0.00 \mathrm{E}+00$ & $0.00 \mathrm{E}+00$ & $0.00 \mathrm{E}+00$ \\
\hline $\mathrm{K}(\mathrm{mol} / \mathrm{L})$ & $1.34 \mathrm{E}-01$ & $1.34 \mathrm{E}-01$ & $1.34 \mathrm{E}-01$ & $5.98 \mathrm{E}-02$ & $5.98 \mathrm{E}-02$ & $5.98 \mathrm{E}-02$ & $5.98 \mathrm{E}-02$ & $4.81 \mathrm{E}-03$ & $3.90 \mathrm{E}-03$ & $4.28 \mathrm{E}-03$ & $4.28 \mathrm{E}-03$ & $0.00 \mathrm{E}+00$ & $0.00 \mathrm{E}+00$ & $0.00 \mathrm{E}+00$ & $0.00 \mathrm{E}+00$ & $0.00 \mathrm{E}+00$ & $0.00 \mathrm{E}+00$ & $0.00 \mathrm{E}+00$ & $0.00 \mathrm{E}+00$ \\
\hline${ }^{137} \mathrm{Cs}(\mathrm{Ci} / \mathrm{L})$ & $2.40 \mathrm{E}-01$ & $2.40 \mathrm{E}-01$ & $2.40 \mathrm{E}-01$ & $1.07 \mathrm{E}-01$ & $1.98 \mathrm{E}-02$ & $1.00 \mathrm{E}-04$ & $1.00 \mathrm{E}-04$ & $1.40 \mathrm{E}+00$ & $2.53 \mathrm{E}-01$ & $7.60 \mathrm{E}-01$ & $7.59 \mathrm{E}-01$ & $0.00 \mathrm{E}+00$ & $0.00 \mathrm{E}+00$ & $0.00 \mathrm{E}+00$ & $0.00 \mathrm{E}+00$ & $0.00 \mathrm{E}+00$ & $0.00 \mathrm{E}+00$ & $0.00 \mathrm{E}+00$ & $0.00 \mathrm{E}+00$ \\
\hline \multicolumn{20}{|c|}{ Insoluble Components (kgh) } \\
\hline Suspended Solids & $4.52 \mathrm{E}+00$ & $4.52 \mathrm{E}+00$ & $4.52 \mathrm{E}-04$ & $4.52 \mathrm{E}-04$ & $4.52 \mathrm{E}-04$ & $4.52 \mathrm{E}-04$ & $4.48 \mathrm{E}-04$ & $2.29 \mathrm{E}-06$ & $2.29 \mathrm{E}-06$ & $4.57 \mathrm{E}-06$ & $4.57 \mathrm{E}-06$ & $0.00 \mathrm{E}+00$ & $0.00 \mathrm{E}+00$ & $0.00 \mathrm{E}+00$ & $0.00 \mathrm{E}+00$ & $0.00 \mathrm{E}+00$ & $0.00 \mathrm{E}+00$ & $0.00 \mathrm{E}+00$ & $0.00 \mathrm{E}+00$ \\
\hline Resin & $0.00 \mathrm{E}+00$ & $0.00 \mathrm{E}+00$ & $0.00 \mathrm{E}+00$ & $0.00 \mathrm{E}+00$ & $0.00 \mathrm{E}+00$ & $0.00 \mathrm{E}+00$ & $0.00 \mathrm{E}+00$ & $0.00 \mathrm{E}+00$ & $0.00 \mathrm{E}+00$ & $0.00 \mathrm{E}+00$ & $0.00 \mathrm{E}+00$ & $0.00 \mathrm{E}+00$ & $0.00 \mathrm{E}+00$ & $0.00 \mathrm{E}+00$ & $4.13 \mathrm{E}-02$ & $4.13 \mathrm{E}-02$ & $8.27 \mathrm{E}-02$ & $8.27 \mathrm{E}-02$ & $0.00 \mathrm{E}+00$ \\
\hline Stream Number & 30 & 31 & 100 & 101 & 102 & 103 & 104 & 105 & 106 & $\begin{array}{lll}107 \\
\end{array}$ & 108 & 109 & 110 & 111 & 112 & 113 & 114 & 115 & 116 \\
\hline 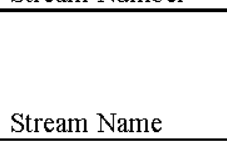 & $\begin{array}{c}\text { Lead } \\
\text { Column } \\
\text { Regenerate } \\
\text { Displace }\end{array}$ & $\begin{array}{c}\text { Polishing } \\
\text { Column } \\
\text { Regenerate } \\
\text { Displace }\end{array}$ & $\begin{array}{l}\text { Dilution } \\
\text { NaOH }\end{array}$ & $\begin{array}{c}\text { Waste Feed } \\
\text { Dilution } \\
\text { Water }\end{array}$ & $\begin{array}{l}0.1 \mathrm{M} \\
\mathrm{NaOH}\end{array}$ & $\begin{array}{l}0.45 \mathrm{M} \\
\mathrm{HNO} 3\end{array}$ & $\begin{array}{l}\text { Rinse } \\
\text { Water }\end{array}$ & $\begin{array}{l}0.1 \mathrm{M} \\
\mathrm{NaOH}\end{array}$ & $\begin{array}{l}0.45 \mathrm{M} \\
\mathrm{HNO}\end{array}$ & $\begin{array}{l}\text { Rinse } \\
\text { Water }\end{array}$ & $\begin{array}{l}0.5 \mathrm{M} \\
\mathrm{NaOH}\end{array}$ & $\begin{array}{l}0.5 \mathrm{M} \\
\mathrm{NaOH}\end{array}$ & $\begin{array}{c}\mathrm{NaOH} \\
\text { Adjustment } \\
\text { Solution }\end{array}$ & $\begin{array}{c}\mathrm{NaNO2} \\
\text { Adjustment } \\
\text { Solution }\end{array}$ & $\begin{array}{c}\text { Cs Product } \\
\text { Dilution } \\
\text { Water }\end{array}$ & $\begin{array}{l}\text { LC Fresh } \\
\text { Resin } \\
\text { Slurry }\end{array}$ & $\begin{array}{l}\text { PC Fresh } \\
\text { Resin } \\
\text { Slurry }\end{array}$ & $\begin{array}{c}\text { LC } \\
\text { Fluidizing } \\
\text { Water }\end{array}$ & $\begin{array}{c}\mathrm{PC} \\
\text { Fluidizing } \\
\text { WWater }\end{array}$ \\
\hline \multicolumn{20}{|l|}{ Physical Properties } \\
\hline Volume (L/h) & $7.09 \mathrm{E}+00$ & $7.09 \mathrm{E}+00$ & $1.63 \mathrm{E}+02$ & $6.45 \mathrm{E}+02$ & $1.03 \mathrm{E}+01$ & $6.20 \mathrm{E}+01$ & $1.58 \mathrm{E}+01$ & $1.03 \mathrm{E}+01$ & $6.20 \mathrm{E}+01$ & $1.58 \mathrm{E}+01$ & $1.36 \mathrm{E}+01$ & $1.36 \mathrm{E}+01$ & $9.35 \mathrm{E}-02$ & $0.00 \mathrm{E}+00$ & $0.00 \mathrm{E}+00$ & $2.85 \mathrm{E}-01$ & $2.85 \mathrm{E}-01$ & $3.58 \mathrm{E}-01$ & $3.58 \mathrm{E}-01$ \\
\hline Volume (gpm) & $3.12 \mathrm{E}-02$ & $3.12 \mathrm{E}-02$ & $7.17 \mathrm{E}-01$ & $2.84 \mathrm{E}+00$ & $4.55 \mathrm{E}-02$ & $2.73 \mathrm{E}-01$ & $6.98 \mathrm{E}-02$ & $4.55 \mathrm{E}-02$ & $2.73 \mathrm{E}-01$ & $6.98 \mathrm{E}-02$ & $6.01 \mathrm{E}-02$ & $6.01 \mathrm{E}-02$ & $4.12 \mathrm{E}-04$ & $0.00 \mathrm{E}+00$ & $0.00 \mathrm{E}+00$ & $1.26 \mathrm{E}-03$ & $1.26 \mathrm{E}-03$ & $1.58 \mathrm{E}-03$ & $1.58 \mathrm{E}-03$ \\
\hline Density $(\mathrm{kg} / \mathrm{L})$ & $1.27 \mathrm{E}+00$ & $1.27 \mathrm{E}+00$ & $1.53 \mathrm{E}+00$ & $1.00 \mathrm{E}+00$ & $1.00 \mathrm{E}+00$ & $1.01 \mathrm{E}+00$ & $1.00 \mathrm{E}+00$ & $1.00 \mathrm{E}+00$ & $1.01 \mathrm{E}+00$ & $1.00 \mathrm{E}+00$ & $1.02 \mathrm{E}+00$ & $1.02 \mathrm{E}+00$ & $1.53 \mathrm{E}+00$ & $1.14 \mathrm{E}+00$ & $1.00 \mathrm{E}+00$ & $1.04 \mathrm{E}+00$ & $1.04 \mathrm{E}+00$ & $1.00 \mathrm{E}+00$ & $1.00 \mathrm{E}+00$ \\
\hline $\operatorname{TDS}(\mathrm{kg} / \mathrm{h})$ & $2.58 \mathrm{E}+00$ & $2.58 \mathrm{E}+00$ & $1.24 \mathrm{E}+02$ & $0.00 \mathrm{E}+00$ & $0.00 \mathrm{E}+00$ & $0.00 \mathrm{E}+00$ & $0.00 \mathrm{E}+00$ & $0.00 \mathrm{E}+00$ & $0.00 \mathrm{E}+00$ & $0.00 \mathrm{E}+00$ & $0.00 \mathrm{E}+00$ & $0.00 \mathrm{E}+00$ & $7.13 \mathrm{E}-02$ & $0.00 \mathrm{E}+00$ & $0.00 \mathrm{E}+00$ & $0.00 \mathrm{E}+00$ & $0.00 \mathrm{E}+00$ & $0.00 \mathrm{E}+00$ & $0.00 \mathrm{E}+00$ \\
\hline $\mathrm{Al}(\mathrm{mol} / \mathrm{L})$ & $3.54 \mathrm{E}-01$ & $3.54 \mathrm{E}-01$ & $0.00 \mathrm{E}+00$ & $0.00 \mathrm{E}+00$ & $0.00 \mathrm{E}+00$ & $0.00 \mathrm{E}+00$ & $0.00 \mathrm{E}+00$ & $0.00 \mathrm{E}+00$ & $0.00 \mathrm{E}+00$ & $0.00 \mathrm{E}+00$ & $0.00 \mathrm{E}+00$ & $0.00 \mathrm{E}+00$ & $0.00 \mathrm{E}+00$ & $0.00 \mathrm{E}+00$ & $0.00 \mathrm{E}+00$ & $0.00 \mathrm{E}+00$ & $0.00 \mathrm{E}+00$ & $0.00 \mathrm{E}+00$ & $0.00 \mathrm{E}+00$ \\
\hline Free $\mathrm{OH}(\mathrm{mol} / \mathrm{L})$ & $2.84 \mathrm{E}+00$ & $2.84 \mathrm{E}+00$ & $1.91 \mathrm{E}-01$ & $0.00 \mathrm{E}+00$ & $1.00 \mathrm{E}-01$ & $0.00 \mathrm{E}+00$ & $0.00 \mathrm{E}+00$ & $1.00 \mathrm{E}-01$ & $0.00 \mathrm{E}+00$ & $0.00 \mathrm{E}+00$ & $5.00 \mathrm{E}-01$ & $5.00 \mathrm{E}-01$ & $1.91 \mathrm{E}+01$ & $0.00 \mathrm{E}+00$ & $0.00 \mathrm{E}+00$ & $0.00 \mathrm{E}+00$ & $0.00 \mathrm{E}+00$ & $0.00 \mathrm{E}+00$ & $0.00 \mathrm{E}+00$ \\
\hline $\mathrm{Cs}(\mathrm{mo} / \mathrm{L})$ & $4.33 \mathrm{E}-08$ & $4.33 \mathrm{E}-08$ & $0.00 \mathrm{E}+00$ & $0.00 \mathrm{E}+00$ & $0.00 \mathrm{E}+00$ & $0.00 \mathrm{E}+00$ & $0.00 \mathrm{E}+00$ & $0.00 \mathrm{E}+00$ & $0.00 \mathrm{E}+00$ & $0.00 \mathrm{E}+00$ & $0.00 \mathrm{E}+00$ & $0.00 \mathrm{E}+00$ & $0.00 \mathrm{E}+00$ & $0.00 \mathrm{E}+00$ & $0.00 \mathrm{E}+00$ & $0.00 \mathrm{E}+00$ & $0.00 \mathrm{E}+00$ & $0.00 \mathrm{E}+00$ & $0.00 \mathrm{E}+00$ \\
\hline $\mathrm{Na}(\mathrm{mol} / \mathrm{L})$ & $6.00 \mathrm{E}+00$ & $6.00 \mathrm{E}+00$ & $1.91 \mathrm{E}-01$ & $0.00 \mathrm{E}+00$ & $1.00 \mathrm{E}-01$ & $0.00 \mathrm{E}+00$ & $0.00 \mathrm{E}+00$ & $1.00 \mathrm{E}-01$ & $0.00 \mathrm{E}+00$ & $0.00 \mathrm{E}+00$ & $5.00 \mathrm{E}-01$ & $5.00 \mathrm{E}-01$ & $1.91 \mathrm{E}+01$ & $0.00 \mathrm{E}+00$ & $0.00 \mathrm{E}+00$ & $0.00 \mathrm{E}+00$ & $0.00 \mathrm{E}+00$ & $0.00 \mathrm{E}+00$ & $0.00 \mathrm{E}+00$ \\
\hline $\mathrm{K}(\mathrm{mol} / \mathrm{L})$ & $\begin{array}{l}5.98 \mathrm{E}-02 \\
\end{array}$ & $5.98 \mathrm{E}-02$ & $0.00 \mathrm{E}+00$ & $0.00 \mathrm{E}+00$ & $0.00 \mathrm{E}+00$ & $0.00 \mathrm{E}+00$ & $0.00 \mathrm{E}+00$ & $0.00 \mathrm{E}+00$ & $0.00 \mathrm{E}+00$ & $0.00 \mathrm{E}+00$ & $0.00 \mathrm{E}+00$ & $0.00 \mathrm{E}+00$ & $0.00 \mathrm{E}+00$ & $0.00 \mathrm{E}+00$ & $0.00 \mathrm{E}+00$ & $0.00 \mathrm{E}+00$ & $0.00 \mathrm{E}+00$ & $0.00 \mathrm{E}+00$ & $0.00 \mathrm{E}+00$ \\
\hline${ }^{137} \mathrm{Cs}(\mathrm{Ci} / \mathrm{L})$ & $1.00 \mathrm{E}-04$ & $1.00 \mathrm{E}-04$ & $0.00 \mathrm{E}+00$ & $0.00 \mathrm{E}+00$ & $0.00 \mathrm{E}+00$ & $0.00 \mathrm{E}+00$ & $0.00 \mathrm{E}+00$ & $0.00 \mathrm{E}+00$ & $0.00 \mathrm{E}+00$ & $0.00 \mathrm{E}+00$ & $0.00 \mathrm{E}+00$ & $0.00 \mathrm{E}+00$ & $0.00 \mathrm{E}+00$ & $0.00 \mathrm{E}+00$ & $0.00 \mathrm{E}+00$ & $0.00 \mathrm{E}+00$ & $0.00 \mathrm{E}+00$ & $0.00 \mathrm{E}+00$ & $0.00 \mathrm{E}+00$ \\
\hline \multicolumn{20}{|c|}{ Insoluble Components ( $\mathrm{kg} / \mathrm{h})$} \\
\hline Suspended Solids & $2.29 \mathrm{E}-06$ & $2.29 \mathrm{E}-06$ & $0.00 \mathrm{E}+00$ & $0.00 \mathrm{E}+00$ & $0.00 \mathrm{E}+00$ & $0.00 \mathrm{E}+00$ & $0.00 \mathrm{E}+00$ & $0.00 \mathrm{E}+00$ & $0.00 \mathrm{E}+00$ & $0.00 \mathrm{E}+00$ & $0.00 \mathrm{E}+00$ & $0.00 \mathrm{E}+00$ & $0.00 \mathrm{E}+00$ & $0.00 \mathrm{E}+00$ & $0.00 \mathrm{E}+00$ & $0.00 \mathrm{E}+00$ & $0.00 \mathrm{E}+00$ & $0.00 \mathrm{E}+00$ & $0.00 \mathrm{E}+00$ \\
\hline Resin & $0.00 \mathrm{E}+00$ & $0.00 \mathrm{E}+00$ & \begin{tabular}{l|l}
$0.00 \mathrm{E}+00$ & \\
\end{tabular} & $0.00 \mathrm{E}+00$ & $0.00 \mathrm{E}+00$ & $0.00 \mathrm{E}+00$ & $0.00 \mathrm{E}+00$ & $0.00 \mathrm{E}+00$ & $0.00 \mathrm{E}+00$ & $0.00 \mathrm{E}+00$ & $0.00 \mathrm{E}+00$ & $0.00 \mathrm{E}+00$ & $0.00 \mathrm{E}+00$ & $0.00 \mathrm{E}+00$ & $0.00 \mathrm{E}+00$ & $4.13 \mathrm{E}-02$ & $4.13 \mathrm{E}-02$ & $0.00 \mathrm{E}+00$ & $0.00 \mathrm{E}+00$ \\
\hline \multicolumn{20}{|c|}{ - } \\
\hline
\end{tabular}


Table 6-17 Mass Balance Summary for Generic Filter with Ion

Exchange Cesium Separation - Waste Feed Batch \#5, AP-105

\begin{tabular}{|c|c|c|c|c|c|c|c|c|c|c|c|c|c|c|c|c|c|c|c|}
\hline Stream Number & 1 & 2 & 3 & 4 & 5 & 6 & 7 & 8 & 9 & 10 & 11 & 14 & 15 & 16 & 17 & 18 & 19 & 20 & 21 \\
\hline Stream Name & $\begin{array}{l}\text { Waste Feed } \\
\text { from DST }\end{array}$ & $\begin{array}{c}\text { Concentrat } \\
\text { e Return to } \\
\text { DST }\end{array}$ & $\begin{array}{l}\text { Filtrate to } \\
\quad \mathrm{Cs} \\
\text { Separation }\end{array}$ & $\begin{array}{l}\text { Waste Feed } \\
\text { to Lead } \\
\text { Column }\end{array}$ & $\begin{array}{l}\text { Feed do } \\
\text { Polishing } \\
\text { Column }\end{array}$ & $\begin{array}{l}\text { LAW } \\
\text { Product }\end{array}$ & $\begin{array}{l}\text { LAW to } \\
\text { WTP }\end{array}$ & $\begin{array}{c}\text { LC Eluate } \\
\text { to Cs } \\
\text { Product } \\
\text { Tank } \\
\end{array}$ & $\begin{array}{c}\text { PC Eluate } \\
\text { to Cs } \\
\text { Product } \\
\text { Tank } \\
\end{array}$ & Cs Product & $\begin{array}{c}\text { Cs Product } \\
\text { to DST }\end{array}$ & $\begin{array}{l}\text { Bed } \\
\text { Changeout } \\
\text { Effluents }\end{array}$ & $\begin{array}{l}\text { LC Freshh } \\
\text { Resin } \\
\text { Decant }\end{array}$ & $\begin{array}{l}\text { PC Fresh } \\
\text { Resin } \\
\text { Decant }\end{array}$ & $\begin{array}{l}\text { LC Spent } \\
\text { Resin } \\
\text { Discharge }\end{array}$ & $\begin{array}{l}\text { PC Spent } \\
\text { Resin } \\
\text { Discharge }\end{array}$ & $\begin{array}{l}\text { Spent Resin } \\
\text { Slurry }\end{array}$ & $\begin{array}{l}\text { Spent Resin } \\
\text { to Disposal }\end{array}$ & $\begin{array}{c}\text { Resin } \\
\text { Dewatering } \\
\text { Effluent }\end{array}$ \\
\hline \multicolumn{20}{|l|}{ Physical Properties } \\
\hline Volume (L/h) & $6.75 \mathrm{E}+02$ & $1.36 \mathrm{E}+01$ & $6.62 \mathrm{E}+02$ & $1.40 \mathrm{E}+03$ & $1.40 \mathrm{E}+03$ & $.40 \mathrm{E}+03$ & $1.39 \mathrm{E}+03$ & $9.36 \mathrm{E}+01$ & $1.16 \mathrm{E}+02$ & $2.11 \mathrm{E}+02$ & $2.12 \mathrm{E}+02$ & $1.30 \mathrm{E}+00$ & $3.55 \mathrm{E}-01$ & $3.55 \mathrm{E}-01$ & 3.28E-01 & 3.28E-01 & $6.55 \mathrm{E}-01$ & $0.00 \mathrm{E}+00$ & $5.91 \mathrm{E}-01$ \\
\hline Volume (gpm) & $2.97 \mathrm{E}+00$ & $5.98 \mathrm{E}-02$ & $2.91 \mathrm{E}+00$ & $6.18 \mathrm{E}+00$ & $6.18 \mathrm{E}+00$ & $6.18 \mathrm{E}+00$ & $6.12 \mathrm{E}+00$ & $4.12 \mathrm{E}-01$ & $5.09 \mathrm{E}-01$ & $9.27 \mathrm{E}-01$ & $9.33 \mathrm{E}-01$ & $5.73 \mathrm{E}-03$ & $1.56 \mathrm{E}-03$ & $1.56 \mathrm{E}-03$ & $1.44 \mathrm{E}-03$ & $1.44 \mathrm{E}-03$ & $2.89 \mathrm{E}-03$ & $0.00 \mathrm{E}+00$ & $2.60 \mathrm{E}-03$ \\
\hline Density $(\mathrm{kg} / \mathrm{L})$ & $1.41 \mathrm{E}+00$ & $1.41 \mathrm{E}+00$ & $1.41 \mathrm{E}+00$ & $1.27 \mathrm{E}+00$ & $1.27 \mathrm{E}+00$ & $1.27 \mathrm{E}+00$ & $1.27 \mathrm{E}+00$ & $1.02 \mathrm{E}+00$ & $1.02 \mathrm{E}+00$ & $1.03 \mathrm{E}+00$ & $1.04 \mathrm{E}+00$ & $3.00 \mathrm{E}+00$ & $1.00 \mathrm{E}+00$ & $1.00 \mathrm{E}+00$ & $1.04 \mathrm{E}+00$ & $1.04 \mathrm{E}+00$ & $1.04 \mathrm{E}+00$ & $0.00 \mathrm{E}+00$ & $1.00 \mathrm{E}+00$ \\
\hline TDS $(\mathrm{kg} / \mathrm{h})$ & $4.26 \mathrm{E}+02$ & $8.56 \mathrm{E}+00$ & $4.17 \mathrm{E}+02$ & $5.19 \mathrm{E}+02$ & $5.19 \mathrm{E}+02$ & $5.19 \mathrm{E}+02$ & $5.13 \mathrm{E}+02$ & $4.46 \mathrm{E}+00$ & $4.45 \mathrm{E}+00$ & $8.92 \mathrm{E}+00$ & $9.96 \mathrm{E}+00$ & $0.00 \mathrm{E}+00$ & $0.00 \mathrm{E}+00$ & $0.00 \mathrm{E}+00$ & $0.00 \mathrm{E}+00$ & $0.00 \mathrm{E}+00$ & $0.00 \mathrm{E}+00$ & $0.00 \mathrm{E}+00$ & $0.00 \mathrm{E}+00$ \\
\hline $\mathrm{Al}(\mathrm{mol} / \mathrm{L})$ & $6.99 \mathrm{E}-01$ & $6.99 \mathrm{E}-01$ & $6.99 \mathrm{E}-01$ & $3.30 \mathrm{E}-01$ & $3.30 \mathrm{E}-01$ & $3.30 \mathrm{E}-01$ & $3.30 \mathrm{E}-01$ & $2.65 \mathrm{E}-02$ & $2.15 \mathrm{E}-02$ & $2.36 \mathrm{E}-02$ & $2.34 \mathrm{E}-02$ & $0.00 \mathrm{E}+00$ & $0.00 \mathrm{E}+00$ & $0.00 \mathrm{E}+00$ & $0.00 \mathrm{E}+00$ & $0.00 \mathrm{E}+00$ & $0.00 \mathrm{E}+00$ & $0.00 \mathrm{E}+00$ & $0.00 \mathrm{E}+00$ \\
\hline Free $\mathrm{OH}(\mathrm{mol} / \mathrm{L})$ & $1.91 \mathrm{E}+00$ & $1.91 \mathrm{E}+00$ & $1.91 \mathrm{E}+00$ & $2.71 \mathrm{E}+00$ & $2.71 \mathrm{E}+00$ & $2.71 \mathrm{E}+00$ & $2.71 \mathrm{E}+00$ & $-9.58 \mathrm{E}-03^{(4)}$ & $-7.76 \mathrm{E}-03^{(4)}$ & $-8.52 \mathrm{E}-03^{(4)}$ & $1.14 \mathrm{E}-01$ & $0.00 \mathrm{E}+00$ & $0.00 \mathrm{E}+00$ & $0.00 \mathrm{E}+00$ & $0.00 \mathrm{E}+00$ & $0.00 \mathrm{E}+00$ & $0.00 \mathrm{E}+00$ & $0.00 \mathrm{E}+00$ & $0.00 \mathrm{E}+00$ \\
\hline $\mathrm{Cs}(\mathrm{mol} / \mathrm{L})$ & $1.17 \mathrm{E}-04$ & $1.17 \mathrm{E}-04$ & $1.17 \mathrm{E}-04$ & $5.53 \mathrm{E}-05$ & $9.44 \mathrm{E}-06$ & $4.33 \mathrm{E}-08$ & $4.33 \mathrm{E}-08$ & $6.88 \mathrm{E}-04$ & $1.14 \mathrm{E}-04$ & $3.69 \mathrm{E}-04$ & $3.66 \mathrm{E}-04$ & $0.00 \mathrm{E}+00$ & $0.00 \mathrm{E}+00$ & $0.00 \mathrm{E}+00$ & $0.00 \mathrm{E}+00$ & $0.00 \mathrm{E}+00$ & $0.00 \mathrm{E}+00$ & $0.00 \mathrm{E}+00$ & $0.00 \mathrm{E}+00$ \\
\hline $\mathrm{Na}(\mathrm{mol} / \mathrm{L})$ & $8.90 \mathrm{E}+00$ & $8.90 \mathrm{E}+00$ & $8.90 \mathrm{E}+00$ & $6.00 \mathrm{E}+00$ & $6.00 \mathrm{E}+00$ & $6.00 \mathrm{E}+00$ & $6.00 \mathrm{E}+00$ & $5.71 \mathrm{E}-01$ & $4.63 \mathrm{E}-01$ & $5.10 \mathrm{E}-01$ & $6.30 \mathrm{E}-01$ & $0.00 \mathrm{E}+00$ & $0.00 \mathrm{E}+00$ & $0.00 \mathrm{E}+00$ & $0.00 \mathrm{E}+00$ & $0.00 \mathrm{E}+00$ & $0.00 \mathrm{E}+00$ & $0.00 \mathrm{E}+00$ & $0.00 \mathrm{E}+00$ \\
\hline $\mathrm{K}(\mathrm{mol} / \mathrm{L})$ & $1.01 \mathrm{E}-01$ & 1E-01 & $1.01 \mathrm{E}-01$ & $4.75 \mathrm{E}-02$ & $4.75 \mathrm{E}-02$ & $4.75 \mathrm{E}-02$ & $4.75 \mathrm{E}-02$ & $3.82 \mathrm{E}-03$ & $3.10 \mathrm{E}-03$ & $3.40 \mathrm{E}-03$ & $3.38 \mathrm{E}-03$ & $0.00 \mathrm{E}+00$ & $0.00 \mathrm{E}+00$ & $0.00 \mathrm{E}+00$ & $0.00 \mathrm{E}+00$ & $0.00 \mathrm{E}+00$ & $0.00 \mathrm{E}+00$ & $0.00 \mathrm{E}+00$ & $0.00 \mathrm{E}+00$ \\
\hline${ }^{137} \mathrm{Cs}(\mathrm{Cl} / \mathrm{L})$ & $2.73 \mathrm{E}-01$ & $2.73 \mathrm{E}-01$ & $2.73 \mathrm{E}-01$ & $1.28 \mathrm{E}-01$ & $2.19 \mathrm{E}-02$ & $1.00 \mathrm{E}-04$ & $1.00 \mathrm{E}-04$ & $1.60 \mathrm{E}+00$ & $2.65 \mathrm{E}-01$ & $8.56 \mathrm{E}-01$ & $8.50 \mathrm{E}-01$ & $0.00 \mathrm{E}+00$ & $0.00 \mathrm{E}+00$ & $0.00 \mathrm{E}+00$ & $0.00 \mathrm{E}+00$ & $0.00 \mathrm{E}+00$ & $0.00 \mathrm{E}+00$ & $0.00 \mathrm{E}+00$ & $0.00 \mathrm{E}+00$ \\
\hline \multicolumn{20}{|c|}{ Insoluble Components $(\mathrm{kg} / \mathrm{h}$} \\
\hline Suspended Solids & $4.80 \mathrm{E}+00$ & $4.80 \mathrm{E}+00$ & $4.80 \mathrm{E}-04$ & $4.80 \mathrm{E}-04$ & $4.80 \mathrm{E}-04$ & $4.80 \mathrm{E}-04$ & $4.75 \mathrm{E}-04$ & $2.57 \mathrm{E}-06$ & $2.57 \mathrm{E}-06$ & $5.15 \mathrm{E}-06$ & $5.15 \mathrm{E}-06$ & $0.00 \mathrm{E}+00$ & $0.00 \mathrm{E}+00$ & $0.00 \mathrm{E}+00$ & $0.00 \mathrm{E}+00$ & $0.00 \mathrm{E}+00$ & $0.00 \mathrm{E}+00$ & $0.00 \mathrm{E}+00$ & $0.00 \mathrm{E}+00$ \\
\hline Resin & $0.00 \mathrm{E}+00$ & $0.00 \mathrm{E}+00$ & $0.00 \mathrm{E}+00$ & $0.00 \mathrm{E}+00$ & $0.00 \mathrm{E}+00$ & $0.00 \mathrm{E}+00$ & $0.00 \mathrm{E}+00$ & $0.00 \mathrm{E}+00$ & $0.00 \mathrm{E}+00$ & $0.00 \mathrm{E}+00$ & $0.00 \mathrm{E}+00$ & $0.00 \mathrm{E}+00$ & $0.00 \mathrm{E}+00$ & $0.00 \mathrm{E}+00$ & $4.39 \mathrm{E}-02$ & $4.39 \mathrm{E}-02$ & $8.78 \mathrm{E}-02$ & $8.78 \mathrm{E}-02$ & $0.00 \mathrm{E}+00$ \\
\hline Stream Number & 30 & 31 & $\begin{array}{lll}100 \\
\end{array}$ & 101 & & $\overline{11}$ & 104 & & & & 108 & 109 & 110 & 111 & 112 & 113 & $\begin{array}{llll}114 & & & \end{array}$ & 115 & 16 \\
\hline & $\begin{array}{c}\text { Lead } \\
\text { Column } \\
\text { Regenerate }\end{array}$ & $\begin{array}{c}\text { Polishing } \\
\text { Column } \\
\text { Regenerate }\end{array}$ & $\begin{array}{l}\text { Dilution } \\
\mathrm{NaOH}\end{array}$ & $\begin{array}{l}\text { Waste Feed } \\
\text { Dilution } \\
\text { Water }\end{array}$ & $\begin{array}{l}0.1 \mathrm{M} \\
\mathrm{NaOH}\end{array}$ & $\begin{array}{l}0.45 \mathrm{M} \\
\mathrm{HNO} 3\end{array}$ & $\begin{array}{l}\text { Rinse } \\
\text { Water }\end{array}$ & $\begin{array}{l}0.1 \mathrm{M} \\
\mathrm{NaOH}\end{array}$ & $\begin{array}{l}0.45 \mathrm{M} \\
\mathrm{HNO} 3\end{array}$ & $\begin{array}{l}\text { Rinse } \\
\text { Water }\end{array}$ & $\begin{array}{l}0.5 \mathrm{M} \\
\mathrm{NaOH}\end{array}$ & $\begin{array}{l}0.5 \mathrm{M} \\
\mathrm{NaOH}\end{array}$ & $\begin{array}{c}\mathrm{NaOH} \\
\text { Adjustment } \\
\text { Solutitiont }\end{array}$ & \begin{tabular}{|c|} 
NaNO2 \\
Adjustment \\
Solution
\end{tabular} & $\begin{array}{l}\text { Cs Product } \\
\text { Dilution } \\
\text { Water }\end{array}$ & $\begin{array}{l}\text { LC Fresh } \\
\text { Resin } \\
\text { Slurry }\end{array}$ & $\begin{array}{l}\text { PC Fresh } \\
\text { Resin } \\
\text { Slurry }\end{array}$ & $\begin{array}{c}\mathrm{LC} \\
\text { Fluidizing } \\
\text { Whater }\end{array}$ & $\begin{array}{c}\mathrm{PC} \\
\text { Fluidizing } \\
\text { Whater }\end{array}$ \\
\hline \multicolumn{20}{|l|}{ Physical Properties } \\
\hline Volume $(\mathrm{L} / \mathrm{h})$ & $7.53 \mathrm{E}+00$ & $7.53 \mathrm{E}+00$ & $1.33 \mathrm{E}+02$ & $6.43 \mathrm{E}+02$ & $1.10 \mathrm{E}+01$ & $6.58 \mathrm{E}+01$ & $1.68 \mathrm{E}+01$ & $1.10 \mathrm{E}+01$ & $6.58 \mathrm{E}+01$ & $1.68 \mathrm{E}+01$ & $1.45 \mathrm{E}+01$ & $1.45 \mathrm{E}+01$ & $1.36 \mathrm{E}+00$ & $0.00 \mathrm{E}+00$ & $0.00 \mathrm{E}+00$ & $3.03 \mathrm{E}-01$ & $3.03 \mathrm{E}-01$ & $3.80 \mathrm{E}-01$ & $3.80 \mathrm{E}-01$ \\
\hline Volume (gpm) & $3.32 \mathrm{E}-02$ & $3.32 \mathrm{E}-02$ & $5.86 \mathrm{E}-01$ & $2.83 \mathrm{E}+00$ & $4.83 \mathrm{E}-02$ & $2.90 \mathrm{E}-01$ & $7.41 \mathrm{E}-02$ & $4.83 \mathrm{E}-02$ & $2.90 \mathrm{E}-01$ & $7.41 \mathrm{E}-02$ & $6.38 \mathrm{E}-02$ & $6.38 \mathrm{E}-02$ & $5.99 \mathrm{E}-03$ & $0.00 \mathrm{E}+00$ & $0.00 \mathrm{E}+00$ & $1.33 \mathrm{E}-03$ & $1.33 \mathrm{E}-03$ & $1.68 \mathrm{E}-03$ & $1.68 \mathrm{E}-03$ \\
\hline Density $(\mathrm{kg} / \mathrm{L})$ & $1.27 \mathrm{E}+00$ & $1.27 \mathrm{E}+00$ & $1.53 \mathrm{E}+00$ & $1.00 \mathrm{E}+00$ & $1.00 \mathrm{E}+00$ & $1.01 \mathrm{E}+00$ & $1.00 \mathrm{E}+00$ & $1.00 \mathrm{E}+00$ & $1.01 \mathrm{E}+00$ & $1.00 \mathrm{E}+00$ & $1.02 \mathrm{E}+00$ & $1.02 \mathrm{E}+00$ & $1.53 \mathrm{E}+00$ & $1.14 \mathrm{E}+00$ & $1.00 \mathrm{E}+00$ & $1.04 \mathrm{E}+00$ & $1.04 \mathrm{E}+00$ & $1.00 \mathrm{E}+00$ & $1.00 \mathrm{E}+00$ \\
\hline TDS $(\mathrm{kg} / \mathrm{h})$ & $2.78 \mathrm{E}+00$ & $2.78 \mathrm{E}+00$ & $1.01 \mathrm{E}+02$ & $0.00 \mathrm{E}+00$ & $0.00 \mathrm{E}+00$ & $0.00 \mathrm{E}+00$ & $0.00 \mathrm{E}+00$ & $0.00 \mathrm{E}+00$ & $0.00 \mathrm{E}+00$ & $0.00 \mathrm{E}+00$ & $0.00 \mathrm{E}+00$ & $0.00 \mathrm{E}+00$ & $1.04 \mathrm{E}+00$ & $0.00 \mathrm{E}+00$ & $0.00 \mathrm{E}+00$ & $0.00 \mathrm{E}+00$ & $0.00 \mathrm{E}+00$ & $0.00 \mathrm{E}+00$ & $0.00 \mathrm{E}+00$ \\
\hline $\mathrm{Al}(\mathrm{mol} / \mathrm{L})$ & $3.30 \mathrm{E}-01$ & $3.30 \mathrm{E}-01$ & $0.00 \mathrm{E}+00$ & $0.00 \mathrm{E}+00$ & $0.00 \mathrm{E}+00$ & $0.00 \mathrm{E}+00$ & $0.00 \mathrm{E}+00$ & $0.00 \mathrm{E}+00$ & $0.00 \mathrm{E}+00$ & $0.00 \mathrm{E}+00$ & $0.00 \mathrm{E}+00$ & $0.00 \mathrm{E}+00$ & $0.00 \mathrm{E}+00$ & $0.00 \mathrm{E}+00$ & $0.00 \mathrm{E}+00$ & $0.00 \mathrm{E}+00$ & $0.00 \mathrm{E}+00$ & $0.00 \mathrm{E}+00$ & $0.00 \mathrm{E}+00$ \\
\hline Free $\mathrm{OH}(\mathrm{mol} / \mathrm{L})$ & $2.71 \mathrm{E}+00$ & $2.71 \mathrm{E}$ & $1.91 \mathrm{E}$ & $0.00 \mathrm{E}$ & $1.00 \mathrm{E}$ & $0.00 \mathrm{E}+00$ & $0.00 \mathrm{E}+00$ & $1.00 \mathrm{E}-01$ & $0.00 \mathrm{E}+00$ & $0.00 \mathrm{E}+00$ & $5.00 \mathrm{E}-01$ & $5.00 \mathrm{E}-01$ & $1.91 \mathrm{E}+01$ & $0.00 \mathrm{E}+00$ & $0.00 \mathrm{E}+00$ & $0.00 \mathrm{E}+00$ & $0.00 \mathrm{E}+00$ & $0.00 \mathrm{E}+00$ & $0.00 \mathrm{E}+00$ \\
\hline $\mathrm{Cs}(\mathrm{mol} / \mathrm{L})$ & $4.33 \mathrm{E}-08$ & $4.33 \mathrm{E}-08$ & $0.00 \mathrm{E}+00$ & $0.00 \mathrm{E}+00$ & $0.00 \mathrm{E}+00$ & $0.00 \mathrm{E}+00$ & $0.00 \mathrm{E}+00$ & $0.00 \mathrm{E}+00$ & $0.00 \mathrm{E}+00$ & $0.00 \mathrm{E}+00$ & $0.00 \mathrm{E}+00$ & $0.00 \mathrm{E}+00$ & $0.00 \mathrm{E}+00$ & $0.00 \mathrm{E}+00$ & $0.00 \mathrm{E}+00$ & $0.00 \mathrm{E}+00$ & $0.00 \mathrm{E}+00$ & $0.00 \mathrm{E}+00$ & $0.00 \mathrm{E}+00$ \\
\hline $\mathrm{Na}(\mathrm{mol} / \mathrm{L})$ & $6.00 \mathrm{E}+00$ & $6.00 \mathrm{E}+00$ & $1.91 \mathrm{E}+01$ & $0.00 \mathrm{E}+00$ & $1.00 \mathrm{E}-01$ & $0.00 \mathrm{E}+00$ & $0.00 \mathrm{E}+00$ & $1.00 \mathrm{E}-01$ & $0.00 \mathrm{E}+00$ & $0.00 \mathrm{E}+00$ & $5.00 \mathrm{E}-01$ & $5.00 \mathrm{E}-01$ & $1.91 \mathrm{E}+01$ & $0.00 \mathrm{E}+00$ & $0.00 \mathrm{E}+00$ & $0.00 \mathrm{E}+00$ & $0.00 \mathrm{E}+00$ & $0.00 \mathrm{E}+00$ & $0.00 \mathrm{E}+00$ \\
\hline $\mathrm{K}(\mathrm{mol} / \mathrm{L})$ & $4.75 \mathrm{E}-02$ & $4.75 \mathrm{E}-$ & $0.00 \mathrm{E}+$ & $0.00 \mathrm{E}-$ & $0.00 \mathrm{E}+00$ & $0.00 \mathrm{E}+$ & $0.00 \mathrm{E}+00$ & $0.00 \mathrm{I}$ & $0.00 \mathrm{E}+00$ & $0.00 \mathrm{E}+00$ & $0.00 \mathrm{E}+00$ & $0.00 \mathrm{E}+00$ & $0.00 \mathrm{E}+00$ & $0.00 \mathrm{E}+00$ & $0.00 \mathrm{E}+00$ & $0.00 \mathrm{E}+00$ & $0.00 \mathrm{E}+00$ & $0.00 \mathrm{E}+00$ & $0.00 \mathrm{E}+00$ \\
\hline${ }^{137} \mathrm{Cs}(\mathrm{Ci} / \mathrm{L})$ & $1.00 \mathrm{E}-04$ & $1.00 \mathrm{E}-04$ & $0.00 \mathrm{E}+00$ & $0.00 \mathrm{E}+00$ & $0.00 \mathrm{E}+00$ & $0.00 \mathrm{E}+00$ & $0.00 \mathrm{E}+00$ & $0.00 \mathrm{E}+00$ & $0.00 \mathrm{E}+00$ & $0.00 \mathrm{E}+00$ & $0.00 \mathrm{E}+00$ & $0.00 \mathrm{E}+00$ & $0.00 \mathrm{E}+00$ & $0.00 \mathrm{E}+00$ & $0.00 \mathrm{E}+00$ & $0.00 \mathrm{E}+00$ & $0.00 \mathrm{E}+00$ & $0.00 \mathrm{E}+00$ & $0.00 \mathrm{E}+00$ \\
\hline \multicolumn{20}{|l|}{ Insoluble Comp } \\
\hline Suspended Solids & $2.57 \mathrm{E}-06$ & 2.5 & $0.6>$ & & $0.00 \mathrm{E}^{-} \mathrm{C}$ & $0.00 \mathrm{E}$ & $0.00 \mathrm{E}+00$ & & 00 & 0.001 & DUE +00 & . & 0.00ETOU & or & 00 & 00 & $.00 \mathrm{E}+00$ & $.00 \mathrm{E}+00$ & $0.00 \mathrm{E}+00$ \\
\hline Resin & $0.00 \mathrm{E}+00$ & $0.00 \mathrm{E}+00$ & $0.00 \mathrm{E}+00$ & $0.00 \mathrm{E}+00$ & $0.00 \mathrm{E}+00$ & $0.00 \mathrm{E}+00$ & $0.00 \mathrm{E}+00$ & $0.00 \mathrm{E}+00$ & $0.00 \mathrm{E}+00$ & $0.00 \mathrm{E}+00$ & $0.00 \mathrm{E}+00$ & $0.00 \mathrm{E}+00$ & $0.00 \mathrm{E}+00$ & $0.00 \mathrm{E}+00$ & $0.00 \mathrm{E}+00$ & $4.39 \mathrm{E}-02$ & $4.39 \mathrm{E}-02$ & $0.00 \mathrm{E}+00$ & $0.00 \mathrm{E}+00$ \\
\hline \multirow{2}{*}{\multicolumn{20}{|c|}{3}} \\
\hline & & & & & & & & & & & & & & & & & & & \\
\hline $\begin{array}{l}\mathrm{C} \\
\mathrm{T}\end{array}$ & & & & & & & & & & & & & & & & & & & \\
\hline
\end{tabular}


Table 6-18 Mass Balance Summary for Generic Filter with Ion

Exchange Cesium Separation - Waste Feed Batch \#6, AP-108

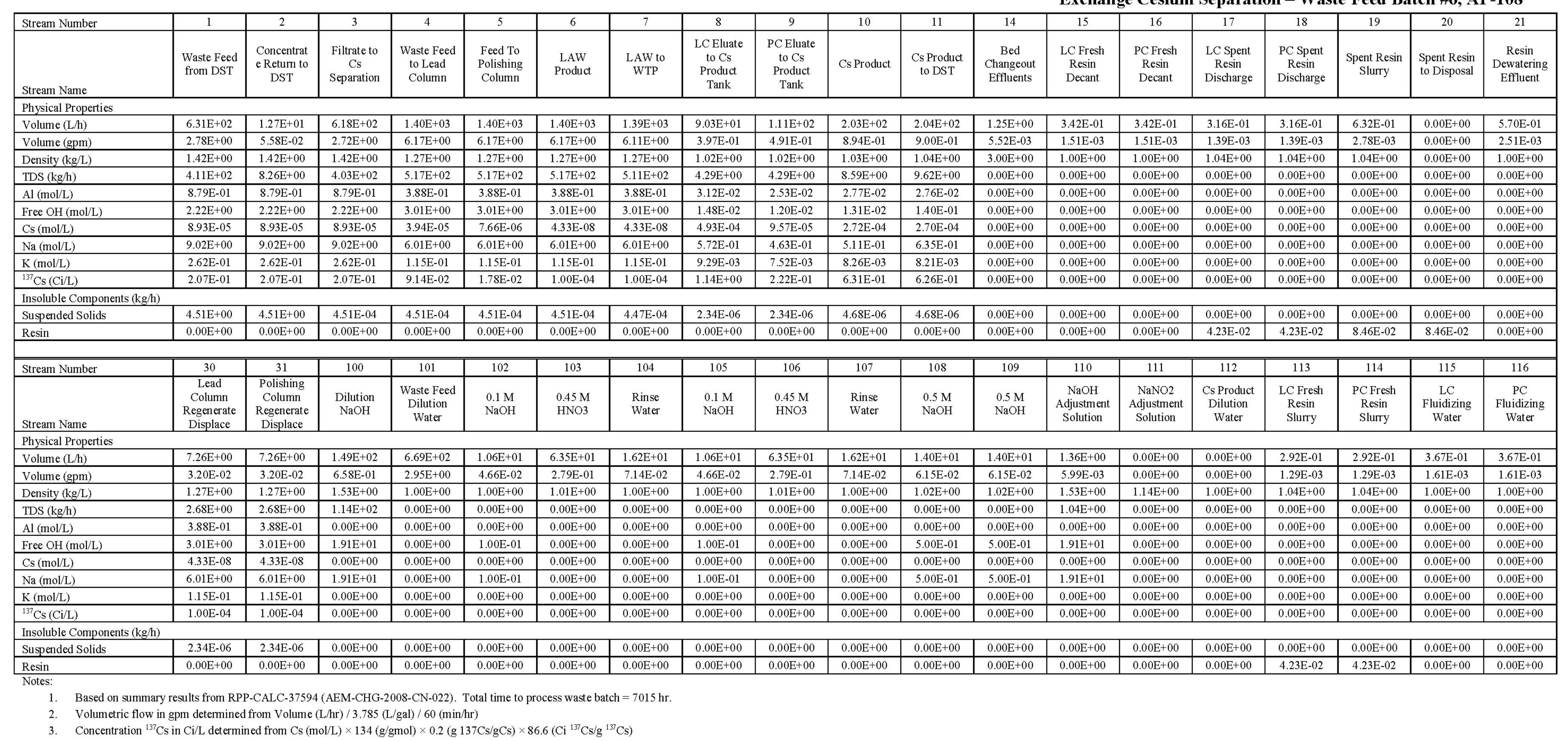


Table 6-20 Mass Balance Summary for Generic Filter with Ion

Exchange Cesium Separation - Waste Feed Batch \#8, AN-104




6.1.6.2 Spent Resin Composition. Material balance estimates did not attempt to track the small masses of waste components that could be remaining on spent resin. The small quantities associated with the spent resin would not have a significant impact on the time averaged mass rate of components in liquid streams. Therefore, the composition of spent resin is described by test data obtained from resin samples after processing actual waste using laboratory scale equipment.

Spent resin analyses are reported in WTP-RPT-144, Spherical Resorcinol-Formaldehyde Resin Analysis Following Actual Hanford Tank Waste Processing using the resin in two laboratoryscale columns to process a series of actual waste samples with material from resin lot $5 \mathrm{E}$ 370/641. The sequence of wastes processed began with AP-101 simulant, followed by actual wastes from AP-101 and AN-102. A total of three column test runs were performed with varying loading and elution cycle volumes and the two columns swapped between lead and lag positions between test runs. Spent resin dose rates at contact prior to sample analysis for the two resin samples, each with a dry $\mathrm{H}$-form mass of $2.92 \mathrm{~g}$, were $<0.5 \mathrm{mR} / \mathrm{hr}$ (Column A) and 2.5 $\mathrm{mR} / \mathrm{hr}$ (Column B).

Both columns were eluted with $30 \mathrm{BV}$ of $0.5 \mathrm{M} \mathrm{HNO}_{3}$ and rinsed with $3 \mathrm{BV}$ of water prior to spent resin analysis. Table 6-21 summarizes the results of analyzing the two resin samples (an entire laboratory scale resin bed represents a single resin sample). The results summarized in Table 6-21 are based on acid digestion of resin samples and should not be confused with toxic characteristic leach procedure results. A number of elements were found to have concentrated on the resin, including $\mathrm{Ag}, \mathrm{As}, \mathrm{Ba}, \mathrm{Cr}, \mathrm{Ni}$, and $\mathrm{Pb}$. Other elements identified on the spent resin based on information only results included $\mathrm{Co}, \mathrm{Cu}, \mathrm{Fe}$, and $\mathrm{Zr}$. The maximum ${ }^{137} \mathrm{Cs}$ concentration reported is $3.68 \mu \mathrm{Ci} / \mathrm{g}$ dry $\mathrm{H}$-form resin. Total alpha concentrations ranged from 0.6 to $2.4 \mathrm{nCi} / \mathrm{g}$ dry $\mathrm{H}$-form resin.

Table 6-21 Summary of Spent Resin Metals and Radionuclide Concentrations after Processing a Sequence of Actual Waste Samples in Column Tests

\begin{tabular}{|c|c|c|}
\hline Component & Resin A & Resin B \\
\hline Metals & $\boldsymbol{\mu g} / \mathbf{g}$ dry H-form resin & $\boldsymbol{\mu g} / \mathbf{g}$ dry H-form resin \\
\hline $\mathrm{Ag}$ & {$[3.1]^{(2)}$} & {$[3.4]^{(2)}$} \\
\hline $\mathrm{As}$ & $<6.4$ & {$[6.9]$} \\
\hline $\mathrm{Ba}$ & {$[1.5]$} & {$[1.0]$} \\
\hline $\mathrm{Cd}$ & {$[0.58]$} & {$[0.69]$} \\
\hline $\mathrm{Cr}$ & 338 & 337 \\
\hline $\mathrm{Cs}(\mathrm{total})$ & 0.0204 & 0.187 \\
\hline $\mathrm{Na}$ & {$[68]$} & {$[160]$} \\
\hline $\mathrm{Ni}$ & 26.1 & {$[9.7]$} \\
\hline $\mathrm{Pb}$ & {$[9.5]$} & {$[8.6]$} \\
\hline $\mathrm{Se}$ & {$[8.8]$} & {$[9.5]$} \\
\hline $\mathrm{Th}$ & $<75$ & $<74$ \\
\hline $\mathrm{U}$ & 193 & 101 \\
\hline Radionuclides & $\boldsymbol{\mu C i} / \mathbf{g}$ dry H-form resin & $\boldsymbol{\mu C i}$ /g dry H-form resin \\
\hline
\end{tabular}


Table 6-21 Summary of Spent Resin Metals and Radionuclide Concentrations after Processing a Sequence of Actual Waste Samples in Column Tests

\begin{tabular}{|c|c|c|}
\hline Component & Resin A & Resin B \\
\hline${ }^{60} \mathrm{Co}$ & 0.0787 & 0.0196 \\
\hline${ }^{126} \mathrm{Sn} / \mathrm{Sb}$ & 0.000358 & $<0.0008$ \\
\hline${ }^{99} \mathrm{Tc}$ & 0.321 & 0.330 \\
\hline${ }^{106} \mathrm{Ru}$ & $<0.001$ & $<0.001$ \\
\hline${ }^{134} \mathrm{Cs}$ & $<0.0001$ & $<0.00008$ \\
\hline${ }^{137} \mathrm{Cs}$ & 0.352 & 3.68 \\
\hline${ }^{154} \mathrm{Eu}$ & $<0.0002$ & $<0.0001$ \\
\hline${ }^{155} \mathrm{Eu}$ & $<0.0004$ & $<0.003$ \\
\hline Sum of beta & 0.753 & 4.02 \\
\hline Total beta & 0.660 & 3.70 \\
\hline Transuranics & $\mathbf{n C i} / \mathbf{g}$ dry H-form resin & nCi/g dry H-form resin \\
\hline${ }^{238} \mathrm{Pu}$ & 0.361 & 0.169 \\
\hline${ }^{239+240} \mathrm{Pu}$ & 1.72 & 0.621 \\
\hline${ }^{241} \mathrm{Am}$ & 0.272 & 0.241 \\
\hline${ }^{242} \mathrm{Cm}$ & $<0.01$ & $<0.01$ \\
\hline${ }^{243+244} \mathrm{Cm}$ & $<0.02$ & $<0.02$ \\
\hline Sum of alpha & 2.35 & 1.04 \\
\hline Total alpha & 1.86 & 0.632 \\
\hline
\end{tabular}

Notes:

1. Reported values greater than detection limits for spent resin reported in WTP-RPT-144, Spherical ResorcinolFormaldehyde Resin Analysis Following Actual Hanford Tank Waste Processing (Table S.1 and Table 3.3). Analyses are based on acid digestion of resin samples and are not applicable for comparison to toxicity characteristics leach procedure criteria. Does not list opportunistic analytes reported for information only.

2. Bracketed results are greater than the method detection limit but less than the estimated quantification limit and errors are likely to exceed $15 \%$.

3. Values reported for ${ }^{99} \mathrm{Tc}$ are $18.9 \mu \mathrm{g} / \mathrm{g}$ and $19.4 \mu \mathrm{g} / \mathrm{g}$ for Resin $\mathrm{A}$ and Resin B, respectively. These were converted to a curie basis by the conversion factor for ${ }^{99} \mathrm{Tc}$ of $0.017 \mathrm{Ci} / \mathrm{g}$ to simplify results presentation.

The results indicate that the spent resin is expected to be disposed as non-TRU solid waste. Resin bulk density is estimated at $0.3 \mathrm{~kg}$ dry $\mathrm{H}$-form resin/L, which can be used to convert the values in Table 6-21 to a volumetric basis. For example, the spent resin is projected to contain between $1 \mathrm{E}-04$ to $1.1 \mathrm{E}-03 \mathrm{Ci}^{137} \mathrm{Cs} / \mathrm{L}$, based on the range of resin sample analyses results [e.g., $\left(0.352 \mathrm{E}-06 \mathrm{Ci}^{137} \mathrm{Cs} / \mathrm{g}\right.$ resin $) \times(1000 \mathrm{~g} / \mathrm{kg}) \times(0.3 \mathrm{~kg}$ resin $/ \mathrm{L}$ resin $\left.)\right]$. For a resin disposal package containing two spent resin beds, the cesium inventory is estimated to range from 0.12 to $1.4 \mathrm{Ci}{ }^{137} \mathrm{Cs}\left[\right.$ e.g., $(2) \times(614 \mathrm{~L} /$ resin bed $) \times\left(1 \mathrm{E}-04 \mathrm{Ci}^{137} \mathrm{Cs} / \mathrm{L}\right.$ resin $\left.)\right]$.

6.1.6.3 Energy Balances. Limited energy balances were prepared to support description of the ion exchange process since the unit operations do not involve large process solution temperature or phase changes. AEM-CHG-2008-CN-011 in RPP-CALC-37594 indicates that a heat exchanger duty of $\sim 160,000 \mathrm{BTU} / \mathrm{hr}$ is projected to support cooling the ion exchange column feed based on the maximum feed rate and waste entering the cesium separation system at an assumed temperature of $40^{\circ} \mathrm{C}$. 
AEM-CHG-2008-CN-014 in RPP-CALC-37594 performs an energy balance to estimate air flows associated with drying spent resin in a cask. Spent resin drying is performed by a flow of dry compressed air passing through the spent resin cask after loading. The resin drying is performed at a cask temperature of $\sim 25^{\circ} \mathrm{C}$. The energy balance indicates that a heated air stream of $100 \mathrm{SCFM}$ at $75^{\circ} \mathrm{C}$ will remove the cask water inventory in $\sim 1$ week of operation (spent resin is generated 2 to 3 times per year). Air heater and condenser duties are estimated at $\sim 10,000$ $\mathrm{BTU} / \mathrm{hr}$ for this system.

6.1.6.4 Key System Temperatures and Pressures. Detailed calculations of system temperatures and pressures were not included in the material balances for technology comparisons. This section describes ion exchange system temperatures and pressures which may be considered important to a comparison with other cesium separation alternatives.

The ion exchange system generally operates at temperature near $25^{\circ} \mathrm{C}$ and process solutions are maintained at, or near, this temperature to satisfy the selected ion exchange operating conditions. The primary exception to the general temperature occurs during water removal from a spent resin cask. In this case, an air temperature of $75^{\circ} \mathrm{C}$ was selected as input to the spent resin cask to promote water removal over a period of approximately 1 week.

Process streams are maintained at slightly less than atmospheric pressure in most vessels within the ion exchange process. Maximum liquid stream pressures are characterized by the discharge pressure of pumps. The largest pressure drop is projected to occur across the two resin beds during the loading cycle. In this case, the feed pump must transfer waste liquid through both resin beds in series. Pressure drop across a single resin bed can be estimated based on the resin permeability as shown by Equation 6.1-16 (242590-WTP-RPT-07-005, Section 8.1).

\section{Equation 6.1-16}

where:

$$
\Delta \mathrm{P}=\frac{\mathrm{V}_{0} \mathrm{~L} \mu}{\mathrm{K}}
$$

$\Delta \mathrm{P}$ is the pressure drop across the bed, $\mathrm{Pa}$

$\mathrm{V}_{0}$ is the fluid superficial velocity, $\mathrm{m} / \mathrm{s}$

$\mathrm{L}$ is the bed length, $\mathrm{m}$

$\mu$ is the fluid viscosity, $\mathrm{kg} / \mathrm{m}-\mathrm{s}$ or Pa-s

$\mathrm{K}$ is the bed permeability, 3E-10 $\mathrm{m}^{2}$ for resin bed (from 24590-WTP-RPT-07-005,

Section 8.1)

The maximum loading cycle waste flow rate is $30.7 \mathrm{~L} / \mathrm{min}$ (from Table $6-4$ ), or $5.1 \mathrm{E}-04 \mathrm{~m}^{3} / \mathrm{s}$ $\left(0.0307 \mathrm{~m}^{3} / \mathrm{min}\right) /(60 \mathrm{~s} / \mathrm{min})$. The column diameter is $0.867 \mathrm{~m}$, cross-section area is $0.59 \mathrm{~m}^{2}$, and resin bed length is $1.04 \mathrm{~m}$ from Figure 6-7. The loading cycle flow rate and column crosssection are produces a superficial velocity of $8.6 \mathrm{E}-04 \mathrm{~m} / \mathrm{s}$. Waste viscosity is assumed to be a maximum of $5 \mathrm{cP}$, or $0.005 \mathrm{~Pa}$-s. Therefore, the pressure drop across a single resin bed is estimated by Equation 6.1-17. 


\section{Equation 6.1-17}

$$
\Delta \mathrm{P}=\frac{\left(8.6 \times 10^{-4} \mathrm{~m} / \mathrm{s}\right)(1.04 \mathrm{~m})(0.005 \mathrm{~Pa}-\mathrm{s})}{\left(3 \times 10^{-10} \mathrm{~m}^{2}\right)}=1.5 \times 10^{4} \mathrm{~Pa}=2.1 \mathrm{psi}
$$

Equation 6.1-17 indicates that the maximum liquid stream pressure in the ion exchange system is estimated to be on the order of 4 to $5 \mathrm{psi}$ above line pressures associated with liquid head and pipe wall friction forces.

\subsubsection{Equipment List and Sizing}

Table 6-22 provides a summary of major equipment required for the pre-conceptual ion exchange process. 
RPP-RPT-37551, Rev. 1

Table 6-22 Ion Exchange Equipment List

\begin{tabular}{|c|c|c|c|c|c|}
\hline Qty & Component & $\begin{array}{l}\text { Process } \\
\text { Sizing }\end{array}$ & $\begin{array}{c}\text { Physical } \\
\text { Dimensions }\end{array}$ & Features & Comments \\
\hline 1 & Inline Mixer & & & & \\
\hline 1 & Feed Receipt Tank & $\begin{array}{l}14,400 \text { gal } \\
\text { total capacity }\end{array}$ & $13.5-\mathrm{ft} \mathrm{D} \times 13.5-\mathrm{ft} \mathrm{H}$ & $\begin{array}{l}\text { Clean out jet to empty tank in case of failed } \\
\text { pump } \\
\text { Nozzles: (3) process piping } \\
\text { (1) wash } \\
\text { (1) off gas } \\
\text { (1) pump } \\
\text { (3) instrumentation } \\
\text { (1) PRV } \\
\text { I\&C: Level } \\
\text { Temperature } \\
\text { Pressure control (offgas) }\end{array}$ & $\begin{array}{l}\text { Volume to store one day of waste feed at the } \\
\text { maximum flow rate }\end{array}$ \\
\hline 1 & Feed Pump & $10 \mathrm{gpm}$ & & $\begin{array}{l}\text { Tank top mounted, vertical pump } \\
\text { I\&C: Discharge pressure } \\
\text { Flow control } \\
\text { VFD }\end{array}$ & $\begin{array}{l}\text { Flow rate is the maximum waste feed flow } \\
\text { rate of } 8.0 \mathrm{gpm} .\end{array}$ \\
\hline 1 & Feed Heat Exchanger & $160,000 \mathrm{Btu} / \mathrm{hr}$ & & $\begin{array}{l}\text { Chilled water supply/return } \\
\text { I\&C: Temperature control }\end{array}$ & $\begin{array}{l}\text { Sized to lower feed stream temperature drop } \\
\text { of } 15 \mathrm{C} \text { at the maximum flow rate. }\end{array}$ \\
\hline 2 & LAW Product Tanks & $\begin{array}{l}57,500 \text { gal } \\
\text { total capacity }\end{array}$ & 21.4-ft D x 21.4-ft H & $\begin{array}{l}\text { Clean out jet to empty tank in case of failed } \\
\text { pump } \\
\text { Nozzles: (3) process piping } \\
\text { (1) off gas } \\
\text { (1) wash } \\
\text { (1) pump } \\
\text { (3) instrumentation } \\
\text { (1) sample } \\
\text { (1) PRV } \\
\text { I\&C: Level } \\
\text { Temperature } \\
\text { Pressure control (offgas) } \\
\text { Radiation monitor on inflow }\end{array}$ & $\begin{array}{l}\text { Volume for storing four days of treated LAW } \\
\text { at the maximum production rate in each tank }\end{array}$ \\
\hline 2 & LAW Product Pumps & $100 \mathrm{gpm}$ & & $\begin{array}{l}\text { Tank top mounted, vertical pump } \\
\text { I\&C: Discharge pressure } \\
\text { Flow control } \\
\text { VFD }\end{array}$ & $\begin{array}{l}\text { Design basis flow rate for feed to LAW is } 88 \\
\text { gpm. }\end{array}$ \\
\hline
\end{tabular}


RPP-RPT-37551, Rev. 1

Table 6-22 Ion Exchange Equipment List

\begin{tabular}{|c|c|c|c|c|c|}
\hline Qty & Component & $\begin{array}{l}\text { Process } \\
\text { Sizing }\end{array}$ & $\begin{array}{c}\text { Physical } \\
\text { Dimensions }\end{array}$ & Features & Comments \\
\hline 1 & Cs Product Tank & $\begin{array}{l}7,700 \text { gal } \\
\text { total capacity }\end{array}$ & 10.9-ft D x 10.9-ft H & $\begin{array}{l}\text { Clean out jet to empty tank in case of failed } \\
\text { pump } \\
\text { Nozzles: (5) process piping } \\
\text { (1) off gas } \\
\text { (1) wash } \\
\text { (1) pump } \\
\text { (3) instrumentation } \\
\text { (1) sample } \\
\text { (1) PRV } \\
\text { I\&C: Level } \\
\text { Temperature } \\
\text { Pressure control (offgas) } \\
\text { pH probe }\end{array}$ & $\begin{array}{l}\text { Volume for storing two elution/rinse cycles } \\
\text { plus additions to comply with tank farm } \\
\text { corrosion criteria. }\end{array}$ \\
\hline 1 & Cs Product Pump & $100 \mathrm{gpm}$ & & $\begin{array}{l}\text { Tank top mounted, vertical pump } \\
\text { I\&C: Discharge pressure } \\
\text { Flow control } \\
\text { VFD } \\
\end{array}$ & $\begin{array}{l}\text { Flow rate for return to tank farms assumed to } \\
\text { be approximately } 75 \mathrm{gpm} .\end{array}$ \\
\hline \multicolumn{6}{|c|}{ IX Column } \\
\hline 2 & IX Column & & $\begin{array}{l}\text { 34-in } \mathrm{D} \times 68 \text {-in } \mathrm{H} \text {, } \\
\text { internal dimensions }\end{array}$ & $\begin{array}{l}\text { (2) resin retention screens internal to column } \\
\text { Resin fluidization / extraction cone } \\
\text { Remote connector heads } \\
\text { Nozzles: (10) process piping } \\
\quad \text { (4) instrumentation } \\
\text { I\&C: (2) Temperature } \\
\text { (1) Differential pressure } \\
\text { (2) Remote gamma monitors }\end{array}$ & \\
\hline \multicolumn{6}{|c|}{ Spent Resin Sy stem } \\
\hline 1 & $\begin{array}{c}\text { Spent Resin } \\
\text { Accumulation Tank }\end{array}$ & $\begin{array}{l}2,000 \text { gal } \\
\text { total capacity }\end{array}$ & $7.0-\mathrm{ft} \mathrm{D} \times 7.0-\mathrm{ft} \mathrm{H}$ & $\begin{array}{l}\text { Clean out jet to empty tank in case of failed } \\
\text { pump } \\
\text { Mixer } \\
\text { Nozzles: (2) process piping } \\
\text { (1) off gas } \\
\text { (1) wash } \\
\text { (1) pump } \\
\text { (3) instrumentation } \\
\text { (1) PRV } \\
\text { I\&C: Level } \\
\text { Temperature } \\
\text { Pressure control (offgas) }\end{array}$ & $\begin{array}{l}\text { Volume to contain spent resin removal slurry } \\
\text { ( } 2.6 \mathrm{BV} / \text { column) plus fresh resin addition } \\
\text { overflow from both a lead and polishing } \\
\text { column replacement. }\end{array}$ \\
\hline
\end{tabular}


RPP-RPT-37551, Rev. 1

Table 6-22 Ion Exchange Equipment List

\begin{tabular}{|c|c|c|c|c|c|}
\hline \multicolumn{6}{|c|}{ (6 sheets) } \\
\hline Qty & Component & $\begin{array}{l}\text { Process } \\
\text { Sizing }\end{array}$ & $\begin{array}{c}\text { Physical } \\
\text { Dimensions }\end{array}$ & Features & Comments \\
\hline 1 & Spent Resin Pump & $5 \mathrm{gpm}$ & & $\begin{array}{l}\text { Tank top mounted, vertical pump } \\
\text { I\&C: Discharge pressure } \\
\text { Flow control } \\
\text { VFD }\end{array}$ & \\
\hline 13 & $\begin{array}{l}\text { Spent Resin Disposal } \\
\text { Cask }\end{array}$ & $\begin{array}{l}400 \text { gal total } \\
\text { capacity }\end{array}$ & 4.1-ft D x 4.1-ft H & $\begin{array}{l}\text { Contact handled, custom disposal cask for } \\
\text { contaminated waste with resin screen, fill, } \\
\text { effluent and process air connections. }\end{array}$ & $\begin{array}{l}\text { Volume to contain resin from two columns } \\
\text { plus } 20 \% \text { contingency for screen and top } \\
\text { void. }\end{array}$ \\
\hline 1 & Condenser & $10,000 \mathrm{Btu} / \mathrm{hr}$ & & & $\begin{array}{l}\text { Sized to condense saturated air for drying } \\
\text { spent resin cask within one week }\end{array}$ \\
\hline \multicolumn{4}{|c|}{$\begin{array}{l}\text { Chemical Storage Tanks, } \\
\text { IX System }\end{array}$} & \multicolumn{2}{|l|}{$\begin{array}{l}\text { All chemical storage tanks require level } \\
\text { indication, fill and distribution piping, freeze } \\
\text { protection, and containment structure (see } \\
\text { below). }\end{array}$} \\
\hline 1 & Bulk $\mathrm{NaOH}, 50 \mathrm{wt} \%$ & $12,500 \mathrm{gal}$ & $12.9-\mathrm{ft} \mathrm{D} \times 12.9-\mathrm{ft} \mathrm{H}$ & $\begin{array}{l}\text { Carbon Steel } \\
\text { Two Pumps } \\
3 \mathrm{gpm} \\
5 \mathrm{gpm}\end{array}$ & $\begin{array}{l}\text { Volume for a minimum of } 1 \text { week supply, in } \\
\text { multiples of the delivery volume of } 5000 \text { gal. }\end{array}$ \\
\hline 1 & $0.1 \mathrm{M} \mathrm{NaOH}$ & $2,100 \mathrm{gal}$ & $7.0-\mathrm{ft} \mathrm{D} \times 7.0-\mathrm{ft} \mathrm{H}$ & $\begin{array}{l}\text { Carbon Steel } \\
\text { Mixer } \\
20 \text { gpm Pump }\end{array}$ & $\begin{array}{l}\text { Volume to store solution for LAW } \\
\text { displacement to support two elutions of both } \\
\text { columns. }\end{array}$ \\
\hline 1 & $0.5 \mathrm{M} \mathrm{NaOH}$ & $2,700 \mathrm{gal}$ & 7.7-ft D x 7.7-ft H & $\begin{array}{l}\text { Carbon Steel } \\
\text { Mixer } \\
25 \text { gpm Pump }\end{array}$ & $\begin{array}{l}\text { Volume to store solution for column } \\
\text { regeneration to support two elutions of both } \\
\text { columns. }\end{array}$ \\
\hline 1 & $\begin{array}{l}\text { Bulk } \mathrm{HNO}_{3}, 60 \mathrm{wt} \% \\
(12.2 \mathrm{M})\end{array}$ & $6,500 \mathrm{gal}$ & 10.3-ft D x 10.3-ft H & $\begin{array}{l}\text { Stainless Steel } \\
10 \text { gpm Pump }\end{array}$ & $\begin{array}{l}\text { Volume to receive } 5000 \text { gal from tank truck } \\
\text { plus minimum heel to produce eluant for one } \\
\text { elution of both column. }\end{array}$ \\
\hline 1 & $0.45 \mathrm{M} \mathrm{HNO}_{3}$ & $12,500 \mathrm{gal}$ & 12.9-ft D x 12.9-ft H & $\begin{array}{l}\text { Stainless Steel } \\
\text { Mixer } \\
10 \text { gpm Pump }\end{array}$ & $\begin{array}{l}\text { Volume to store two elution volumes for both } \\
\text { columns. }\end{array}$ \\
\hline 1 & Bulk $\mathrm{NaNO}_{2}, 20 \mathrm{wt} \%$ & $\begin{array}{l}\text { One } 55 \text { gal } \\
\text { drum }\end{array}$ & & 1 gpm Pump & Routine usage not expected. \\
\hline 1 & Water & $5,000 \mathrm{gal}$ & 9.5-ft D x 9.5-ft H & $\begin{array}{l}\text { Carbon Steel } \\
\text { Four Pumps } \\
5 \mathrm{gpm} \\
20 \mathrm{gpm} \\
75 \mathrm{gpm} \\
100 \mathrm{gpm}\end{array}$ & $\begin{array}{l}\text { Volume of tank to store } 60 \% \text { of one day } \\
\text { process requirement }\end{array}$ \\
\hline
\end{tabular}


RPP-RPT-37551, Rev. 1

Table 6-22 Ion Exchange Equipment List

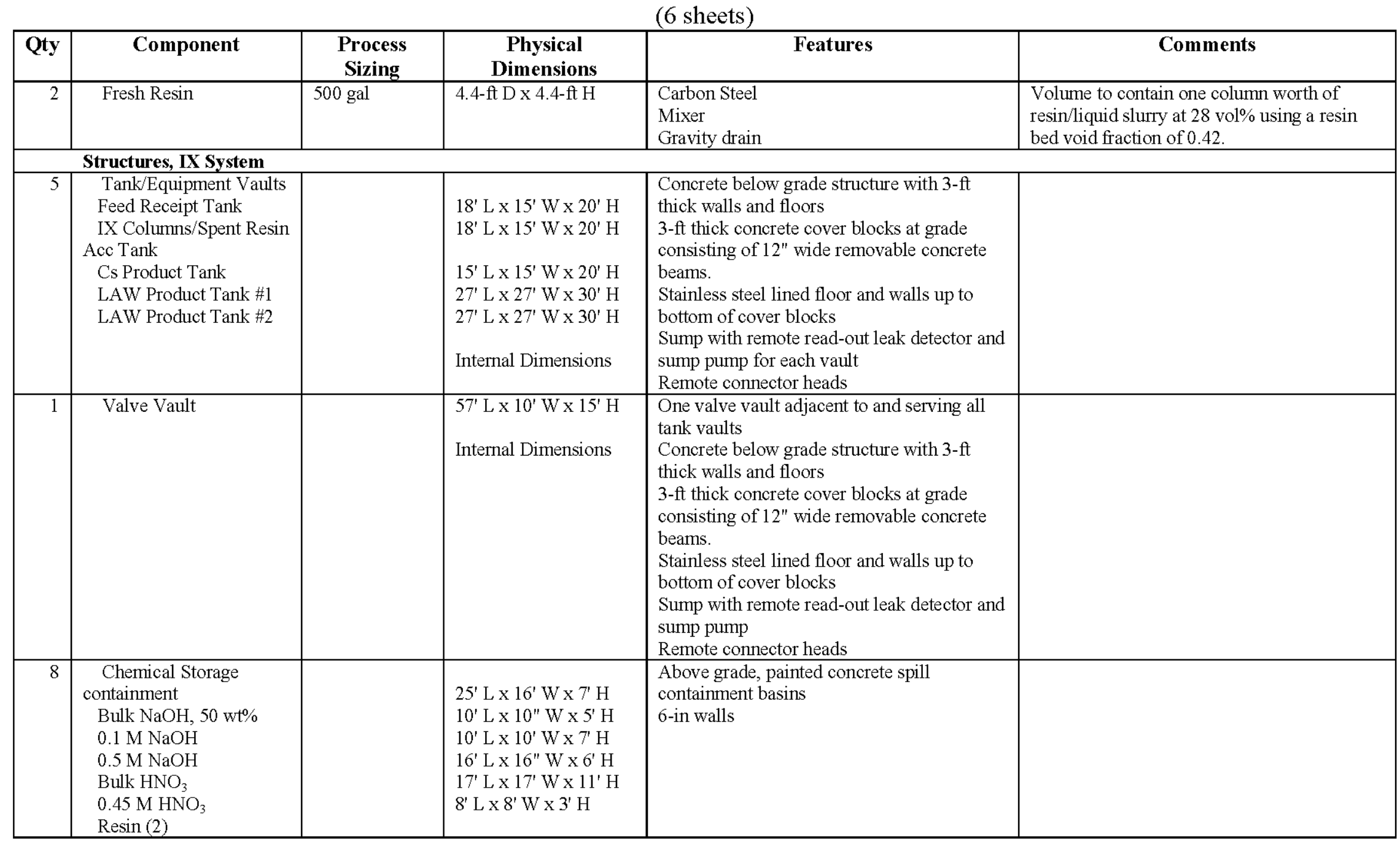




\section{Table 6-22 Ion Exchange Equipment List}

\begin{tabular}{|c|c|c|c|c|c|}
\hline \multicolumn{6}{|c|}{ (6 sheets) } \\
\hline Qty & Component & $\begin{array}{c}\text { Process } \\
\text { Sizing }\end{array}$ & $\begin{array}{c}\text { Physical } \\
\text { Dimensions }\end{array}$ & Features & Comments \\
\hline 1 & $\begin{array}{l}\text { Spent Resin Cask } \\
\text { Loadout Station }\end{array}$ & & $12^{\prime} \mathrm{L} \times 10^{\prime} \mathrm{W} \times 12^{\prime} \mathrm{H}$ & $\begin{array}{l}\text { Above grade building. } \\
\text { Disposal cask on/off-load with contact } \\
\text { handled connections for fill, effluent, process } \\
\text { air, and offgas condenser. } \\
\text { Offgas condenser located here. } \\
\text { Hoist for cask handling }\end{array}$ & \\
\hline \multicolumn{6}{|c|}{ PUREX type jumpers } \\
\hline & $\begin{array}{l}\text { Feed Receipt Tank } \\
\text { Vault }\end{array}$ & & & $\begin{array}{l}\text { (2) Process } \\
\text { (1) Electrical power } \\
\text { (2) Instrument }\end{array}$ & $\begin{array}{l}\text { Pump } \\
\text { Level and temperature instrumentation. }\end{array}$ \\
\hline & IX Column Vault & & & $\begin{array}{l}\text { (21) Process } \\
\text { (1) Electrical power } \\
\text { (8) Instrument }\end{array}$ & $\begin{array}{l}\text { IX columns ( } 10 \text { process and } 3 \text { instrument } \\
\text { each) } \\
\text { Spent Resin pump, level and temperature } \\
\text { instrumentation. }\end{array}$ \\
\hline & Cs Product Tank Vault & & & $\begin{array}{l}\text { (2) Process } \\
\text { (1) Electrical power } \\
\text { (2) Instrument }\end{array}$ & $\begin{array}{l}\text { Pump } \\
\text { Level and temperature instrumentation. }\end{array}$ \\
\hline & $\begin{array}{l}\text { LAW Product Tank \#1 } \\
\text { Vault }\end{array}$ & & & $\begin{array}{l}\text { (2) Process } \\
\text { (1) Electrical power } \\
\text { (2) Instrument } \\
\end{array}$ & $\begin{array}{l}\text { Pump } \\
\text { Level and temperature instrumentation. }\end{array}$ \\
\hline & $\begin{array}{l}\text { LAW Product Tank \#2 } \\
\text { Vault }\end{array}$ & & & $\begin{array}{l}\text { (2) Process } \\
\text { (1) Electrical power } \\
\text { (2) Instrument } \\
\end{array}$ & $\begin{array}{l}\text { Pump } \\
\text { Level and temperature instrumentation. }\end{array}$ \\
\hline & Valve Vault & & & $\begin{array}{l}\text { (22) Process } \\
\text { (20) Electrical power }\end{array}$ & $\begin{array}{l}\text { Assume two MOV's or instruments per } \\
\text { process line. } \\
\text { Inline mixer, Feed heat exchanger }\end{array}$ \\
\hline \multicolumn{6}{|c|}{ General Notes: } \\
\hline & $\begin{array}{l}\text { 1. All tanks are designe } \\
\text { 2. All process piping is } \\
\text { 3. All process equipmer } \\
\text { 4. See Common Equipn } \\
\text { 5. Tanks are sized assur }\end{array}$ & $\begin{array}{l}\text { ricated and } \\
\text { ned, fabrica } \\
\text { emical equip } \\
\text { List for proc } \\
\text { a working v }\end{array}$ & $\begin{array}{l}\text { and to ASME Section VI } \\
\text { and to and offgas piping is } n \\
\text { ffgas, vault ventilation, } \\
\text { he equal to } 80 \% \text { of the } t\end{array}$ & $\begin{array}{l}\text { ufactured from } 304 \mathrm{~L} \text { or } 316 \mathrm{~L} \mathrm{SS} \text {. } \\
\text { circulation } \mathrm{AHU} \text {, and chilled water systems. } \\
1 \text { capacity. }\end{array}$ & \\
\hline
\end{tabular}




\subsubsection{Process Consumables Summary}

Peak process chemical usage is summarized in Table 6-23 based on the maximum flow of each makeup stream determined for the different waste compositions. A total of 13 resin bed replacements are estimated to be required to process the first 8 waste batches. Processing these waste batches over a $5 \mathrm{yr}$ period is used to the annual resin usage (13 resin replacements $\times$ $325 \mathrm{gal}$ resin/replacement $/ 5 \mathrm{yr}$ ). Maximum process chemical usage is summarized as follows, on an annual basis.

- Water - 2,400,00 gal $/ \mathrm{yr}$

- $19 \mathrm{M} \mathrm{NaOH}-390,000 \mathrm{gal} / \mathrm{yr}$

- $12.2 \mathrm{M} \mathrm{HNO}_{3}-10,000 \mathrm{gal} / \mathrm{yr}$

- $4 \mathrm{M} \mathrm{NaNO}_{2}-0$

- Spherical Resorcinol-Formaldehyde Resin - $845 \mathrm{gal} / \mathrm{yr}$

Note that no NaNO2 is currently projected to be required to adjust the composition of solutions returned to DSTs from the ion exchange system. This result is observed because each rinse/elution/regeneration cycle composite waste includes nitrite ion associated with 2 column liquid holdup volumes with a composition equivalent to the waste feed. The capability to add $\mathrm{NaNO}_{2}$ was maintained in the ion exchange system to accommodate potential uncertainty or variability in the waste nitrite ion concentration.

\section{$\underline{\text { Peak Electrical Power Estimate }}$}

Ion exchange process equipment $\quad 19 \mathrm{kw}$ Process chilled water system $\quad 56 \mathrm{kw}$

Total $75 \mathrm{kw}^{1}$

${ }^{1}$ Does not include feed filtration, lighting, ventilation, control room, compressed air and other support functions. 
RPP-RPT-37551, Rev. 1

Table 6-23 Bulk Caustic and Water Usage for Ion Exchange

\begin{tabular}{|c|c|c|c|c|c|c|c|}
\hline $\begin{array}{c}\text { Stream } \\
\#\end{array}$ & Description & $\begin{array}{c}\text { Steady } \\
\text { State Flow, } \\
\text { L/hr } \\
\end{array}$ & Composition & $\begin{array}{c}19 \mathrm{M} \mathrm{NaOH} \\
\text { Equivalent } \\
\text { Flow, L/hr }\end{array}$ & $\begin{array}{c}\text { Makeup } \\
\text { Water Flow, } \\
\text { L/hr }{ }^{(3)} \\
\end{array}$ & $\begin{array}{c}4 \mathrm{M} \mathrm{NaNO}_{2} \\
\text { Equivalent } \\
\text { Flow, L/hr }\end{array}$ & $\begin{array}{c}\text { Waste in } \\
\text { Process for } \\
\text { Maximum } \\
\text { Usage }\end{array}$ \\
\hline 100 & Dilution $\mathrm{NaOH}$ & 163 & $19 \mathrm{M} \mathrm{NaOH}$ & 163 & & & AP-103 \\
\hline 101 & Waste Feed Dilution Water & 669 & Water & & 669 & & AP-108 \\
\hline 102 & $0.1 \mathrm{M} \mathrm{NaOH}$ & 19.5 & $0.1 \mathrm{M} \mathrm{NaOH}$ & 0.103 & 19.4 & & $\mathrm{AP}-107$ \\
\hline 103 & $0.45 \mathrm{M} \mathrm{HNO}_{3}$ & 117 & $0.45 \mathrm{M} \mathrm{HNO} 3$ & & 112.7 & & AP-107 \\
\hline 104 & Rinse Water & 29.8 & Water & & 29.8 & & AP-107 \\
\hline 105 & $0.1 \mathrm{M} \mathrm{NaOH}$ & 19.5 & $0.1 \mathrm{M} \mathrm{NaOH}$ & 0.103 & 19.4 & & AP-107 \\
\hline 106 & $0.45 \mathrm{M} \mathrm{HNO}_{3}$ & 117 & $0.45 \mathrm{M} \mathrm{HNO} 3$ & & 112.7 & & AP-107 \\
\hline 107 & Rinse Water & 29.8 & Water & & 29.8 & & AP-107 \\
\hline 108 & $0.5 \mathrm{M} \mathrm{NaOH}$ & 25.7 & $0.5 \mathrm{M} \mathrm{NaOH}$ & 0.68 & 25.0 & & $\mathrm{AP}-107$ \\
\hline 109 & $0.5 \mathrm{M} \mathrm{NaOH}$ & 25.7 & $0.5 \mathrm{M} \mathrm{NaOH}$ & 0.68 & 25.0 & & $\mathrm{AP}-107$ \\
\hline 110 & $\mathrm{NaOH}$ Adjustment Solution & 3.15 & $19 \mathrm{M} \mathrm{NaOH}$ & 3.15 & & & AP-107 \\
\hline 111 & $\mathrm{NaNO}_{2}$ Adjustment Solution & 0 & $4 \mathrm{MNaNO} 2$ & & & 0 & $\mathrm{AP}-107$ \\
\hline 112 & Cs Product Dilution Water & 0 & Water & & & & AP-107 \\
\hline 113 & Lead Column Fresh Resin Slurry & 0.538 & $\sim 0.8 \mathrm{M} \mathrm{NaOH}$ & 0.023 & 0.52 & & AP-107 \\
\hline 114 & Polishing Column Fresh Resin Slurry & 0.538 & $\sim 0.8 \mathrm{M} \mathrm{NaOH}$ & 0.023 & 0.52 & & AP-107 \\
\hline 115 & Lead Column Fluidizing Water & 0.675 & Water & & 0.675 & & AP-107 \\
\hline 116 & Polishing Column Fluidizing Water & 0.675 & Water & & 0.675 & & AP-107 \\
\hline \multicolumn{4}{|c|}{ Total Usage Rate $(\mathrm{L} / \mathrm{hr})=$} & 167.8 & 1045.2 & 0.0 & \\
\hline \multicolumn{4}{|c|}{ Total Usage Rate $(\mathrm{gpm})=$} & 0.74 & 4.60 & 0.00 & \\
\hline
\end{tabular}

1. Steady state flows are taken from the material balance results for the Ion Exchange Cs separation alternative. The maximum flow rate from the different waste feed compositions, identified as "Waste in Process for Maximum Usage", is used for vessel sizing. References: RPP-CALC-37594 [AEM-CHG-2008-CN-018 (AP103), AEM-CHG-2008-CN-021 (AP-107), and AEM-CHG-2008-CN-022 (AP-108)].

2. The equivalent $19 \mathrm{M} \mathrm{NaOH}$ flow rate is determined from the steady state flow rate by [Stream $\mathrm{NaOH}$ concentration] $\times$ [Steady State Flow] / [19 $\mathrm{M} \mathrm{NaOH]}$. As an example, for Stream \#102: Equivalent $19 \mathrm{M} \mathrm{NaOH}=[0.1 \mathrm{M}] \times[19.5 \mathrm{~L} / \mathrm{hr}] /[19 \mathrm{M}]=0.103 \mathrm{~L} / \mathrm{hr}$.

3. Makeup water flow is determined by a simple volumetric difference between the steady state flow and $19 \mathrm{M} \mathrm{NaOH}$ equivalent flow. As an example, for Stream \#102: Makeup water flow $=19.5 \mathrm{~L} / \mathrm{hr}-0.1 \mathrm{~L} / \mathrm{hr}=19.4 \mathrm{~L} / \mathrm{hr}$.

4. Water usage for Streams \#103 and \#106 are obtained based on production of $\mathrm{HNO}$ from combining water with $12.2 \mathrm{M} \mathrm{HNO}_{3}$. As an example, for Stream \#103: Makeup water flow $=117 \mathrm{~L} / \mathrm{hr}-\left(0.45 \mathrm{M} \mathrm{HNO}_{3}\right) \times(117 \mathrm{~L} / \mathrm{hr}) /\left(12.2 \mathrm{M} \mathrm{HNO}_{3}\right)=112.7 \mathrm{~L} / \mathrm{hr}$. 


\subsubsection{Preliminary Risks/Issues and Potential Optimization}

A preliminary risks and issues identified during preparation of this study are summarized below.

- Ion exchange liquid phase flow - use of upflow for the liquid phase flow during the loading cycle may improve column performance as the resin bed is reused. The performance improvement would conceptually be obtained by eluting with a liquid phase flow in the opposite direction to the loading cycle liquid phase flow, maintaining reduced cesium loading of resin on the product end of each column. The liquid phase flow directions used in this study are consistent with the approach currently planned for the WTP Pretreatment facility ion exchange system.

- The approach described for drying spent resin prior to disposal is similar to the approach planned by the WTP Pretreatment facility. However, testing to identify potential drying issues with achieving an endpoint consistent with the solid waste acceptance criteria are not currently available.

- The resin bed and column sizes incorporated in this study were determined using inputs consistent with the alternate technologies under consideration. If selected, it is anticipated that the resin bed size will grow to introduce more conservatism in the design basis. Simply changing the definition of the loading cycle endpoint will increase the column size. Since much of the tank sizing basis is related to the resin bed volume, it should be anticipated that ion exchange vessels will increase in size if this technology is selected for more detailed evaluation.

- Test data with actual waste is limited to laboratory scale tests. While actual and simulant data obtained to date produce consistent results, there is a risk that a new process issue could be identified during operation at full scale with actual waste that was not identified during simulant testing.

- Equipment designs to control the potential accumulation of hydrogen gas in ion exchange columns were not reviewed as part of this pre-conceptual study effort. Equipment to control the potential for hydrogen accumulation has been incorporated in the WTP ion exchange columns. However, a review is required to determine if the WTP concept can be operated with columns located in a vault structure instead of a hot cell (WTP equipment location

Concepts for the ion exchange technology described in this pre-conceptual study would likely be modified if the technology is selected for implementation. Potential optimization studies include:

- Disposal of spent resin by ion exchange column replacement rather than slurry of resin to a disposal cask.

- Ion exchange liquid phase flow - use of upflow for the liquid phase flow during the loading cycle may improve column performance as the resin bed is reused. The performance improvement would conceptually be obtained by eluting with a liquid phase flow in the opposite direction to the liquid phase flow, maintaining reduced cesium loading of resin on the product end of each column. The liquid phase flow directions 
used in this study are consistent with the approach currently planned for the WTP Pretreatment facility ion exchange system.

- Caustic addition estimates for diluting waste to 6 molar sodium are based on a simplified, conservative approximation of alumina solubility. It may be possible to reduce sodium additions by reducing the conservatism of the alumina solubility relationship by using a more complex analysis of ionic strength for each waste composition processed.

- Alternatives may be available to simplify pipe routing, reduce the number of valves, and reduce the potential for cross contamination of the treated LAW product. For example, it may be beneficial to perform rinse and elution cycles that added only to the polishing column that is then passed back to the lead column is series rather than performing these steps in parallel.

\subsection{FRACTIONAL CRYSTALLIZATION}

Fractional crystallization is a commercially proven process, typically used for pharmaceuticals (purifying drugs) and industrial chemicals (cleansers, fertilizers, etc.). Fractional crystallization works by evaporating feedstock and selectively forming pure crystalline products, as discussed more fully in RPP-PLAN-27238, Hanford Medium/Low Curie Waste Pretreatment ProjectPretreatment Process Plan. During formation of crystalline products, impurities are excluded from the growing crystal lattices due to differences in ionic radii. For the operating ranges proposed, the soluble radionuclides such as ${ }^{137} \mathrm{Cs}$ and ${ }^{99} \mathrm{Tc}$ are far from their saturation concentrations and do not crystallize from solution during evaporation. For the current study, the crystallized salts represent the decontaminated LAW product to be transferred to WTP. Prior to transfer the crystals will be redissolved by dilution with water to the desired transfer concentration.

\subsubsection{Literature Survey}

Since December 2004 a program has been actively pursued to develop fractional crystallization for treatment of Hanford tank waste. This program has progressed from laboratory testing with simulants and actual waste through engineering scale tests of a 20 Liter continuous crystallizer system and solids liquid separation equipment. A pilot plant with approximate 5000 liter crystallizer has been constructed and is currently undergoing startup tests.

Crystallization of Hanford waste and Hanford-type wastes has been practiced in the Hanford 242-A and 242-S evaporators and similar industrial processes for many years. The operational 242-A evaporator is used to reduce waste volume by evaporating water and crystallizing sodium salts from Hanford waste. However, the crystallized salts are not separated and decontaminated from the residual liquor at the 242-A evaporator. Some incidental fractional crystallization separation is performed in the tank farms. As the evaporator product cools and ages in the underground tanks, lower solubility salts crystallize and settle. By removal of supernate and 
interstitial liquor, content of ${ }^{137} \mathrm{Cs},{ }^{99} \mathrm{Tc}$ and other high solubility components are reduced in the resulting saltcake as compared to the original bulk waste. Due to non-ideal crystallization conditions, some soluble components are trapped in occlusions so that decontamination of the salt crystals in the in-tank process is not as effective as expected in a crystallization and crystal washing process designed for this purpose.

Although equilibrium thermodynamic modeling indicates high sodium yields $(>90 \%)$ are theoretically possible by fractional crystallization of Hanford waste, it is expected that chemical or physical limitations will restrict the extent of sodium salt recovery. Model calculations and testing both show that single-shell tank (SST) saltcake type wastes are easier to process by fractional crystallization and provide substantially higher yields of decontaminated salt product than do the DST supernates. This is primarily related to the increased concentrations of nitrite, soluble aluminum, and hydroxide in the DST supernates. Selection of waste feeds that are low in these components could significantly improve yield of decontaminated sodium product while allowing less severe/difficult crystallization process conditions. Alternately, the DST supernates could be preprocessed upstream of crystallization to reduce content of these components (e.g., by oxidation of nitrite to nitrate, partial neutralization of hydroxide with nitric acid or carbon dioxide, and/or precipitation of aluminum as gibbsite or low solubility lithium/aluminum compounds).

Depending on relative abundance, sodium sulfate double salts such as burkeite $\left[\mathrm{Na}_{6}\left(\mathrm{SO}_{4}\right)_{2} \mathrm{CO}_{3}\right]$ or the sodium sulfate-fluoride double salt shairerite $\left(\mathrm{Na}_{3} \mathrm{FSO}_{4}\right)$ typically crystallize first upon evaporation of waste. This is usually followed by crystallization of sodium carbonate monohydrate $\left(\mathrm{Na}_{2} \mathrm{CO}_{3} \cdot 1 \mathrm{H}_{2} \mathrm{O}\right)$. Depending on relative abundance, sodium nitrate and/or sodium nitrite may crystallize upon further evaporation. Other sodium salts may crystallize including oxalate, chloride, and acetate if anions are present in significant concentrations.

Because solubility is temperature dependent, equilibrium crystallization yield is usually increased by reducing temperature. The difference in solubility behavior between the sulfate containing salts and other salts provides for a relatively simple scheme for splitting the decontaminated product into a low volume high sulfate stream and a higher volume low sulfate stream. This could be advantageous if there is a desire to reduce sulfate in the feed to the WTP. Equipment for splitting the sulfate between product streams is included in the preliminary equipment and facility design concept developed for this study.

To remove interstitial contamination, mother liquor is separated and washed from the crystal cake. To achieve a high degree of decontamination, effective deliquoring and crystal washing are required. Centrifugation offers the highest extent of deliquoring, and is the method used in the proposed process concept. To further reduce interstitial contamination, the crystal cake is washed during the centrifugation process to displace contaminated liquor with clean liquid. The extent of decontamination during the wash process depends on the ratio of wash liquid to interstitial liquor.

In 2004, fractional crystallization was selected for evaluation as a pretreatment process for LAW to ensure that problematic waste components are diverted preferentially to the Bulk Vitrification Facility, while radionuclides (primarily ${ }^{137} \mathrm{Cs}$ and ${ }^{99} \mathrm{Tc}$ ) are diverted to the WTP. In December 
2004, CH2M HILL Hanford Group awarded a contract for development of fractional crystallization to a team led by AREVA NC, and including Georgia Institute of Technology, Swenson Technology, Inc. and AREVA NP. A substantial amount of testing and engineering work has subsequently been completed under this ongoing program. A pilot plant has been constructed that is currently undergoing startup testing.

Initial Phase I work was structured to demonstrate that fractional crystallization could be used to pre-treat Hanford tank wastes and to provide data to develop a pilot plant design. Two primary reports were issued to summarize Phase I work completed through the end of 2005: RPP-PLAN27238, Hanford Medium/Low Curie Waste Pretreatment Project-Pretreatment Process Plan; and RPP-RPT-27239 Hanford Medium/Low Curie Waste Pretreatment Project - Phase I Laboratory Report.

RPP-PLAN-27238 provides a summary of engineering work through late 2005, including:

- Basic chemical engineering concepts are reviewed to provide an understanding of unique characteristics of this technology and its application to the Hanford tank wastes.

- Use of a thermodynamic chemical process model, Environmental Simulation Program (ESP) by OLI Systems, Inc, is discussed. The model is used to evaluate the process by investigating waste constituent properties such as Gibbs free energy, solid phases, solution ionic strength, and effects of $\mathrm{pH}$, temperature, water content, etc. The model was used to guide laboratory simulant experiments, and to estimate actual waste behavior in process equipment.

- Flowsheet development and concept selection work is discussed.

- A pre-conceptual design concept is proposed. The report includes preliminary process definition, equipment sizing, facility layout, and construction cost estimates for producing a nominal $5 \mathrm{gpm}$ of decontaminated product to the supplemental immobilization (BV) facility.

- Implementation plans, schedules, and life cycle costs are provided for a system to be deployed near the proposed demonstration bulk vitrification system in the Hanford $200 \mathrm{~W}$ area.

A single facility was proposed by RPP-PLAN-27238 for both demonstration studies (two years) and production capability (17 years). The functions and basic characteristics of the proposed process components were used as the bases for an as low as reasonably achievable study and a qualitative preliminary hazard assessment. Based on these evaluations the Fractional Crystallization Facility was conservatively designated as a Category 2, non-reactor nuclear facility in accordance with DOE-STD-1027-92. This designation was then used to evaluate life cycle cost (including design, construction, testing, operation, and decontamination and decommissioning - D\&D). A schedule, which allows for design work to proceed in parallel with Phase II radioactive waste testing, was also proposed.

RPP-RPT-27239 summarizes results of Phase I testing work through the end of 2005 . To meet the challenges of separating pure sodium salts from Hanford waste, fractional crystallization process development follows a graduated approach. The simplest chemical systems are studied, tested, and validated against thermodynamic models, and then more and more complex systems 
are tested until representative SST/DST waste simulants are used. "Hot" crystallization tests are then conducted on actual Hanford tank waste and results are compared with the stimulant results to verify acceptability of using simulants for testing.

In Hanford tank waste, the solubility of components cannot be predicted from solubility diagrams or by hand calculation techniques because of the complexity of the chemistry. To predict solubility of components, yield during crystallization, and the extent of decontamination, computational thermodynamic models are used. Thermodynamic modeling was used to plan laboratory experiments and develop process flowsheets. In each case, thermodynamic modeling proved adequate to estimate the outcome of the experiments.

Laboratory experimentation determined that the major sodium crystal crops form in two distinct sizes in batch crystallization. Burkeite and sodium carbonate monohydrate grow slowly and form small crystals (10-20 micron), while sodium nitrate and nitrite grow rapidly and form large crystals ( $>100$ micron). The relative abundance of these crystal systems varies depending on the waste feedstock. Testing also verified model predictions that SST saltcake type wastes provide a significantly higher yield of decontaminated sodium salt product than DST supernates. For example, laboratory tests showed the following net sodium yields in the decontaminated salt product:

- $\quad$ SST early feed, run $26,58.1 \%$ sodium yield

- $\quad$ SST late feed, run $27,74.7 \%$ sodium yield

- DST feed, run $31,43.9 \%$ sodium yield

Additional testing results are described in RPP-31983-FP, Fractional Crystallization of Hanford Single-Shell Tank Wastes - Laboratory Development, RPP-RPT-31352, Fractional Crystallization Flowsheet Testing with Actual Tank Waste, RPP-RPT-31998, Fractional Crystallization Laboratory Testing for Inclusion and Co-Precipitation with Actual Tank Waste, and RPP-RPT-26474, Fractional Crystallization of Waste from Tank 241-S-112. Testing included batch crystallizations using a reactor with a mechanical mixer and heating jacket operated under vacuum.

Three flowsheet tests with actual waste were completed in the 222-S Laboratory Hot Cells: SST Early Stage 1, SST Early Stage 2, and SST late Stage 1. The tests with actual waste focused on SST waste and feed requirements for the supplemental treatment system (e. g. bulk vitrification). For some tests the product crystals were redissolved and a second crystallization was performed, closely simulating the two stage crystallization process proposed herein.

Important findings from testing with actual waste include:

- "Results conclusively show, with both simulated and actual tank waste samples, that the desired separations are achievable."

- "Actual tank waste samples behaved the same as simulated waste samples. There were no significant differences in the physical behavior of the actual vs. simulated tank waste..."

- "Tests demonstrated that the process exceeded all of the separation criteria established for the program." Note that for this program a .01 sulfate to sodium criteria was placed on 
the purge stream - not on the crystal product, because the purge stream was intended to go to WTP, while the decontaminated sodium product was intended to go to BV. This is the reverse of the IPS study flowsheet.

- An overall Cs decontamination factor (DF) of 18100 was measured when product from the first crystallization from actual waste was redissolved and recrystallized.

- The decontamination factor for ${ }^{90} \mathrm{Sr}$ was measured as 1.3 when product from the first crystallization from actual waste was redissolved and recrystallized. This indicates that strontium co-crystallizes with some sodium salts. This is not expected to be a problem for the current study since separation of ${ }^{90} \mathrm{Sr}$ is not required to meet the IPS study product specification.

RPP-30995-FP, Fractional Crystallization of Hanford Single-Shell Tank Waste from Concept to Pilot Plant was issued in early 2007, and summarizes results of process development work through the end of 2006. Key items:

- Phase I results were reviewed by a Technical Assessment Team (TAT) made up of independent technical experts. The Technical Assessment Team recommendations were used to guide subsequent development work.

- Crystallizer system testing was performed with simulants at Swenson Technology, Inc. Testing utilized a 20 liter draft tube entry crystallizer set up to allow continuous mode operation. Process design of the test system was reasonably prototypic and provided recirculating flow from the crystallizer through the reboiler and continuous feed and crystallizer product discharge. Results verified overall process functionality and provided data needed for design of the pilot plant system. Best results were found with 4 to 8 hours residence time in the crystallizer. Solids washing and solid/liquid separation equipment testing was performed at Swenson Technology, Inc. to support selection of equipment to be used for the pilot plant. Testing included a hydraulic elutriation column, batch filter, and centrifuge. Testing of centrifuge separation and cake washing was performed with a bench scale centrifuge. A cesium decontamination factor (DF) of 167 was obtained. Successful test results supported selection of a "peeler" type centrifuge for the pilot plant.

RPP-RPT-36854, Fractional Crystallization Feed Envelope, was issued in March 2008 and defines a proposed feed envelope range for the fractional crystallization process under development for Hanford. The proposed feed envelope is based on batch crystallization tests with a matrix of feed compositions plus data from prior work. Review of the IPS feed batch compositions shows that most identified components are within the feed envelope ranges with the exception of nitrite. Nitrite is well above the feed envelope limit for IPS batch 2, 4, and 5. The fractional crystallization process will function with these high nitrite levels; however, net sodium yield in the decontaminated product will be reduced. Alternatives to increase net sodium yield may include selection of waste feeds that are better suited to fractional crystallization or oxidation of nitrite to nitrate using ozone or hydrogen peroxide. The feed envelope also includes limits for three organic compounds that do not appear in the IPS feed batch definition. 
Additional technical references were supplied by CH2MHILL specifically to support development of the IPS pre-conceptual candidate technology descriptions, e-mail T. H. May to G. E. Stegen, "FW: Data Disk," (May, T. H., 2008-05-09). This reference includes the following files:

- GROUP1_PREP.xls, GROUP2_PREP.xls, GROUP3_PREP.xls, GROUP4_PREP.xls, GROUP5_PREP.xls, and IPT_SURVEYS_3.xls provide equilibrium crystallization yields from batch boildown of five different waste compositions. The fractional yield as a solid crystalline product is calculated for each crystallized sodium salt anion and for total sodium. The five starting waste compositions are similar to the compositions used for the IPS study.

- IPT_GROUP_1_RECRYSTALLIZATION.xls provides mass balance and stream property calculations for a two stage fractional crystallization process based on the "group 1" waste composition. This calculation was developed using existing flowsheet models that incorporate complex thermodynamic calculations for high salt content aqueous streams.

Section 6.2.3 discusses how information from these references was used in developing mass balance calculations.

\subsubsection{Process Description}

In the fractional crystallization process, waste is concentrated by evaporation until sodium salts exceed their solubility limits. Cesium and other soluble isotopes remain in the liquid phase (liquor) while sodium salts form solid crystals. The liquor is separated from the crystals which represent the decontaminated product. Decontaminated sodium salt crystals may be produced as a solid product or may be completely or partially re-dissolved with water to produce a liquid or slurry product.

A number of potential flowsheet options can be considered for treating Hanford tank wastes using fractional crystallization. This section describes the example process approach used for mass balances and equipment sizing herein. Optimization studies during the early design phases will be performed to consider alternate approaches and finalize process definition. Section 6.2.8 discusses potential optimization items that may be considered.

A two stage crystallization approach has been selected for the IPS down selection evaluation, in which the partially decontaminated sodium salt product from the first stage is re-dissolved and fed to a second stage crystallizer. The second stage provides additional decontamination of the product and appears likely to be needed to meet the relatively low ${ }^{137} \mathrm{Cs}$ specification for processing DST supernates to meet WTP requirements. Need for the second stage should be determined by the pilot plant testing that is currently in progress. Wash liquor from crystal decontamination and the purge stream from the second stage crystallizer are recycled internally to maximize net yield of decontaminated product. 
Figure 6-12 and Figure 6-13 show the process flow diagrams for the first and second crystallization stages respectively. Tank waste is first filtered in a unit operation separate from fractional crystallization to remove suspended solids (see Section 5). Filtrate flows to the Feed Receipt Tank, which provides buffer storage capacity. Waste feed (Stream 4) is transferred continuously to the first stage crystallizer to maintain stable steady-state operating conditions.

The crystallizer is operated under vacuum (typically .035 to 0.1 atmospheres absolute) to maintain boiling temperatures in the 40 to $60 \mathrm{C}$ range needed for crystallization. A relatively large recirculation stream flows from the bottom of the crystallizer through the steam heated reboiler, which provides heat for water evaporation. A slurry containing crystals and liquor is drawn off the crystallizer and pumped (Stream 19) to a centrifuge for separation of liquor from the crystals followed by crystal washing to remove residual contamination. A concentrated (nominal $10 \mathrm{~mole} /$ liter Sodium) salt solution is used for washing to avoid significant dissolution of crystals in the centrifuge. Washed crystals are discharged to a dissolver tank where water is added and the slurry is heated to re-dissolve most of the sodium salts. A small amount of low solubility and/or slow dissolving salts such as oxalate, sulfate, and burkeite $\left[\mathrm{Na}_{6}\left(\mathrm{SO}_{4}\right)_{2} \mathrm{CO}_{3}\right]$, may remain as suspended solids in the dissolver product. Part of the dissolver product is recycled to the centrifuge as wash solution to decontaminate the crystal cake.

In order to eliminate residual fine crystals that could reduce crystal cake permeability the dissolver product is first processed through a filter. Filtrate (Stream 10) is recycled for washing crystals in the centrifuge. The non-filtrate stream from the filter contains about half the liquid and all the residual solids. A small amount of additional dilution water may be added as it exits the filter to help dissolved residual solids and the combined stream (20) is then transferred to the second stage crystallizer.

A portion of the liquor stream from the centrifuge is recycled to the crystallizer, while the remainder (Stream 13) is purged to the Cesium Product Tank. It may be diluted with water in the Cesium Product Tank if needed prior to return to a DST.

Vapor from the crystallizer (Stream 5) flows through a de-entrainer and demister in the top of the crystallizer to remove entrained contaminants, and then flows to the first stage condenser where the bulk of the water vapor is condensed. Remaining water vapor and non-condensable gases then flow through two steam jet eductors with condensers which maintain vacuum on the crystallizer. Vent gas is filtered prior to discharge to the environment 
Figure 6-12 Fractional Crystallization First Stage Process Flow Diagram

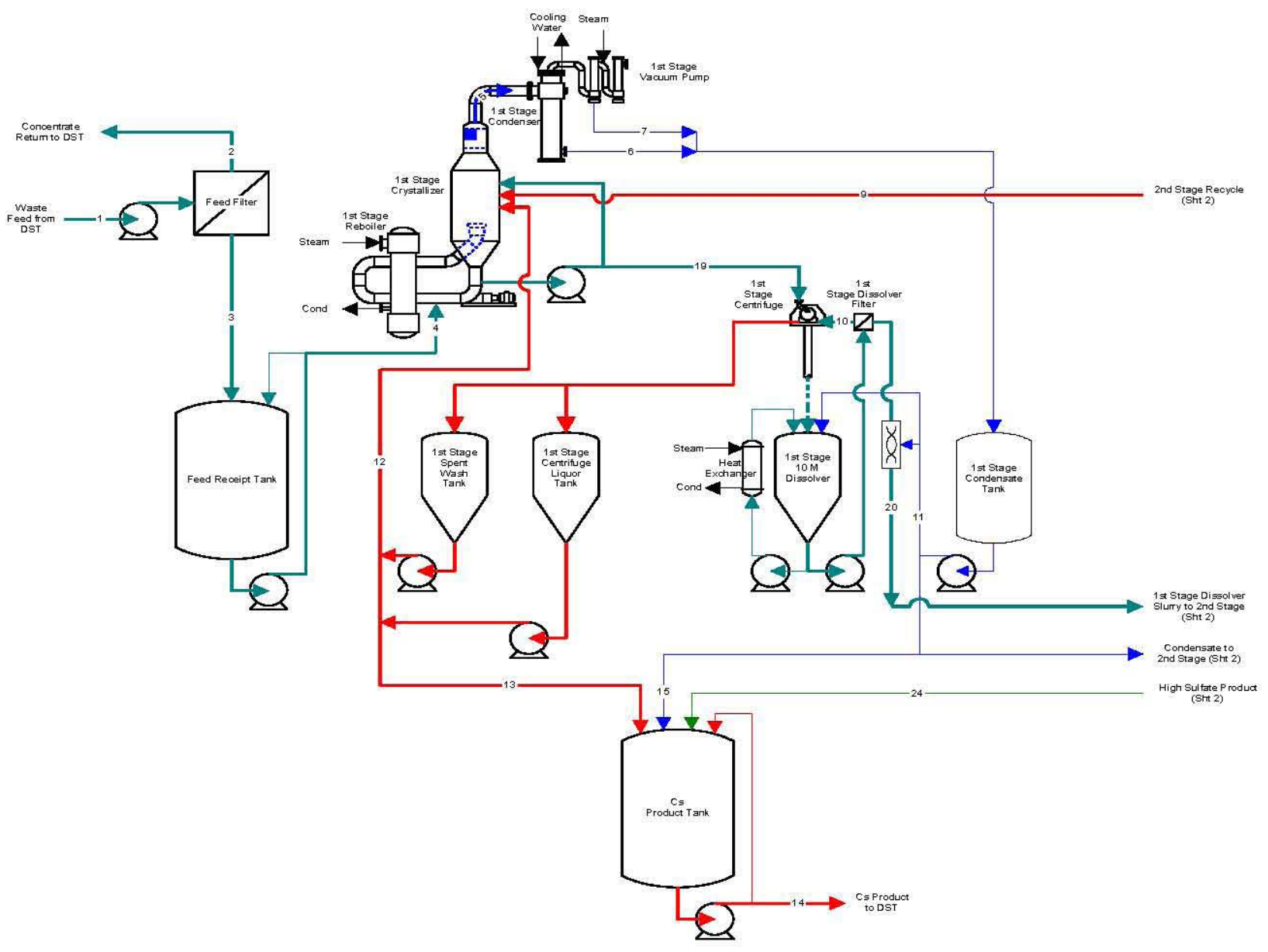


Figure 6-13 Fractional Crystallization Second Stage Process Flow Diagram

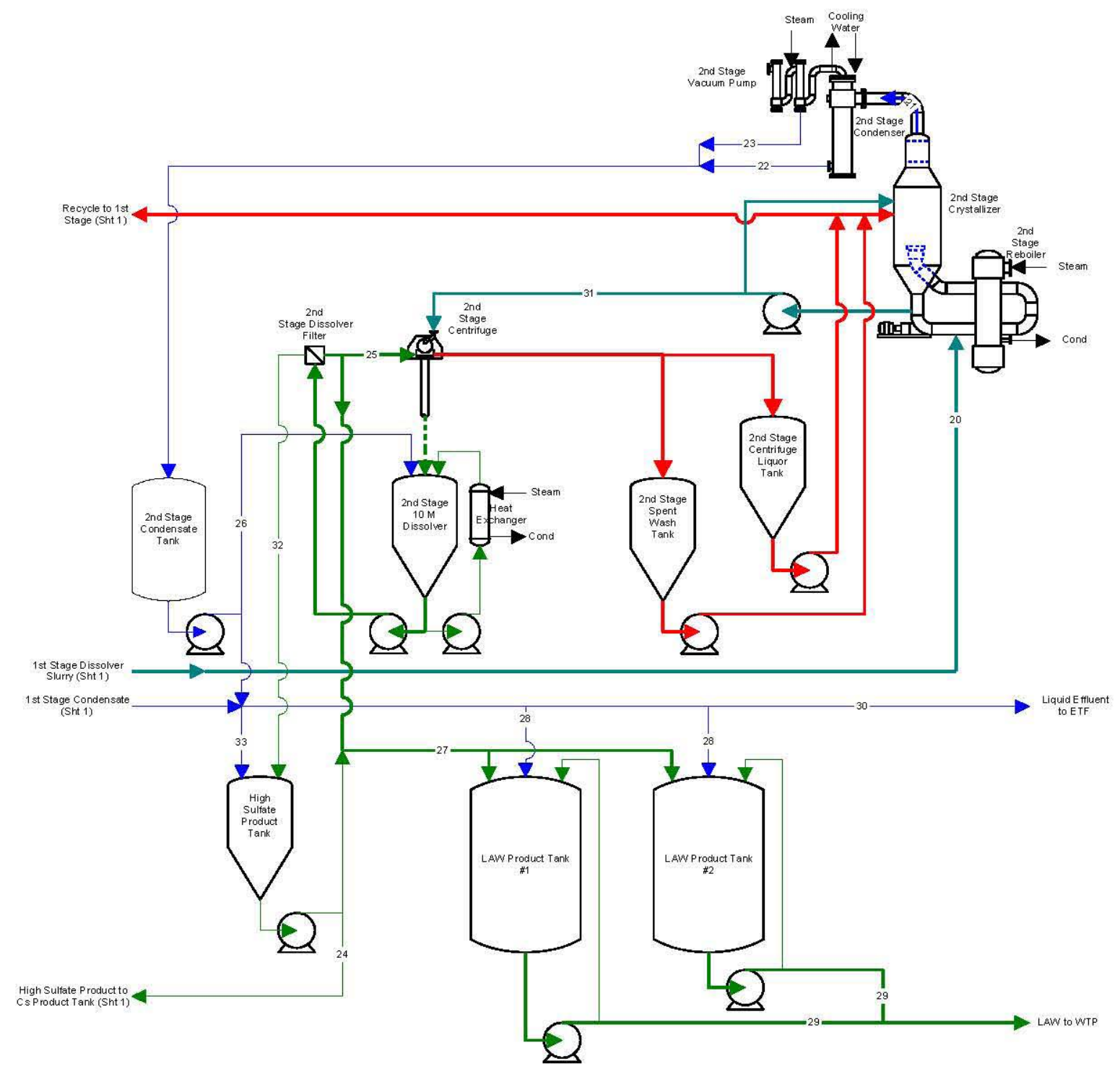


Process condensate is collected from the primary condenser and steam jets and is used for dissolution and dilution of product as needed. Surplus process condensate (Stream 30) is transferred to an external treatment facility, assumed to be the Effluent Treatment Facility (ETF). Efficient deentrainment is required to remove waste particles from steam generated in the crystallizer. To assure ETF acceptance requirements for ${ }^{137} \mathrm{Cs}$ are met a minimum decontamination factor of $3 \times 10^{5}$ must be specified as a design requirement for the crystallizer (defined as the ratio of cesium concentration in the crystallizer concentrate divided by the concentration in the condensate). Process condensate will have trace amounts of other contaminants expected to be at levels similar to process condensate from the 242-A Evaporator.

The second stage crystallizer system operates essentially the same as the first stage, except that feed comes from the first stage dissolver (Stream 20), the purge (Stream 9) is recycled to the first stage crystallizer, and the second stage dissolver and product filtration has the additional function of controlling sulfate in the LAW product and is therefore sized and operated somewhat differently than the first stage. Dilution water addition to the dissolver is controlled so that most of the sulfate remains as undissolved crystals. Most of the liquid is passed through the filter media ( $90 \%$ or more versus about $50 \%$ for the first stage). This produces a concentrated highsulfate slurry and a low-sulfate filtrate. About half the filtrate (stream 25) is recycled for washing filter cake in the centrifuge.

Balance of the filtrate represents the primary LAW product, and is transferred to the LAW Product Tanks. The high-sulfate stream from the filter is collected in a separate High Sulfate Product Tank and may be split between the LAW Product Tank and the cesium product tank in order to control the amount of sulfate in the LAW product. The combined low-sulfate and highsulfate LAW products (stream 27) are accumulated in the LAW Product Tanks and may be diluted further with water as needed prior to transfer to WTP (Stream 29).

Because the first stage delivers a concentrated product, the second-stage crystallizer evaporation duty is significantly lower than the first stage. Operating conditions and stream properties in the second stage may also be significantly different because of the reduced concentration of low solubility waste components.

The process is controlled to maintain steady-state operation of the entire crystallizer system. Process variables, including temperatures, pressures, crystallizer slurry density, flow rates, tank levels, etc. are measured and controlled to maintain process variables at set point values.

Routine sampling and analysis is not expected to be needed for process control, assuming the feed has been characterized in advance for each batch. Sampling of selected process streams is performed occasionally on an as-needed basis to support optimization, troubleshooting, and regulatory compliance documentation. Efficiency of ${ }^{137} \mathrm{Cs}$ decontamination in each crystallizer stage is monitored in real time by measuring gamma radiation dose rates of the dissolver tank and/or dissolver product. Amount of dissolved product recycled for washing centrifuge cake is adjusted as needed to assure target ${ }^{137} \mathrm{Cs}$ decontamination is achieved. 
Off-spec product is recycled to the crystallizer feed tank. Draining and flushing capability is provided to reduce personnel dose rate and allow certain maintenance functions to be performed. Capability is provided to empty the crystallizer contents back to the feed tank during unplanned shutdowns.

The control system allows manual operation during startup and shutdown, but operates in an automatic mode during normal conditions. Initially, the feed tank and crystallizer are charged with fresh feed solution and vacuum is drawn on the system before feed is heated in the reboiler. Additional feed is added as needed to maintain constant liquid level in the crystallizer as water is evaporated.

\subsubsection{Input Data and Assumptions}

Feed composition input data is discussed in Section 2.0 and other interface requirements are discussed in Section 3.0. Additional technical references discussed below were supplied by CH2M HILL specifically to support development of the IPS pre-conceptual candidate technology descriptions, May, T. H., 2008-05-09. The following discusses the approach for calculating numerical values for input parameters from information in these references. Calculation of the parameters was performed by spreadsheet FC-1-8 Input Parameter Supporting Calculations, SVF-1505.xls.

Group 1 through group 5 compositions were developed by CH2M HILL to provide a reduced number of waste compositions for testing using simulants that could be produced by adjustments to existing simulants, as summarized in Interoffice Memorandum 74A10-DLH08-151, "Test Plan for Simulant Modifications to Support the Interim Pretreatment System," (74A10-DLH-08-151-Memorandum). The group waste compositions are roughly comparable to IPS batch compositions as follows

\begin{tabular}{|l|l|l|}
\hline Group number & IPS Batches & IPS Prestaging Tanks \\
\hline 1 & $3,7,14^{1}$ & $\begin{array}{l}\text { 241-AP-101, 241-AP-107, } \\
\text { 241-SY-101 }\end{array}$ \\
\hline 2 & $1,4,5,11^{1}$ & $\begin{array}{l}\text { 241-AP-103, 241-AP-104, } \\
\text { 241-AP-105, 241-AW-101 }\end{array}$ \\
\hline 3 & 2,6 & 241-AP-102, 241-AP-108 \\
\hline 4 & $8,9^{1}, 10^{1}$ & $\begin{array}{l}\text { 241-AN-104, 241-AN-105, } \\
\text { 241-AN-103 }\end{array}$ \\
\hline 5 & $\begin{array}{l}\text { Not part of first 8 IPS waste } \\
\text { batches (Case 1), 12 and 13 } \\
\text { for Case 2 }\end{array}$ & 241-AW-104, 241-AP-106 \\
\hline $15^{1}$ & 241-S-109 \\
\hline SST Late & \multicolumn{2}{|l}{} \\
\hline 1. Case 2 only & \multicolumn{2}{|l}{} \\
\hline
\end{tabular}


GROUP1_PREP.xls, GROUP2_PREP.xls, GROUP3_PREP.xls, GROUP4_PREP.xls, and GROUP5_PREP.xls provide calculated equilibrium crystallization yields and selected stream properties, for batch boildown of the "group one" through "group five" waste compositions. The fractional yield as a solid crystalline product is calculated for each crystallized sodium salt anion and for total sodium. For the mass balance calculations each waste feed batch is first assigned to one of the waste groups, shown above, with similar composition. Values for $\mathrm{Y}_{\mathrm{i}}$ for anions are then based the fractional yield values calculated from the reference for the assigned group number. Values for first stage evaporator operating pressure were also obtained from these References.

IPT_GROUP_1_RECRYSTALLIZATION.xls provides results of detailed mass balance and stream property calculations for a two stage crystallization process based on the "Group 1" waste (similar to IPS Batch 3 and Batch 7 waste compositions). These calculations were made using an existing model that incorporates equilibrium thermodynamic modeling of the crystallizer and other process steps. These results were used as the bases for a number of parameters as follows.

Dissolved Solids. Numerical values for weight fraction dissolved solids parameters $\left(\mathrm{X}_{\mathrm{s}, \mathrm{i}}\right)$ were calculated directly from total solids and total mass of analogous streams in IPT_GROUP_1_RECRYSTALLIZATION.xls. Adjustments were made as needed for minor differences in the flow sheet (e. g. the two dissolver output streams were combined and the two centrifuge liquor discharge streams were combined in making the calculations.

Crystallized Solids. Numerical values for weight fraction crystallized solids $\left(\mathrm{SC}_{\mathrm{i}}\right)$ were calculated directly from total solid phase mass and total mass of analogous streams in IPT_GROUP_1_RECRYSTALLIZATION.xls.

Wash Recycle Factors (WF1, WF2) were calculated directly from the corresponding stream values in IPT_GROUP_1_RECRYSTALLIZATION.xls.

Decontamination factors (DF1, DF2) were assumed equal to the values calculated in IPT_GROUP_1_RECRYSTALLIZATION.xls. In all cases these result in cesium concentrations below the WTP feed limits. In theory, the waste recycle factors could be reduced on a batch by batch basis to allow the cesium concentration to increase up to the limit. This refinement was not included in the calculations, but should not materially affect the overall assessment.

Stage two recycle factors $\left(\mathrm{RF}_{\mathrm{i}}\right)$ and efficiency factors $\left(\mathrm{EF}_{\mathrm{i}}\right)$ were developed based on results in IPT_GROUP_1_RECRYSTALLIZATION.xls.

Key input parameters used in the mass balance spreadsheet calculation are shown in Table 6-24 and Table 6-25. 
Table 6-24 Mass Balance Input Parameters, Constant for All Waste Feed Batches

\begin{tabular}{|c|c|c|c|c|}
\hline \multicolumn{5}{|c|}{ (2 sheets) } \\
\hline $\begin{array}{l}\text { Parameter } \\
\text { Symbol }\end{array}$ & Component (i) & Parameter Name & Value & Source or Basis \\
\hline & Suspended solids & $\begin{array}{l}\text { wt } \% \text { Total Suspended Solids } \\
\text { (TSS) in feed }\end{array}$ & 0.5 & Study basis \\
\hline & Suspended solids & $\begin{array}{l}\text { Feed Filtrations, Solids Removal } \\
\text { Efficiency \% }\end{array}$ & 99.99 & Study basis \\
\hline & Suspended solids & $\begin{array}{l}\text { Target Solids in Concentrate } \\
\text { from Feed Filtration, w } \%\end{array}$ & 20 & Study basis \\
\hline EFi & $\mathrm{Cl}$ & Efficiency Factor & 0.96 & SVF-1505 \\
\hline $\mathrm{EFi}$ & $\mathrm{CO} 3$ & Efficiency Factor & 0.99 & SVF-1505 \\
\hline $\mathrm{EFi}$ & $\mathrm{F}$ & Efficiency Factor & 0.96 & SVF-1505 \\
\hline $\mathrm{EFi}$ & $\mathrm{NO} 2$ & Efficiency Factor & 0.98 & SVF-1505 \\
\hline $\mathrm{EFi}$ & $\mathrm{NO} 3$ & Efficiency Factor & 0.99 & SVF-1505 \\
\hline $\mathrm{EFi}$ & $\mathrm{SO} 4$ & Efficiency Factor & 1.00 & SVF-1505 \\
\hline$\overline{E F i}$ & TOC as Acetate & Efficiency Factor & 0.99 & SVF-1505 \\
\hline $\mathrm{EFi}$ & Oxalate & Efficiency Factor & 1.00 & SVF-1505 \\
\hline DF1 & $\begin{array}{l}\text { Non-crystallized } \\
\text { components except } \\
\text { water }\end{array}$ & $\begin{array}{l}\text { Decontamination Factor, Stage } \\
\text { One }\end{array}$ & 124 & SVF-1505 \\
\hline$\overline{\mathrm{DF} 2}$ & $\begin{array}{l}\text { Non-crystallized } \\
\text { components except } \\
\text { water }\end{array}$ & $\begin{array}{l}\text { Decontamination Factor, Stage } \\
\text { One }\end{array}$ & 55 & SVF-1505 \\
\hline $\mathrm{Xs}, 9$ & Dissolved Solids & $\begin{array}{l}\text { second stage purge (recycle to } \\
\text { first stage crystallizer) wt } \\
\text { fraction dissolved solids }\end{array}$ & 0.635 & SVF-1505 \\
\hline $\mathrm{Xs}, 10$ & Dissolved Solids & $\begin{array}{l}\text { first stage centrifuge wash liquor } \\
\text { weight fraction dissolved solids }\end{array}$ & 0.555 & SVF-1505 \\
\hline $\mathrm{Xs}, 13$ & Dissolved Solids & $\begin{array}{l}\text { first stage purge (concentrated } \\
\text { cesium product)weight fraction } \\
\text { dissolved solids }\end{array}$ & 0.609 & SVF-1505 \\
\hline $\mathrm{Xs}, 19$ & Dissolved Solids & $\begin{array}{l}\text { First stage crystallizer product } \\
\text { (liquid phase) wt fraction } \\
\text { dissolved solids }\end{array}$ & 0.609 & SVF-1505 \\
\hline $\mathrm{Xs}, 20$ & Dissolved Solids & $\begin{array}{l}\text { First stage dissolver product or } \\
\text { second stage crystallizer feed }\end{array}$ & 0.375 & SVF-1505 \\
\hline $\mathrm{Xs}, 25$ & Dissolved Solids & $\begin{array}{l}\text { second stage centrifuge wash } \\
\text { liquor weight fraction dissolved } \\
\text { solids }\end{array}$ & 0.554 & SVF-1505 \\
\hline $\mathrm{Xs}, 27$ & Dissolved Solids & $\begin{array}{l}\text { Second stage dissolver product } \\
\text { weight fraction dissolved solids }\end{array}$ & 0.574 & SVF-1505 \\
\hline $\mathrm{Xs,29}$ & Dissolved Solids & $\begin{array}{l}\text { LAW product to WTP weight } \\
\text { fraction dissolved solids }\end{array}$ & $\mathrm{N} / \mathrm{A}$ & $\begin{array}{l}\text { Adjust to get desired sodium } \\
\text { molarity }\end{array}$ \\
\hline $\mathrm{CNa}, 29$ & Sodium & $\begin{array}{l}\text { LAW product to WTP, sodium } \\
\text { concentration mole/ } 1\end{array}$ & 9.000 & $\begin{array}{l}\text { Approximate target } \\
\text { concentration. May be } \\
\text { adjusted to meet WTP needs } \\
\text { as required }\end{array}$ \\
\hline$\overline{X s, 31}$ & Dissolved Solids & $\begin{array}{l}\text { second stage crystallizer product } \\
\text { (liquid phase) weight fraction } \\
\text { dissolved solids }\end{array}$ & 0.635 & SVF-1505 \\
\hline $\mathrm{Xs}, 32$ & Dissolved Solids & Second stage dissolver sulfate & 0.367 & SVF-1505 \\
\hline
\end{tabular}


Table 6-24 Mass Balance Input Parameters, Constant for All Waste Feed Batches

\begin{tabular}{|l|l|l|l|l|}
\hline $\begin{array}{l}\text { Parameter } \\
\text { Symbol }\end{array}$ & Component (i) & Parameter Name & Value & Source or Basis \\
\hline & & $\begin{array}{l}\text { product weight fraction } \\
\text { dissolved solids }\end{array}$ & & \\
\hline SC19 & Crystallized Solids & $\begin{array}{l}\text { First stage crystallizer product } \\
\text { weight fraction crystallized } \\
\text { solids }\end{array}$ & 0.300 & SVF-1505 \\
\hline SC31 & Crystallized Solids & $\begin{array}{l}\text { Second stage crystallizer } \\
\text { product weight fraction } \\
\text { crystallized solids }\end{array}$ & 0.30 & SVF-1505 \\
\hline WF1 & N/A & $\begin{array}{l}\text { Ratio of wash liquor recycle to } \\
\text { product, stage one }\end{array}$ & 1.00 & SVF-1505 \\
\hline WF2 & N/A & $\begin{array}{l}\text { Ratio of wash liquor recycle to } \\
\text { product, stage 2 }\end{array}$ & 1.00 & SVF-1505 \\
\hline RFi & Cl & Recycle fraction from stage 2 & 1.39 & SVF-1505 \\
\hline RFi & CO3 & Recycle fraction from stage 2 & 0.040 & SVF-1505 \\
\hline RFi & F & Recycle fraction from stage 2 & 0.050 & SVF-1505 \\
\hline RFi & Na & Recycle fraction from stage 2 & N/A & $\begin{array}{l}\text { Must be Calculated from } \\
\text { anion recycle rate. }\end{array}$ \\
\hline RFi & NO2 & Recycle fraction from stage 2 & 0.58 & SVF-1505 \\
\hline RFi & SO4 & Recycle fraction from stage 2 & 0.070 & SVF-1505 \\
\hline RFi & Acetate & Recycle fraction from stage 2 & 0.001 & SVF-1505 \\
\hline RFi & Oxalate & Recycle fraction from stage 2 & 0.59 & SVF-1505 \\
\hline RFi & Water fraction from stage 2 & 0.004 & SVF-1505 \\
\hline $\begin{array}{l}\text { Steam Jet } \\
\text { flow, Stage 1 }\end{array}$ & Kg water per hour & $\begin{array}{l}\text { Calc AEM-CHG-2008-CN- } \\
013 \text { included in RPP-CALC- } \\
\text { Ka water per hour }\end{array}$ \\
\hline $\begin{array}{l}\text { Steam Jet } \\
\text { flow, Stage 2 }\end{array}$ & & $\begin{array}{l}\text { Calc AEM-CHG-2008-CN- } \\
013, \text { included in RPP-CALC- } \\
37594\end{array}$ \\
\hline
\end{tabular}

Table 6-25 Theoretical Yield Input Data

\begin{tabular}{|c|c|c|c|c|c|c|}
\hline $\begin{array}{c}\text { Group \# } \\
\text { Feed Batch \# }\end{array}$ & $\begin{array}{c}1 \\
3,7,14^{1}\end{array}$ & $\begin{array}{c}2 \\
1,4,5,11^{1}\end{array}$ & $\begin{array}{c}3 \\
2,6\end{array}$ & $\begin{array}{c}4 \\
8,9^{1}, 10^{1}\end{array}$ & $\begin{array}{c}5 \\
12^{1}, 13^{1}\end{array}$ & $\begin{array}{c}\text { Late SST } \\
15^{1}\end{array}$ \\
\hline Component (i) & \multicolumn{6}{|c|}{ Theoretical Yield (Yi) } \\
\hline $\mathrm{Cl}$ & 0.345 & 0.469 & 0.467 & 0.310 & 0.399 & 0.400 \\
\hline $\mathrm{CO}_{3}$ & 0.954 & 0.892 & 0.894 & 0.908 & 0.887 & 0.850 \\
\hline $\mathrm{F}$ & 0.674 & 0.481 & 0.261 & 0.550 & 0.456 & 0.500 \\
\hline $\mathrm{NO}_{2}$ & 0.540 & 0.525 & 0.586 & 0.527 & 0.433 & 0.010 \\
\hline $\mathrm{NO}_{3}$ & 0.836 & 0.698 & 0.652 & 0.498 & 0.658 & 0.922 \\
\hline $\mathrm{SO}_{4}$ & 0.996 & 0.996 & 0.995 & 0.987 & 0.997 & 0.999 \\
\hline Acetate & 0.658 & 0.226 & 0.244 & 0.073 & 0.162 & 0.150 \\
\hline Oxalate & 0.998 & 0.995 & 0.995 & 0.995 & 0.991 & 0.990 \\
\hline $\mathrm{Al}$ and $\mathrm{PO} 4$ & 0.000 & 0.000 & 0.000 & 0.000 & 0.000 & 0.000 \\
\hline
\end{tabular}

Source: SVF-1500, FC-1-8 Input Parameter Supporting Calculations, SVF-1505.xls.

1. Case 2 only

Additional assumptions used in the calculations are described in Section 6.2.4. 


\subsubsection{Flowsheet Methodology}

To facilitate mass balance and equipment sizing estimates for the current study, CH2M HILL made several previous calculations available (see Section 6.2.3). With adjustments for differences in waste composition and production capacity, these provide a suitable basis for preliminary evaluations such as the current study. This section describes the approach used for calculation of the fractional crystallization mass balance spreadsheets (SVF-1498), including assumptions and input data. Stream number callouts in this Section refer to streams identified in Figures 6-12 and 6-13. The calculation methods include a number of input parameters. Unless otherwise stated, the sources and bases for the input parameters are discussed in Section 6.2.3.

6.2.4.1 Nomenclature. The following nomenclature is defined to support description of the fractional crystallization flowsheet methodology.

$M_{i, n}$ is the mass flow rate of component $i, \mathrm{~kg} / \mathrm{hr}$ in stream $\mathrm{n}$.

$R_{i, n}$ is the radioisotope flow rate of component $i$ in stream $n, C i / h r$.

$\mathrm{V}_{\mathrm{n}}$ is the volumetric flow rate of stream $\mathrm{n}$, liters per hour.

$\rho_{\mathrm{n}}$ is the density of stream $\mathrm{n}$ liquid phase, $\mathrm{kg} / \mathrm{liter}$.

$\mathrm{C}_{\mathrm{i}, \mathrm{n}}$ is the concentration of component $\mathrm{i}$ in stream $\mathrm{n}$ liquid phase, g-mole/liter or $\mathrm{C} i /$ liter.

$\mathrm{m}_{\mathrm{i}, \mathrm{n}}$ is the molal concentration of component $\mathrm{i}$ in stream $\mathrm{n}$ liquid phase, gmol component $\mathrm{i} / \mathrm{kg}$ water.

$\mathrm{MW}_{\mathrm{i}}$ is the molecular weight of component $\mathrm{i}$, note that this may be applied to a cation, anion or compound.

$\mathrm{X}_{\mathrm{i}, \mathrm{n}}$ is the weight fraction of component $\mathrm{i}$ in the liquid phase of stream $\mathrm{n}$.

$\mathrm{s}$ is the component designator for total dissolved solids, e. $\mathrm{g} . \mathrm{X}_{\mathrm{s}, \mathrm{n}}$ is the weight fraction of total dissolved solids in the liquid phase of stream $n$.

$\mathrm{M}_{\mathrm{s}, \mathrm{n}}=$ summation of $\mathrm{M}_{\mathrm{i}, \mathrm{n}}$ for all components except water.

$\mathrm{SC}_{\mathrm{n}}$ is the weight fraction crystallized solids in stream $\mathrm{n}, \mathrm{kg}$ crystallized solids/(kg crystallized solids $+\mathrm{kg}$ liquid phase).

$M_{s c, n}$ is the mass flow of crystallized solids in stream $n, \mathrm{~kg} / \mathrm{hr}$.

6.2.4.2 Calculation Methods and Assumptions. This section describes the approach used for calculations in the fractional crystallization mass balance spreadsheets (SVF-1498). This spreadsheet calculates only selected steady state stream properties, and has a number of limitations. Specifically:

- The spreadsheet does not include calculation of tritium $\left({ }^{3} \mathrm{H}\right)$ flows. These will be calculated separately as needed. 
- Blending part of the high sulfate product into the cesium product is not included, i. e. streams 24 and 32 are set equal to zero.

- Steam flows for the vacuum steam jets are not included and must be calculated separately and provided as inputs.

6.2.4.2.1 Decontaminated Product. Decontaminated product (stream 27) flows from the second stage crystallization system. For crystallized anion components the mass of each component is calculated as a function of the feed (stream 4) as follows:

$$
\mathrm{M}_{\mathrm{i}, 27}=\mathrm{M}_{\mathrm{i}, 4} * \mathrm{Y}_{\mathrm{i}} * \mathrm{EF}_{\mathrm{i}}
$$

where input parameters $\mathrm{Y}_{\mathrm{i}}$ and $\mathrm{EF}_{\mathrm{i}}$ (theoretical yield and efficiency factor respectively) are estimated for each waste batch. Input parameters $\mathrm{Y}_{\mathrm{i}}$ (theoretical yield) are based on theoretical yields from batch boil down calculations. Efficiency factors $(<1)$ may be defined for some components to account for potential yield losses.

Total sodium in the product is then calculated by assuming anion yields are in the form of their associated sodium salts $\left(\mathrm{NaNO}_{2}, \mathrm{NaNO}_{3}, \mathrm{Na}_{2} \mathrm{CO}_{3}, \mathrm{Na}_{2} \mathrm{SO}_{4}, \mathrm{Na}_{3} \mathrm{PO} 4, \mathrm{Na}_{2}\right.$ oxalate, $\mathrm{NaCl}, \mathrm{NaF}$, etc.) For components that are not crystallized, flow rate in the product is determined from the decontamination factors for stage 1 and 2, DF 1 and DF2 respectively (input parameters).

$$
\begin{aligned}
& \mathrm{M}_{\mathrm{i}, 4} / \mathrm{M}_{\mathrm{Na}, 4}=\mathrm{DF} 1 * \mathrm{DF} 2 * \mathrm{M}_{\mathrm{i}, 27} / \mathrm{M}_{\mathrm{Na}, 27}, \\
& \mathrm{R}_{\mathrm{i}, 4} / \mathrm{M}_{\mathrm{Na}, 4}=\mathrm{DF} 1 * \mathrm{DF} 2 * \mathrm{R}_{\mathrm{i}, 27} / \mathrm{M}_{\mathrm{Na}, 27} .
\end{aligned}
$$

Or rearranging

$$
\begin{aligned}
& M_{\mathrm{i}, 27}=M_{\mathrm{Na}, 27} * \mathrm{M}_{\mathrm{i}, 4} /\left(\mathrm{M}_{\mathrm{Na}, 4} * \mathrm{DF} 1 * \mathrm{DF} 2\right), \\
& \mathrm{R}_{\mathrm{i}, 27}=\mathrm{M}_{\mathrm{Na}, 27} * \mathrm{R}_{\mathrm{i}, 4} /\left(\mathrm{M}_{\mathrm{Na}, 4} * \mathrm{DF} 1 * \mathrm{DF} 2\right) .
\end{aligned}
$$

With the exception of ${ }^{90} \mathrm{Sr}$ it is assumed that liquid phase radioisotopes included in the waste inventory do not crystallize. Testing with actual waste samples showed a total DF for ${ }^{90} \mathrm{Sr}$ of 1.3 after two crystallization stages, versus a DF of 18,100 for ${ }^{137} \mathrm{Cs}$ (RPP-RPT-31352, Fractional Crystallization Flowsheet Testing with Actual Tank Waste). Therefore, for the current calculation it is assumed that the ${ }^{90} \mathrm{Sr} / \mathrm{Na}$ ratio is constant, i.e. each stage DF is equal to 1. Note that there are a few components that may be crystallized for some batches but not for others, e. g. $\mathrm{Cl}, \mathrm{F}$, and $\mathrm{NO}_{2}$.

6.2.4.2.2 Crystallizer 1 Feed (Stream 3 or 4). The study basis defines a required annual average net product requirement of 1175 metric tons per year of sodium in the decontaminated product transferred to WTP, assuming a $70 \%$ total operating efficiency. Fractional crystallization is considered to be continuous process. Therefore, the instantaneous design product rate is $1680 \mathrm{MT} / \mathrm{yr}$ based on $1 / .7$ times the required annual production rate of 1175 metric tons sodium. Waste feed composition is defined as a set of input parameters. No dilution, preconcentration, or chemical addition is required upstream of the crystallizer feed. The 
preceding section defines the net product yield in terms of the crystallizer feed rate. Feed rate is then calculated from the ratio of sodium in the feed to net sodium in the product and the required net product sodium.

6.2.4.2.3 Internal Streams. Internal streams and water balance are calculated using the following methods and assumptions.

1. The amount of water added to the dissolvers is controlled so that the liquor for washing solids in the centrifuge is essentially saturated with sodium (a small amount of suspended salt crystals will remain that are filtered out of the recycled wash liquor). The mass balance assumes no solids are lost with the liquor from the centrifuge, and no solids are dissolved during washing. Therefore total crystallized solids in the centrifuge feed equal the total dissolved solids in stream $10+$ stream 20 :

$$
\begin{aligned}
& \mathrm{M}_{\mathrm{sc}, 19}=\mathrm{M}_{\mathrm{s}, 10}+\mathrm{M}_{\mathrm{s}, 20} \text { for stage } 1, \\
& \mathrm{M}_{\mathrm{sc}, 31}=\mathrm{M}_{\mathrm{s}, 25}+\mathrm{M}_{\mathrm{s}, 27} \text { for stage } 2 .
\end{aligned}
$$

Note that a small amount of undissolved crystals may remain in the dissolver product. For simplicity, these are carried as dissolved solids in stream 20 and 27.

2. It is assumed that all water required for dissolution is added via stream 11 and 26 for the first and second stage respectively. Hydrates and residual liquid film in the solids are ignored (this results in a slight overestimate of the amount of added water). Therefore,

$$
\begin{aligned}
& M_{H 2 O, 11}=M_{H 2 O, 10}+M_{H 2 O, 20} \text { for stage 1, } \\
& M_{H 2 O, 26}=M_{H 2 O, 27}+M_{H 2 O, 25} \text { for stage 2 }
\end{aligned}
$$

3. Decontamination factors. Decontamination factors, DF1 and DF2 are specified separately for the stage 1 and stage 2 crystallization respectively. They are defined in terms of the ratio of contaminant concentration to concentration of sodium as follows, and are assumed to be constant for all components that are soluble, i. e. not crystallized.

$$
\begin{aligned}
& \text { DF1 }=\left(\mathrm{M}_{\mathrm{i}, 4} / \mathrm{M}_{\mathrm{Na}, 4)} /\left(\mathrm{M}_{\mathrm{i}, 20} / \mathrm{M}_{\mathrm{Na}, 20),}\right)\right. \\
& \text { DF1 }=\left(\mathrm{R}_{\mathrm{i}, 4} / \mathrm{M}_{\mathrm{Na}, 4}\right) /\left(\mathrm{R}_{\mathrm{i}, 20} / \mathrm{M}_{\mathrm{Na}, 20}\right) \\
& \text { DF2 }=\left(\mathrm{M}_{\mathrm{i}, 20} / \mathrm{M}_{\mathrm{Na}, 20)} / \mathrm{M}_{\mathrm{i}, 27} / \mathrm{M}_{\mathrm{Na}, 27),}\right. \\
& \text { DF2 }=\left(\mathrm{R}_{\mathrm{i}, 20} / \mathrm{M}_{\mathrm{Na}, 20}\right) /\left(\mathrm{R}_{\mathrm{i}, 27} / \mathrm{M}_{\mathrm{Na}, 27}\right) .
\end{aligned}
$$

Or rearranging

$$
\begin{aligned}
& \mathrm{M}_{\mathrm{i}, 20}=\mathrm{M}_{\mathrm{Na}, 20} * \mathrm{M}_{\mathrm{i}, 4} /\left(\mathrm{M}_{\mathrm{Na}, 4} * \mathrm{DF} 1\right), \\
& \mathrm{R}_{\mathrm{i}, 20}=\mathrm{M}_{\mathrm{Na}, 20} * \mathrm{R}_{\mathrm{i}, 4} /\left(\mathrm{M}_{\mathrm{Na}, 4} * \mathrm{DF} 1\right) .
\end{aligned}
$$

4. Dissolved solids content of selected streams are provided as input data as follows:

$\mathrm{X}_{\mathrm{S}, 27}$ second stage dissolver product,

$\mathrm{X}_{\mathrm{s}, 29}$ or $\mathrm{C}_{\mathrm{Na}, 29} \mathrm{LAW}$ product to WTP, 
$\mathrm{X}_{\mathrm{S}, 20}$ first stage dissolver product or second stage crystallizer feed,

$\mathrm{X}_{\mathrm{s}, 19}$ first stage crystallizer product (liquid phase),

$\mathrm{X}_{\mathrm{s}, 31}$ second stage crystallizer product (liquid phase),

$\mathrm{X}_{\mathrm{s}, 10}$ first stage centrifuge wash liquor,

$\mathrm{X}_{\mathrm{s}, 25}$ second stage centrifuge wash liquor,

$\mathrm{X}_{\mathrm{s}, 13}$ first stage purge (concentrated cesium product),

$\mathrm{X}_{\mathrm{S}, 9}$ second stage purge (recycle to first stage crystallizer),

Note that for stream $10,25,19$, and 31 , individual dissolved components are not calculated for this mass balance, only total dissolved solids.

5. Crystallized solids content (weight fraction) of dissolver output streams are provided as input data as follows:

$\mathrm{SC}_{19}$ first stage crystallizer product, $\mathrm{SC}_{31}$ second stage crystallizer product.

6. Wash Recycle Factors. In the $10 \mathrm{M}$ dissolvers water is added to dissolve the decontaminated crystal solids. The resulting liquor is split into two streams using a filter. Filtrate (Streams 10 and 25 ) is recycled for washing the solids cake in the centrifuge. Unfiltered liquor containing a small amount of remaining undissolved solids (Stream 20) is fed to the second stage crystallizer or Stream 27 is transferred to the LAW product tank. The fraction of dissolver product recycled for washing may be varied depending on the decontamination factor required (more recycle wash gives better decontamination). The amount recycled will be specified by ratio to the product solution solids:

$\mathrm{M}_{\mathrm{s}, 10}=\mathrm{M}_{\mathrm{s}, 20} * \mathrm{WF} 1$ first stage

$\mathrm{M}_{\mathrm{s}, 25}=\mathrm{M}_{\mathrm{s}, 27} * \mathrm{WF} 2$ second stage.

Where WF1 and WF2 are input factors.

7. Stage Two Recycle Factors. A portion of the second stage crystallizer feed (stream 20) will be returned (stream 9) from the second stage for recycle in the first stage crystallizer. Second stage feed components other than water must report to either the product or the recycle, assuming loss to the evaporator overhead condensate is negligible.

$$
\mathrm{M}_{\mathrm{i}, 20}=\mathrm{M}_{\mathrm{i}, 9}+\mathrm{M}_{\mathrm{i}, 27} .
$$

For soluble components that are not crystallized the stream 9 flows can be calculated from the decontamination factors. For components that are at least partially crystallized, a factor " $\mathrm{RF}_{\mathrm{i}}$ " is defined to allow estimation of the recycle flow as a ratio to the net product yield, i.e.

$$
\mathrm{RF}_{\mathrm{i}}=\mathrm{M}_{\mathrm{i}, 9} / \mathrm{M}_{\mathrm{i}, 27}
$$


An exception is sodium. Sodium in stream 9 must be calculated from the associated anion flows in the recycle stream. Calculations used to estimate values for the $\mathrm{RF}_{\mathrm{i}}$ were performed for a single waste composition. Extrapolating these results to other compositions provides only a rough estimate of stream 9 compositions; however, the differences should not have a material impact at the current preliminary study level of detail.

8. Cesium Product Purge, Water Balance and Steam Generation. Dissolved solids in the first stage cesium product purge (Stream 13) are calculated by difference; i. e., total feeds to combined stage one and two minus total products. Assuming steady state operation and no losses to the crystallizer vents:

$\mathrm{M}_{\mathrm{i}, 13}=\mathrm{M}_{\mathrm{i}, 4}-\mathrm{M}_{\mathrm{i}, 27}$.

Similarly, the crystallizer overhead steam rate is determined by the overall water balance (note that boundaries for these balances are selected to avoid internal recycle streams within each stage):

$$
\begin{aligned}
& M_{\mathrm{H} 20,5}=M_{\mathrm{H} 20,4}+\mathrm{M}_{\mathrm{H} 2 \mathrm{O}, 11}+\mathrm{M}_{\mathrm{H} 20,9}-\mathrm{M}_{\mathrm{H} 20,20}-\mathrm{M}_{\mathrm{H} 20,13} \text { (First Stage), } \\
& \mathrm{M}_{\mathrm{H} 20,21}=\mathrm{M}_{\mathrm{H} 20,20}+\mathrm{M}_{\mathrm{H} 2 \mathrm{O}, 26}-\mathrm{M}_{\mathrm{H} 20,27}-\mathrm{M}_{\mathrm{H} 20,9}+\mathrm{M}_{\mathrm{H} 2 \mathrm{O}, 33}-\mathrm{M}_{\mathrm{H} 20,24} \text { (Second Stage). }
\end{aligned}
$$

The assumption for the current mass balance model calculation is that streams 33 and 24 are zero. Therefore the second stage balance reduces to

$$
\mathrm{M}_{\mathrm{H} 20,21}=\mathrm{M}_{\mathrm{H} 20,20}+\mathrm{M}_{\mathrm{H} 2 \mathrm{O}, 26}-\mathrm{M}_{\mathrm{H} 20,27}-\mathrm{M}_{\mathrm{H} 20,9} \text { (Second Stage). }
$$

Water in streams 9, 13, and 19 are calculated from input parameter values for weight fraction solids in each stream.

$$
\begin{aligned}
& \mathrm{X}_{\mathrm{s}, 9}=\mathrm{M}_{\mathrm{s}, 9} /\left(\mathrm{M}_{\mathrm{s}, 9}+\mathrm{M}_{\mathrm{H} 2 \mathrm{O}, 9}\right) \\
& \mathrm{X}_{\mathrm{s}, 13}=\mathrm{M}_{\mathrm{s}, 13} /\left(\mathrm{M}_{\mathrm{s}, 13}+\mathrm{M}_{\mathrm{H} 2 \mathrm{O}, 13}\right), \\
& \mathrm{X}_{\mathrm{s}, 19}=\mathrm{M}_{\mathrm{s}, 19} /\left(\mathrm{M}_{\mathrm{s}, 19}+\mathrm{M}_{\mathrm{H} 2 \mathrm{O}, 19}\right)
\end{aligned}
$$

Or rearranging:

$$
\begin{aligned}
& \mathrm{M}_{\mathrm{H} 2 \mathrm{O}, 9}=\mathrm{M}_{\mathrm{s}, 9} *\left(1-\mathrm{X}_{\mathrm{s}, 9}\right) / \mathrm{X}_{\mathrm{s}, 9}, \\
& \mathrm{M}_{\mathrm{H} 2 \mathrm{O}, 13}=\mathrm{M}_{\mathrm{s}, 13} *\left(1-\mathrm{X}_{\mathrm{s}, 13}\right) / \mathrm{X}_{\mathrm{s}, 13} \\
& \mathrm{M}_{\mathrm{H} 2 \mathrm{O}, 19}=\mathrm{M}_{\mathrm{s}, 19} *\left(1-\mathrm{X}_{\mathrm{s}, 19}\right) / \mathrm{X}_{\mathrm{s}, 19}
\end{aligned}
$$

9. Process condensate. The primary condensers condense nearly all steam from evaporation. Therefore, for simplicity stream 6 and stream 22 are set equal to the crystallizer boilup, i. e. 


$$
\begin{aligned}
& \mathrm{M}_{\mathrm{H} 2 \mathrm{O}, 6}=\mathrm{M}_{\mathrm{H} 2 \mathrm{O}, 5} \\
& \mathrm{M}_{\mathrm{H} 2 \mathrm{O}, 22}=\mathrm{M}_{\mathrm{H} 2 \mathrm{O}, 21}
\end{aligned}
$$

This results in a slight overestimate for streams 6 and 22 and a compensating slight underestimate for streams 7 and 23. Streams 7 and 23 are calculated separately based on the steam flow required to maintain vacuum in the crystallizers.

Net process condensate discharge (stream 30) is calculated from an overall balance, i.e., total water in input streams minus total water in other products. For the combined first and second stage:

$$
\mathrm{M}_{\mathrm{H} 20,30}=\mathrm{M}_{\mathrm{H} 20,4}+\mathrm{M}_{\mathrm{H} 20,7}+\mathrm{M}_{\mathrm{H} 20,23}-\mathrm{M}_{\mathrm{H} 20,14}-\mathrm{M}_{\mathrm{H} 20,29}
$$

\subsubsection{Material and Energy Balances}

A summary of fractional crystallization mass balance calculation results for each of the Case 1 eight feed batches and 16 Case 2 feed batches is shown in Table 6-26. Complete results of the calculations are provided in RPP-CALC-37594.

Review of stream 4 volumes shows that feed rates vary significantly between batches. This is because of differences in the fractional yield of decontaminated sodium product estimated for each batch and differences in sodium concentration in the initial feed batch. Batch 8 requires by far the highest feed rate, 3920 liters $/ \mathrm{hr}(17.3 \mathrm{gpm})$ or between 1.6 and 2.3 times the other batches, in order to maintain the specified production rate of LAW to WTP. This is because of the relatively low net yield of sodium in the LAW for Batch 8 (35.4\% of the waste feed). Batch 8 establishes the sizing basis for the front end of the process. Primary sizing impacts of the high feed rates are seen in the initial feed filtration step, and the crystallizer feed tank, crystallizer 1 reboiler, recirculation pump, and condenser. Other portions of the fractional crystallization system are not substantially affected by the low sodium yield and resulting high feed rate.

The mass balance results show that WTP LAW cesium specification is expected to be met for all batches. For the WTP LAW product as shown, sulfate to sodium ratios are estimated to be over the envelope A limit but less than the envelope B limit. As discussed in section 6.2.8, a portion of the high sulfate product can be blended into the Cs product if desired to bring the WTP LAW below the envelope A limit if needed. Based on the defined feed compositions, the mass balance calculations indicate that all other WTP and bulk vitrification acceptance criteria will be met by the selected pre-conceptual fractional crystallization process. As currently shown, the two primary products, stream 29 (LAW to WTP) and Stream 14 (Cs product to DST), are diluted to about 9 mole/liter sodium concentration for transfer. These products can be diluted to a higher or lower concentration if needed depending on the requirements of the receiving entity. 
Table 6-26 Fractional Crystallization Mass Balance Summary (8 sheets)

\begin{tabular}{|c|c|c|c|c|c|c|c|c|c|c|c|c|c|c|c|c|}
\hline Batch \# & 1 & Tank & 241-AP-104 & & & & & & & & & & & & & \\
\hline Stream Number & 4 & 6 & 7 & 19 & 10 & 20 & 22 & 23 & 9 & 31 & 25 & 13 & 14 & 27 & 29 & 30 \\
\hline Description & $\begin{array}{l}\text { Waste Feed } \\
\text { to 1st Stage } \\
\text { Crystallizer }\end{array}$ & $\begin{array}{l}\text { 1st Stage } \\
\text { Boilup } \\
\text { Cond. }\end{array}$ & $\begin{array}{l}\text { 1st Stage } \\
\text { Vacuum } \\
\text { Jet } 1 \text { Cond. }\end{array}$ & $\begin{array}{l}\text { 1st Stage } \\
\text { Crystallizer } \\
\text { Product }^{1}\end{array}$ & $\begin{array}{c}\text { 1st Stage } \\
\text { Centrifuge } \\
\text { Wash } \\
\text { Liquor }\end{array}$ & $\begin{array}{l}\text { 1st Stage } \\
\text { Dissolver } \\
\text { Slurry }\end{array}$ & $\begin{array}{l}\text { 2nd Stage } \\
\text { Boilup } \\
\text { Cond. }\end{array}$ & $\begin{array}{l}\text { 2nd Stage } \\
\text { Vacuum } \\
\text { Jet } 1 \text { Cond. }\end{array}$ & $\begin{array}{c}\text { 2nd Stage } \\
\text { Spent } \\
\text { Wash } \\
\text { Recycle }\end{array}$ & $\begin{array}{l}\text { 2nd Stage } \\
\text { Crystallizer } \\
\text { Product }^{1}\end{array}$ & $\begin{array}{l}\text { 2nd Stage } \\
\text { Centrifuge } \\
\text { Wash } \\
\text { Liquor }\end{array}$ & $\begin{array}{l}\text { 1st Stage } \\
\text { Spent } \\
\text { Wash } \\
\text { Purge }\end{array}$ & $\begin{array}{l}\text { Cs Product } \\
\text { to DST }{ }^{2}\end{array}$ & $\begin{array}{c}\text { LAW } \\
\text { Product }^{2}\end{array}$ & $\begin{array}{l}\text { LAW to } \\
\text { WTP }^{2}\end{array}$ & $\begin{array}{l}\text { Liquid } \\
\text { Effluent to } \\
\text { ETF }\end{array}$ \\
\hline Volume $(\mathrm{L} / \mathrm{h})^{1}$ & $1.96 \mathrm{E}+03$ & $1.81 \mathrm{E}+03$ & $1.25 \mathrm{E}+02$ & $2.14 \mathrm{E}+03$ & $8.54 \mathrm{E}+02$ & $1.42 \mathrm{E}+03$ & $1.64 \mathrm{E}+03$ & $6.18 \mathrm{E}+01$ & $9.82 \mathrm{E}+01$ & $1.82 \mathrm{E}+03$ & $7.38 \mathrm{E}+02$ & $6.18 \mathrm{E}+02$ & $9.33 \mathrm{E}+02$ & $7.04 \mathrm{E}+02$ & $9.42 \mathrm{E}+02$ & $3.47 \mathrm{E}+02$ \\
\hline Volume $(\mathrm{gpm})^{1}$ & $8.65 \mathrm{E}+00$ & $7.95 \mathrm{E}+00$ & $5.51 \mathrm{E}-01$ & $9.42 \mathrm{E}+00$ & $3.76 \mathrm{E}+00$ & $6.27 \mathrm{E}+00$ & $7.22 \mathrm{E}+00$ & $2.72 \mathrm{E}-01$ & $4.32 \mathrm{E}-01$ & $8.00 \mathrm{E}+00$ & $3.25 \mathrm{E}+00$ & $2.72 \mathrm{E}+00$ & $4.11 \mathrm{E}+00$ & $3.10 \mathrm{E}+00$ & $4.15 \mathrm{E}+00$ & $1.53 \mathrm{E}+00$ \\
\hline Liquid Density $(\mathrm{kg} / \mathrm{L})^{1}$ & 1.41 & 1.00 & 1.00 & 1.57 & 1.51 & 1.35 & 1.00 & 1.00 & 1.59 & 1.59 & 1.51 & 1.57 & 1.41 & 1.53 & 1.43 & 1.00 \\
\hline $137 \mathrm{Cs}(\mathrm{Ci} / \mathrm{L})$ & $1.92 \mathrm{E}-01$ & -- & -- & -- & -- & $1.25 \mathrm{E}-03$ & -- & -- & $1.79 \mathrm{E}-02$ & -- & -- & $6.09 \mathrm{E}-01$ & $4.04 \mathrm{E}-01$ & $3.95 \mathrm{E}-05$ & $2.95 \mathrm{E}-05$ & -- \\
\hline $\mathrm{Na}(\mathrm{mol} / \mathrm{L})$ & $8.43 \mathrm{E}+00$ & -- & -- & -- & -- & $6.83 \mathrm{E}+00$ & -- & -- & $1.41 \mathrm{E}+01$ & -- & -- & $1.33 \mathrm{E}+01$ & $8.81 \mathrm{E}+00$ & $1.18 \mathrm{E}+01$ & $8.85 \mathrm{E}+00$ & -- \\
\hline $\mathrm{Na}(\mathrm{kg} / \mathrm{h})$ & $3.80 \mathrm{E}+02$ & -- & -- & -- & -- & $2.23 \mathrm{E}+02$ & -- & -- & $3.19 \mathrm{E}+01$ & -- & -- & $1.89 \mathrm{E}+02$ & $1.89 \mathrm{E}+02$ & $1.92 \mathrm{E}+02$ & $1.92 \mathrm{E}+02$ & -- \\
\hline $\mathrm{SO} 4(\mathrm{~kg} / \mathrm{h})^{2}$ & $1.18 \mathrm{E}+01$ & -- & -- & -- & -- & $1.18 \mathrm{E}+01$ & -- & -- & $1.17 \mathrm{E}-02$ & -- & -- & $4.72 \mathrm{E}-02$ & $4.72 \mathrm{E}-02$ & $1.17 \mathrm{E}+01$ & $1.17 \mathrm{E}+01$ & -- \\
\hline Water $(\mathrm{kg} / \mathrm{hr})$ & $1.55 \mathrm{E}+03$ & $1.81 \mathrm{E}+03$ & $1.25 \mathrm{E}+02$ & $1.31 \mathrm{E}+03$ & $5.76 \mathrm{E}+02$ & $1.20 \mathrm{E}+03$ & $1.64 \mathrm{E}+03$ & $6.18 \mathrm{E}+01$ & $5.70 \mathrm{E}+01$ & $1.05 \mathrm{E}+03$ & $4.98 \mathrm{E}+02$ & $3.78 \mathrm{E}+02$ & $6.92 \mathrm{E}+02$ & $4.59 \mathrm{E}+02$ & $6.98 \mathrm{E}+02$ & $3.47 \mathrm{E}+02$ \\
\hline Dissolved Solids (kg/h) & $1.21 \mathrm{E}+03$ & -- & -- & $2.04 \mathrm{E}+03$ & $7.18 \mathrm{E}+02$ & $7.18 \mathrm{E}+02$ & -- & -- & $9.91 \mathrm{E}+01$ & $1.83 \mathrm{E}+03$ & $6.19 \mathrm{E}+02$ & $5.90 \mathrm{E}+02$ & $5.90 \mathrm{E}+02$ & $6.19 \mathrm{E}+02$ & $6.19 \mathrm{E}+02$ & -- \\
\hline Crystal Solids (kg/h) & -- & -- & -- & $1.44 \mathrm{E}+03$ & -- & -- & -- & -- & -- & $1.24 \mathrm{E}+03$ & -- & -- & -- & -- & -- & -- \\
\hline Process time@100\% TOE hrs & 1929 & -- & -- & -- & -- & -- & -- & -- & -- & -- & -- & -- & -- & -- & -- & -- \\
\hline Process time@70\% TOE hrs & 2755 & -- & -- & -- & -- & -- & -- & -- & -- & -- & -- & -- & -- & -- & -- & -- \\
\hline
\end{tabular}

\begin{tabular}{|c|c|c|c|c|c|c|c|c|c|c|c|c|c|c|c|c|}
\hline Batch \# & 2 & Tank & 241-AP-10 & & & & & & & & & & & & & \\
\hline Stream Number & 4 & 6 & 7 & 19 & 10 & 20 & 22 & 23 & 9 & 31 & 25 & 13 & 14 & 27 & 29 & 30 \\
\hline Description & $\begin{array}{l}\text { Waste Feed } \\
\text { to 1st Stage } \\
\text { Crystallizer }\end{array}$ & $\begin{array}{l}\text { 1st Stage } \\
\text { Boilup } \\
\text { Cond. }\end{array}$ & $\begin{array}{c}\text { 1st Stage } \\
\text { Vacuum } \\
\text { Jet } 1 \text { Cond. }\end{array}$ & $\begin{array}{l}\text { 1st Stage } \\
\text { Crystallizer } \\
\text { Product }^{1}\end{array}$ & $\begin{array}{c}\text { 1st Stage } \\
\text { Centrifuge } \\
\text { Wash } \\
\text { Liquor }\end{array}$ & $\begin{array}{l}\text { 1st Stage } \\
\text { Dissolver } \\
\text { Slurry }\end{array}$ & $\begin{array}{l}\text { 2nd Stage } \\
\text { Boilup } \\
\text { Cond. }\end{array}$ & $\begin{array}{l}\text { 2nd Stage } \\
\text { Vacuum } \\
\text { Jet } 1 \text { Cond. }\end{array}$ & $\begin{array}{c}\text { 2nd Stage } \\
\text { Spent } \\
\text { Wash } \\
\text { Recycle }\end{array}$ & $\begin{array}{l}\text { 2nd Stage } \\
\text { Crystallizer } \\
\text { Product }^{{ }^{2}}\end{array}$ & $\begin{array}{c}\text { 2nd Stage } \\
\text { Centrifuge } \\
\text { Wash } \\
\text { Liquor }\end{array}$ & $\begin{array}{l}\text { 1st Stage } \\
\text { Spent } \\
\text { Wash } \\
\text { Purge }\end{array}$ & $\begin{array}{l}\text { Cs Product } \\
\text { to } \mathrm{DST}^{2}\end{array}$ & $\begin{array}{c}\text { LAW } \\
\text { Product }^{2}\end{array}$ & $\begin{array}{l}\text { LAW to } \\
\text { WTP }^{2}\end{array}$ & $\begin{array}{l}\text { Liquid } \\
\text { Effluent to } \\
\text { ETF }\end{array}$ \\
\hline Volume $(\mathrm{L} / \mathrm{h})^{1}$ & $2.45 \mathrm{E}+03$ & $2.16 \mathrm{E}+03$ & $1.25 \mathrm{E}+02$ & $2.30 \mathrm{E}+03$ & $9.19 \mathrm{E}+02$ & $1.53 \mathrm{E}+03$ & $1.70 \mathrm{E}+03$ & $6.18 \mathrm{E}+01$ & $1.52 \mathrm{E}+02$ & $1.82 \mathrm{E}+03$ & $7.39 \mathrm{E}+02$ & $8.45 \mathrm{E}+02$ & $1.27 \mathrm{E}+03$ & $7.04 \mathrm{E}+02$ & $9.43 \mathrm{E}+02$ & $5.14 \mathrm{E}+02$ \\
\hline Volume $(\mathrm{gpm})^{1}$ & $1.08 \mathrm{E}+01$ & $9.53 \mathrm{E}+00$ & $5.51 \mathrm{E}-01$ & $1.01 \mathrm{E}+01$ & $4.05 \mathrm{E}+00$ & $6.75 \mathrm{E}+00$ & $7.49 \mathrm{E}+00$ & $2.72 \mathrm{E}-01$ & $6.67 \mathrm{E}-01$ & $8.01 \mathrm{E}+00$ & $3.25 \mathrm{E}+00$ & $3.72 \mathrm{E}+00$ & $5.61 \mathrm{E}+00$ & $3.10 \mathrm{E}+00$ & $4.15 \mathrm{E}+00$ & $2.27 \mathrm{E}+00$ \\
\hline Liquid Density $(\mathrm{kg} / \mathrm{L})^{1}$ & 1.39 & 1.00 & 1.00 & 1.57 & 1.51 & 1.35 & 1.00 & 1.00 & 1.59 & 1.59 & 1.51 & 1.57 & 1.41 & 1.53 & 1.43 & 1.00 \\
\hline $137 \mathrm{Cs}(\mathrm{Ci} / \mathrm{L})$ & $2.41 \mathrm{E}-01$ & -- & -- & -- & -- & $1.66 \mathrm{E}-03$ & -- & -- & $1.65 \mathrm{E}-02$ & -- & -- & $6.96 \mathrm{E}-01$ & $4.62 \mathrm{E}-01$ & $5.19 \mathrm{E}-05$ & $3.88 \mathrm{E}-05$ & -- \\
\hline $\mathrm{Na}(\mathrm{mol} / \mathrm{L})$ & $8.04 \mathrm{E}+00$ & -- & -- & -- & -- & $6.86 \mathrm{E}+00$ & -- & -- & $1.44 \mathrm{E}+01$ & -- & -- & $1.34 \mathrm{E}+01$ & $8.90 \mathrm{E}+00$ & $1.18 \mathrm{E}+01$ & $8.84 \mathrm{E}+00$ & -- \\
\hline $\mathrm{Na}(\mathrm{kg} / \mathrm{h})$ & $4.52 \mathrm{E}+02$ & -- & -- & -- & -- & $2.42 \mathrm{E}+02$ & -- & -- & $5.00 \mathrm{E}+01$ & -- & -- & $2.61 \mathrm{E}+02$ & $2.61 \mathrm{E}+02$ & $1.92 \mathrm{E}+02$ & $1.92 \mathrm{E}+02$ & -- \\
\hline $\mathrm{SO} 4(\mathrm{~kg} / \mathrm{h})^{2}$ & $6.44 \mathrm{E}+00$ & -- & -- & -- & -- & $6.41 \mathrm{E}+00$ & -- & -- & $6.41 \mathrm{E}-03$ & -- & -- & $3.22 \mathrm{E}-02$ & $3.22 \mathrm{E}-02$ & $6.41 \mathrm{E}+00$ & $6.41 \mathrm{E}+00$ & -- \\
\hline Water $(\mathrm{kg} / \mathrm{hr})$ & $1.97 \mathrm{E}+03$ & $2.16 \mathrm{E}+03$ & $1.25 \mathrm{E}+02$ & $1.41 \mathrm{E}+03$ & $6.20 \mathrm{E}+02$ & $1.29 \mathrm{E}+03$ & $1.70 \mathrm{E}+03$ & $6.18 \mathrm{E}+01$ & $8.80 \mathrm{E}+01$ & $1.06 \mathrm{E}+03$ & $4.99 \mathrm{E}+02$ & $5.17 \mathrm{E}+02$ & $9.47 \mathrm{E}+02$ & $4.60 \mathrm{E}+02$ & $6.99 \mathrm{E}+02$ & $5.14 \mathrm{E}+02$ \\
\hline Dissolved Solids (kg/h) & $1.43 \mathrm{E}+03$ & -- & -- & $2.20 \mathrm{E}+03$ & $7.73 \mathrm{E}+02$ & $7.73 \mathrm{E}+02$ & -- & -- & $1.53 \mathrm{E}+02$ & $1.84 \mathrm{E}+03$ & $6.20 \mathrm{E}+02$ & $8.06 \mathrm{E}+02$ & $8.06 \mathrm{E}+02$ & $6.20 \mathrm{E}+02$ & $6.20 \mathrm{E}+02$ & -- \\
\hline Crystal Solids $(\mathrm{kg} / \mathrm{h})$ & -- & -- & -- & $1.55 \mathrm{E}+03$ & -- & -- & -- & -- & -- & $1.24 \mathrm{E}+03$ & -- & -- & -- & -- & -- & -- \\
\hline Process time $@ 100 \%$ TOE hrs & 1636 & -- & -- & -- & -- & -- & -- & -- & -- & -- & -- & -- & -- & - & -- & -- \\
\hline Process time $@ 70 \%$ TOE hrs & 2336 & -- & -- & -- & & -- & -- & -- & -- & -- & -- & -- & -- & -- & -- & -- \\
\hline
\end{tabular}

\begin{tabular}{|l|l|}
\hline Process time@70\% TOE hrs & 2336 \\
\hline
\end{tabular}

1. Volume and density of liquid phase only.

. $\mathrm{Sulfite}$ con be directed to $\mathrm{LAW}$ or $\mathrm{Cs}$ product stream as needed to meet product specifications. 
Table 6-26 Fractional Crystallization Mass Balance Summary

\begin{tabular}{|c|c|c|c|c|c|c|c|c|c|c|c|c|c|c|c|c|}
\hline \multirow{2}{*}{\multicolumn{17}{|c|}{ (8 sheets) }} \\
\hline Batch \# & 3 & Tank & & & & & & & & & & & & & & \\
\hline Stream Number & 4 & 6 & 7 & 19 & 10 & 20 & 22 & 23 & 9 & 31 & 25 & 13 & 14 & 27 & 29 & 30 \\
\hline Description & $\begin{array}{c}\text { Waste Feed to } \\
1 \text { st Stage } \\
\text { Crystallizer }\end{array}$ & $\begin{array}{c}\text { 1st Stage } \\
\text { Boilup Cond. }\end{array}$ & $\begin{array}{c}\text { 1st Stage } \\
\text { Vacuum } \\
\text { Jet } 1 \text { Cond. }\end{array}$ & $\begin{array}{l}\text { 1st Stage } \\
\text { Crystallizer } \\
\text { Product }^{1}\end{array}$ & $\begin{array}{c}\text { 1st Stage } \\
\text { Centrifuge } \\
\text { Wash Liquor }\end{array}$ & $\begin{array}{c}\text { 1st Stage } \\
\text { Dissolver } \\
\text { Slurry }\end{array}$ & $\mid \begin{array}{c}\text { 2nd Stage } \\
\text { Boilup Cond. }\end{array}$ & $\begin{array}{l}\text { 2nd Stage } \\
\text { Vacuum } \\
\text { Jet } 1 \text { Cond. }\end{array}$ & $\begin{array}{l}\text { 2nd Stage } \\
\text { Spent Wash } \\
\text { Recycle }\end{array}$ & $\begin{array}{c}\text { 2nd Stage } \\
\text { Crystallizer }^{\text {Product }^{1}}\end{array}$ & $\begin{array}{c}\text { 2nd Stage } \\
\text { Centrifuge } \\
\text { Wash Liquor }\end{array}$ & $\begin{array}{c}\text { 1st Stage } \\
\text { Spent Wash } \\
\text { Purge }\end{array}$ & $\begin{array}{c}\text { Cs Product to } \\
\text { DST }^{2}\end{array}$ & $\begin{array}{l}\text { LAW } \\
\text { Product }^{2}\end{array}$ & $\begin{array}{l}\text { LAW to } \\
\text { WTP }^{2}\end{array}$ & $\begin{array}{l}\text { Liquid } \\
\text { Effluent to } \\
\text { ETF }\end{array}$ \\
\hline Volume $(\mathrm{L} / \mathrm{h})^{1}$ & $1.53 \mathrm{E}+03$ & $1.57 \mathrm{E}+03$ & $1.25 \mathrm{E}+02$ & $2.10 \mathrm{E}+03$ & $8.38 \mathrm{E}+02$ & $1.40 \mathrm{E}+03$ & $1.64 \mathrm{E}+03$ & $6.18 \mathrm{E}+01$ & $31 \mathrm{E}+01$ & $1.85 \mathrm{E}+03$ & $7.52 \mathrm{E}+02$ & $3.68 \mathrm{E}+02$ & $5.59 \mathrm{E}+02$ & $7.17 \mathrm{E}+02$ & $9.60 \mathrm{E}+02$ & $2.50 \mathrm{E}+02$ \\
\hline Volume $(\mathrm{gpm})^{1}$ & $6.75 \mathrm{E}+00$ & $6.93 \mathrm{E}+00$ & $5.51 \mathrm{E}-01$ & $9.25 \mathrm{E}+00$ & $3.69 \mathrm{E}+00$ & $6.15 \mathrm{E}+00$ & $7.23 \mathrm{E}+00$ & $2.72 \mathrm{E}-01$ & $3.22 \mathrm{E}-01$ & $8.16 \mathrm{E}+00$ & $3.31 \mathrm{E}+00$ & $1.62 \mathrm{E}+00$ & $2.46 \mathrm{E}+00$ & $3.16 \mathrm{E}+00$ & $4.23 \mathrm{E}+00$ & $1.10 \mathrm{E}+00$ \\
\hline Liquid Density $(\mathrm{kg} / \mathrm{L})^{1}$ & 1.42 & 1.00 & 1.00 & 1.57 & 1.51 & 1.35 & 1.00 & 1.00 & 1.59 & 1.59 & 1.51 & 1.57 & 1.41 & 1.53 & 1.43 & 1.00 \\
\hline $137 \mathrm{Cs}(\mathrm{Ci} / \mathrm{L})$ & $3.09 \mathrm{E}-01$ & -- & -- & -- & -- & $1.91 \mathrm{E}-03$ & -- & -- & $3.59 \mathrm{E}-02$ & -- & -- & $1.29 \mathrm{E}+00$ & $8.48 \mathrm{E}-01$ & $6.05 \mathrm{E}-05$ & $4.52 \mathrm{E}-05$ & -- \\
\hline $\mathrm{Na}(\mathrm{mol} / \mathrm{L})$ & $8.71 \mathrm{E}+00$ & -- & -- & -- & -- & $6.68 \mathrm{E}+00$ & -- & -- & $1.36 \mathrm{E}+01$ & -- & -- & $1.36 \mathrm{E}+01$ & $8.98 \mathrm{E}+00$ & $1.16 \mathrm{E}+01$ & $8.68 \mathrm{E}+00$ & -- \\
\hline $\mathrm{Na}(\mathrm{kg} / \mathrm{h})$ & $3.07 \mathrm{E}+02$ & -- & -- & -- & -- & $2.14 \mathrm{E}+02$ & -- & -- & $2.29 \mathrm{E}+01$ & -- & -- & $1.15 \mathrm{E}+02$ & $1.15 \mathrm{E}+02$ & $1.92 \mathrm{E}+02$ & $1.92 \mathrm{E}+02$ & -- \\
\hline $\mathrm{SO} 4(\mathrm{~kg} / \mathrm{h})^{2}$ & $1.61 \mathrm{E}+01$ & -- & -- & -- & -- & $1.61 \mathrm{E}+01$ & -- & -- & $1.61 \mathrm{E}-02$ & -- & -- & $6.45 \mathrm{E}-02$ & $6.45 \mathrm{E}-02$ & $1.61 \mathrm{E}+01$ & $1.61 \mathrm{E}+01$ & -- \\
\hline Water $(\mathrm{kg} / \mathrm{hr})$ & $1.19 \mathrm{E}+03$ & $1.57 \mathrm{E}+03$ & $1.25 \mathrm{E}+02$ & $1.29 \mathrm{E}+03$ & $5.65 \mathrm{E}+02$ & $1.18 \mathrm{E}+03$ & $1.64 \mathrm{E}+03$ & $6.18 \mathrm{E}+01$ & $4.24 \mathrm{E}+01$ & $1.07 \mathrm{E}+03$ & $5.08 \mathrm{E}+02$ & $2.25 \mathrm{E}+02$ & $4.16 \mathrm{E}+02$ & $4.68 \mathrm{E}+02$ & $7.12 \mathrm{E}+02$ & $2.50 \mathrm{E}+02$ \\
\hline Dissolved Solids $(\mathrm{kg} / \mathrm{h})$ & $9.82 \mathrm{E}+02$ & -- & -- & $2.00 \mathrm{E}+03$ & $7.05 \mathrm{E}+02$ & $7.05 \mathrm{E}+02$ & -- & -- & $7.38 \mathrm{E}+01$ & $1.87 \mathrm{E}+03$ & $6.31 \mathrm{E}+02$ & $3.51 \mathrm{E}+02$ & $3.51 \mathrm{E}+02$ & $6.31 \mathrm{E}+02$ & $6.31 \mathrm{E}+02$ & -- \\
\hline Crystal Solids $(\mathrm{kg} / \mathrm{h})$ & -- & -- & -- & $1.41 \mathrm{E}+03$ & -- & -- & -- & -- & -- & $1.26 \mathrm{E}+03$ & -- & -- & -- & -- & -- & -- \\
\hline Process time@100\% TOE hrs & 2693 & -- & -- & -- & -- & -- & -- & -- & -- & -- & -- & -- & -- & -- & -- & -- \\
\hline Process time@70\% TOE hrs & 3848 & -- & -- & -- & -- & -- & -- & -- & -- & -- & -- & -- & -- & -- & -- & -- \\
\hline
\end{tabular}

\begin{tabular}{|c|c|c|c|c|c|c|c|c|c|c|c|c|c|c|c|c|}
\hline Batch \# & 4 & Tank & 241-AP-103 & & & & & & & & & & & & & \\
\hline Stream Number & 4 & 6 & 7 & 19 & 10 & 20 & 22 & 23 & 9 & 31 & 25 & 13 & 14 & 27 & 29 & 30 \\
\hline Description & $\begin{array}{c}\text { Waste Feed to } \\
\text { 1st Stage } \\
\text { Crystallizer }\end{array}$ & $\begin{array}{c}\text { 1st Stage } \\
\text { Boilup Cond. }\end{array}$ & $\begin{array}{c}\text { 1st Stage } \\
\text { Vacuum } \\
\text { Jet } 1 \text { Cond. }\end{array}$ & $\begin{array}{l}\text { 1st Stage } \\
\text { Crystallizer } \\
\text { Product }^{1}\end{array}$ & $\begin{array}{c}\text { 1st Stage } \\
\text { Centrifuge } \\
\text { Wash Liquor }\end{array}$ & $\begin{array}{c}\text { 1st Stage } \\
\text { Dissolver } \\
\text { Slurry }\end{array}$ & $\begin{array}{c}\text { 2nd Stage } \\
\text { Boilup Cond. }\end{array}$ & $\begin{array}{l}\text { 2nd Stage } \\
\text { Vacuum } \\
\text { Jet } 1 \text { Cond. }\end{array}$ & $\begin{array}{l}\text { 2nd Stage } \\
\text { Spent Wash } \\
\text { Recycle }\end{array}$ & $\begin{array}{l}\text { 2nd Stage } \\
\text { Crystallizer } \\
\text { Product }^{1}\end{array}$ & $\begin{array}{c}\text { 2nd Stage } \\
\text { Centrifuge } \\
\text { Wash Liquor }\end{array}$ & $\begin{array}{c}\text { 1st Stage } \\
\text { Spent Wash } \\
\text { Purge }\end{array}$ & $\begin{array}{c}\text { Cs Product to } \\
\text { DST }^{2}\end{array}$ & $\begin{array}{l}\text { LAW } \\
\text { Product }^{2}\end{array}$ & $\begin{array}{l}\text { LAW to } \\
\text { WTP }^{2}\end{array}$ & $\begin{array}{l}\text { Liquid } \\
\text { Effluent to } \\
\text { ETF }\end{array}$ \\
\hline Volume $(\mathrm{L} / \mathrm{h})^{1}$ & $1.97 \mathrm{E}+03$ & $1.80 \mathrm{E}+03$ & $1.25 \mathrm{E}+02$ & $2.13 \mathrm{E}+03$ & $8.50 \mathrm{E}+02$ & $1.42 \mathrm{E}+03$ & $1.60 \mathrm{E}+03$ & $6.18 \mathrm{E}+01$ & $1.19 \mathrm{E}+02$ & $1.74 \mathrm{E}+03$ & $7.08 \mathrm{E}+02$ & $6.51 \mathrm{E}+02$ & $9.53 \mathrm{E}+02$ & $6.75 \mathrm{E}+02$ & $9.32 \mathrm{E}+02$ & $3.45 \mathrm{E}+02$ \\
\hline${\text { Volume }(\mathrm{gpm})^{1}}^{1}$ & $8.68 \mathrm{E}+00$ & $7.92 \mathrm{E}+00$ & $5.51 \mathrm{E}-01$ & $9.38 \mathrm{E}+00$ & $3.74 \mathrm{E}+00$ & $6.24 \mathrm{E}+00$ & $7.05 \mathrm{E}+00$ & $2.72 \mathrm{E}-01$ & $5.26 \mathrm{E}-01$ & $7.68 \mathrm{E}+00$ & $3.12 \mathrm{E}+00$ & $2.87 \mathrm{E}+00$ & $4.20 \mathrm{E}+00$ & $2.97 \mathrm{E}+00$ & $4.10 \mathrm{E}+00$ & $1.52 \mathrm{E}+00$ \\
\hline Liquid Density $(\mathrm{kg} / \mathrm{L})^{1}$ & 1.41 & 1.00 & 1.00 & 1.57 & 1.51 & 1.35 & 1.00 & 1.00 & 1.59 & 1.59 & 1.51 & 1.57 & 1.42 & 1.53 & 1.42 & 1.00 \\
\hline $137 \mathrm{Cs}(\mathrm{Ci} / \mathrm{L})$ & $2.40 \mathrm{E}-01$ & -- & -- & -- & -- & $1.62 \mathrm{E}-03$ & -- & -- & $1.90 \mathrm{E}-02$ & -- & -- & $7.27 \mathrm{E}-01$ & 4.97E-01 & $5.13 \mathrm{E}-05$ & $3.72 \mathrm{E}-05$ & -- \\
\hline $\mathrm{Na}(\mathrm{mol} / \mathrm{L})$ & $8.47 \mathrm{E}+00$ & -- & -- & -- & -- & $7.10 \mathrm{E}+00$ & -- & -- & $1.44 \mathrm{E}+01$ & -- & -- & $1.28 \mathrm{E}+01$ & $8.77 \mathrm{E}+00$ & $1.23 \mathrm{E}+01$ & $8.95 \mathrm{E}+00$ & -- \\
\hline $\mathrm{Na}(\mathrm{kg} / \mathrm{h})$ & $3.84 \mathrm{E}+02$ & -- & -- & -- & -- & $2.31 \mathrm{E}+02$ & -- & -- & $3.96 \mathrm{E}+01$ & -- & -- & $1.92 \mathrm{E}+02$ & $1.92 \mathrm{E}+02$ & $1.92 \mathrm{E}+02$ & $1.92 \mathrm{E}+02$ & -- \\
\hline $\mathrm{SO} 4(\mathrm{~kg} / \mathrm{h})^{2}$ & $1.11 \mathrm{E}+01$ & -- & -- & -- & -- & $1.11 \mathrm{E}+01$ & -- & -- & $1.11 \mathrm{E}-02$ & -- & -- & $4.45 \mathrm{E}-02$ & $4.45 \mathrm{E}-02$ & $1.11 \mathrm{E}+01$ & $1.11 \mathrm{E}+01$ & -- \\
\hline Water $(\mathrm{kg} / \mathrm{hr})$ & $1.56 \mathrm{E}+03$ & $1.80 \mathrm{E}+03$ & $1.25 \mathrm{E}+02$ & $1.30 \mathrm{E}+03$ & $5.73 \mathrm{E}+02$ & $1.19 \mathrm{E}+03$ & $1.60 \mathrm{E}+03$ & $6.18 \mathrm{E}+01$ & $6.93 \mathrm{E}+01$ & $1.01 \mathrm{E}+03$ & $4.78 \mathrm{E}+02$ & $3.98 \mathrm{E}+02$ & $7.00 \mathrm{E}+02$ & $4.41 \mathrm{E}+02$ & $6.97 \mathrm{E}+02$ & $3.45 \mathrm{E}+02$ \\
\hline Dissolved Solids (kg $/ \mathrm{h})$ & $1.22 \mathrm{E}+03$ & -- & -- & $2.03 \mathrm{E}+03$ & $7.15 \mathrm{E}+02$ & $7.15 \mathrm{E}+02$ & -- & -- & $1.21 \mathrm{E}+02$ & $1.76 \mathrm{E}+03$ & $5.94 \mathrm{E}+02$ & $6.21 \mathrm{E}+02$ & $6.21 \mathrm{E}+02$ & $5.94 \mathrm{E}+02$ & $5.94 \mathrm{E}+02$ & -- \\
\hline Crystal Solids $(\mathrm{kg} / \mathrm{h})$ & -- & -- & -- & $1.43 \mathrm{E}+03$ & -- & -- & -- & -- & -- & $1.19 \mathrm{E}+03$ & -- & -- & -- & -- & -- & -- \\
\hline Proc. time- $100 \%$ TOE hrs & 2155 & -- & -- & -- & -- & -- & -- & -- & -- & -- & -- & -- & -- & -- & -- & -- \\
\hline Proc. time- $70 \%$ TOE hrs & 3078 & -- & - & - & -- & -- & -- & -- & -- & -- & -- & -- & -- & -- & -- & -- \\
\hline
\end{tabular}

Proc. time-70\% TOE hrs

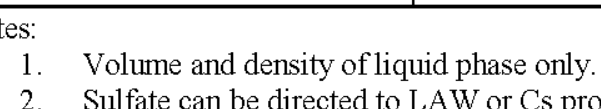

2. Sulfate con be directed to $\mathrm{LAW}$ or $\mathrm{CS}$ product stream as needed to meet product specifications. 
RPP-RPT-37551, Rev. 1

Table 6-26 Fractional Crystallization Mass Balance Summary

\begin{tabular}{|c|c|c|c|c|c|c|c|c|c|c|c|c|c|c|c|c|}
\hline \multicolumn{17}{|c|}{ (8 sheets) } \\
\hline Batch $\#$ & 5 & Tank & 241-AP-105 & & & & & & & & & & & & & \\
\hline Stream Number & 4 & 6 & 7 & 19 & 10 & 20 & 22 & 23 & 9 & 31 & 25 & 13 & 14 & 27 & 29 & 30 \\
\hline Description & $\begin{array}{l}\text { Waste Feed to } \\
1 \text { st Stage } \\
\text { Crystallizer }\end{array}$ & $\begin{array}{c}\text { 1st Stage } \\
\text { Boilup Cond. }\end{array}$ & $\begin{array}{l}\text { 1st Stage } \\
\text { Vacuum } \\
\text { Jet 1 Cond. }\end{array}$ & $\begin{array}{l}\text { 1st Stage } \\
\text { Crystallizer }^{\text {Product }}{ }^{1}\end{array}$ & $\begin{array}{c}\text { 1st Stage } \\
\text { Centrifuge } \\
\text { Wash Liquor }\end{array}$ & $\begin{array}{l}\text { 1st Stage } \\
\text { Dissolver } \\
\text { Slurry }\end{array}$ & $\begin{array}{l}\text { 2nd Stage } \\
\text { Boilup Cond. }\end{array}$ & $\begin{array}{l}\text { 2nd Stage } \\
\text { Vacuum } \\
\text { Jet } 1 \text { Cond. }\end{array}$ & $\begin{array}{l}\text { 2nd Stage } \\
\text { Spent Wash } \\
\text { Recycle }\end{array}$ & $\begin{array}{c}\text { 2nd Stage } \\
\text { Crystallizer } \\
\text { Product }^{1}\end{array}$ & \begin{tabular}{|c|} 
2nd Stage \\
Centrifuge \\
Wash Liquor
\end{tabular} & \begin{tabular}{|l} 
1st Stage \\
Spent Wash \\
Purge
\end{tabular} & $\mid \begin{array}{c}\text { Cs Product to } \\
\text { DST }^{2}\end{array}$ & $\begin{array}{l}\text { LAW } \\
\text { Product }^{2}\end{array}$ & $\begin{array}{l}\text { LAW to } \\
\text { WTP }^{2}\end{array}$ & $\begin{array}{l}\text { Liquid } \\
\text { Effluent to } \\
\text { ETF }\end{array}$ \\
\hline Volume $(\mathrm{L} / \mathrm{h})^{1}$ & $2.05 \mathrm{E}+03$ & $1.85 \mathrm{E}+03$ & $1.25 \mathrm{E}+02$ & $2.24 \mathrm{E}+03$ & $8.95 \mathrm{E}+02$ & $1.49 \mathrm{E}+03$ & $1.66 \mathrm{E}+03$ & $6.18 \mathrm{E}+01$ & $1.43 \mathrm{E}+02$ & $1.79 \mathrm{E}+03$ & $7.25 \mathrm{E}+02$ & $7.15 \mathrm{E}+02$ & $1.11 \mathrm{E}+03$ & $6.91 \mathrm{E}+02$ & $9.26 \mathrm{E}+02$ & $2.68 \mathrm{E}+02$ \\
\hline Volume $(\mathrm{gpm})^{1}$ & $9.01 \mathrm{E}+00$ & $8.15 \mathrm{E}+00$ & $5.51 \mathrm{E}-01$ & $9.88 \mathrm{E}+00$ & $3.94 \mathrm{E}+00$ & $6.57 \mathrm{E}+00$ & $7.32 \mathrm{E}+00$ & $2.72 \mathrm{E}-01$ & $6.30 \mathrm{E}-01$ & $7.86 \mathrm{E}+00$ & $3.19 \mathrm{E}+00$ & $3.15 \mathrm{E}+00$ & $4.90 \mathrm{E}+00$ & $3.04 \mathrm{E}+00$ & $4.08 \mathrm{E}+00$ & $1.18 \mathrm{E}+00$ \\
\hline Liquid Density $(\mathrm{kg} / \mathrm{L})^{1}$ & 1.41 & 1.00 & 1.00 & 1.57 & 1.51 & 1.35 & 1.00 & 1.00 & 1.59 & 1.59 & 1.51 & 1.57 & 1.40 & 1.53 & 1.43 & 1.00 \\
\hline $137 \mathrm{Cs}(\mathrm{Ci} / \mathrm{L})$ & $2.73 \mathrm{E}-01$ & -- & - & -- & -- & $1.72 \mathrm{E}-03$ & -- & -- & $1.77 \mathrm{E}-02$ & -- & -- & $7.79 \mathrm{E}-01$ & $5.02 \mathrm{E}-01$ & $5.42 \mathrm{E}-05$ & $4.04 \mathrm{E}-05$ & -- \\
\hline $\mathrm{Na}(\mathrm{mol} / \mathrm{L})$ & $8.90 \mathrm{E}+00$ & -- & -- & -- & -- & $6.97 \mathrm{E}+00$ & -- & -- & $1.45 \mathrm{E}+01$ & -- & -- & $1.38 \mathrm{E}+01$ & $8.88 \mathrm{E}+00$ & $1.21 \mathrm{E}+01$ & $9.00 \mathrm{E}+00$ & -- \\
\hline $\mathrm{Na}(\mathrm{kg} / \mathrm{h})$ & $4.18 \mathrm{E}+02$ & -- & - & - & -- & $2.39 \mathrm{E}+02$ & - & - & $4.76 \mathrm{E}+01$ & -- & - & $2.27 \mathrm{E}+02$ & $2.27 \mathrm{E}+02$ & $1.92 \mathrm{E}+02$ & $1.92 \mathrm{E}+02$ & -- \\
\hline $\mathrm{SO} 4(\mathrm{~kg} / \mathrm{h})^{2}$ & $1.25 \mathrm{E}+01$ & -- & -- & -- & -- & $1.25 \mathrm{E}+01$ & -- & -- & $1.25 \mathrm{E}-02$ & -- & -- & $5.01 \mathrm{E}-02$ & $5.01 \mathrm{E}-02$ & $1.25 \mathrm{E}+01$ & $1.25 \mathrm{E}+01$ & -- \\
\hline Water $(\mathrm{kg} / \mathrm{hr})$ & $1.60 \mathrm{E}+03$ & $1.85 \mathrm{E}+03$ & $1.25 \mathrm{E}+02$ & $1.37 \mathrm{E}+03$ & $6.04 \mathrm{E}+02$ & $1.26 \mathrm{E}+03$ & $1.66 \mathrm{E}+03$ & $6.18 \mathrm{E}+01$ & $8.30 \mathrm{E}+01$ & $1.04 \mathrm{E}+03$ & $4.90 \mathrm{E}+02$ & $4.38 \mathrm{E}+02$ & $8.34 \mathrm{E}+02$ & $4.51 \mathrm{E}+02$ & $6.86 \mathrm{E}+02$ & $2.68 \mathrm{E}+02$ \\
\hline Dissolved Solids $(\mathrm{kg} / \mathrm{h})$ & $1.29 \mathrm{E}+03$ & -- & -- & $2.14 \mathrm{E}+03$ & $7.53 \mathrm{E}+02$ & $7.53 \mathrm{E}+02$ & -- & -- & $1.44 \mathrm{E}+02$ & $1.80 \mathrm{E}+03$ & $6.08 \mathrm{E}+02$ & $6.82 \mathrm{E}+02$ & $6.82 \mathrm{E}+02$ & $6.08 \mathrm{E}+02$ & $6.08 \mathrm{E}+02$ & -- \\
\hline rystal Solids $(\mathrm{kg} / \mathrm{h})$ & -- & -- & -- & $1.51 \mathrm{E}+03$ & -- & -- & -- & -- & -- & $1.22 \mathrm{E}+03$ & -- & -- & -- & -- & -- & -- \\
\hline cess time@100\% TOE hrs & 1927 & -- & -- & -- & -- & -- & -- & -- & -- & -- & -- & -- & -- & -- & -- & -- \\
\hline ocess time @70\% TOE hrs & 2753 & -- & -- & -- & -- & - & -- & -- & -- & -- & -- & -- & - & -- & -- & -- \\
\hline
\end{tabular}

\begin{tabular}{|c|c|c|c|c|c|c|c|c|c|c|c|c|c|c|c|c|}
\hline Batch \# & 6 & Tank & 241-AP-108 & & & & & & & & & & & & & \\
\hline Stream Number & 4 & 6 & 7 & 19 & 10 & 20 & 22 & 23 & 9 & 31 & 25 & 13 & 14 & 27 & 29 & 30 \\
\hline Description & $\begin{array}{c}\text { Waste Feed to } \\
\text { 1st Stage } \\
\text { Crystallizer }\end{array}$ & $\begin{array}{c}\text { 1st Stage } \\
\text { Boilup } \\
\text { Condensate }\end{array}$ & $\begin{array}{c}\text { 1st Stage } \\
\text { Vacuum } \\
\text { Jet 1 } \\
\text { Condensate }\end{array}$ & $\begin{array}{c}\text { 1st Stage } \\
\text { Crystallizer } \\
\text { Product1 }\end{array}$ & \begin{tabular}{|c|} 
1st Stage \\
Centrifuge \\
Wash Liquor
\end{tabular} & $\begin{array}{l}\text { 1st Stage } \\
\text { Dissolver } \\
\text { Slurry }\end{array}$ & $\begin{array}{c}\text { 2nd Stage } \\
\text { Boilup } \\
\text { Condensate }\end{array}$ & $\begin{array}{c}\text { 2nd Stage } \\
\text { Vacuum } \\
\text { Jet } 1 \\
\text { Condensate }\end{array}$ & $\begin{array}{l}\text { 2nd Stage } \\
\text { Spent Wash } \\
\text { Recycle }\end{array}$ & $\begin{array}{c}\text { 2nd Stage } \\
\text { Crystallizer } \\
\text { Product 1 }\end{array}$ & $\begin{array}{c}\text { 2nd Stage } \\
\text { Centrifuge } \\
\text { Wash Liquor }\end{array}$ & $\begin{array}{c}\text { 1st Stage } \\
\text { Spent Wash } \\
\text { Purge }\end{array}$ & $\begin{array}{c}\text { Cs Product to } \\
\text { DST2 }\end{array} \mid$ & $\begin{array}{c}\text { LAW } \\
\text { Product2 }\end{array}$ & $\begin{array}{l}\text { LAW to } \\
\text { WTP2 }\end{array}$ & $\begin{array}{l}\text { Liquid } \\
\text { Effluent to } \\
\text { ETF }\end{array}$ \\
\hline Volume $(\mathrm{L} / \mathrm{h})^{1}$ & $2.04 \mathrm{E}+03$ & $1.76 \mathrm{E}+03$ & $1.25 \mathrm{E}+02$ & $2.17 \mathrm{E}+03$ & $8.65 \mathrm{E}+02$ & $1.44 \mathrm{E}+03$ & $1.63 \mathrm{E}+03$ & $6.18 \mathrm{E}+01$ & $1.23 \mathrm{E}+02$ & $1.77 \mathrm{E}+03$ & $7.19 \mathrm{E}+02$ & $7.61 \mathrm{E}+02$ & $1.15 \mathrm{E}+03$ & $6.85 \mathrm{E}+02$ & $9.45 \mathrm{E}+02$ & $2.01 \mathrm{E}+02$ \\
\hline Volume $(\mathrm{gpm})^{1}$ & $8.98 \mathrm{E}+00$ & $7.76 \mathrm{E}+00$ & $5.51 \mathrm{E}-01$ & $9.54 \mathrm{E}+00$ & $3.81 \mathrm{E}+00$ & $6.35 \mathrm{E}+00$ & $7.17 \mathrm{E}+00$ & $2.72 \mathrm{E}-01$ & $5.41 \mathrm{E}-01$ & $7.79 \mathrm{E}+00$ & $3.16 \mathrm{E}+00$ & $3.35 \mathrm{E}+00$ & $5.06 \mathrm{E}+00$ & $3.02 \mathrm{E}+00$ & $4.16 \mathrm{E}+00$ & $8.86 \mathrm{E}-01$ \\
\hline Liquid Density $(\mathrm{kg} / \mathrm{L})^{1}$ & 1.42 & 1.00 & 1.00 & 1.57 & 1.51 & 1.35 & 1.00 & 1.00 & 1.59 & 1.59 & 1.51 & 1.57 & 1.41 & 1.53 & 1.42 & 1.00 \\
\hline $137 \mathrm{Cs}(\mathrm{Ci} / \mathrm{L})$ & $2.07 \mathrm{E}-01$ & -- & -- & -- & -- & $1.30 \mathrm{E}-03$ & -- & -- & $1.50 \mathrm{E}-02$ & -- & -- & $5.55 \mathrm{E}-01$ & $3.68 \mathrm{E}-01$ & $4.10 \mathrm{E}-05$ & $2.97 \mathrm{E}-05$ & -- \\
\hline $\mathrm{Na}(\mathrm{mol} / \mathrm{L})$ & $9.02 \mathrm{E}+00$ & -- & -- & -- & -- & $7.00 \mathrm{E}+00$ & -- & -- & $1.43 \mathrm{E}+01$ & -- & -- & $1.32 \mathrm{E}+01$ & $8.75 \mathrm{E}+00$ & $1.22 \mathrm{E}+01$ & $8.82 \mathrm{E}+00$ & -- \\
\hline $\mathrm{Na}(\mathrm{kg} / \mathrm{h})$ & $4.23 \mathrm{E}+02$ & -- & -- & -- & -- & $2.32 \mathrm{E}+02$ & -- & -- & $4.05 \mathrm{E}+01$ & -- & -- & $2.31 \mathrm{E}+02$ & $2.31 \mathrm{E}+02$ & $1.92 \mathrm{E}+02$ & $1.92 \mathrm{E}+02$ & -- \\
\hline $\mathrm{SO} 4(\mathrm{~kg} / \mathrm{h})^{2}$ & $9.63 \mathrm{E}+00$ & -- & -- & -- & -- & $9.59 \mathrm{E}+00$ & -- & -- & $9.58 \mathrm{E}-03$ & -- & -- & $4.81 \mathrm{E}-02$ & $4.81 \mathrm{E}-02$ & $9.58 \mathrm{E}+00$ & $9.58 \mathrm{E}+00$ & -- \\
\hline Water $(\mathrm{kg} / \mathrm{hr})$ & $1.57 \mathrm{E}+03$ & $1.76 \mathrm{E}+03$ & $1.25 \mathrm{E}+02$ & $1.33 \mathrm{E}+03$ & $5.83 \mathrm{E}+02$ & $1.21 \mathrm{E}+03$ & $1.63 \mathrm{E}+03$ & $6.18 \mathrm{E}+01$ & $7.13 \mathrm{E}+01$ & $1.03 \mathrm{E}+03$ & $4.85 \mathrm{E}+02$ & $4.66 \mathrm{E}+02$ & $8.53 \mathrm{E}+02$ & $4.47 \mathrm{E}+02$ & $7.08 \mathrm{E}+02$ & $2.01 \mathrm{E}+02$ \\
\hline Dissolved Solids (kg/h) & $1.33 \mathrm{E}+03$ & -- & -- & $2.07 \mathrm{E}+03$ & $7.27 \mathrm{E}+02$ & $7.27 \mathrm{E}+02$ & -- & -- & $1.24 \mathrm{E}+02$ & $1.79 \mathrm{E}+03$ & $6.03 \mathrm{E}+02$ & $7.26 \mathrm{E}+02$ & $7.26 \mathrm{E}+02$ & $6.03 \mathrm{E}+02$ & $6.03 \mathrm{E}+02$ & -- \\
\hline Crystal Solids $(\mathrm{kg} / \mathrm{h})$ & -- & -- & -- & $1.45 \mathrm{E}+03$ & -- & -- & -- & -- & -- & $1.21 \mathrm{E}+03$ & -- & -- & -- & -- & -- & -- \\
\hline Process time@100\% TOE hrs & 2127 & -- & -- & -- & -- & -- & -- & -- & -- & -- & -- & -- & -- & -- & -- & -- \\
\hline Process time $@ 70 \%$ TOE hrs & 3038 & -- & -- & -- & -- & -- & -- & -- & -- & -- & -- & -- & -- & -- & -- & -- \\
\hline
\end{tabular}

Process time@ $@ 70^{\circ}$ TOE

1. Volume and density of liquid phase only.

1. Volume and density of liquid phase only.
2. Sulfate can be directed to LAW or Cs product stream as needed to meet product specifications 
Table 6-26 Fractional Crystallization Mass Balance Summary

\begin{tabular}{|c|c|c|c|c|c|c|c|c|c|c|c|c|c|c|c|c|}
\hline \multicolumn{17}{|c|}{ (8 sheets) } \\
\hline Batch \# & 7 & Tank & 241-AP-107 & & & & & & & & & & & & & \\
\hline Stream Number & 4 & 6 & 7 & 19 & 10 & 20 & 22 & 23 & 9 & 31 & 25 & 13 & 14 & 27 & 29 & 30 \\
\hline Description & $\begin{array}{l}\text { Waste Feed to } \\
1 \text { st Stage } \\
\text { Crystallizer }\end{array}$ & $\begin{array}{c}\text { 1st Stage } \\
\text { Boilup Cond. }\end{array}$ & $\begin{array}{l}\text { 1st Stage } \\
\text { Vacuum } \\
\text { Jet } 1 \text { Cond. }\end{array}$ & $\begin{array}{l}\text { 1st Stage } \\
\text { Crystallizer } \\
\text { Product }^{1}\end{array}$ & $\begin{array}{c}\text { 1st Stage } \\
\text { Centrifuge } \\
\text { Wash Liquor }\end{array}$ & $\begin{array}{c}\text { 1st Stage } \\
\text { Dissolver } \\
\text { Slurry }\end{array}$ & $\begin{array}{l}\text { 2nd Stage } \\
\text { Boilup Cond. }\end{array}$ & $\begin{array}{l}\text { 2nd Stage } \\
\text { Vacuum } \\
\text { Jet } 1 \text { Cond. }\end{array}$ & $\begin{array}{l}\text { 2nd Stage } \\
\text { Spent Wash } \\
\text { Recycle }\end{array}$ & $\begin{array}{l}\text { 2nd Stage } \\
\text { Crystallizer }^{\text {Product }}{ }^{1}\end{array}$ & $\begin{array}{c}\text { 2nd Stage } \\
\text { Centrifuge } \\
\text { Wash Liquor }\end{array}$ & $\begin{array}{l}\text { 1st Stage } \\
\text { Spent Wash } \\
\text { Purge }\end{array}$ & $\begin{array}{c}\text { Cs Product to } \\
\mathrm{DST}^{2}\end{array}$ & $\begin{array}{l}\text { LAW } \\
\text { Product }^{2}\end{array}$ & $\begin{array}{l}\text { LAW to } \\
\text { WTP }^{2}\end{array}$ & $\begin{array}{l}\text { Liquid } \\
\text { Effluent to } \\
\text { ETF }\end{array}$ \\
\hline Volume $(\mathrm{L} / \mathrm{h})^{1}$ & $1.71 \mathrm{E}+03$ & $1.78 \mathrm{E}+03$ & $25 \mathrm{E}+02$ & $2.07 \mathrm{E}+03$ & $8.25 \mathrm{E}+02$ & $1.38 \mathrm{E}+03$ & $1.60 \mathrm{E}+03$ & $6.18 \mathrm{E}+01$ & $8.07 \mathrm{E}+01$ & $1.80 \mathrm{E}+03$ & $7.30 \mathrm{E}+02$ & $3.67 \mathrm{E}+02$ & $5.79 \mathrm{E}+02$ & $6.96 \mathrm{E}+02$ & $9.60 \mathrm{E}+02$ & $4.31 \mathrm{E}+02$ \\
\hline Volume $(\mathrm{gpm})^{1}$ & $7.55 \mathrm{E}+00$ & $7.83 \mathrm{E}+00$ & $5.51 \mathrm{E}-01$ & $9.10 \mathrm{E}+00$ & $3.63 \mathrm{E}+00$ & $6.06 \mathrm{E}+00$ & $7.06 \mathrm{E}+00$ & $2.72 \mathrm{E}-01$ & $3.55 \mathrm{E}-01$ & $7.91 \mathrm{E}+00$ & $3.21 \mathrm{E}+00$ & $1.62 \mathrm{E}+00$ & $2.55 \mathrm{E}+00$ & $3.06 \mathrm{E}+00$ & $4.23 \mathrm{E}+00$ & $1.90 \mathrm{E}+00$ \\
\hline Liquid Density $(\mathrm{kg} / \mathrm{L})^{1}$ & 1.38 & 1.00 & 1.00 & 1.57 & 1.51 & 1.35 & 1.00 & 1.00 & 1.59 & 1.59 & 1.51 & 1.57 & 1.40 & 1.53 & 1.42 & 1.00 \\
\hline $137 \mathrm{Cs}(\mathrm{Ci} / \mathrm{L})$ & $6.30 \mathrm{E}-01$ & -- & -- & -- & -- & $4.45 \mathrm{E}-03$ & -- & - & $7.46 \mathrm{E}-02$ & -- & -- & $2.94 \mathrm{E}+00$ & $1.87 \mathrm{E}+00$ & $1.41 \mathrm{E}-04$ & $1.02 \mathrm{E}-04$ & -- \\
\hline $\mathrm{Na}(\mathrm{mol} / \mathrm{L})$ & $7.86 \mathrm{E}+00$ & -- & -- & -- & -- & $6.88 \mathrm{E}+00$ & -- & -- & $1.39 \mathrm{E}+01$ & -- & -- & $1.40 \mathrm{E}+01$ & $8.87 \mathrm{E}+00$ & $1.20 \mathrm{E}+01$ & $8.68 \mathrm{E}+00$ & -- \\
\hline $\mathrm{Na}(\mathrm{kg} / \mathrm{h})$ & $3.10 \mathrm{E}+02$ & -- & -- & -- & -- & $2.17 \mathrm{E}+02$ & -- & -- & $2.58 \mathrm{E}+01$ & -- & -- & $1.18 \mathrm{E}+02$ & $1.18 \mathrm{E}+02$ & $1.92 \mathrm{E}+02$ & $1.92 \mathrm{E}+02$ & -- \\
\hline $\mathrm{SO} 4(\mathrm{~kg} / \mathrm{h})^{2}$ & $2.59 \mathrm{E}+01$ & -- & -- & -- & -- & $2.58 \mathrm{E}+01$ & -- & -- & $2.58 \mathrm{E}-02$ & -- & -- & $1.04 \mathrm{E}-01$ & $1.04 \mathrm{E}-01$ & $2.58 \mathrm{E}+01$ & $2.58 \mathrm{E}+01$ & -- \\
\hline Water $(\mathrm{kg} / \mathrm{hr})$ & $1.40 \mathrm{E}+03$ & $1.78 \mathrm{E}+03$ & $1.25 \mathrm{E}+02$ & $1.26 \mathrm{E}+03$ & $5.56 \mathrm{E}+02$ & $1.16 \mathrm{E}+03$ & $1.60 \mathrm{E}+03$ & $6.18 \mathrm{E}+01$ & $4.68 \mathrm{E}+01$ & $1.04 \mathrm{E}+03$ & $4.93 \mathrm{E}+02$ & $2.25 \mathrm{E}+02$ & $4.37 \mathrm{E}+02$ & $4.54 \mathrm{E}+02$ & $7.19 \mathrm{E}+02$ & $4.31 \mathrm{E}+02$ \\
\hline Dissolved Solids $(\mathrm{kg} / \mathrm{h})$ & $9.62 \mathrm{E}+02$ & -- & -- & $1.97 \mathrm{E}+03$ & $6.94 \mathrm{E}+02$ & $6.94 \mathrm{E}+02$ & -- & -- & $8.15 \mathrm{E}+01$ & $1.81 \mathrm{E}+03$ & $6.12 \mathrm{E}+02$ & $3.50 \mathrm{E}+02$ & $3.50 \mathrm{E}+02$ & $6.12 \mathrm{E}+02$ & $6.12 \mathrm{E}+02$ & -- \\
\hline $\begin{array}{l}\text { Crystal Solids }(\mathrm{kg} / \mathrm{h}) \\
\end{array}$ & - & -- & -- & $1.39 \mathrm{E}+03$ & -- & -- & -- & - & -- & $1.22 \mathrm{E}+03$ & -- & -- & -- & -- & -- & -- \\
\hline ocess time $@ 100 \%$ TOE hrs & 25 & -- & -- & -- & -- & -- & -- & -- & -- & -- & -- & -- & -- & -- & -- & -- \\
\hline ocess time@70\% TOE hrs & 3597 & -- & -- & -- & - & - & -- & - & - & - & -- & -- & -- & -- & -- & -- \\
\hline
\end{tabular}

\begin{tabular}{|c|c|c|c|c|c|c|c|c|c|c|c|c|c|c|c|c|}
\hline Batch \# & 8 & Tank & 241-AN-104 & & & & & & & & & & & & & \\
\hline Stream Number & 4 & 6 & 7 & 19 & 10 & 20 & 22 & 23 & 9 & 31 & 25 & 13 & 14 & 27 & 29 & 30 \\
\hline Description & $\begin{array}{c}\text { Waste Feed to } \\
1 \text { st Stage } \\
\text { Crystallizer }\end{array}$ & \begin{tabular}{|c} 
1st Stage \\
Boilup \\
Condensate
\end{tabular} & $\begin{array}{c}\text { 1st Stage } \\
\text { Vacuum } \\
\text { Jet } 1 \\
\text { Condensate }\end{array}$ & $\begin{array}{c}\text { 1st Stage } \\
\text { Crystallizer } \\
\text { Product1 }\end{array}$ & $\begin{array}{c}\text { 1st Stage } \\
\text { Centrifuge } \\
\text { Wash Liquor }\end{array}$ & $\begin{array}{c}\text { 1st Stage } \\
\text { Dissolver } \\
\text { Slurry }\end{array}$ & $\begin{array}{l}\text { 2nd Stage } \\
\text { Boilup } \\
\text { Condensate }\end{array}$ & $\begin{array}{l}\text { 2nd Stage } \\
\text { Vacuum } \\
\text { Jet } 1 \\
\text { Condensate }\end{array}$ & $\begin{array}{l}\text { 2nd Stage } \\
\text { Spent Wash } \\
\text { Recycle }\end{array}$ & $\begin{array}{l}\text { 2nd Stage } \\
\text { Crystallizer } \\
\text { Productl }\end{array}$ & $\begin{array}{c}\text { 2nd Stage } \\
\text { Centrifuge } \\
\text { Wash Liquor }\end{array}$ & $\begin{array}{l}\text { 1st Stage } \\
\text { Spent Wash } \\
\text { Purge }\end{array}$ & $\begin{array}{c}\text { Cs Product to } \\
\text { DST2 }\end{array}$ & $\begin{array}{c}\text { LAW } \\
\text { Product2 }\end{array}$ & $\begin{array}{l}\text { LAW to } \\
\text { WTP2 }\end{array}$ & $\begin{array}{c}\text { Liquid } \\
\text { Effluent to } \\
\text { ETF }\end{array}$ \\
\hline Volume $(\mathrm{L} / \mathrm{h})^{1}$ & $3.92 \mathrm{E}+03$ & $3.44 \mathrm{E}+03$ & $1.25 \mathrm{E}+02$ & $2.10 \mathrm{E}+03$ & $8.38 \mathrm{E}+02$ & $1.40 \mathrm{E}+03$ & $1.57 \mathrm{E}+03$ & $6.18 \mathrm{E}+01$ & $1.26 \mathrm{E}+02$ & $1.69 \mathrm{E}+03$ & $6.88 \mathrm{E}+02$ & $1.08 \mathrm{E}+03$ & $1.73 \mathrm{E}+03$ & $6.56 \mathrm{E}+02$ & $9.32 \mathrm{E}+02$ & $1.63 \mathrm{E}+03$ \\
\hline${\text { Volume }(\mathrm{gpm})^{1}}^{1}$ & $1.73 \mathrm{E}+01$ & $1.51 \mathrm{E}+01$ & $5.51 \mathrm{E}-01$ & $9.24 \mathrm{E}+00$ & $3.69 \mathrm{E}+00$ & $6.15 \mathrm{E}+00$ & $6.90 \mathrm{E}+00$ & $2.72 \mathrm{E}-01$ & $5.57 \mathrm{E}-01$ & $7.45 \mathrm{E}+00$ & $3.03 \mathrm{E}+00$ & $4.75 \mathrm{E}+00$ & $7.62 \mathrm{E}+00$ & $2.89 \mathrm{E}+00$ & $4.11 \mathrm{E}+00$ & $7.18 \mathrm{E}+00$ \\
\hline Liquid Density $(\mathrm{kg} / \mathrm{L})^{1}$ & 1.29 & 1.00 & 1.00 & 1.57 & 1.51 & 1.35 & 1.00 & 1.00 & 1.59 & 1.59 & 1.51 & 1.57 & 1.40 & 1.53 & 1.41 & 1.00 \\
\hline $137 \mathrm{Cs}(\mathrm{Ci} / \mathrm{L})$ & $1.89 \mathrm{E}-01$ & -- & -- & -- & -- & $1.85 \mathrm{E}-03$ & -- & -- & $2.01 \mathrm{E}-02$ & -- & -- & $6.86 \mathrm{E}-01$ & $4.28 \mathrm{E}-01$ & $5.87 \mathrm{E}-05$ & $4.13 \mathrm{E}-05$ & -- \\
\hline $\mathrm{Na}(\mathrm{mol} / \mathrm{L})$ & $6.00 \mathrm{E}+00$ & -- & -- & -- & -- & $7.28 \mathrm{E}+00$ & -- & -- & $1.45 \mathrm{E}+01$ & -- & -- & $1.41 \mathrm{E}+01$ & $8.78 \mathrm{E}+00$ & $1.27 \mathrm{E}+01$ & $8.94 \mathrm{E}+00$ & -- \\
\hline $\mathrm{Na}(\mathrm{kg} / \mathrm{h})$ & $5.41 \mathrm{E}+02$ & -- & -- & -- & -- & $2.34 \mathrm{E}+02$ & -- & -- & $4.22 \mathrm{E}+01$ & -- & -- & $3.49 \mathrm{E}+02$ & $3.49 \mathrm{E}+02$ & $1.92 \mathrm{E}+02$ & $1.92 \mathrm{E}+02$ & -- \\
\hline $\mathrm{SO} 4(\mathrm{~kg} / \mathrm{h})^{2}$ & $1.73 \mathrm{E}+01$ & -- & -- & -- & -- & $1.71 \mathrm{E}+01$ & -- & -- & $1.71 \mathrm{E}-02$ & -- & -- & $2.25 \mathrm{E}-01$ & $2.25 \mathrm{E}-01$ & $1.71 \mathrm{E}+01$ & $1.71 \mathrm{E}+01$ & -- \\
\hline Water $(\mathrm{kg} / \mathrm{hr})$ & $3.46 \mathrm{E}+03$ & $3.44 \mathrm{E}+03$ & $1.25 \mathrm{E}+02$ & $1.28 \mathrm{E}+03$ & $5.65 \mathrm{E}+02$ & $1.18 \mathrm{E}+03$ & $1.57 \mathrm{E}+03$ & $6.18 \mathrm{E}+01$ & $7.34 \mathrm{E}+01$ & $9.82 \mathrm{E}+02$ & $4.64 \mathrm{E}+02$ & $6.60 \mathrm{E}+02$ & $1.31 \mathrm{E}+03$ & $4.28 \mathrm{E}+02$ & $7.05 \mathrm{E}+02$ & $1.63 \mathrm{E}+03$ \\
\hline Dissolved Solids $(\mathrm{kg} / \mathrm{h})$ & $1.61 \mathrm{E}+03$ & -- & -- & $2.00 \mathrm{E}+03$ & $7.04 \mathrm{E}+02$ & $7.04 \mathrm{E}+02$ & -- & -- & $1.28 \mathrm{E}+02$ & $1.71 \mathrm{E}+03$ & $5.77 \mathrm{E}+02$ & $1.03 \mathrm{E}+03$ & $1.03 \mathrm{E}+03$ & $5.77 \mathrm{E}+02$ & $5.77 \mathrm{E}+02$ & -- \\
\hline Crystal Solids $(\mathrm{kg} / \mathrm{h})$ & -- & -- & -- & $1.41 \mathrm{E}+03$ & -- & -- & -- & -- & -- & $1.15 \mathrm{E}+03$ & - & -- & -- & -- & -- & -- \\
\hline Process time@100\% TOE hrs & 1410 & -- & -- & -- & -- & -- & -- & -- & -- & -- & - & -- & -- & -- & -- & -- \\
\hline Process time@70\% TOE hrs & 2015 & -- & -- & -- & -- & -- & -- & -- & -- & -- & -- & -- & -- & -- & -- & -- \\
\hline
\end{tabular}

Notes:
1.

1. Volume and density of liquid phase only.
2. Sulfate can be directed to LAW or Cs pro 
Table 6-26 Fractional Crystallization Mass Balance Summary

\begin{tabular}{|c|c|c|c|c|c|c|c|c|c|c|c|c|c|c|c|c|}
\hline \multicolumn{17}{|c|}{ ( 8 sheets) } \\
\hline Batch \# & 9 & Tank & 241-AN-105 & & & & & & & & & & & & & \\
\hline Stream Number & 4 & 6 & 7 & 19 & 10 & 20 & 22 & 23 & 9 & 31 & 25 & 13 & 14 & 27 & 29 & 30 \\
\hline Description & $\begin{array}{c}\text { Waste Feed to } \\
\text { 1st Stage } \\
\text { Crystallizer }\end{array}$ & $\begin{array}{c}\text { 1st Stage } \\
\text { Boilup Cond. }\end{array}$ & $\begin{array}{l}\text { 1st Stage } \\
\text { Vacuum } \\
\text { Jet } 1 \text { Cond. }\end{array}$ & $\begin{array}{l}\text { 1st Stage } \\
\text { Crystallizer } \\
\text { Product }^{1}\end{array}$ & $\begin{array}{c}\text { 1st Stage } \\
\text { Centrifuge } \\
\text { Wash Liquor }\end{array}$ & $\begin{array}{l}\text { 1st Stage } \\
\text { Dissolver } \\
\text { Slurry }\end{array}$ & $\begin{array}{c}\text { 2nd Stage } \\
\text { Boilup Cond. }\end{array}$ & $\begin{array}{l}\text { 2nd Stage } \\
\text { Vacuum } \\
\text { Jet } 1 \text { Cond. }\end{array}$ & $\begin{array}{l}\text { 2nd Stage } \\
\text { Spent Wash } \\
\text { Recycle }\end{array}$ & $\begin{array}{l}\text { 2nd Stage } \\
\text { Crystallizer } \\
\text { Product }^{1}\end{array}$ & $\begin{array}{c}\text { 2nd Stage } \\
\text { Centrifuge } \\
\text { Wash Liquor }\end{array}$ & $\begin{array}{l}\text { 1st Stage } \\
\text { Spent Wash } \\
\text { Purge }\end{array}$ & $\begin{array}{c}\text { Cs Product to } \\
\text { DST }^{2}\end{array}$ & $\begin{array}{l}\text { LAW } \\
\text { Product }^{2}\end{array}$ & $\begin{array}{l}\text { LAW to } \\
\text { WTP }^{2}\end{array}$ & $\begin{array}{l}\text { Liquid } \\
\text { Effluent to } \\
\text { ETF }\end{array}$ \\
\hline Volume $(\mathrm{L} / \mathrm{h})^{1}$ & $3.63 \mathrm{E}+03$ & $3.21 \mathrm{E}+03$ & $1.25 \mathrm{E}+02$ & $2.05 \mathrm{E}+03$ & $8.19 \mathrm{E}+02$ & $1.36 \mathrm{E}+03$ & $1.53 \mathrm{E}+03$ & $6.18 \mathrm{E}+01$ & $1.25 \mathrm{E}+02$ & $1.65 \mathrm{E}+03$ & $6.70 \mathrm{E}+02$ & $9.98 \mathrm{E}+02$ & $1.50 \mathrm{E}+03$ & $6.39 \mathrm{E}+02$ & $9.37 \mathrm{E}+02$ & $1.55 \mathrm{E}+03$ \\
\hline Volume $(\mathrm{gpm})^{1}$ & $1.60 \mathrm{E}+01$ & $1.41 \mathrm{E}+01$ & $5.51 \mathrm{E}-01$ & $9.03 \mathrm{E}+00$ & $3.60 \mathrm{E}+00$ & $6.01 \mathrm{E}+00$ & $6.73 \mathrm{E}+00$ & $2.72 \mathrm{E}-01$ & $5.50 \mathrm{E}-01$ & $7.26 \mathrm{E}+00$ & $2.95 \mathrm{E}+00$ & $4.39 \mathrm{E}+00$ & $6.63 \mathrm{E}+00$ & $2.81 \mathrm{E}+00$ & $4.13 \mathrm{E}+00$ & $6.83 \mathrm{E}+00$ \\
\hline Liquid Density $(\mathrm{kg} / \mathrm{L})^{1}$ & 1.30 & 1.00 & 1.00 & 1.57 & 1.51 & 1.35 & 1.00 & 1.00 & 1.59 & 1.59 & 1.51 & 1.57 & 1.41 & 1.53 & 1.40 & 1.00 \\
\hline $137 \mathrm{Cs}(\mathrm{Ci} / \mathrm{L})$ & $1.85 \mathrm{E}-01$ & & & & & $1.85 \mathrm{E}-03$ & & & $1.99 \mathrm{E}-02$ & & & $6.73 \mathrm{E}-01$ & $4.47 \mathrm{E}-01$ & $5.89 \mathrm{E}-05$ & $4.02 \mathrm{E}-05$ & \\
\hline$\overline{\mathrm{Na}(\mathrm{mol} / \mathrm{L})}$ & $6.00 \mathrm{E}+00$ & & & & & $7.45 \mathrm{E}+00$ & & & $1.46 \mathrm{E}+01$ & & & $1.35 \mathrm{E}+01$ & $8.96 \mathrm{E}+00$ & $1.30 \mathrm{E}+01$ & $8.90 \mathrm{E}+00$ & \\
\hline $\mathrm{Na}(\mathrm{kg} / \mathrm{h})$ & $5.01 \mathrm{E}+02$ & & & & & $2.34 \mathrm{E}+02$ & & & $4.20 \mathrm{E}+01$ & & & $3.10 \mathrm{E}+02$ & $3.10 \mathrm{E}+02$ & $1.92 \mathrm{E}+02$ & $1.92 \mathrm{E}+02$ & \\
\hline $\mathrm{SO} 4(\mathrm{~kg} / \mathrm{h})^{2}$ & $1.27 \mathrm{E}+01$ & & & & & $1.25 \mathrm{E}+01$ & & & $1.25 \mathrm{E}-02$ & & & $1.65 \mathrm{E}-01$ & $1.65 \mathrm{E}-01$ & $1.25 \mathrm{E}+01$ & $1.25 \mathrm{E}+01$ & \\
\hline Water $(\mathrm{kg} / \mathrm{hr})$ & $3.20 \mathrm{E}+03$ & $3.21 \mathrm{E}+03$ & $1.25 \mathrm{E}+02$ & $1.25 \mathrm{E}+03$ & $5.52 \mathrm{E}+02$ & $1.15 \mathrm{E}+03$ & $1.53 \mathrm{E}+03$ & $6.18 \mathrm{E}+01$ & $7.25 \mathrm{E}+01$ & $9.57 \mathrm{E}+02$ & $4.52 \mathrm{E}+02$ & $6.11 \mathrm{E}+02$ & $1.12 \mathrm{E}+03$ & $4.17 \mathrm{E}+02$ & $7.15 \mathrm{E}+02$ & $1.55 \mathrm{E}+03$ \\
\hline Dissolved Solids (kg/h) & $1.51 \mathrm{E}+03$ & & & $1.96 \mathrm{E}+03$ & $6.88 \mathrm{E}+02$ & $6.88 \mathrm{E}+02$ & & & $1.26 \mathrm{E}+02$ & $1.67 \mathrm{E}+03$ & $5.62 \mathrm{E}+02$ & $9.52 \mathrm{E}+02$ & $9.52 \mathrm{E}+02$ & $5.62 \mathrm{E}+02$ & $5.62 \mathrm{E}+02$ & \\
\hline Crystal Solids $(\mathrm{kg} / \mathrm{h})$ & & & & $1.38 \mathrm{E}+03$ & & & & & & $1.12 \mathrm{E}+03$ & & & & & & \\
\hline Process time@100\% TOE hrs & 1,646 & -- & -- & -- & -- & -- & -- & -- & -- & -- & -- & -- & -- & -- & -- & -- \\
\hline Process time@ $@ 70 \%$ TOE hrs & 2,352 & -- & -- & -- & -- & -- & -- & -- & -- & -- & -- & -- & -- & -- & -- & -- \\
\hline
\end{tabular}

\begin{tabular}{|c|c|c|c|c|c|c|c|c|c|c|c|c|c|c|c|c|}
\hline Batch \# & 10 & Tank & 241-AN-103 & & & & & & & & & & & & & \\
\hline Stream Number & 4 & 6 & 7 & 19 & 10 & 20 & 22 & 23 & 9 & 31 & 25 & 13 & 14 & 27 & 29 & 30 \\
\hline Description & $\begin{array}{c}\text { Waste Feed to } \\
1 \text { st Stage } \\
\text { Crystallizer }\end{array}$ & $\begin{array}{c}\text { 1st Stage } \\
\text { Boilup } \\
\text { Condensate }\end{array}$ & \begin{tabular}{|c} 
1st Stage \\
Vacuum \\
Jet 1 \\
Condensate
\end{tabular} & $\begin{array}{l}\text { 1st Stage } \\
\text { Crystallizer } \\
\text { Product1 }\end{array}$ & $\begin{array}{c}\text { 1st Stage } \\
\text { Centrifuge } \\
\text { Wash Liquor }\end{array}$ & $\begin{array}{l}\text { 1st Stage } \\
\text { Dissolver } \\
\text { Slurry }\end{array}$ & $\begin{array}{l}\text { 2nd Stage } \\
\text { Boilup } \\
\text { Condensate }\end{array}$ & $\begin{array}{l}\text { 2nd Stage } \\
\text { Vacuum } \\
\text { Jet } 1 \\
\text { Condensate }\end{array}$ & $\begin{array}{l}\text { 2nd Stage } \\
\text { Spent Wash } \\
\text { Recycle }\end{array}$ & $\begin{array}{l}\text { 2nd Stage } \\
\text { Crystallizer } \\
\text { Productl }\end{array}$ & $\begin{array}{c}\text { 2nd Stage } \\
\text { Centrifuge } \\
\text { Wash Liquor }\end{array}$ & $\begin{array}{l}\text { 1st Stage } \\
\text { Spent Wash } \\
\text { Purge }\end{array}$ & $\begin{array}{c}\text { Cs Product to } \\
\text { DST2 }\end{array}$ & $\begin{array}{c}\text { LAW } \\
\text { Product2 }\end{array}$ & $\begin{array}{l}\text { LAW to } \\
\text { WTP2 }\end{array}$ & $\begin{array}{l}\text { Liquid } \\
\text { Effluent to } \\
\text { ETF }\end{array}$ \\
\hline \begin{tabular}{|l} 
Volume $(\mathrm{L} / \mathrm{h})^{1}$ \\
\end{tabular} & $4.65 \mathrm{E}+03$ & $3.78 \mathrm{E}+03$ & $1.25 \mathrm{E}+02$ & $2.26 \mathrm{E}+03$ & $9.02 \mathrm{E}+02$ & $1.50 \mathrm{E}+03$ & $1.66 \mathrm{E}+03$ & $6.18 \mathrm{E}+01$ & $1.57 \mathrm{E}+02$ & $1.76 \mathrm{E}+03$ & $7.15 \mathrm{E}+02$ & $1.55 \mathrm{E}+03$ & $2.20 \mathrm{E}+03$ & $6.82 \mathrm{E}+02$ & $9.41 \mathrm{E}+02$ & $1.91 \mathrm{E}+03$ \\
\hline Volume $(\mathrm{gmm})^{1}$ & $2.05 \mathrm{E}+01$ & $1.67 \mathrm{E}+01$ & $5.51 \mathrm{E}-01$ & $9.95 \mathrm{E}+00$ & $3.97 \mathrm{E}+00$ & $6.62 \mathrm{E}+00$ & $7.30 \mathrm{E}+00$ & $2.72 \mathrm{E}-01$ & $6.93 \mathrm{E}-01$ & $7.75 \mathrm{E}+00$ & $3.15 \mathrm{E}+00$ & $6.81 \mathrm{E}+00$ & $9.68 \mathrm{E}+00$ & $3.00 \mathrm{E}+00$ & $4.14 \mathrm{E}+00$ & $8.43 \mathrm{E}+00$ \\
\hline Liquid Density $(\mathrm{kg} / \mathrm{L})^{1}$ & 1.31 & 1.00 & 1.00 & 1.57 & 1.51 & 1.35 & 1.00 & 1.00 & 1.59 & 1.59 & 1.51 & 1.57 & 1.43 & 1.53 & 1.42 & 1.00 \\
\hline $137 \mathrm{Cs}(\mathrm{Ci} / \mathrm{L})$ & $2.12 \mathrm{E}-01$ & & & & & $2.01 \mathrm{E}-03$ & & & $1.89 \mathrm{E}-02$ & & & $6.37 \mathrm{E}-01$ & $4.48 \mathrm{E}-01$ & $6.33 \mathrm{E}-05$ & $4.59 \mathrm{E}-05$ & \\
\hline $\mathrm{Na}(\mathrm{mol} / \mathrm{L})$ & $6.00 \mathrm{E}+00$ & & & & & $7.05 \mathrm{E}+00$ & & & $1.44 \mathrm{E}+01$ & & & $1.26 \mathrm{E}+01$ & $8.90 \mathrm{E}+00$ & $1.22 \mathrm{E}+01$ & $8.86 \mathrm{E}+00$ & \\
\hline $\mathrm{Na}(\mathrm{kg} / \mathrm{h})$ & $6.41 \mathrm{E}+02$ & & & & & $2.44 \mathrm{E}+02$ & & & $5.21 \mathrm{E}+01$ & & & $4.49 \mathrm{E}+02$ & $4.49 \mathrm{E}+02$ & $1.92 \mathrm{E}+02$ & $1.92 \mathrm{E}+02$ & \\
\hline $\mathrm{SO} 4(\mathrm{~kg} / \mathrm{h})^{2}$ & $7.21 \mathrm{E}+00$ & & & & & $7.12 \mathrm{E}+00$ & & & $7.12 \mathrm{E}-03$ & & & $9.37 \mathrm{E}-02$ & $9.37 \mathrm{E}-02$ & $7.12 \mathrm{E}+00$ & $7.12 \mathrm{E}+00$ & \\
\hline Water $(\mathrm{kg} / \mathrm{hr})$ & $4.03 \mathrm{E}+03$ & $3.78 \mathrm{E}+03$ & $1.25 \mathrm{E}+02$ & $1.38 \mathrm{E}+03$ & $6.08 \mathrm{E}+02$ & $1.27 \mathrm{E}+03$ & $1.66 \mathrm{E}+03$ & $6.18 \mathrm{E}+01$ & $9.13 \mathrm{E}+01$ & $1.02 \mathrm{E}+03$ & $4.83 \mathrm{E}+02$ & $9.46 \mathrm{E}+02$ & $1.60 \mathrm{E}+03$ & $4.45 \mathrm{E}+02$ & $7.04 \mathrm{E}+02$ & $1.91 \mathrm{E}+03$ \\
\hline Dissolved Solids $(\mathrm{kg} / \mathrm{h})$ & $2.07 \mathrm{E}+03$ & & & $2.16 \mathrm{E}+03$ & $7.58 \mathrm{E}+02$ & $7.58 \mathrm{E}+02$ & & & $1.59 \mathrm{E}+02$ & $1.78 \mathrm{E}+03$ & $6.00 \mathrm{E}+02$ & $1.47 \mathrm{E}+03$ & $1.47 \mathrm{E}+03$ & $6.00 \mathrm{E}+02$ & $6.00 \mathrm{E}+02$ & \\
\hline Crystal Solids $(\mathrm{kg} / \mathrm{h})$ & & & & $1.52 \mathrm{E}+03$ & & & & & & $1.20 \mathrm{E}+03$ & & & & & & \\
\hline Process time@100\% TOE hrs & 1,661 & -- & -- & -- & -- & -- & -- & -- & -- & -- & -- & -- & -- & -- & -- & -- \\
\hline Process time@70\% TOE hrs & 2,372 & -- & -- & -- & -- & -- & -- & -- & -- & -- & -- & -- & -- & -- & -- & -- \\
\hline
\end{tabular}

Notes:

1. Volume and density of liquid phase only.
2. Sulfate can be directed to LAW or Cs prod 
Table 6-26 Fractional Crystallization Mass Balance Summary

\begin{tabular}{|c|c|c|c|c|c|c|c|c|c|c|c|c|c|c|c|c|}
\hline \multicolumn{17}{|c|}{ (8 sheets) } \\
\hline Batch \# & 11 & Tank & 241-AW-101 & & & & & & & & & & & & & \\
\hline Stream Number & 4 & 6 & 7 & 19 & 10 & 20 & 22 & 23 & 9 & 31 & 25 & 13 & 14 & 27 & 29 & 30 \\
\hline Description & $\begin{array}{l}\text { Waste Feed to } \\
1 \text { st Stage } \\
\text { Crystallizer }\end{array}$ & $\begin{array}{c}\text { 1st Stage } \\
\text { Boilup Cond. }\end{array}$ & $\begin{array}{l}\text { 1st Stage } \\
\text { Vacuum } \\
\text { Jet } 1 \text { Cond. }\end{array}$ & $\begin{array}{l}\text { 1st Stage } \\
\text { Crystallizer } \\
\text { Product }^{1}\end{array}$ & $\begin{array}{c}\text { 1st Stage } \\
\text { Centrifuge } \\
\text { Wash Liquor }\end{array}$ & $\begin{array}{c}\text { 1st Stage } \\
\text { Dissolver } \\
\text { Slurry }\end{array}$ & $\begin{array}{c}\text { 2nd Stage } \\
\text { Boilup Cond. }\end{array}$ & $\begin{array}{l}\text { 2nd Stage } \\
\text { Vacuum } \\
\text { Jet } 1 \text { Cond. }\end{array}$ & $\begin{array}{l}\text { 2nd Stage } \\
\text { Spent Wash } \\
\text { Recycle }\end{array}$ & $\begin{array}{l}\text { 2nd Stage } \\
\text { Crystallizer }^{\text {Product }}{ }^{1}\end{array}$ & \begin{tabular}{|c|} 
2nd Stage \\
Centrifuge \\
Wash Liquor
\end{tabular} & $\begin{array}{l}\text { 1st Stage } \\
\text { Spent Wash } \\
\text { Purge }\end{array}$ & $\left|\begin{array}{c}\text { Cs Product to } \\
\text { DST }^{2}\end{array}\right|$ & $\begin{array}{l}\text { LAW } \\
\text { Product }^{2}\end{array}$ & $\begin{array}{l}\text { LAW to } \\
\text { WTP }^{2}\end{array}$ & $\begin{array}{l}\text { Liquid } \\
\text { Effluent to } \\
\text { ETF }\end{array}$ \\
\hline Volume $(\mathrm{L} / \mathrm{h})^{1}$ & $3.90 \mathrm{E}+03$ & $3.45 \mathrm{E}+03$ & $1.25 \mathrm{E}+02$ & $2.22 \mathrm{E}+03$ & $8.85 \mathrm{E}+02$ & $1.48 \mathrm{E}+03$ & $1.66 \mathrm{E}+03$ & $6.18 \mathrm{E}+01$ & $1.29 \mathrm{E}+02$ & $1.80 \mathrm{E}+03$ & $7.32 \mathrm{E}+02$ & $1.06 \mathrm{E}+03$ & $1.70 \mathrm{E}+03$ & $6.98 \mathrm{E}+02$ & $9.35 \mathrm{E}+02$ & $1.63 \mathrm{E}+03$ \\
\hline Volume $(\mathrm{gpm})^{1}$ & $1.72 \mathrm{E}+01$ & $1.52 \mathrm{E}+01$ & 5.51E-01 & $9.77 \mathrm{E}+00$ & $3.90 \mathrm{E}+00$ & $6.50 \mathrm{E}+00$ & $7.32 \mathrm{E}+00$ & $2.72 \mathrm{E}-01$ & $5.68 \mathrm{E}-01$ & $7.94 \mathrm{E}+00$ & $3.22 \mathrm{E}+00$ & $4.68 \mathrm{E}+00$ & $7.50 \mathrm{E}+00$ & $3.07 \mathrm{E}+00$ & $4.12 \mathrm{E}+00$ & $7.17 \mathrm{E}+00$ \\
\hline Liquid Density $(\mathrm{kg} / \mathrm{L})^{1}$ & 1.30 & 1.00 & 1.00 & 1.57 & 1.51 & 1.35 & 1.00 & 1.00 & 1.59 & 1.59 & 1.51 & 1.57 & 1.40 & 1.53 & 1.43 & 1.00 \\
\hline $137 \mathrm{Cs}(\mathrm{Ci} / \mathrm{L})$ & $1.99 \mathrm{E}-01$ & & & & & $1.84 \mathrm{E}-03$ & & & $2.08 \mathrm{E}-02$ & & & $7.28 \mathrm{E}-01$ & $4.55 \mathrm{E}-01$ & $5.80 \mathrm{E}-05$ & $4.33 \mathrm{E}-05$ & \\
\hline$\overline{\mathrm{Na}(\mathrm{mol} / \mathrm{L})}$ & $6.00 \mathrm{E}+00$ & & & & & $6.90 \mathrm{E}+00$ & & & $1.43 \mathrm{E}+01$ & & & $1.42 \mathrm{E}+01$ & $8.83 \mathrm{E}+00$ & $1.19 \mathrm{E}+01$ & $8.92 \mathrm{E}+00$ & \\
\hline $\mathrm{Na}(\mathrm{kg} / \mathrm{h})$ & $5.38 \mathrm{E}+02$ & & & & & $2.34 \mathrm{E}+02$ & & & $4.24 \mathrm{E}+01$ & & & $3.46 \mathrm{E}+02$ & $3.46 \mathrm{E}+02$ & $1.92 \mathrm{E}+02$ & $1.92 \mathrm{E}+02$ & \\
\hline $\mathrm{SO} 4(\mathrm{~kg} / \mathrm{h})^{2}$ & $5.70 \mathrm{E}+00$ & & & & & $5.68 \mathrm{E}+00$ & & & $5.67 \mathrm{E}-03$ & & & $2.28 \mathrm{E}-02$ & $2.28 \mathrm{E}-02$ & $5.67 \mathrm{E}+00$ & $5.67 \mathrm{E}+00$ & \\
\hline Water $(\mathrm{kg} / \mathrm{hr})$ & $3.43 \mathrm{E}+03$ & $3.45 \mathrm{E}+03$ & $1.25 \mathrm{E}+02$ & $1.36 \mathrm{E}+03$ & $5.97 \mathrm{E}+02$ & $1.24 \mathrm{E}+03$ & $1.66 \mathrm{E}+03$ & $6.18 \mathrm{E}+01$ & $7.49 \mathrm{E}+01$ & $1.05 \mathrm{E}+03$ & $4.94 \mathrm{E}+02$ & $6.51 \mathrm{E}+02$ & $1.29 \mathrm{E}+03$ & $4.56 \mathrm{E}+02$ & $6.92 \mathrm{E}+02$ & $1.63 \mathrm{E}+03$ \\
\hline Dissolved Solids $(\mathrm{kg} / \mathrm{h})$ & $1.63 \mathrm{E}+03$ & & & $2.12 \mathrm{E}+03$ & $7.44 \mathrm{E}+02$ & $7.44 \mathrm{E}+02$ & & & $1.30 \mathrm{E}+02$ & $1.82 \mathrm{E}+03$ & $6.14 \mathrm{E}+02$ & $1.01 \mathrm{E}+03$ & $1.01 \mathrm{E}+03$ & $6.14 \mathrm{E}+02$ & $6.14 \mathrm{E}+02$ & \\
\hline \begin{tabular}{|l|} 
Crystal Solids $(\mathrm{kg} / \mathrm{h})$ \\
\end{tabular} & & & & $1.49 \mathrm{E}+03$ & & & & & & $1.23 \mathrm{E}+03$ & & & & & & \\
\hline rocess time@100\% TOE hrs & 1,888 & -- & -- & -- & -- & -- & -- & -- & -- & -- & -- & -- & -- & -- & -- & -- \\
\hline cess time@70\% TOE hrs & 2,696 & -- & -- & -- & - & - & - & - & - & - & - & -- & - & -- & - & -- \\
\hline
\end{tabular}

\begin{tabular}{|c|c|c|c|c|c|c|c|c|c|c|c|c|c|c|c|c|}
\hline Batch \# & 12 & Tank & 241-AW-104 & & & & & & & & & & & & & \\
\hline Stream Number & 4 & 6 & 7 & 19 & 10 & 20 & 22 & 23 & 9 & 31 & 25 & 13 & 14 & 27 & 29 & 30 \\
\hline Description & $\begin{array}{l}\text { Waste Feed to } \\
1 \text { st Stage } \\
\text { Crystallizer }\end{array}$ & \begin{tabular}{|c} 
1st Stage \\
Boilup \\
Condensate
\end{tabular} & $\begin{array}{c}\text { 1st Stage } \\
\text { Vacuum } \\
\text { Jet } 1 \\
\text { Condensate }\end{array}$ & $\begin{array}{c}\text { 1st Stage } \\
\text { Crystallizer } \\
\text { Product1 }\end{array}$ & $\begin{array}{c}\text { 1st Stage } \\
\text { Centrifuge } \\
\text { Wash Liquor }\end{array}$ & $\begin{array}{l}\text { 1st Stage } \\
\text { Dissolver } \\
\text { Slurry }\end{array}$ & $\begin{array}{l}\text { 2nd Stage } \\
\text { Boilup } \\
\text { Condensate }\end{array}$ & $\begin{array}{l}\text { 2nd Stage } \\
\text { Vacuum } \\
\text { Jet } 1 \\
\text { Condensate }\end{array}$ & $\begin{array}{l}\text { 2nd Stage } \\
\text { Spent Wash } \\
\text { Recycle }\end{array}$ & $\begin{array}{l}\text { 2nd Stage } \\
\text { Crystallizer } \\
\text { Productl }\end{array}$ & $\begin{array}{l}\text { 2nd Stage } \\
\text { Centrifuge } \\
\text { Wash Liquor }\end{array}$ & $\begin{array}{l}\text { 1st Stage } \\
\text { Spent Wash } \\
\text { Purge }\end{array}$ & $\begin{array}{c}\text { Cs Product to } \\
\text { DST2 }\end{array}$ & $\begin{array}{c}\text { LAW } \\
\text { Product2 }\end{array}$ & $\begin{array}{l}\text { LAW to } \\
\text { WTP2 }\end{array}$ & $\begin{array}{c}\text { Liquid } \\
\text { Effluent to } \\
\text { ETF }\end{array}$ \\
\hline Volume $(\mathrm{L} / \mathrm{h})^{1}$ & $3.19 \mathrm{E}+03$ & $2.90 \mathrm{E}+03$ & $1.25 \mathrm{E}+02$ & $2.05 \mathrm{E}+03$ & $8.19 \mathrm{E}+02$ & $1.37 \mathrm{E}+03$ & $1.55 \mathrm{E}+03$ & $6.18 \mathrm{E}+01$ & $1.11 \mathrm{E}+02$ & $1.69 \mathrm{E}+03$ & $6.87 \mathrm{E}+02$ & $8.22 \mathrm{E}+02$ & $1.20 \mathrm{E}+03$ & $6.55 \mathrm{E}+02$ & $9.32 \mathrm{E}+02$ & $1.39 \mathrm{E}+03$ \\
\hline${\text { Volume }(\mathrm{gpm})^{1}}^{1}$ & $1.40 \mathrm{E}+01$ & $1.28 \mathrm{E}+01$ & $5.51 \mathrm{E}-01$ & $9.04 \mathrm{E}+00$ & $3.61 \mathrm{E}+00$ & $6.01 \mathrm{E}+00$ & $6.82 \mathrm{E}+00$ & $2.72 \mathrm{E}-01$ & $4.90 \mathrm{E}-01$ & $7.45 \mathrm{E}+00$ & $3.03 \mathrm{E}+00$ & $3.62 \mathrm{E}+00$ & $5.30 \mathrm{E}+00$ & $2.88 \mathrm{E}+00$ & $4.10 \mathrm{E}+00$ & $6.11 \mathrm{E}+00$ \\
\hline Liquid Density $(\mathrm{kg} / \mathrm{L})^{1}$ & 1.30 & 1.00 & 1.00 & 1.57 & 1.51 & 1.35 & 1.00 & 1.00 & 1.59 & 1.59 & 1.51 & 1.57 & 1.42 & 1.53 & 1.41 & 1.00 \\
\hline $137 \mathrm{Cs}(\mathrm{Ci} / \mathrm{L})$ & $1.65 \mathrm{E}-01$ & & & & & $1.61 \mathrm{E}-03$ & & & $1.95 \mathrm{E}-02$ & & & $6.39 \mathrm{E}-01$ & $4.36 \mathrm{E}-01$ & $5.12 \mathrm{E}-05$ & $3.60 \mathrm{E}-05$ & \\
\hline $\mathrm{Na}(\mathrm{mol} / \mathrm{L})$ & $6.00 \mathrm{E}+00$ & & & & & $7.29 \mathrm{E}+00$ & & & $1.45 \mathrm{E}+01$ & & & $1.31 \mathrm{E}+01$ & $8.97 \mathrm{E}+00$ & $1.27 \mathrm{E}+01$ & $8.95 \mathrm{E}+00$ & \\
\hline $\mathrm{Na}(\mathrm{kg} / \mathrm{h})$ & $4.40 \mathrm{E}+02$ & & & & & $2.29 \mathrm{E}+02$ & & & $3.72 \mathrm{E}+01$ & & & $2.48 \mathrm{E}+02$ & $2.48 \mathrm{E}+02$ & $1.92 \mathrm{E}+02$ & $1.92 \mathrm{E}+02$ & \\
\hline $\mathrm{SO} 4(\mathrm{~kg} / \mathrm{h})^{2}$ & $1.74 \mathrm{E}+01$ & & & & & $1.74 \mathrm{E}+01$ & & & $1.73 \mathrm{E}-02$ & & & $5.48 \mathrm{E}-02$ & $5.48 \mathrm{E}-02$ & $1.73 \mathrm{E}+01$ & $1.73 \mathrm{E}+01$ & \\
\hline Water $(\mathrm{kg} / \mathrm{hr})$ & $2.79 \mathrm{E}+03$ & $2.90 \mathrm{E}+03$ & $1.25 \mathrm{E}+02$ & $1.26 \mathrm{E}+03$ & $5.52 \mathrm{E}+02$ & $1.15 \mathrm{E}+03$ & $1.55 \mathrm{E}+03$ & $6.18 \mathrm{E}+01$ & $6.46 \mathrm{E}+01$ & $9.82 \mathrm{E}+02$ & $4.64 \mathrm{E}+02$ & $5.03 \mathrm{E}+02$ & $8.84 \mathrm{E}+02$ & $4.28 \mathrm{E}+02$ & $7.04 \mathrm{E}+02$ & $1.39 \mathrm{E}+03$ \\
\hline Dissolved Solids $(\mathrm{kg} / \mathrm{h})$ & $1.36 \mathrm{E}+03$ & & & $1.96 \mathrm{E}+03$ & $6.89 \mathrm{E}+02$ & $6.89 \mathrm{E}+02$ & & & $1.12 \mathrm{E}+02$ & $1.71 \mathrm{E}+03$ & $5.76 \mathrm{E}+02$ & $7.84 \mathrm{E}+02$ & $7.84 \mathrm{E}+02$ & $5.76 \mathrm{E}+02$ & $5.76 \mathrm{E}+02$ & \\
\hline Crystal Solids $(\mathrm{kg} / \mathrm{h})$ & & & & $1.38 \mathrm{E}+03$ & & & & & & $1.15 \mathrm{E}+03$ & & & & & & \\
\hline Process time@100\% TOE hrs & 1,767 & -- & -- & -- & -- & -- & -- & -- & -- & -- & - & -- & -- & -- & -- & -- \\
\hline Process time@70\% TOE hrs & 2,524 & -- & -- & -- & -- & -- & -- & -- & -- & -- & -- & -- & -- & -- & -- & -- \\
\hline
\end{tabular}

1. Volume and density of liquid phase only.
2. Sulfate can be directed to LAW or Cs product stream as needed to meet product specifications. 
Table 6-26 Fractional Crystallization Mass Balance Summary

\begin{tabular}{|c|c|c|c|c|c|c|c|c|c|c|c|c|c|c|c|c|}
\hline \multicolumn{17}{|c|}{ (8 sheets) } \\
\hline Batch \# & 13 & Tank & 241-AP-106 & & & & & & & & & & & & & \\
\hline Stream Number & 4 & 6 & 7 & 19 & 10 & 20 & 22 & 23 & 9 & 31 & 25 & 13 & 14 & 27 & 29 & 30 \\
\hline Description & $\begin{array}{l}\text { Waste Feed to } \\
\text { 1st Stage } \\
\text { Crystallizer }\end{array}$ & $\begin{array}{c}\text { 1st Stage } \\
\text { Boilup Cond. }\end{array}$ & $\begin{array}{l}\text { 1st Stage } \\
\text { Vacuum } \\
\text { Jet } 1 \text { Cond. }\end{array}$ & $\begin{array}{c}\text { 1st Stage } \\
\text { Crystallizer } \\
\text { Product }^{1}\end{array}$ & $\begin{array}{c}\text { 1st Stage } \\
\text { Centrifuge } \\
\text { Wash Liquor }\end{array}$ & $\begin{array}{l}\text { 1st Stage } \\
\text { Dissolver } \\
\text { Slurry }\end{array}$ & $\begin{array}{c}\text { 2nd Stage } \\
\text { Boilup Cond. }\end{array}$ & $\begin{array}{l}\text { 2nd Stage } \\
\text { Vacuum } \\
\text { Jet } 1 \text { Cond. }\end{array}$ & $\begin{array}{l}\text { 2nd Stage } \\
\text { Spent Wash } \\
\text { Recycle }\end{array}$ & $\begin{array}{c}\text { 2nd Stage } \\
\text { Crystallizer }^{\text {Product }^{1}}\end{array}$ & $\begin{array}{c}\text { 2nd Stage } \\
\text { Centrifuge } \\
\text { Wash Liquor }\end{array}$ & $\begin{array}{l}\text { 1st Stage } \\
\text { Spent Wash } \\
\text { Purge }\end{array}$ & $\begin{array}{c}\text { Cs Product to } \\
\text { DST }^{2}\end{array}$ & $\begin{array}{l}\text { LAW } \\
\text { Product }^{2}\end{array}$ & $\begin{array}{l}\text { LAW to } \\
\text { WTP }^{2}\end{array}$ & $\begin{array}{l}\text { Liquid } \\
\text { Effluent to } \\
\text { ETF }\end{array}$ \\
\hline Volume $(\mathrm{L} / \mathrm{h})^{1}$ & $3.77 \mathrm{E}+03$ & $3.61 \mathrm{E}+03$ & $1.25 \mathrm{E}+02$ & $1.97 \mathrm{E}+03$ & $7.85 \mathrm{E}+02$ & $1.31 \mathrm{E}+03$ & $1.50 \mathrm{E}+03$ & $6.18 \mathrm{E}+01$ & $46 \mathrm{E}+01$ & $1.66 \mathrm{E}+03$ & $6.72 \mathrm{E}+02$ & $6.99 \mathrm{E}+02$ & $9.93 \mathrm{E}+02$ & $6.41 \mathrm{E}+02$ & $9.40 \mathrm{E}+02$ & $2.20 \mathrm{E}+03$ \\
\hline Volume $(\mathrm{gpm})^{1}$ & $1.66 \mathrm{E}+01$ & $1.59 \mathrm{E}+01$ & $5.51 \mathrm{E}-01$ & $8.66 \mathrm{E}+00$ & $3.46 \mathrm{E}+00$ & $5.76 \mathrm{E}+00$ & $6.61 \mathrm{E}+00$ & $2.72 \mathrm{E}-01$ & $4.17 \mathrm{E}-01$ & $7.29 \mathrm{E}+00$ & $2.96 \mathrm{E}+00$ & $3.08 \mathrm{E}+00$ & $4.37 \mathrm{E}+00$ & $2.82 \mathrm{E}+00$ & $4.14 \mathrm{E}+00$ & $9.70 \mathrm{E}+00$ \\
\hline Liquid Density $(\mathrm{kg} / \mathrm{L})^{1}$ & 1.24 & 1.00 & 1.00 & 1.57 & 1.51 & 1.35 & 1.00 & 1.00 & 1.59 & 1.59 & 1.51 & 1.57 & 1.43 & 1.53 & 1.40 & 1.00 \\
\hline $137 \mathrm{Cs}(\mathrm{Ci} / \mathrm{L})$ & $1.75 \mathrm{E}-01$ & & & & & $2.33 \mathrm{E}-03$ & & & $3.17 \mathrm{E}-02$ & & & $9.47 \mathrm{E}-01$ & $6.66 \mathrm{E}-01$ & 7.42E-05 & $5.06 \mathrm{E}-05$ & \\
\hline $\mathrm{Na}(\mathrm{mol} / \mathrm{L})$ & $4.50 \mathrm{E}+00$ & & & & & $7.42 \mathrm{E}+00$ & & & $1.45 \mathrm{E}+01$ & & & $1.24 \mathrm{E}+01$ & $8.71 \mathrm{E}+00$ & $1.30 \mathrm{E}+01$ & $8.86 \mathrm{E}+00$ & \\
\hline $\mathrm{Na}(\mathrm{kg} / \mathrm{h})$ & $3.90 \mathrm{E}+02$ & & & & & $2.23 \mathrm{E}+02$ & & & $3.16 \mathrm{E}+01$ & & & $1.99 \mathrm{E}+02$ & $1.99 \mathrm{E}+02$ & $1.92 \mathrm{E}+02$ & $1.92 \mathrm{E}+02$ & \\
\hline $\mathrm{SO} 4(\mathrm{~kg} / \mathrm{h})^{2}$ & $1.41 \mathrm{E}+01$ & & & & & $1.41 \mathrm{E}+01$ & & & $1.41 \mathrm{E}-02$ & & & $4.44 \mathrm{E}-02$ & $4.44 \mathrm{E}-02$ & $1.41 \mathrm{E}+01$ & $1.41 \mathrm{E}+01$ & \\
\hline Water $(\mathrm{kg} / \mathrm{hr})$ & $3.45 \mathrm{E}+03$ & $3.61 \mathrm{E}+03$ & $1.25 \mathrm{E}+02$ & $1.20 \mathrm{E}+03$ & $5.29 \mathrm{E}+02$ & $1.10 \mathrm{E}+03$ & $1.50 \mathrm{E}+03$ & $6.18 \mathrm{E}+01$ & $5.49 \mathrm{E}+01$ & $9.61 \mathrm{E}+02$ & $4.54 \mathrm{E}+02$ & $4.27 \mathrm{E}+02$ & $7.22 \mathrm{E}+02$ & $4.19 \mathrm{E}+02$ & $7.18 \mathrm{E}+02$ & $2.20 \mathrm{E}+03$ \\
\hline Dissolved Solids ( $\mathrm{kg} / \mathrm{h})$ & $1.23 \mathrm{E}+03$ & & & $1.88 \mathrm{E}+03$ & $6.60 \mathrm{E}+02$ & $6.60 \mathrm{E}+02$ & & & $9.55 \mathrm{E}+01$ & $1.67 \mathrm{E}+03$ & $5.64 \mathrm{E}+02$ & $6.66 \mathrm{E}+02$ & $6.66 \mathrm{E}+02$ & $5.64 \mathrm{E}+02$ & $5.64 \mathrm{E}+02$ & \\
\hline Crystal Solids $(\mathrm{kg} / \mathrm{h})$ & & & & $1.32 \mathrm{E}+03$ & & & & & & $1.13 \mathrm{E}+03$ & & & & & & \\
\hline Process time@100\% TOE hrs & 1,140 & -- & - & -- & -- & -- & -- & - & -- & -- & -- & -- & -- & -- & -- & -- \\
\hline Process time@ $070 \% \mathrm{TOE}$ hrs & 1,628 & -- & -- & -- & -- & -- & -- & -- & -- & -- & -- & -- & -- & -- & -- & -- \\
\hline
\end{tabular}

\begin{tabular}{|c|c|c|c|c|c|c|c|c|c|c|c|c|c|c|c|c|}
\hline Batch \# & 14 & Tank & 241-SY-101 & & & & & & & & & & & & & \\
\hline Stream Number & 4 & 6 & 7 & 19 & 10 & 20 & 22 & 23 & 9 & 31 & 25 & 13 & 14 & 27 & 29 & 30 \\
\hline Description & $\begin{array}{c}\text { Waste Feed to } \\
\text { 1st Stage } \\
\text { Crystallizer }\end{array}$ & $\begin{array}{c}\text { 1st Stage } \\
\text { Boilup } \\
\text { Condensate }\end{array}$ & $\begin{array}{c}\text { 1st Stage } \\
\text { Vacuum } \\
\text { Jet } 1 \\
\text { Condensate }\end{array}$ & $\begin{array}{l}\text { 1st Stage } \\
\text { Crystallizer } \\
\text { Product1 }\end{array}$ & $\begin{array}{c}\text { 1st Stage } \\
\text { Centrifuge } \\
\text { Wash Liquor }\end{array}$ & $\begin{array}{l}\text { 1st Stage } \\
\text { Dissolver } \\
\text { Slurry }\end{array}$ & $\begin{array}{l}\text { 2nd Stage } \\
\text { Boilup } \\
\text { Condensate }\end{array}$ & $\begin{array}{l}\text { 2nd Stage } \\
\text { Vacuum } \\
\text { Jet } 1 \\
\text { Condensate }\end{array}$ & $\begin{array}{l}\text { 2nd Stage } \\
\text { Spent Wash } \\
\text { Recycle }\end{array}$ & $\begin{array}{l}\text { 2nd Stage } \\
\text { Crystallizer } \\
\text { Product1 }\end{array}$ & $\begin{array}{l}\text { 2nd Stage } \\
\text { Centrifuge } \\
\text { Wash Liquor }\end{array}$ & $\begin{array}{l}\text { 1st Stage } \\
\text { Spent Wash } \\
\text { Purge }\end{array}$ & $\begin{array}{c}\text { Cs Product to } \\
\text { DST2 }\end{array}$ & $\begin{array}{l}\text { LAW } \\
\text { Product2 }\end{array}$ & $\begin{array}{l}\text { LAW to } \\
\text { WTP2 }\end{array}$ & $\begin{array}{l}\text { Liquid } \\
\text { Effluent to } \\
\text { ETF }\end{array}$ \\
\hline Volume $(\mathrm{L} / \mathrm{h})^{1}$ & $7.24 \mathrm{E}+03$ & $7.25 \mathrm{E}+03$ & $1.25 \mathrm{E}+02$ & $2.08 \mathrm{E}+03$ & $8.31 \mathrm{E}+02$ & $1.39 \mathrm{E}+03$ & $1.63 \mathrm{E}+03$ & $6.18 \mathrm{E}+01$ & $7.08 \mathrm{E}+01$ & $1.84 \mathrm{E}+03$ & $7.48 \mathrm{E}+02$ & $5.82 \mathrm{E}+02$ & $1.06 \mathrm{E}+03$ & $7.13 \mathrm{E}+02$ & $9.55 \mathrm{E}+02$ & $5.66 \mathrm{E}+03$ \\
\hline Volume $(\mathrm{gpm})^{1}$ & $3.19 \mathrm{E}+01$ & $3.19 \mathrm{E}+01$ & $5.51 \mathrm{E}-01$ & $9.17 \mathrm{E}+00$ & $3.66 \mathrm{E}+00$ & $6.10 \mathrm{E}+00$ & $7.18 \mathrm{E}+00$ & $2.72 \mathrm{E}-01$ & $3.12 \mathrm{E}-01$ & $8.11 \mathrm{E}+00$ & $3.29 \mathrm{E}+00$ & $2.56 \mathrm{E}+00$ & $4.66 \mathrm{E}+00$ & $3.14 \mathrm{E}+00$ & $4.21 \mathrm{E}+00$ & $2.49 \mathrm{E}+01$ \\
\hline Liquid Density $(\mathrm{kg} / \mathrm{L})^{1}$ & 1.13 & 1.00 & 1.00 & 1.57 & 1.51 & 1.35 & 1.00 & 1.00 & 1.59 & 1.59 & 1.51 & 1.57 & 1.36 & 1.53 & 1.43 & 1.00 \\
\hline $137 \mathrm{Cs}(\mathrm{Ci} / \mathrm{L})$ & $2.56 \mathrm{E}-02$ & & & & & $5.67 \mathrm{E}-04$ & & & $1.09 \mathrm{E}-02$ & & & $3.19 \mathrm{E}-01$ & $1.75 \mathrm{E}-01$ & $1.80 \mathrm{E}-05$ & $1.34 \mathrm{E}-05$ & \\
\hline $\mathrm{Na}(\mathrm{mol} / \mathrm{L})$ & $2.44 \mathrm{E}+00$ & & & & & $6.70 \mathrm{E}+00$ & & & $1.35 \mathrm{E}+01$ & & & $1.61 \mathrm{E}+01$ & $8.83 \mathrm{E}+00$ & $1.17 \mathrm{E}+01$ & $8.73 \mathrm{E}+00$ & \\
\hline $\mathrm{Na}(\mathrm{kg} / \mathrm{h})$ & $4.07 \mathrm{E}+02$ & & & & & $2.14 \mathrm{E}+02$ & & & $2.20 \mathrm{E}+01$ & & & $2.15 \mathrm{E}+02$ & $2.15 \mathrm{E}+02$ & $1.92 \mathrm{E}+02$ & $1.92 \mathrm{E}+02$ & \\
\hline $\mathrm{SO} 4(\mathrm{~kg} / \mathrm{h})^{2}$ & $1.46 \mathrm{E}+01$ & & & & & $1.46 \mathrm{E}+01$ & & & $1.46 \mathrm{E}-02$ & & & $5.86 \mathrm{E}-02$ & $5.86 \mathrm{E}-02$ & $1.46 \mathrm{E}+01$ & $1.46 \mathrm{E}+01$ & \\
\hline Water $(\mathrm{kg} / \mathrm{hr})$ & $7.01 \mathrm{E}+03$ & $7.25 \mathrm{E}+03$ & $1.25 \mathrm{E}+02$ & $1.27 \mathrm{E}+03$ & $5.61 \mathrm{E}+02$ & $1.17 \mathrm{E}+03$ & $1.63 \mathrm{E}+03$ & $6.18 \mathrm{E}+01$ & $4.11 \mathrm{E}+01$ & $1.07 \mathrm{E}+03$ & $5.05 \mathrm{E}+02$ & $3.56 \mathrm{E}+02$ & $8.33 \mathrm{E}+02$ & $4.66 \mathrm{E}+02$ & $7.08 \mathrm{E}+02$ & $5.66 \mathrm{E}+03$ \\
\hline Dissolved Solids $(\mathrm{kg} / \mathrm{h})$ & $1.18 \mathrm{E}+03$ & & & $1.99 \mathrm{E}+03$ & $6.99 \mathrm{E}+02$ & $6.99 \mathrm{E}+02$ & & & $7.14 \mathrm{E}+01$ & $1.86 \mathrm{E}+03$ & $6.27 \mathrm{E}+02$ & $5.55 \mathrm{E}+02$ & $5.55 \mathrm{E}+02$ & $6.27 \mathrm{E}+02$ & $6.27 \mathrm{E}+02$ & \\
\hline Crystal Solids $(\mathrm{kg} / \mathrm{h})$ & & & & $1.40 \mathrm{E}+03$ & & & & & & $1.25 \mathrm{E}+03$ & & & & & & \\
\hline Process time@100\% TOE hrs & 445 & -- & -- & -- & -- & -- & -- & -- & -- & -- & -- & -- & -- & -- & -- & -- \\
\hline Process time@770\% TOE hrs & 636 & -- & -- & -- & -- & -- & -- & -- & -- & -- & -- & -- & -- & -- & -- & -- \\
\hline
\end{tabular}

Notes:

1. Volume and density of liquid phase only.
2. Sulfate can be directed to LAW or Cs product stream as needed to meet product specifications. 
Table 6-26 Fractional Crystallization Mass Balance Summary

\begin{tabular}{|c|c|c|c|c|c|c|c|c|c|c|c|c|c|c|c|c|}
\hline \multicolumn{17}{|c|}{ (8 sheets) } \\
\hline Batch \# & 15 & Tank & 241-S-109 & & & & & & & & & & & & & \\
\hline Stream Number & 4 & 6 & 7 & 19 & 10 & 20 & 22 & 23 & 9 & 31 & 25 & 13 & 14 & 27 & 29 & 30 \\
\hline Description & $\begin{array}{l}\text { Waste Feed to } \\
1 \text { st Stage } \\
\text { Crystallizer }\end{array}$ & $\begin{array}{c}\text { 1st Stage } \\
\text { Boilup Cond. }\end{array}$ & $\begin{array}{l}\text { 1st Stage } \\
\text { Vacuum } \\
\text { Jet } 1 \text { Cond. }\end{array}$ & $\begin{array}{l}\text { 1st Stage } \\
\text { Crystallizer } \\
\text { Product }^{1}\end{array}$ & $\begin{array}{c}\text { 1st Stage } \\
\text { Centrifuge } \\
\text { Wash Liquor }\end{array}$ & $\begin{array}{c}\text { 1st Stage } \\
\text { Dissolver } \\
\text { Slurry }\end{array}$ & $\begin{array}{c}\text { 2nd Stage } \\
\text { Boilup Cond. }\end{array}$ & $\begin{array}{l}\text { 2nd Stage } \\
\text { Vacuum } \\
\text { Jet } 1 \text { Cond. }\end{array}$ & $\begin{array}{l}\text { 2nd Stage } \\
\text { Spent Wash } \\
\text { Recycle }\end{array}$ & $\begin{array}{l}\text { 2nd Stage } \\
\text { Crystallizer }^{\text {Product }}{ }^{1}\end{array}$ & $\begin{array}{c}\text { 2nd Stage } \\
\text { Centrifuge } \\
\text { Wash Liquor }\end{array}$ & $\begin{array}{l}\text { 1st Stage } \\
\text { Spent Wash } \\
\text { Purge }\end{array}$ & $\left|\begin{array}{c}\text { Cs Product to } \\
\text { DST }^{2}\end{array}\right|$ & $\begin{array}{l}\text { LAW } \\
\text { Product }^{2}\end{array}$ & $\begin{array}{l}\text { LAW to } \\
\text { WTP }^{2}\end{array}$ & $\begin{array}{l}\text { Liquid } \\
\text { Effluent to } \\
\text { ETF }\end{array}$ \\
\hline Volume $(\mathrm{L} / \mathrm{h})^{1}$ & $1.65 \mathrm{E}+03$ & $1.94 \mathrm{E}+03$ & $1.25 \mathrm{E}+02$ & $2.24 \mathrm{E}+03$ & $8.95 \mathrm{E}+02$ & $1.49 \mathrm{E}+03$ & $1.79 \mathrm{E}+03$ & $6.18 \mathrm{E}+01$ & $4.85 \mathrm{E}+01$ & $2.06 \mathrm{E}+03$ & $8.38 \mathrm{E}+02$ & $1.35 \mathrm{E}+02$ & $1.77 \mathrm{E}+02$ & $7.99 \mathrm{E}+02$ & $9.53 \mathrm{E}+02$ & $7.78 \mathrm{E}+02$ \\
\hline Volume $(\mathrm{gpm})^{1}$ & $7.27 \mathrm{E}+00$ & $8.54 \mathrm{E}+00$ & 5.51E-01 & $9.87 \mathrm{E}+00$ & $3.94 \mathrm{E}+00$ & $6.57 \mathrm{E}+00$ & $7.90 \mathrm{E}+00$ & $2.72 \mathrm{E}-01$ & $2.14 \mathrm{E}-01$ & $9.09 \mathrm{E}+00$ & $3.69 \mathrm{E}+00$ & $5.96 \mathrm{E}-01$ & $7.77 \mathrm{E}-01$ & $3.52 \mathrm{E}+00$ & $4.20 \mathrm{E}+00$ & $3.42 \mathrm{E}+00$ \\
\hline Liquid Density $(\mathrm{kg} / \mathrm{L})^{1}$ & 1.35 & 1.00 & 1.00 & 1.57 & 1.51 & 1.35 & 1.00 & 1.00 & 1.59 & 1.59 & 1.51 & 1.57 & 1.46 & 1.53 & 1.47 & 1.00 \\
\hline $137 \mathrm{Cs}(\mathrm{Ci} / \mathrm{L})$ & $7.22 \mathrm{E}-03$ & & & & & $5.80 \mathrm{E}-05$ & & & $1.75 \mathrm{E}-03$ & & & $8.80 \mathrm{E}-02$ & $6.75 \mathrm{E}-02$ & $1.84 \mathrm{E}-06$ & $1.54 \mathrm{E}-06$ & \\
\hline$\overline{\mathrm{Na}(\mathrm{mol} / \mathrm{L})}$ & $6.00 \mathrm{E}+00$ & & & & & $5.98 \mathrm{E}+00$ & & & $1.19 \mathrm{E}+01$ & & & $1.16 \mathrm{E}+01$ & $8.90 \mathrm{E}+00$ & $1.04 \mathrm{E}+01$ & $8.75 \mathrm{E}+00$ & \\
\hline \multicolumn{17}{|l|}{$\mathrm{Na}(\mathrm{kg} / \mathrm{h})$} \\
\hline $\mathrm{SO} 4(\mathrm{~kg} / \mathrm{h})^{2}$ & $2.28 \mathrm{E}+02$ & & & & & $2.05 \mathrm{E}+02$ & & & $1.33 \mathrm{E}+01$ & & & $3.61 \mathrm{E}+01$ & $3.61 \mathrm{E}+01$ & $1.92 \mathrm{E}+02$ & $1.92 \mathrm{E}+02$ & \\
\hline Water $(\mathrm{kg} / \mathrm{hr})$ & $7.88 \mathrm{E}+00$ & & & & & $7.88 \mathrm{E}+00$ & & & $7.87 \mathrm{E}-03$ & & & $7.88 \mathrm{E}-03$ & $7.88 \mathrm{E}-03$ & $7.87 \mathrm{E}+00$ & $7.87 \mathrm{E}+00$ & \\
\hline Dissolved Solids $(\mathrm{kg} / \mathrm{h})$ & $1.39 \mathrm{E}+03$ & $1.94 \mathrm{E}+03$ & $1.25 \mathrm{E}+02$ & $1.37 \mathrm{E}+03$ & $6.03 \mathrm{E}+02$ & $1.26 \mathrm{E}+03$ & $1.79 \mathrm{E}+03$ & $6.18 \mathrm{E}+01$ & $2.81 \mathrm{E}+01$ & $1.20 \mathrm{E}+03$ & $5.66 \mathrm{E}+02$ & $8.28 \mathrm{E}+01$ & $1.24 \mathrm{E}+02$ & $5.22 \mathrm{E}+02$ & $6.76 \mathrm{E}+02$ & $7.78 \mathrm{E}+02$ \\
\hline \begin{tabular}{|l|} 
Crystal Solids $(\mathrm{kg} / \mathrm{h})$ \\
\end{tabular} & $8.32 \mathrm{E}+02$ & & & $2.14 \mathrm{E}+03$ & $7.52 \mathrm{E}+02$ & $7.52 \mathrm{E}+02$ & & & $4.89 \mathrm{E}+01$ & $2.08 \mathrm{E}+03$ & $7.03 \mathrm{E}+02$ & $1.29 \mathrm{E}+02$ & $1.29 \mathrm{E}+02$ & $7.03 \mathrm{E}+02$ & $7.03 \mathrm{E}+02$ & \\
\hline rocess time@100\% TOE hrs & 3,337 & -- & -- & -- & -- & -- & -- & -- & -- & -- & -- & -- & -- & -- & -- & -- \\
\hline rocess time@70\% TOE hrs & 4,767 & -- & -- & -- & - & -- & -- & -- & -- & -- & -- & -- & -- & -- & -- & -- \\
\hline
\end{tabular}

\begin{tabular}{|c|c|c|c|c|c|c|c|c|c|c|c|c|c|c|c|c|}
\hline Batch \# & 16 & Tank & $241-\mathrm{S}-109 \mathrm{ec}$ & & & & & & & & & & & & & \\
\hline Stream Number & 4 & 6 & 7 & 19 & 10 & 20 & 22 & 23 & 9 & 31 & 25 & 13 & 14 & 27 & 29 & 30 \\
\hline Description & $\begin{array}{c}\text { Waste Feed to } \\
\text { 1st Stage } \\
\text { Crystallizer }\end{array}$ & \begin{tabular}{|c} 
1st Stage \\
Boilup \\
Condensate
\end{tabular} & $\begin{array}{c}\text { 1st Stage } \\
\text { Vacuum } \\
\text { Jet } 1 \\
\text { Condensate }\end{array}$ & $\begin{array}{l}\text { 1st Stage } \\
\text { Crystallizer } \\
\text { Product1 }\end{array}$ & $\begin{array}{c}\text { 1st Stage } \\
\text { Centrifuge } \\
\text { Wash Liquor }\end{array}$ & $\begin{array}{l}\text { 1st Stage } \\
\text { Dissolver } \\
\text { Slurry }\end{array}$ & $\begin{array}{l}\text { 2nd Stage } \\
\text { Boilup } \\
\text { Condensate }\end{array}$ & $\begin{array}{l}\text { 2nd Stage } \\
\text { Vacuum } \\
\text { Jet } 1 \\
\text { Condensate }\end{array}$ & $\begin{array}{l}\text { 2nd Stage } \\
\text { Spent Wash } \\
\text { Recycle }\end{array}$ & $\begin{array}{l}\text { 2nd Stage } \\
\text { Crystallizer } \\
\text { Product1 }\end{array}$ & $\begin{array}{c}\text { 2nd Stage } \\
\text { Centrifuge } \\
\text { Wash Liquor }\end{array}$ & $\begin{array}{l}\text { 1st Stage } \\
\text { Spent Wash } \\
\text { Purge }\end{array}$ & $\begin{array}{c}\text { Cs Product to } \\
\text { DST2 }\end{array}$ & $\begin{array}{c}\text { LAW } \\
\text { Product2 }\end{array}$ & $\begin{array}{l}\text { LAW to } \\
\text { WTP2 }\end{array}$ & $\begin{array}{c}\text { Liquid } \\
\text { Effluent to } \\
\text { ETF }\end{array}$ \\
\hline Volume $(\mathrm{L} / \mathrm{h})^{1}$ & $1.65 \mathrm{E}+03$ & $1.94 \mathrm{E}+03$ & $1.25 \mathrm{E}+02$ & $2.24 \mathrm{E}+03$ & $8.95 \mathrm{E}+02$ & $1.49 \mathrm{E}+03$ & $1.79 \mathrm{E}+03$ & $6.18 \mathrm{E}+01$ & $4.85 \mathrm{E}+01$ & $2.06 \mathrm{E}+03$ & $8.38 \mathrm{E}+02$ & $1.35 \mathrm{E}+02$ & $1.77 \mathrm{E}+02$ & $7.99 \mathrm{E}+02$ & $9.53 \mathrm{E}+02$ & $7.78 \mathrm{E}+02$ \\
\hline${\text { Volume }(\mathrm{gpm})^{1}}^{1}$ & $7.27 \mathrm{E}+00$ & $8.54 \mathrm{E}+00$ & $5.51 \mathrm{E}-01$ & $9.87 \mathrm{E}+00$ & $3.94 \mathrm{E}+00$ & $6.57 \mathrm{E}+00$ & $7.90 \mathrm{E}+00$ & $2.72 \mathrm{E}-01$ & $2.14 \mathrm{E}-01$ & $9.09 \mathrm{E}+00$ & $3.69 \mathrm{E}+00$ & $5.96 \mathrm{E}-01$ & $7.77 \mathrm{E}-01$ & $3.52 \mathrm{E}+00$ & $4.20 \mathrm{E}+00$ & $3.42 \mathrm{E}+00$ \\
\hline Liquid Density $(\mathrm{kg} / \mathrm{L})^{1}$ & 1.35 & 1.00 & 1.00 & 1.57 & 1.51 & 1.35 & 1.00 & 1.00 & 1.59 & 1.59 & 1.51 & 1.57 & 1.46 & 1.53 & 1.47 & 1.00 \\
\hline $137 \mathrm{Cs}(\mathrm{Ci} / \mathrm{L})$ & $7.22 \mathrm{E}-03$ & & & & & $5.80 \mathrm{E}-05$ & & & $1.75 \mathrm{E}-03$ & & & $8.80 \mathrm{E}-02$ & $6.75 \mathrm{E}-02$ & $1.84 \mathrm{E}-06$ & $1.54 \mathrm{E}-06$ & \\
\hline $\mathrm{Na}(\mathrm{mol} / \mathrm{L})$ & $6.00 \mathrm{E}+00$ & & & & & $5.98 \mathrm{E}+00$ & & & $1.19 \mathrm{E}+01$ & & & $1.16 \mathrm{E}+01$ & $8.90 \mathrm{E}+00$ & $1.04 \mathrm{E}+01$ & $8.75 \mathrm{E}+00$ & \\
\hline \multicolumn{17}{|l|}{$\mathrm{Na}(\mathrm{kg} / \mathrm{h})$} \\
\hline $\mathrm{SO} 4(\mathrm{~kg} / \mathrm{h})^{2}$ & $2.28 \mathrm{E}+02$ & & & & & $2.05 \mathrm{E}+02$ & & & $1.33 \mathrm{E}+01$ & & & $3.61 \mathrm{E}+01$ & $3.61 \mathrm{E}+01$ & $1.92 \mathrm{E}+02$ & $1.92 \mathrm{E}+02$ & \\
\hline Water $(\mathrm{kg} / \mathrm{hr})$ & $7.88 \mathrm{E}+00$ & & & & & $7.88 \mathrm{E}+00$ & & & $7.87 \mathrm{E}-03$ & & & $7.88 \mathrm{E}-03$ & $7.88 \mathrm{E}-03$ & $7.87 \mathrm{E}+00$ & $7.87 \mathrm{E}+00$ & \\
\hline Dissolved Solids $(\mathrm{kg} / \mathrm{h})$ & $1.39 \mathrm{E}+03$ & $1.94 \mathrm{E}+03$ & $1.25 \mathrm{E}+02$ & $1.37 \mathrm{E}+03$ & $6.03 \mathrm{E}+02$ & $1.26 \mathrm{E}+03$ & $1.79 \mathrm{E}+03$ & $6.18 \mathrm{E}+01$ & $2.81 \mathrm{E}+01$ & $1.20 \mathrm{E}+03$ & $5.66 \mathrm{E}+02$ & $8.28 \mathrm{E}+01$ & $1.24 \mathrm{E}+02$ & $5.22 \mathrm{E}+02$ & $6.76 \mathrm{E}+02$ & $7.78 \mathrm{E}+02$ \\
\hline Crystal Solids $(\mathrm{kg} / \mathrm{h})$ & $8.32 \mathrm{E}+02$ & & & $2.14 \mathrm{E}+03$ & $7.52 \mathrm{E}+02$ & $7.52 \mathrm{E}+02$ & & & $4.89 \mathrm{E}+01$ & $2.08 \mathrm{E}+03$ & $7.03 \mathrm{E}+02$ & $1.29 \mathrm{E}+02$ & $1.29 \mathrm{E}+02$ & $7.03 \mathrm{E}+02$ & $7.03 \mathrm{E}+02$ & \\
\hline Process time@100\% TOE hrs & 2,169 & -- & -- & -- & -- & -- & -- & -- & -- & -- & - & -- & -- & -- & -- & -- \\
\hline Process time@70\% TOE hrs & 3,098 & -- & -- & -- & -- & -- & -- & -- & -- & -- & -- & -- & -- & -- & -- & -- \\
\hline
\end{tabular}

otes:

1. Volume and density of liquid phase only.
2. Sulfate can be directed to LAW or Cs prod 
Detailed calculations of system temperatures and pressures were not included in the material balances for technology comparisons. The nominal steady state crystallizer operating temperature is $50 \mathrm{C}$ for identified IPS waste feed batches. The reboiler (waste side), centrifuge, dissolver, product filter, pumps, and interconnecting piping operate near the crystallizer temperature. The reboiler uses low pressure saturated steam for heating, and the vacuum steam jets uses medium pressure steam (approximately $100 \mathrm{psig}$ ). The crystallizer will be operated under vacuum. Minimum pressure (maximum vacuum) of 0.035 atmosphere absolute is estimated for batch 8 . Reboiler recirculation uses a low head axial flow pump with a discharge pressure of about $20 \mathrm{psi}$. Other process pumps are expected to have typical discharge pressures on the order of 20 to $100 \mathrm{psig}$.

\subsubsection{Equipment List and Sizing}

Table 6-27 provides a summary of major equipment required for the pre-conceptual fractional crystallization process. 
Table 6-27 Fractional Crystallization Equipment List

(9 sheets)

\begin{tabular}{|c|c|c|c|c|c|}
\hline Qty & Component & Process Sizing & Physical Dimensions & Features & Comments \\
\hline 1 & Feed Receipt Tank & $\begin{array}{l}32,000 \text { gal total } \\
\text { capacity }\end{array}$ & 17.6-ft D x 17.6-ft H & $\begin{array}{l}\text { Clean out jet to empty tank in } \\
\text { case of failed pump } \\
\text { Nozzles: (3) process piping } \\
\text { (1) off gas } \\
\text { (1) pump } \\
\text { (3) instrumentation } \\
\text { (1) PRV } \\
\text { I\&C: Level } \\
\text { Temperature } \\
\text { Pressure control (offgas) }\end{array}$ & $\begin{array}{l}\text { Provides } 1 \text { day of crystallizer feed for } \\
\text { the worst case feed flow rate }\end{array}$ \\
\hline 1 & Feed Pump, Crystallizer 1 & $25 \mathrm{gpm}$ & & $\begin{array}{l}\text { Tank top mounted, vertical } \\
\text { pump } \\
\text { I\&C: Discharge pressure } \\
\text { Flow control } \\
\text { VFD } \\
\end{array}$ & $\begin{array}{l}\text { Flow rate is the maximum waste feed } \\
\text { flow rate of } 17.3 \mathrm{gpm} .\end{array}$ \\
\hline 2 & LAW Product Tanks & $\begin{array}{l}23,000 \text { gal total } \\
\text { capacity }\end{array}$ & 15.8-ft D x 15.8-ft H & $\begin{array}{l}\text { Clean out jet to empty tank in } \\
\text { case of failed pump } \\
\text { Nozzles: (4) process piping } \\
\text { (1) off gas } \\
\text { (1) pump } \\
\text { (1) mixer } \\
\text { (3) instrumentation } \\
\text { (1) sample } \\
\text { (1) PRV } \\
\text { I\&C: Level } \\
\text { Temperature } \\
\text { Pressure control (offgas) } \\
\text { Radiation monitor on } \\
\text { inflow }\end{array}$ & $\begin{array}{l}\text { Working volume for storing four days } \\
\text { of treated LAW at the maximum } \\
\text { production rate in each tank }\end{array}$ \\
\hline 2 & LAW Product Pumps & $100 \mathrm{gpm}$ & & $\begin{array}{l}\text { Tank top mounted, vertical } \\
\text { pump } \\
\text { I\&C: Discharge pressure } \\
\text { Flow control } \\
\text { VFD } \\
\end{array}$ & $\begin{array}{l}\text { Design basis flow rate for feed to } \\
\text { LAW is } 88 \mathrm{gpm} \text {. }\end{array}$ \\
\hline
\end{tabular}


RPP-RPT-37551, Rev. 1

Table 6-27 Fractional Crystallization Equipment List

(9 sheets)

\begin{tabular}{|c|c|c|c|c|c|}
\hline$\overline{\text { Qty }}$ & Component & Process Sizing & Physical Dimensions & Features & Comments \\
\hline 1 & Cs Product Tank & $\begin{array}{l}8,600 \text { gal total } \\
\text { capacity }\end{array}$ & 11.4-ft D x 11.4-ft H & $\begin{array}{l}\text { Clean out jet to empty tank in } \\
\text { case of failed pump } \\
\text { Nozzles: (4) process piping } \\
\text { (1) off gas } \\
\text { (1) pump } \\
\text { (3) instrumentation } \\
\text { (1) sample } \\
\text { (1) PRV } \\
\text { I\&C: Level } \\
\text { Temperature control } \\
\text { Pressure control (offgas) }\end{array}$ & $\begin{array}{l}\text { Volume for storing one day of input } \\
\text { from the worst case throughput. }\end{array}$ \\
\hline 1 & Cs Product Pump & $100 \mathrm{gpm}$ & & $\begin{array}{l}\text { Tank top mounted, vertical } \\
\text { pump } \\
\text { I\&C: Discharge pressure } \\
\text { Flow control } \\
\text { VFD } \\
\end{array}$ & $\begin{array}{l}\text { Flow rate for return to tank farms } \\
\text { assumed to be approximately } 75 \mathrm{gpm} \text {. }\end{array}$ \\
\hline \multicolumn{6}{|c|}{ 1st Stage Cry stallization } \\
\hline 1 & Reboiler, 1st stage & $11,000,000 \mathrm{BTU} / \mathrm{hr}$ & & $\begin{array}{l}\text { Includes small condensate } \\
\text { pump }\end{array}$ & Sized based on highest boilup rate. \\
\hline 1 & Crystallizer, 1st stage & $\begin{array}{l}6200 \text { gal working } \\
\text { volume }\end{array}$ & $\begin{array}{l}8 \mathrm{ft} \mathrm{minimum} \mathrm{freeboard} \mathrm{including} \\
\text { transition to demister. Approx } 9 \mathrm{ft} 9 \\
\text { inch outside diameter X } 23 \mathrm{ft} \text { tall } \\
\text { vessel plus } 4 \mathrm{ft} \mathrm{dia} \mathrm{X} 4 \mathrm{ft} \text { demister } \\
\text { section on top. }\end{array}$ & Design for full vacuum & $\begin{array}{l}\text { Crystallizer volume is sized to provide } \\
\text { an } 8 \text { hour residence time at the } \\
\text { maximum centrifuge feed rate (Stream } \\
\text { 19). }\end{array}$ \\
\hline 1 & $\begin{array}{l}\text { Crystallizer } \\
\text { Recirculation Pump, 1st } \\
\text { stage }\end{array}$ & $\begin{array}{l}5600 \text { gpm low head } \\
20 \mathrm{psid} \\
125 \mathrm{Hp}\end{array}$ & & & $\begin{array}{l}\text { Flow based on scale factor comparing } \\
\text { the boilup rate with that of the } 242 \mathrm{~A} \\
\text { Evaporator }(0.4 \text { for Stage } 1) \text {. }\end{array}$ \\
\hline 1 & Condenser, 1st stage & $8,500,000 \mathrm{Btu} / \mathrm{hr}$ & & $\begin{array}{l}\text { Includes small condensate } \\
\text { pump }\end{array}$ & $\begin{array}{l}\text { Sized to condense maximum boilup } \\
\text { rate. }\end{array}$ \\
\hline 1 & $\begin{array}{l}\text { Condenser Vacuum } \\
\text { Pump (steam powered } \\
\text { eductor), 1st stage }\end{array}$ & $\begin{array}{l}131 \mathrm{lb} / \mathrm{hr} \text { saturated air, } \\
0.035 \mathrm{~atm} \text { suction } \\
\text { pressure }\end{array}$ & & Steam Powered Eductor & $\begin{array}{l}\text { Non-condensable suction flow of } 40 \\
1 \mathrm{~b} / \mathrm{hr} \text { based on scale factor comparing } \\
\text { the boilup rate with that of the } 242 \mathrm{~A} \\
\text { Evaporator }(0.4 \text { for Stage } 1)\end{array}$ \\
\hline 1 & $\begin{array}{l}\text { Centrifuge Feed Pump, } \\
\text { 1st stage }\end{array}$ & $\begin{array}{l}15 \text { gpm crystal slurry, } \\
\text { density } 1.74\end{array}$ & & & $\begin{array}{l}\text { Based on maximum steady state flow } \\
\text { of slurry from the crystallizer (Stream } \\
\text { 19) }\end{array}$ \\
\hline
\end{tabular}


RPP-RPT-37551, Rev. 1

Table 6-27 Fractional Crystallization Equipment List

(9 sheets)

\begin{tabular}{|c|c|c|c|c|c|}
\hline Qty & Component & Process Sizing & Physical Dimensions & Features & Comments \\
\hline 1 & Centrifuge, 1st stage & $\begin{array}{l}15 \text { gpm crystal slurry, } \\
\text { feed, } 1800 \mathrm{~kg} / \mathrm{hr} \\
(4000 \mathrm{lb} / \mathrm{hr}) \text { solids } \\
\text { product }\end{array}$ & & Peeler type centrifuge & $\begin{array}{l}\text { Based on maximum steady state flow } \\
\text { of slurry from the crystallizer (Stream } \\
\text { 19) }\end{array}$ \\
\hline 1 & Dissolver Tank, 1st stage & $\begin{array}{l}1,000 \text { gal working } \\
\text { volume }\end{array}$ & $5.0-\mathrm{ft} \mathrm{D} \times 10.0-\mathrm{ft} \mathrm{H}$ & $\begin{array}{l}\text { Nozzles: (4) process piping } \\
\text { (1) off gas } \\
\text { (1) pump } \\
\text { (3) instrumentation } \\
\text { (1) PRV } \\
\text { I\&C: Level } \\
\text { Temperature } \\
\text { Pressure control (offgas) }\end{array}$ & Standardized in-cell process tank \\
\hline 1 & $\begin{array}{l}\text { Dissolver Recirculation } \\
\text { Pump, 1st stage }\end{array}$ & $60 \mathrm{gpm}$ & & $\begin{array}{l}\text { Tank top mounted, vertical } \\
\text { pump } \\
\text { I\&C: Discharge pressure } \\
\text { Flow control } \\
\text { VFD } \\
\end{array}$ & $\begin{array}{l}\text { Sized for maximum heat exchanger } \\
\text { temperature difference of } 20 \mathrm{~F} \text {. }\end{array}$ \\
\hline 1 & $\begin{array}{l}\text { Dissolver Discharge } \\
\text { Pump, 1st stage }\end{array}$ & $20 \mathrm{gpm}$ & & $\begin{array}{l}\text { Tank top mounted, vertical } \\
\text { pump } \\
\text { I\&C: Discharge pressure } \\
\text { Flow control } \\
\text { VFD } \\
\end{array}$ & $\begin{array}{l}\text { Flow rate based on } 1.5 \mathrm{X} \text { the worst } \\
\text { case dissolver discharge flow rate. }\end{array}$ \\
\hline 1 & Dissolver filter, 1st stage & $\begin{array}{l}\text { Feed } 15 \mathrm{gpm} \text {, filtrate } \\
6 \mathrm{gpm}\end{array}$ & & $\begin{array}{l}5 \text { micron pore size, } 70 \mathrm{psi} \\
\text { filter differential pressure }\end{array}$ & $\begin{array}{l}\text { Filtrate is } 1.5 \mathrm{X} \text { maximum steady state } \\
\text { rate (Batch 2) }\end{array}$ \\
\hline 1 & $\begin{array}{c}\text { Dissolver Heat } \\
\text { Exchanger, 1st stage }\end{array}$ & $600,000 \mathrm{Btu} / \mathrm{hr}$ & & & $\begin{array}{l}\text { Sized to heat highest flow rate of } \\
\text { added dissolution water from } 70 \mathrm{~F} \text { to } \\
140 \mathrm{~F} \text {, times } 2 \mathrm{X} \text {. }\end{array}$ \\
\hline 1 & $\begin{array}{l}\text { Condensate Tank, 1st } \\
\text { stage }\end{array}$ & $\begin{array}{l}2,000 \text { gal working } \\
\text { volume }\end{array}$ & $7.0-\mathrm{ft} \mathrm{D} \times 7.0-\mathrm{ft} \mathrm{H}$ & $\begin{array}{l}\text { Outside, double wall tank } \\
\text { Nozzles: (2) process piping } \\
\text { (1) off gas } \\
\text { (1) pump } \\
\text { (3) instrumentation } \\
\text { (1) PRV } \\
\text { I\&C: Level } \\
\text { Temperature } \\
\text { Pressure control (offgas) } \\
\text { Leak detection } \\
\end{array}$ & $\begin{array}{l}\text { Volume to store } 2 \text { hour capacity for } \\
\text { worst case condensate flow rate. }\end{array}$ \\
\hline
\end{tabular}


RPP-RPT-37551, Rev. 1

Table 6-27 Fractional Crystallization Equipment List

(9 sheets)

\begin{tabular}{|c|c|c|c|c|c|}
\hline Qty & Component & Process Sizing & Physical Dimensions & Features & Comments \\
\hline 1 & $\begin{array}{l}\text { Condensate Pump, 1st } \\
\text { stage }\end{array}$ & $40 \mathrm{gpm}$ & & $\begin{array}{l}\text { Tank top mounted, vertical } \\
\text { pump } \\
\text { I\&C: Discharge pressure } \\
\text { Flow control } \\
\text { VFD }\end{array}$ & $\begin{array}{l}\text { Flow rate based on } 2.5 \mathrm{X} \text { the worst } \\
\text { case condensate flow rate. }\end{array}$ \\
\hline 1 & $\begin{array}{l}\text { Spent Wash Tank, 1st } \\
\text { stage }\end{array}$ & $\begin{array}{l}1,000 \text { gal working } \\
\text { volume }\end{array}$ & $5.0-\mathrm{ft} \mathrm{D} \times 10.0-\mathrm{ft} \mathrm{H}$ & $\begin{array}{l}\text { Nozzles: (2) process piping } \\
\text { (1) off gas } \\
\text { (1) pump } \\
\text { (3) instrumentation } \\
\text { (1) PRV } \\
\text { I\&C: Level } \\
\text { Temperature } \\
\text { Pressure control (offgas) }\end{array}$ & Standardized in-cell process tank \\
\hline 1 & $\begin{array}{l}\text { Spent Wash Pump, 1st } \\
\text { stage }\end{array}$ & $15 \mathrm{gpm}$ & & $\begin{array}{l}\text { Tank top mounted, vertical } \\
\text { pump } \\
\text { I\&C: Discharge pressure } \\
\text { Flow control } \\
\text { VFD }\end{array}$ & $\begin{array}{l}\text { Flow rate based on } 2.5 \mathrm{X} \text { the worst } \\
\text { case wash liquor flow rate. }\end{array}$ \\
\hline 1 & $\begin{array}{l}\text { Centrifuge Liquor Tank, } \\
\text { 1st stage }\end{array}$ & $\begin{array}{l}1,000 \text { gal working } \\
\text { volume }\end{array}$ & $5.0-\mathrm{ft} \mathrm{D} \times 10.0-\mathrm{ft} \mathrm{H}$ & $\begin{array}{l}\text { Nozzles: (2) process piping } \\
\text { (1) off gas } \\
\text { (1) pump } \\
\text { (3) instrumentation } \\
\text { (1) PRV } \\
\text { I\&C: Level } \\
\text { Temperature } \\
\text { Pressure control (offgas) }\end{array}$ & Standardized in-cell process tank \\
\hline 1 & $\begin{array}{l}\text { Centrifuge Liquor pump, } \\
\text { 1st stage }\end{array}$ & $25 \mathrm{gpm}$ & & $\begin{array}{l}\text { Tank top mounted, vertical } \\
\text { pump } \\
\text { I\&C: Discharge pressure } \\
\text { Flow control } \\
\text { VFD } \\
\end{array}$ & $\begin{array}{l}\text { Flow rate based on } 2.5 \mathrm{X} \text { the worst } \\
\text { case crystallizer product flow rate. }\end{array}$ \\
\hline \multicolumn{6}{|c|}{ 2nd Stage Crystallization } \\
\hline 1 & Reboiler, 2nd stage & $5,500,000 \mathrm{BTU} / \mathrm{hr}$ & & $\begin{array}{l}\text { Includes small condensate } \\
\text { pump }\end{array}$ & Sized based on highest boilup rate. \\
\hline
\end{tabular}


RPP-RPT-37551, Rev. 1

Table 6-27 Fractional Crystallization Equipment List

(9 sheets)

\begin{tabular}{|c|c|c|c|c|c|}
\hline$\overline{\text { Qty }}$ & Component & Process Sizing & Physical Dimensions & Features & Comments \\
\hline 1 & Crystallizer, 2nd stage & $\begin{array}{l}6200 \text { gal working } \\
\text { volume }\end{array}$ & $\begin{array}{l}8 \mathrm{ft} \text { minimum freeboard including } \\
\text { transition to demister. Approx } 9 \mathrm{ft} 9 \\
\text { inch outside diameter X } 23 \mathrm{ft} \text { tall } \\
\text { vessel plus } 4 \mathrm{ft} \mathrm{dia} \mathrm{X} 4 \mathrm{ft} \text { demister } \\
\text { section on top. }\end{array}$ & Design for full vacuum & $\begin{array}{l}\text { Crystallizer volume is sized to provide } \\
\text { an } 8 \text { hour residence time at the } \\
\text { maximum centrifuge feed rate (Stream } \\
\text { 19). } 5000 \text { gal for Stage } 2 \text {, but } \\
\text { Crystallizer is sized to be equal to } \\
\text { Stage } 1 .\end{array}$ \\
\hline 1 & $\begin{array}{l}\text { Crystallizer } \\
\text { Recirculation Pump, 2nd } \\
\text { stage }\end{array}$ & $\begin{array}{l}2800 \text { gpm low head } \\
20 \text { psid } \\
75 \mathrm{Hp}\end{array}$ & & & $\begin{array}{l}\text { Flow based on scale factor comparing } \\
\text { the boilup rate with that of the } 242 \mathrm{~A} \\
\text { Evaporator }(0.2 \text { for Stage } 2) \text {. }\end{array}$ \\
\hline 1 & Condenser, 2nd stage & $4,500,000 \mathrm{Btu} / \mathrm{hr}$ & & $\begin{array}{l}\text { Includes small condensate } \\
\text { pump }\end{array}$ & $\begin{array}{l}\text { Sized to condense maximum boilup } \\
\text { rate. }\end{array}$ \\
\hline 1 & \begin{tabular}{l}
\multicolumn{1}{c}{ Condenser Vacuum } \\
Pump (Steam Powered \\
Eductor), 2nd stage
\end{tabular} & $\begin{array}{l}65 \mathrm{lb} / \mathrm{hr} \text { air saturated } \\
\text { with water vapor, } 0.57 \\
\text { psia suction pressure }\end{array}$ & & (Steam Powered Eductor) & $\begin{array}{l}\text { Non-condensable suction flow of } 20 \\
\mathrm{lb} / \mathrm{hr} \text { based on scale factor comparing } \\
\text { the boilup rate with that of the } 242 \mathrm{~A} \\
\text { Evaporator }(0.2 \text { for Stage } 2) \text {. }\end{array}$ \\
\hline 1 & $\begin{array}{l}\text { Centrifuge Feed Pump, } \\
\text { 2nd stage }\end{array}$ & $\begin{array}{l}\text { Size same as first } \\
\text { stage }\end{array}$ & & & Size same as first stage \\
\hline 1 & Centrifuge, 2nd stage & $\begin{array}{l}\text { Size same as first } \\
\text { stage }\end{array}$ & & Peeler type centrifuge & Size same as first stage \\
\hline 1 & $\begin{array}{l}\text { Dissolver Tank, 2nd } \\
\text { stage }\end{array}$ & $\begin{array}{l}1,000 \text { gal working } \\
\text { volume }\end{array}$ & $5.0-\mathrm{ft} \mathrm{D} \times 10.0-\mathrm{ft} \mathrm{H}$ & $\begin{array}{l}\text { Nozzles: (4) process piping } \\
\text { (1) off gas } \\
\text { (1) pump } \\
\text { (3) instrumentation } \\
\text { (1) PRV } \\
\text { I\&C: Level } \\
\text { Temperature } \\
\text { Pressure control (offgas) }\end{array}$ & Standardized in-cell process tank \\
\hline 1 & $\begin{array}{l}\text { Dissolver Recirculation } \\
\text { Pump, 2nd stage }\end{array}$ & $30 \mathrm{gpm}$ & & $\begin{array}{l}\text { Tank top mounted, vertical } \\
\text { pump } \\
\text { I\&C: Discharge pressure } \\
\text { Flow control } \\
\text { VFD }\end{array}$ & $\begin{array}{l}\text { Sized for maximum heat exchanger } \\
\text { temperature difference of } 20 \mathrm{~F} \text {. }\end{array}$ \\
\hline 1 & $\begin{array}{l}\text { Dissolver Discharge } \\
\text { Pump, 2nd stage }\end{array}$ & $15 \mathrm{gpm}$ & & $\begin{array}{l}\text { Tank top mounted, vertical } \\
\text { pump } \\
\text { I\&C: Discharge pressure } \\
\text { Flow control } \\
\text { VFD }\end{array}$ & $\begin{array}{l}\text { Flow rate based on } 1.5 \mathrm{X} \text { the worst } \\
\text { case dissolver discharge flow rate. }\end{array}$ \\
\hline
\end{tabular}


Table 6-27 Fractional Crystallization Equipment List

(9 sheets)

\begin{tabular}{|c|c|c|c|c|c|}
\hline Qty & Component & Process Sizing & Physical Dimensions & Features & Comments \\
\hline 1 & $\begin{array}{c}\text { Dissolver Heat } \\
\text { Exchanger, 2nd stage }\end{array}$ & $300,000 \mathrm{Btu} / \mathrm{hr}$ & & & $\begin{array}{l}\text { Sized to heat highest flow rate of } \\
\text { added dissolution water from } 40 \mathrm{~F} \text { to } \\
140 \mathrm{~F} \text {, times } 2 \mathrm{X} \text {. }\end{array}$ \\
\hline 1 & $\begin{array}{l}\text { Dissolver filter, 2nd } \\
\text { stage }\end{array}$ & $\begin{array}{l}\text { Feed } 10 \mathrm{gpm} \text {, filtrate } \\
8 \mathrm{gpm}\end{array}$ & & $\begin{array}{l}5 \text { micron pore size, } 70 \mathrm{psi} \\
\text { filter differential pressure }\end{array}$ & $\begin{array}{l}\text { Feed is } 1.5 \mathrm{X} \text { and filtrate is } 1.4 \mathrm{X} \\
\text { maximum steady state rate for filter } \\
\text { feed (Batch 2). Sized to allow } \\
\text { flexibility to provide concentrated } \\
\text { sulfate product (filter product slurry) }\end{array}$ \\
\hline 1 & $\begin{array}{l}\text { Condensate Tank, 2nd } \\
\text { stage }\end{array}$ & $\begin{array}{l}2,000 \text { gal total } \\
\text { capacity }\end{array}$ & $7.0-\mathrm{ft} \mathrm{D} \times 7.0-\mathrm{ft} \mathrm{H}$ & $\begin{array}{l}\text { Outside, double wall tank } \\
\text { Nozzles: (2) process piping } \\
\text { (1) off gas } \\
\text { (1) pump } \\
\text { (3) instrumentation } \\
\text { (1) PRV } \\
\text { I\&C: Level } \\
\text { Temperature } \\
\text { Pressure control (offgas) } \\
\text { Leak detection }\end{array}$ & $\begin{array}{l}\text { Volume to store } 2 \text { hour capacity for } \\
\text { worst case condensate flow rate. }\end{array}$ \\
\hline 1 & $\begin{array}{l}\text { Condensate Pump, 2nd } \\
\text { stage }\end{array}$ & $20 \mathrm{gpm}$ & & $\begin{array}{l}\text { Tank top mounted, vertical } \\
\text { pump } \\
\text { I\&C: Discharge pressure } \\
\text { Flow control } \\
\text { VFD } \\
\end{array}$ & $\begin{array}{l}\text { Flow rate based on } 2.5 \mathrm{X} \text { the worst } \\
\text { case condensate flow rate. }\end{array}$ \\
\hline 1 & $\begin{array}{l}\text { Spent Wash Tank, 2nd } \\
\text { stage }\end{array}$ & $\begin{array}{l}1,000 \text { gal working } \\
\text { volume }\end{array}$ & $5.0-\mathrm{ft} \mathrm{D} \times 10.0-\mathrm{ft} \mathrm{H}$ & $\begin{array}{l}\text { Nozzles: (2) process piping } \\
\text { (1) off gas } \\
\text { (1) pump } \\
\text { (3) instrumentation } \\
\text { (1) PRV } \\
\text { I\&C: Level } \\
\text { Temperature } \\
\text { Pressure control (offgas) }\end{array}$ & Standardized in-cell process tank \\
\hline 1 & $\begin{array}{l}\text { Spent Wash Pump, 2nd } \\
\text { stage }\end{array}$ & $10 \mathrm{gpm}$ & & $\begin{array}{l}\text { Tank top mounted, vertical } \\
\text { pump } \\
\text { I\&C: Discharge pressure } \\
\text { Flow control } \\
\text { VFD } \\
\end{array}$ & $\begin{array}{l}\text { Flow rate based on } 2.5 \mathrm{X} \text { the worst } \\
\text { case wash liquor flow rate. }\end{array}$ \\
\hline
\end{tabular}


RPP-RPT-37551, Rev. 1

Table 6-27 Fractional Crystallization Equipment List

(9 sheets)

\begin{tabular}{|c|c|c|c|c|c|}
\hline Qty & Component & Process Sizing & Physical Dimensions & Features & Comments \\
\hline 1 & $\begin{array}{l}\text { Centrifuge Liquor Tank, } \\
\text { 2nd stage }\end{array}$ & $\begin{array}{l}1,000 \text { gal working } \\
\text { volume }\end{array}$ & $5.0-\mathrm{ft} \mathrm{D} \times 10.0-\mathrm{ft} \mathrm{H}$ & $\begin{array}{l}\text { Nozzles: (2) process piping } \\
\text { (1) off gas } \\
\text { (1) pump } \\
\text { (3) instrumentation } \\
\text { (1) PRV } \\
\text { I\&C: Level } \\
\text { Temperature } \\
\text { Pressure control (offgas) }\end{array}$ & Standardized in-cell process tank. \\
\hline 1 & $\begin{array}{l}\text { Centrifuge Liquor pump, } \\
\text { 2nd stage }\end{array}$ & $20 \mathrm{gpm}$ & & $\begin{array}{l}\text { Tank top mounted, vertical } \\
\text { pump } \\
\text { I\&C: Discharge pressure } \\
\text { Flow control } \\
\text { VFD } \\
\end{array}$ & $\begin{array}{l}2.5 \text { times maximum Stream } 31 \text { liquid } \\
\text { phase }\end{array}$ \\
\hline 1 & $\begin{array}{l}\text { High sulfate product } \\
\text { Tank, 2nd stage }\end{array}$ & $\begin{array}{l}1,000 \text { gal working } \\
\text { volume }\end{array}$ & $5.0-\mathrm{ft} \mathrm{D} \times 10.0-\mathrm{ft} \mathrm{H}$ & $\begin{array}{l}\text { Nozzles: (2) process piping } \\
\text { (1) off gas } \\
\text { (1) pump } \\
\text { (3) instrumentation } \\
\text { (1) PRV } \\
\text { I\&C: Level } \\
\text { Temperature } \\
\text { Pressure control (offgas) }\end{array}$ & Standardized in-cell process tank \\
\hline 1 & $\begin{array}{l}\text { High sulfate product } \\
\text { Pump, 2nd stage }\end{array}$ & $10 \mathrm{gpm}$ & & $\begin{array}{l}\text { Tank top mounted, vertical } \\
\text { pump } \\
\text { I\&C: Discharge pressure } \\
\text { Flow control } \\
\text { VFD } \\
\end{array}$ & $\begin{array}{l}\text { Sized the same as the 2nd stage } \\
\text { dissolver pump }\end{array}$ \\
\hline \multicolumn{6}{|c|}{ Miscellaneous } \\
\hline 1 & Steam Supply System & $\begin{array}{l}25,000 \mathrm{lb} / \mathrm{hr} \\
100 \mathrm{psig} \text { (vacuum } \\
\text { pumps) } \\
3 \text { psig (reboilers) }\end{array}$ & & $\begin{array}{l}\text { Loads: (2) Reboilers } \\
\text { (2) Vacuum Pumps } \\
\text { (2) Dissolver } \mathrm{Hx}\end{array}$ & $\begin{array}{l}\text { Based on condensing } 3 \text { psig steam in } \\
\text { reboiler and dissolver plus vacuum } \\
\text { pump steam demand. }\end{array}$ \\
\hline \multicolumn{6}{|c|}{ Structures, FC System } \\
\hline 1 & Crystallizer Building & & $\begin{array}{l}80^{\prime} \mathrm{L} \times 30^{\prime} \mathrm{W} \times 38^{\prime} \mathrm{H} \\
\text { Base } 18^{\prime} \text { below grade }\end{array}$ & $\begin{array}{l}\text { Separate process, } \\
\text { maintenance and operating } \\
\text { areas. See layout. } \\
\text { Process area below grade } \\
\text { with similar construction as } \\
\text { Tank/Equipment vaults. }\end{array}$ & See section 8 for description of layout \\
\hline
\end{tabular}


RPP-RPT-37551, Rev. 1

Table 6-27 Fractional Crystallization Equipment List

(9 sheets)

\begin{tabular}{|c|c|c|c|c|c|}
\hline$\overline{\text { Qty }}$ & Component & Process Sizing & Physical Dimensions & Features & Comments \\
\hline 4 & $\begin{array}{l}\text { Tank/Equipment Vaults } \\
\text { Feed Receipt Tank } \\
\text { Cs Product Tank } \\
\text { LAW Product Tank \#1 } \\
\text { LAW Product Tank \#2 }\end{array}$ & & $\begin{array}{l}22^{\prime} \mathrm{L} \times 22^{\prime} \mathrm{W} \times 25^{\prime} \mathrm{H} \\
22^{\prime} \mathrm{L} \times 16^{\prime} \mathrm{W} \times 25^{\prime} \mathrm{H} \\
23^{\prime} \mathrm{L} \times 20^{\prime} \mathrm{W} \times 25^{\prime} \mathrm{H} \\
23^{\prime} \mathrm{L} \times 20^{\prime} \mathrm{W} \times 25^{\prime} \mathrm{H} \\
\end{array}$ & $\begin{array}{l}\text { Concrete below grade } \\
\text { structure with } 3 \text {-ft thick walls } \\
\text { and floors } \\
\text { 3-ft thick concrete cover } \\
\text { blocks at grade consisting of } \\
12 \text { 2" wide removable concrete } \\
\text { beams. } \\
\text { Stainless steel lined floor and } \\
\text { walls up to bottom of cover } \\
\text { blocks } \\
\text { Sump with remote read-out } \\
\text { leak detector and sump pump } \\
\text { for each vault } \\
\text { Remote connector heads }\end{array}$ & \\
\hline 1 & Valve Vault & & $\begin{array}{l}22^{\prime} \mathrm{L} \times 10^{\prime} \mathrm{W} \times 15^{\prime} \mathrm{H} \\
\text { Internal Dimensions }\end{array}$ & $\begin{array}{l}\text { One valve vault adjacent to } \\
\text { and serving all tank vaults } \\
\text { Concrete below grade } \\
\text { structure with } 3 \text {-ft thick walls } \\
\text { and floors } \\
\text { 3-ft thick concrete cover } \\
\text { blocks at grade consisting of } \\
12 \text { " wide removable concrete } \\
\text { beams. } \\
\text { Stainless steel lined floor and } \\
\text { walls up to bottom of cover } \\
\text { blocks } \\
\text { Sump with remote read-out } \\
\text { leak detector and sump pump } \\
\text { Remote connector heads }\end{array}$ & \\
\hline 4 & $\begin{array}{l}\text { Equipment Pads } \\
\text { Condensate Tank, 1st } \\
\text { Stage } \\
\text { Condensate Tank, 2nd } \\
\text { Stage } \\
\text { Steam Boiler } \\
\text { Chiller (see Common } \\
\text { Equipment) }\end{array}$ & & $\begin{array}{l}17^{\prime} \mathrm{L} \times 17^{\prime} \mathrm{W} \\
14^{\prime} \mathrm{L} \times 14^{\prime} \mathrm{W} \\
16^{\prime} \mathrm{L} \times 14^{\prime} \mathrm{W}\end{array}$ & 8-in thick pad & \\
\hline
\end{tabular}


RPP-RPT-37551, Rev. 1

Table 6-27 Fractional Crystallization Equipment List (9 sheets)

\begin{tabular}{|l|c|c|c|c|c|}
\hline Qty & Component & Process Sizing & Physical Dimensions & Features & Comments \\
\hline
\end{tabular}

neral Notes:

1. All tanks are designed, fabricated and tested to ASME Section VIII

2. All process piping is designed, fabricated and tested to ASME B31.3

3. All process equipment, chemical equipment and offgas piping is manufactured from $304 \mathrm{~L}$ or $316 \mathrm{~L}$ SS

4. See Common Equipment List for process offgas, vault ventilation, recirculation AHU, and chilled water systems.

5. Tanks are sized assuming a working volume equal to $80 \%$ of the total capacity. 


\subsubsection{Process Consumables Summary}

The fractional crystallization process does not require chemical additives or consumable resins, solvents, filters, etc. Primary process consumables are steam and electricity.

Maximum steam use for process heating is estimated at 25000 pounds per hour. Except for a small fraction used for the steam vacuum jets, the condensate is returned for reuse or disposal. Steam and condensate disposition would be provided by a new or existing system. Per agreement on scope of the current study, CH2MHILL Hanford is responsible for defining the systems for supplying steam and dispositioning condensate.

Steam demand for the crystallizer reboilers will vary substantially from batch to batch because of variation in feed concentration and net sodium yield fraction.

Estimated maximum power demand is listed below for steady state operation with the worst case (Batch 8) waste feed.

Fractional crystallization process equipment Process chilled water system

Total
$175 \mathrm{kw}$

$800 \mathrm{kw}$

$975 \mathrm{kw}^{1}$

${ }^{1}$ Does not include feed filtration, product transfer pumps, lighting, ventilation, control room and other support functions.

The process chilled water system utilizes a closed loop of water that is cooled with a refrigeration system. Crystallizer steam condensing is the primary load for the chilled water system. The chiller power load will vary substantially seasonally and from batch to batch because of variation in ambient temperature and crystallizer steam usage and related condenser load. Heat rejection from the refrigeration system requires a maximum of approximately 1700 gpm of cooling water. Once through flow of raw water could be considered as currently used at the 242-A evaporator, or a recirculation system could be used with a cooling tower. A cooling tower based system would result in a maximum $35 \mathrm{gpm}$ water evaporation, $70 \mathrm{gpm}$ raw water makeup, and about $35 \mathrm{gpm}$ purge water returned for disposal.

\subsubsection{Risk/Issue Identification and Potential Optimization Items}

This section discusses risks, technical issues, and potential optimization items related to use of fractional crystallization technology. This includes potential problems and unknowns, and potential optimization items related to design, operation, and integration of the fractional crystallization process into tank farm operations. 
6.2.8.1 Risk and Issue Identification. During review of fractional crystallization technology and its proposed use for treating Hanford tank waste potential risks and issues were identified as discussed below.

- Pilot plant testing has not yet been completed. This creates uncertainty in equipment and process performance estimates. In addition, initially planned pilot testing was focused on different objectives, requirements, and target tank wastes than the early LAW IPS scenario. Potential mitigation includes completion of planned testing and extended pilot plant testing to provide more focus on IPS objectives and needs, in conjunction with firming up the flowsheet and equipment selection for fractional crystallization to support IPS.

- Extension of Evaporation Endpoint Above Ranges Tested. Some planned IPS waste feeds are difficult to crystallize, resulting in low sodium yield in the LAW product. Early process development work focused on 20 mole/ 1 ionic strength as the end point of evaporation (for example, see RPP-PLAN-27238 page E-4). For the current study a higher evaporation cut off of about 23 mole/1 ionic strength has been used to provide reasonable net sodium yields with wastes chosen for IPS technology comparisons in the current study. Because previous evaluations and test data have been in the lower range, there is increased risk of unexpected behavior and processing problems at the higher concentrations. Primary mitigation is to perform laboratory and pilot plant testing at higher evaporation end point to verify acceptable behavior. In addition, other approaches to increase the sodium yield may be considered as discussed in Section 6.2.8.2.

- Sulfate disposition. Fractional crystallization preferentially removes sulfate from the waste. At flowsheet dissolver conditions, most sulfate remains in the solids while the bulk of the sodium is dissolved. The dissolver product stream can be split into low sulfate and high sulfate fractions by filtration. With a blended LAW product containing both the high and low sulfate products, mass balance calculations show sulfate to sodium ratios in the overall product are above the WTP envelope A limit but below the envelope $\mathrm{B}$ limit. Part of the high sulfate product may be blended into the Cs product so that the primary LAW product meets the envelope A limit. The flowsheet could be tuned so that both the decontaminated product and the high cesium purge are within the sulfate $/ \mathrm{Na}$ limits. Another alternative is to collect the high sulfate product separately as a segregated low activity waste product and dispose of the sulfate by some means other than vitrification in WTP, e. g. by processing it in the ETF. The base case mass balance includes the sulfate in the primary LAW product, resulting in compositions above envelope A but below envelope B. Equipment is provided to allow the high sulfate stream to be blended into the $\mathrm{Cs}$ to meet the Envelope A limit. Additional equipment is expected to be required to treat the high sulfate product to meet ETF waste acceptance requirements. Preferred method of dispositioning the sulfate will need to be finalized prior to detailed design to allow equipment and flowsheet design to be finalized. Flexibility could be provided to allow operations to control how the sulfate is directed on a case by case basis. 
- High Aluminum Content of Cesium Product Stream. Fractional crystallization returns essentially all soluble aluminum and hydroxide from the waste feed to the high cesium product. When this waste is eventually processed through ion exchange at the WTP a substantial amount of sodium hydroxide will need to be added to avoid aluminum hydroxide precipitation. Analysis of sodium addition required was outside the scope of the current study. Precipitation of aluminum and removal as a solid prior to processing in the WTP ion exchange system is the only mitigation identified. Preliminary testing suggests that aluminum can be precipitated as gibbsite or low solubility lithium/aluminum compounds that may be decontaminated by water washing. If aluminum bearing solids were removed and sufficiently decontaminated, they could potentially be disposed of by incorporation in LAW glass or possibly as a separate secondary waste product, eliminating the need for supplemental sodium hydroxide addition.

- Tank farm operations impacts. Batch processing times will be lower for fractional crystallization than for the other technologies because sodium hydroxide addition is not needed by the process and because a significant fraction of the feed sodium reports to the high cesium stream. Impacts to tank farm operations of the more frequent batch change out and other operational features of this technology remain to be evaluated. Some mitigation may be provided by immediate waste volume reduction provided by fractional crystallization (net volume of the two product streams will typically be less than the volume of the waste feed), and by the fact that the fractional crystallization facility can perform some of the waste concentration functions of 242-A. Options discussed in Section 6.2.8.2 for increasing the fractional sodium yield would also help mitigate the tank farm operations impacts by reducing the number of batches required and increasing batch processing times.

- Effects of minor components. Laboratory fractional crystallization tests have been performed on several samples of actual waste, and these tests have shown behavior that reasonably matches tests with simulants. However, specific wastes planned for IPS have not been tested, and there may be a possibility of unexpected behavior due to minor and trace components. Mitigation is to perform laboratory testing on at least some of the planned wastes under conditions close to those planned for the IPS flowsheet.

6.2.8.2 Optimization of Design and Operations. A number of items were identified during development of the IPS pre-conceptual candidate technology descriptions related to optimization of the design and operating concepts and/or overall evaluation of the advantages and disadvantages of the technology. Items judged to be a potential significance to the current evaluation are discussed in this section. None of these are necessarily recommended at this time but could be candidates pending more detailed evaluation.

- Potential Shutdown of 242-A. The capabilities of the proposed fractional crystallization process and facility may allow an early shut down of the 242-A Evaporator. For simple waste concentration operation, the centrifuge would be bypassed and the crystallizer product would be directly discharged to the Cs product tank. The pre-conceptual design for the first and second stage crystallizers provides about $40 \%$ and $20 \%$ of the $242-\mathrm{A}$ evaporation capacity respectively. Reduction of future 242 -A upgrade and operating costs could offset part of the added cost of the new fractional crystallization system. 
- Optimization of the approach for treating wastes that are difficult to crystallize. Initial calculations for the current study indicated unacceptably low net sodium yields for some of the proposed IPS feed batches with the 20 mole/ 1 ionic strength end point (e. g. some were below $10 \%$ ). Several alternatives have been identified to increase sodium yield, including: oxidize nitrite to nitrate using ozone or hydrogen peroxide; remove soluble aluminum by precipitation as gibbsite or low solubility lithium/aluminum compounds; partially neutralize hydroxide with carbon dioxide or nitric acid; continue evaporation to a higher ionic strength endpoint; and/or substitute different wastes (e. g. saltcake) for some of the more unfavorable IPS waste batches. Several of these methods are potentially feasible and attractive for increasing sodium yields, however, it was not feasible to fully evaluate them and define a preferred approach within constraints of the current study. Therefore, increasing the ionic strength endpoint for evaporation was selected for the example process and facility concept in the current task. This appears to be a reasonable choice, but it carries some added risk. Time constraints did not allow evaluation of other alternatives, which could be preferable. Even with the $23 \mathrm{M}$ ionic strength option, a number of optimization items remain that will need to be resolved to finalize design. Identified alternatives are briefly discussed below.

- Increase evaporation end point to $23 \mathrm{Mole} /$ liter. Mass balance calculations show that increasing the evaporation end point should be moderately effective in increasing sodium yield to the LAW product. However, yields for most batches are still projected to be less than $50 \%$ and batch 8 is estimated at about $35 \%$. These relatively low yields result in a significant size increase for the front end systems and equipment, e. g. feed filtration, feed receipt tank, and first stage reboiler, condenser, condenser cooling system, and condensate tank. In addition the required high crystallizer operating vacuum requires chilled water to condense steam. It may be feasible to reduce impacts to feed filtration by moving this step to filtration of the product from the first stage dissolver. This should substantially reduce size of the filter system but would complicate the dissolver system and potentially increase alpha and strontium contamination levels in the first stage crystallizer system.

- Modify feed batch selection. If it is feasible to substitute wastes that are more easily crystallized for some of the more difficult waste batches, it could allow significant reduction in the size and cost of some of the front end equipment for crystallization, or alternatively it could allow reduction of the evaporation end point to a level that has less risk of problems (higher confidence). Previous work on fractional crystallization has shown that single shell tank saltcake type wastes can be processed by fractional crystallization with significantly better performance than double shell tank wastes containing high concentrations of nitrite, aluminum, and hydroxide.

- Pretreatment of Waste upstream of crystallization. Several methods have been identified to improve performance by pre-treating waste upstream of crystallization (see for example RPP-PLAN-27238). Oxidation of nitrite to nitrate is expected to significantly increase sodium yield in the LAW product and/or reduce the need to increase evaporation end point. Early testing work on complexant destruction showed that nitrite is readily oxidized by ozone. Hydrogen peroxide is also a candidate reagent for nitrite oxidation. Another 
approach is to reduce dissolved aluminum content by precipitation, either as low solubility lithium/aluminum compounds or as gibbsite. Aluminum precipitation coupled with partial neutralization of hydroxide using either nitric acid or carbon dioxide will provide further improvement of net LAW sodium yield (Reference: IPT_SURVEYS_3.xls from May, T. H., 2008-05-09. An additional advantage of aluminum precipitation is that it will reduce or eliminate the need to add sodium hydroxide when the high cesium product is processed later through the WTP pretreatment process.

- General Design Optimization. A number of additional general process optimization issues were identified, including:

It may be preferable to preheat the feed prior to injecting it into the crystallizer; it may be advantageous to split the crystallizer condenser load so that the initial condensation uses cooling water and the final condensation only is done using chilled water and/or to use chilled water only when deep vacuum is required, it may be feasible to achieve the required cesium decontamination with a single stage (pilot plant performance data is needed to evaluate this).

\subsection{CAUSTIC-SIDE SOLVENT EXTRACTION}

Since its inception the nuclear industry has successfully used solvent extraction to separate radionuclides. The experience base includes exposing various organic solvents to high radiation fields without experiencing catastrophic degradation rates. The typical key to solvent extraction's effectiveness is development of an organic solvent that is sufficiently selective in adsorption of the target radionuclide(s).

Oak Ridge National Laboratory has developed a solvent that is relatively selective for cesium removal from an alkaline solution. The solvent consists of calix[4]arene-bis(tert-octylbenzo-crown-6) extractant (BOBCalixC6) dissolved in an inert hydrocarbon matrix (Isopar ${ }^{\circledR} \mathrm{L}$ ). The solvent contains a modifier, which is an alkyl aryl polyether, to keep the extractant dissolved in the solvent and increase its ability to absorb cesium in the extraction section. The modifier is 1-(2,2,3,3,-tetrafluoropropoxy)-3-(4-secbutylphenoxy)-2-propanol and is called Cs-7SB. The solvent contains a suppressant, trioctylamine (TOA), which inhibits the effects of anionic organic impurities and improves the back-extraction of Cs from the solvent in the stripping section.

This development resulted in efforts to deploy the Caustic-Side Solvent Extraction (CSSX) process at the Savannah River Site to extract Cs from alkaline supernate and dissolved salt cake wastes. The Savannah River Site's Modular CSSX Unit (MCU) began processing tank waste in May 2008. 


\subsubsection{Literature Survey}

Recent CSSX technology development work presented in "Alternatives to Nitric Acid Stripping in the Caustic-Side Solvent Extraction (CSSX) Process for Cesium Removal from Alkaline High-Level Waste" (Delmau et al. 2008) proposed flow sheet modifications that would increase the efficiency of $\mathrm{Cs}$ stripping. This work recommends replacing the nitric acid scrubbing and stripping solutions with $0.1 \underline{\mathrm{M} \mathrm{NaOH}}$ and $0.01 \underline{\mathrm{M}}$ boric acid $\left(\mathrm{H}_{3} \mathrm{BO}_{3}\right)$, respectively. Also proposed is replacing BOBCalixC6 with a more soluble analog extractant, calyx[4] arene-bis(2ethylhexylbenzo-18crown-6) (BEHBCalixC6) and TOA with N,N'-bis(cyclohexyl)-N"'isotridecylguanidine (LIX 79). These modifications are expected to increase CSSX performance for the case where it's applied to high potassium-content feeds, such as those at Hanford. However, the potential performance increase isn't incorporated into this study because a considerable amount of additional development would be required before these modifications could be adopted as a basis for design.

While Delmau et al. 2008 has recently proposed modifying the solvent composition to optimize it for high potassium-content feeds, the BOBCalixC6 solvent composition will perform adequately with some Hanford Site feed batches. The chemical and physical properties of this solvent are extensively reported in ORNL/TM-2002/190, Caustic-Side Solvent Extraction: Chemical and Physical Properties of the Optimized Solvent. Measured physical properties include density, viscosity, and thermal stability.

Of particular value is distribution of minor organic and inorganic components that are generally not reported in the extensive body of CSSX literature. Based on mass balance data presented in ORNL/TM-2002/190 about $0.023 \%$ of $\mathrm{Na}$ and $12.2 \%$ of $\mathrm{K}$ in the waste feed are extracted into the solvent. After the second scrub stage only $1.05 \%$ of the $\mathrm{Na}$ and $0.218 \%$ of the $\mathrm{K}$ remain in the solvent.

The conclusion reported in ORNL/TM-2002/190 was that solvent losses through degradation were negligible. Entrainment of solvent in the aqueous streams was the dominant loss mechanism. Test results reported in WSRC-TR-2005-00182, Examination of Organic Carryover from 2-cm Contactors to Support the Modular CSSX Unit, indicated that organic carryover after decanting was bounded by $417 \mathrm{ppm}$ of Isopar L. Therefore, solvent replenishment should be much less that one process inventory (180 to 390 gal) per year.

Since the late 1990's the Savannah River Site, in conjunction with Oak Ridge National Laboratory and Argonne National Laboratory, has been developing the CSSX process. In 2002 the results of "hot" laboratory-scale testing were reported in WSRC-TR-2002-00243, High Level Waste Demonstration of the Caustic-Side Solvent Extraction Process with Optimized Solvent in the 2-cm Centrifugal Contactor Apparatus using Tank 37H/44F Supernate, and WSRC-TR-2002-00307, Demonstration of Caustic-Side Solvent Extraction with Optimized Solvent in the 2-cm Centrifugal Contactor Apparatus using Dissolved Salt Cake from Tank $37 H$. These test using actual tank waste verified that the CSSX process could yield sufficient cesium removal that the decontaminated waste was suitable for immobilization in grout and onsite disposal. The results were sufficiently positive that efforts were initiated to take the CSSX process to a full-scale production facility. 
The heat imparted by the contactors into the fluids was estimated by ANL-00/31, Temperature Management of Centrifugal Contactors for Caustic-Side Solvent Extraction of Cesium from Tank Waste. The cesium distribution coefficient $\left(\mathrm{D}_{\mathrm{Cs}}\right)$ is a strong function of temperature. A lower fluid temperature is favorable to extraction while a higher temperature more conducive to stripping. For this reason $25^{\circ} \mathrm{C}$ or less is the preferred operating temperature for extraction. ANL-00/31 determined that the contactor motor was the dominate heat source, contributing more than $90 \%$ of the overall heat load.

Efforts have also been directed towards understanding the influence of waste components on CSSX performance. WSRC-TR-2005-00258 investigated 12 waste feed components (i.e., $\mathrm{Na}^{+}$,

$\mathrm{K}^{+}, \mathrm{Cs}^{+}, \mathrm{OH}^{-}, \mathrm{NO}_{3}^{-}, \mathrm{NO}_{2}^{-}, \mathrm{Cl}^{-}, \mathrm{F}^{-}, \mathrm{SO}_{4}{ }^{-2}, \mathrm{PO}_{4}^{-3}, \mathrm{CO}_{3}^{-2}$, and $\mathrm{AlO}_{2}{ }^{-}$) and determined that potassium exhibits the strongest detrimental influence on $\mathrm{D}_{\mathrm{Cs}}$ for extraction. A neural network model was also developed to predict $\mathrm{D}_{\mathrm{Cs}}$ for extraction given a waste feed composition. This correlation predicted $\mathrm{D}_{\mathrm{Cs}}$ values within $15 \%$ of those predicted by a more rigorous, but complex model termed SXFIT.

In 2004 a conceptual design for the MCU was completed and documented in ORNL/TM-2004/59, Conceptual Design of a Simplified Skid-Mounted Caustic-Side Solvent Extraction Process for Removal of Cesium for Savannah River Site High-Level Waste. The throughput of the MCU process is similar to that required for IPS ( 6 to $8 \mathrm{gpm}$ ). However, the MCU is design to only achieve a decontamination factor $\left(\mathrm{Ci}^{137} \mathrm{Cs}\right.$ in waste feed divided by $\mathrm{Ci}^{137} \mathrm{Cs}$ in decontaminated product) of 12 versus the IPS requirement of 1,000 to 4,000 . This difference in decontamination factor directly translates into the number of contactors that must be included in the respective flow sheets (seven in the extraction section of the MCU versus 14 in the IPS).

In 2007 the Savannah River Site completed construction and assembly of the MCU facility. Cold testing was conducted after assembly to assess process performance. Conclusions derived from the test are presented in WSRC-STI-2007-00580, Full-Scale Testing of a Caustic Side Solvent Extraction System to Remove Cesium from Savannah River Site Waste. Overall, test results were in agreement with expectations.

Work is underway at Oak Ridge National Laboratory to test CSSX using simulants of the eight IPS feed batches. Reported results are expected at the end of May 2008. Preliminary results indicate that the number of required equilibrium stages range from 13 to 105 using the BOBCalixC6 solvent if the organic to aqueous flow rate ratio $(\mathrm{O} / \mathrm{A})$ is fixed at 0.3 . Using the $\mathrm{BEHBCalixC6}$ solvent the required equilibrium stages are reduced to 6 to 10 for an $\mathrm{O} / \mathrm{A}$ of 0.3 .

\subsubsection{Caustic-Side Solvent Extraction Process Description}

Figure 6-14 depicts the CSSX flow sheet proposed for the IPS. This flow sheet is functionally equivalent to that implemented in the Savannah River Site's Modular CSSX Unit (MCU), which was initially developed by the Argonne National Laboratory. The flow sheet represents a continuous process that includes multiple steps. 
Figure 6-14 Caustic-Side Solvent Extraction Process Flow Diagram

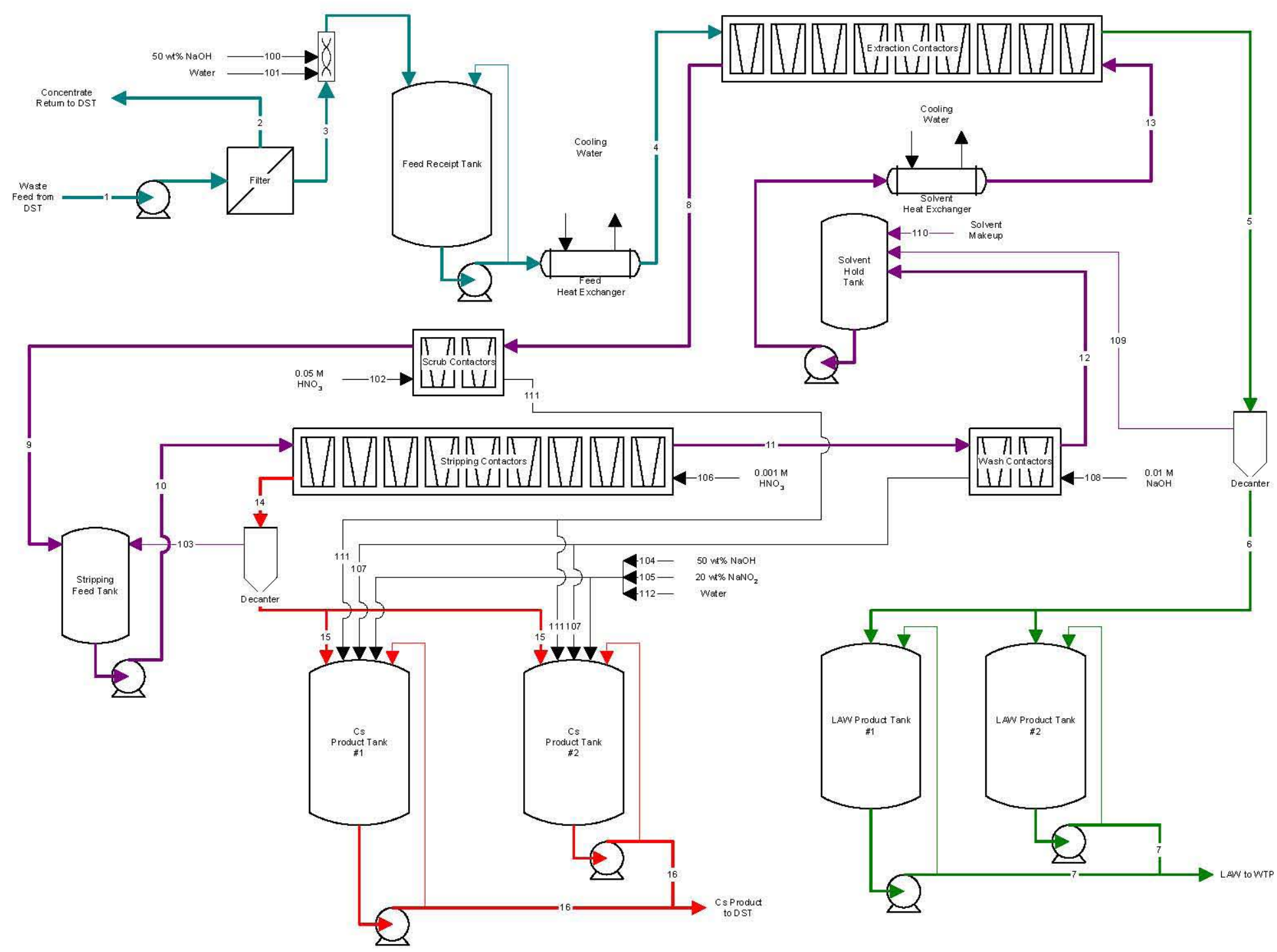


The first step is adjustment of the waste feed with caustic and water to yield a $6 \underline{\mathrm{M}}$ sodium product. This adjustment is required to preclude precipitation of $\mathrm{Al}(\mathrm{OH})_{4}$ when the feed is cooled to $25^{\circ} \mathrm{C}$. Operation of the extraction section at $25^{\circ} \mathrm{C}$ is required to yield the best cesium removal performance.

In the extraction section the aqueous feed stream is mixed with the organic solvent, which is immiscible with the aqueous phase. During this contacting cesium (the target component) undergoes transfer from the aqueous stream to the organic stream. Other non-target components (predominately sodium and potassium) are also absorbed into the organic phase during extraction. However, most non-target components remain in the aqueous feed stream. Following extraction the feed stream (termed raffinate) is depleted in cesium to the desired level and becomes acceptable for transfer to the WTP as LAW.

After extraction the cesium-loaded organic (termed the extract) is routed to the scrubbing operation where it is contacted with a dilute $(0.05 \underline{\mathrm{M}})$ nitric acid solution. The purpose of scrubbing is to remove the $\mathrm{Na}$ and $\mathrm{K}$ impurities from the extract, prior to cesium stripping. The scrubbed organic then proceeds to the stripping operation.

In a deviation from the MCU flow sheet the aqueous stream is routed to Cs Product Tank. For the CSSX applications at Hanford there is little benefit in returning to the LAW product the relatively small quantities of $\mathrm{Na}$ and $\mathrm{K}$ separated during extraction. To compensate for nitric acid neutralization mixing the aqueous scrubbing solution with waste feed prior to extraction (as is done in the MCU flow sheet) would require addition of even more caustic than that needed to preclude $\mathrm{Al}(\mathrm{OH})_{4}$ precipitation. The increase in aqueous flow rate to extraction can also result in a higher organic flow rate and/or greater number of contactors. Therefore, for CSSX applications at Hanford it's preferable to blend spent scrubbing solution with the Cs product.

During stripping the solvent is again contacted with a dilute $(0.001 \underline{\mathrm{M}})$ nitric acid solution which causes most of the Cs ions to transfer from the organic to the aqueous phase. The Cs-loaded aqueous stream is collected, chemically adjusted to meet tank farm acceptance specifications, and subsequently transferred to a DST.

Following stripping the Cs-depleted solvent is routed to the washing operation where it is contacted with a dilute $(0.01 \underline{\mathrm{M}})$ caustic solution. The washing step serves to remove trace organic impurities that are the result of solvent degradation. The organic stream is recycled to extraction after washing to begin the process anew.

In a second deviation from the MCU flow sheet the caustic wash stream is routed to Cs Product Tank; the MCU flow sheet sends this stream to the LAW Product Tank. For the CSSX applications at Hanford the Cs product must be adjusted with caustic and sodium nitrite to satisfy the tank farm corrosion specification. Sending the aqueous stream to the Cs Product Tank Mixing offsets some sodium that would otherwise have to be added for chemical adjustment.

The solvent extraction process (i.e., extraction, scrubbing, stripping, and washing operations) is carried out using a series of centrifugal contactors. Figure 6-15 is a schematic of a contactor and 
Figure 6-16 is a rendering of a prototypical 2-stage contactor unit. As reported in LWO-SPT-2007-000245, Scale-up of Caustic-Side Solvent Extraction Process for Removal of Cesium at Savannah River Site, full-scale contactor performance was confirmed to be sufficient to support MCU design basis requirements.

\section{Figure 6-15 Centrifugal Contactor Schematic}

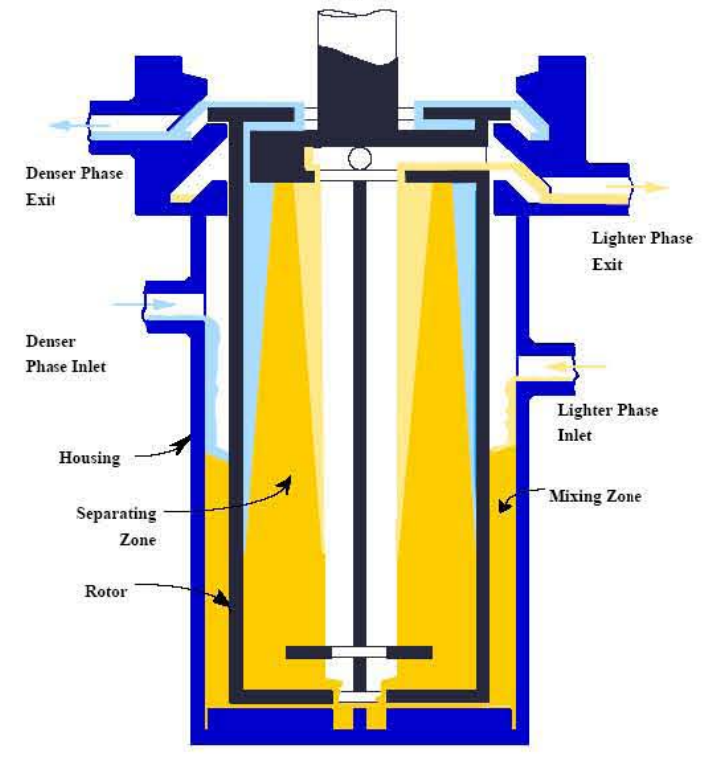

Figure 6-16 Prototypical 2-Stage Contactor Unit

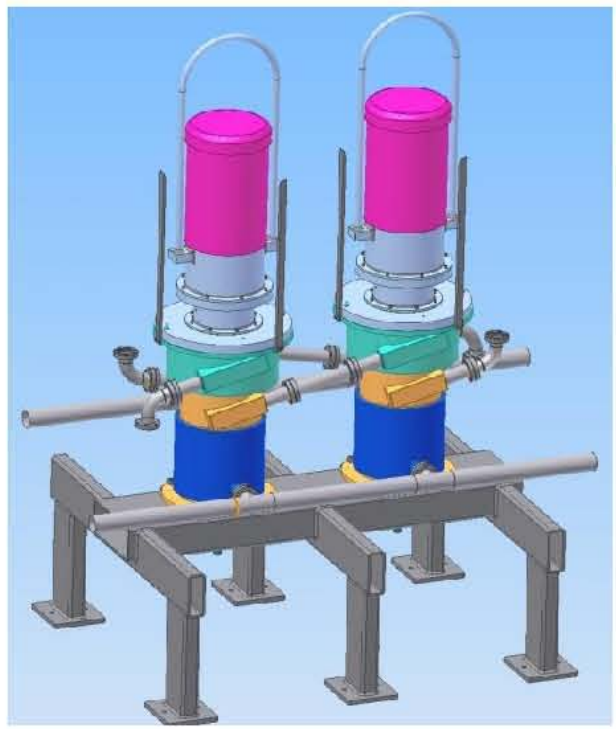

The annular centrifugal contactor was developed at Argonne National Laboratory in the early 1970s for carrying out solvent extraction operations required in the nuclear industry. Costner Industries Nevada Corporation has been supplying commercially-available units to the Savannah River Site for their MCU project. In stagewise solvent extraction, two immiscible liquids are 
contacted and then separated at each stage. For continuous countercurrent operation, the immiscible liquids move in opposite directions as they flow from stage to stage.

The entering immiscible liquids are mixed in the annular region outside the spinning rotor. The mixture is disengaged by the centrifugal force in the separating zone of the rotor. The separated liquids are then forced to move out separate rotor exits by the two rotor weirs (the upper weir for the more-dense phase, the lower weir for the less-dense phase), where they are captured by separate collector rings near the top of the contactor housing. The liquids then flow by gravity to the appropriate next stage. A motor located above the rotor spins the rotor.

The efficiency to which the CSSX process extracts Cs from the feed stream is directly related to cesium distribution coefficient $\left(\mathrm{D}_{\mathrm{Cs}}\right)$, which is related to specific feed composition being processed. WSRC-TR-2005-00258, Waste and Solvent Composition Limits for Modular Caustic-Side Solvent Extraction Unit $(M C U)$, identified a correlation that reasonably predicts $\mathrm{D}_{\mathrm{Cs}}$ for a given feed composition. SVF-1496, "IPS CSSX Cesium Distribution Coefficients Calculation" used this correlation to estimate the $\mathrm{D}_{\mathrm{Cs}}$ for the eight feed batches being evaluated in this effort. The resultant estimated $\mathrm{D}_{\mathrm{Cs}}$ are presented in Table 6-28.

Table 6-28 Predicted Cesium Distribution Coefficients for Extraction

\begin{tabular}{|c|c|}
\hline Feed Batch & Cesium Distribution Coefficient \\
\hline $241-\mathrm{AP}-104$ & 3.42 \\
\hline $241-\mathrm{AP}-102$ & 4.59 \\
\hline $241-\mathrm{AP}-101$ & 2.98 \\
\hline $241-\mathrm{AP}-103$ & 3.79 \\
\hline $241-\mathrm{AP}-105$ & 4.65 \\
\hline $241-\mathrm{AP}-108$ & 2.58 \\
\hline $241-\mathrm{AP}-107$ & 5.53 \\
\hline $241-\mathrm{AN}-104$ & 8.05 \\
\hline
\end{tabular}

The low $\mathrm{D}_{\mathrm{Cs}}$ estimated for 241-AP-101 and 241-AP-108 are caused by the high potassium content in these tank batches. For comparison purposes nine was used as the design basis $\mathrm{D}_{\mathrm{Cs}}$ for Savannah River Site's MCU. This higher $\mathrm{D}_{\mathrm{Cs}}$ value is a direct result of the Savannah River Site's tank waste having relatively low potassium concentrations.

\subsubsection{Input Data}

The majority of user-supplied input parameters are constant for the mass balance calculation across all feed batches. These common parameters and their bases are identified in Table 6-29. 
Table 6-29 User-Supplied Input Parameters Common to all Feed Batches

\begin{tabular}{|c|c|c|c|}
\hline \multicolumn{4}{|c|}{ (2 sheets) } \\
\hline Parameter & Value & Units & Basis \\
\hline \multicolumn{4}{|l|}{ General } \\
\hline \multicolumn{4}{|l|}{ Molecular Weight: } \\
\hline $\mathrm{Al}(\mathrm{OH}) 4$ & 94.9815 & $\mathrm{~g} / \mathrm{mol}$ & Periodic Table of Elements \\
\hline $\mathrm{Cs}$ & 134 & $\mathrm{~g} / \mathrm{mol}$ & Study basis \\
\hline $\mathrm{OH}$ & 17.0073 & $\mathrm{~g} / \mathrm{mol}$ & Periodic Table of Elements \\
\hline $\mathrm{Na}$ & 22.9898 & $\mathrm{~g} / \mathrm{mol}$ & Periodic Table of Elements \\
\hline NO3 & 62.0049 & $\mathrm{~g} / \mathrm{mol}$ & Periodic Table of Elements \\
\hline $\mathrm{NO} 2$ & 46.0055 & $\mathrm{~g} / \mathrm{mol}$ & Periodic Table of Elements \\
\hline $137 \mathrm{mBa} / 137 \mathrm{Cs}$ Ratio & 0.944 & $\mathrm{Ci} / \mathrm{Ci}$ & $\begin{array}{l}\text { CBU-SPT-2004-00059, Preliminary Material } \\
\text { Balance for the Modular CSSX Unit }\end{array}$ \\
\hline \multicolumn{4}{|l|}{ Waste Feed } \\
\hline Total Suspended Solids $(\mathrm{TSS})=$ & 0.5 & $\mathrm{wt} \%$ & Study basis \\
\hline \multicolumn{4}{|l|}{ Filtration } \\
\hline Solids Removal Efficiency $=$ & 99.99 & $\%$ & Study basis \\
\hline Solids in Concentrate $=$ & 20 & $\mathrm{wt} \%$ & Study basis \\
\hline \multicolumn{4}{|l|}{ Feed Preparation } \\
\hline Target Feed $\mathrm{Na}$ Concentration $=$ & 6 & $\mathrm{~mol} / \mathrm{L}$ & Study basis \\
\hline $\mathrm{NaOH}$ Dilution Concentration $=$ & 0.5 & wt fraction & Engineering judgment \\
\hline $\mathrm{NaOH}$ Solution Density $=$ & 1.5253 & $\mathrm{~kg} / \mathrm{L}$ & $\begin{array}{l}\text { Perry \& Chilton, Chemical Engineering } \\
\text { Handbook, 5th ed. }\end{array}$ \\
\hline \multicolumn{4}{|l|}{ Cesium Extraction } \\
\hline $\mathrm{K}$ Extraction $=$ & 12.2 & $\%$ & $\begin{array}{l}\text { ORNL/TM-2002/190, Conceptual Design of a } \\
\text { Simplified Skid-Mounted Caustic-Side Solvent } \\
\text { Extraction Process for Removal of Cesium } \\
\text { from Savannah River Site High-Level Waste }\end{array}$ \\
\hline Na Extraction $=$ & 0.023 & $\%$ & ORNL/TM-2002/190 \\
\hline Solvent Density $=$ & 0.767 & $\mathrm{~kg} / \mathrm{L}$ & Material Safety Data Sheet from Exxon Mobil \\
\hline Solvent Entrainment $=$ & 1 & vol $\%$ & CBU-SPT-2004-00059 \\
\hline \multicolumn{4}{|l|}{ Solvent Scrubbing } \\
\hline K Extraction $=$ & 99.78 & $\%$ & ORNL/TM-2002/190 \\
\hline Na Extraction $=$ & 98.95 & $\%$ & ORNL/TM-2002/190 \\
\hline Target $\mathrm{O} / \mathrm{A}$ Flow Ratio $=$ & 5.00 & & CBU-SPT-2004-00059 \\
\hline Nitric Acid Solution Density $=$ & 1 & $\mathrm{~kg} / \mathrm{L}$ & $\begin{array}{l}\text { Perry \& Chilton, Chemical Engineering } \\
\text { Handbook, 5th ed. }\end{array}$ \\
\hline \multicolumn{4}{|l|}{ Solvent Stripping } \\
\hline $\mathrm{DCs}=$ & 0.16 & $\begin{array}{l}\text { M Cs org/ } \\
\underline{M} \text { Cs aq }\end{array}$ & $\begin{array}{l}\text { WSRC-RP-2005-01970, Cesium Concentration } \\
\text { in MCU Solvent }\end{array}$ \\
\hline
\end{tabular}


Table 6-29 User-Supplied Input Parameters Common to all Feed Batches

\begin{tabular}{|c|c|c|c|}
\hline \multicolumn{4}{|c|}{ (2 sheets) } \\
\hline Parameter & Value & Units & Basis \\
\hline Nitric Acid Solution Density $=$ & 1 & $\mathrm{~kg} / \mathrm{L}$ & $\begin{array}{l}\text { Perry \& Chilton, Chemical Engineering } \\
\text { Handbook, 5th ed. }\end{array}$ \\
\hline Solvent Entrainment $=$ & 1 & vol \% & CBU-SPT-2004-00059 \\
\hline \multicolumn{4}{|l|}{ Solvent Washing } \\
\hline Target $\mathrm{O} / \mathrm{A}$ Flow Ratio $=$ & 5.00 & & CBU-SPT-2004-00059 \\
\hline Caustic Solution Density $=$ & 1 & $\mathrm{~kg} / \mathrm{L}$ & $\begin{array}{l}\text { Perry \& Chilton, Chemical Engineering } \\
\text { Handbook, 5th ed. }\end{array}$ \\
\hline Solvent Makeup Rate $=$ & & $\mathrm{L} / \mathrm{hr}$ & \\
\hline \multicolumn{4}{|l|}{ Cs Product Adjustment } \\
\hline Target $\mathrm{OH}$ Conc $=$ & 0.010 & $\mathrm{~mol} / \mathrm{L}$ & $\begin{array}{l}\text { HNF-SD-WM-OCD-015, Tank Farms Waste } \\
\text { Transfer Compatibility Program }\end{array}$ \\
\hline Target NO2 Conc $=$ & 0.011 & $\mathrm{~mol} / \mathrm{L}$ & HNF-SD-WM-OCD-015 \\
\hline Target $\mathrm{NO} 3 /(\mathrm{OH}+\mathrm{NO} 2)$ Ratio $<=$ & 2.5 & $\mathrm{~mol} / \mathrm{mol}$ & HNF-SD-WM-OCD-015 \\
\hline $\mathrm{NaOH}$ Adjustment Concentration $=$ & 50 & $\mathrm{wt} \%$ & Engineering judgment \\
\hline $\mathrm{NaOH}$ Solution Density $=$ & 1.5253 & $\mathrm{~kg} / \mathrm{L}$ & $\begin{array}{l}\text { Perry \& Chilton, Chemical Engineering } \\
\text { Handbook, 5th ed. }\end{array}$ \\
\hline NaNO2 Adjustment Concentration $=$ & 20 & $\mathrm{wt} \%$ & Engineering judgment \\
\hline NaNO2 Solution Density $=$ & 1.1394 & $\mathrm{~kg} / \mathrm{L}$ & $\begin{array}{l}\text { Perry \& Chilton, Chemical Engineering } \\
\text { Handbook, 5th ed. }\end{array}$ \\
\hline Water Addition Rate $=$ & 0 & $\mathrm{~L} / \mathrm{hr}$ & \\
\hline \multicolumn{4}{|l|}{ LAW Product } \\
\hline Target $137 \mathrm{Cs} / \mathrm{Na}$ Ratio $=$ & $1.68 \mathrm{E}-05$ & $\mathrm{Ci} / \mathrm{mol}$ & Study constraint \\
\hline Production Rate $=$ & 1175 & $\mathrm{MT} / \mathrm{yr} \mathrm{Na}$ & Study constraint \\
\hline Total Operating Efficiency $=$ & 70 & $\%$ & Study constraint \\
\hline
\end{tabular}

Several user-supplied input parameters are specific to a given feed batch mass balance. The sodium addition to the feed required to preclude aluminate ion precipitation when the feed is cooled to $25^{\circ} \mathrm{C}$ varies by batch. The specific value determined for each batch and the basis for this value is discussed in Section 6.1.3.1.

The remaining feed-specific parameters are identified in Table 6-30. The cesium distribution coefficient $\left(\mathrm{D}_{\mathrm{Cs}}\right)$ is taken from Table 6-28. The decontamination factor (DF) is fixed by the cesium limit imposed on the LAW product. The organic to aqueous ratios are determined graphically within the mass balance calculation as discussed in Section 6.3.5, assuming 12 theoretical equilibrium stages in both extraction and stripping. 
Table 6-30 Feed-Specific User-Supplied Input Parameters

\begin{tabular}{|c|c|c|c|c|}
\hline Feed Batch & $\mathbf{D}_{\mathrm{Cs}}$ & DF & Extraction O/A & Stripping O/A \\
\hline $241-\mathrm{AP}-104$ & 3.42 & 958 & 0.53 & 3.45 \\
\hline $241-\mathrm{AP}-102$ & 4.59 & 1135 & 0.40 & 3.40 \\
\hline $241-\mathrm{AP}-101$ & 2.98 & 1654 & 0.64 & 3.30 \\
\hline $241-\mathrm{AP}-103$ & 3.79 & 1066 & 0.48 & 3.40 \\
\hline $241-\mathrm{AP}-105$ & 4.65 & 1275 & 0.40 & 3.40 \\
\hline $241-\mathrm{AP}-108$ & 2.58 & 906 & 0.70 & 3.50 \\
\hline $241-\mathrm{AP}-107$ & 5.53 & 3637 & 0.37 & 3.00 \\
\hline $241-\mathrm{AN}-104$ & 8.05 & 1237 & 0.23 & 3.40 \\
\hline
\end{tabular}

Notes:

1. $\mathrm{D}_{\mathrm{Cs}}=$ Cesium distribution coefficient in extraction section

2. $\mathrm{DF}=$ Decontamination factor (cesium in waste feed divided by cesium in low-activity waste)

3. $\mathrm{O} / \mathrm{A}=$ Organic to aqueous flow rate ratio

\subsubsection{Assumptions}

The flow sheet and mass balance was developed using technical information generated primarily for Savannah River Site tank waste and the MCU Project. The principal assumption is that this CSSX performance data is applicable to Hanford tank waste processing.

\subsubsection{Flowsheet Methodology}

The allowable cesium content in LAW to the WTP defines the quantity of cesium that must be removed in the extraction section and eventually in the cesium product. The key to the mass balance is determining the number of centrifugal contactors and $\mathrm{O} / \mathrm{A}$ needed to provide the required cesium removal performance. The number of equilibrium stages required for each contacting operation (extraction, scrubbing, stripping, and washing) is a function of the $\mathrm{Cs}$ distribution coefficient and organic to aqueous flow rate ratio $(\mathrm{O} / \mathrm{A})$ at each step. This is illustrated by the following discussion.

Figure 6-17 depicts the flows within the extraction section. Extraction section performance is defined by Equation 6.3-1. 
Figure 6-17 Staged Equilibrium Extraction Section

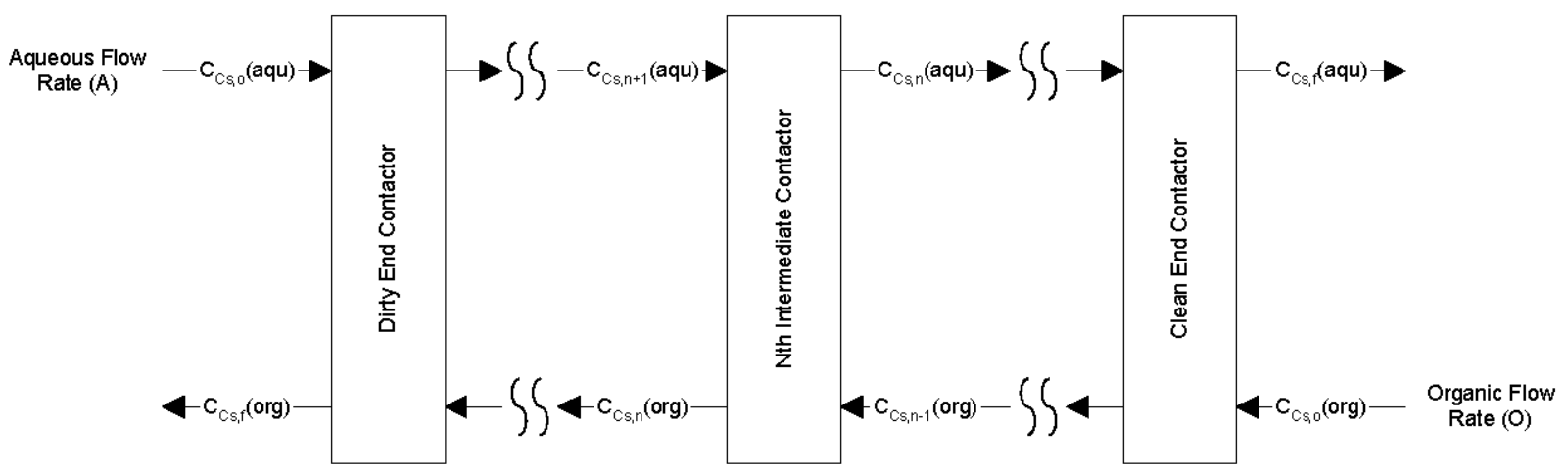

\section{Equation 6.3-1}

$$
\begin{gathered}
\text { Distribution Coefficient }(D)=\frac{\left(C_{C s, n}(\text { org })\right)}{\left(C_{C s, n}(\text { aqu })\right.} \\
\text { Where } C_{C s, n}(\text { org })=\text { Cs concentration in the organic phase }\left(\frac{\mathrm{mol}}{L}\right) \\
\text { and } C_{C s, n}(\text { aqu })=\text { Cs concentration in the aqueous phase }\left(\frac{\mathrm{mol}}{L}\right) \\
\text { Organic to Aqueous Ratio }=\frac{O\left(\frac{L}{h}\right)}{A\left(\frac{L}{h}\right)} \\
\text { Equilibrium Line }=C_{C s, n}(\text { aqu })=C_{C s, n}(\text { org }) * \frac{1}{D} \\
\text { Operating Line }=C_{C s, n}(\text { aqu })=C_{C s, o}(\text { aqu })+\left[\frac{O}{A} *\left(C_{C s, n}(\text { org })-C_{C s, o}(\text { org })\right)\right.
\end{gathered}
$$

The concentrations $\mathrm{C}_{\mathrm{Cs}, \mathrm{o}}(\mathrm{aqu})$ and $\mathrm{C}_{\mathrm{Cs}, \mathrm{f}}(\mathrm{aqu})$ are fixed by the required waste feed throughput and LAW product specification for $\mathrm{Cs}$ content. $\mathrm{C}_{\mathrm{Cs}, \mathrm{f}}(\mathrm{org})$ is set by the $\mathrm{O} / \mathrm{A}$ and mass balance of $\mathrm{Cs}$ extraction from the aqueous stream $\left[\mathrm{M}_{\mathrm{Cs}, \mathrm{o}}(\mathrm{aqu})-\mathrm{M}_{\mathrm{Cs}, \mathrm{f}}(\mathrm{aqu})+\mathrm{M}_{\mathrm{Cs}, \mathrm{o}}(\mathrm{org})=\mathrm{M}_{\mathrm{Cs}, \mathrm{f}}(\right.$ org $\left.)\right]$.

$\mathrm{C}_{\mathrm{Cs}, \mathrm{o}}(\mathrm{Org})$ is a function of the stripping section operation and can vary between zero to $100 \%$ of the equilibrium concentration with $\mathrm{C}_{\mathrm{Cs}, \mathrm{o}}(\mathrm{aqu})$.

Selection of $0 \%$ equilibrium for $\mathrm{C}_{\mathrm{Cs}, 0}(\mathrm{org})\left[\mathrm{C}_{\mathrm{Cs}, \mathrm{o}}(\mathrm{org})=0\right]$ is not realistically attainable, whereas $100 \%$ equilibrium would negate the effectiveness of the clean end contactor. Therefore, $\mathrm{C}_{\mathrm{Cs}, \mathrm{o}}$ (org) is set at a value between zero and $100 \%$ of equilibrium where the Cs concentration of the incoming organic will result in an effective clean end contactor extraction but not over burden the stripping section operation (decrease its $\mathrm{O} / \mathrm{A}$ to an impractically low value). Figure 6-18 presents the results of plotting the equilibrium and operating lines on a log-log graph. 
Figure 6-18 Example Extraction McCabe-Thiele Diagram

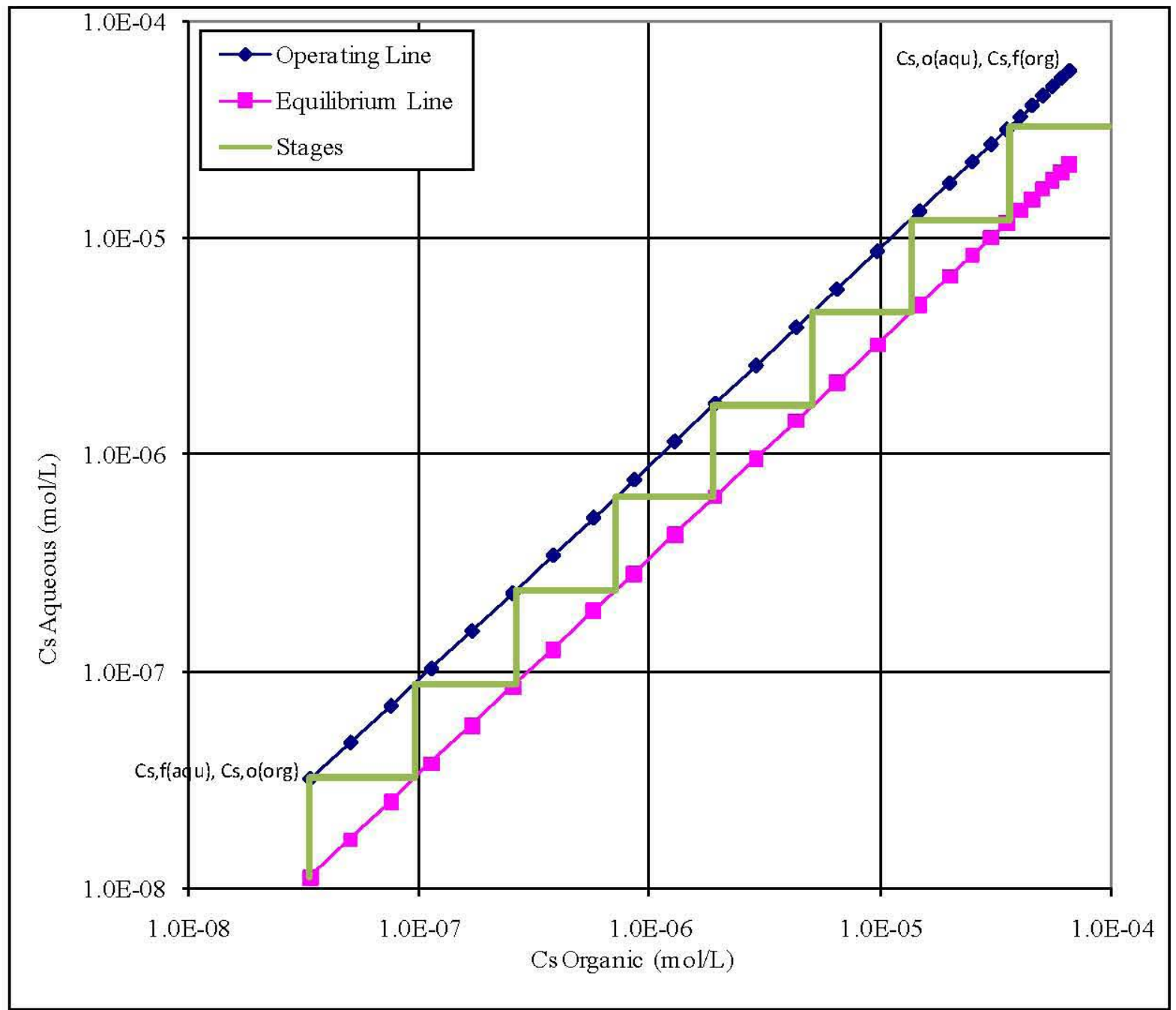

Equilibrium stages (100\% theoretical efficiency) are counted by drawing a vertical line from the equilibrium line to the operating line that passes through the point $\mathrm{C}_{\mathrm{Cs}, \mathrm{f}}(\mathrm{aqu}), \mathrm{C}_{\mathrm{Cs}, \mathrm{o}}(\mathrm{org})$, then a horizontal line from this point back to the equilibrium line. The total number of step required to reach the point $\mathrm{C}_{\mathrm{Cs}, \mathrm{o}}(\mathrm{aqu}), \mathrm{C}_{\mathrm{Cs}, \mathrm{f}}(\mathrm{org})$ defines the number of equilibrium stages. By changing the $\mathrm{O} / \mathrm{A}$ the number of stages can varied from one to infinity. Neither extreme is practical.

A small number of stages is desirable from a facility footprint perspective, but this generates a relatively large volume of cesium product that subsequently consumes double-shell tanks storage capacity. Conversely, a greater number of contactors yields a more concentrated cesium product, but adversely translates into a higher capital cost (both facility and equipment). For this example eight equilibrium stages appear to provide sufficient extraction performance at a reasonable $\mathrm{O} / \mathrm{A}$ based on engineering judgment.

Figure 6-19 depicts the flows within the stripping section. Equations for the stripping section are identical to the extraction section, but different values for $\mathrm{D}, \mathrm{O} / \mathrm{A}$, and $\mathrm{C}_{\mathrm{Cs}, \mathrm{o}}(\mathrm{aqu})$ are input for 
these variables. The organic volumetric flow rate $(\mathrm{O})$ is fixed by the extraction calculation, as are $\mathrm{C}_{\mathrm{Cs}, \mathrm{o}}\left(\right.$ org) $\left[\mathrm{C}_{\mathrm{Cs}, \mathrm{f}}(\mathrm{org})\right.$ in extraction equals $\mathrm{C}_{\mathrm{Cs}, \mathrm{o}}\left(\right.$ org) in stripping] and $\mathrm{C}_{\mathrm{Cs}, \mathrm{f}}(\mathrm{org})\left[\mathrm{C}_{\mathrm{Cs}, \mathrm{o}}\right.$ (org) in extraction equals $\mathrm{C}_{\mathrm{Cs}, \mathrm{f}}(\mathrm{org})$ in stripping]. $\mathrm{C}_{\mathrm{Cs}, \mathrm{f}}(\mathrm{aqu})$ is set by the $\mathrm{O} / \mathrm{A}$ and mass balance of $\mathrm{Cs}$ stripping from the organic stream $\left[\left(\mathrm{M}_{\mathrm{Cs}, \mathrm{o}}(\mathrm{org})-\mathrm{M}_{\mathrm{Cs}, \mathrm{f}}(\mathrm{org})+\mathrm{M}_{\mathrm{Cs}, \mathrm{o}}(\mathrm{aqu})=\mathrm{M}_{\mathrm{Cs}, \mathrm{f}}(\mathrm{aqu})\right]\right.$.

Figure 6-19 Staged Equilibrium Stripping Section

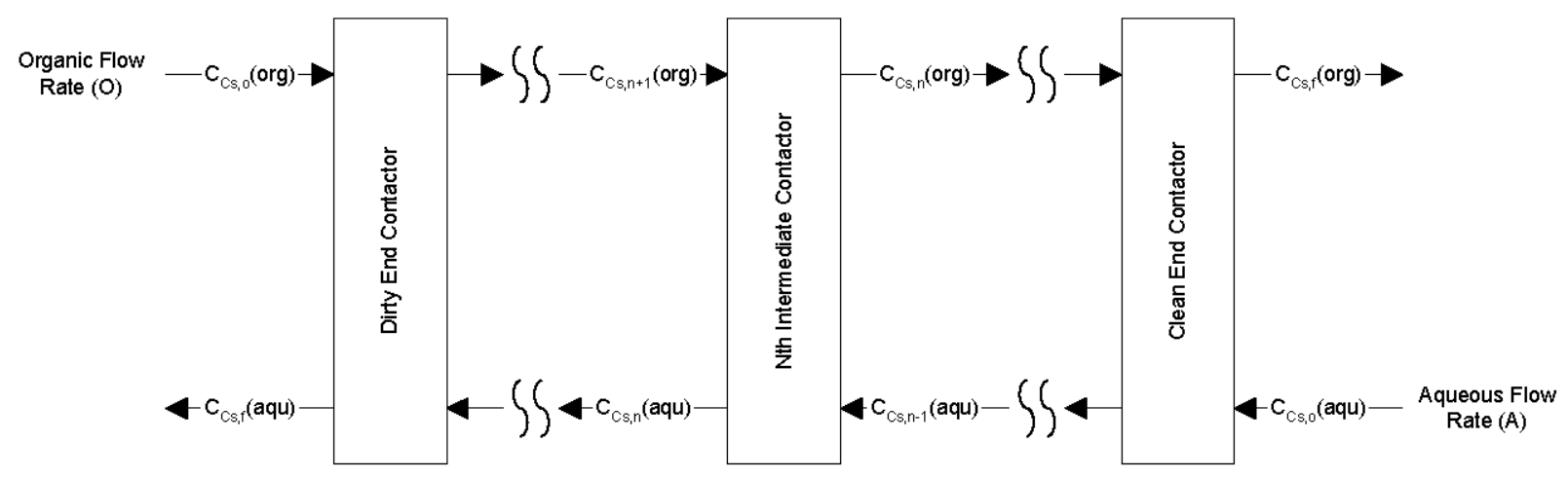

While $\mathrm{C}_{\mathrm{Cs}, \mathrm{o}}(\mathrm{aqu})$ equals zero in the operating line equation because the aqueous stripping solution is a fresh chemical addition, this point cannot be plotted on a log-log graph. Therefore, a pseudo concentration is specified for $\mathrm{C}_{\mathrm{Cs}, 0}(\mathrm{aqu})$ that is a value between zero and $100 \%$ of equilibrium. Because stepping off the equilibrium stages starts from this point vertically, the specific value selected doesn't materially affect the calculation. The specific value selected is primarily for aesthetics (i.e., to yield a straight line). Figure 6-20 presents the results of plotting the equilibrium and operating lines on a log-log graph. 
Figure 6-20 Example Stripping McCabe-Thiele Diagram

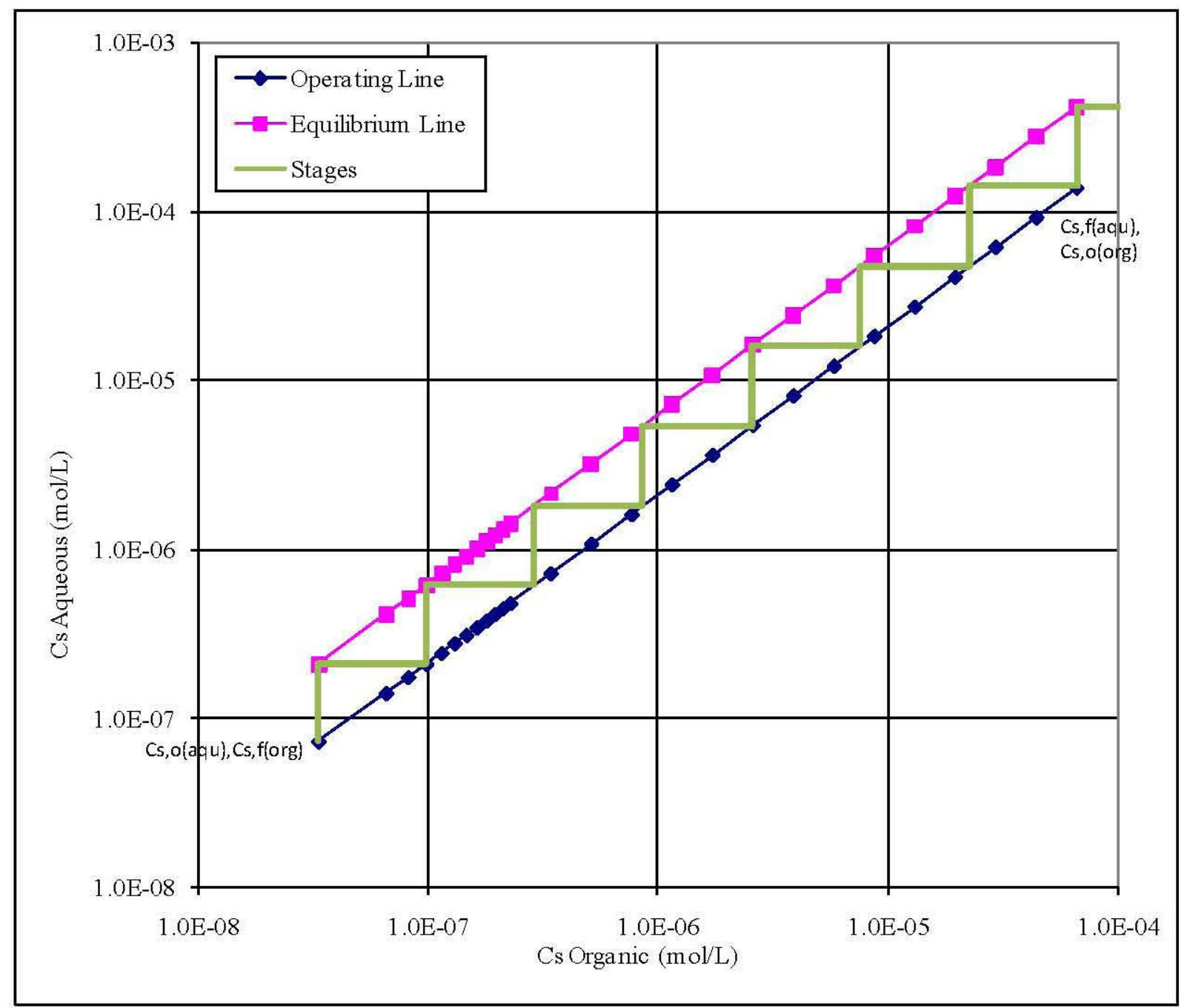

Equilibrium stages ( $100 \%$ theoretical efficiency) are counted in a manner identical to that described for extraction. For this example eight equilibrium stages appear to provide sufficient stripping performance at a reasonable $\mathrm{O} / \mathrm{A}$.

With the $\mathrm{O} / \mathrm{A}$ and number of theoretical stages determined, the mass balance is conceptually simple. Excluding $\mathrm{Cs}, \mathrm{K}$, and $\mathrm{Na}$, all other feed components stay in the aqueous phase as it passes through the extraction section. The desired quantity of cesium and about $0.023 \%$ of $\mathrm{Na}$ and $12.2 \%$ of $\mathrm{K}$ in the feed stream are absorbed into the organic stream. Subsequently, these components are scrubbed/stripped from the organic stream and routed to the Cs Product Tank. 


\subsubsection{Mass Balance Results}

Table 6-31 through Table 6-38 present summary mass balance results. These results were generated by entering the input data into SVF-1500, "IPS Caustic-Side Solvent Extraction Mass Balance Model." More detailed results are available in RPP-CALC-37579, Supporting Calculations for Interim Pretreatment System Pre-Conceptual Candidate Technology Descriptions.

The mass balance results are based on 12 theoretical equilibrium stages for both extraction and stripping. This is presumed to correspond to 14 and 23 actual equilibrium stages in extraction and stripping, respectively. This assumption was made to yield mass balances consistent with results cited in an e-mail from J. F. Birdwell to M. E. Johnson, "CSSX Flow Sheet Calculations" (Birdwell, J. F., 2008-05-16).

It is important to note that various input parameters (e.g., cesium distribution coefficients) and computational methodologies differed between those underlying Birdwell, J. F., 2008-05-16, and those used in this study. Therefore, inconsistencies between the two sources are observed. However, the Birdwell, J. F., 2008-05-16, results were used to define the total number of contactors to be specified in this study's equipment list.

Detailed calculations of system temperatures and pressures were not included in the material balances for technology comparisons. The caustic side solvent extraction process operates near ambient temperature and pressure. For optimum performance the CSSX extraction section must be operated $25^{\circ} \mathrm{C}$ or lower, while the stripping section is operated at about $35^{\circ} \mathrm{C}$ to improve stripping. The contactors are equipped with cooling jackets and will be maintained well below the solvent flash point (about $64{ }^{\circ} \mathrm{C}$ ). Process vessels and centrifugal contactors are maintained at slightly less than the ambient vault pressure. Maximum liquid stream pressures are characterized by the discharge pressure of pumps. 
Table 6-31 Caustic-Side Solvent Extraction Mass Balance Summary for 241-AN-104

\begin{tabular}{|c|c|c|c|c|c|c|c|c|c|c|c|c|c|c|}
\hline Stream Number & 1 & 2 & 3 & 4 & 5 & 7 & 8 & 9 & 10 & 11 & 12 & 13 & 14 & 15 \\
\hline Stream Name & $\begin{array}{l}\text { Waste Feed } \\
\text { from DST }\end{array}$ & $\begin{array}{c}\text { Concentrate } \\
\text { Return to } \\
\text { DST } \\
\end{array}$ & $\begin{array}{c}\text { Filtrate to Cs } \\
\text { Separation } \\
\end{array}$ & $\begin{array}{c}\text { Waste Feed } \\
\text { to Extraction }\end{array}$ & $\begin{array}{c}\text { LAW } \\
\text { Product }\end{array}$ & $\begin{array}{l}\text { LAW to } \\
\text { WTP }\end{array}$ & $\begin{array}{c}\text { Cs Loaded } \\
\text { Solvent } \\
\end{array}$ & $\begin{array}{c}\text { Scrubbed } \\
\text { Solvent }\end{array}$ & $\begin{array}{c}\text { Loaded } \\
\text { Solvent to } \\
\text { Stripping } \\
\end{array}$ & $\begin{array}{c}\text { Stripped } \\
\text { Solvent } \\
\end{array}$ & $\begin{array}{l}\text { Washed } \\
\text { Solvent }\end{array}$ & $\begin{array}{c}\text { Washed } \\
\text { Solvent to } \\
\text { Extraction } \\
\end{array}$ & $\begin{array}{l}\text { Loaded } \\
\text { Stripping } \\
\text { Solution } \\
\end{array}$ & Cs Product \\
\hline \multicolumn{15}{|l|}{ Physical Properties } \\
\hline Volume $(\mathrm{L} / \mathrm{h})$ & $9.35 \mathrm{E}+02$ & $1.88 \mathrm{E}+01$ & $9.17 \mathrm{E}+02$ & $1.39 \mathrm{E}+03$ & $1.40 \mathrm{E}+03$ & $1.39 \mathrm{E}+03$ & $3.08 \mathrm{E}+02$ & $3.08 \mathrm{E}+02$ & $3.09 \mathrm{E}+02$ & $3.08 \mathrm{E}+02$ & $3.08 \mathrm{E}+02$ & $3.22 \mathrm{E}+02$ & $9.19 \mathrm{E}+01$ & $9.10 \mathrm{E}+01$ \\
\hline Volume (gpm) & $4.12 \mathrm{E}+00$ & $8.28 \mathrm{E}-02$ & $4.04 \mathrm{E}+00$ & $6.11 \mathrm{E}+00$ & $6.17 \mathrm{E}+00$ & $6.11 \mathrm{E}+00$ & $1.36 \mathrm{E}+00$ & $1.36 \mathrm{E}+00$ & $1.36 \mathrm{E}+00$ & $1.36 \mathrm{E}+00$ & $1.36 \mathrm{E}+00$ & $1.42 \mathrm{E}+00$ & $4.05 \mathrm{E}-01$ & 4.01E-01 \\
\hline Density $(\mathrm{kg} / \mathrm{L})$ & 1.29 & 1.29 & 1.29 & 1.26 & 1.26 & 1.26 & 0.77 & 0.77 & 0.77 & 0.77 & 0.77 & 0.77 & 1.00 & 1.00 \\
\hline TDS $(\mathrm{kg} / \mathrm{h})$ & $3.83 \mathrm{E}+02$ & $7.71 \mathrm{E}+00$ & $3.76 \mathrm{E}+02$ & $4.89 \mathrm{E}+02$ & $4.89 \mathrm{E}+02$ & $4.89 \mathrm{E}+02$ & $2.88 \mathrm{E}-01$ & $1.10 \mathrm{E}-02$ & $1.10 \mathrm{E}-02$ & $6.44 \mathrm{E}-06$ & $6.44 \mathrm{E}-06$ & $6.44 \mathrm{E}-06$ & $1.51 \mathrm{E}-02$ & 4.31E-01 \\
\hline $\mathrm{Al}(\mathrm{mol} / \mathrm{L})$ & $6.48 \mathrm{E}-01$ & $6.48 \mathrm{E}-01$ & $6.48 \mathrm{E}-01$ & $4.28 \mathrm{E}-01$ & 4.24E-01 & $4.28 \mathrm{E}-01$ & -- & -- & -- & -- & -- & -- & -- & -- \\
\hline Free $\mathrm{OH}(\mathrm{mol} / \mathrm{L})$ & $1.76 \mathrm{E}+00$ & $1.76 \mathrm{E}+00$ & $1.76 \mathrm{E}+00$ & $3.20 \mathrm{E}+00$ & $3.17 \mathrm{E}+00$ & $3.20 \mathrm{E}+00$ & -- & -- & -- & -- & -- & -- & -- & -- \\
\hline $\mathrm{Cs}(\mathrm{mol} / \mathrm{L})$ & $8.14 \mathrm{E}-05$ & $8.14 \mathrm{E}-05$ & $8.14 \mathrm{E}-05$ & $5.38 \mathrm{E}-05$ & $4.30 \mathrm{E}-08$ & $4.35 \mathrm{E}-08$ & $2.42 \mathrm{E}-04$ & -- & $2.41 \mathrm{E}-04$ & $1.56 \mathrm{E}-07$ & $1.56 \mathrm{E}-07$ & $1.49 \mathrm{E}-07$ & $8.11 \mathrm{E}-04$ & -- \\
\hline $\mathrm{Na}(\mathrm{mol} / \mathrm{L})$ & $6.00 \mathrm{E}+00$ & $6.00 \mathrm{E}+00$ & $6.00 \mathrm{E}+00$ & $6.01 \mathrm{E}+00$ & $5.94 \mathrm{E}+00$ & $6.00 \mathrm{E}+00$ & $6.22 \mathrm{E}-03$ & -- & $6.51 \mathrm{E}-05$ & -- & -- & -- & $2.19 \mathrm{E}-04$ & -- \\
\hline $137 \mathrm{Cs}(\mathrm{Ci} / \mathrm{L})$ & $1.89 \mathrm{E}-01$ & $1.89 \mathrm{E}-01$ & $1.89 \mathrm{E}-01$ & $1.25 \mathrm{E}-01$ & $9.99 \mathrm{E}-05$ & $1.01 \mathrm{E}-04$ & $5.61 \mathrm{E}-01$ & $5.61 \mathrm{E}-01$ & $5.60 \mathrm{E}-01$ & 3.62E-04 & $3.62 \mathrm{E}-04$ & $3.46 \mathrm{E}-04$ & $1.88 \mathrm{E}+00$ & $1.90 \mathrm{E}+00$ \\
\hline \multicolumn{15}{|c|}{ Insoluble Components (kg/h) } \\
\hline Suspended Solids & $6.08 \mathrm{E}+00$ & $6.08 \mathrm{E}+00$ & $6.08 \mathrm{E}-04$ & $6.08 \mathrm{E}-04$ & $6.08 \mathrm{E}-04$ & $6.08 \mathrm{E}-04$ & -- & -- & -- & -- & -- & -- & -- & -- \\
\hline Solvent & -- & -- & -- & -- & $1.08 \mathrm{E}+01$ & -- & $2.37 \mathrm{E}+02$ & $2.37 \mathrm{E}+02$ & $2.37 \mathrm{E}+02$ & $2.37 \mathrm{E}+02$ & $2.37 \mathrm{E}+02$ & $2.47 \mathrm{E}+02$ & 7.05E-01 & -- \\
\hline Stream Number & 16 & 100 & 101 & 102 & 103 & 104 & 105 & 106 & 107 & 108 & 109 & 110 & 111 & 112 \\
\hline Stream Name & $\begin{array}{l}\text { Cs Product } \\
\text { to DST }\end{array}$ & $\begin{array}{c}\text { Dilution } \\
\mathrm{NaOH}\end{array}$ & $\begin{array}{c}\text { Waste Feed } \\
\text { Dilution } \\
\text { Water }\end{array}$ & $\begin{array}{l}0.05 \mathrm{M} \\
\text { HNO3 }\end{array}$ & $\begin{array}{c}\text { Stripping } \\
\text { Solution } \\
\text { Decant } \\
\text { Solvent }\end{array}$ & $\begin{array}{c}\mathrm{NaOH} \\
\text { Adjustment } \\
\text { Solution } \\
\end{array}$ & $\begin{array}{c}\mathrm{NaNO2} \\
\text { Adjustment } \\
\text { Solution } \\
\end{array}$ & $\begin{array}{c}0.001 \mathrm{M} \\
\mathrm{HNO3}\end{array}$ & $\begin{array}{l}\text { Spent Wash } \\
\text { Solution }\end{array}$ & $\begin{array}{l}0.01 \mathrm{M} \\
\mathrm{NaOH} \\
\end{array}$ & $\begin{array}{l}\text { LAW Stream } \\
\text { Decant } \\
\text { Solvent }\end{array}$ & $\begin{array}{l}\text { Solvent } \\
\text { Makeup }\end{array}$ & $\begin{array}{l}\text { Spent Scrub } \\
\text { Solution }\end{array}$ & $\begin{array}{l}\text { Cs Product } \\
\text { Dilution } \\
\text { Water }\end{array}$ \\
\hline \multicolumn{15}{|l|}{ Physical Properties } \\
\hline Volume $(\mathrm{L} / \mathrm{h})$ & $1.53 \mathrm{E}+02$ & $1.49 \mathrm{E}+02$ & $3.35 \mathrm{E}+02$ & $6.17 \mathrm{E}+01$ & $9.19 \mathrm{E}-01$ & $2.15 \mathrm{E}-01$ & $5.11 \mathrm{E}-01$ & $9.10 \mathrm{E}+01$ & $6.17 \mathrm{E}+01$ & $6.17 \mathrm{E}+01$ & $1.40 \mathrm{E}+01$ & -- & $6.17 \mathrm{E}+01$ & -- \\
\hline Volume (gpm) & $6.76 \mathrm{E}-01$ & $6.55 \mathrm{E}-01$ & $1.47 \mathrm{E}+00$ & $2.72 \mathrm{E}-01$ & $4.05 \mathrm{E}-03$ & $9.45 \mathrm{E}-04$ & $2.25 \mathrm{E}-03$ & $4.01 \mathrm{E}-01$ & $2.72 \mathrm{E}-01$ & $2.72 \mathrm{E}-01$ & $6.17 \mathrm{E}-02$ & -- & $2.72 \mathrm{E}-01$ & -- \\
\hline Density $(\mathrm{kg} / \mathrm{L})$ & 1.00 & 1.53 & 1.00 & 1.00 & 0.77 & 1.53 & 1.14 & 1.00 & 1.00 & 1.00 & 0.77 & 0.77 & 1.00 & 1.00 \\
\hline TDS $(\mathrm{kg} / \mathrm{h})$ & 7.35E-01 & $1.13 \mathrm{E}+02$ & -- & $1.39 \mathrm{E}-01$ & -- & $1.64 \mathrm{E}-01$ & $1.16 \mathrm{E}-01$ & $4.09 \mathrm{E}-03$ & $2.47 \mathrm{E}-02$ & $2.47 \mathrm{E}-02$ & -- & -- & $4.16 \mathrm{E}-01$ & \\
\hline $\mathrm{Al}(\mathrm{mol} / \mathrm{L})$ & -- & -- & -- & -- & -- & -- & -- & -- & -- & -- & -- & -- & -- & -- \\
\hline Free $\mathrm{OH}(\mathrm{mol} / \mathrm{L})$ & $1.00 \mathrm{E}-02$ & $1.91 \mathrm{E}+01$ & -- & -- & -- & $1.91 \mathrm{E}+01$ & -- & -- & $1.00 \mathrm{E}-02$ & $1.00 \mathrm{E}-02$ & -- & -- & -- & -- \\
\hline $\mathrm{Cs}(\mathrm{mol} / \mathrm{L})$ & $4.86 \mathrm{E}-04$ & & -- & -- & -- & -- & -- & -- & -- & -- & -- & -- & -- & -- \\
\hline $\mathrm{Na}(\mathrm{mol} / \mathrm{L})$ & $5.42 \mathrm{E}-02$ & $1.91 \mathrm{E}+01$ & -- & -- & -- & $1.91 \mathrm{E}+01$ & $3.30 \mathrm{E}+00$ & -- & $1.00 \mathrm{E}-02$ & $1.00 \mathrm{E}-02$ & -- & -- & $3.08 \mathrm{E}-02$ & -- \\
\hline $137 \mathrm{Cs}(\mathrm{Ci} / \mathrm{L})$ & $1.13 \mathrm{E}+00$ & -- & -- & -- & -- & -- & -- & -- & -- & -- & -- & -- & -- & -- \\
\hline \multicolumn{15}{|c|}{ Insoluble Components $(\mathrm{kg} / \mathrm{h})$} \\
\hline Suspended Solids & -- & -- & -- & -- & -- & -- & -- & -- & -- & -- & -- & -- & -- & -- \\
\hline Solvent & -- & -- & -- & -- & $7.05 \mathrm{E}-01$ & -- & -- & -- & -- & -- & $1.08 \mathrm{E}+01$ & -- & -- & -- \\
\hline
\end{tabular}

TDS = Total Dissolved Solids 
Table 6-32 Caustic-Side Solvent Extraction Mass Balance Summary for 241-AP-101

\begin{tabular}{|c|c|c|c|c|c|c|c|c|c|c|c|c|c|c|}
\hline Stream Number & 1 & 2 & 3 & 4 & 5 & 7 & 8 & 9 & 10 & 11 & 12 & 13 & 14 & 15 \\
\hline Stream Name & $\begin{array}{l}\text { Waste Feed } \\
\text { from DST }\end{array}$ & $\begin{array}{c}\text { Concentrate } \\
\text { Return to } \\
\text { DST } \\
\end{array}$ & $\begin{array}{c}\text { Filtrate to Cs } \\
\text { Separation }\end{array}$ & $\begin{array}{c}\text { Waste Feed } \\
\text { to Extraction }\end{array}$ & $\begin{array}{c}\text { LAW } \\
\text { Product }\end{array}$ & $\begin{array}{l}\text { LAW to } \\
\text { WTP }\end{array}$ & $\begin{array}{c}\text { Cs Loaded } \\
\text { Solvent }\end{array}$ & $\begin{array}{c}\text { Scrubbed } \\
\text { Solvent }\end{array}$ & $\begin{array}{c}\text { Loaded } \\
\text { Solvent to } \\
\text { Stripping } \\
\end{array}$ & $\begin{array}{c}\text { Stripped } \\
\text { Solvent }\end{array}$ & $\begin{array}{l}\text { Washed } \\
\text { Solvent }\end{array}$ & $\begin{array}{c}\text { Washed } \\
\text { Solvent to } \\
\text { Extraction }\end{array}$ & $\begin{array}{c}\text { Loaded } \\
\text { Stripping } \\
\text { Solution } \\
\end{array}$ & Cs Product \\
\hline \multicolumn{15}{|l|}{ Physical Properties } \\
\hline Volume $(\mathrm{L} / \mathrm{h})$ & $7.64 \mathrm{E}+02$ & $1.54 \mathrm{E}+01$ & $7.49 \mathrm{E}+02$ & $1.39 \mathrm{E}+03$ & $1.40 \mathrm{E}+03$ & $1.39 \mathrm{E}+03$ & $8.85 \mathrm{E}+02$ & $8.85 \mathrm{E}+02$ & $8.88 \mathrm{E}+02$ & $8.85 \mathrm{E}+02$ & $8.85 \mathrm{E}+02$ & $8.99 \mathrm{E}+02$ & $2.72 \mathrm{E}+02$ & $2.69 \mathrm{E}+02$ \\
\hline Volume (gpm) & $3.36 \mathrm{E}+00$ & $6.76 \mathrm{E}-02$ & $3.30 \mathrm{E}+00$ & $6.12 \mathrm{E}+00$ & $6.19 \mathrm{E}+00$ & $6.12 \mathrm{E}+00$ & $3.90 \mathrm{E}+00$ & $3.90 \mathrm{E}+00$ & $3.91 \mathrm{E}+00$ & $3.90 \mathrm{E}+00$ & $3.90 \mathrm{E}+00$ & $3.96 \mathrm{E}+00$ & $1.20 \mathrm{E}+00$ & $1.18 \mathrm{E}+00$ \\
\hline Density $(\mathrm{kg} / \mathrm{L})$ & 1.42 & 1.42 & 1.42 & 1.29 & 1.28 & 1.28 & 0.77 & 0.77 & 0.77 & 0.77 & 0.77 & 0.77 & 1.00 & 1.00 \\
\hline TDS $(\mathrm{kg} / \mathrm{h})$ & $4.90 \mathrm{E}+02$ & $9.85 \mathrm{E}+00$ & $4.80 \mathrm{E}+02$ & $5.53 \mathrm{E}+02$ & $5.52 \mathrm{E}+02$ & $5.52 \mathrm{E}+02$ & $8.22 \mathrm{E}-01$ & $1.55 \mathrm{E}-02$ & $1.55 \mathrm{E}-02$ & $6.83 \mathrm{E}-06$ & $6.83 \mathrm{E}-06$ & $6.83 \mathrm{E}-06$ & $2.76 \mathrm{E}-02$ & $1.23 \mathrm{E}+00$ \\
\hline $\mathrm{Al}(\mathrm{mol} / \mathrm{L})$ & $4.35 \mathrm{E}-01$ & 4.35E-01 & 4.35E-01 & $2.34 \mathrm{E}-01$ & $2.32 \mathrm{E}-01$ & $2.34 \mathrm{E}-01$ & -- & -- & -- & -- & -- & -- & -- & -- \\
\hline Free $\mathrm{OH}(\mathrm{mol} / \mathrm{L})$ & $1.53 \mathrm{E}+00$ & $1.53 \mathrm{E}+00$ & $1.53 \mathrm{E}+00$ & $2.13 \mathrm{E}+00$ & $2.10 \mathrm{E}+00$ & $2.13 \mathrm{E}+00$ & -- & -- & -- & -- & -- & -- & -- & -- \\
\hline $\mathrm{Cs}(\mathrm{mol} / \mathrm{L})$ & $1.33 \mathrm{E}-04$ & $1.33 \mathrm{E}-04$ & $1.33 \mathrm{E}-04$ & 7.17E-05 & 4.29E-08 & $4.34 \mathrm{E}-08$ & 1.13E-04 & -- & $1.12 \mathrm{E}-04$ & $5.76 \mathrm{E}-08$ & $5.76 \mathrm{E}-08$ & $5.67 \mathrm{E}-08$ & $3.67 \mathrm{E}-04$ & -- \\
\hline $\mathrm{Na}(\mathrm{mol} / \mathrm{L})$ & $8.71 \mathrm{E}+00$ & $8.71 \mathrm{E}+00$ & $8.71 \mathrm{E}+00$ & $6.00 \mathrm{E}+00$ & $5.93 \mathrm{E}+00$ & $5.99 \mathrm{E}+00$ & $2.17 \mathrm{E}-03$ & -- & $2.27 \mathrm{E}-05$ & & & & 7.41E-05 & -- \\
\hline $137 \mathrm{Cs}(\mathrm{Ci} / \mathrm{L})$ & 3.09E-01 & $3.09 \mathrm{E}-01$ & 3.09E-01 & $1.67 \mathrm{E}-01$ & $9.97 \mathrm{E}-05$ & $1.01 \mathrm{E}-04$ & 2.62E-01 & $2.62 \mathrm{E}-01$ & $2.61 \mathrm{E}-01$ & $1.34 \mathrm{E}-04$ & $1.34 \mathrm{E}-04$ & $1.32 \mathrm{E}-04$ & $8.52 \mathrm{E}-01$ & $8.60 \mathrm{E}-01$ \\
\hline \multicolumn{15}{|c|}{ Insoluble Components $(\mathrm{kg} / \mathrm{h})$} \\
\hline Suspended Solids & $5.45 \mathrm{E}+00$ & $5.45 \mathrm{E}+00$ & $5.45 \mathrm{E}-04$ & $5.45 \mathrm{E}-04$ & $5.45 \mathrm{E}-04$ & $5.45 \mathrm{E}-04$ & -- & -- & -- & -- & -- & -- & -- & -- \\
\hline Solvent & -- & -- & -- & -- & $1.08 \mathrm{E}+01$ & -- & $6.79 \mathrm{E}+02$ & $6.79 \mathrm{E}+02$ & $6.81 \mathrm{E}+02$ & $6.79 \mathrm{E}+02$ & $6.79 \mathrm{E}+02$ & $6.90 \mathrm{E}+02$ & $2.08 \mathrm{E}+00$ & -- \\
\hline Stream Number & 16 & 100 & 101 & 102 & 103 & 104 & 105 & 106 & 107 & 108 & 109 & 110 & 111 & 112 \\
\hline Stream Name & $\begin{array}{l}\text { Cs Product } \\
\text { to DST }\end{array}$ & $\begin{array}{c}\text { Dilution } \\
\mathrm{NaOH}\end{array}$ & $\begin{array}{l}\text { Waste Feed } \\
\text { Dilution } \\
\text { Water }\end{array}$ & $\begin{array}{l}0.05 \mathrm{M} \\
\text { HNO3 }\end{array}$ & $\begin{array}{l}\text { Stripping } \\
\text { Solution } \\
\text { Decant } \\
\text { Solvent } \\
\end{array}$ & $\begin{array}{c}\mathrm{NaOH} \\
\text { Adjustment } \\
\text { Solution }\end{array}$ & $\begin{array}{c}\text { NaNO2 } \\
\text { Adjustment } \\
\text { Solution }\end{array}$ & $\begin{array}{c}0.001 \mathrm{M} \\
\mathrm{HNO3} \\
\end{array}$ & $\begin{array}{c}\text { Spent Wash } \\
\text { Solution }\end{array}$ & $\begin{array}{l}\text { 0.01 M } \\
\mathrm{NaOH}\end{array}$ & $\begin{array}{c}\text { LAW Stream } \\
\text { Decant } \\
\text { Solvent }\end{array}$ & $\begin{array}{c}\text { Solvent } \\
\text { Makeup }\end{array}$ & $\begin{array}{c}\text { Spent Scrub } \\
\text { Solution }\end{array}$ & $\begin{array}{l}\text { Cs Product } \\
\text { Dilution } \\
\text { Water }\end{array}$ \\
\hline \multicolumn{15}{|l|}{ Physical Properties } \\
\hline Volume $(\mathrm{L} / \mathrm{h})$ & $4.48 \mathrm{E}+02$ & $9.51 \mathrm{E}+01$ & $5.80 \mathrm{E}+02$ & $1.77 \mathrm{E}+02$ & $2.72 \mathrm{E}+00$ & $6.20 \mathrm{E}-01$ & $1.49 \mathrm{E}+00$ & $2.69 \mathrm{E}+02$ & $1.77 \mathrm{E}+02$ & $1.77 \mathrm{E}+02$ & $1.40 \mathrm{E}+01$ & -- & $1.77 \mathrm{E}+02$ & -- \\
\hline Volume (gpm) & $1.97 \mathrm{E}+00$ & 4.19E-01 & $2.55 \mathrm{E}+00$ & $7.79 \mathrm{E}-01$ & $1.20 \mathrm{E}-02$ & $2.73 \mathrm{E}-03$ & $6.57 \mathrm{E}-03$ & $1.18 \mathrm{E}+00$ & $7.79 \mathrm{E}-01$ & $7.79 \mathrm{E}-01$ & $6.19 \mathrm{E}-02$ & -- & $7.79 \mathrm{E}-01$ & -- \\
\hline Density $(\mathrm{kg} / \mathrm{L})$ & 1.00 & 1.53 & 1.00 & 1.00 & 0.77 & 1.53 & 1.14 & 1.00 & 1.00 & 1.00 & 0.77 & 0.77 & 1.00 & 1.00 \\
\hline TDS $(\mathrm{kg} / \mathrm{h})$ & $2.12 \mathrm{E}+00$ & $7.25 \mathrm{E}+01$ & -- & 3.98E-01 & -- & $4.73 \mathrm{E}-01$ & $3.40 \mathrm{E}-01$ & $1.21 \mathrm{E}-02$ & $7.08 \mathrm{E}-02$ & $7.08 \mathrm{E}-02$ & -- & -- & $1.20 \mathrm{E}+00$ & -- \\
\hline $\mathrm{Al}(\mathrm{mol} / \mathrm{L})$ & -- & -- & -- & -- & -- & -- & -- & -- & -- & -- & -- & -- & -- & -- \\
\hline Free $\mathrm{OH}(\mathrm{mol} / \mathrm{L})$ & $1.00 \mathrm{E}-02$ & $1.91 \mathrm{E}+01$ & -- & -- & -- & $1.91 \mathrm{E}+01$ & -- & -- & $1.00 \mathrm{E}-02$ & $1.00 \mathrm{E}-02$ & -- & -- & -- & -- \\
\hline $\mathrm{Cs}(\mathrm{mol} / \mathrm{L})$ & $2.23 \mathrm{E}-04$ & -- & -- & -- & -- & -- & -- & -- & -- & -- & -- & -- & -- & -- \\
\hline $\mathrm{Na}(\mathrm{mol} / \mathrm{L})$ & $4.56 \mathrm{E}-02$ & $1.91 \mathrm{E}+01$ & -- & -- & -- & $1.91 \mathrm{E}+01$ & $3.30 \mathrm{E}+00$ & -- & $1.00 \mathrm{E}-02$ & $1.00 \mathrm{E}-02$ & -- & -- & $1.07 \mathrm{E}-02$ & -- \\
\hline $137 \mathrm{Cs}(\mathrm{Ci} / \mathrm{L})$ & $5.16 \mathrm{E}-01$ & -- & -- & -- & -- & -- & -- & -- & -- & -- & -- & -- & -- & -- \\
\hline \multicolumn{15}{|c|}{ Insoluble Components $(\mathrm{kg} / \mathrm{h})$} \\
\hline Suspended Solids & -- & -- & -- & -- & -- & -- & -- & -- & -- & -- & -- & -- & -- & -- \\
\hline Solvent & -- & -- & -- & -- & $2.08 \mathrm{E}+00$ & $\overline{--}$ & -- & -- & -- & -- & $1.08 \mathrm{E}+01$ & $\overline{--}$ & -- & -- \\
\hline
\end{tabular}

TDS = Total Dissolved Solids 
Table 6-33 Caustic-Side Solvent Extraction Mass Balance Summary for 241-AP-102

\begin{tabular}{|c|c|c|c|c|c|c|c|c|c|c|c|c|c|c|}
\hline Stream Number & 1 & 2 & 3 & 4 & 5 & 7 & 8 & 9 & 10 & 11 & 12 & 13 & 14 & 15 \\
\hline Stream Name & $\begin{array}{l}\text { Waste Feed } \\
\text { from DST }\end{array}$ & \begin{tabular}{|c|} 
Concentrate \\
Return to DST \\
\end{tabular} & \begin{tabular}{|c|} 
Filtrate to Cs \\
Separation \\
\end{tabular} & $\begin{array}{c}\text { Waste Feed to } \\
\text { Extraction }\end{array}$ & LAW Product & LAW to WTP & $\begin{array}{l}\text { Cs Loaded } \\
\text { Solvent } \\
\end{array}$ & $\begin{array}{c}\text { Scrubbed } \\
\text { Solvent }\end{array}$ & $\begin{array}{c}\text { Loaded Solvent } \\
\text { to Stripping }\end{array}$ & $\begin{array}{c}\text { Stripped } \\
\text { Solvent }\end{array}$ & Washed Solvent & $\begin{array}{c}\text { Washed } \\
\text { Solvent to } \\
\text { Extraction } \\
\end{array}$ & $\begin{array}{c}\text { Loaded } \\
\text { Stripping } \\
\text { Solution } \\
\end{array}$ & Cs Product \\
\hline \multicolumn{15}{|l|}{ Physical Properties } \\
\hline Volume (L/h) & $6.74 \mathrm{E}+02$ & $1.36 \mathrm{E}+01$ & $6.61 \mathrm{E}+02$ & $1.39 \mathrm{E}+03$ & $1.40 \mathrm{E}+03$ & $1.39 \mathrm{E}+03$ & $5.47 \mathrm{E}+02$ & $5.47 \mathrm{E}+02$ & $5.49 \mathrm{E}+02$ & $5.47 \mathrm{E}+02$ & $5.47 \mathrm{E}+02$ & $5.61 \mathrm{E}+02$ & $1.63 \mathrm{E}+02$ & $1.61 \mathrm{E}+02$ \\
\hline Volume (gpm) & $2.97 \mathrm{E}+00$ & $5.97 \mathrm{E}-02$ & $2.91 \mathrm{E}+00$ & $6.12 \mathrm{E}+00$ & $6.18 \mathrm{E}+00$ & $6.12 \mathrm{E}+00$ & $2.41 \mathrm{E}+00$ & $2.41 \mathrm{E}+00$ & $2.42 \mathrm{E}+00$ & $2.41 \mathrm{E}+00$ & $2.41 \mathrm{E}+00$ & $2.47 \mathrm{E}+00$ & $7.18 \mathrm{E}-01$ & $7.11 \mathrm{E}-01$ \\
\hline Density $(\mathrm{kg} / \mathrm{L})$ & 1.39 & 1.39 & 1.39 & 1.27 & 1.26 & 1.26 & 0.77 & 0.77 & 0.77 & 0.77 & 0.77 & 0.77 & 1.00 & 1.00 \\
\hline TDS $(\mathrm{kg} / \mathrm{h})$ & 3.93E+02 & $7.89 \mathrm{E}+00$ & $3.85 \mathrm{E}+02$ & $5.06 \mathrm{E}+02$ & $5.05 \mathrm{E}+02$ & $5.05 \mathrm{E}+02$ & $4.22 \mathrm{E}-01$ & $1.04 \mathrm{E}-02$ & $1.04 \mathrm{E}-02$ & $7.24 \mathrm{E}-06$ & $7.24 \mathrm{E}-06$ & $7.24 \mathrm{E}-06$ & $1.77 \mathrm{E}-02$ & $6.75 \mathrm{E}-01$ \\
\hline $\mathrm{Al}(\mathrm{mol} / \mathrm{L})$ & $8.51 \mathrm{E}-01$ & $8.51 \mathrm{E}-01$ & $8.51 \mathrm{E}-01$ & 4.05E-01 & 4.01E-01 & 4.05E-01 & -- & -- & -- & -- & -- & -- & -- & -- \\
\hline Free $\mathrm{OH}(\mathrm{mol} / \mathrm{L})$ & $1.91 \mathrm{E}+00$ & $1.91 \mathrm{E}+00$ & $1.91 \mathrm{E}+00$ & $3.09 \mathrm{E}+00$ & $3.05 \mathrm{E}+00$ & $3.09 \mathrm{E}+00$ & -- & -- & -- & -- & -- & -- & -- & -- \\
\hline $\mathrm{Cs}(\mathrm{mol} / \mathrm{L})$ & $1.04 \mathrm{E}-04$ & $1.04 \mathrm{E}-04$ & $1.04 \mathrm{E}-04$ & $4.93 \mathrm{E}-05$ & $4.30 \mathrm{E}-08$ & $4.34 \mathrm{E}-08$ & $1.25 \mathrm{E}-04$ & -- & $1.25 \mathrm{E}-04$ & $9.87 \mathrm{E}-08$ & $9.87 \mathrm{E}-08$ & $9.62 \mathrm{E}-08$ & $4.20 \mathrm{E}-04$ & -- \\
\hline $\mathrm{Na}(\mathrm{mol} / \mathrm{L})$ & $8.04 \mathrm{E}+00$ & $8.04 \mathrm{E}+00$ & $8.04 \mathrm{E}+00$ & $6.00 \mathrm{E}+00$ & $5.94 \mathrm{E}+00$ & $6.00 \mathrm{E}+00$ & $3.50 \mathrm{E}-03$ & -- & $3.67 \mathrm{E}-05$ & -- & -- & -- & $1.23 \mathrm{E}-04$ & -- \\
\hline $137 \mathrm{Cs}(\mathrm{Ci} / \mathrm{L})$ & $2.41 \mathrm{E}-01$ & $2.41 \mathrm{E}-01$ & 2.41E-01 & $1.14 \mathrm{E}-01$ & $9.98 \mathrm{E}-05$ & $1.01 \mathrm{E}-04$ & $2.90 \mathrm{E}-01$ & $2.90 \mathrm{E}-01$ & $2.89 \mathrm{E}-01$ & $2.29 \mathrm{E}-04$ & $2.29 \mathrm{E}-04$ & $2.23 \mathrm{E}-04$ & $9.74 \mathrm{E}-01$ & $9.83 \mathrm{E}-01$ \\
\hline \multicolumn{15}{|c|}{ Insoluble Components (kg/h) } \\
\hline Suspended Solids & $4.70 \mathrm{E}+00$ & $4.70 \mathrm{E}+00$ & $4.70 \mathrm{E}-04$ & $4.70 \mathrm{E}-04$ & $4.70 \mathrm{E}-04$ & $4.70 \mathrm{E}-04$ & -- & -- & -- & -- & -- & -- & -- & -- \\
\hline Solvent & -- & -- & -- & -- & $1.08 \mathrm{E}+01$ & -- & $4.20 \mathrm{E}+02$ & $4.20 \mathrm{E}+02$ & $4.21 \mathrm{E}+02$ & $4.20 \mathrm{E}+02$ & $4.20 \mathrm{E}+02$ & $4.31 \mathrm{E}+02$ & $1.25 \mathrm{E}+00$ & -- \\
\hline Stream Number & 16 & 100 & 101 & 102 & 103 & 104 & 105 & 106 & 107 & 108 & 109 & 110 & 111 & 112 \\
\hline Stream Name & $\begin{array}{c}\text { Cs Product to } \\
\text { DST } \\
\end{array}$ & Dilution $\mathrm{NaOH}$ & \begin{tabular}{|c|} 
Waste Feed \\
Dilution \\
Water \\
\end{tabular} & 0.05 M HNO3 & \begin{tabular}{|c|}
$\begin{array}{c}\text { Stripping } \\
\text { Solution Decant } \\
\text { Solvent }\end{array}$ \\
\end{tabular} & \begin{tabular}{|c|}
$\mathrm{NaOH}$ \\
Adjustment \\
Solution \\
\end{tabular} & $\begin{array}{c}\mathrm{NaNO2} \\
\text { Adjustment } \\
\text { Solution } \\
\end{array}$ & 0.001 M HNO3 & $\begin{array}{c}\text { Spent Wash } \\
\text { Solution }\end{array}$ & $0.01 \mathrm{M} \mathrm{NaOH}$ & $\begin{array}{c}\text { LAW Stream } \\
\text { Decant Solvent }\end{array}$ & $\begin{array}{c}\text { Solvent } \\
\text { Makeup }\end{array}$ & $\begin{array}{c}\text { Spent Scrub } \\
\text { Solution } \\
\end{array}$ & \begin{tabular}{|c} 
Cs Product \\
Dilution Water
\end{tabular} \\
\hline \multicolumn{15}{|l|}{ Physical Properties } \\
\hline Volume (L/h) & $2.72 \mathrm{E}+02$ & $1.59 \mathrm{E}+02$ & $5.98 \mathrm{E}+02$ & $1.09 \mathrm{E}+02$ & $1.63 \mathrm{E}+00$ & $3.81 \mathrm{E}-01$ & $9.07 \mathrm{E}-01$ & $1.61 \mathrm{E}+02$ & $1.09 \mathrm{E}+02$ & $1.09 \mathrm{E}+02$ & $1.40 \mathrm{E}+01$ & -- & $1.09 \mathrm{E}+02$ & -- \\
\hline Volume (gpm) & $1.20 \mathrm{E}+00$ & $6.99 \mathrm{E}-01$ & $2.63 \mathrm{E}+00$ & 4.82E-01 & $7.18 \mathrm{E}-03$ & $1.68 \mathrm{E}-03$ & 3.99E-03 & 7.11E-01 & 4.82E-01 & 4.82E-01 & $6.18 \mathrm{E}-02$ & -- & $4.82 \mathrm{E}-01$ & -- \\
\hline Density $(\mathrm{kg} / \mathrm{L})$ & 1.00 & 1.53 & 1.00 & 1.00 & 0.77 & 1.53 & 1.14 & 1.00 & 1.00 & 1.00 & 0.77 & 0.77 & 1.00 & 1.00 \\
\hline TDS $(\mathrm{kg} / \mathrm{h})$ & $1.22 \mathrm{E}+00$ & $1.21 \mathrm{E}+02$ & -- & $2.46 \mathrm{E}-01$ & -- & $2.90 \mathrm{E}-01$ & $2.07 \mathrm{E}-01$ & $7.26 \mathrm{E}-03$ & 4.38E-02 & 4.38E-02 & -- & -- & $6.57 \mathrm{E}-01$ & -- \\
\hline $\mathrm{Al}(\mathrm{mol} / \mathrm{L})$ & -- & -- & -- & -- & -- & -- & -- & -- & -- & -- & -- & -- & -- & -- \\
\hline Free $\mathrm{OH}(\mathrm{mol} / \mathrm{L})$ & $1.00 \mathrm{E}-02$ & $1.91 \mathrm{E}+01$ & -- & -- & -- & $1.91 \mathrm{E}+01$ & & -- & $1.00 \mathrm{E}-02$ & $1.00 \mathrm{E}-02$ & -- & -- & -- & -- \\
\hline $\mathrm{Cs}(\mathrm{mol} / \mathrm{L})$ & $2.51 \mathrm{E}-04$ & -- & -- & -- & -- & -- & -- & -- & -- & -- & -- & -- & -- & -- \\
\hline $\mathrm{Na}(\mathrm{mol} / \mathrm{L})$ & $4.87 \mathrm{E}-02$ & $1.91 \mathrm{E}+01$ & -- & -- & -- & $1.91 \mathrm{E}+01$ & $3.30 \mathrm{E}+00$ & -- & $1.00 \mathrm{E}-02$ & $1.00 \mathrm{E}-02$ & -- & -- & $1.73 \mathrm{E}-02$ & -- \\
\hline $137 \mathrm{Cs}(\mathrm{Ci} / \mathrm{L})$ & 5.83E-01 & -- & -- & -- & -- & -- & -- & -- & -- & -- & -- & -- & -- & -- \\
\hline \multicolumn{15}{|c|}{ Insoluble Components (kg/h) } \\
\hline Suspended Solids & -- & -- & -- & -- & -- & -- & -- & -- & -- & -- & -- & -- & -- & -- \\
\hline Solvent & -- & -- & -- & -- & $1.25 \mathrm{E}+00$ & -- & -- & -- & -- & -- & $1.08 \mathrm{E}+01$ & -- & -- & -- \\
\hline
\end{tabular}

TDS $=$ Total Dissolved Solids 
Table 6-34 Caustic-Side Solvent Extraction Mass Balance Summary for 241-AP-103

\begin{tabular}{|c|c|c|c|c|c|c|c|c|c|c|c|c|c|c|}
\hline Stream Number & 1 & 2 & 3 & 4 & 5 & 7 & 8 & 9 & 10 & 11 & 12 & 13 & 14 & 15 \\
\hline Stream Name & $\begin{array}{l}\text { Waste Feed } \\
\text { from DST }\end{array}$ & $\begin{array}{c}\text { Concentrate } \\
\text { Return to } \\
\text { DST } \\
\end{array}$ & $\begin{array}{l}\text { Filtrate to Cs } \\
\text { Separation }\end{array}$ & $\begin{array}{c}\text { Waste Feed to } \\
\text { Extraction }\end{array}$ & LAW Product & LAW to WTP & $\begin{array}{c}\text { Cs Loaded } \\
\text { Solvent }\end{array}$ & $\begin{array}{c}\text { Scrubbed } \\
\text { Solvent }\end{array}$ & $\begin{array}{c}\text { Loaded Solvent } \\
\text { to Stripping }\end{array}$ & $\begin{array}{c}\text { Stripped } \\
\text { Solvent }\end{array}$ & $\begin{array}{l}\text { Washed } \\
\text { Solvent }\end{array}$ & \begin{tabular}{|c|}
$\begin{array}{c}\text { Washed Solvent } \\
\text { to Extraction }\end{array}$ \\
\end{tabular} & $\begin{array}{c}\text { Loaded } \\
\text { Stripping } \\
\text { Solution } \\
\end{array}$ & Cs Product \\
\hline \multicolumn{15}{|l|}{ Physical Properties } \\
\hline Volume $(\mathrm{L} / \mathrm{h})$ & $6.34 \mathrm{E}+02$ & $1.27 \mathrm{E}+01$ & $6.21 \mathrm{E}+02$ & $1.39 \mathrm{E}+03$ & $1.40 \mathrm{E}+03$ & $1.39 \mathrm{E}+03$ & $6.60 \mathrm{E}+02$ & $6.60 \mathrm{E}+02$ & $6.61 \mathrm{E}+02$ & $6.60 \mathrm{E}+02$ & $6.60 \mathrm{E}+02$ & $6.74 \mathrm{E}+02$ & $1.97 \mathrm{E}+02$ & $1.95 \mathrm{E}+02$ \\
\hline Volume (gpm) & $2.79 \mathrm{E}+00$ & $5.61 \mathrm{E}-02$ & $2.74 \mathrm{E}+00$ & $6.12 \mathrm{E}+00$ & $6.18 \mathrm{E}+00$ & $6.12 \mathrm{E}+00$ & $2.90 \mathrm{E}+00$ & $2.90 \mathrm{E}+00$ & $2.91 \mathrm{E}+00$ & $2.90 \mathrm{E}+00$ & $2.90 \mathrm{E}+00$ & $2.97 \mathrm{E}+00$ & $8.65 \mathrm{E}-01$ & $8.57 \mathrm{E}-01$ \\
\hline Density $(\mathrm{kg} / \mathrm{L})$ & 1.41 & 1.41 & 1.41 & 1.27 & 1.26 & 1.26 & 0.77 & 0.77 & 0.77 & 0.77 & 0.77 & 0.77 & 1.00 & 1.00 \\
\hline TDS $(\mathrm{kg} / \mathrm{h})$ & $3.91 \mathrm{E}+02$ & $7.86 \mathrm{E}+00$ & $3.83 \mathrm{E}+02$ & $5.06 \mathrm{E}+02$ & $5.06 \mathrm{E}+02$ & $5.06 \mathrm{E}+02$ & 4.49E-01 & $9.95 \mathrm{E}-03$ & $9.95 \mathrm{E}-03$ & $7.20 \mathrm{E}-06$ & $7.20 \mathrm{E}-06$ & $7.20 \mathrm{E}-06$ & $1.87 \mathrm{E}-02$ & $7.55 \mathrm{E}-01$ \\
\hline $\mathrm{Al}(\mathrm{mol} / \mathrm{L})$ & 7.92E-01 & 7.92E-01 & 7.92E-01 & $3.54 \mathrm{E}-01$ & $3.51 \mathrm{E}-01$ & $3.54 \mathrm{E}-01$ & -- & -- & -- & -- & -- & -- & -- & -- \\
\hline Free $\mathrm{OH}(\mathrm{mol} / \mathrm{L})$ & $1.40 \mathrm{E}+00$ & $1.40 \mathrm{E}+00$ & $1.40 \mathrm{E}+00$ & $2.84 \mathrm{E}+00$ & $2.81 \mathrm{E}+00$ & $2.84 \mathrm{E}+00$ & -- & -- & -- & -- & -- & -- & -- & -- \\
\hline$\overline{\mathrm{Cs}(\mathrm{mol} / \mathrm{L})}$ & $1.04 \mathrm{E}-04$ & $1.04 \mathrm{E}-04$ & $1.04 \mathrm{E}-04$ & $4.63 \mathrm{E}-05$ & $4.30 \mathrm{E}-08$ & $4.34 \mathrm{E}-08$ & $9.75 \mathrm{E}-05$ & -- & $9.72 \mathrm{E}-05$ & $8.15 \mathrm{E}-08$ & $8.15 \mathrm{E}-08$ & $7.98 \mathrm{E}-08$ & $3.27 \mathrm{E}-04$ & -- \\
\hline $\mathrm{Na}(\mathrm{mol} / \mathrm{L})$ & $8.47 \mathrm{E}+00$ & $8.47 \mathrm{E}+00$ & $8.47 \mathrm{E}+00$ & $6.00 \mathrm{E}+00$ & $5.94 \mathrm{E}+00$ & $6.00 \mathrm{E}+00$ & $2.91 \mathrm{E}-03$ & -- & $3.04 \mathrm{E}-05$ & & & & $1.02 \mathrm{E}-04$ & -- \\
\hline $137 \mathrm{Cs}(\mathrm{Ci} / \mathrm{L})$ & $2.40 \mathrm{E}-01$ & $2.40 \mathrm{E}-01$ & $2.40 \mathrm{E}-01$ & $1.07 \mathrm{E}-01$ & $9.98 \mathrm{E}-05$ & $1.01 \mathrm{E}-04$ & $2.26 \mathrm{E}-01$ & $2.26 \mathrm{E}-01$ & $2.26 \mathrm{E}-01$ & $1.89 \mathrm{E}-04$ & $1.89 \mathrm{E}-04$ & $1.85 \mathrm{E}-04$ & $7.59 \mathrm{E}-01$ & $7.67 \mathrm{E}-01$ \\
\hline \multicolumn{15}{|c|}{ Insoluble Components (kg/h) } \\
\hline Suspended Solids & $4.48 \mathrm{E}+00$ & $4.48 \mathrm{E}+00$ & $4.48 \mathrm{E}-04$ & $4.48 \mathrm{E}-04$ & $4.48 \mathrm{E}-04$ & $4.48 \mathrm{E}-04$ & -- & -- & -- & -- & -- & -- & -- & -- \\
\hline Solvent & -- & -- & -- & -- & $1.08 \mathrm{E}+01$ & -- & $5.06 \mathrm{E}+02$ & $5.06 \mathrm{E}+02$ & $5.07 \mathrm{E}+02$ & $5.06 \mathrm{E}+02$ & $5.06 \mathrm{E}+02$ & $5.17 \mathrm{E}+02$ & $1.51 \mathrm{E}+00$ & -- \\
\hline Stream Number & 16 & 100 & 101 & 102 & 103 & 104 & 105 & 106 & 107 & 108 & 109 & 110 & 111 & 112 \\
\hline Stream Name & $\begin{array}{c}\text { Cs Product to } \\
\text { DST }\end{array}$ & $\begin{array}{c}\text { Dilution } \\
\mathrm{NaOH}\end{array}$ & $\begin{array}{c}\text { Waste Feed } \\
\text { Dilution Water }\end{array}$ & 0.05 M HNO3 & $\begin{array}{c}\text { Stripping } \\
\text { Solution } \\
\text { Decant } \\
\text { Solvent } \\
\end{array}$ & \begin{tabular}{|c|}
$\mathrm{NaOH}$ \\
$\begin{array}{c}\mathrm{NaOH} \\
\text { Solution }\end{array}$ \\
\end{tabular} & $\begin{array}{c}\text { NaNO2 } \\
\text { Adjustment } \\
\text { Solution } \\
\end{array}$ & $0.001 \mathrm{M}$ HNO3 & $\begin{array}{c}\text { Spent Wash } \\
\text { Solution }\end{array}$ & $0.01 \mathrm{M} \mathrm{NaOH}$ & $\begin{array}{c}\text { LAW Stream } \\
\text { Decant } \\
\text { Solvent } \\
\end{array}$ & Solvent Makeup & $\begin{array}{c}\text { Spent Scrub } \\
\text { Solution }\end{array}$ & \begin{tabular}{|c} 
Cs Product \\
Dilution Water
\end{tabular} \\
\hline \multicolumn{15}{|l|}{ Physical Properties } \\
\hline Volume (L/h) & $3.28 \mathrm{E}+02$ & $1.61 \mathrm{E}+02$ & $6.38 \mathrm{E}+02$ & $1.32 \mathrm{E}+02$ & $1.97 \mathrm{E}+00$ & $4.59 \mathrm{E}-01$ & $1.09 \mathrm{E}+00$ & $1.95 \mathrm{E}+02$ & $1.32 \mathrm{E}+02$ & $1.32 \mathrm{E}+02$ & $1.40 \mathrm{E}+01$ & -- & $1.32 \mathrm{E}+02$ & -- \\
\hline Volume (gpm) & $1.44 \mathrm{E}+00$ & $7.10 \mathrm{E}-01$ & $2.81 \mathrm{E}+00$ & $5.81 \mathrm{E}-01$ & $8.65 \mathrm{E}-03$ & $2.02 \mathrm{E}-03$ & $4.81 \mathrm{E}-03$ & $8.57 \mathrm{E}-01$ & $5.81 \mathrm{E}-01$ & $5.81 \mathrm{E}-01$ & $6.18 \mathrm{E}-02$ & -- & $5.81 \mathrm{E}-01$ & -- \\
\hline Density $(\mathrm{kg} / \mathrm{L})$ & 1.00 & 1.53 & 1.00 & 1.00 & 0.77 & 1.53 & 1.14 & 1.00 & 1.00 & 1.00 & 0.77 & 0.77 & 1.00 & 1.00 \\
\hline $\operatorname{TDS}(\mathrm{kg} / \mathrm{h})$ & $1.41 \mathrm{E}+00$ & $1.23 \mathrm{E}+02$ & -- & $2.97 \mathrm{E}-01$ & -- & 3.50E-01 & $2.49 \mathrm{E}-01$ & $8.75 \mathrm{E}-03$ & $5.28 \mathrm{E}-02$ & $5.28 \mathrm{E}-02$ & -- & -- & $7.36 \mathrm{E}-01$ & -- \\
\hline $\mathrm{Al}(\mathrm{mol} / \mathrm{L})$ & -- & -- & -- & -- & -- & -- & -- & -- & -- & -- & -- & -- & -- & -- \\
\hline Free $\mathrm{OH}(\mathrm{mol} / \mathrm{L})$ & $1.00 \mathrm{E}-02$ & $1.91 \mathrm{E}+01$ & -- & -- & -- & $1.91 \mathrm{E}+01$ & -- & -- & $1.00 \mathrm{E}-02$ & $1.00 \mathrm{E}-02$ & -- & -- & -- & -- \\
\hline $\mathrm{Cs}(\mathrm{mol} / \mathrm{L})$ & $1.96 \mathrm{E}-04$ & -- & -- & -- & -- & -- & -- & -- & -- & -- & -- & -- & -- & -- \\
\hline $\mathrm{Na}(\mathrm{mol} / \mathrm{L})$ & $4.75 \mathrm{E}-02$ & $1.91 \mathrm{E}+01$ & -- & -- & -- & $1.91 \mathrm{E}+01$ & $3.30 \mathrm{E}+00$ & -- & $1.00 \mathrm{E}-02$ & $1.00 \mathrm{E}-02$ & -- & -- & $1.44 \mathrm{E}-02$ & -- \\
\hline $137 \mathrm{Cs}(\mathrm{Ci} / \mathrm{L})$ & $4.55 \mathrm{E}-01$ & & -- & -- & -- & -- & -- & -- & -- & -- & -- & -- & -- & -- \\
\hline \multicolumn{15}{|c|}{ Insoluble Components $(\mathrm{kg} / \mathrm{h})$} \\
\hline Suspended Solids & -- & -- & -- & -- & -- & -- & -- & -- & -- & -- & -- & -- & -- & -- \\
\hline Solvent & -- & -- & -- & -- & $1.51 \mathrm{E}+00$ & -- & -- & -- & -- & -- & $1.08 \mathrm{E}+01$ & -- & -- & -- \\
\hline
\end{tabular}

TDS $=$ Total Dissolved Solids 
Table 6-35 Caustic-Side Solvent Extraction Mass Balance Summary for 241-AP-104

\begin{tabular}{|c|c|c|c|c|c|c|c|c|c|c|c|c|c|c|}
\hline Stream Number & 1 & 2 & 3 & 4 & 5 & 7 & 8 & 9 & 10 & 11 & 12 & 13 & 14 & 15 \\
\hline Stream Name & $\begin{array}{l}\text { Waste Feed } \\
\text { from DST }\end{array}$ & $\begin{array}{c}\text { Concentrate } \\
\text { Return to } \\
\text { DST } \\
\end{array}$ & $\begin{array}{c}\text { Filtrate to } \mathrm{Cs} \\
\text { Separation }\end{array}$ & $\begin{array}{c}\text { Waste Feed } \\
\text { to Extraction }\end{array}$ & $\begin{array}{c}\text { LAW } \\
\text { Product }\end{array}$ & $\begin{array}{l}\text { LAW to } \\
\text { WTP }\end{array}$ & $\begin{array}{c}\text { Cs Loaded } \\
\text { Solvent }\end{array}$ & $\begin{array}{c}\begin{array}{c}\text { Scrubbed } \\
\text { Solvent }\end{array} \\
\end{array}$ & $\begin{array}{c}\text { Loaded } \\
\text { Solvent to } \\
\text { Stripping } \\
\end{array}$ & $\begin{array}{c}\text { Stripped } \\
\text { Solvent }\end{array}$ & $\begin{array}{l}\text { Washed } \\
\text { Solvent }\end{array}$ & $\begin{array}{c}\text { Washed } \\
\text { Solvent to } \\
\text { Extraction }\end{array}$ & $\begin{array}{c}\text { Loaded } \\
\text { Stripping } \\
\text { Solution } \\
\end{array}$ & Cs Product \\
\hline \multicolumn{15}{|l|}{ Physical Properties } \\
\hline Volume $(\mathrm{L} / \mathrm{h})$ & $7.14 \mathrm{E}+02$ & $1.43 \mathrm{E}+01$ & $6.99 \mathrm{E}+02$ & $1.39 \mathrm{E}+03$ & $1.40 \mathrm{E}+03$ & $1.39 \mathrm{E}+03$ & $7.30 \mathrm{E}+02$ & $7.30 \mathrm{E}+02$ & $7.32 \mathrm{E}+02$ & $7.30 \mathrm{E}+02$ & $7.30 \mathrm{E}+02$ & $7.44 \mathrm{E}+02$ & $2.14 \mathrm{E}+02$ & $2.12 \mathrm{E}+02$ \\
\hline Volume (gpm) & $3.14 \mathrm{E}+00$ & $6.32 \mathrm{E}-02$ & $3.08 \mathrm{E}+00$ & $6.12 \mathrm{E}+00$ & $6.18 \mathrm{E}+00$ & $6.12 \mathrm{E}+00$ & $3.21 \mathrm{E}+00$ & $3.21 \mathrm{E}+00$ & $3.22 \mathrm{E}+00$ & $3.21 \mathrm{E}+00$ & $3.21 \mathrm{E}+00$ & $3.27 \mathrm{E}+00$ & $9.43 \mathrm{E}-01$ & $9.34 \mathrm{E}-01$ \\
\hline Density $(\mathrm{kg} / \mathrm{L})$ & 1.41 & 1.41 & 1.41 & 1.27 & 1.27 & 1.27 & 0.77 & 0.77 & 0.77 & 0.77 & 0.77 & 0.77 & 1.00 & 1.00 \\
\hline TDS $(\mathrm{kg} / \mathrm{h})$ & $4.39 \mathrm{E}+02$ & $8.83 \mathrm{E}+00$ & $4.31 \mathrm{E}+02$ & $5.28 \mathrm{E}+02$ & $5.28 \mathrm{E}+02$ & $5.28 \mathrm{E}+02$ & $6.00 \mathrm{E}-01$ & $9.41 \mathrm{E}-03$ & $9.41 \mathrm{E}-03$ & $6.47 \mathrm{E}-06$ & $6.47 \mathrm{E}-06$ & $6.47 \mathrm{E}-06$ & $1.89 \mathrm{E}-02$ & $9.38 \mathrm{E}-01$ \\
\hline $\mathrm{Al}(\mathrm{mol} / \mathrm{L})$ & $6.04 \mathrm{E}-01$ & $6.04 \mathrm{E}-01$ & $6.04 \mathrm{E}-01$ & $3.04 \mathrm{E}-01$ & $3.01 \mathrm{E}-01$ & 3.04E-01 & -- & -- & -- & -- & -- & -- & -- & -- \\
\hline Free $\mathrm{OH}(\mathrm{mol} / \mathrm{L})$ & $1.60 \mathrm{E}+00$ & $1.60 \mathrm{E}+00$ & $1.60 \mathrm{E}+00$ & $2.56 \mathrm{E}+00$ & $2.54 \mathrm{E}+00$ & $2.56 \mathrm{E}+00$ & -- & -- & -- & -- & -- & -- & -- & -- \\
\hline $\mathrm{Cs}(\mathrm{mol} / \mathrm{L})$ & $8.26 \mathrm{E}-05$ & $8.26 \mathrm{E}-05$ & $8.26 \mathrm{E}-05$ & 4.16E-05 & 4.30E-08 & 4.34E-08 & 7.92E-05 & -- & $7.90 \mathrm{E}-05$ & $6.62 \mathrm{E}-08$ & $6.62 \mathrm{E}-08$ & $6.49 \mathrm{E}-08$ & 2.69E-04 & -- \\
\hline $\mathrm{Na}(\mathrm{mol} / \mathrm{L})$ & $8.43 \mathrm{E}+00$ & $8.43 \mathrm{E}+00$ & $8.43 \mathrm{E}+00$ & $6.00 \mathrm{E}+00$ & $5.94 \mathrm{E}+00$ & $6.00 \mathrm{E}+00$ & $2.63 \mathrm{E}-03$ & -- & $2.75 \mathrm{E}-05$ & & & & 9.40E-05 & -- \\
\hline $137 \mathrm{Cs}(\mathrm{Ci} / \mathrm{L})$ & $1.92 \mathrm{E}-01$ & $1.92 \mathrm{E}-01$ & $1.92 \mathrm{E}-01$ & $9.65 \mathrm{E}-02$ & $9.98 \mathrm{E}-05$ & $1.01 \mathrm{E}-04$ & $1.84 \mathrm{E}-01$ & $1.84 \mathrm{E}-01$ & $1.83 \mathrm{E}-01$ & $1.54 \mathrm{E}-04$ & $1.54 \mathrm{E}-04$ & $1.51 \mathrm{E}-04$ & $6.25 \mathrm{E}-01$ & $6.32 \mathrm{E}-01$ \\
\hline \multicolumn{15}{|c|}{ Insoluble Components $(\mathrm{kg} / \mathrm{h})$} \\
\hline Suspended Solids & $5.04 \mathrm{E}+00$ & $5.04 \mathrm{E}+00$ & $5.04 \mathrm{E}-04$ & $5.04 \mathrm{E}-04$ & $5.04 \mathrm{E}-04$ & $5.04 \mathrm{E}-04$ & -- & -- & -- & -- & -- & -- & -- & -- \\
\hline Solvent & -- & -- & -- & -- & $1.08 \mathrm{E}+01$ & -- & $5.60 \mathrm{E}+02$ & $5.60 \mathrm{E}+02$ & $5.61 \mathrm{E}+02$ & $5.60 \mathrm{E}+02$ & $5.60 \mathrm{E}+02$ & $5.70 \mathrm{E}+02$ & $1.64 \mathrm{E}+00$ & -- \\
\hline Stream Number & 16 & 100 & 101 & 102 & 103 & 104 & 105 & 106 & 107 & 108 & 109 & 110 & 111 & 112 \\
\hline Stream Name & $\begin{array}{l}\text { Cs Product } \\
\text { to DST }\end{array}$ & $\begin{array}{c}\text { Dilution } \\
\mathrm{NaOH}\end{array}$ & $\begin{array}{c}\text { Waste Feed } \\
\text { Dilution } \\
\text { Water }\end{array}$ & $\begin{array}{l}0.05 \mathrm{M} \\
\text { HNO3 }\end{array}$ & $\begin{array}{l}\text { Stripping } \\
\text { Solution } \\
\text { Decant } \\
\text { Solvent } \\
\end{array}$ & $\begin{array}{c}\mathrm{NaOH} \\
\text { Adjustment } \\
\text { Solution }\end{array}$ & $\begin{array}{c}\mathrm{NaNO2} \\
\text { Adjustment } \\
\text { Solution }\end{array}$ & $\begin{array}{c}0.001 \mathrm{M} \\
\text { HNO3 }\end{array}$ & $\begin{array}{c}\text { Spent Wash } \\
\text { Solution }\end{array}$ & $\begin{array}{l}0.01 \mathrm{M} \\
\mathrm{NaOH}\end{array}$ & $\begin{array}{c}\text { LAW Stream } \\
\text { Decant } \\
\text { Solvent }\end{array}$ & $\begin{array}{l}\text { Solvent } \\
\text { Makeup }\end{array}$ & $\begin{array}{l}\text { Spent Scrub } \\
\text { Solution }\end{array}$ & $\begin{array}{c}\text { Cs Product } \\
\text { Dilution } \\
\text { Water }\end{array}$ \\
\hline \multicolumn{15}{|l|}{ Physical Properties } \\
\hline Volume $(\mathrm{L} / \mathrm{h})$ & $3.60 \mathrm{E}+02$ & $1.28 \mathrm{E}+02$ & $5.92 \mathrm{E}+02$ & $1.46 \mathrm{E}+02$ & $2.14 \mathrm{E}+00$ & $5.06 \mathrm{E}-01$ & $1.20 \mathrm{E}+00$ & $2.12 \mathrm{E}+02$ & $1.46 \mathrm{E}+02$ & $1.46 \mathrm{E}+02$ & $1.40 \mathrm{E}+01$ & -- & $1.46 \mathrm{E}+02$ & -- \\
\hline Volume (gpm) & $1.58 \mathrm{E}+00$ & $5.64 \mathrm{E}-01$ & $2.61 \mathrm{E}+00$ & $6.42 \mathrm{E}-01$ & $9.43 \mathrm{E}-03$ & $2.23 \mathrm{E}-03$ & $5.27 \mathrm{E}-03$ & 9.34E-01 & $6.42 \mathrm{E}-01$ & $6.42 \mathrm{E}-01$ & $6.18 \mathrm{E}-02$ & -- & $6.42 \mathrm{E}-01$ & -- \\
\hline Density $(\mathrm{kg} / \mathrm{L})$ & 1.00 & 1.53 & 1.00 & 1.00 & 0.77 & 1.53 & 1.14 & 1.00 & 1.00 & 1.00 & 0.77 & 0.77 & 1.00 & 1.00 \\
\hline $\operatorname{TDS}(\mathrm{kg} / \mathrm{h})$ & $1.65 \mathrm{E}+00$ & $9.77 \mathrm{E}+01$ & -- & $3.28 \mathrm{E}-01$ & & $3.86 \mathrm{E}-01$ & $2.73 \mathrm{E}-01$ & $9.54 \mathrm{E}-03$ & $5.84 \mathrm{E}-02$ & $5.84 \mathrm{E}-02$ & - & -- & $9.19 \mathrm{E}-01$ & -- \\
\hline $\mathrm{Al}(\mathrm{mol} / \mathrm{L})$ & -- & -- & -- & -- & -- & -- & -- & -- & -- & -- & -- & -- & -- & -- \\
\hline Free $\mathrm{OH}(\mathrm{mol} / \mathrm{L})$ & $1.00 \mathrm{E}-02$ & $1.91 \mathrm{E}+01$ & -- & - & -- & $1.91 \mathrm{E}+01$ & - & -- & $1.00 \mathrm{E}-02$ & $1.00 \mathrm{E}-02$ & -- & -- & - & -- \\
\hline $\mathrm{Cs}(\mathrm{mol} / \mathrm{L})$ & $1.60 \mathrm{E}-04$ & -- & -- & -- & -- & -- & -- & -- & -- & -- & -- & -- & -- & -- \\
\hline $\mathrm{Na}(\mathrm{mol} / \mathrm{L})$ & $4.72 \mathrm{E}-02$ & $1.91 \mathrm{E}+01$ & -- & -- & -- & $1.91 \mathrm{E}+01$ & $3.30 \mathrm{E}+00$ & -- & $1.00 \mathrm{E}-02$ & $1.00 \mathrm{E}-02$ & -- & -- & $1.30 \mathrm{E}-02$ & -- \\
\hline $137 \mathrm{Cs}(\mathrm{Ci} / \mathrm{L})$ & $3.72 \mathrm{E}-01$ & -- & -- & -- & -- & -- & -- & -- & -- & -- & -- & -- & -- & -- \\
\hline \multicolumn{15}{|c|}{ Insoluble Components $(\mathrm{kg} / \mathrm{h})$} \\
\hline Suspended Solids & -- & -- & -- & -- & -- & -- & -- & -- & -- & -- & -- & -- & -- & -- \\
\hline Solvent & -- & -- & -- & -- & $1.64 \mathrm{E}+00$ & -- & -- & -- & -- & -- & $1.08 \mathrm{E}+01$ & -- & -- & -- \\
\hline
\end{tabular}

TDS $=$ Total Dissolved Solids 
Table 6-36 Caustic-Side Solvent Extraction Mass Balance Summary for 241-AP-105

\begin{tabular}{|c|c|c|c|c|c|c|c|c|c|c|c|c|c|c|}
\hline Stream Number & 1 & 2 & 3 & 4 & 5 & 7 & 8 & 9 & 10 & 11 & 12 & 13 & 14 & 15 \\
\hline Stream Name & $\begin{array}{l}\text { Waste Feed } \\
\text { from DST }\end{array}$ & \begin{tabular}{|c} 
Concentrate \\
Return to DST
\end{tabular} & \begin{tabular}{|c|} 
Filtrate to Cs \\
Separation
\end{tabular} & $\begin{array}{c}\text { Waste Feed to } \\
\text { Extraction }\end{array}$ & LAW Product & LAW to WTP & $\begin{array}{c}\text { Cs Loaded } \\
\text { Solvent }\end{array}$ & $\begin{array}{c}\text { Scrubbed } \\
\text { Solvent }\end{array}$ & $\begin{array}{c}\text { Loaded Solvent } \\
\text { to Stripping }\end{array}$ & $\begin{array}{l}\text { Stripped } \\
\text { Solvent }\end{array}$ & $\begin{array}{l}\text { Washed } \\
\text { Solvent }\end{array}$ & $\mid \begin{array}{c}\text { Washed Solvent } \\
\text { to Extraction }\end{array}$ & $\begin{array}{l}\text { Loaded } \\
\text { Stripping } \\
\text { Solution }\end{array}$ & Cs Product \\
\hline \multicolumn{15}{|l|}{ Physical Properties } \\
\hline Volume (L/h) & $6.68 \mathrm{E}+02$ & $1.34 \mathrm{E}+01$ & $6.55 \mathrm{E}+02$ & $1.39 \mathrm{E}+03$ & $1.40 \mathrm{E}+03$ & $1.39 \mathrm{E}+03$ & $5.47 \mathrm{E}+02$ & $5.47 \mathrm{E}+02$ & $5.49 \mathrm{E}+02$ & $5.47 \mathrm{E}+02$ & $5.47 \mathrm{E}+02$ & $5.61 \mathrm{E}+02$ & $1.63 \mathrm{E}+02$ & $1.61 \mathrm{E}+02$ \\
\hline Volume (gpm) & $2.94 \mathrm{E}+00$ & $5.92 \mathrm{E}-02$ & $2.88 \mathrm{E}+00$ & $6.12 \mathrm{E}+00$ & $6.18 \mathrm{E}+00$ & $6.12 \mathrm{E}+00$ & $2.41 \mathrm{E}+00$ & $2.41 \mathrm{E}+00$ & $2.42 \mathrm{E}+00$ & $2.41 \mathrm{E}+00$ & $2.41 \mathrm{E}+00$ & $2.47 \mathrm{E}+00$ & 7.18E-01 & 7.11E-01 \\
\hline Density $(\mathrm{kg} / \mathrm{L})$ & 1.41 & 1.41 & 1.41 & 1.27 & 1.27 & 1.27 & 0.77 & 0.77 & 0.77 & 0.77 & 0.77 & 0.77 & 1.00 & 1.00 \\
\hline $\operatorname{TDS}(\mathrm{kg} / \mathrm{h})$ & $4.22 \mathrm{E}+02$ & $8.47 \mathrm{E}+00$ & 4.13E+02 & $5.13 \mathrm{E}+02$ & $5.13 \mathrm{E}+02$ & $5.13 \mathrm{E}+02$ & $3.69 \mathrm{E}-01$ & $1.15 \mathrm{E}-02$ & $1.15 \mathrm{E}-02$ & 7.33E-06 & 7.33E-06 & 7.33E-06 & $1.87 \mathrm{E}-02$ & $6.23 \mathrm{E}-01$ \\
\hline $\mathrm{Al}(\mathrm{mol} / \mathrm{L})$ & $6.99 \mathrm{E}-01$ & $6.99 \mathrm{E}-01$ & $6.99 \mathrm{E}-01$ & $3.30 \mathrm{E}-01$ & $3.26 \mathrm{E}-01$ & $3.30 \mathrm{E}-01$ & -- & -- & -- & -- & -- & -- & -- & -- \\
\hline Free $\mathrm{OH}(\mathrm{mol} / \mathrm{L})$ & $1.91 \mathrm{E}+00$ & $1.91 \mathrm{E}+00$ & $1.91 \mathrm{E}+00$ & $2.71 \mathrm{E}+00$ & $2.68 \mathrm{E}+00$ & $2.71 \mathrm{E}+00$ & -- & -- & -- & -- & -- & -- & -- & -- \\
\hline $\mathrm{Cs}(\mathrm{mol} / \mathrm{L})$ & $1.17 \mathrm{E}-04$ & $1.17 \mathrm{E}-04$ & $1.17 \mathrm{E}-04$ & $5.53 \mathrm{E}-05$ & $4.30 \mathrm{E}-08$ & $4.34 \mathrm{E}-08$ & $1.40 \mathrm{E}-04$ & $\overline{--}$ & $1.40 \mathrm{E}-04$ & $9.99 \mathrm{E}-08$ & $9.99 \mathrm{E}-08$ & $9.74 \mathrm{E}-08$ & $4.71 \mathrm{E}-04$ & $\overline{--}$ \\
\hline $\mathrm{Na}(\mathrm{mol} / \mathrm{L})$ & $8.90 \mathrm{E}+00$ & $8.90 \mathrm{E}+00$ & $8.90 \mathrm{E}+00$ & $6.00 \mathrm{E}+00$ & $5.94 \mathrm{E}+00$ & $6.00 \mathrm{E}+00$ & $3.50 \mathrm{E}-03$ & -- & $3.67 \mathrm{E}-05$ & -- & -- & -- & $1.23 \mathrm{E}-04$ & -- \\
\hline $137 \mathrm{Cs}(\mathrm{Ci} / \mathrm{L})$ & $2.73 \mathrm{E}-01$ & $2.73 \mathrm{E}-01$ & $2.73 \mathrm{E}-01$ & $1.28 \mathrm{E}-01$ & $9.97 \mathrm{E}-05$ & $1.01 \mathrm{E}-04$ & $3.26 \mathrm{E}-01$ & $3.26 \mathrm{E}-01$ & $3.25 \mathrm{E}-01$ & $2.32 \mathrm{E}-04$ & $2.32 \mathrm{E}-04$ & $2.26 \mathrm{E}-04$ & $1.09 \mathrm{E}+00$ & $1.10 \mathrm{E}+00$ \\
\hline \multicolumn{15}{|c|}{ Insoluble Components $(\mathrm{kg} / \mathrm{h})$} \\
\hline \begin{tabular}{|l} 
Suspended Solids \\
\end{tabular} & $4.75 \mathrm{E}+00$ & $4.75 \mathrm{E}+00$ & $4.75 \mathrm{E}-04$ & $4.75 \mathrm{E}-04$ & $4.75 \mathrm{E}-04$ & $4.75 \mathrm{E}-04$ & -- & -- & -- & -- & -- & -- & -- & -- \\
\hline Solvent & -- & -- & -- & -- & $1.08 \mathrm{E}+01$ & -- & $4.20 \mathrm{E}+02$ & $4.20 \mathrm{E}+02$ & $4.21 \mathrm{E}+02$ & $4.20 \mathrm{E}+02$ & $4.20 \mathrm{E}+02$ & $4.31 \mathrm{E}+02$ & $1.25 \mathrm{E}+00$ & -- \\
\hline Stream Number & 16 & 100 & 101 & 102 & 103 & 104 & 105 & 106 & 107 & 108 & 109 & 110 & 111 & 112 \\
\hline Stream Name & $\begin{array}{c}\text { Cs Product to } \\
\text { DST }\end{array}$ & $\begin{array}{c}\text { Dilution } \\
\mathrm{NaOH}\end{array}$ & $\begin{array}{c}\text { Waste Feed } \\
\text { Dilution } \\
\text { Water } \\
\end{array}$ & $0.05 \mathrm{M} \mathrm{HNO} 3$ & \begin{tabular}{|c|} 
Stripping \\
Solution Decant \\
Solvent
\end{tabular} & $\begin{array}{c}\mathrm{NaOH} \\
\text { Adjustment } \\
\text { Solution }\end{array}$ & \begin{tabular}{|c|} 
NaNO2 \\
Adjustment \\
Solution \\
\end{tabular} & $\begin{array}{c}0.001 \mathrm{M} \\
\mathrm{HNO3} \\
\end{array}$ & $\begin{array}{c}\text { Spent Wash } \\
\text { Solution }\end{array}$ & $0.01 \mathrm{M} \mathrm{NaOH}$ & $\begin{array}{c}\text { LAW Stream } \\
\text { Decant } \\
\text { Solvent } \\
\end{array}$ & Solvent Makeup & $\begin{array}{c}\text { Spent Scrub } \\
\text { Solution }\end{array}$ & $\begin{array}{c}\text { Cs Product } \\
\text { Dilution Water }\end{array}$ \\
\hline \multicolumn{15}{|l|}{ Physical Properties } \\
\hline Volume (L/h) & $2.72 \mathrm{E}+02$ & $1.32 \mathrm{E}+02$ & $6.36 \mathrm{E}+02$ & $1.09 \mathrm{E}+02$ & $1.63 \mathrm{E}+00$ & $3.81 \mathrm{E}-01$ & $9.07 \mathrm{E}-01$ & $1.61 \mathrm{E}+02$ & $1.09 \mathrm{E}+02$ & $1.09 \mathrm{E}+02$ & $1.40 \mathrm{E}+01$ & -- & $1.09 \mathrm{E}+02$ & -- \\
\hline Volume (gpm) & $1.20 \mathrm{E}+00$ & $5.80 \mathrm{E}-01$ & $2.80 \mathrm{E}+00$ & $4.82 \mathrm{E}-01$ & $7.18 \mathrm{E}-03$ & $1.68 \mathrm{E}-03$ & $3.99 \mathrm{E}-03$ & $7.11 \mathrm{E}-01$ & $4.82 \mathrm{E}-01$ & $4.82 \mathrm{E}-01$ & $6.18 \mathrm{E}-02$ & -- & $4.82 \mathrm{E}-01$ & -- \\
\hline Density $(\mathrm{kg} / \mathrm{L})$ & 1.00 & 1.53 & 1.00 & 1.00 & 0.77 & 1.53 & 1.14 & 1.00 & 1.00 & 1.00 & 0.77 & 0.77 & 1.00 & 1.00 \\
\hline TDS $(\mathrm{kg} / \mathrm{h})$ & $1.16 \mathrm{E}+00$ & $1.00 \mathrm{E}+02$ & -- & $2.46 \mathrm{E}-01$ & -- & $2.90 \mathrm{E}-01$ & $2.07 \mathrm{E}-01$ & $7.27 \mathrm{E}-03$ & $4.38 \mathrm{E}-02$ & $4.38 \mathrm{E}-02$ & -- & -- & $6.04 \mathrm{E}-01$ & -- \\
\hline $\mathrm{Al}(\mathrm{mol} / \mathrm{L})$ & -- & -- & -- & -- & -- & -- & -- & -- & -- & -- & -- & -- & -- & -- \\
\hline Free $\mathrm{OH}(\mathrm{mol} / \mathrm{L})$ & $1.00 \mathrm{E}-02$ & $1.91 \mathrm{E}+01$ & -- & -- & -- & $1.91 \mathrm{E}+01$ & -- & -- & $1.00 \mathrm{E}-02$ & $1.00 \mathrm{E}-02$ & -- & -- & -- & -- \\
\hline $\mathrm{Cs}(\mathrm{mol} / \mathrm{L})$ & $2.82 \mathrm{E}-04$ & -- & -- & -- & -- & -- & -- & -- & -- & -- & -- & -- & -- & -- \\
\hline $\mathrm{Na}(\mathrm{mol} / \mathrm{L})$ & $4.87 \mathrm{E}-02$ & $1.91 \mathrm{E}+01$ & -- & -- & -- & $1.91 \mathrm{E}+01$ & $3.30 \mathrm{E}+00$ & -- & $1.00 \mathrm{E}-02$ & $1.00 \mathrm{E}-02$ & -- & -- & $1.73 \mathrm{E}-02$ & -- \\
\hline $137 \mathrm{Cs}(\mathrm{Ci} / \mathrm{L})$ & $6.55 \mathrm{E}-01$ & -- & -- & -- & -- & -- & -- & -- & -- & -- & -- & -- & -- & -- \\
\hline \multicolumn{15}{|c|}{ Insoluble Components $(\mathrm{kg} / \mathrm{h})$} \\
\hline Suspended Solids & -- & -- & -- & -- & -- & -- & -- & -- & -- & -- & -- & -- & -- & -- \\
\hline Solvent & -- & - & -- & -- & $1.25 \mathrm{E}+00$ & -- & -- & - & - & -- & $1.08 \mathrm{E}+01$ & -- & -- & -- \\
\hline
\end{tabular}

TDS = Total Dissolved Solids 
Table 6-37 Caustic-Side Solvent Extraction Mass Balance Summary for 241-AP-107

\begin{tabular}{|c|c|c|c|c|c|c|c|c|c|c|c|c|c|c|}
\hline Stream Number & 1 & 2 & 3 & 4 & 5 & 7 & 8 & 9 & 10 & 11 & 12 & 13 & 14 & 15 \\
\hline Stream Name & $\begin{array}{l}\text { Waste Feed } \\
\text { from DST }\end{array}$ & $\begin{array}{c}\text { Concentrate } \\
\text { Return to } \\
\text { DST } \\
\end{array}$ & $\begin{array}{c}\text { Filtrate to Cs } \\
\text { Separation }\end{array}$ & $\begin{array}{c}\text { Waste Feed } \\
\text { to Extraction }\end{array}$ & $\begin{array}{c}\text { LAW } \\
\text { Product }\end{array}$ & $\begin{array}{l}\text { LAW to } \\
\text { WTP }\end{array}$ & $\begin{array}{c}\text { Cs Loaded } \\
\text { Solvent }\end{array}$ & $\begin{array}{c}\text { Scrubbed } \\
\text { Solvent }\end{array}$ & $\begin{array}{c}\text { Loaded } \\
\text { Solvent to } \\
\text { Stripping } \\
\end{array}$ & $\begin{array}{c}\text { Stripped } \\
\text { Solvent }\end{array}$ & $\begin{array}{l}\text { Washed } \\
\text { Solvent }\end{array}$ & $\begin{array}{c}\text { Washed } \\
\text { Solvent to } \\
\text { Extraction }\end{array}$ & $\begin{array}{c}\text { Loaded } \\
\text { Stripping } \\
\text { Solution } \\
\end{array}$ & Cs Product \\
\hline \multicolumn{15}{|l|}{ Physical Properties } \\
\hline Volume $(\mathrm{L} / \mathrm{h})$ & $8.25 \mathrm{E}+02$ & $1.66 \mathrm{E}+01$ & $8.09 \mathrm{E}+02$ & $1.39 \mathrm{E}+03$ & $1.40 \mathrm{E}+03$ & $1.39 \mathrm{E}+03$ & $5.05 \mathrm{E}+02$ & $5.05 \mathrm{E}+02$ & $5.07 \mathrm{E}+02$ & $5.05 \mathrm{E}+02$ & $5.05 \mathrm{E}+02$ & $5.20 \mathrm{E}+02$ & $1.71 \mathrm{E}+02$ & $1.69 \mathrm{E}+02$ \\
\hline Volume (gpm) & $3.63 \mathrm{E}+00$ & $7.30 \mathrm{E}-02$ & $3.56 \mathrm{E}+00$ & $6.12 \mathrm{E}+00$ & $6.18 \mathrm{E}+00$ & $6.12 \mathrm{E}+00$ & $2.23 \mathrm{E}+00$ & $2.23 \mathrm{E}+00$ & $2.23 \mathrm{E}+00$ & $2.23 \mathrm{E}+00$ & $2.23 \mathrm{E}+00$ & $2.29 \mathrm{E}+00$ & $7.52 \mathrm{E}-01$ & $7.44 \mathrm{E}-01$ \\
\hline Density $(\mathrm{kg} / \mathrm{L})$ & 1.38 & 1.38 & 1.38 & 1.28 & 1.27 & 1.28 & 0.77 & 0.77 & 0.77 & 0.77 & 0.77 & 0.77 & 1.00 & 1.00 \\
\hline TDS $(\mathrm{kg} / \mathrm{h})$ & $4.63 \mathrm{E}+02$ & $9.31 \mathrm{E}+00$ & $4.54 \mathrm{E}+02$ & $5.33 \mathrm{E}+02$ & $5.33 \mathrm{E}+02$ & $5.33 \mathrm{E}+02$ & $4.52 \mathrm{E}-01$ & $3.07 \mathrm{E}-02$ & $3.07 \mathrm{E}-02$ & $7.24 \mathrm{E}-06$ & $7.24 \mathrm{E}-06$ & $7.24 \mathrm{E}-06$ & $3.83 \mathrm{E}-02$ & $6.87 \mathrm{E}-01$ \\
\hline $\mathrm{Al}(\mathrm{mol} / \mathrm{L})$ & $4.11 \mathrm{E}-01$ & 4.11E-01 & 4.11E-01 & $2.39 \mathrm{E}-01$ & $2.37 \mathrm{E}-01$ & $2.39 \mathrm{E}-01$ & -- & -- & -- & -- & -- & -- & -- & -- \\
\hline Free $\mathrm{OH}(\mathrm{mol} / \mathrm{L})$ & $1.27 \mathrm{E}+00$ & $1.27 \mathrm{E}+00$ & $1.27 \mathrm{E}+00$ & $2.17 \mathrm{E}+00$ & $2.14 \mathrm{E}+00$ & $2.17 \mathrm{E}+00$ & -- & -- & -- & -- & -- & -- & -- & -- \\
\hline $\mathrm{Cs}(\mathrm{mol} / \mathrm{L})$ & $2.71 \mathrm{E}-04$ & $2.71 \mathrm{E}-04$ & $2.71 \mathrm{E}-04$ & $1.58 \mathrm{E}-04$ & 4.30E-08 & 4.34E-08 & 4.34E-04 & -- & 4.33E-04 & $1.07 \mathrm{E}-07$ & $1.07 \mathrm{E}-07$ & $1.04 \mathrm{E}-07$ & $1.28 \mathrm{E}-03$ & -- \\
\hline $\mathrm{Na}(\mathrm{mol} / \mathrm{L})$ & $7.86 \mathrm{E}+00$ & $7.86 \mathrm{E}+00$ & $7.86 \mathrm{E}+00$ & $6.00 \mathrm{E}+00$ & $5.94 \mathrm{E}+00$ & $6.00 \mathrm{E}+00$ & $3.79 \mathrm{E}-03$ & -- & 3.97E-05 & -- & -- & -- & $1.18 \mathrm{E}-04$ & -- \\
\hline $137 \mathrm{Cs}(\mathrm{Ci} / \mathrm{L})$ & $6.30 \mathrm{E}-01$ & $6.30 \mathrm{E}-01$ & $6.30 \mathrm{E}-01$ & $3.66 \mathrm{E}-01$ & $9.97 \mathrm{E}-05$ & $1.01 \mathrm{E}-04$ & $1.01 \mathrm{E}+00$ & $1.01 \mathrm{E}+00$ & $1.00 \mathrm{E}+00$ & $2.48 \mathrm{E}-04$ & $2.48 \mathrm{E}-04$ & $2.41 \mathrm{E}-04$ & $2.98 \mathrm{E}+00$ & $3.01 \mathrm{E}+00$ \\
\hline \multicolumn{15}{|c|}{ Insoluble Components $(\mathrm{kg} / \mathrm{h})$} \\
\hline Suspended Solids & $5.71 \mathrm{E}+00$ & $5.71 \mathrm{E}+00$ & $5.71 \mathrm{E}-04$ & $5.71 \mathrm{E}-04$ & $5.71 \mathrm{E}-04$ & $5.71 \mathrm{E}-04$ & -- & -- & -- & -- & -- & -- & -- & -- \\
\hline Solvent & -- & -- & -- & -- & $1.08 \mathrm{E}+01$ & -- & $3.88 \mathrm{E}+02$ & $3.88 \mathrm{E}+02$ & $3.89 \mathrm{E}+02$ & $3.88 \mathrm{E}+02$ & $3.88 \mathrm{E}+02$ & $3.98 \mathrm{E}+02$ & $1.31 \mathrm{E}+00$ & -- \\
\hline Stream Number & 16 & 100 & 101 & 102 & 103 & 104 & 105 & 106 & 107 & 108 & 109 & 110 & 111 & 112 \\
\hline Stream Name & $\begin{array}{l}\text { Cs Product } \\
\text { to DST }\end{array}$ & $\begin{array}{c}\text { Dilution } \\
\mathrm{NaOH}\end{array}$ & $\begin{array}{l}\text { Waste Feed } \\
\text { Dilution } \\
\text { Water }\end{array}$ & $\begin{array}{l}0.05 \mathrm{M} \\
\text { HNO3 }\end{array}$ & $\begin{array}{l}\text { Stripping } \\
\text { Solution } \\
\text { Decant } \\
\text { Solvent } \\
\end{array}$ & $\begin{array}{c}\mathrm{NaOH} \\
\text { Adjustment } \\
\text { Solution }\end{array}$ & $\begin{array}{c}\text { NaNO2 } \\
\text { Adjustment } \\
\text { Solution }\end{array}$ & $\begin{array}{c}0.001 \mathrm{M} \\
\mathrm{HNO3} \\
\end{array}$ & $\begin{array}{c}\text { Spent Wash } \\
\text { Solution }\end{array}$ & $\begin{array}{l}\text { 0.01 M } \\
\mathrm{NaOH}\end{array}$ & $\begin{array}{c}\text { LAW Stream } \\
\text { Decant } \\
\text { Solvent }\end{array}$ & $\begin{array}{c}\text { Solvent } \\
\text { Makeup }\end{array}$ & $\begin{array}{c}\text { Spent Scrub } \\
\text { Solution }\end{array}$ & $\begin{array}{l}\text { Cs Product } \\
\text { Dilution } \\
\text { Water }\end{array}$ \\
\hline \multicolumn{15}{|l|}{ Physical Properties } \\
\hline Volume $(\mathrm{L} / \mathrm{h})$ & $2.71 \mathrm{E}+02$ & $1.04 \mathrm{E}+02$ & $5.03 \mathrm{E}+02$ & $1.01 \mathrm{E}+02$ & $1.71 \mathrm{E}+00$ & 3.63E-01 & $9.04 \mathrm{E}-01$ & $1.69 \mathrm{E}+02$ & $1.01 \mathrm{E}+02$ & $1.01 \mathrm{E}+02$ & $1.40 \mathrm{E}+01$ & -- & $1.01 \mathrm{E}+02$ & -- \\
\hline Volume (gpm) & $1.20 \mathrm{E}+00$ & $4.58 \mathrm{E}-01$ & $2.21 \mathrm{E}+00$ & 4.45E-01 & $7.52 \mathrm{E}-03$ & $1.60 \mathrm{E}-03$ & $3.98 \mathrm{E}-03$ & 7.44E-01 & 4.45E-01 & $4.45 \mathrm{E}-01$ & $6.18 \mathrm{E}-02$ & -- & 4.45E-01 & -- \\
\hline Density $(\mathrm{kg} / \mathrm{L})$ & 1.00 & 1.53 & 1.00 & 1.00 & 0.77 & 1.53 & 1.14 & 1.00 & 1.00 & 1.00 & 0.77 & 0.77 & 1.00 & 1.00 \\
\hline TDS $(\mathrm{kg} / \mathrm{h})$ & $1.21 \mathrm{E}+00$ & $7.94 \mathrm{E}+01$ & -- & 2.27E-01 & -- & $2.77 \mathrm{E}-01$ & $2.06 \mathrm{E}-01$ & $7.61 \mathrm{E}-03$ & 4.04E-02 & $4.04 \mathrm{E}-02$ & -- & -- & $6.48 \mathrm{E}-01$ & -- \\
\hline $\mathrm{Al}(\mathrm{mol} / \mathrm{L})$ & -- & -- & -- & -- & -- & -- & -- & -- & -- & -- & -- & -- & -- & -- \\
\hline Free $\mathrm{OH}(\mathrm{mol} / \mathrm{L})$ & $1.00 \mathrm{E}-02$ & $1.91 \mathrm{E}+01$ & -- & -- & -- & $1.91 \mathrm{E}+01$ & -- & -- & $1.00 \mathrm{E}-02$ & $1.00 \mathrm{E}-02$ & -- & -- & -- & -- \\
\hline $\mathrm{Cs}(\mathrm{mol} / \mathrm{L})$ & $8.08 \mathrm{E}-04$ & -- & -- & -- & -- & -- & -- & -- & -- & -- & -- & -- & -- & -- \\
\hline $\mathrm{Na}(\mathrm{mol} / \mathrm{L})$ & $4.73 \mathrm{E}-02$ & $1.91 \mathrm{E}+01$ & -- & -- & -- & $1.91 \mathrm{E}+01$ & $3.30 \mathrm{E}+00$ & -- & $1.00 \mathrm{E}-02$ & $1.00 \mathrm{E}-02$ & -- & -- & $1.88 \mathrm{E}-02$ & -- \\
\hline $137 \mathrm{Cs}(\mathrm{Ci} / \mathrm{L})$ & $1.88 \mathrm{E}+00$ & -- & -- & -- & -- & -- & -- & -- & -- & -- & -- & -- & -- & -- \\
\hline \multicolumn{15}{|c|}{ Insoluble Components $(\mathrm{kg} / \mathrm{h})$} \\
\hline Suspended Solids & -- & -- & -- & -- & -- & -- & -- & -- & -- & -- & -- & -- & -- & -- \\
\hline Solvent & -- & -- & -- & -- & $1.31 \mathrm{E}+00$ & $\overline{--}$ & -- & -- & -- & -- & $1.08 \mathrm{E}+01$ & $\overline{--}$ & -- & -- \\
\hline
\end{tabular}

TDS $=$ Total Dissolved Solids 
Table 6-38 Caustic-Side Solvent Extraction Mass Balance Summary for 241-AP-107

\begin{tabular}{|c|c|c|c|c|c|c|c|c|c|c|c|c|c|c|}
\hline Stream Number & 1 & 2 & 3 & 4 & 5 & 7 & 8 & 9 & 10 & 11 & 12 & 13 & 14 & 15 \\
\hline Stream Name & $\begin{array}{l}\text { Waste Feed } \\
\text { from DST }\end{array}$ & $\begin{array}{c}\text { Concentrate } \\
\text { Return to } \\
\text { DST } \\
\end{array}$ & $\begin{array}{c}\text { Filtrate to Cs } \\
\text { Separation }\end{array}$ & $\begin{array}{c}\text { Waste Feed } \\
\text { to Extraction }\end{array}$ & $\begin{array}{c}\text { LAW } \\
\text { Product }\end{array}$ & $\begin{array}{l}\text { LAW to } \\
\text { WTP }\end{array}$ & $\begin{array}{c}\text { Cs Loaded } \\
\text { Solvent }\end{array}$ & $\begin{array}{c}\text { Scrubbed } \\
\text { Solvent }\end{array}$ & $\begin{array}{c}\text { Loaded } \\
\text { Solvent to } \\
\text { Stripping } \\
\end{array}$ & $\begin{array}{c}\text { Stripped } \\
\text { Solvent }\end{array}$ & $\begin{array}{l}\text { Washed } \\
\text { Solvent }\end{array}$ & $\begin{array}{c}\text { Washed } \\
\text { Solvent to } \\
\text { Extraction }\end{array}$ & $\begin{array}{c}\text { Loaded } \\
\text { Stripping } \\
\text { Solution } \\
\end{array}$ & Cs Product \\
\hline \multicolumn{15}{|l|}{ Physical Properties } \\
\hline Volume $(\mathrm{L} / \mathrm{h})$ & $6.25 \mathrm{E}+02$ & $1.26 \mathrm{E}+01$ & $6.12 \mathrm{E}+02$ & $1.39 \mathrm{E}+03$ & $1.40 \mathrm{E}+03$ & $1.39 \mathrm{E}+03$ & $9.67 \mathrm{E}+02$ & $9.67 \mathrm{E}+02$ & $9.70 \mathrm{E}+02$ & $9.67 \mathrm{E}+02$ & $9.67 \mathrm{E}+02$ & $9.81 \mathrm{E}+02$ & $2.80 \mathrm{E}+02$ & $2.77 \mathrm{E}+02$ \\
\hline Volume (gpm) & $2.75 \mathrm{E}+00$ & $5.53 \mathrm{E}-02$ & $2.69 \mathrm{E}+00$ & $6.11 \mathrm{E}+00$ & $6.17 \mathrm{E}+00$ & $6.11 \mathrm{E}+00$ & $4.26 \mathrm{E}+00$ & $4.26 \mathrm{E}+00$ & $4.27 \mathrm{E}+00$ & $4.26 \mathrm{E}+00$ & $4.26 \mathrm{E}+00$ & $4.32 \mathrm{E}+00$ & $1.23 \mathrm{E}+00$ & $1.22 \mathrm{E}+00$ \\
\hline Density $(\mathrm{kg} / \mathrm{L})$ & 1.42 & 1.42 & 1.42 & 1.27 & 1.27 & 1.27 & 0.77 & 0.77 & 0.77 & 0.77 & 0.77 & 0.77 & 1.00 & 1.00 \\
\hline TDS $(\mathrm{kg} / \mathrm{h})$ & $4.07 \mathrm{E}+02$ & $8.18 \mathrm{E}+00$ & $3.99 \mathrm{E}+02$ & $5.12 \mathrm{E}+02$ & $5.11 \mathrm{E}+02$ & $5.11 \mathrm{E}+02$ & $8.16 \mathrm{E}-01$ & $9.47 \mathrm{E}-03$ & $9.47 \mathrm{E}-03$ & $7.20 \mathrm{E}-06$ & $7.20 \mathrm{E}-06$ & $7.20 \mathrm{E}-06$ & $2.19 \mathrm{E}-02$ & $1.26 \mathrm{E}+00$ \\
\hline $\mathrm{Al}(\mathrm{mol} / \mathrm{L})$ & $8.79 \mathrm{E}-01$ & $8.79 \mathrm{E}-01$ & $8.79 \mathrm{E}-01$ & $3.88 \mathrm{E}-01$ & $3.84 \mathrm{E}-01$ & 3.88E-01 & -- & -- & -- & -- & -- & -- & -- & -- \\
\hline Free $\mathrm{OH}(\mathrm{mol} / \mathrm{L})$ & $2.22 \mathrm{E}+00$ & $2.22 \mathrm{E}+00$ & $2.22 \mathrm{E}+00$ & $3.01 \mathrm{E}+00$ & $2.98 \mathrm{E}+00$ & $3.01 \mathrm{E}+00$ & -- & -- & -- & -- & -- & -- & -- & -- \\
\hline $\mathrm{Cs}(\mathrm{mol} / \mathrm{L})$ & $8.93 \mathrm{E}-05$ & 8.93E-05 & $8.93 \mathrm{E}-05$ & $3.94 \mathrm{E}-05$ & $4.30 \mathrm{E}-08$ & $4.35 \mathrm{E}-08$ & $5.65 \mathrm{E}-05$ & -- & $5.63 \mathrm{E}-05$ & $5.55 \mathrm{E}-08$ & $5.55 \mathrm{E}-08$ & $5.47 \mathrm{E}-08$ & $1.95 \mathrm{E}-04$ & -- \\
\hline $\mathrm{Na}(\mathrm{mol} / \mathrm{L})$ & $9.02 \mathrm{E}+00$ & $9.02 \mathrm{E}+00$ & $9.02 \mathrm{E}+00$ & $6.01 \mathrm{E}+00$ & $5.95 \mathrm{E}+00$ & $6.01 \mathrm{E}+00$ & $1.98 \mathrm{E}-03$ & -- & $2.08 \mathrm{E}-05$ & -- & -- & -- & 7.19E-05 & -- \\
\hline $137 \mathrm{Cs}(\mathrm{Ci} / \mathrm{L})$ & $2.07 \mathrm{E}-01$ & $2.07 \mathrm{E}-01$ & $2.07 \mathrm{E}-01$ & $9.14 \mathrm{E}-02$ & 9.99E-05 & $1.01 \mathrm{E}-04$ & $1.31 \mathrm{E}-01$ & $1.31 \mathrm{E}-01$ & $1.31 \mathrm{E}-01$ & $1.29 \mathrm{E}-04$ & $1.29 \mathrm{E}-04$ & $1.27 \mathrm{E}-04$ & $4.53 \mathrm{E}-01$ & $4.57 \mathrm{E}-01$ \\
\hline \multicolumn{15}{|c|}{ Insoluble Components $(\mathrm{kg} / \mathrm{h})$} \\
\hline Suspended Solids & $4.47 \mathrm{E}+00$ & $4.47 \mathrm{E}+00$ & 4.47E-04 & 4.47E-04 & 4.47E-04 & 4.47E-04 & -- & -- & -- & -- & -- & -- & -- & -- \\
\hline Solvent & -- & -- & -- & -- & $1.07 \mathrm{E}+01$ & -- & $7.42 \mathrm{E}+02$ & $7.42 \mathrm{E}+02$ & $7.44 \mathrm{E}+02$ & $7.42 \mathrm{E}+02$ & $7.42 \mathrm{E}+02$ & $7.52 \mathrm{E}+02$ & $2.15 \mathrm{E}+00$ & -- \\
\hline Stream Number & 16 & 100 & 101 & 102 & 103 & 104 & 105 & 106 & 107 & 108 & 109 & 110 & 111 & 112 \\
\hline Stream Name & $\begin{array}{l}\text { Cs Product } \\
\text { to DST }\end{array}$ & $\begin{array}{c}\text { Dilution } \\
\mathrm{NaOH}\end{array}$ & $\begin{array}{l}\text { Waste Feed } \\
\text { Dilution } \\
\text { Water }\end{array}$ & $\begin{array}{l}0.05 \mathrm{M} \\
\text { HNO3 }\end{array}$ & $\begin{array}{l}\text { Stripping } \\
\text { Solution } \\
\text { Decant } \\
\text { Solvent } \\
\end{array}$ & $\begin{array}{c}\mathrm{NaOH} \\
\text { Adjustment } \\
\text { Solution }\end{array}$ & $\begin{array}{c}\text { NaNO2 } \\
\text { Adjustment } \\
\text { Solution }\end{array}$ & $\begin{array}{c}0.001 \mathrm{M} \\
\mathrm{HNO3} \\
\end{array}$ & $\begin{array}{c}\text { Spent Wash } \\
\text { Solution }\end{array}$ & $\begin{array}{l}\text { 0.01 M } \\
\mathrm{NaOH}\end{array}$ & $\begin{array}{c}\text { LAW Stream } \\
\text { Decant } \\
\text { Solvent }\end{array}$ & $\begin{array}{c}\text { Solvent } \\
\text { Makeup }\end{array}$ & $\begin{array}{c}\text { Spent Scrub } \\
\text { Solution }\end{array}$ & $\begin{array}{l}\text { Cs Product } \\
\text { Dilution } \\
\text { Water }\end{array}$ \\
\hline \multicolumn{15}{|l|}{ Physical Properties } \\
\hline Volume $(\mathrm{L} / \mathrm{h})$ & $4.73 \mathrm{E}+02$ & $1.48 \mathrm{E}+02$ & $6.62 \mathrm{E}+02$ & $1.93 \mathrm{E}+02$ & $2.80 \mathrm{E}+00$ & $6.68 \mathrm{E}-01$ & $1.57 \mathrm{E}+00$ & $2.77 \mathrm{E}+02$ & $1.93 \mathrm{E}+02$ & $1.93 \mathrm{E}+02$ & $1.40 \mathrm{E}+01$ & -- & $1.93 \mathrm{E}+02$ & -- \\
\hline Volume (gpm) & $2.08 \mathrm{E}+00$ & $6.51 \mathrm{E}-01$ & $2.92 \mathrm{E}+00$ & $8.52 \mathrm{E}-01$ & $1.23 \mathrm{E}-02$ & $2.94 \mathrm{E}-03$ & $6.93 \mathrm{E}-03$ & $1.22 \mathrm{E}+00$ & $8.52 \mathrm{E}-01$ & $8.52 \mathrm{E}-01$ & $6.17 \mathrm{E}-02$ & -- & $8.52 \mathrm{E}-01$ & -- \\
\hline Density $(\mathrm{kg} / \mathrm{L})$ & 1.00 & 1.53 & 1.00 & 1.00 & 0.77 & 1.53 & 1.14 & 1.00 & 1.00 & 1.00 & 0.77 & 0.77 & 1.00 & 1.00 \\
\hline TDS $(\mathrm{kg} / \mathrm{h})$ & $2.21 \mathrm{E}+00$ & $1.13 \mathrm{E}+02$ & -- & $4.35 \mathrm{E}-01$ & -- & $5.10 \mathrm{E}-01$ & $3.59 \mathrm{E}-01$ & $1.25 \mathrm{E}-02$ & $7.74 \mathrm{E}-02$ & $7.74 \mathrm{E}-02$ & -- & -- & $1.24 \mathrm{E}+00$ & \\
\hline $\mathrm{Al}(\mathrm{mol} / \mathrm{L})$ & -- & -- & -- & -- & -- & -- & -- & -- & -- & -- & -- & -- & -- & -- \\
\hline Free $\mathrm{OH}(\mathrm{mol} / \mathrm{L})$ & $1.00 \mathrm{E}-02$ & $1.91 \mathrm{E}+01$ & -- & -- & -- & $1.91 \mathrm{E}+01$ & -- & -- & $1.00 \mathrm{E}-02$ & $1.00 \mathrm{E}-02$ & -- & -- & -- & -- \\
\hline $\mathrm{Cs}(\mathrm{mol} / \mathrm{L})$ & $1.15 \mathrm{E}-04$ & & -- & -- & -- & -- & -- & -- & & & -- & -- & -- & -- \\
\hline $\mathrm{Na}(\mathrm{mol} / \mathrm{L})$ & $4.61 \mathrm{E}-02$ & $1.91 \mathrm{E}+01$ & -- & -- & -- & $1.91 \mathrm{E}+01$ & $3.30 \mathrm{E}+00$ & -- & $1.00 \mathrm{E}-02$ & $1.00 \mathrm{E}-02$ & -- & -- & $9.81 \mathrm{E}-03$ & -- \\
\hline $137 \mathrm{Cs}(\mathrm{Ci} / \mathrm{L})$ & $2.68 \mathrm{E}-01$ & -- & -- & -- & -- & -- & -- & -- & -- & -- & -- & -- & -- & -- \\
\hline \multicolumn{15}{|c|}{ Insoluble Components $(\mathrm{kg} / \mathrm{h})$} \\
\hline Suspended Solids & -- & -- & -- & -- & -- & -- & -- & -- & -- & -- & -- & -- & -- & -- \\
\hline Solvent & -- & -- & -- & -- & $2.15 \mathrm{E}+00$ & $\overline{--}$ & -- & -- & -- & -- & $1.07 \mathrm{E}+01$ & $\overline{--}$ & -- & -- \\
\hline
\end{tabular}

TDS = Total Dissolved Solids 


\subsubsection{Process Equipment}

Figure 6-21 provides the vendor (Costner Industries Nevada Corporation, www. cincmfg.com) specification sheet for the $25 \mathrm{~cm}$ rotor centrifugal contactor. Table 6-39 provides a summary of major equipment required for the pre-conceptual CSSX process.

\section{Figure 6-21 Centrifugal Contactor Specification}

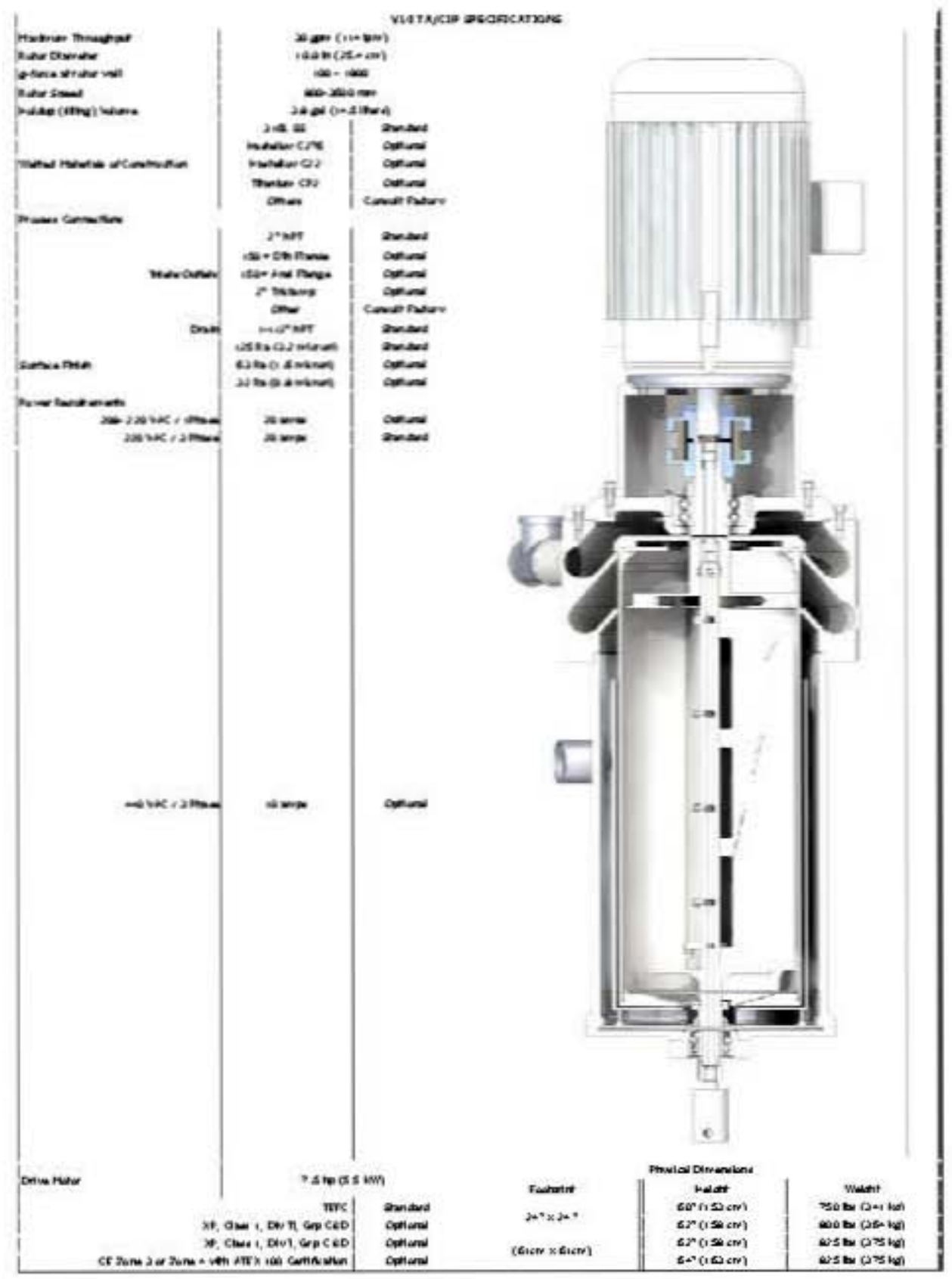


Table 6-39 Caustic Side Solvent Extraction Equipment List

\begin{tabular}{|c|c|c|c|c|c|}
\hline Qty & Component & Process Sizing & Physical Dimensions & Features & Comments \\
\hline 1 & Inline Mixer & & & & \\
\hline 1 & Feed Receipt Tank & $\begin{array}{l}11,500 \text { gal total } \\
\text { capacity }\end{array}$ & $12.5-\mathrm{ft} \mathrm{D} \times 12.5-\mathrm{ft} \mathrm{H}$ & $\begin{array}{l}\text { Clean out jet to empty tank in case of } \\
\text { failed pump } \\
\text { Nozzles: (3) process piping } \\
\text { (1) off gas } \\
\text { (1) pump } \\
\text { (3) instrumentation } \\
\text { (1) PRV } \\
\text { I\&C: Level } \\
\text { Temperature } \\
\text { Pressure control (offgas) }\end{array}$ & $\begin{array}{l}\text { Volume to store one day of waste } \\
\text { feed at the maximum flow rate }\end{array}$ \\
\hline 1 & Feed Pump & $10 \mathrm{gpm}$ & & $\begin{array}{l}\text { Tank top mounted, vertical pump } \\
\text { I\&C: Discharge pressure } \\
\text { Flow control } \\
\text { VFD } \\
\end{array}$ & $\begin{array}{l}\text { Flow rate is the maximum waste } \\
\text { feed flow rate of } 6.1 \mathrm{gpm} .\end{array}$ \\
\hline 1 & Feed Heat Exchanger & $120,000 \mathrm{Btu} / \mathrm{hr}$ & & $\begin{array}{l}\text { Chilled water supply/return } \\
\text { I\&C: Temperature control }\end{array}$ & $\begin{array}{l}\text { Sized to lower feed stream } \\
\text { temperature drop of } 15 \mathrm{C} \text { at the } \\
\text { maximum flow rate. }\end{array}$ \\
\hline 2 & LAW Product Tanks & $\begin{array}{l}45,000 \text { gal total } \\
\text { capacity }\end{array}$ & 19.7-ft D x 19.7-ft H & $\begin{array}{l}\text { Clean out jet to empty tank in case of } \\
\text { failed pump } \\
\text { Nozzles: (3) process piping } \\
\text { (1) off gas } \\
\text { (1) pump } \\
\text { (3) instrumentation } \\
\text { (1) sample } \\
\text { (1) PRV } \\
\text { I\&C: Level } \\
\text { Temperature } \\
\text { Pressure control (offgas) } \\
\text { Radiation monitor on inflow } \\
\end{array}$ & $\begin{array}{l}\text { Volume for storing four days of } \\
\text { treated LAW at the maximum } \\
\text { production rate in each tank }\end{array}$ \\
\hline 2 & LAW Product Pumps & $100 \mathrm{gpm}$ & & $\begin{array}{l}\text { Tank top mounted, vertical pump } \\
\text { I\&C: Discharge pressure } \\
\text { Flow control } \\
\text { VFD } \\
\end{array}$ & $\begin{array}{l}\text { Design basis flow rate for feed to } \\
\text { LAW is } 88 \mathrm{gpm} .\end{array}$ \\
\hline 1 & LAW Product Decanter & $1000 \mathrm{gal}$ & 3-ft D x 12-ft L & Horizontal tank & Estimated volume \\
\hline
\end{tabular}




\section{Table 6-39 Caustic Side Solvent Extraction Equipment List}

\begin{tabular}{|c|c|c|c|c|c|}
\hline Qty & Component & Process Sizing & Physical Dimensions & Features & Comments \\
\hline 2 & Cs Product Tanks & $\begin{array}{l}5,700 \text { gal total } \\
\text { capacity }\end{array}$ & 9.9-ft D x 9.9-ft H & $\begin{array}{l}\text { Clean out jet to empty tank in case of } \\
\text { failed pump } \\
\text { Nozzles: (5) process piping } \\
\text { (2) cooling coil } \\
\text { (1) off gas } \\
\text { (1) pump } \\
\text { (1) mixer } \\
\text { (3) instrumentation } \\
\text { (1) sample } \\
\text { (1) PRV } \\
\text { I\&C: Level } \\
\text { Temperature control } \\
\text { Pressure control (offgas) } \\
\text { pH probe }\end{array}$ & $\begin{array}{l}\text { Volume for storing } 1.5 \text { days of } \\
\text { cesium product at the highest } \\
\text { throughput. }\end{array}$ \\
\hline 2 & Cs Product Pumps & $100 \mathrm{gpm}$ & & $\begin{array}{l}\text { Tank top mounted, vertical pump } \\
\text { I\&C: Discharge pressure } \\
\text { Flow control } \\
\text { VFD } \\
\end{array}$ & $\begin{array}{l}\text { Flow rate for return to tank farms } \\
\text { assumed to be approximately } 75 \\
\text { gpm. }\end{array}$ \\
\hline 1 & Cs Product Decanter & $1000 \mathrm{gal}$ & 3-ft D x 12-ft L & Horizontal tank & Estimated volume \\
\hline \multicolumn{6}{|c|}{ Solvent Extraction } \\
\hline 43 & Contactors & 10 in rotor diameter & & & $\begin{array}{l}14 \text { extraction } \\
23 \text { stripping } \\
4 \text { scrub } \\
2 \text { wash }\end{array}$ \\
\hline 1 & Stripping Feed Tank & 550 gal total capacity & $4.5-\mathrm{ft} \mathrm{D} \times 4.5-\mathrm{ft} \mathrm{H}$ & $\begin{array}{l}\text { Nozzles: (3) process piping } \\
\text { (1) off gas } \\
\text { (1) pump } \\
\text { (3) instrumentation } \\
\text { (1) PRV } \\
\text { I\&C: Level } \\
\text { Temperature } \\
\text { Pressure control (offgas) }\end{array}$ & $\begin{array}{l}\text { Volume to store complete drain of } \\
\text { contactors and associated piping. }\end{array}$ \\
\hline 1 & Stripping Feed Pump & $10 \mathrm{gpm}$ & & $\begin{array}{l}\text { Tank top mounted, vertical pump } \\
\text { I\&C: Discharge pressure } \\
\text { Flow control } \\
\text { VFD } \\
\end{array}$ & $\begin{array}{l}\text { Flow rate is the maximum flow rate } \\
\text { of } 4.3 \mathrm{gpm}\end{array}$ \\
\hline
\end{tabular}




\section{Table 6-39 Caustic Side Solvent Extraction Equipment List}

\begin{tabular}{|c|c|c|c|c|c|}
\hline Qty & Component & Process Sizing & Physical Dimensions & Features & Comments \\
\hline 1 & Solvent Hold Tank & 550 gal total capacity & $4.5-\mathrm{ft} \mathrm{D} \times 4.5-\mathrm{ft} \mathrm{H}$ & $\begin{array}{l}\text { Nozzles: (4) process piping } \\
\text { (1) off gas } \\
\text { (1) pump } \\
\text { (3) instrumentation } \\
\text { (1) PRV } \\
\text { I\&C: Level } \\
\text { Temperature } \\
\text { Pressure control (offgas) }\end{array}$ & $\begin{array}{l}\text { Volume to store complete drain of } \\
\text { contactors and associated piping. }\end{array}$ \\
\hline 1 & Solvent Hold Pump & $10 \mathrm{gpm}$ & & $\begin{array}{l}\text { Tank top mounted, vertical pump } \\
\text { I\&C: Discharge pressure } \\
\text { Flow control } \\
\text { VFD } \\
\end{array}$ & $\begin{array}{l}\text { Flow rate is the maximum flow rate } \\
\text { of } 4.3 \mathrm{gpm}\end{array}$ \\
\hline 1 & Solvent Heat Exchanger & $22,000 \mathrm{BTU} / \mathrm{hr}$ & & & $\begin{array}{l}\text { Sized to lower feed stream } \\
\text { temperature drop of } 15 \mathrm{C} \text { at the } \\
\text { maximum flow rate. }\end{array}$ \\
\hline \multicolumn{4}{|c|}{ Chemical Storage Tanks, CSSX System } & \multicolumn{2}{|c|}{$\begin{array}{l}\text { All chemical storage tanks require level indication, fill and distribution piping, } \\
\text { and containment structure (see below). }\end{array}$} \\
\hline 1 & Bulk NaOH, 50 wt\% & $12,500 \mathrm{gal}$ & 12.9-ft D x 12.9-ft H & $\begin{array}{l}\text { Carbon Steel } \\
\text { Two Pumps } \\
3 \mathrm{gpm} \\
0.5 \mathrm{gpm}\end{array}$ & $\begin{array}{l}\text { Volume for a minimum of } 1 \text { week } \\
\text { supply, in multiples of the delivery } \\
\text { volume of } 5000 \text { gal. }\end{array}$ \\
\hline 2 & $0.01 \mathrm{M} \mathrm{NaOH}$ & $1,000 \mathrm{gal}$ & $5.5-\mathrm{ft} \mathrm{D} \times 5.5-\mathrm{ft} \mathrm{H}$ & $\begin{array}{l}\text { Carbon Steel } \\
\text { Mixer } \\
3 \text { gpm Pump }\end{array}$ & $\begin{array}{l}\text { Volume to store } 60 \% \text { of daily usage } \\
\text { in each of two tanks to ensure } \\
\text { continuous supply. }\end{array}$ \\
\hline 1 & Bulk $\mathrm{HNO}_{3}$ & One 55-gal drum & & $\begin{array}{l}\text { Stainless Steel } \\
0.5 \mathrm{gpm} \text { Pump } \\
\end{array}$ & $\begin{array}{l}\text { Volume for a minimum of } 1 \text { week } \\
\text { supply }\end{array}$ \\
\hline 2 & $0.05 \mathrm{M} \mathrm{HNO}_{3}$ & $1,000 \mathrm{gal}$ & $5.5-\mathrm{ft} \mathrm{D} \times 5.5-\mathrm{ft} \mathrm{H}$ & $\begin{array}{l}\text { Stainless Steel } \\
\text { Mixer } \\
3 \text { gpm Pump } \\
\end{array}$ & $\begin{array}{l}\text { Volume to store } 60 \% \text { of daily usage } \\
\text { in each of two tanks to ensure } \\
\text { continuous supply. }\end{array}$ \\
\hline 2 & $0.001 \mathrm{M} \mathrm{HNO}_{3}$ & $1,400 \mathrm{gal}$ & $6.2-\mathrm{ft} \mathrm{D} \times 6.2-\mathrm{ft} \mathrm{H}$ & $\begin{array}{l}\text { Stainless Steel } \\
\text { Mixer } \\
3 \text { gpm Pump }\end{array}$ & $\begin{array}{l}\text { Volume to store } 60 \% \text { of daily usage } \\
\text { in each of two tanks to ensure } \\
\text { continuous supply. }\end{array}$ \\
\hline 1 & Bulk $\mathrm{NaNO}_{2}, 20 \mathrm{wt} \%$ & Two 55-gal drums & & $\begin{array}{l}\text { Carbon Steel } \\
0.5 \text { gpm Pump }\end{array}$ & $\begin{array}{l}\text { Volume for a minimum of } 1 \text { week } \\
\text { supply. }\end{array}$ \\
\hline 1 & Water & $6,300 \mathrm{gal}$ & $10.2-\mathrm{ft} \mathrm{D} \times 10.2-\mathrm{ft} \mathrm{H}$ & $\begin{array}{l}\text { Carbon Steel } \\
\text { Two Pumps } \\
5 \text { gpm } \\
15 \mathrm{gpm}\end{array}$ & $\begin{array}{l}\text { Volume of tank to store } 60 \% \text { of one } \\
\text { day process requirement }\end{array}$ \\
\hline
\end{tabular}


Table 6-39 Caustic Side Solvent Extraction Equipment List

\begin{tabular}{|c|c|c|c|c|c|}
\hline Qty & Component & Process Sizing & Physical Dimensions & Features & Comments \\
\hline & Miscellaneous & & & & \\
\hline 1 & Offgas Adsorber & $300 \mathrm{scfm}$ & & $\begin{array}{l}\text { Add to offgas filter train } \\
\text { I\&C: Differential pressure } \\
\text { Temperature }\end{array}$ & $\begin{array}{l}\text { Required based on presence of } \\
\text { organic solvent. Solvent offgas DF } \\
\text { not determined. }\end{array}$ \\
\hline \multicolumn{6}{|c|}{ Structures, CSSX System } \\
\hline 7 & $\begin{array}{l}\text { Tank/Equipment Vaults } \\
\text { Feed Tank } \\
\text { Cs Product Tank \#1 } \\
\text { Cs Product Tank \#2 } \\
\text { LAW Product Tank \#1 } \\
\text { LAW Product Tank \#2 } \\
\text { Contactors } \\
\text { Solvent/Stripping Tanks }\end{array}$ & & $\begin{array}{l}15^{\prime} \mathrm{L} \times 15^{\prime} \mathrm{W} \times 20^{\prime} \mathrm{H} \\
18^{\prime} \mathrm{L} \times 16^{\prime} \mathrm{W} \times 20^{\prime} \mathrm{H} \\
18^{\prime} \mathrm{L} \times 16^{\prime} \mathrm{W} \times 20^{\prime} \mathrm{H} \\
26^{\prime} \mathrm{L} \times 26^{\prime} \mathrm{W} \times 30^{\prime} \mathrm{H} \\
26^{\prime} \mathrm{L} \times 26^{\prime} \mathrm{W} \times 30^{\prime} \mathrm{H} \\
60^{\prime} \mathrm{L} \times 15^{\prime} \mathrm{W} \times 15^{\prime} \mathrm{H} \\
15^{\prime} \mathrm{L} \times 15^{\prime} \mathrm{W} \times 15^{\prime} \mathrm{H} \\
\text { Internal Dimensions }\end{array}$ & $\begin{array}{l}\text { Concrete below grade structure with } 3 \text { - } \\
\mathrm{ft} \mathrm{thick} \mathrm{walls} \mathrm{and} \mathrm{floors} \\
3 \text {-ft thick concrete cover blocks at grade } \\
\text { consisting of } 12 \text { " wide removable } \\
\text { concrete beams. } \\
\text { Stainless steel lined floor and walls up } \\
\text { to bottom of cover blocks } \\
\text { Sump with remote read-out leak } \\
\text { detector and sump pump for each vault } \\
\text { Remote connector heads }\end{array}$ & \\
\hline 1 & Valve Vault & & $\begin{array}{l}96^{\prime} \mathrm{L} \times 10^{\prime} \mathrm{W} \times 15^{\prime} \mathrm{H} \\
\text { Internal Dimensions }\end{array}$ & $\begin{array}{l}\text { One valve vault adjacent to and serving } \\
\text { all tank vaults } \\
\text { Concrete below grade structure with } 3 \text { - } \\
\text { ft thick walls and floors } \\
\text { 3-ft thick concrete cover blocks at grade } \\
\text { consisting of } 12^{\prime \prime} \text { wide removable } \\
\text { concrete beams. } \\
\text { Stainless steel lined floor and walls up } \\
\text { to bottom of cover blocks } \\
\text { Sump with remote read-out leak } \\
\text { detector and sump pump } \\
\text { Remote connector heads }\end{array}$ & \\
\hline 7 & $\begin{array}{l}\text { Chemical Storage } \\
\text { containment } \\
\text { Bulk NaOH, } 50 \mathrm{wt} \% \\
0.01 \mathrm{M} \mathrm{NaOH}^{2}(2) \\
{\text { Bulk } \mathrm{HNO}_{3}}_{0.05 \mathrm{M} \mathrm{HNO}_{3}(2)} \\
0.001 \mathrm{M} \mathrm{HNO}_{3}(2) \\
\text { Bulk } \mathrm{NaNO}_{2}, 20 \mathrm{wt} \% \\
\text { Water }\end{array}$ & & $\begin{array}{l}17^{\prime} \mathrm{L} \times 15^{\prime} \mathrm{W} \times 14^{\prime} \mathrm{H} \\
10^{\prime} \mathrm{L} \times 10^{\prime} \mathrm{W} \times 2^{\prime} \mathrm{H} \\
5^{\prime} \mathrm{L} \times 5^{\prime} \mathrm{W} \times 6-\mathrm{in} \mathrm{H} \\
10^{\prime} \mathrm{L} \times 10^{\prime} \mathrm{W} \times 2^{\prime} \mathrm{H} \\
11^{\prime} \mathrm{L} \times 10^{\prime} \mathrm{W} \times 3^{\prime} \mathrm{H} \\
11^{\prime} \mathrm{L} \times 5^{\prime} \mathrm{W} \times 6-\mathrm{in} \mathrm{H} \\
17^{\prime} \mathrm{L} \times 15^{\prime} \mathrm{W} \text { pad }\end{array}$ & $\begin{array}{l}\text { Above grade, painted concrete spill } \\
\text { containment basins } \\
6 \text {-in walls }\end{array}$ & \\
\hline \multicolumn{6}{|c|}{ PUREX type jumpers } \\
\hline
\end{tabular}


Table 6-39 Caustic Side Solvent Extraction Equipment List

\begin{tabular}{|c|c|c|c|c|c|}
\hline Qty & Component & Process Sizing & Physical Dimensions & Features & Comments \\
\hline & Feed Receipt Tank Vault & & & $\begin{array}{l}\text { (2) Process } \\
\text { (1) Electrical power } \\
\text { (2) Instrument }\end{array}$ & $\begin{array}{l}\text { Pump } \\
\text { Level and temperature } \\
\text { instrumentation. }\end{array}$ \\
\hline & Contactors Vault & & & (3) Process & $\begin{array}{l}\text { Assume that the contactors are } \\
\text { modular to facilitate removal. }\end{array}$ \\
\hline & $\begin{array}{l}\text { Solvent/Stripping Tanks } \\
\text { Vault }\end{array}$ & & & $\begin{array}{l}\text { (5) Process } \\
\text { (2) Electrical power } \\
\text { (4) Instrument }\end{array}$ & $\begin{array}{l}\text { Pump } \\
\text { Heat exchanger } \\
\text { Level and temperature } \\
\text { instrumentation. }\end{array}$ \\
\hline & Cs Product Tank \#1 Vault & & & $\begin{array}{l}\text { (2) Process } \\
\text { (1) Electrical power } \\
\text { (2) Instrument }\end{array}$ & $\begin{array}{l}\text { Pump } \\
\text { Level and temperature } \\
\text { instrumentation. }\end{array}$ \\
\hline & Cs Product Tank \#1 Vault & & & $\begin{array}{l}\text { (2) Process } \\
\text { (1) Electrical power } \\
\text { (2) Instrument }\end{array}$ & $\begin{array}{l}\text { Pump } \\
\text { Level and temperature } \\
\text { instrumentation. }\end{array}$ \\
\hline & $\begin{array}{l}\text { LAW Product Tank \#1 } \\
\text { Vault }\end{array}$ & & & $\begin{array}{l}\text { (2) Process } \\
\text { (1) Electrical power } \\
\text { (2) Instrument }\end{array}$ & $\begin{array}{l}\text { Pump } \\
\text { Level and temperature } \\
\text { instrumentation. }\end{array}$ \\
\hline & $\begin{array}{l}\text { LAW Product Tank \#2 } \\
\text { Vault }\end{array}$ & & & $\begin{array}{l}\text { (2) Process } \\
\text { (1) Electrical power } \\
\text { (2) Instrument } \\
\end{array}$ & $\begin{array}{l}\text { Pump } \\
\text { Level and temperature } \\
\text { instrumentation. }\end{array}$ \\
\hline & Valve Vault & & & $\begin{array}{l}\text { (30) Process } \\
\text { (28) Electrical power }\end{array}$ & $\begin{array}{l}\text { Assume two MOV's or instruments } \\
\text { per process line. } \\
\text { Inline mixer, Feed heat exchanger }\end{array}$ \\
\hline
\end{tabular}

General Notes:

1. All tanks are designed, fabricated and tested to ASME Section VIII

2. All process piping is designed, fabricated and tested to ASME B31.3

3. All process equipment, chemical equipment and offgas piping is manufactured from $304 \mathrm{~L}$ or $316 \mathrm{~L}$ SS.

4. All components of exhaust side offgas and ventilation systems are designed, fabricated and tested to ASME AG-1

5. See Common Equipment List for process offgas, vault ventilation, recirculation AHU, and chilled water systems.

6. Tanks are sized assuming a working volume equal to $80 \%$ of the total capacity. 


\subsubsection{Process Consumables Summary}

Table 6-40 provides the peak chemical usage (time-average) for the worst case feed processing.

$\underline{\text { Peak Electrical Power Estimate }}$

Solvent Extraction process equipment

Process chilled water system

Total
$263 \mathrm{kw}$

$68 \mathrm{kw}$

$331 \mathrm{kw}^{1}$

${ }^{1}$ Does not include feed filtration, lighting, ventilation, control room and other support functions. 
Table 6-40 Peak Chemical Usage for Caustic-Side Solvent Extraction

\begin{tabular}{|c|c|c|c|c|c|c|c|c|}
\hline $\begin{array}{c}\text { Stream } \\
\#\end{array}$ & Description & $\begin{array}{c}\text { Steady } \\
\text { State } \\
\text { Flow, } \\
\text { L/hr }\end{array}$ & Composition & $\begin{array}{c}19 \mathrm{M} \\
\text { NaOH } \\
\text { Equivalent } \\
\text { Flow, L/hr }\end{array}$ & $\begin{array}{c}12.2 \mathrm{M} \\
\text { HNO3 } \\
\text { Equivalent } \\
\text { Flow, L/hr }\end{array}$ & $\begin{array}{c}\text { Makeup } \\
\text { Water } \\
\text { Flow, L/hr }\end{array}$ & $\begin{array}{c}4 \mathrm{M} \\
\text { NaNO2 } \\
\text { Equivalent } \\
\text { Flow, L/hr }\end{array}$ & $\begin{array}{c}\text { Waste in } \\
\text { process for } \\
\text { maximum } \\
\text { usage }\end{array}$ \\
\hline 100 & $\begin{array}{l}\text { Waste Feed Dilution } \\
\mathrm{NaOH}\end{array}$ & 161 & $19 \mathrm{M} \mathrm{NaOH}$ & 161 & & & & AP-103 \\
\hline 101 & Waste Feed Dilution Water & 662 & Water & & & 662 & & AP-108 \\
\hline 102 & $0.05 \mathrm{MHNO}_{3}$ & 193 & $0.05 \mathrm{M} \mathrm{HNO}_{3}$ & & 0.79 & 192.2 & & AP-108 \\
\hline 104 & $\begin{array}{l}\mathrm{NaOH} \text { Adjustment } \\
\text { Solution }\end{array}$ & 0.668 & $19 \mathrm{M} \mathrm{NaOH}$ & 0.668 & & & & AP-108 \\
\hline 105 & $\begin{array}{l}\text { NaNO2 Adjustment } \\
\text { Solution }\end{array}$ & 1.57 & $4 \mathrm{MNaNO} 2$ & & & & 1.57 & AP-108 \\
\hline 106 & $0.001 \mathrm{M} \mathrm{HNO}_{3}$ & 277 & $0.001 \mathrm{M} \mathrm{HNO}_{3}$ & & 0.023 & 277.0 & & AP-108 \\
\hline 108 & $0.01 \mathrm{MNaOH}$ & 193 & $0.01 \mathrm{MNaOH}$ & 0.102 & & 192.9 & & AP-108 \\
\hline 112 & Cs Product Dilution Water & 0 & Water & & & 0 & & AP-108 \\
\hline \multirow{2}{*}{\multicolumn{4}{|c|}{$\begin{array}{r}\text { Total Usage Rate }= \\
\text { Total Usage Rate }(\mathrm{gpm})=\end{array}$}} & 161.8 & 0.81 & 1324.1 & 1.57 & \\
\hline & & & & 0.71 & 0.0036 & 5.8 & 0.0069 & \\
\hline
\end{tabular}

Note: In addition to the above usages, one solvent inventory replacement (180 to $390 \mathrm{gal})$ is expected no more frequently than annually. 


\subsubsection{Preliminary Risks/Issues and Potential Optimization}

Although the Savannah River Site's MCU has began processing tank waste, its waste feed throughput is constrained to about $1 / 3$ the design capacity. This limitation was imposed because excessive foaming/entrainment in the contactors was observed during startup testing. It has been postulated that the ventilation system serving the contactors is undersized, but a consensus on a definitive root cause does not yet exist.

For the IPS the CSSX flow sheet has a substantially greater number of contactors than the MCU (43 versus 18). This is a result of the high potassium content of some Hanford feed batches, the need to attain a higher cesium decontamination factor (4,000 versus 12 for the MCU), and the desire to minimize the volume of cesium product returned to the DST system. However, the number of contactors could be reduced to at least 34 if a larger volume, but more dilute cesium product were acceptable.

The cesium product can always be concentrated in the 242-A Evaporator, but staging the dilute material prior to an evaporator campaign can create logistical issues within the DST system. Alternately, an evaporator could be incorporated into the CSSX flow sheet. This option, however, requires a thorough analysis as to whether the reduction in contactors outweighs the cost of an evaporator.

A substantial reduction in the number of contactors could also be realized if the modifications proposed by Delmau et al. 2008 are validated by future development activities. Birdwell, J. F., 2008-05-16, predicted that switching to the BEHBCalixC6 solvent would reduce the number of contactors from 43 (used in this study) to 16 , while yielding an equivalent performance. Further development work to verify the modifications proposed by Delmau et al. 2008 is, therefore, warranted.

A final consideration is the potential for residual solvent to be carried in the Cs and LAW products. The MCU design went to great lengths to preclude a substantial organic carryover into discharge products. At the SRS, both the vitrification and saltstone processes generation temperatures that exceed the flash point of the solvent $\left(148^{\circ} \mathrm{F}\right)$. Similar concerns would exist with solvent extraction deployment at Hanford.

\subsection{CESIUM SEPARATION ALTERNATIVES COMPARISON}

Tables 6-41 and 6-42 present the overall sodium balance for the candidate cesium separation technologies for Cases 1 and 2 respectively. The difference in Na processed in waste feed and $\mathrm{Na}$ generated in the LAW and Cs products is the result of chemical additions necessary for the separation process operation. For ion exchange and solvent extraction, the Na sent to the WTP is about $45 \%$ greater than the Na content of waste feed processed. Given that fractional crystallization doesn't add $\mathrm{Na}$ during processing, its $\mathrm{Na}$ output equals the $\mathrm{Na}$ input from waste feed. 
ORP has chartered the development of a Caustic Management strategy for the entire River Protection Project. This Strategy includes sodium additions from a variety of sources, including tank corrosion, management of aluminum precipitation, caustic recycle and other innovations within the WTP flowsheet. As one part of this effort, EM-21 has chartered an independent review group to evaluate a range of caustic managment options for the ORP mission. This effort will include continued refining of aluminum solubility in tank farm and WTP solutions and could potentially improve the efficiency of IX and caustic side solvent extraction by the reduction the cold sodium hydroxide additions. IPS project should track these ongoing efforts to determine if further optimization of these flowsheets is possible. 
Table 6-41 Sodium Balance Comparison Case 1 (8 Tank Basis)

\begin{tabular}{|c|c|c|c|c|c|c|c|c|c|c|}
\hline \multirow[b]{2}{*}{$\begin{array}{c}\text { Waste } \\
\text { Feed Batch }\end{array}$} & \multirow[b]{2}{*}{$\begin{array}{l}\text { Sodium in } \\
\text { Waste } \\
\text { Feed } \\
\text { Processed } \\
\text { (MT Na) }\end{array}$} & \multicolumn{3}{|c|}{ Caustic-Side Solvent Extraction } & \multicolumn{3}{|c|}{ Ion Exchange } & \multicolumn{3}{|c|}{ Fractional Crystallization } \\
\hline & & $\begin{array}{l}\text { Hours of } \\
\text { Operation }\end{array}$ & $\begin{array}{c}\text { Sodium in } \\
\text { LAW } \\
\text { Product } \\
\text { Produced } \\
\text { (MT Na) }\end{array}$ & $\begin{array}{l}\text { Sodium in } \\
\text { Cesium } \\
\text { Product } \\
\text { Produced } \\
\text { (MT Na) }\end{array}$ & $\begin{array}{l}\text { Hours of } \\
\text { Operation }\end{array}$ & $\begin{array}{c}\text { Sodium in } \\
\text { LAW } \\
\text { Product } \\
\text { Produced } \\
\text { (MT Na) }\end{array}$ & $\begin{array}{l}\text { Sodium in } \\
\text { Cesium } \\
\text { Product } \\
\text { Produced } \\
\text { (MT Na) }\end{array}$ & $\begin{array}{l}\text { Hours of } \\
\text { Operation }\end{array}$ & $\begin{array}{l}\text { Sodium in } \\
\text { LAW } \\
\text { Product } \\
\text { Produced } \\
\text { (MT Na) }\end{array}$ & $\begin{array}{l}\text { Sodium in } \\
\text { Cesium } \\
\text { Product } \\
\text { Produced } \\
\text { (MT Na) }\end{array}$ \\
\hline AP-104 & 734 & 5,414 & 1,037 & 4 & 5,360 & 1,027 & 16 & 1,929 & 370 & 364 \\
\hline AP-102 & 740 & 6,060 & 1,161 & 4 & 5,999 & 1,150 & 18 & 1,636 & 313 & 427 \\
\hline AP-101 & 827 & 5,511 & 1,056 & 4 & 5,438 & 1,042 & 23 & 2,693 & 516 & 310 \\
\hline $\mathrm{AP}-103$ & 827 & 6,833 & 1,309 & 4 & 6,768 & 1,297 & 19 & 2,155 & 413 & 414 \\
\hline AP-105 & 807 & 6,022 & 1,154 & 3 & 5,959 & 1,142 & 18 & 1,927 & 369 & 437 \\
\hline AP-108 & 899 & 7,087 & 1,358 & 6 & 7,015 & 1,344 & 21 & 2,127 & 408 & 491 \\
\hline AP-107 & 780 & 5,340 & 1,023 & 2 & 5,241 & 1,004 & 30 & 2,518 & 482 & 297 \\
\hline AN-104 & 763 & 6,031 & 1,156 & 2 & 5,970 & 1,144 & 18 & 1,411 & 270 & 493 \\
\hline Total & 6,376 & 48,298 & 9,255 & 29 & 47,750 & 9,150 & 163 & 16,396 & 3,142 & 3,234 \\
\hline
\end{tabular}

Operating hours are equivalent to $100 \%$ total operating efficiency 
Table 6-42 Sodium Balance Comparison Case 2 (5 Year Basis)

\begin{tabular}{|c|c|c|c|c|c|c|c|c|c|c|}
\hline \multirow[b]{2}{*}{$\begin{array}{c}\text { Waste } \\
\text { Feed Batch }\end{array}$} & \multirow[b]{2}{*}{$\begin{array}{l}\text { Sodium in } \\
\text { Waste } \\
\text { Feed } \\
\text { Processed } \\
\text { (MT Na) }\end{array}$} & \multicolumn{3}{|c|}{ Caustic-Side Solvent Extraction } & \multicolumn{3}{|c|}{ Ion Exchange } & \multicolumn{3}{|c|}{ Fractional Crystallization } \\
\hline & & $\begin{array}{l}\text { Hours of } \\
\text { Operation }^{1}\end{array}$ & $\begin{array}{c}\text { Sodium in } \\
\text { LAW } \\
\text { Product } \\
\text { Produced } \\
\text { (MT Na) }\end{array}$ & $\begin{array}{l}\text { Sodium in } \\
\text { Cesium } \\
\text { Product } \\
\text { Produced } \\
\text { (MT Na) }\end{array}$ & $\begin{array}{l}\text { Hours of } \\
\text { Operation }\end{array}$ & $\begin{array}{c}\text { Sodium in } \\
\text { LAW } \\
\text { Product } \\
\text { Produced } \\
\text { (MT Na) }\end{array}$ & $\begin{array}{l}\text { Sodium in } \\
\text { Cesium } \\
\text { Product } \\
\text { Produced } \\
\text { (MT Na) }\end{array}$ & $\begin{array}{l}\text { Hours of } \\
\text { Operation }\end{array}$ & $\begin{array}{c}\text { Sodium in } \\
\text { LAW } \\
\text { Product } \\
\text { Produced } \\
\text { (MT Na) }\end{array}$ & $\begin{array}{c}\text { Sodium in } \\
\text { Cesium } \\
\text { Product } \\
\text { Produced } \\
\text { (MT Na) }\end{array}$ \\
\hline AP-104 & 734 & 5,414 & 1,037 & 4 & 5,360 & 1,027 & 16 & 1,929 & 370 & 364 \\
\hline AP-102 & 740 & 6,060 & 1,161 & 4 & 5,999 & 1,150 & 18 & 1,636 & 313 & 427 \\
\hline AP-101 & 827 & 5,511 & 1,056 & 4 & 5,438 & 1,042 & 23 & 2,693 & 516 & 310 \\
\hline AP-103 & 827 & 6,833 & 1,309 & 4 & 6,768 & 1,297 & 19 & 2,155 & 413 & 414 \\
\hline AP-105 & 807 & 5,949 & 1,126 & 3 & 5,959 & 1,142 & 18 & 1,927 & 369 & 437 \\
\hline AP-108 & 899 & & & & 1,104 & 33 & 1 & 2,127 & 408 & 491 \\
\hline AP-107 & 780 & & & & & & & 2,518 & 482 & 297 \\
\hline AN-104 & 763 & & & & & & & 1,411 & 270 & 493 \\
\hline AN- $105^{2}$ & 826 & & & & & & & 1,646 & 315 & 511 \\
\hline AN-103 & 1065 & & & & & & & 1,661 & 318 & 747 \\
\hline AW-101 & 1,015 & & & & & & & 1,888 & 362 & 653 \\
\hline AW-104 & 777 & & & & & & & 1,767 & 339 & 438 \\
\hline AP-106 & 445 & & & & & & & 1,140 & 218 & 227 \\
\hline SY-101 & 181 & & & & & & & 445 & 85 & 96 \\
\hline S-109 & 760 & & & & & & & 3,337 & 639 & 121 \\
\hline $\mathrm{S}-109 \mathrm{Eq}^{3}$ & 495 & & & & & & & 2,174 & 271 & 224 \\
\hline Total & 11,941 & 29,767 & 5689 & 19 & 30,628 & 5,691 & 95 & 30,453 & 5,690 & 6,251 \\
\hline
\end{tabular}

4. Operating hours are equivalent to $100 \%$ total operating efficiency

5. Assuming $100 \%$ of high sulfate stream sent to tank farms

6. S-109 Eq represents a generic SST with composition the same as S-109 
Although fractional crystallization returns a substantial quantity of $\mathrm{Na}$ to tank farms with the $\mathrm{Cs}$ product, it produces a LAW product with a lower content of ${ }^{99} \mathrm{Tc}$ and ${ }^{129} \mathrm{I}$ as illustrated in Table 6-43. Both ion exchange and solvent extraction essentially remove only Cs from the waste feed. However, all the candidate separation technologies can satisfy the WTP acceptance specification for radionuclide content.

A similar differentiation exists for the Cs product returned to the DST system. Table 6-44 compares the radionuclide content of the $\mathrm{Cs}$ product to unit dose and concentration limits for waste transfers into the DST system. All the candidate separation technologies can satisfy the DST acceptance specification for radionuclide content.

Table 6-45 provides the overall volume comparison for the candidate cesium separation technologies. While the solvent extraction generates a relatively large volume of Cs product, the $\mathrm{Cs}$ concentration of this material is rather dilute (ranging from 0.19 to $1.62 \mathrm{Ci} / \mathrm{L}{ }^{137} \mathrm{Cs}$ ). The volume could be substantially reduced by processing the material through the 242-A evaporator or incorporation of an evaporator into the solvent extraction flow sheet.

For fractional crystallization the relatively low volumetric quantity of LAW product is partly attributable to the inability of this technology to partition the bulk of waste feed $\mathrm{Na}$ into the LAW product. However, this technology inherently produces a highly concentrated LAW product that must be diluted with water to about $9 \underline{\mathrm{M}} \mathrm{Na}$ prior to transport to the WTP. The ion exchange and solvent extraction technologies must dilute waste feed to $6 \underline{\mathrm{M}} \mathrm{Na}$ prior to processing this material and, consequently; send more dilute LAW to the WTP.

Table 6-46 identifies the estimated consumable usage for processing all eight waste feed batches by each candidate technology. The difference in chemical usage between ion exchange and solvent extraction is relatively insignificant. The greater variance is between fractional crystallization and the other two candidate cesium separation technologies. Other than some infrequent caustic usage for maintenance purposes, the fractional crystallization process doesn't require chemical additions to support processing. 
Table 6-43 Low-Activity Waste Radionuclide Content Comparison

\begin{tabular}{|c|c|c|c|c|c|c|c|}
\hline \multirow[b]{3}{*}{ Radionuclide } & \multirow[b]{2}{*}{$\begin{array}{c}\text { WTP } \\
\text { Specification }\end{array}$} & \multicolumn{2}{|c|}{ Caustic-Side Solvent Extraction } & \multicolumn{2}{|c|}{ Ion Exchange } & \multicolumn{2}{|c|}{ Fractional Crystallization } \\
\hline & & $\begin{array}{c}\text { Worst Case } \\
\text { LAW Product }\end{array}$ & $\begin{array}{c}\text { Processing Feed } \\
\text { Batch }\end{array}$ & $\begin{array}{c}\text { Worst Case } \\
\text { LAW Product }\end{array}$ & $\begin{array}{c}\text { Processing Feed } \\
\text { Batch }\end{array}$ & $\begin{array}{c}\text { Worst Case } \\
\text { LAW Product }\end{array}$ & $\begin{array}{c}\text { Processing Feed } \\
\text { Batch }\end{array}$ \\
\hline & \multicolumn{7}{|c|}{ (Ci/g-mol Na) } \\
\hline${ }^{137} \mathrm{Cs}$ & $1.68 \mathrm{E}-05$ & $1.68 \mathrm{E}-05$ & All & $1.68 \mathrm{E}-05$ & All & $1.18 \mathrm{E}-05$ & AP-107 \\
\hline${ }^{154} \mathrm{Eu}$ & $1.62 \mathrm{E}-05$ & $3.71 \mathrm{E}-06$ & $\mathrm{AP}-105$ & $3.71 \mathrm{E}-06$ & $\mathrm{AP}-105$ & $7.78 \mathrm{E}-10$ & $\mathrm{AP}-105$ \\
\hline${ }^{60} \mathrm{Co}$ & $1.65 \mathrm{E}-06$ & $8.86 \mathrm{E}-07$ & AP-107 & $8.86 \mathrm{E}-07$ & AP-107 & $1.71 \mathrm{E}-10$ & AP-107 \\
\hline${ }^{90} \mathrm{Sr}$ & $1.12 \mathrm{E}-03$ & $1.69 \mathrm{E}-04$ & AP-107 & $1.69 \mathrm{E}-04$ & AP-107 & $2.55 \mathrm{E}-04$ & $\mathrm{AP}-103$ \\
\hline${ }^{99} \mathrm{Tc}$ & $1.68 \mathrm{E}-04$ & $1.97 \mathrm{E}-05$ & AP-107 & $1.97 \mathrm{E}-05$ & AP-107 & $3.83 \mathrm{E}-09$ & AP-103 \\
\hline${ }^{129} \mathrm{~T}$ & NA & $2.44 \mathrm{E}-08$ & AP-102 & $2.43 \mathrm{E}-08$ & AP-102 & $5.63 \mathrm{E}-12$ & AP-103 \\
\hline${ }^{233} \mathrm{U}$ & $1.30 \mathrm{E}-08$ & 2.14E-09 & AP-102 & 2.14E-09 & $\mathrm{AP}-102$ & $4.92 \mathrm{E}-13$ & $\mathrm{AP}-102$ \\
\hline${ }^{235} \mathrm{U}$ & $6.00 \mathrm{E}-11$ & $4.76 \mathrm{E}-11$ & AP-107 & $4.76 \mathrm{E}-11$ & $\mathrm{AP}-107$ & $9.16 \mathrm{E}-15$ & $\mathrm{AP}-107$ \\
\hline${ }^{239} \mathrm{Pu}$ & $6.10 \mathrm{E}-07$ & 4.17E-07 & AP-107 & 4.17E-07 & AP-107 & $8.02 \mathrm{E}-11$ & AP-107 \\
\hline TRU & $1.30 \mathrm{E}-05$ & $5.16 \mathrm{E}-07$ & AP-103 & $5.16 \mathrm{E}-07$ & AP-103 & $1.20 \mathrm{E}-10$ & AP-103 \\
\hline
\end{tabular}

"Processing feed batch" is the feed batch that yields the highest radionuclide concentration in the resultant low-activity waste (LAW) product. 
Table 6-44 Cesium Product Radionuclide Content Comparison ${ }^{1}$

\begin{tabular}{|l|c|r|r|r|}
\cline { 3 - 5 } \multicolumn{2}{c|}{} & \multicolumn{2}{c|}{ Cs Product } \\
\hline \multicolumn{1}{c|}{ Attribute } & Limit & $\begin{array}{c}\text { Caustic-Side } \\
\text { Solvent Extraction }\end{array}$ & Ion Exchange & $\begin{array}{c}\text { Fractional } \\
\text { Crystallization }\end{array}$ \\
\hline ULD Offsite Liquid(Sv/L) & $1.50 \mathrm{E}+03$ & $3.01 \mathrm{E}+02$ & $2.35 \mathrm{E}+02$ & $3.73 \mathrm{E}+02$ \\
\hline ULD Onsite Liquid (Sv/L) & $1.00 \mathrm{E}+03$ & $4.39 \mathrm{E}+02$ & $3.42 \mathrm{E}+02$ & $4.98 \mathrm{E}+02$ \\
\hline 90Sr Liquid (Bq/L) & $3.50 \mathrm{E}+09$ & $0.00 \mathrm{E}+00$ & $2.67 \mathrm{E}+06$ & $8.28 \mathrm{E}+07$ \\
\hline $137 \mathrm{Cs}$ Liquid (Bq/L) & $2.90 \mathrm{E}+12$ & $6.55 \mathrm{E}+10$ & $5.10 \mathrm{E}+10$ & $6.90 \mathrm{E}+10$ \\
\hline Pu Equivalent (g/L) & $1.00 \mathrm{E}-03$ & $0.00 \mathrm{E}+00$ & $1.25 \mathrm{E}-05$ & $8.99 \mathrm{E}-04$ \\
\hline
\end{tabular}

ULD = Unit liter dose

1. The ULDs are compared on an 8 tank basis. 
Table 6-45 Volume Comparison

\begin{tabular}{|c|c|c|c|c|c|c|c|}
\hline \multirow[b]{2}{*}{$\begin{array}{c}\text { Waste Feed } \\
\text { Batch }\end{array}$} & \multirow[b]{2}{*}{$\begin{array}{c}\text { Waste Feed } \\
\text { Processed (L) }\end{array}$} & \multicolumn{2}{|c|}{ Caustic-Side Solvent Extraction } & \multicolumn{2}{|c|}{ Ion Exchange } & \multicolumn{2}{|c|}{ Fractional Crystallization } \\
\hline & & $\begin{array}{l}\text { LAW Product } \\
\text { Produced (L) }\end{array}$ & $\begin{array}{l}\text { Cesium Product } \\
\text { Produced (L) }\end{array}$ & $\begin{array}{l}\text { LAW Product } \\
\text { Produced (L) }\end{array}$ & $\begin{array}{l}\text { Cesium Product } \\
\text { Produced (L) }\end{array}$ & $\begin{array}{l}\text { LAW Product } \\
\text { Produced (L) }\end{array}$ & $\begin{array}{l}\text { Cesium Product } \\
\text { Produced (L) }\end{array}$ \\
\hline AN-104 & $5.53 \mathrm{E}+06$ & $8.37 \mathrm{E}+06$ & $9.23 \mathrm{E}+05$ & $8.29 \mathrm{E}+06$ & $1.21 \mathrm{E}+06$ & $1.32 \mathrm{E}+06$ & $2.44 \mathrm{E}+06$ \\
\hline AP-101 & $4.13 \mathrm{E}+06$ & $7.66 \mathrm{E}+06$ & $2.47 \mathrm{E}+06$ & $7.56 \mathrm{E}+06$ & $1.47 \mathrm{E}+06$ & $2.59 \mathrm{E}+06$ & $1.50 \mathrm{E}+06$ \\
\hline AP-102 & $4.00 \mathrm{E}+06$ & $8.42 \mathrm{E}+06$ & $1.65 \mathrm{E}+06$ & $8.33 \mathrm{E}+06$ & $1.22 \mathrm{E}+06$ & $1.54 \mathrm{E}+06$ & $2.09 \mathrm{E}+06$ \\
\hline AP-103 & $4.24 \mathrm{E}+06$ & $9.49 \mathrm{E}+06$ & $2.24 \mathrm{E}+06$ & $9.40 \mathrm{E}+06$ & $1.34 \mathrm{E}+06$ & $2.01 \mathrm{E}+06$ & $2.05 \mathrm{E}+06$ \\
\hline AP-104 & $3.79 \mathrm{E}+06$ & $7.52 \mathrm{E}+06$ & $1.95 \mathrm{E}+06$ & $7.44 \mathrm{E}+06$ & $1.07 \mathrm{E}+06$ & $1.82 \mathrm{E}+06$ & $1.80 \mathrm{E}+06$ \\
\hline AP-105 & $3.94 \mathrm{E}+06$ & $8.37 \mathrm{E}+06$ & $1.64 \mathrm{E}+06$ & $8.28 \mathrm{E}+06$ & $1.26 \mathrm{E}+06$ & $1.78 \mathrm{E}+06$ & $2.14 \mathrm{E}+06$ \\
\hline AP-107 & $4.32 \mathrm{E}+06$ & $7.42 \mathrm{E}+06$ & $1.45 \mathrm{E}+06$ & $7.28 \mathrm{E}+06$ & $1.97 \mathrm{E}+06$ & $2.42 \mathrm{E}+06$ & $1.46 \mathrm{E}+06$ \\
\hline AP-108 & $4.34 \mathrm{E}+06$ & $9.83 \mathrm{E}+06$ & $3.35 \mathrm{E}+06$ & $9.73 \mathrm{E}+06$ & $1.43 \mathrm{E}+06$ & $2.01 \mathrm{E}+06$ & $2.44 \mathrm{E}+06$ \\
\hline Total & $3.43 \mathrm{E}+07$ & $6.71 \mathrm{E}+07$ & $1.57 \mathrm{E}+07$ & $6.63 \mathrm{E}+07$ & $1.12 \mathrm{E}+07$ & $1.55 \mathrm{E}+07$ & $1.59 \mathrm{E}+07$ \\
\hline
\end{tabular}


Table 6-46 Consumable Usage Comparison

\begin{tabular}{|l|r|r|r|r|r|}
\hline \multicolumn{1}{|c|}{$\begin{array}{c}\text { Candidate } \\
\text { Technology }\end{array}$} & $\begin{array}{c}\mathbf{5 0} \mathbf{w t} \% \mathbf{~ N a O H} \\
\text { (gal) }\end{array}$ & $\begin{array}{c}\mathbf{6 0} \mathbf{~ w t \% ~ H N O} \\
\text { (gal) }\end{array}$ & $\begin{array}{c}\text { NaNO } \\
\text { (kg) }\end{array}$ & $\begin{array}{c}\text { Water } \\
\text { (gal) }\end{array}$ & \multicolumn{1}{c|}{$\begin{array}{c}\text { Power } \\
\text { (kw-hr) }\end{array}$} \\
\hline Ion Exchange & $1,800,000$ & 62,000 & 0 & $20,000,000$ & $7,700,000$ \\
\hline $\begin{array}{l}\text { Fractional } \\
\text { Crystallization }\end{array}$ & 0 & 0 & 0 & 810,000 & $19,700,000$ \\
\hline $\begin{array}{l}\text { Caustic-Side Solvent } \\
\text { Extraction }\end{array}$ & $1,700,000$ & 6,600 & 12,000 & $13,000,000$ & $20,000,000$ \\
\hline
\end{tabular}

Notes:

1. Usage is for processing all eight waste feed batches

2. Power does not include lighting, ventilation, compressed air, and other support functions

Only one routine secondary waste stream (excluding failed equipment and personnel protection equipment) is generated by each of the candidate technologies that must be addressed by interfaces external to the tank farm system. The secondary waste streams are summarized as follows:

- Ion Exchange - Resin in the ion exchange columns slowly degrades with reuse and must be replaced when cesium removal becomes inefficient. Spent resin is periodically disposed as a solid waste.

- Fractional Crystallization - Process condensate is continuously generated by the concentrators. Excess condensate, not reused for crystallized solids washing or dissolution, is transferred to the Effluent Treatment Facility

- Solvent Extraction - Solvent in the extraction system slowly degrades with reuse and must be replaced when cesium removal becomes inefficient. The solvent inventory is periodically replaced, mixed with an adsorbent, and disposed as solid waste.

Table 6-47 presents a comparison of the footprint associated with the shield vault and process building for each candidate technology. In all instances the crossflow filter requires a greater footprint. Regardless of filtration technology selected, the footprint gets progressively larger from ion exchange through fractional crystallization to solvent extraction.

Table 6-47 Process Vault plus Process Building Footprint Comparison

\begin{tabular}{|l|c|c|}
\cline { 2 - 3 } \multicolumn{1}{c|}{} & \multicolumn{2}{c|}{ Process Vault Footprint $\left(\mathbf{f t}^{\mathbf{2}}\right.$ ) } \\
\hline \multirow{2}{*}{ Technology } & Rotary Microfilter & Crossflow Filter \\
\hline Ion Exchange & 4,032 & 4,610 \\
\hline Fractional Crystallization & 5,699 & 5,963 \\
\hline Caustic-Side Solvent Extraction & 6,016 & 6,628 \\
\hline
\end{tabular}




\subsection{CESIUM SEPARATION 5 YEAR BASELINE}

This section provides a comparison of the three cesium separation technology material flows assuming a common operating time period, where the IPS supports 5 years of LAW vitrification system production. In each case, the IPS is assumed to transfer treated LAW to the vitrification system at a rate equivalent to $1175 \mathrm{MT} \mathrm{Na} / \mathrm{yr}$.

\subsubsection{Waste Batches}

The number of waste batches required to support the initial 5 years of LAW vitrification system operating is influenced by the path of sodium in the cesium separation technology material balance. Waste is diluted to $6 \mathrm{M} \mathrm{Na}$ prior to processing through either the ion exchange or solvent extraction cesium separation unit operations. The waste is diluted by a caustic addition stream to reach conditions where alumina does not precipitate to form solids in the IPS waste feed. The caustic addition reduces the quantity of existing waste stored in double-shell tanks that is processed through the cesium separation unit operation (ion exchange or solvent extraction) over a fixed operating period.

Waste dilution for the ion exchange and solvent extraction technologies is similar. Figure 6-22 indicates that either ion exchange or solvent extraction technologies are predicted to process the first five waste batches, plus part of the sixth batch, in the first 5 years of IPS operation assuming a $70 \%$ TOE. Note that Figure 6-22 is based on 70\% TOE unlike the hours of operation in table $6-42$ which are based on $100 \%$ TOE. Ion exchange is predicted to process a fraction of the $6^{\text {th }}$ feed batch, while solvent extraction processes five feed batchs. This small difference is attributed to the return of a small quantity of waste to double-shell tank storage during the feed displacement cycle of the ion exchange system. Figure 6-23 and Figure 6-24 indicate that the relative quantity of waste and cold sodium in LAW transferred to the vitrification system is similar for the ion exchange and solvent extraction systems. Approximately $30 \%$ of the sodium in LAW transferred to vitrification originates in cold chemical additions used to support the cesium separation system operation. 
Figure 6-22 Waste Batches Processed over Initial 5 yr IPS Operating Period - Ion Exchange and Solvent Extraction Cesium Separation Technologies

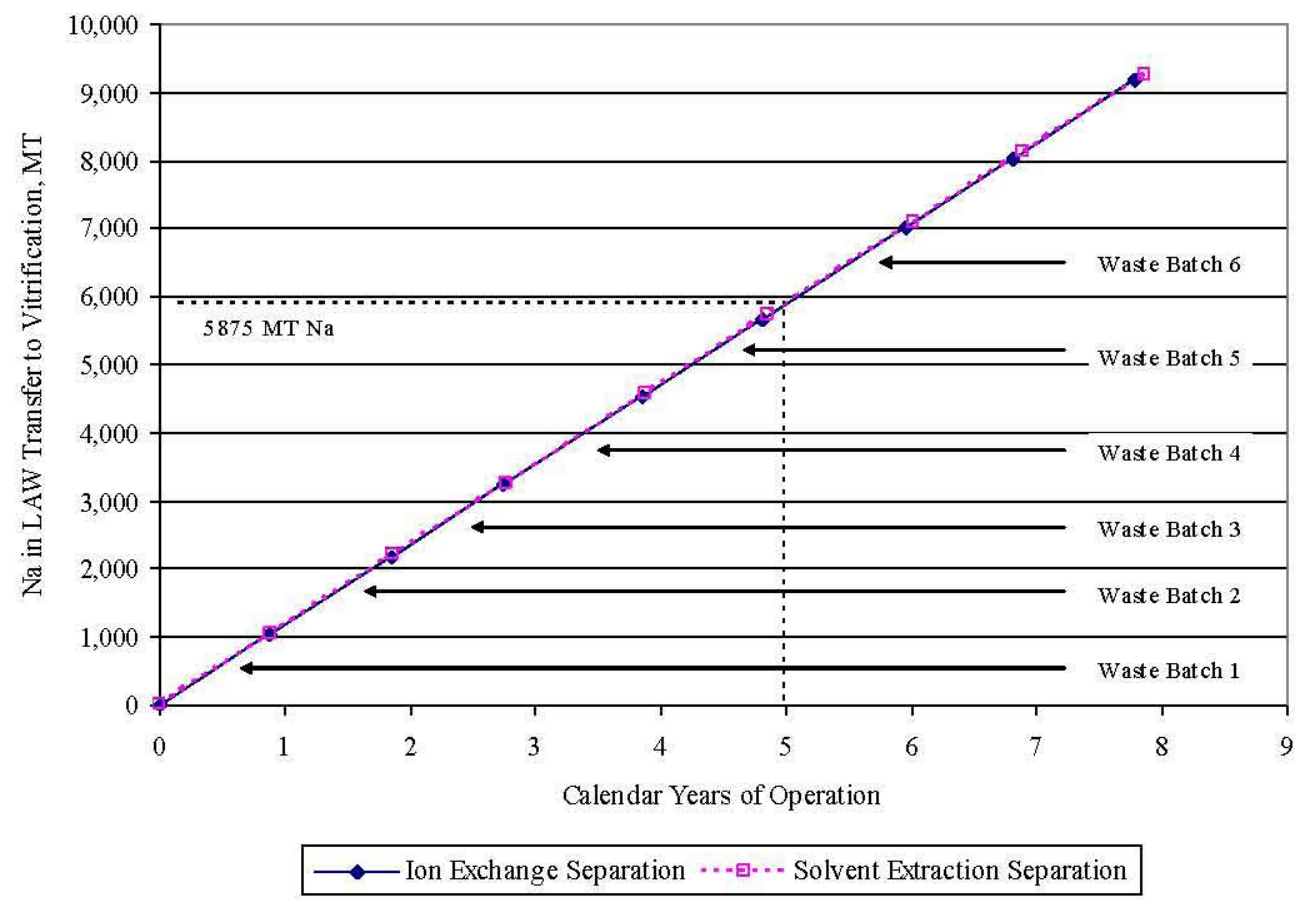

Figure 6-23 Waste Sodium and Total Sodium in LAW Transferred to Vitrification - Ion Exchange Cesium Separation Technology






\section{Figure 6-24 Waste Sodium and Total Sodium in LAW Transferred to Vitrification - Solvent Extraction Cesium Separation Technology}

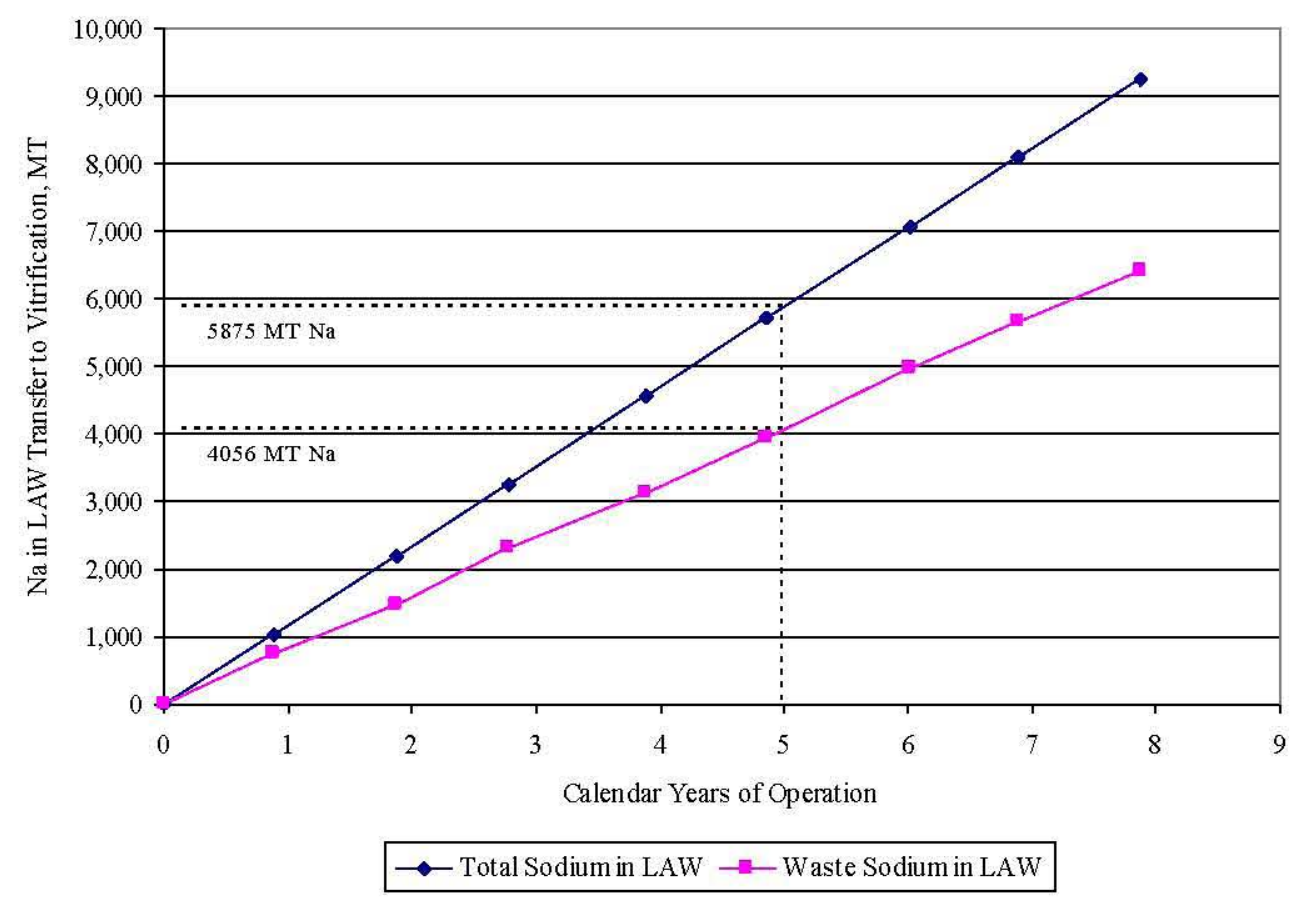

The fractional crystallization cesium separation unit operation does not require significant sodium additions from cold chemicals as part of the operation. The number of waste batches required to support IPS operation is determined by the split of sodium between LAW transferred to the vitrification system and waste returned to double-shell tank storage. The sodium split depends on the waste anion composition. Figure 6-25 indicates that the number of waste batches needed to support operation of the fractional crystallization cesium separation alternative over the first 5 years of IPS operation exceeds the eight waste batches defined as a basis for material balance descriptions.

The number of additional tanks needed by fractional crystallization depends upon how fractional crystallization is operated. In the baseline case, sulfates are not recycled back to tank farms. This results in sulfate limited glass at the LAW facility (see Figures B-4, B-5, and B-6 from SVF-1513) which reduces the LAW through put. In this case, waste from the SSTs is not required to complete a 5 year mission at IPS. If sulfates are separated at $\mathrm{FC}$ and recycled back to tank farms, then the LAW facility is not limited by sulfates and waste from S-109 and S-109 eq are necessary to complete a 5 year IPS mission. The analysis of DST space impact in section 6.5.2 assumes that sulfates are recycled. 


\section{Figure 6-25 Waste Batches Processed over Initial 5 yr IPS Operating Period - Fractional} Crystallization Cesium Separation Technology

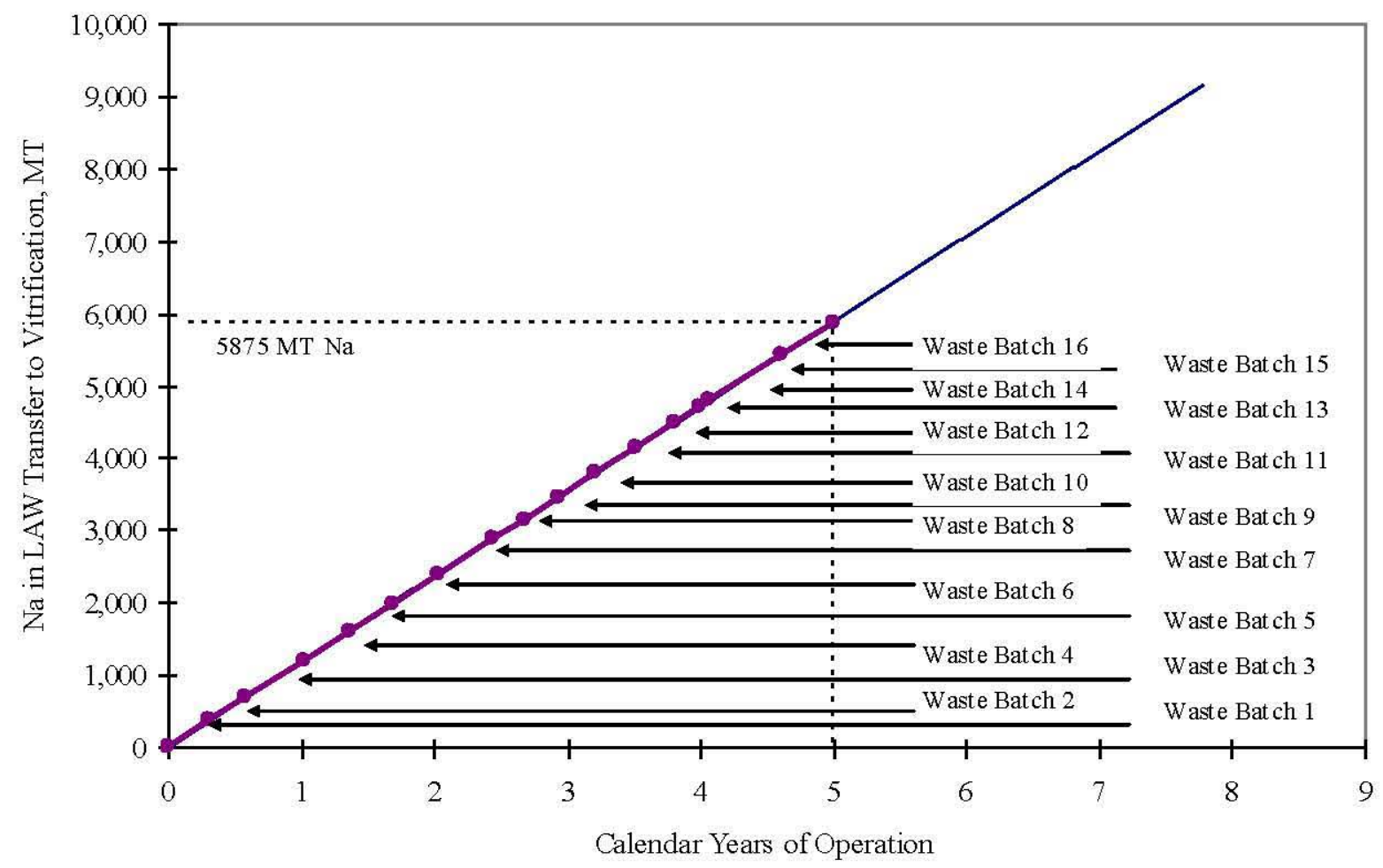

Ion Exchange/Solvent Extraction Separation $\rightarrow$ Fractional Crystallization Separation

A total of sixteen waste batches were defined to approximate the initial 5 years of IPS operation in this white paper. Since the projected split of sodium between LAW transferred to vitrification and returned to double-shell tank storage is composition dependent, the number of feed waste batches required to operate the fractional crystallization technology will depend on the waste selected as feed for the IPS. Waste batches 9 through 13 represent supernate and dissolved solids from AN-105, AN-103, AW-101, AW-104, and AP-106. Waste batch 14 represents supernate from SY-101, while waste batch 15 is based on supernate from dissolving salt cake in S-109. Additional feed waste was projected to be required beyond these 15 waste batches to complete the first 5 years of IPS operation. Therefore, waste batch 16 is based on the S-109 composition, assuming it originates from a different single-shell tank with similar salt cake composition. Selection of single-shell tank salt cake feeds with lower phosphate ion concentrations could reduce the volume of fractional crystallization waste returns to double-shell tanks.

Waste component splits for the fractional crystallization material balances are estimated from more detailed thermodynamic calculations performed for waste composition groups. The material balance splits for each feed are based on the group assignments shown in Table 6-48. 
Table 6-48 Waste Group Assignments Estimating Fractional Crystallization Component Splits in Waste Batches 9 through 16

\begin{tabular}{|c|c|c|}
\hline Waste Batch & Originating Waste Tank & Waste Group Assignment \\
\hline 9 & AN-105 & 4 \\
\hline 10 & AN-103 & 4 \\
\hline 11 & AW-101 & 5 \\
\hline 12 & AW-104 & 5 \\
\hline 13 & AP-106 & 1 \\
\hline 14 & SY-101 & Late SST $^{(1)}$ \\
\hline $15 / 16$ & S-109 & \\
Notes: \\
1. Defined in RPP-PLAN-27238, Hanford Medium/Low Curie Waste PretreatmentProject-Pretreatment Process Plan
\end{tabular}

\subsubsection{Stored Waste Volume Changes}

Material balances prepared for each cesium separation technology were used to predict the change in waste volume stored in double-shell tanks during the first 5 years of IPS operation. The stored waste volume changes were determined for each waste batch by comparing the volume of waste processed with the volume of waste returned to tank farms. Figure 6-26 indicates the basic volume comparison for the ion exchange cesium separation technology. Over the $5 \mathrm{yr}$ operating period, approximately $5,500 \mathrm{kgal}$ of waste is projected to be removed from the double-shell waste tanks, while approximately $1,800 \mathrm{kgal}$ of waste is returned containing separated cesium from the ion exchange system. Waste returns from the ion exchange system could be reduced if concentrated. Figure 6-26 indicates that the volume of ion exchange waste returns would not be significantly different from the as-generated waste volume if a concentrated from $0.79 \mathrm{Ci}^{137} \mathrm{Cs} / \mathrm{L}$ to $0.8 \mathrm{Ci}^{137} \mathrm{Cs} / \mathrm{L}$, but could be reduced to approximately $1,000 \mathrm{kgal}$ if concentrated to $1.5 \mathrm{Ci}^{137} \mathrm{Cs} / \mathrm{L}$. Figure 6-27 indicates the net change in available double-shell tank waste storage for the ion exchange cesium separation technology varies from 3,700 to 4,700 kgal, depending on concentration limits allowed for returned waste. 
Figure 6-26 DST Waste Volume Removed and Returned by IPS Operation - Ion Exchange Cesium Separation Technology

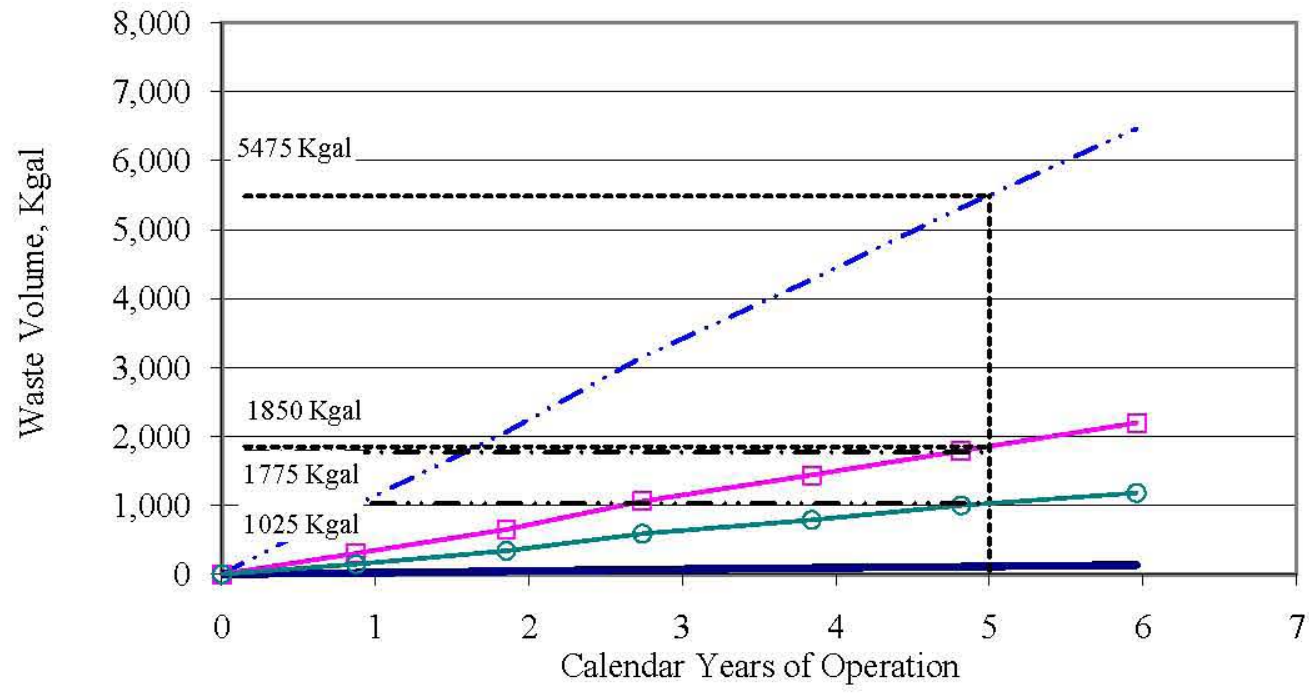

$-\cdots-$ Waste Removed as IPS Feed
Solids Concentrate Remaining in DSTs
- As Generated Cs Product Returned to DSTs
- Concentrate Cs Product to $1.5 \mathrm{Ci} / \mathrm{L}$

Figure 6-27 Net Change in Available Double-Shell Tank Waste Storage Space - Ion Exchange Cesium Separation Technology

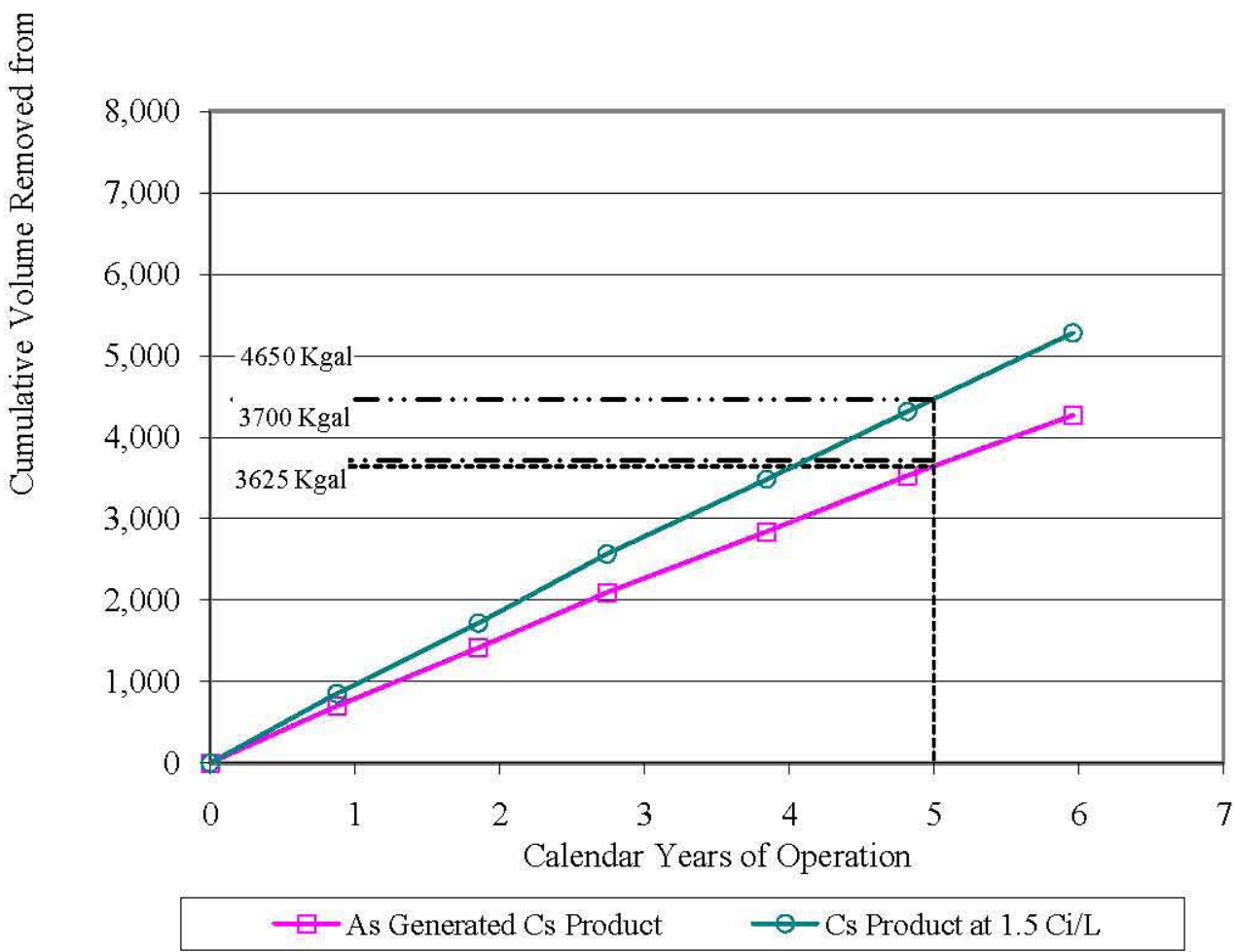


Figure 6-28 indicates similar volume comparisons for the solvent extraction technology implemented in the IPS for cesium separation. Over the $5 \mathrm{yr}$ operating period, approximately $5,500 \mathrm{kgal}$ of waste is projected to be removed from the double-shell waste tanks, while approximately $2,900 \mathrm{kgal}$ of waste is returned containing separated cesium. Waste returns from the solvent extraction system could also be reduced if concentrated. Figure 6-28 indicates that the volume of solvent extraction waste returns could be reduced to approximately $1,800 \mathrm{kgal}$ if concentrated from $0.52 \mathrm{Ci}^{137} \mathrm{Cs} / \mathrm{L}$ to $0.8 \mathrm{Ci}^{137} \mathrm{Cs} / \mathrm{L}$. The return volume would be reduced to approximately $1,000 \mathrm{kgal}$ if concentrated to $1.5 \mathrm{Ci}^{137} \mathrm{Cs} / \mathrm{L}$. Figure $6-29$ indicates the net change in available double-shell tank waste storage for the solvent extraction cesium separation technology varies from 2,600 to $4,700 \mathrm{kgal}$, depending on concentration limits allowed for returned waste.

\section{Figure 6-28 Waste Volume Removed and Returned by IPS Operation - Solvent Extraction Cesium Separation Technology}

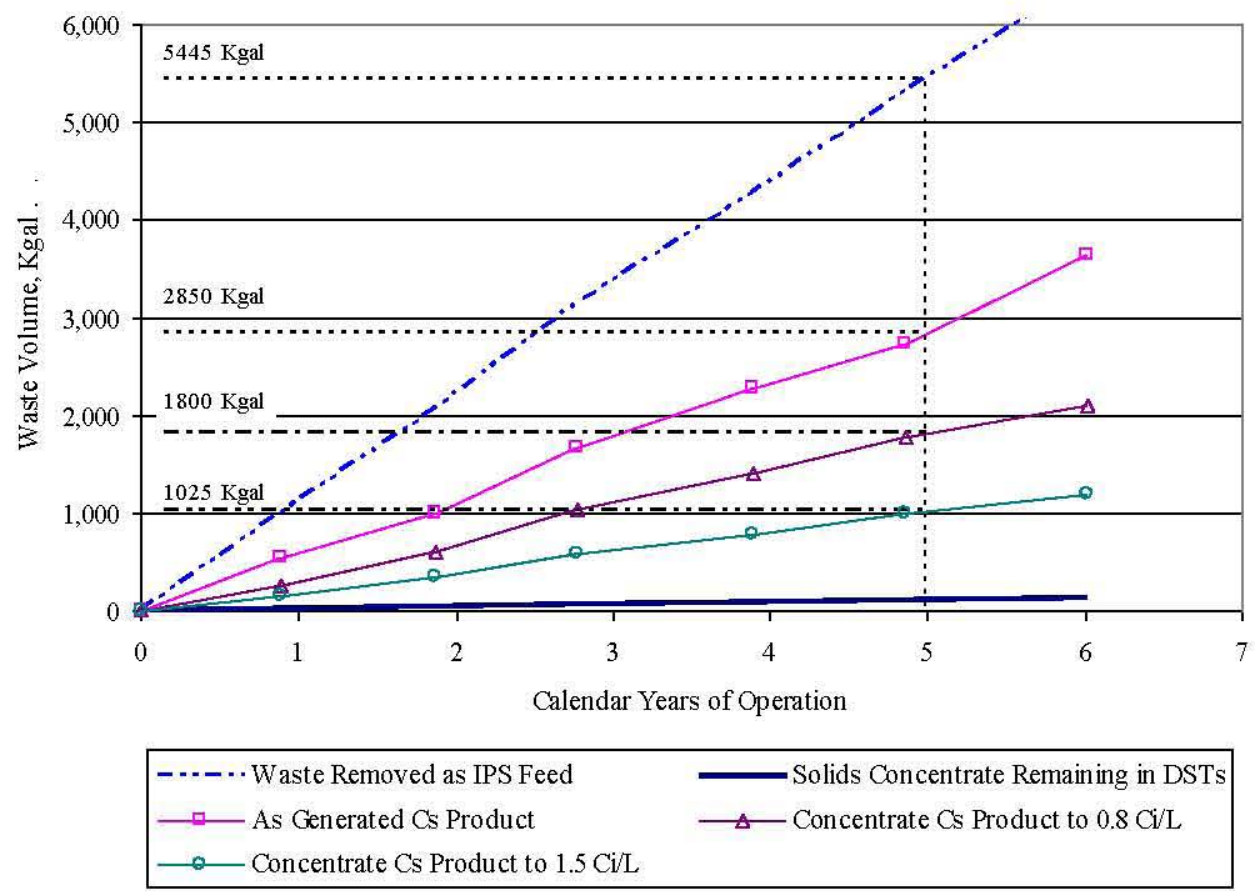


Figure 6-29 Net Change in Available Double-Shell Tank Waste Storage Space - Solvent Extraction Cesium Separation Technology

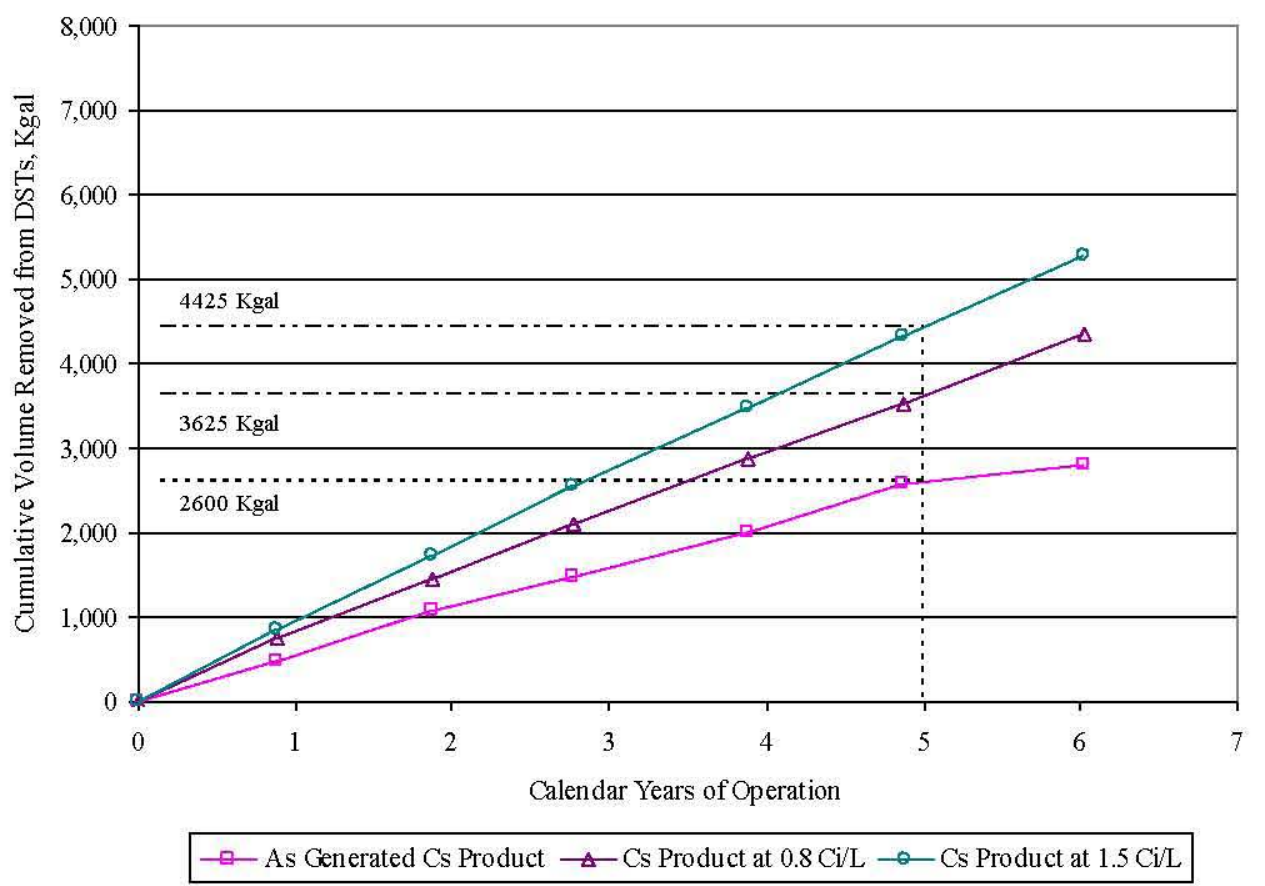

Figure 6-30 indicates the double-shell tank waste volume changes for the fractional crystallization technology implemented in the IPS for cesium separation. The volume change estimates are more complex for the fractional crystallization system since some double-shell tank waste solids are dissolved as part of the feed preparation activities and waste is introduced into the double-shell tank system from single-shell tanks to provide sufficient feed material over the 5 yr operating period. Based on estimates of the original waste volume, Figure 6-30 estimates that feed to the fractional crystallization system will remove approximately $15,000 \mathrm{kgal}$ of waste from double-shell tanks. This is different from the summation of the wasts volumes listed in table 2-3 and 6-45 because saltcake dissolution results in a waste volume larger than the tank being retrieved.

Volume change estimates are also dependent on concentration limits used as a basis for water additions to waste concentrate returned to the tank farm system. Figure 6-30 indicates that waste returns to the double-shell tank system are estimated to be approximately $8,500 \mathrm{kgal}$ based on a sodium concentration of $9 \mathrm{M}$. If waste returns are limited to $0.1 \mathrm{M}$ phosphate ion, the volume of waste returns are estimated to increase to approximately 12,000 kgal. Figure 6-31 indicates the net change in available double-shell tank waste storage for the fractional crystallization cesium separation technology varies from 2,800 to $6,500 \mathrm{kgal}$, depending on concentration limits allowed for returned waste. Volume removed from DSTs in Figures 6-30 and 6-31 level out or decrease for year four because saltcake dissolution of SSTs does not reduce DST tank volume 
Figure 6-30 Waste Volume Removed and Returned by IPS Operation - Fractional Crystallization Cesium Separation Technology

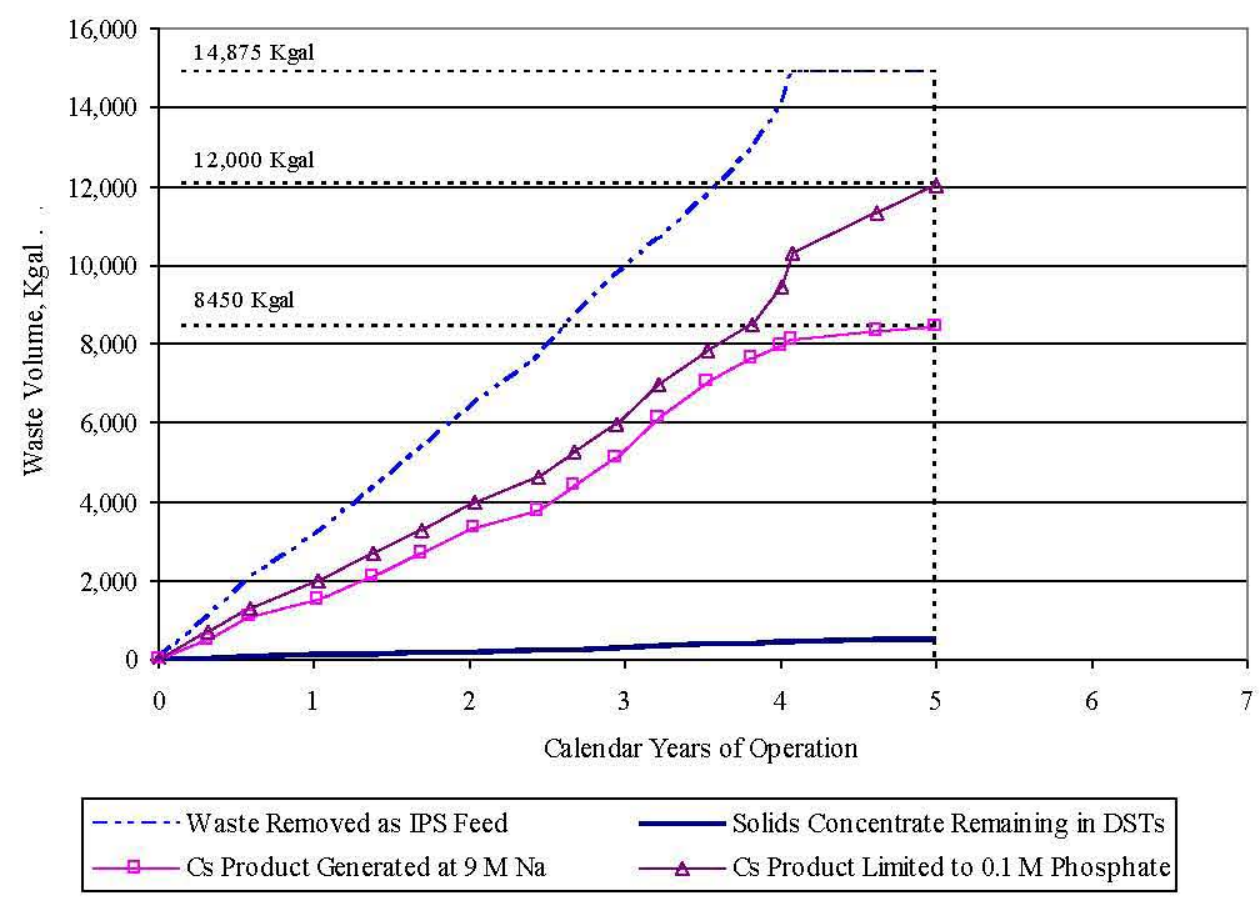

Figure 6-31 Net Change in Available Double-Shell Tank Waste Storage Space Fractional Crystallization Cesium Separation Technology

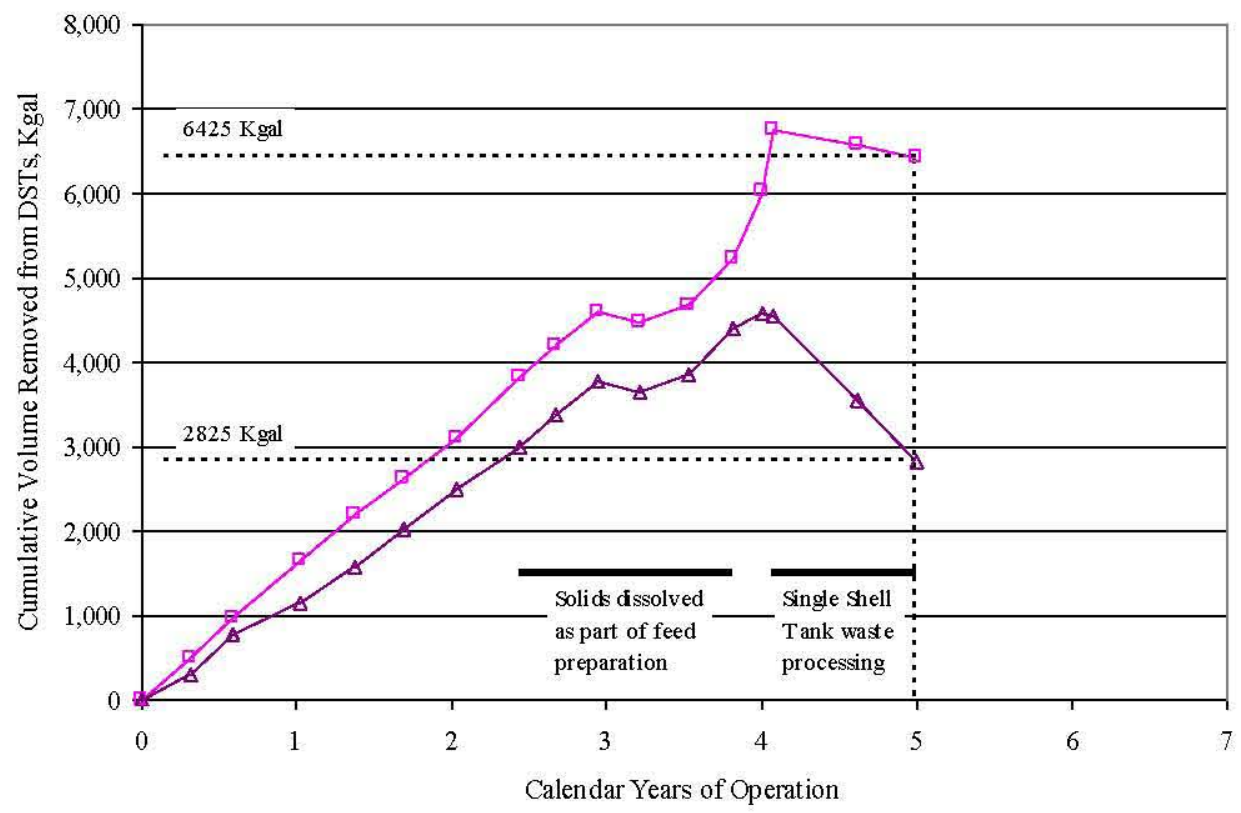

$\square-$ Cs Product Generated at $9 \mathrm{M} \mathrm{Na} \triangle$ Cs Product Limited to $0.1 \mathrm{M}$ Phosphate 
A comparison of the double-shell tank waste storage that becomes available as a result of implementing the alternative cesium separation technologies in the IPS depends on the concentration limits assumed to be applied to the waste returns. Figure 6-32 provides a comparison of the alternatives assuming ion exchange waste returns as stored at the as-generated composition (already at $0.8 \mathrm{Ci}^{137} \mathrm{Cs} / \mathrm{L}$ ) and solvent extraction waste returns are concentrated to the evaporator limit of $0.8 \mathrm{Ci}^{137} \mathrm{Cs} / \mathrm{L}$. Fractional crystallization results are shown for the two cases considered, where waste returns are either stored at $9 \mathrm{M} \mathrm{Na}$ or limited to $0.1 \mathrm{M}$ phosphate ion.

Figure 6-32 Comparison of Net Change in Available Waste Storage Space for Alternative Cesium Separation Technologies

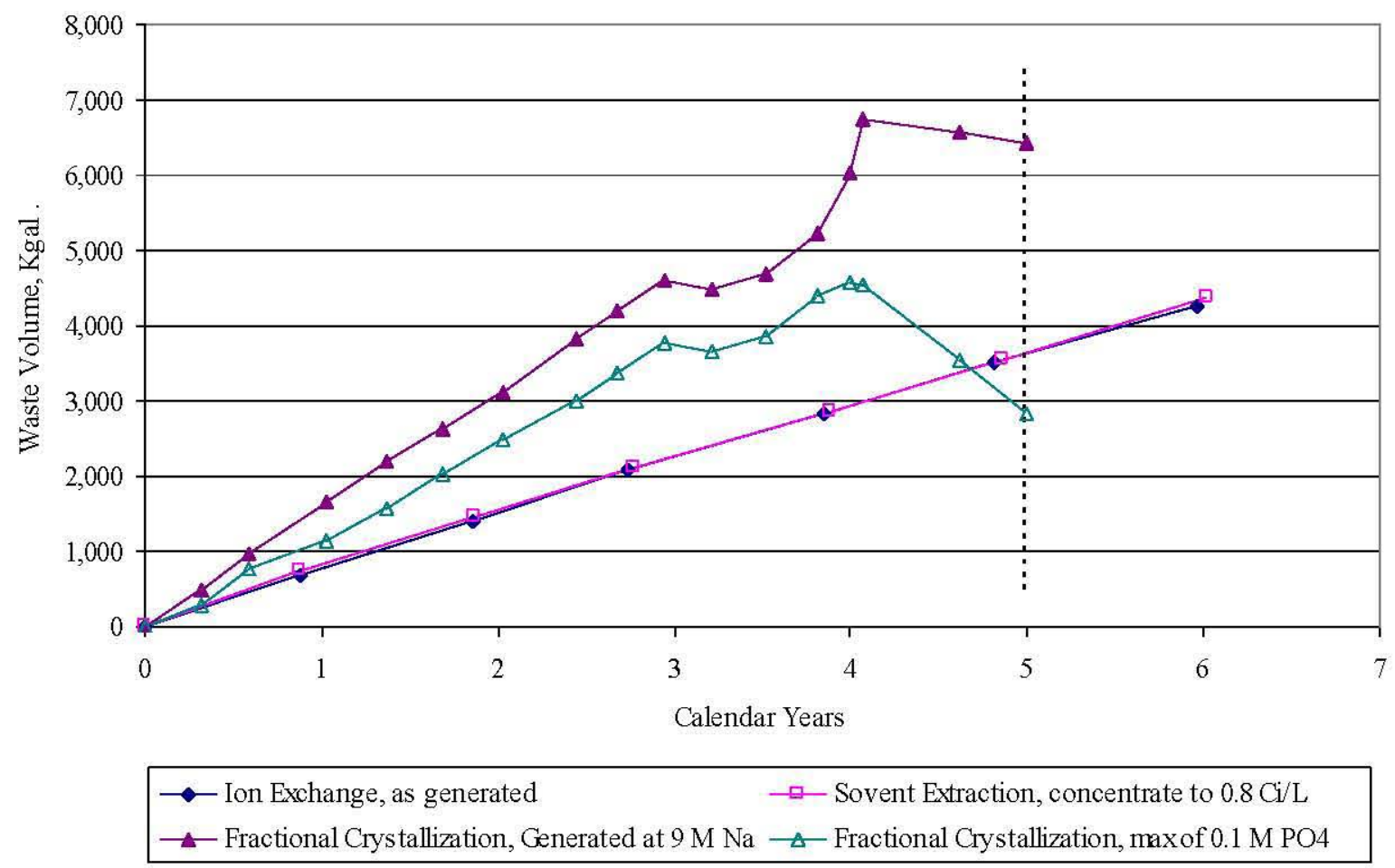




\subsection{SUPPORT SYSTEMS}

This section includes a discussion of systems required to support either the facility or the process, but that do not affect the technical basis for down selection of alternatives. Discussion in this study and sizing estimates are warranted, however, to determine any cost impacts due to different sizing and different system requirements for each solids separation and cesium extraction technology alternative. Refer to the equipment list for comparative sizing.

\subsection{PROCESS OFFGAS SYSTEM}

The functions of the process offgas system are to maintain primary confinement of radioactive materials in the process and to treat the offgas prior to discharge to the environment. Primary confinement is achieved by maintaining a pressure of $-1.0 \mathrm{in} \mathrm{wg}$ in the headspace of process tanks and equipment during all normal process evolutions. The baseline offgas treatment equipment for all technology alternatives includes a demister, prefilter, heater, and two stages of high-efficiency particulate air (HEPA) filters. An adsorber is required for the Solvent Extraction option due to expected VOC content of the offgas stream. Refer to Figure, Figure 7-2, and Figure 7-3 for an over view of the process offgas system.

Figure 7-1 Ion Exchange Process Offgas System

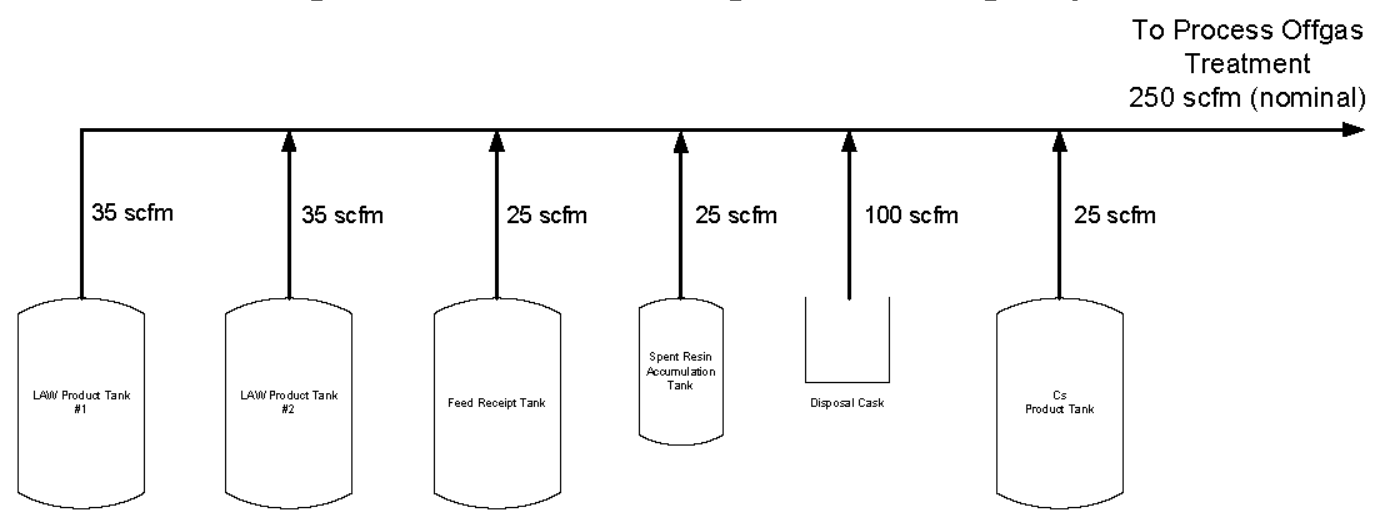


Figure 7-2 Fractional Crystallization Process Offgas System

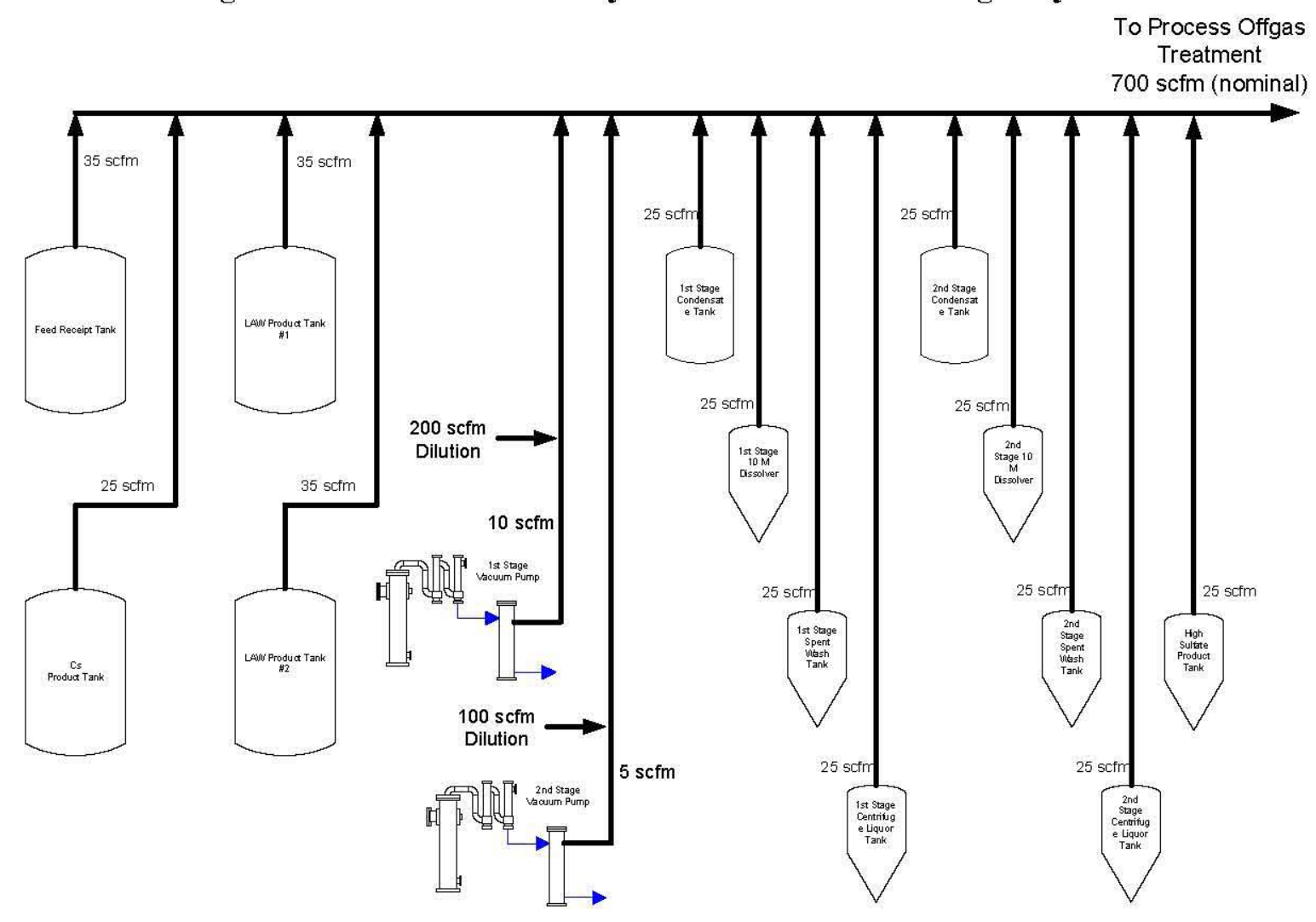

Figure 7-3 Solvent Extraction Process Offgas System

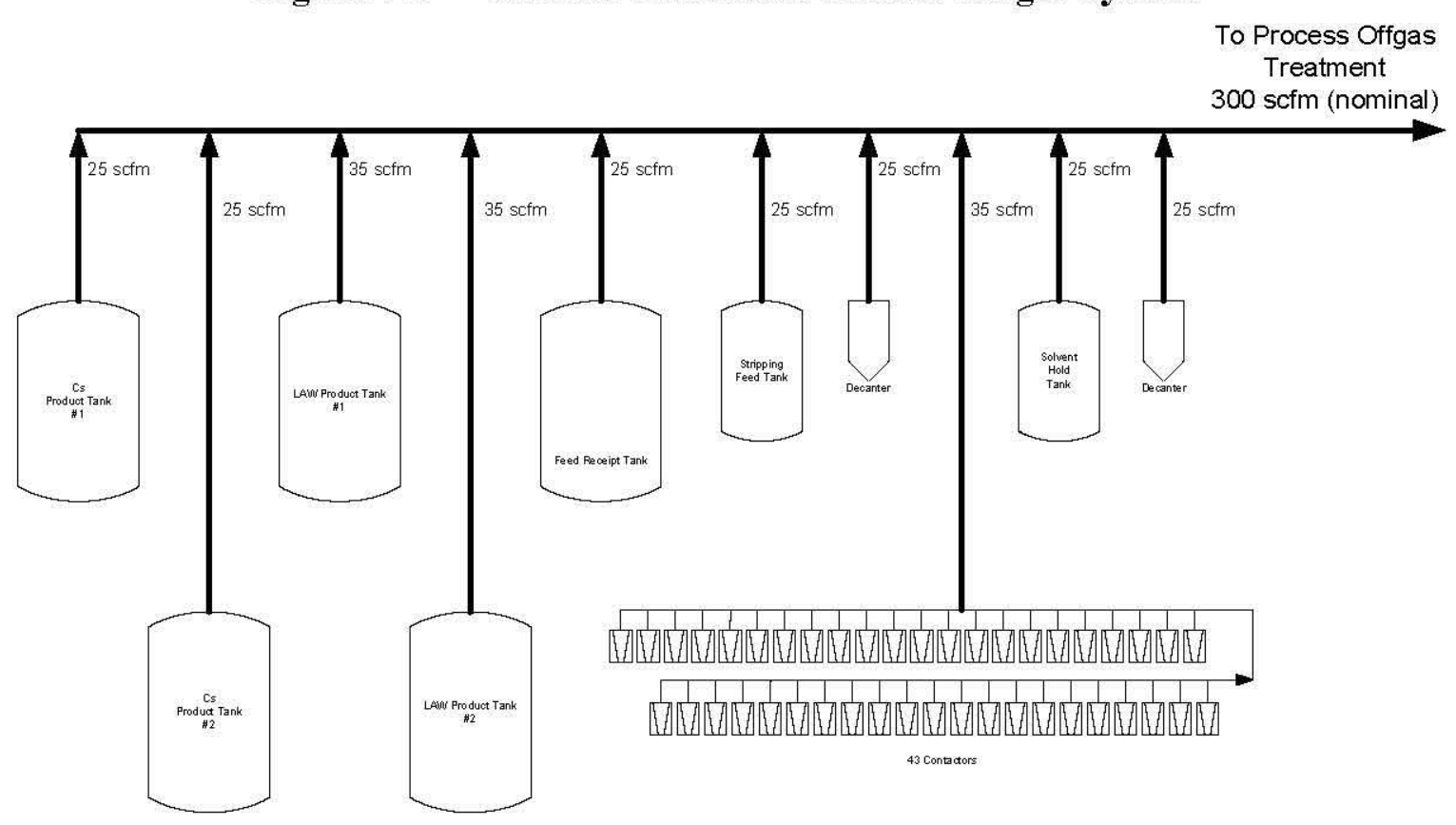




\subsection{VAULT VENTILATION SYSTEM}

The functions of the vault ventilation system are to maintain secondary confinement of radioactive materials, to maintain the temperature within the process enclosures, to prevent moisture accumulation in the equipment vaults, and to treat and monitor the gaseous effluent from the vault enclosures prior to discharge to the environment. Secondary confinement is achieved by maintaining a pressure of $-0.2 \mathrm{in} \mathrm{wg}$ in the equipment vaults. Temperature is maintained with a recirculation air handling unit (AHU) that is independent of the exhaust system. This will minimize the required once-through ventilation flow rate and size of the exhaust filter train.

Moisture accumulation is prevented through active ventilation of the equipment vaults with outside air. Ventilation air enters the vault enclosure through a HEPA filtered air inlet and is exhausted through an exhaust filter train. The standard effluent treatment equipment for all technology options includes a demister, prefilter, heater and two stages of HEPA filters.

The effluent is monitored with a Continuous Effluent Monitoring System (CEMS) prior to discharge out the stack. It is expected that this will be a permitted system under state and federal radioactive air emission regulations. This system is expected to be identical for all technology options except for sizing of the recirculation cooler, which is based on different heat loads from process equipment.

Exhaust airflow capacity for all technology alternatives is selected at $1000 \mathrm{scfm}$ based on maximum capacity for a single 24" x 24" HEPA filter. Exact flow rate determination has not been performed, but $1000 \mathrm{cfm}$ provides a reasonable baseline. Recirculation cooler sizing varies for each technology alternative and is sized simply by summing the estimated heat loads. The recirculation cooler includes a prefilter, chilled water cooling coil and fan. A duct heater in the filtered inlet provides the required vault enclosure heating for freeze protection. Refer to Figure 7-4 for an over view of the vault ventilation system.

The Fractional Crystallization alternative is more of a building type structure with an operating corridor and maintenance area. These spaces will have higher occupancy rates than the underground vault enclosures and will likely require a higher ventilation flow rate then the 1000 scfm baseline to maintain air quality.

\subsection{CHILLED WATER SYSTEM}

The function of the chilled water system is to remove heat from the vault recirculation AHU and from process heat exchangers and condensers. This is a typical industrial chilled water system including a chiller, recirculation pump, expansion tank, and distribution piping. Chilled water system sizing varies for each technology alternative and is sized simply by summing the estimated loads to provide a gross refrigeration load. 
The entire condenser load in the Fractional Crystallization option is assigned to the chilled water system. This is because the small temperature difference between the condenser $(\sim 80 \mathrm{~F})$ and raw water supply $(\sim 72 \mathrm{~F})$ is expected to result in an impractical size for the condensers. An optimization effort is recommended to use raw water for a portion of the condenser load, thus reducing the capacity requirement and power consumption for the chilled water system.

\subsection{STEAM SYSTEM}

Steam is required for the Fractional Crystallization alternative only and is used in both stages for the reboiler of the crystallizer slurry and for heating the dissolver tanks.

\subsection{OTHER SYSTEMS}

Additional support systems include electrical power distribution, backup power, control systems, sampling systems, and compressed air systems. These systems are assumed to present no significant differentiation between the technology alternatives.

\subsection{EQUIPMENT LIST}

Table 7-1 provides a summary of major equipment required for the support systems common to all technology alternatives. 
Figure 7-4 Vault Ventilation System and Process Offgas Treatment

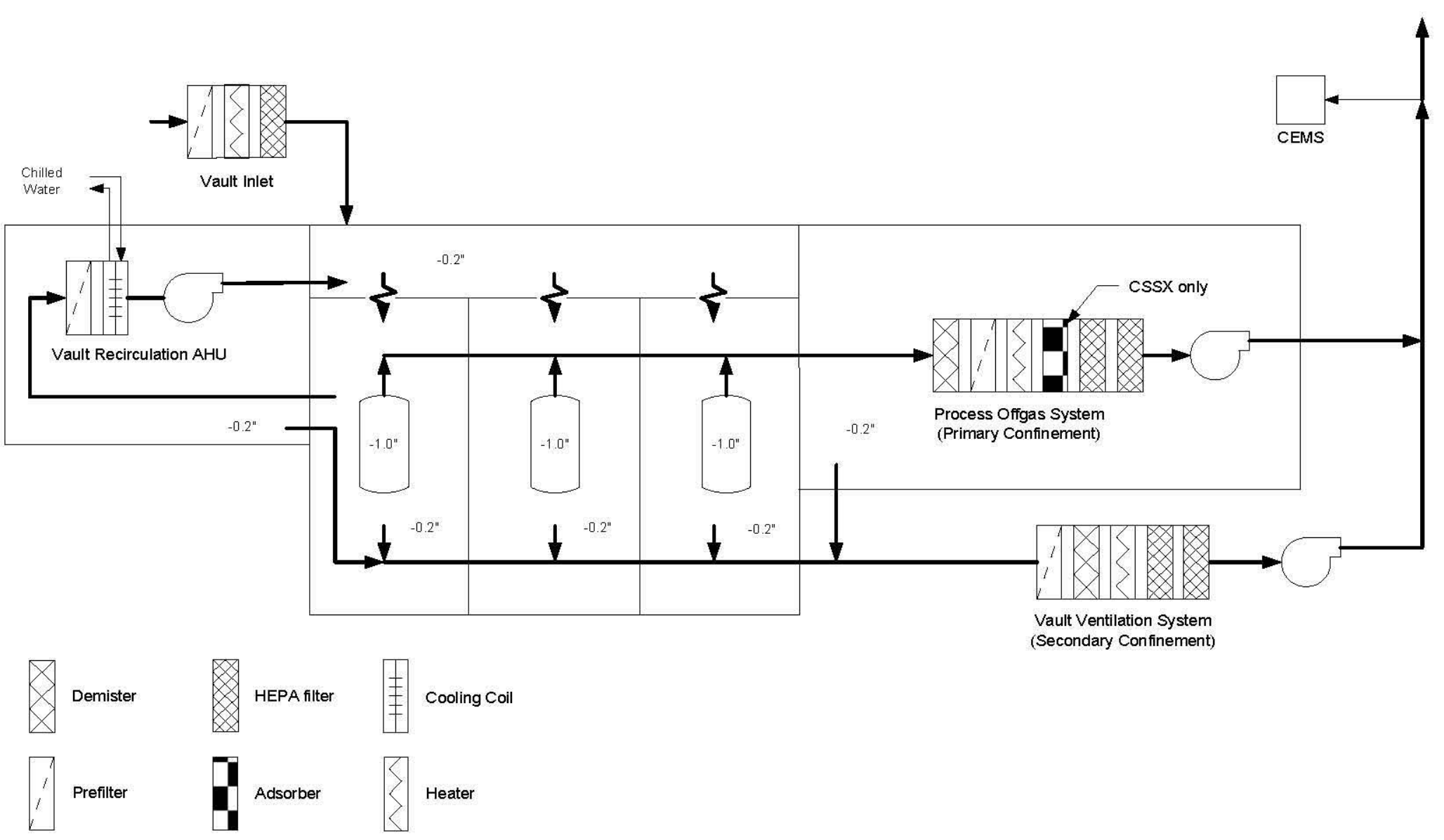


RPP-RPT-37551, Rev. 1

\section{Table 7-1 Common Equipment List}

\begin{tabular}{|c|c|c|c|c|c|}
\hline Qty & Component & Process Sizing & Physical Dimensions & Features & Comments \\
\hline \multicolumn{6}{|c|}{ Common Equipment: } \\
\hline & $\begin{array}{l}\text { Transfer Lines } \\
\text { Waste feed/Cs product return } \\
\text { LAW product transfer to WTP } \\
\text { Filter concentrate return }\end{array}$ & & $\begin{array}{l}160 \mathrm{ft} \mathrm{L} \\
160 \mathrm{ft} \mathrm{L} \\
890 \mathrm{ft} \mathrm{L}\end{array}$ & $\begin{array}{l}\text { IPS Candidate Site \#1 and tie in to } \\
\text { existing LAW Feed Transfer Lines } \\
\text { 3"SN-700-M9 \& 3"SN-701-M9. } \\
\text { Filter concentrate return line to } 241 \text { - } \\
\text { AP-02A valve pit. } \\
\text { Double encased, 3" SS with leak } \\
\text { detection. } \\
\text { Same line used for waste feed and } \\
\text { Cs product return. }\end{array}$ & $\begin{array}{l}\text { Filter concentrate return line } \\
\text { required for crossflow filter and } \\
\text { for FC paired with RMF option. }\end{array}$ \\
\hline & Electrical supply and MCC & & & & Discrimination not evaluated \\
\hline & Backup power & & & & Discrimination not evaluated \\
\hline & Control systems & & & & Discrimination not evaluated \\
\hline & Sampling system & & & & Discrimination not evaluated \\
\hline & Compressed air system & & & & Discrimination not evaluated \\
\hline \multicolumn{6}{|c|}{ Process Offgas System } \\
\hline 1 & Offgas Filter Train & $250 / 700 / 300^{*} \mathrm{cfm}$ & & $\begin{array}{l}\text { Prefilter, demister, heater, } 2 \text { HEPA } \\
\text { filters, filter test sections, } \\
\text { condensate collection } \\
\text { I\&C: (3) Filter dP } \\
\text { Demister dP } \\
\text { Heater dT }\end{array}$ & $\begin{array}{l}\text { Sized based on predicted air in- } \\
\text { leakage, worst case process tank } \\
\text { in-flow and other process } \\
\text { specific offgas flows. }\end{array}$ \\
\hline 1 & Offgas fan & $250 / 700 / 300^{*} \mathrm{cfm}$ & & $\begin{array}{l}\text { I\&C: Differential pressure } \\
\text { Flow control } \\
\text { VFD }\end{array}$ & $\begin{array}{l}\text { Sized based on predicted air in- } \\
\text { leakage, worst case process tank } \\
\text { in-flow and other process } \\
\text { specific offgas flows. }\end{array}$ \\
\hline \multicolumn{6}{|c|}{ Vault Ventilation Sy stem } \\
\hline 1 & HEPA filtered vault inlet & $\begin{array}{l}1000 \mathrm{cfm} \\
35 \mathrm{~kW} \text { heater }\end{array}$ & & $\begin{array}{l}\text { Prefilter, heater, HEPA filter, } \\
\text { control damper } \\
\text { I\&C: Vault pressure control } \\
\text { (2) Filter dP } \\
\text { Heater dT control }\end{array}$ & $\begin{array}{l}\text { Heater sized for freeze } \\
\text { protection. }\end{array}$ \\
\hline
\end{tabular}


RPP-RPT-37551, Rev. 1

\section{Table 7-1 Common Equipment List}

\begin{tabular}{|c|c|c|c|c|c|}
\hline Qty & Component & Process Sizing & Physical Dimensions & Features & Comments \\
\hline 1 & Exhaust Filter Train & $1000 \mathrm{cfm}$ & & $\begin{array}{l}\text { Prefilter, demister, heater, } 2 \text { HEPA } \\
\text { filters, filter test sections, } \\
\text { condensate collection } \\
\text { I\&C: (3) Filter dP } \\
\text { Demister dP } \\
\text { Heater dT control }\end{array}$ & $\begin{array}{l}\text { Flow rate to match rated capacity } \\
\text { of single } 24 \text {-in x } 24 \text {-in HEPA } \\
\text { filter. }\end{array}$ \\
\hline 1 & Exhaust fan & $1000 \mathrm{cfm}$ & & $\begin{array}{l}\text { I\&C: Differential pressure } \\
\text { Flow control } \\
\text { VFD }\end{array}$ & $\begin{array}{l}\text { Flow rate to match rated capacity } \\
\text { of single } 24 \text {-in x } 24 \text {-in HEPA } \\
\text { filter. }\end{array}$ \\
\hline 1 & CEMS & & & $\begin{array}{l}\text { WAC-246-247 permitted monitoring } \\
\text { system }\end{array}$ & \\
\hline 1 & Stack & & & & Discrimination not evaluated \\
\hline 1 & Vault Recirculation AHU & & & $\begin{array}{l}\text { Air handling unit loads vary for six } \\
\text { possible process configurations }\end{array}$ & $\begin{array}{l}\text { Sized for cooling loads from } \\
\text { electric motors, process } \\
\text { equipment at elevated } \\
\text { temperatures, and } 1000 \mathrm{cfm} \text { of } \\
\text { ventilation air }\end{array}$ \\
\hline & $\begin{array}{l}\text { IX system with: } \\
\text { Rotary microfilter } \\
\text { Crossflow filter }\end{array}$ & 5 ton & & $\begin{array}{l}\text { Prefilter, cooling coil, fan } \\
\text { I\&C: Filter and coil dP } \\
\text { Coil dT } \\
\text { Vault temperature control }\end{array}$ & \\
\hline & $\begin{array}{l}\text { FC system with: } \\
\text { Rotary microfilter } \\
\text { Crossflow filter }\end{array}$ & $\begin{array}{l}35 \text { ton } \\
35 \text { ton }\end{array}$ & & $\begin{array}{l}\text { Prefilter, cooling coil, fan } \\
\text { I\&C: Filter and coil dP } \\
\text { Coil dT } \\
\text { Vault temperature control }\end{array}$ & \\
\hline & $\begin{array}{l}\text { CSSX system with: } \\
\text { Rotary microfilter } \\
\text { Crossflow filter }\end{array}$ & $\begin{array}{l}17 \text { ton } \\
20 \text { ton }\end{array}$ & & $\begin{array}{l}\text { Prefilter, cooling coil, fan } \\
\text { I\&C: Filter and coil dP } \\
\text { Coil dT } \\
\text { Vault temperature control }\end{array}$ & \\
\hline
\end{tabular}


RPP-RPT-37551, Rev. 1

Table 7-1 Common Equipment List

\begin{tabular}{|c|c|c|c|c|c|}
\hline Qty & Component & Process Sizing & Physical Dimensions & Features & Comments \\
\hline 1 & Chilled Water System & & & $\begin{array}{l}\text { Includes chiller, circulation pump, } \\
\text { expansion tank and distribution } \\
\text { piping for different loads for six } \\
\text { possible process configurations. }\end{array}$ & $\begin{array}{l}\text { Sized for process loads and } \\
\text { Recirculation AHU load. }\end{array}$ \\
\hline & $\begin{array}{l}\text { IX system with: } \\
\text { Rotary microfilter } \\
\text { Crossflow filter }\end{array}$ & $\begin{array}{l}20 \text { ton } \\
45 \text { ton }\end{array}$ & & $\begin{array}{l}\text { Air-cooled chiller } \\
\text { Loads: Feed Hx } \\
\text { Spent Resin Condenser } \\
\text { Recirculation AHU } \\
\text { (Filter Feed Tank) }\end{array}$ & \\
\hline & $\begin{array}{l}\text { FC system with: } \\
\text { Rotary microfilter } \\
\text { Crossflow filter }\end{array}$ & $\begin{array}{l}1200 \text { ton } \\
1300 \text { ton }\end{array}$ & & $\begin{array}{l}\text { Water cooled chiller. } \\
\text { With recirculated water and cooling } \\
\text { tower for heat rejection. } \\
\text { Loads: 1st stage condenser } \\
\text { 2nd stage condenser } \\
\text { Vacuum pump condensers } \\
\text { Recirculation AHU } \\
\text { (Filter Feed Tank) }\end{array}$ & \\
\hline & $\begin{array}{l}\text { CSSX system with: } \\
\text { Rotary microfilter } \\
\text { Crossflow filter }\end{array}$ & $\begin{array}{l}30 \text { ton } \\
55 \text { ton }\end{array}$ & & $\begin{array}{l}\text { Air-cooled chiller } \\
\text { Loads: Feed } \mathrm{Hx} \\
\text { Solvent } \mathrm{Hx} \\
\text { Recirculation AHU } \\
\text { (Filter Feed Tank) }\end{array}$ & \\
\hline \multicolumn{6}{|c|}{ Structures } \\
\hline & $\begin{array}{l}\text { Process Offgas and Recirculation } \\
\text { AHU cell }\end{array}$ & & 32-ft L x 12-ft W x 10-ft H & $\begin{array}{l}\text { Above grade, } 12 \text {-in thick concrete } \\
\text { shielded secondary confinement. } \\
\text { Accessible for maintenance. }\end{array}$ & \\
\hline & $\begin{array}{l}\text { Vault Ventilation System } \\
\text { building }\end{array}$ & & $32-\mathrm{ft} \mathrm{L} \times 12-\mathrm{ft} \mathrm{W} \times 10-\mathrm{ft} \mathrm{H}$ & $\begin{array}{l}\text { Above grade, concrete walled } \\
\text { structure. } \\
\text { Accessible for maintenance. }\end{array}$ & \\
\hline & Sample room & & $15-\mathrm{ft} \mathrm{L} \times 7-\mathrm{ft} \mathrm{W} \times 10-\mathrm{ft} \mathrm{H}$ & $\begin{array}{l}\text { Above grade, concrete walled } \\
\text { structure. }\end{array}$ & \\
\hline
\end{tabular}


RPP-RPT-37551, Rev. 1

\section{Table 7-1 Common Equipment List}

\begin{tabular}{|l|l|l|l|l|l|}
\hline Qty & \multicolumn{1}{|c|}{ Component } & Process Sizing & Physical Dimensions & \multicolumn{1}{c|}{ Features } \\
\hline & Chilled water system pad & & $\begin{array}{l}18 \text {-ft L x 11-ft W (IX) } \\
\text { 30-ft L x 18-ft W (FC) } \\
21-\mathrm{ft} \mathrm{L} \mathrm{10-ft} \mathrm{W} \mathrm{(CSSX)}\end{array}$ & 8 -in thick pad \\
& & & & & \\
\hline & Electrical Equipment Room & & & & \\
\hline & Control Trailer & & & & \\
\hline & & & & Discrimination not evaluated \\
\hline
\end{tabular}

General Notes:

1. All process piping is designed, fabricated and tested to ASME B31.3

2. All process equipment, chemical equipment and offgas piping is manufactured from $304 \mathrm{~L}$ or $316 \mathrm{~L} \mathrm{SS}$.

3. All components of exhaust side offgas and ventilation systems are designed, fabricated and tested to ASME AG-1

* Sizing is for IX / FC / CSSX options respectively. 


\subsection{FACILITY LAYOUTS}

Process system designs and facility layouts used as a basis for the technology descriptions focus on methods that minimize the construction of new facilities that might not be considered the most efficient structure for maintaining entrained solids and cesium separations if the IPS were operated over a 40-year operating period. Process equipment is generally located in underground, shielded vaults with removable concrete beams as cover blocks. The layout for the Fractional Crystallization alternative is more complex given the large overall vertical height of the process equipment and the accessibility requirements for operation and maintenance.

The layout philosophy locates the equipment that contains large radionuclide inventories in separate shielded vaults. Piping within these vaults will likely be all welded to minimize potential leak points, with the exception of jumpers installed to facilitate pump removal. Generally, components that may require maintenance or replacement, such as valves and instrumentation, that are associated with the major tanks and equipment will be removed from the equipment vaults to the maximum extent practical and located in the central valve vault, on jumpers if necessary. Vault covers will consist of removable concrete beams, which will provide maintenance access to all areas of the vaults.

Process support equipment will be located above grade. The process offgas, vault ventilation, recirculation AHU, sampling, and spent resin disposal cask offload for Ion Exchange will be located in enclosed structures with personnel access for operation and maintenance. The chilled water system, chemical reagent tanks (with containment basins), and the steam system for Fractional Crystallization will be located outdoors on concrete pads. The process offgas and recirculation AHU rooms are part of the secondary confinement boundary. Vehicle access must be provided for chemical reagent delivery and spent resin disposal cask delivery and transport.

Six facility layouts are provided that represent the six possible process configurations; i.e. each of the three cesium separation alternatives paired with each of the two solids separation alternatives. An elevation view of the Fractional Crystallization alternative is also provided.

\subsection{ROTARY MICROFILTER SOLIDS SEPARATION}

The modular rotary microfilter design developed by SRS will be modified to fit Hanford DST design such that the filter units can be installed directly into tank risers. This will require installation of an additional pit around an existing riser, similar in construction to the existing central pump pit. The Fractional Crystallization option requires more rotary microfilter units than can be installed into tank risers, so they would need to be collocated with the cesium separation process. In this case, the same modular filter pack design would be utilized and installed in an underground vault similar in construction to the typical tank vaults described above. The footprint allocation is $3.5-\mathrm{ft} \times 3.5$ - $\mathrm{ft}$ for each rotary microfilter unit. 


\subsection{CROSSFLOW FILTER SOLIDS SEPARATION}

The crossflow filtration equipment will be located within an underground vault similar in construction to the typical tank vaults and collocated with the cesium separation process. The crossflow filters will be provided with remote piping connections to allow removal and replacement. The recirculation pump will be located in the valve vault for more accessibility for maintenance.

\subsection{ION EXCHANGE CESIUM SEPARATION}

The ion exchange columns and spent resin accumulation tank will be located within an underground vault similar in construction to the typical tank vaults. All piping to the columns will include jumpers to allow for complete removal and replacement of the columns. Layout of all other equipment follows the general philosophy described above. See Figure 8-1 and Figure 8-2.

\subsection{FRACTIONAL CRYSTALLIZATION CESIUM SEPARATION}

A preliminary concept has been developed for a facility to incorporate the conceptual fractional crystallization process described herein. The concept includes two major facilities for handling the waste, the Crystallizer Process Building and the underground equipment/tank vaults, which are similar to the other cesium separation alternatives and follows the general philosophy described above. See Figure 8-3, Figure 8-4 and Figure 8-5.

The Crystallizer Process Building is divided into two halves, one each for the primary and secondary systems. Each half has two major compartments:

- Process Cell. This is a heavily shielded cell that houses the crystallizer vessel, reboiler, main recirculation pump, process tanks, and filters for each crystallizer stage. Removal and replacement of pumps and other failure items will be via the Process Maintenance Cell above the process tanks, rebuilder and recirculation pump. Heavy shielding between the cells will protect workers in the Process Maintenance Cell from high radiation fields around the crystallizer and process tanks. There will be access for maintenance of selected items via ports through the shielding; however, there is no expected need for personnel entry into the Process Cell during the life of the facility. Pump drive motors, instrumentation and other maintenance items will be located outside the shielding to the extent feasible. 
- Process Maintenance Cell. The Process Maintenance Cell is located above the Process Cell tanks and adjacent to the crystallizer. The basket end of the centrifuge projects into this cell and the crystallizer condenser and vacuum steam jets are located in this cell. Process piping, valves, and the non-contaminated ends of cells equipment (drive motors, actuators, instrumentation etc.) are also located in this cell. Restrictions on certain process operations will be required when personnel are present in this cell, e. g. prior to personnel entry and work in the vicinity of the centrifuge; it must be drained and flushed.

An operating corridor extends along one side of each Process Maintenance Cell. The centrifuges are installed in the wall between the operating corridor and the Process Maintenance Cell, allowing the drive and non-contaminated controls and instrumentation to be accessed from the operating corridor. Double walled process condensate tanks are located outside the process building.

\subsection{SOLVENT EXTRACTION CESIUM SEPARATION}

The centrifugal contactors will be located within an underground vault similar in construction to the typical tank vaults. The footprint allocation is $3-\mathrm{ft} \times 3$ - $\mathrm{ft}$ for each 10 -in rotor contactor. The contactors will be generally hard piped with some level of modularization to allow removal and replacement, if necessary. Layout of all other equipment follows the general philosophy described above. See Figure 8-6 and Figure 8-7. 
Figure 8-1 Ion Exchange with Crossflow Filtration Facility Layout

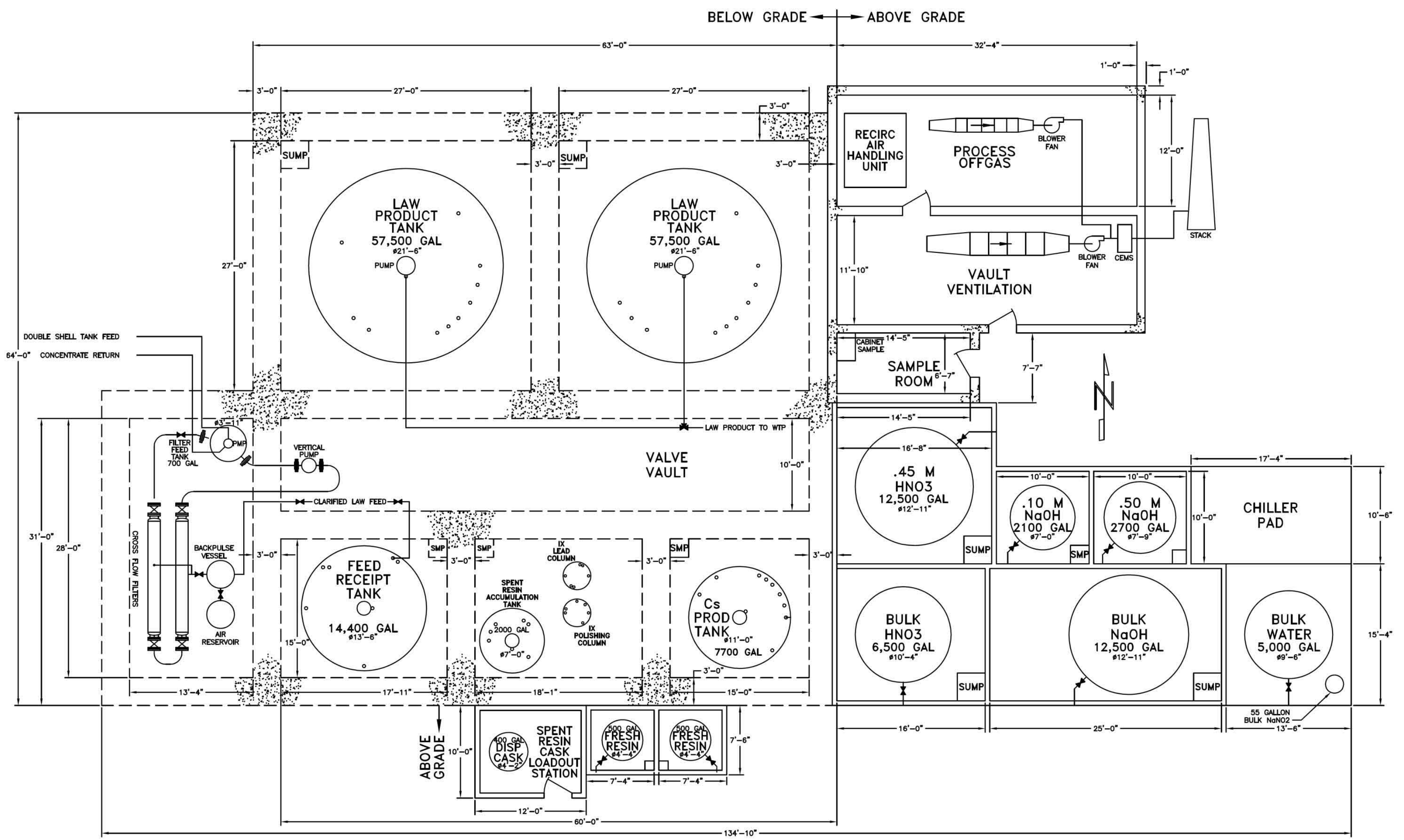


Figure 8-2 Ion Exchange with Rotary Microfiltration Facility Layout

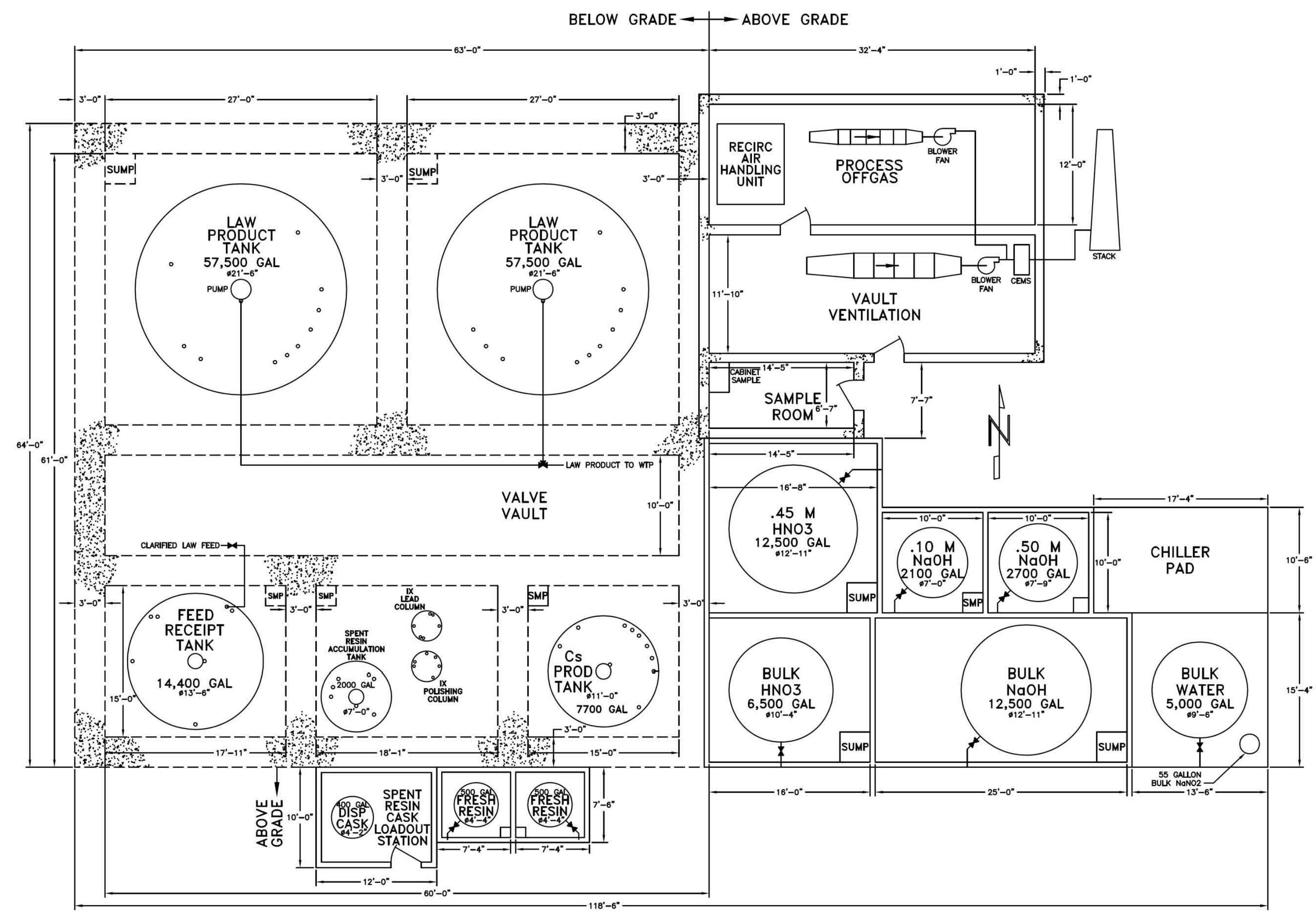


Figure 8-3 Fractional Crystallization with Crossflow Filtration Facility Layout

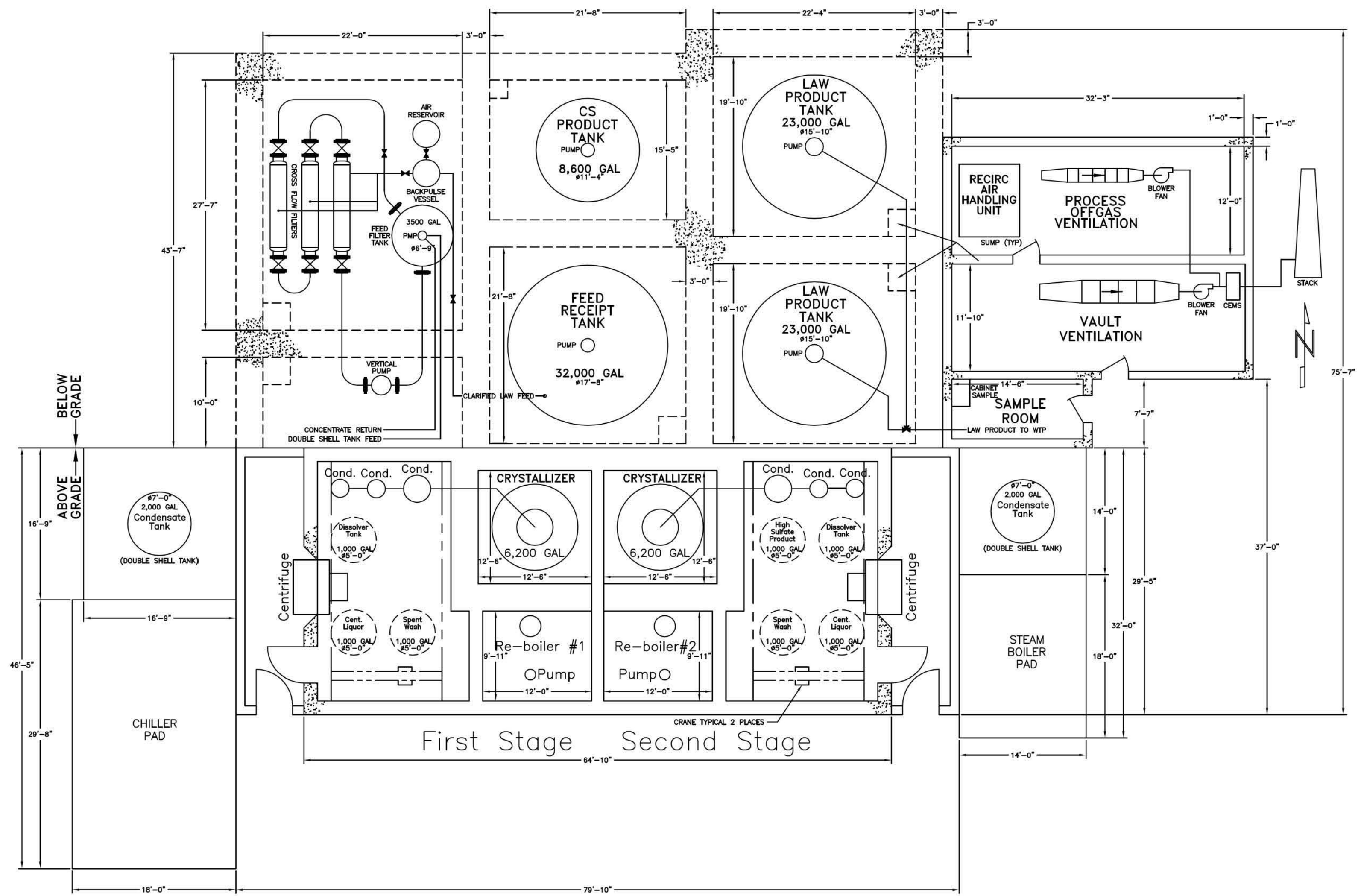


Figure 8-4 Fractional Crystallization with Rotary Microfilter Facility Layout

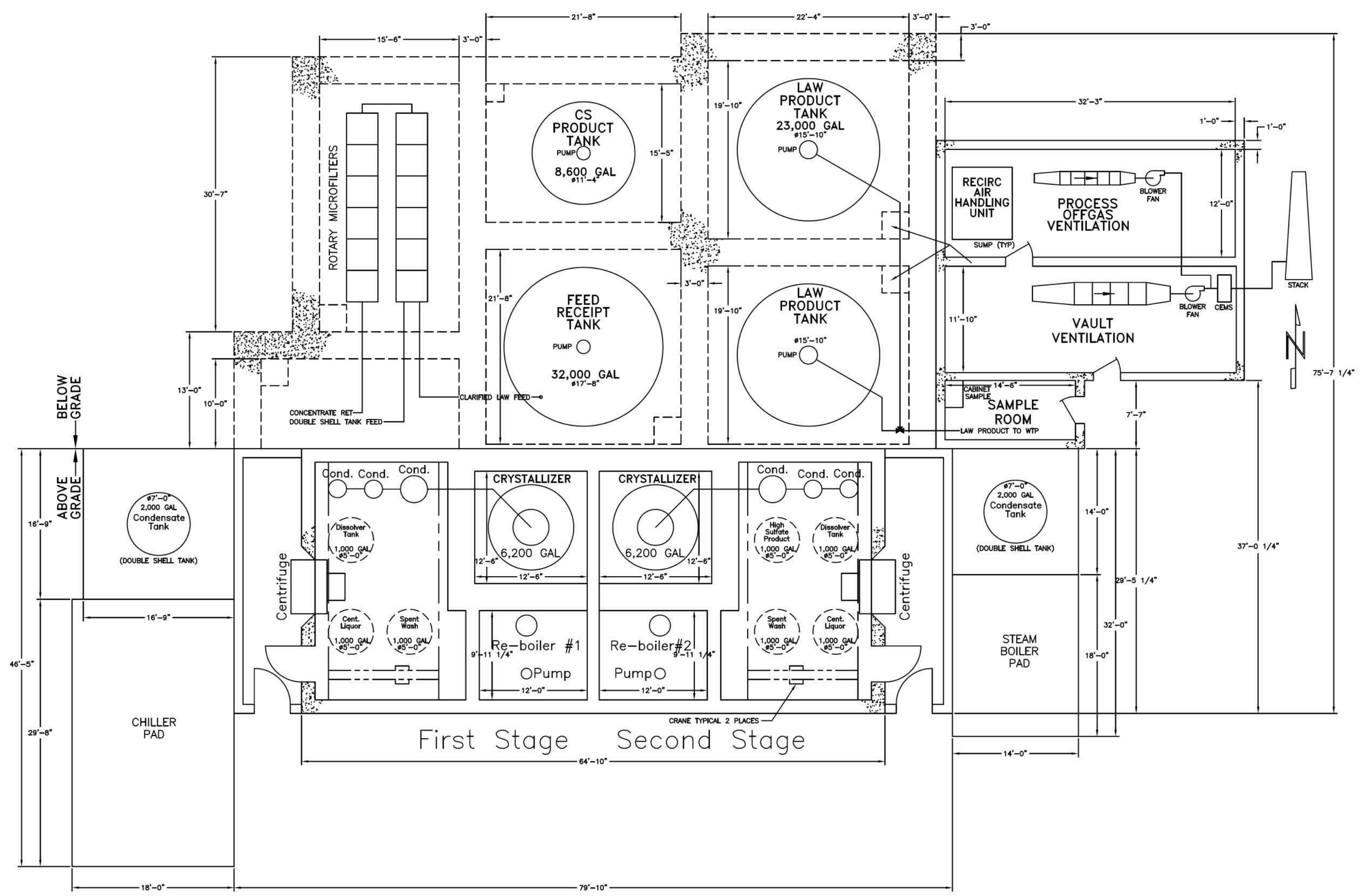




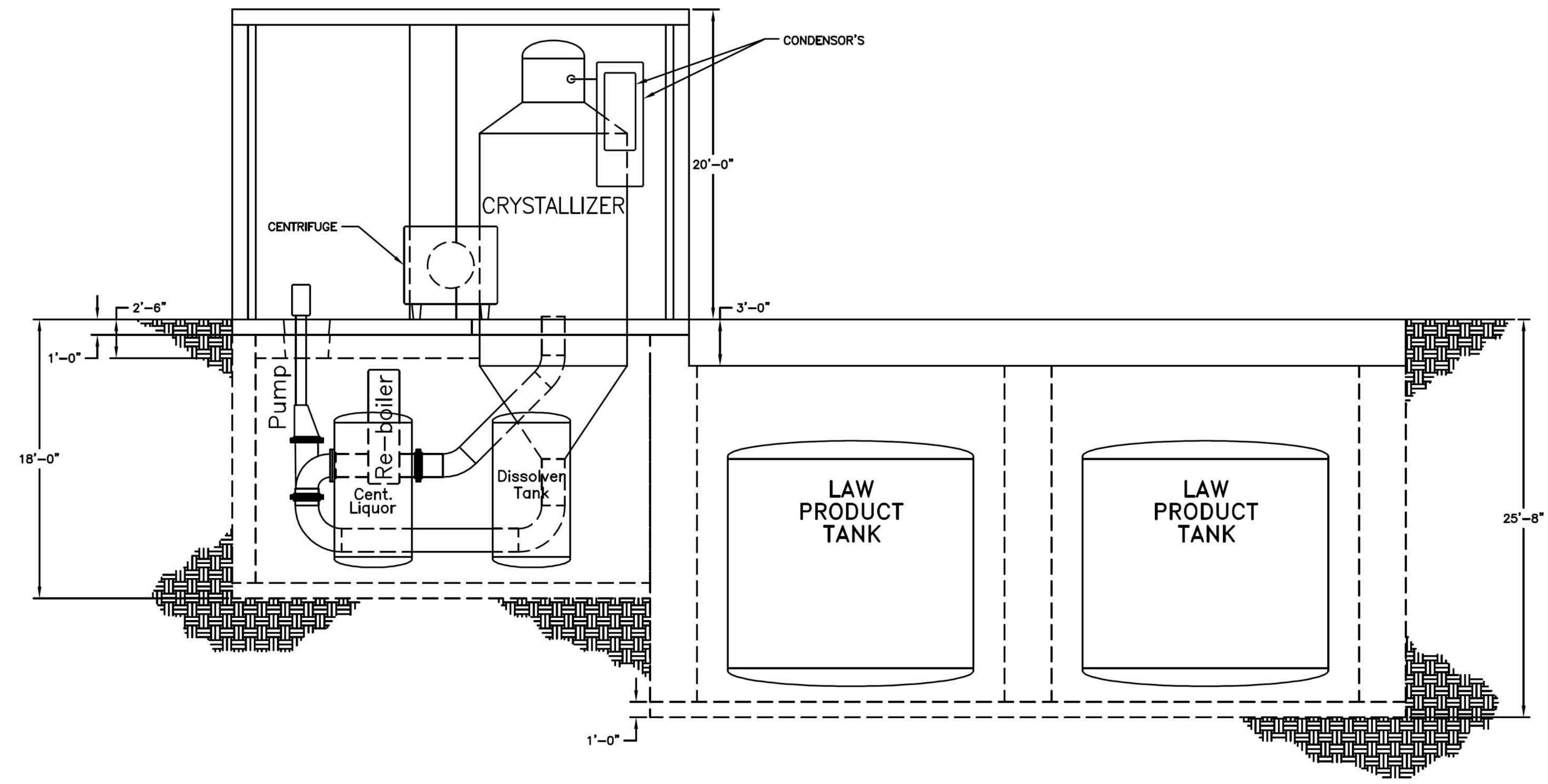




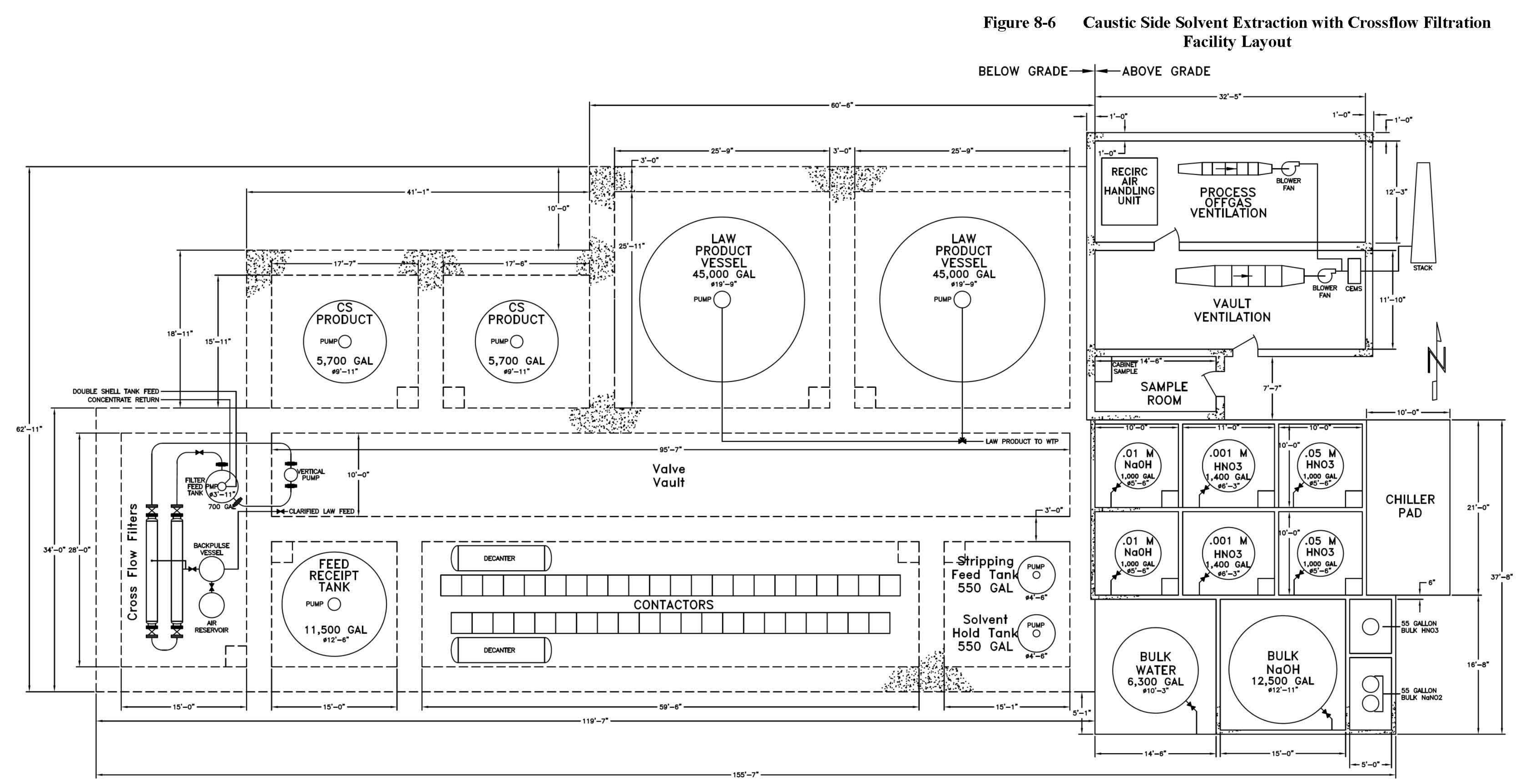


Figure 8-7 Caustic Side Solvent Extraction with Rotary Microfiltration Facility Layout

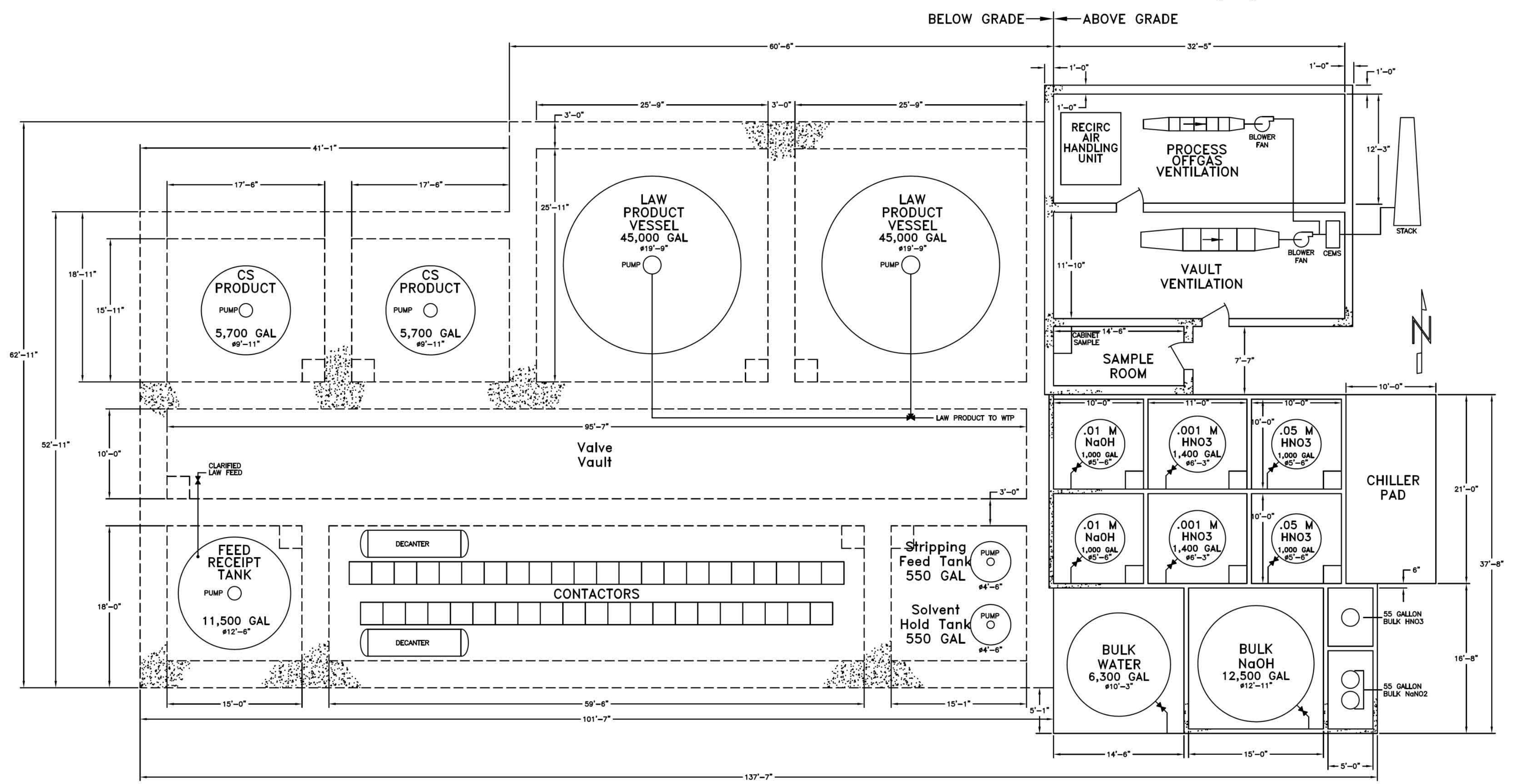




\subsection{CONCLUSIONS}

As indicated in the scope, this document was intended to provide technology description information to support subsequent technology selection activities. Therefore, no attempt was made to develop a recommended technology as part of this study. Comparisons of selected technology characteristics have been summarized at the conclusion of Sections 5.0 and 6.0. However, it should be recognized that additional comparison attributes are expected to be developed as part of subsequent technology selection activities.

\subsection{REFERENCES}

155889, 2008, "Early LAW Waste Receipt Criteria Revision" (memorandum from R. Hanson to S. A. Saunders, April 8), Bechtel National, Inc., Richland, Washington

24590-WTP-RPT-RT-07-005, 2008, Basis of Recommendation for Use of Spherical Resorcinol Formaldehyde Resin as the Primary Cesium Ion Exchange Resin in the WTP, Rev 0 , Bechtel National, Inc., Richland, Washington

24590-WTP-RPT-PT-02-005, 2005, Flowsheet Bases, Assumptions, and Requirements, Rev 3, Bechtel National, Inc., Richland, Washington

74A10-DLH-08-151, 2008, "Test Plan for Simulant Modifications to Support the Interim Pretreatment System," (interoffice memorandum from D. L. Herting to D. W. Hamilton, March 18), CH2MHILL Hanford Group, Inc., Richland, Washington

ANL-00/31, 2001, Temperature Management of Centrifugal Contactors for Caustic-Side Solvent Extraction of Cesium from Tank Waste, Argonne National Laboratory, Chicago, Illinois

Birdwell, J. F., 2008-05-16, "CSSX Flow Sheet Calculations," (e-mail to M. E. Johnson), Oak Ridge National Laboratory, Oak Ridge, Tennessee

BNF-003-98-0221, 2000, Final Report: Pilot-scale Cross-flow Ultrafiltration Test Using a Hanford Site Tank 241-AN-105 Waste Simulant - Envelope A + Entrained Solids, Westinghouse Savannah River Company, Aiken, South Carolina

BNF-003-98-0226, 2000, Final Report: Pilot-scale Cross-flow Ultrafiltration Test Using a Hanford Site Tank 24I-AN-107 Waste Simulant-Envelope C + Entrained Solids + Strontium-Transuranic Precipitation, Westinghouse Savannah River Company, Aiken, South Carolina

CBU-SPT-2004-00059, 2004, Preliminary Material Balance for the Modular CSSX Unit, Rev. 1, Westinghouse Savannah River Company, Aiken, South Carolina 
DE-FC21-94MC31388-30, 1999, EM Task 9-Centrifugal Membrane Filtration, Energy \& Environmental Research Center, University of North Dakota, Grand Forks, North Dakota

Delmau, L. H., Haverlock, T. J., Bazelaire, E., Bonnesen, P. V., Ditto, M. E., and B. A. Moyer, submitted for publication April 2008, "Alternatives to Nitric Acid Stripping in the Caustic-Side Solvent Extraction (CSSX) Process for Cesium Removal from Alkaline High-Level Waste," Solvent Extraction and Ion Exchange.

DOE/ORP-2007-01, 2007, Technology Readiness Assessment for the Supplemental Treatment Program, U.S. Department of Energy, Office of River Protection, Richland, Washington

H-2-69320, 2004, Process Flow Diagram Vacuum Evaporator Crystallizer System, Rev. 2, Vitro Hanford Engineering Services, Richland, Washington

HNF-3172, 2005, Liquid Waste Processing Facilities Waste Acceptance Criteria, Rev 3, Fluor Hanford, Richland, Washington

HNF-EP-0063, 2008, Hanford Site Solid Waste Acceptance Criteria, Rev 14, FLUOR, Richland, Washington

HNF-IP-1266, 2007, Tank Farms Operations Administrative Controls, Rev 5e, CH2M HILL Hanford Group, Inc., Richland, Washington

HNF-SD-WM-OCD-015, 2007, Tank Farms Waste Transfer Compatibility Program, Rev 18, CH2M HILL Hanford Group, Inc., Richland, Washington

LWO-SPT-2007-000245, 2007, Scale-up of Caustic-Side Solvent Extraction Process for Removal of Cesium at Savannah River Site, Washington Savannah River Company, Aiken, South Carolina

May, T. H., 2008-05-09, "FW: Data Disk," (e-mail to G. E. Stegen), CH2M HILL Hanford Group, Inc., Richland, Washington

ORNL/TM-2000/27, 2001, Development and Deployment of a Full-Scale Cross-Flow Filtration System for Treatment of Liquid Low-Level Waste at Oak Ridge National Laboratory, Oak Ridge National Laboratory, Oak Ridge, Tennessee

ORNL/TM-2002/190, 2002, Caustic-Side Solvent Extraction: Chemical and Physical Properties of the Optimized Solvent, Oak Ridge National Laboratory, Oak Ridge, Tennessee

ORNL/TM-2004/59, 2004, Conceptual Design of a Simplified Skid-Mounted Caustic-Side Solvent Extraction Process for Removal of Cesium from Savannah River Site High-Level Waste, Oak Ridge National Laboratory, Oak Ridge, Tennessee

OPR-1 1242, 2008, River Protection Project System Plan, Rev. 3, U.S. Department of Energy, Office of River Protection, Richland, Washington

Perry, R. H. and C. H. Chilton, Chemical Engineer's Handbook, $5^{\text {th }}$ ed., McGraw-Hill Book Company, New York, New York

PNNL-11376, 1996, Bench-Scale Cross Flow Filtration of Tank S-107 Sludge Slurries and Tank C-107 Supernatant, Pacific Northwest National Laboratory, Richland, Washington

RPP-29981, 2007, Evaluation of Starting the Waste Treatment and Immobilization Plant (WTP) Low Activity Waste Facility First, Rev 1, CH2M HILL Hanford Group, Inc., Richland, Washington 
RPP-30993-FP, 2006, Fractional Crystallization of Hanford Single-Shell Tank Wastes-A Modeling Approach, Rev. 0, CH2MHILL Hanford Group, Inc., Richland, Washington

RPP-30995-FP, 2006, Fractional Crystallization of Hanford Single-Shell Tank Waste from Concept to Pilot Plant, Rev. 0, CH2MHILL Hanford Group, Inc., Richland, Washington

RPP-31983-FP, 2006, Fractional Crystallization of Hanford Single-Shell Tank WastesLaboratory Development, Rev. 0, CH2MHILL Hanford Group, Inc., Richland, Washington

RPP-CALC-37594, 2008, Project W-551 Supporting Calculations for Interim Pretreatment System Pre-Conceptual Candidate Technology Descriptions, Rev. 0, CH2M Hill Hanford Group, Inc., Richland, Washington

RPP-PLAN-27238, 2006, Hanford Medium/Low Curie Waste Pretreatment ProjectPretreatment Process Plan, Rev. 0, CH2MHILL Hanford Group, Inc., Richland, Washington

RPP-PLAN-27239, 2006, Hanford Medium/Low Curie Waste Pretreatment Project-Phase I Laboratory Report, Rev. 0, CH2MHILL Hanford Group, Inc., Richland, Washington

RPP-RPT-26474, 2005, Fractional Crystallization of Waste from Tank 241-S-112, Rev. 0, CH2MHILL Hanford Group, Inc., Richland, Washington

RPP-RPT-30160, 2006, Supporting Information for the Evaluation of Waste Treatment and Immobilization Plant (WTP) Low Activity Waste (LAW) Startup First Scenarios, Rev 0, CH2M HILL Hanford Group, Inc., Richland, Washington

RPP-RPT-31352,2007, Fractional Crystallization Flowsheet Testing with Actual Tank Waste, Rev. 1, CH2MHILL Hanford Group, Inc., Richland, Washington

RPP-RPT-31998, 2006, Fractional Crystallization Laboratory Testing for Inclusion and CoPrecipitation with Actual Tank Waste, Rev. 0, CH2MHILL Hanford Group, Inc., Richland, Washington

RPP-RPT-36854, 2007, Fractional Crystallization Feed Envelope, Rev. 0, CH2MHILL Hanford Group, Inc., Richland, Washington

RPP-RPT-37644, 2008, Interim Pretreatment System Mission Scoping Report, Rev 0, CH2MHILL Hanford Group, Inc., Richland, Washington

SVF-1440, 2008, DST Space File M-45-02N Ecology Case (2-7-2008)-8.3r1-2008-02-07-at1339_29_m1.xls, Rev 0, CH2M HILL Hanford Group Inc., Richland, Washington

SVF-1484, "Interim Pretreatment System DST Feed Calculation, SVF-1484 Rev. 0.xls," CH2MHILL Hanford Group, Inc., Richland, Washington

SVF-1493, 2008, "Interim Pretreatment System Adjusted Feed DST Feed Composition Calculation, SVF-1493.xls," Rev. 0, CH2MHILL Hanford Group, Inc., Richland, Washington

SVF-1498, 2008, "IPS Fractional Crystallization Mass Balance Model," Rev. 0, CH2MHILL Hanford Group, Inc., Richland, Washington

SVF-1499, 2008, IPS Ion Exchange Mass Balance Model, Rev 0, CH2MHILL Hanford Group, Inc., Richland, Washington 
SVF-1500, 2008, "IPS Caustic-Side Solvent Extraction Mass Balance Model," Rev. 0, CH2M Hill Hanford Group, Inc., Richland, Washington

SVF-1505, 2008, FC-1-8 Input Parameter Supporting Calculations SVF-1505.xls," Rev. 0, CH2M Hill Hanford Group, Inc., Richland, Washington

SVF-1513, 2008, IPS Qualitative Glass Impacts (5 year).xls." Rev. 0, CH2M Hill Hanford Group, Inc., Richland, Washington

WSRC-MS-2004-00194, 2004, Pilot-Scale Testing of a Rotary Microfilter with Irradiated Filter Disks and Simulated SRS Waste, Westinghouse Savannah River Company, Aiken, South Carolina

WSRC-MS-2004-00646, 2005, Development of a Rotary Microfilter for Savannah River Site High-Level Waste Applications, Westinghouse Savannah River Company, Aiken, South Carolina

WSRC-MS-2006-0115, 2006, Cross-Flow Ultrafiltration Scaling Considerations, Westinghouse Savannah River Company, Aiken, South Carolina

WSRC-RP-2003-00605, 2003, Recommendations for Additional Design Development of Components for the SpinTek Rotary Microfilter Prior to Radioactive Service, Westinghouse Savannah River Company, Aiken, South Carolina

WSRC-RP-2004-00234, 2004, Impact of a Rotary Microfilter on the Savannah River Site High Level Waste System, Westinghouse Savannah River Company, Aiken, South Carolina

WSRC-RP-2005-01970, 2005, Cesium Concentration in MCU Solvent, Rev. 0, Westinghouse Savannah River Company, Aiken, South Carolina

WSRC-STI-2006-00073, 2006, Testing and Evaluation of the Modified Design of the 25 Disk Rotary Microfilter, Westinghouse Savannah River Company, Aiken, South Carolina

WSRC-STI-2007-00030, Ion Exchange Modeling of Cesium Removal from Hanford Waste Using Spherical Resorcinol-Formaldehyde Resin, Rev 0, Washington Savannah River Company, Aiken South Carolina (SCT-M0SRLE60-00-05-00004, Rev 00A)

WSRC-STI-2007-00580, 2007, Full-Scale Testing of a Caustic Side Solvent Extraction System to Remove Cesium from Savannah River Site Radioactive Waste, Rev. 0, Savannah River National Laboratory, Aiken, South Carolina

WSRC-STI-2008-00050, 2008, Development of a Rotary Microfilter for Radioactive Waste Applications, Westinghouse Savannah River Company, Aiken, South Carolina

WSRC-STI-2008-00232, 2008, Modeling of Ion-Exchange for Cesium Removal from Hanford Interim Pretreatment System Feeds, Rev 0, Washington Savannah River Company, Aiken, South Carolina

WSRC-STI-2008-DRAFT, 2008, Testing of a Rotary Microfilter to Support Hanford Applications, Westinghouse Savannah River Company, Aiken, South Carolina

WSRC-TR-2000-00506, 2000, Strontium-Transuranic Precipitation and Crossflow Filtration of 241-AN-102 Large C, Westinghouse Savannah River Company, Aiken, South Carolina

WSRC-TR-2001-00214, 2001, Filtration Systems, Inc., Report for WSRC SpinTek Rotary Microfilter Testing, Westinghouse Savannah River Company, Aiken, South Carolina 
WSRC-TR-2002-00243, 2002, High Level Waste Demonstration of the Caustic-Side Solvent Extraction Process with Optimized Solvent in the 2-cm Centrifugal Contactor Apparatus using Tank 37H/44F Supernate, Rev. 0, Westinghouse Savannah River Company, Aiken, South Carolina

WSRC-TR-2002-00307, 2002, Demonstration of Caustic-Side Solvent Extraction with Optimized Solvent in the 2-cm Centrifugal Contactor Apparatus using Dissolved Salt Cake from Tank 37H, Rev. 1, Westinghouse Savannah River Company, Aiken, South Carolina

WSRC-TR-2002-00526, 2002, Investigation of Alternative Approaches for Cleaning Mott Porous Metals Filters, Westinghouse Savannah River Company, Aiken, South Carolina

WSRC-TR-2002-00530, 2003, Filtration of a Hanford AW-101 Waste Sample (U), Westinghouse Savannah River Company, Aiken, South Carolina

WSRC-TR-2003-00030, 2003, Testing of the SpinTek Rotary Microfilter Using Actual Waste, Westinghouse Savannah River Company, Aiken, South Carolina

WSRC-TR-2003-00071, 2003, Pilot-Scale Testing of a SpinTek Rotary Microfilter with SRS Simulated High Level Waste, Westinghouse Savannah River Company, Aiken, South Carolina

WSRC-TR-2003-00204, 2003, Final Report: Pilot-Scale Cross-Flow Ultrafiltration Test Using a Hanford Site Tank 241-AN-102 Waste Simulant (U), Westinghouse Savannah River Company, Aiken, South Carolina

WSRC-TR-2003-00295, 2003, Filtration of a Hanford AN-104 Sample (U), Westinghouse Savannah River Company, Aiken, South Carolina

WSRC-TR-2003-00469, 2003, Pilot-Scale Testing of a 0.1 Micron Filter with SRS Simulated High Level Waste, Westinghouse Savannah River Company, Aiken, South Carolina

WSRC-TR-2003-00756, 2004, Filtration of a Hanford Site Tank 241-AN-102 Waste Sample with Alternate Sr/TRU Precipitation Conditions at Bench and Pilot Scales, Westinghouse Savannah River Company, Aiken, South Carolina.

WSRC-TR-2004-00047, 2004, Pilot-Scale Testing of a Rotary Microfilter with Irradiated Filter Disks and Simulated SRS Waste, Westinghouse Savannah River Company, Aiken, South Carolina

WSRC-TR-2004-00213, 2004, Pilot-Scale Testing of a SpinTek Rotary Microfilter with Welded Disks and Simulated Savannah River Site High Level Waste, Westinghouse Savannah River Company, Aiken, South Carolina

WSRC-TR-2005-00182, 2005, Examination of Organic Carryover from 2-cm Contactors to Support the Modular CSSX Unit, Rev. 0, Westinghouse Savannah River Company, Aiken, South Carolina

WSRC-TR-2005-00205, 2005, Rotary Microfilter Media Evaluation, Westinghouse Savannah River Company, Aiken, South Carolina

WSRC-TR-2005-00258, 2005, Waste and Solvent Composition Limits for Modular Caustic-Side Solvent Extraction Unit (MCU), Rev. 0, Westinghouse Savannah River Company, Aiken, South Carolina 
WSRC-TR-2005-00570, 2006, Pilot-Scale Hydraulic Testing of Resorcinol Formaldehyde Ion Exchange Resin, Rev 1, Washington Savannah River Company, Aiken South Carolina (SCT-MOSRLE60-00-110-00028, Rev 00B)

WTP-RPT-134, 2006, Spherical Resorcinol-Formaldehyde Resin Testing for ${ }^{137}$ Cs Removal from Simulated and Actual Hanford Waste Tank 241-AP-101 Diluted Feed (Envelope A) Using Small Column Ion Exchange, Rev 0, Battelle - Pacific Northwest Division, Richland, Washington (24590-101-TSA-W000-0004-174-00001, Rev 00A)

WTP-RPT-144, 2006, Spherical Resorcinol-Formaldehyde Resin Analysis Following Actual Hanford Tank Waste Processing, Rev 0, Battelle - Pacific Northwest Division, Richland, Washington

Yaws, C. L., 1977, Physical Properties, A Guide to the Physical, Thermodynamic and Transport Property Data of Industrially Important Chemical Compounds, Chemical Engineering, McGraw-Hill Publishing Co., New York, New York 
RPP-RPT-37551, Rev. 1

APPENDIX

REFERENCED E-MAILS 
Birdwell, J. F., 2008-05-16, "CSSX Flow Sheet Calculations," (e-mail to M. E. Johnson), Oak Ridge National Laboratory, Oak Ridge, Tennessee

From: Johnson, Michael E [mailto:Michael_E_Johnson@RL.gov]

Sent: Friday, May 16, 2008 12:48 PM

To: 'apajunen@charter.net'; Conrad, Elizabeth A; May, Thomas H (Tom);

'aemconsult1@aol.com'

Subject: FW: CSSX flow sheet calculations

We have a slight problem, as noted by Joe below.

I think we should settle on the BOBCalixC6 conditions shown in either line 14 (CF 5) or 16 (CF 2) for simulant 6 (worst-case feed). Line 14 requires 41 actual contactors and line 16 requires 34 actual contactors, excluding solvent cleanup stages.

If we use either of these process conditions, we are definitely going to need an evaporation step to concentrate the cesium strip stream. For example, line 16 indicates the cesium strip flowrate is 0.5 times the LAW feed flowrate and the scrub flowrate is $\sim 0.22$ times the LAW feed flowrate. In other words, 1 gallon of LAW feed comes into the CSSX process and 0.72 gallons of dilute nitric acid (neutralized) goes out. The conditions for line 14 are somewhat better; strip and scrub flowrates are 0.2 and 0.14 times the LAW feed flowrate.

Let talk about this on Monday.

Mike

-----Original Message-----

From: Birdwell Jr, Joseph F. [mailto:birdwelljfjr@ornl.gov]

Sent: Friday, May 16, 2008 12:30 PM

To: Johnson, Michael E

Cc: Moyer, Bruce A.

Subject: CSSX flow sheet calculations

Mike,

I need to ask you to review the flow sheet results again. Bruce pointed out an inconsistency between $\mathrm{CF}$ and phase ratios in my previous results.

It is not possible to achieve a CF of 15 , for example, when then feed-to-strip flow ratio is $1: 1$. An overspecification of phase ratios in my previous code revision made this possible. I have made tne necessary correction and rerun all cases. Please review them.

After running all combinations to determine minimum stage requirements, I 
sorted the results for extreme phase ratios--values that are on the edge of demonstrated contactor operation. (I did bound the minimum stage criteria somewhat; I did not use optimum stage number results when this involved O:A ratios greater than 1.5 because of the loss of beneficial throughput.) Where high phase ratios existed, I adjusted the parameters to bring conditions into more comfortable ranges. This generally resulted in slight increases in stage requirements (generally one or two). These rerun cases are at the bottom of the worksheet.

Please review the revised results and advise as to new CF or DF bounds. When I sort the data by the total number of sctual stages it appears that a $\mathrm{CF}$ of 15 using $\mathrm{BOB}$ is not feasible, based on stage requirements.

I apologize for the confusion I created.

Joseph F. Birdwell, PhD

Nuclear Science and Technology Division

Oak Ridge National Laboratory

Oak Ridge TN 37831-6243

ph: 865.574 .6627

fax: 865.574.6872

e-mail: birdwelljfjr@ornl.gov 
RPP-RPT-37551, Rev. 1

\begin{tabular}{|c|c|c|c|c|c|c|c|c|c|c|c|c|c|c|c|c|c|c|}
\hline Solvent & Simulant & CF & DF & $\begin{array}{l}\text { Solvent-to- } \\
\text { Feed } \\
\text { Ratio }\end{array}$ & $\begin{array}{l}\text { Solvent-to- } \\
\text { Scrub } \\
\text { Ratio }\end{array}$ & & $\begin{array}{l}\text { Solvent-to- } \\
\text { Strip } \\
\text { Ratio }\end{array}$ & $\begin{array}{l}\text { Theor. } \\
\text { Extraction } \\
\text { Stages }\end{array}$ & $\begin{array}{l}\text { Theor. } \\
\text { Stripping } \\
\text { Stages }\end{array}$ & $\begin{array}{l}\text { Actual } \\
\text { Extraction } \\
\text { Stages }\end{array}$ & $\begin{array}{l}\text { Actual } \\
\text { Stripping } \\
\text { Stages }\end{array}$ & $\begin{array}{l}\text { Stage } \\
\text { Efficiency } \\
\%\end{array}$ & $\begin{array}{l}\text { Scrubbing } \\
\text { Stages }\end{array}$ & $\begin{array}{l}\text { Total } \\
\text { Actual } \\
\text { Stages }\end{array}$ & $\begin{array}{l}\text { Total } \\
\text { Extraction } \\
\text { Flow }\end{array}$ & $\begin{array}{l}\text { Total } \\
\text { Scrub } \\
\text { Flow }\end{array}$ & $\begin{array}{l}\text { Total } \\
\text { Strip } \\
\text { Flow }\end{array}$ & $O: A=$ \\
\hline $\mathrm{BOB}$ & 3 & 2 & 5000 & 0.9 & & 5 & 1.8 & 9 & 13 & 11 & 16 & 80 & 4 & 31 & 2.08 & 1.08 & 1.4 & no \\
\hline ВOВ & 3 & 5 & 5000 & 0.65 & & 5 & 3.25 & 11 & 18 & 14 & 22 & 80 & 4 & 40 & 1.78 & 0.78 & 0.85 & no \\
\hline BOB & 3 & 15 & 5000 & 0.45 & & 5 & 6.75 & 18 & 34 & 23 & 43 & 80 & 4 & 70 & 1.54 & 0.54 & 0.516666667 & no \\
\hline BOB & 3 & 2 & 40000 & 1 & & 5 & 2 & 10 & 13 & 13 & 16 & 80 & 4 & 33 & 2.2 & 1.2 & 1.5 & no \\
\hline BOB & 3 & 5 & 40000 & 0.7 & & 5 & 3.5 & 13 & 18 & 16 & 23 & 80 & 4 & 43 & 1.84 & 0.84 & 0.9 & no \\
\hline BOB & 3 & 15 & 40000 & 0.45 & & 5 & 6.75 & 23 & 34 & 29 & 43 & 80 & 4 & 76 & 1.54 & 0.54 & 0.516666667 & no \\
\hline ВOВ & 6 & 2 & 5000 & 0.95 & & 5 & 1.9 & 9 & 13 & 11 & 16 & 80 & 4 & 31 & 2.14 & 1.14 & 1.45 & no \\
\hline вОВ & 6 & 5 & 5000 & 0.7 & & 5 & 3.5 & 12 & 18 & 14 & 23 & 80 & 4 & 41 & 1.84 & 0.84 & 0.9 & 10 \\
\hline ВОВ & 6 & 15 & 5000 & 0.45 & & 5 & 6.75 & 22 & 34 & 27 & 43 & 80 & 4 & 74 & 1.54 & 0.54 & 0.516666667 & no \\
\hline ВОВ & 6 & 2 & 40000 & 1.1 & & 5 & 2.2 & 10 & 14 & 13 & 17 & 80 & 4 & 34 & 2.32 & 1.32 & 1.6 & 10 \\
\hline ВОВ & 6 & 5 & 40000 & 0.75 & & 5 & 3.75 & 14 & 19 & 17 & 24 & 80 & 4 & 45 & 1.9 & 0.9 & 0.95 & no \\
\hline BOB & 6 & 15 & 40000 & 0.47 & & 5 & 7.05 & 25 & 36 & 32 & 45 & 80 & 4 & 81 & 1.564 & 0.564 & 0.536666667 & yes \\
\hline вов & 7 & $\begin{array}{l}2 \\
5\end{array}$ & 5000 & 0.65 & & 5 & 1.3 & 8 & 12 & 9 & 15 & 80 & 4 & 28 & 1.78 & 0.78 & 1.15 & no \\
\hline $\begin{array}{l}\text { BOB } \\
\text { BOB }\end{array}$ & 7 & $\begin{array}{r}5 \\
15\end{array}$ & $\begin{array}{l}5000 \\
5000\end{array}$ & $\begin{array}{l}0.47 \\
0.31\end{array}$ & & $\begin{array}{r}5 \\
5\end{array}$ & $\begin{array}{l}2.35 \\
4.65\end{array}$ & $\begin{array}{l}10 \\
16\end{array}$ & $\begin{array}{l}16 \\
27\end{array}$ & 12 & 20 & $\begin{array}{l}80 \\
80\end{array}$ & $\begin{array}{l}4 \\
4\end{array}$ & $\begin{array}{l}36 \\
57\end{array}$ & $\begin{array}{l}1.564 \\
1372\end{array}$ & $\begin{array}{l}0.564 \\
0.372\end{array}$ & $\begin{array}{r}0.67 \\
0.37666667\end{array}$ & no \\
\hline BOB & 7 & 2 & 40000 & 0.75 & & 5 & 1.5 & 9 & 12 & 11 & 15 & 80 & 4 & 30 & 1.9 & 0.9 & 1.25 & no \\
\hline BOB & 7 & 5 & 40000 & 0.5 & & 5 & 2.5 & 12 & 16 & 14 & 20 & 80 & 4 & 38 & 1.6 & 0.6 & 0.7 & no \\
\hline BOB & 7 & 15 & 40000 & 0.33 & & 5 & 4.95 & 18 & 28 & 23 & 35 & 80 & 4 & 62 & 1.396 & 0.396 & 0.396666667 & no \\
\hline BOB & 8 & 2 & 5000 & 0.5 & & 5 & 1 & 7 & 10 & 9 & 13 & 80 & 4 & 26 & 1.6 & 0.6 & 1 & no \\
\hline BOB & 8 & 5 & 5000 & 0.4 & & 5 & 2 & 8 & 14 & 10 & 17 & 80 & 4 & 31 & 1.48 & 0.48 & 0.6 & no \\
\hline BOB & 8 & 15 & 5000 & 0.25 & & 5 & 3.75 & 12 & 20 & 15 & 25 & 80 & 4 & 44 & 1.3 & 0.3 & 0.316666667 & no \\
\hline ВОВ & 8 & 2 & 40000 & 0.65 & & 5 & 1.3 & 7 & 11 & 9 & 14 & 80 & 4 & 27 & 1.78 & 0.78 & 1.15 & no \\
\hline ВОВ & 8 & 5 & 40000 & 0.43 & & 5 & 2.15 & 9 & 14 & 12 & 18 & 80 & 4 & 34 & 1.516 & 0.516 & 0.63 & no \\
\hline ВОВ & 8 & 15 & 40000 & 0.27 & & 5 & 4.05 & 14 & 21 & 18 & 26 & 80 & 4 & 48 & 1.324 & 0.324 & 0.336666667 & no \\
\hline BEHB & 3 & 2 & 5000 & 1.25 & & 5 & 2.5 & 4 & 5 & 5 & 3 & 80 & 4 & 12 & 2.5 & 1.5 & 1.75 & no \\
\hline BEHB & 3 & 5 & 5000 & 0.75 & & 5 & 3.75 & 5 & 5 & 6 & 6 & 80 & 4 & 16 & 1.9 & 0.9 & 0.95 & no \\
\hline BEHB & 3 & 15 & 5000 & 0.6 & & 5 & 9 & 5 & 6 & 6 & 7 & 80 & 4 & 17 & 1.72 & 0.72 & 0.666666667 & yes \\
\hline BEHB & 3 & 2 & 40000 & 0.8 & & 5 & 1.6 & 6 & 4 & 7 & 5 & 80 & 4 & 16 & 1.96 & 0.96 & 1.3 & no \\
\hline BEHB & 3 & 5 & 40000 & 1 & & 5 & 5 & 5 & 5 & 6 & 6 & 80 & 4 & 16 & 2.2 & 1.2 & 1.2 & no \\
\hline BEHB & 3 & 15 & 40000 & 1 & & 5 & 15 & 5 & 6 & 6 & 8 & 80 & 4 & 18 & 2.2 & 1.2 & 1.066666667 & yes \\
\hline BEHB & 6 & 2 & 5000 & 1.25 & & 5 & 2.5 & 4 & 5 & 5 & 6 & 80 & 4 & 15 & 2.5 & 1.5 & 1.75 & no \\
\hline BEHB & 6 & 5 & 5000 & 0.75 & & 5 & 3.75 & 5 & 5 & 6 & 6 & 80 & 4 & 16 & 1.9 & 0.9 & 0.95 & no \\
\hline BEHB & 6 & 15 & 5000 & 0.6 & & 5 & 9 & 6 & 6 & 7 & 7 & 80 & 4 & 18 & 1.72 & 0.72 & 0.666666667 & yes \\
\hline BEHB & 6 & 2 & 40000 & 0.8 & & 5 & 1.6 & 6 & 4 & 8 & 5 & 80 & 4 & 17 & 1.96 & 0.96 & 1.3 & no \\
\hline BEHB & 6 & 5 & 40000 & 1 & & 5 & 5 & 6 & 5 & 7 & 6 & 80 & 4 & 17 & 2.2 & 1.2 & 1.2 & no \\
\hline BEHB & 6 & 15 & 40000 & 0.7 & & 5 & 10.5 & 7 & 6 & 8 & 7 & 80 & 4 & 19 & 1.84 & 0.84 & 0.766666667 & yes \\
\hline BEHB & 7 & 2 & 5000 & 1.25 & & 5 & 2.5 & 4 & 5 & 4 & 6 & 80 & 4 & 14 & 2.5 & 1.5 & 1.75 & no \\
\hline BEHB & 7 & 5 & 5000 & 0.7 & & 5 & 3.5 & 4 & 6 & 5 & 7 & 80 & 4 & 16 & 1.84 & 0.84 & 0.9 & no \\
\hline BEHB & 7 & 15 & 5000 & 0.6 & & 5 & 9 & 4 & 7 & 5 & 8 & 80 & 4 & 17 & 1.72 & 0.72 & 0.666666667 & yes \\
\hline BEHB & 7 & 2 & 40000 & 0.7 & & 5 & 1.4 & 5 & 5 & 6 & 6 & 80 & 4 & 16 & 1.84 & 0.84 & 1.2 & no \\
\hline BEHB & 7 & 5 & 40000 & 0.7 & & 5 & 3.5 & 5 & 6 & 6 & 7 & 80 & 4 & 17 & 1.84 & 0.84 & 0.9 & no \\
\hline BEHB & 7 & 15 & 40000 & 0.6 & & 5 & 3 & 5 & 7 & 7 & 8 & 80 & 4 & 19 & 1.72 & 0.72 & 0.8 & no \\
\hline BEHB & 8 & 2 & 5000 & 0.75 & & 5 & 1.5 & 4 & 4 & 4 & 5 & 80 & 4 & 13 & 1.9 & 0.9 & 1.25 & no \\
\hline BEHB & 8 & 5 & 5000 & 0.75 & & 5 & 3.75 & 4 & 5 & 4 & 6 & 80 & 4 & 14 & 1.9 & 0.9 & 0.95 & no \\
\hline BEHB & 8 & 15 & 5000 & 0.7 & & 5 & 10.5 & 4 & 6 & 4 & 7 & 80 & 4 & 15 & 1.84 & 0.84 & 0.766666667 & yes \\
\hline BEHB & 8 & 2 & 40000 & 0.6 & & 5 & 1.2 & 5 & 4 & 6 & 5 & 80 & 4 & 15 & 1.72 & 0.72 & 1.1 & no \\
\hline BEHB & 8 & 5 & 40000 & 0.75 & & 5 & 3.75 & 4 & 5 & 5 & 6 & 80 & 4 & 15 & 1.9 & 0.9 & 0.95 & no \\
\hline BEHB & 8 & 15 & 40000 & 0.6 & & 5 & 9 & 5 & 6 & 6 & 7 & 80 & 4 & 17 & 1.72 & 0.72 & 0.6666666667 & yes \\
\hline
\end{tabular}







May, T. H., 2008-05-09, "FW: Data Disk," (e-mail to G. E. Stegen), CH2M HILL Hanford Group, Inc., Richland, Washington

Gary,

Please use the files listed below and provided on a $C D$, as the basis for your calculations.

Tom May

From: GENIESSE Donald (AFS) [mailto:donald.geniesse@areva.com]

Sent: Monday, May 05, 2008 10:42 AM

To: May, Thomas H (Tom)

Cc: Gary Stegen; Nelson, Eric A

Subject: Data Disk

Tom,

I have created a $\mathrm{CD}$ containing the following files:

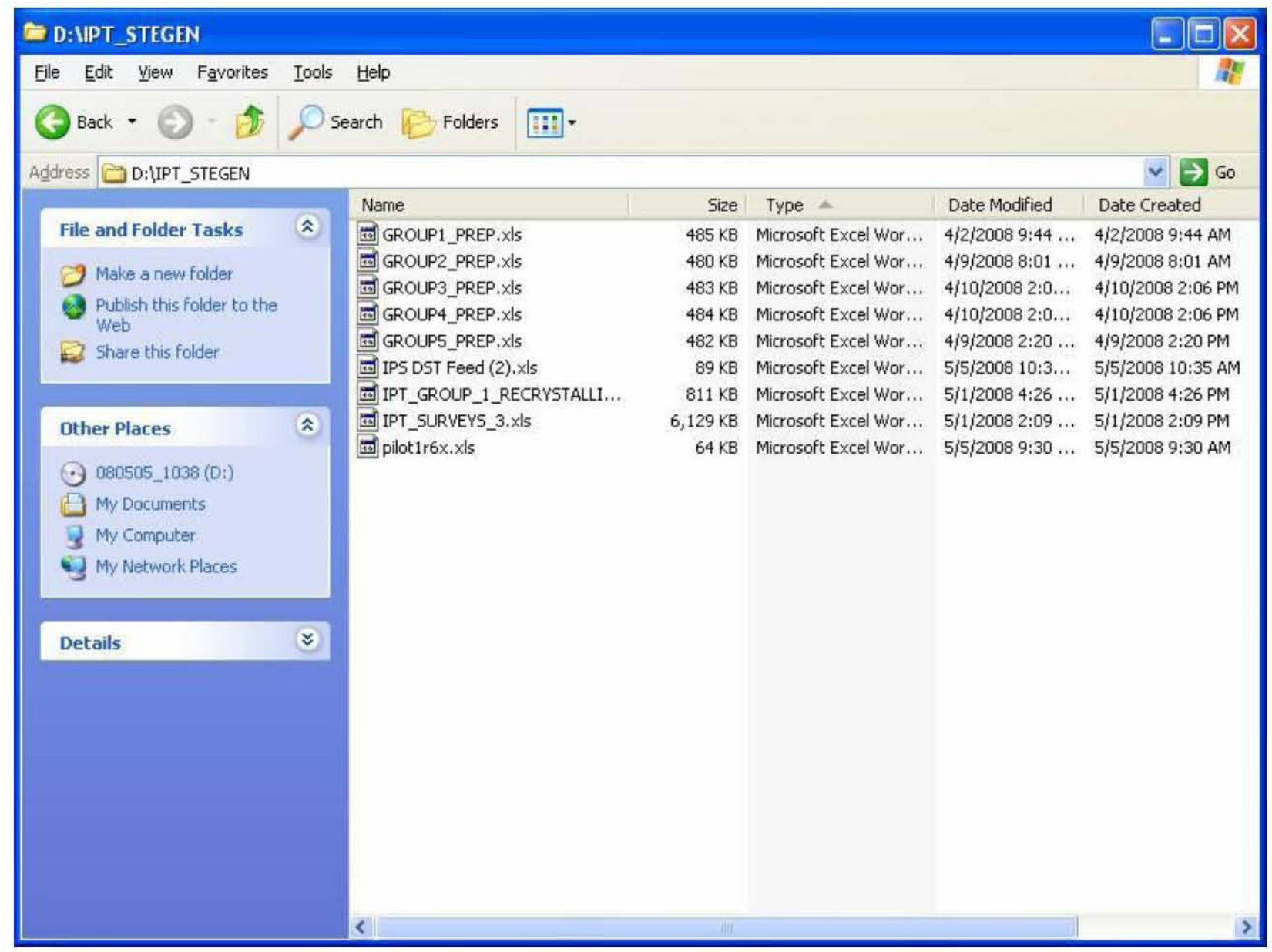

Please advise me how you would like it delivered.

Don Geniesse 
RPP-RPT-37551, Rev. 1

From: May, Thomas H (Tom) [mailto:Thomas_H_Tom_May@RL.gov]

Sent: Monday, May 05, 2008 9:17 AM

To: GENIESSE Donald (AFS)

Cc: Conrad, Elizabeth A

Subject: RE:

Don,

Thanks for these models. Can I get the raw output from you model so that I can track the data between you model and the spreadsheets you gave to Stegan?

Any futher progress on the last data dump for Stegan?

Thanks

Tom May

From: GENIESSE Donald (AFS) [mailto:donald.geniesse@areva.com]

Sent: Monday, April 28, 2008 4:32 PM

To: May, Thomas H (Tom)

Subject: RE:

Let me know if you don't get them this time.

From: May, Thomas H (Tom) [mailto:Thomas_H_Tom_May@RL.gov]

Sent: Monday, April 28, 2008 3:44 PM

To: GENIESSE Donald (AFS)

Subject: RE:

Don,

I did not get the attachments.

Tom

From: GENIESSE Donald (AFS) [mailto:donald.geniesse@areva.com]

Sent: Monday, April 28, 2008 3:09 PM

To: May, Thomas H (Tom)

Cc: Gary Stegen; Nelson, Eric A

Subject: RE:

Tom,

Attached are files IPT_PILOT_GROUP_1_FLOWSHEET.xIs and

RECRYSTALLIZATION_FLOW'WSEET 26 .x. 
RPP-RPT-37551, Rev. 1

diagrams of two fractional crystallization processes. The mass balances were developed using ESP thermodynamic modeling software.

The IPT_PILOT.. file is based upon $1.5 \mathrm{gpm}$ of GROUP 1 (DST) feed to a single stage crystallizer (i.e. SRS Pilot Unit). Theoretical Na yield is $65.7 \%$ and CS DF is 117 .

RECRYSTALLIZATION_FLOWSHEET26.xIs is based upon $5 \mathrm{gpm} 6.4 \mathrm{M}$ Na product using SST simulant chemistry in a two stage recrystallization process. Theoretical Na yield is $68 \%$ and CS DF is 5,257 .

I am developing a two-stage recrystallization process flowsheet for GROUP 1 DST feed that will have similar theoretical Na yield $(\sim 65 \%)$ and Cs DF $(\sim 5,000)$ as the two stage SST flowsheet.

Don Geniesse

$372-8232$ 
RPP-RPT-37551, Rev. 1

APPENDIX B

SVF-1513 OUTPUT 
RPP-RPT-37551, Rev. 1

Table B-1 Summary Comparison

\begin{tabular}{|c|c|c|c|c|c|c|c|c|}
\hline \multicolumn{8}{|c|}{ raore B-1 summary Comparison } & \multirow{2}{*}{ Selected primary disciminators in rose. } \\
\hline \multirow{2}{*}{\multicolumn{2}{|c|}{ Percent High Sulfate Stream Returned to TF: }} & No IPS & $\mathrm{IX}$ & $\overline{F C} \_A$ & $\overline{\mathrm{FC} \mathrm{C}_{-} \mathrm{B}}$ & $\mathrm{FC}_{-} \mathrm{C}$ & $\operatorname{css} x$ & \\
\hline & & & $\mathbf{L}$ & $0 \%$ & $11 \%$ & $100 \%$ & & Commentary \\
\hline \multirow{3}{*}{$\begin{array}{l}\text { Net Waste Processed } \\
\text { (Change to DSTs) }\end{array}$} & MT Na & 0 & 3,843 & 4,736 & 4,898 & 5,534 & 3,885 & \multirow{3}{*}{$\begin{array}{l}\text { For a fixed amount of LAW glass product from pretreated IPS } \\
\text { feed, the FC variants process more waste than IX and CSSX. }\end{array}$} \\
\hline & MT SO4 & 0 & 123 & 327 & 298 & 0 & 124 & \\
\hline & MT Al & 0 & 363 & 0 & 0 & 0 & 363 & \\
\hline \multirow{5}{*}{ SO4:Na Mass Ratio } & All LAW & 0.0643 & L & L & & L & & \multirow{5}{*}{$\begin{array}{l}\text { Average waste produced glass near } \mathrm{SO} 3 \text { limit. Any change in } \\
\text { SO4:Na distribution can increase glass, unless the enriched } \\
\text { stream reports to a more sulfate tolerant process. The selected } \\
\text { IPS feed is lean in } \mathrm{SO} 4 \text { relative to Na. FC_C significantly } \\
\text { increases the SO4:Na ratio for "Other" LAWW. }\end{array}$} \\
\hline & Selected IPS Feed & & 0.0317 & 0.0310 & 0.0311 & 0.0313 & 0.0317 & \\
\hline & "IPS" LAW & & 0.0217 & 0.0687 & 0.0590 & 0.0000 & 0.0217 & \\
\hline & "Other" LAW & & 0.0667 & 0.0638 & 0.0646 & 0.0714 & 0.0667 & \\
\hline & Glass Limit & 0.0647 & 0.0647 & 0.0647 & 0.0647 & 0.0647 & 0.0647 & \\
\hline \multirow{3}{*}{ LAW Glass, MTG } & Total & 376,327 & 399,413 & 382,828 & 381,699 & 412,266 & 399,383 & \multirow{3}{*}{$\begin{array}{l}\text { Glass from IPS is held constant ( } 5 \text { years vitrification). Total LAW } \\
\text { glass increases due to both additional Na added by IPS and by } \\
\text { slightly reduced Na2O loading due to sulfate redistribution. } \\
\text { Sulfate returns from FC_B set to yield minimum total LAW glass. }\end{array}$} \\
\hline & From IPS & & 38,352 & 38,421 & 38,381 & 38,349 & 38,351 & \\
\hline & From Other & & 361,060 & 344,407 & 343,318 & 373,917 & 361,032 & \\
\hline \multirow{3}{*}{$\begin{array}{l}\text { Excess LAW Glass, } \\
\text { MTG }\end{array}$} & Total & 0 & 10,637 & 6,381 & 4,316 & 34,887 & 10,889 & $\begin{array}{l}\text { For FC, returning sulfate stream to the DSTs changes the total } \\
\text { amount of excess glass. }\end{array}$ \\
\hline & From IPS & & 0 & 6,381 & 4,316 & 0 & 0 & $\begin{array}{l}\text { Excess glass from IPS feed due to sulfate at the assumed glass } \\
\text { loading limits. }\end{array}$ \\
\hline & From Other & 0 & 10,637 & 0 & 0 & 34,887 & 10,889 & $\begin{array}{l}\text { Excess glass in remaining feed due to sulfate at the assumed } \\
\text { glass loading limits. }\end{array}$ \\
\hline \multirow{6}{*}{ Al:Na Mass Ratio } & & & & & & & & \\
\hline & All LAW & 0.1 & & & L & & 드. & \multirow{5}{*}{$\begin{array}{l}\text { Selected IPS feed is lean in Al relative to Na. } \\
\text { If AI (or SO4, for that matter) is returned to the DSTs in the solid } \\
\text { phase, may affect WTP UPF system througput and leach } \\
\text { hydroxide demands - NOT EVALUATED }\end{array}$} \\
\hline & Selected IPS Feed & & 0.093 & 0.115 & 0.114 & 0.108 & 0.093 & \\
\hline & "IPS" LAW & & & E & & L & & \\
\hline & "Other" LAW & & 0.117 & 0.126 & 0.126 & 0.128 & 0.117 & \\
\hline & All Waste & 0.146 & 0.150 & 0.159 & 0.160 & 0.161 & 0.150 & \\
\hline \multirow{3}{*}{$\begin{array}{l}\text { Time to Process } \\
\text { Selected Feed } \\
\text { (Years) }\end{array}$} & Pretreatment (IPS) & & 4.84 & 4.04 & 4.30 & 4.84 & 4.84 & \multirow{3}{*}{$\begin{array}{l}\text { The assumed WTP LAW Vit capacity and glass model is } \\
\text { approximately matched to the assumed IPS pretreatment rates } \\
\text { for IX and CSSX and the FC_C variants. There is a benefical } \\
\text { mismatch in duration for the FC_A and FC_B variants - there is } \\
\text { slightly more IPS capacity than needed. }\end{array}$} \\
\hline & Vitrification & & 5.00 & 5.01 & 5.00 & 5.00 & 5.00 & \\
\hline & Time Ratio, Vit:Pretreat & & 1.03 & 1.24 & 1.16 & 1.03 & 1.03 & \\
\hline
\end{tabular}

Enabling Assumptions:

All LAW glass subject to "DOE Model" for determining Na2O loading.

Feed to IPS is adjusted so that each alternative produces enough pretreated LAW to run the WTP LAW Facility for 5 years.

See "Constants \& Inputs" for other assumptions.

Total LAW sodium mass assumes 3M hydroxide endpoint (60,000 MT Na, NOT 90,000 MT Na)

Additional leach sodium may reduce importance of and impacts from the sulfate redistribution. Improved LAW glass models may reduce importance of and impacts from sulfate redistirbution. 
Table B-2 Constants and Inputs



\begin{tabular}{|c|c|c|}
\hline Species & $\begin{array}{l}\text { mw } \\
\text { g per g-mole }\end{array}$ & range name \\
\hline $\mathrm{Na}$ & 22.98977 & $\mathrm{mw} \mathrm{Na}$ \\
\hline 0 & 15.9994 & mw_o \\
\hline$S$ & 32.065 & mw_s \\
\hline $\mathrm{Al}$ & 26.981538 & Mw_Al \\
\hline $\mathrm{H}$ & 1.00794 & mw_H \\
\hline $\mathrm{Na} 2 \mathrm{O}$ & 61.97894 & $\mathrm{mw}^{-} \mathrm{Na} 2 \mathrm{O}$ \\
\hline $\mathrm{SO} 4$ & 96.0626 & mw_SO4 \\
\hline $\mathrm{SO} 3$ & 80.0632 & mw_SO3 \\
\hline $\mathrm{Al}(\mathrm{OH}) 4$ & 95.010898 & mw_Al_OH_4 \\
\hline $\mathrm{Al} 2 \mathrm{O} 3$ & 101.961276 & mw_Al 203 \\
\hline $\mathrm{Kg} / \mathrm{MT}$ & 1000 & kg_per_mt \\
\hline $\begin{array}{l}\text { hr/day } \\
\text { days/year }\end{array}$ & $\begin{array}{r}24 \\
365.24\end{array}$ & $\begin{array}{l}\text { hr_per_d } \\
\text { d_per_yr }\end{array}$ \\
\hline $\mathrm{MTG} / \mathrm{d}$ & 21 & MTG_per_day \\
\hline
\end{tabular}

\begin{tabular}{lrl}
\multicolumn{2}{c}{ DOE LAW Glass Model } \\
Maximum (wt $\%)$ & range name \\
$\mathrm{Na} 2 \mathrm{O}$ & $20.00 \%$ & max_Na2O_DOE \\
$\mathrm{SO} 3$ & $0.80 \%$ & max_SO3_DOE
\end{tabular}

Total starting mass in vitrification facility feed, non-GFC source, MT

LAW SO4

LAW Na

LAW AI

HLW SO4

HLW Na

HLW Al

HLW Solids

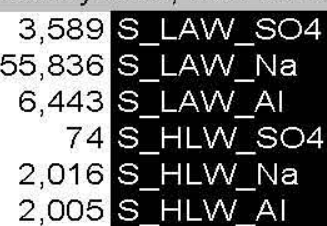

3,589 S_LAW_SO4

55,836 S_LAW_Na

6,443 S LAW AI

74 S_HLW_SO4

2,016 S_HLW_Na

2,005 S HLW A

18,624 S_HLW_Solids 
Table B-3 Ion Exchange 5 Year Mission



\begin{tabular}{|c|c|c|c|c|c|c|c|c|c|c|c|}
\hline \multirow{2}{*}{$\begin{array}{l}\text { Batch } \\
\text { Order }\end{array}$} & \multirow[b]{2}{*}{$\begin{array}{c}\begin{array}{c}\text { Fraction of } \\
\text { Batch }\end{array} \\
\text { Bats }\end{array}$} & \multirow[b]{2}{*}{$\begin{array}{c}\text { Waste Feed } \\
\text { Batch }\end{array}$} & \multicolumn{3}{|c|}{ Removed from DSTs (Stream 3) } & \multicolumn{3}{|c|}{ Returned to DSTs (Stream 11) } & \multicolumn{3}{|c|}{ Net Change to DSTs } \\
\hline & & & MT Na & MT SO4 & MTAl & MT Na & MT SO4 & MT Al & MT Na & MT SO4 & MT Al \\
\hline 8 & $0 \%$ & AN-104 & 0 & 0 & 0 & 0 & 0 & 0 & $\overline{0}$ & 0 & 0 \\
\hline 3 & $100 \%$ & AP-101 & 827 & 43 & 48 & 23 & 1 & 1 & -803 & -43 & -48 \\
\hline 2 & $100 \%$ & AP-102 & 740 & 11 & 92 & 18 & 0 & 1 & -722 & -10 & -91 \\
\hline 4 & $100 \%$ & AP-103 & 827 & 24 & 91 & 16 & 0 & 1 & -811 & -24 & -90 \\
\hline 1 & $100 \%$ & AP-104 & 734 & 23 & 62 & 16 & 0 & 1 & -718 & -23 & -61 \\
\hline 5 & $100 \%$ & AP-105 & 807 & 24 & 74 & 18 & 0 & 1 & -788 & -24 & -74 \\
\hline 7 & $0 \%$ & AP-107 & 0 & 0 & 0 & 0 & 0 & 0 & 0 & 0 & 0 \\
\hline 6 & $3 \%$ & AP-108 & 1 & 0 & 0 & 0 & 0 & 0 & -1 & 0 & 0 \\
\hline 9 & & AN-105 & & & & & & & & & \\
\hline 10 & & AN-103 & & & & & & & & & \\
\hline 11 & & AW-101 & & & & & & & & & \\
\hline 12 & & AW-104 & & & & & & & & & \\
\hline 13 & & AP-106 & & & & & & & & & \\
\hline 14 & & SY-101 & & & & & & & & & \\
\hline 15 & & S-109 & & & & & & & & & \\
\hline \multirow[t]{2}{*}{16} & & S-109 Eq & & & & & & & & & \\
\hline & & Total & 3,934 & 125 & 367 & 91 & 1 & 4 & $-3,843$ & -123 & -363 \\
\hline
\end{tabular}

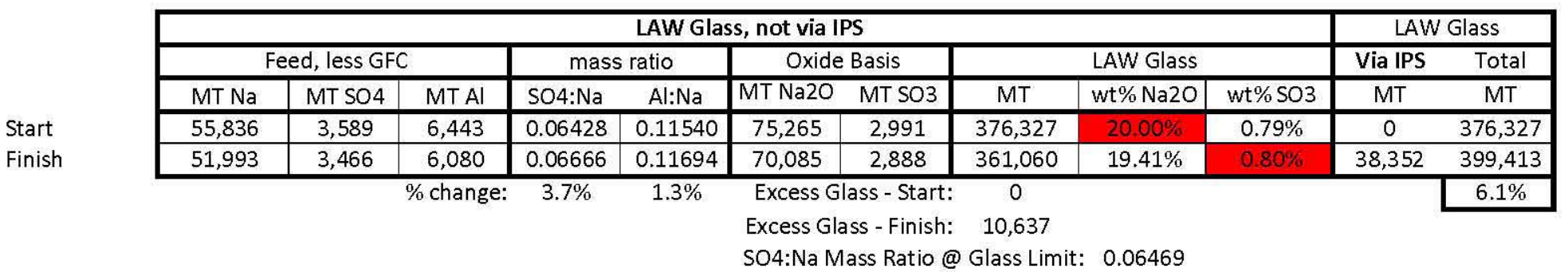

HLW

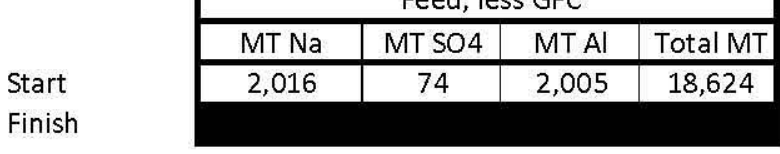


Table B-4 Fractional Crystallization 5 Year Mission with No Sulfate Recycle to Tank Farms

\begin{tabular}{|c|c|c|c|c|c|c|c|c|c|c|c|c|c|c|}
\hline \multirow[b]{3}{*}{$\begin{array}{l}\text { Batch } \\
\text { Order }\end{array}$} & \multirow[b]{3}{*}{$\begin{array}{c}\begin{array}{c}\text { Fraction of } \\
\text { Batch }\end{array} \\
\end{array}$} & \multicolumn{5}{|c|}{ Route this $\%$ of High Sulfate Stream to Tank Farms: } & \multirow{2}{*}{$\frac{0.0 \%}{29)}$} & \multirow{2}{*}{\multicolumn{5}{|c|}{\begin{tabular}{|c|c|}
\multicolumn{2}{|c|}{ LAW Processed by WTP LAW Vit from IPS } \\
Oxide Basis & LAW Glass \\
\end{tabular}}} & \multirow{2}{*}{\multicolumn{2}{|c|}{ Time }} \\
\hline & & & \multicolumn{4}{|c|}{ LAW Product Produced by IPS (Stream 29) } & & & & & & & & \\
\hline & & $\begin{array}{c}\text { Waste Feed } \\
\text { Batch }\end{array}$ & MT Na & MT SO 4 & MT Al & Hours & $\begin{array}{c}\text { Calendar } \\
\text { Years }\end{array}$ & MT Na2O & MT SO3 & MT & wt $\% \mathrm{Na} 2 \mathrm{O}$ & wt $\% \mathrm{SO} 3$ & $\begin{array}{c}\text { Calendar } \\
\text { Hours }\end{array}$ & $\begin{array}{c}\text { Calendar } \\
\text { Years }\end{array}$ \\
\hline 8 & $100 \%$ & AN-104 & 270 & 24 & 0 & 1,411 & 0.23 & 364 & 20 & 2,516 & $14.48 \%$ & $0.80 \%$ & 2,875 & 0.33 \\
\hline 3 & $100 \%$ & AP-101 & 516 & 43 & 0 & 2,693 & 0.44 & 696 & 36 & 4,507 & $15.43 \%$ & $0.80 \%$ & 5,151 & 0.59 \\
\hline 2 & $100 \%$ & AP-102 & 313 & 10 & 0 & 1,636 & 0.27 & 422 & 9 & 2,112 & $20.00 \%$ & $0.41 \%$ & 2,414 & 0.28 \\
\hline 4 & $100 \%$ & AP-103 & 413 & 24 & 0 & 2,155 & 0.35 & 557 & 20 & 2,783 & $20.00 \%$ & $0.72 \%$ & 3,180 & 0.36 \\
\hline 1 & $100 \%$ & AP-104 & 370 & 23 & 0 & 1,929 & 0.31 & 498 & 19 & 2,491 & $20.00 \%$ & $0.76 \%$ & 2,846 & 0.32 \\
\hline 5 & $100 \%$ & AP-105 & 369 & 24 & 0 & 1,927 & 0.31 & 498 & 20 & 2,503 & $19.89 \%$ & $0.80 \%$ & 2,860 & 0.33 \\
\hline 7 & $100 \%$ & AP-107 & 483 & 65 & 0 & 2,518 & 0.41 & 650 & 54 & 6,766 & $9.61 \%$ & $0.80 \%$ & 7,732 & 0.88 \\
\hline 6 & $100 \%$ & AP-108 & 408 & 20 & 0 & 2,127 & 0.35 & 549 & 17 & 2,747 & $20.00 \%$ & $0.62 \%$ & 3,139 & 0.36 \\
\hline 9 & $100 \%$ & AN-105 & 315 & 21 & 0 & 1,646 & 0.27 & 425 & 17 & 2,150 & $19.78 \%$ & $0.80 \%$ & 2,457 & 0.28 \\
\hline 10 & $100 \%$ & AN-103 & 318 & 12 & 0 & 1,661 & 0.27 & 429 & 10 & 2,145 & $20.00 \%$ & $0.46 \%$ & 2,451 & 0.28 \\
\hline 11 & $100 \%$ & AW-101 & 362 & 11 & 0 & 1,888 & 0.31 & 488 & 9 & 2,438 & $20.00 \%$ & $0.37 \%$ & 2,786 & 0.32 \\
\hline 12 & $100 \%$ & AW-104 & 339 & 31 & 0 & 1,767 & 0.29 & 456 & 26 & 3,192 & $14.30 \%$ & $0.80 \%$ & 3,648 & 0.42 \\
\hline 13 & $100 \%$ & AP-106 & 218 & 16 & 0 & 1,140 & 0.19 & 294 & 13 & 1,670 & $17.63 \%$ & $0.80 \%$ & 1,908 & 0.22 \\
\hline 14 & $70 \%$ & SY-101 & 60 & 3 & 0 & 312 & 0.05 & 81 & 3 & 403 & $20.00 \%$ & $0.66 \%$ & 461 & 0.05 \\
\hline 15 & $0 \%$ & S-109 & 0 & 0 & 0 & 0 & 0.00 & 0 & 0 & 0 & \#DIV/O! & \#DIV/0! & 0 & 0.00 \\
\hline \multirow[t]{4}{*}{16} & $0 \%$ & S-109 Eq & 0 & 0 & 0 & 0 & 0.00 & 0 & 0 & 0 & \#DIV/O! & \#DIV/0! & 0 & 0.00 \\
\hline & & Total & 4,754 & 327 & 0 & 24,809 & 4.04 & 6,408 & 272 & 38,421 & $16.68 \%$ & $0.71 \%$ & 43,909 & 5.01 \\
\hline & & & & & & & & & cess Glas & 6,381 & & & & \\
\hline & & Aver & Rate, I & $\mathrm{T} \mathrm{Na} /$ & 1,176 & & & & & & \multicolumn{3}{|r|}{$\mathrm{Na} / \mathrm{Yr}$} & 949 \\
\hline
\end{tabular}

\begin{tabular}{|c|c|c|c|c|c|c|c|c|c|c|c|}
\hline \multirow[b]{2}{*}{$\begin{array}{l}\text { Batch } \\
\text { Order }\end{array}$} & \multirow[b]{2}{*}{$\begin{array}{c}\text { Fraction of } \\
\text { Batch } \\
\end{array}$} & \multirow[b]{2}{*}{$\begin{array}{c}\text { Waste Feed } \\
\text { Batch }\end{array}$} & \multicolumn{3}{|c|}{ Removed from DSTs (Stream 3) } & \multicolumn{3}{|c|}{ Returned to DSTs (Stream 14) } & \multicolumn{3}{|c|}{ Net Change to DSTs } \\
\hline & & & $\mathrm{MT} \mathrm{Na}$ & MT SO4 & MT Al & $\mathrm{MT} \mathrm{Na}$ & MT SO4 & MT Al & MT Na & MT SO4 & MT Al \\
\hline 8 & $100 \%$ & AN-104 & 763 & 24 & 97 & 493 & 0 & 97 & -270 & -24 & 0 \\
\hline 3 & $100 \%$ & AP-101 & 827 & 43 & 48 & 311 & 0 & 48 & -516 & -43 & 0 \\
\hline 2 & $100 \%$ & AP-102 & 740 & 11 & 92 & 427 & 0 & 92 & -313 & -10 & 0 \\
\hline 4 & $100 \%$ & AP-103 & 827 & 24 & 91 & 414 & 0 & 91 & -413 & -24 & 0 \\
\hline 1 & $100 \%$ & AP-104 & 734 & 23 & 62 & 364 & 0 & 62 & -370 & -23 & 0 \\
\hline 5 & $100 \%$ & AP-105 & 807 & 24 & 74 & 437 & 0 & 74 & -369 & -24 & 0 \\
\hline 7 & $100 \%$ & AP-107 & 780 & 65 & 48 & 297 & 0 & 48 & -483 & -65 & 0 \\
\hline 6 & $100 \%$ & AP-108 & 899 & 20 & 103 & 491 & 0 & 103 & -408 & -20 & 0 \\
\hline 9 & $100 \%$ & AN-105 & 826 & 21 & 115 & 510 & 0 & 115 & -315 & -21 & 0 \\
\hline 10 & $100 \%$ & $\mathrm{AN}-103$ & 1,065 & 12 & 233 & 746 & 0 & 233 & -318 & -12 & 0 \\
\hline 11 & $100 \%$ & AW-101 & 1,015 & 11 & 93 & 653 & 0 & 93 & -362 & -11 & 0 \\
\hline 12 & $100 \%$ & AW-104 & 777 & 31 & 101 & 438 & 0 & 101 & -339 & -31 & 0 \\
\hline 13 & $100 \%$ & AP-106 & 445 & 16 & 59 & 227 & 0 & 59 & -218 & -16 & 0 \\
\hline 14 & $70 \%$ & SY-101 & 89 & 3 & 5 & 47 & 0 & 5 & -42 & -3 & 0 \\
\hline 15 & $0 \%$ & S-109 & 0 & 0 & 0 & 0 & 0 & 0 & 0 & 0 & 0 \\
\hline 16 & $0 \%$ & S-109 Eq & 0 & 0 & 0 & 0 & 0 & 0 & 0 & 0 & 0 \\
\hline & & Total & 10,592 & 329 & 1,222 & 5,856 & 2 & 1,222 & $-4,736$ & -327 & 0 \\
\hline
\end{tabular}

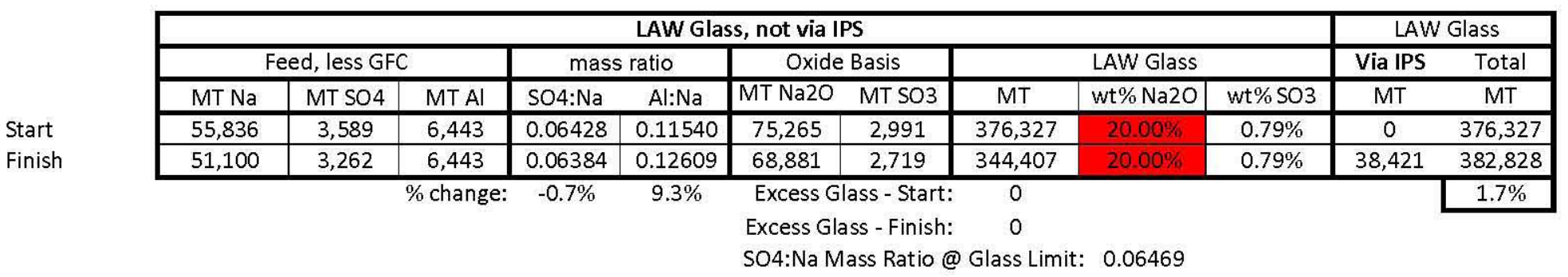

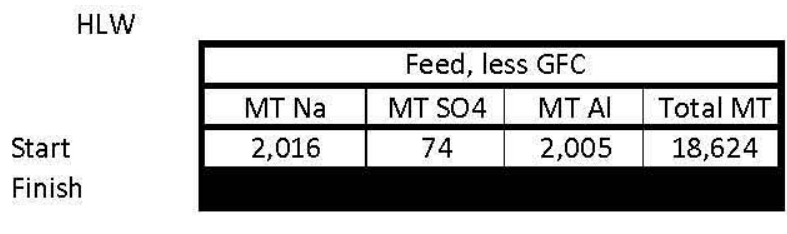


Table B-5 Fractional Crystallization 5 Year Mission $11 \%$ Sulfate Recycle to Tank Farms

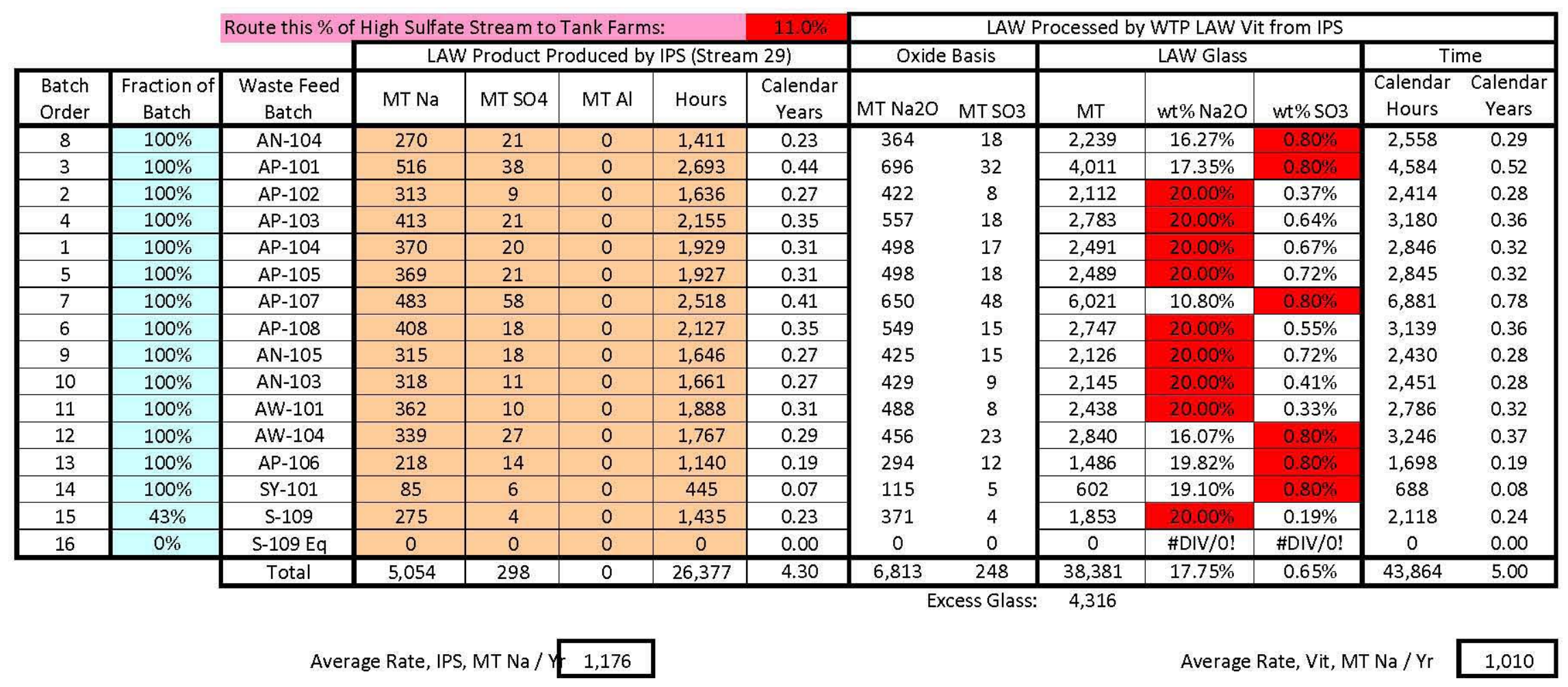

\begin{tabular}{|c|c|c|c|c|c|c|c|c|c|c|c|}
\hline \multirow[b]{2}{*}{$\begin{array}{l}\text { Batch } \\
\text { Order }\end{array}$} & \multirow[b]{2}{*}{$\begin{array}{c}\text { Fraction of } \\
\text { Batch }\end{array}$} & \multirow[b]{2}{*}{$\begin{array}{c}\text { Waste Feed } \\
\text { Batch }\end{array}$} & \multicolumn{3}{|c|}{ Removed from DSTs (Stream 3) } & \multicolumn{3}{|c|}{ Returned to DSTs (Stream 14) } & \multicolumn{3}{|c|}{ Net Change to DSTs } \\
\hline & & & MT Na & MT SO4 & MT Al & MT Na & MT SO4 & MT Al & MT Na & MT SO4 & MT Al \\
\hline 8 & $100 \%$ & AN-104 & 763 & 24 & 97 & 493 & 3 & 97 & -270 & -21 & 0 \\
\hline 3 & $100 \%$ & AP-101 & 827 & 43 & 48 & 311 & 5 & 48 & -516 & -38 & 0 \\
\hline 2 & $100 \%$ & AP-102 & 740 & 11 & 92 & 427 & 1 & 92 & -313 & -9 & 0 \\
\hline 4 & $100 \%$ & AP-103 & 827 & 24 & 91 & 414 & 3 & 91 & -413 & -21 & 0 \\
\hline 1 & $100 \%$ & AP-104 & 734 & 23 & 62 & 364 & 3 & 62 & -370 & -20 & 0 \\
\hline 5 & $100 \%$ & AP-105 & 807 & 24 & 74 & 437 & 3 & 74 & -369 & -21 & 0 \\
\hline 7 & $100 \%$ & AP-107 & 780 & 65 & 48 & 297 & 7 & 48 & -483 & -58 & 0 \\
\hline 6 & $100 \%$ & AP-108 & 899 & 20 & 103 & 491 & 2 & 103 & -408 & -18 & 0 \\
\hline 9 & $100 \%$ & AN-105 & 826 & 21 & 115 & 510 & 3 & 115 & -315 & -18 & 0 \\
\hline 10 & $100 \%$ & AN-103 & 1,065 & 12 & 233 & 746 & 1 & 233 & -318 & -11 & 0 \\
\hline 11 & $100 \%$ & AW-101 & 1,015 & 11 & 93 & 653 & 1 & 93 & -362 & -10 & 0 \\
\hline 12 & $100 \%$ & AW-104 & 777 & 31 & 101 & 438 & 3 & 101 & -339 & -27 & 0 \\
\hline 13 & $100 \%$ & AP-106 & 445 & 16 & 59 & 227 & 2 & 59 & -218 & -14 & 0 \\
\hline 14 & $100 \%$ & SY-101 & 181 & 7 & 11 & 96 & 1 & 11 & -85 & -6 & 0 \\
\hline 15 & $43 \%$ & S-109 & 141 & 5 & 4 & 22 & 1 & 4 & -118 & -4 & 0 \\
\hline 16 & $0 \%$ & $\mathrm{~S}-109 \mathrm{Eq}$ & 0 & 0 & 0 & 0 & 0 & 0 & 0 & 0 & 0 \\
\hline & & Total & 10,824 & 337 & 1,232 & 5,927 & 39 & 1,232 & $-4,898$ & -298 & 0 \\
\hline
\end{tabular}

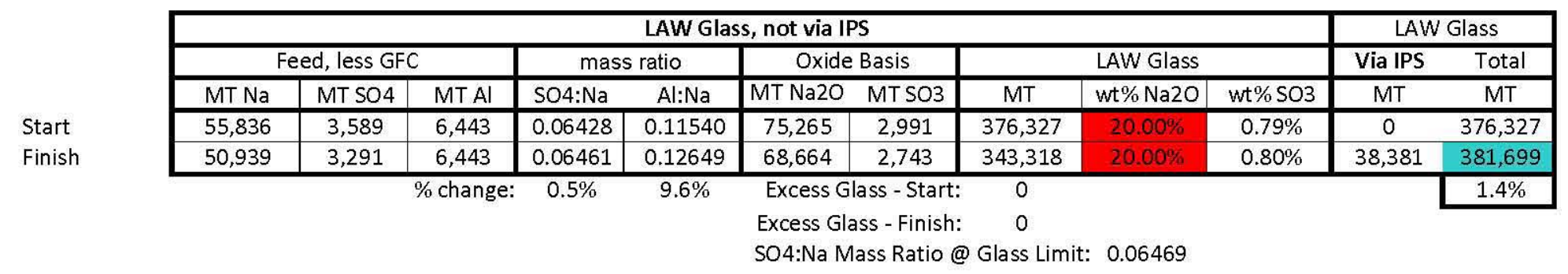

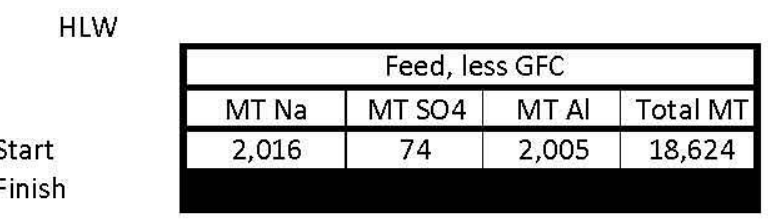


Table B-6 Fractional Crystallization 5 Year Mission $100 \%$ Sulfate Recycle to Tank Farms

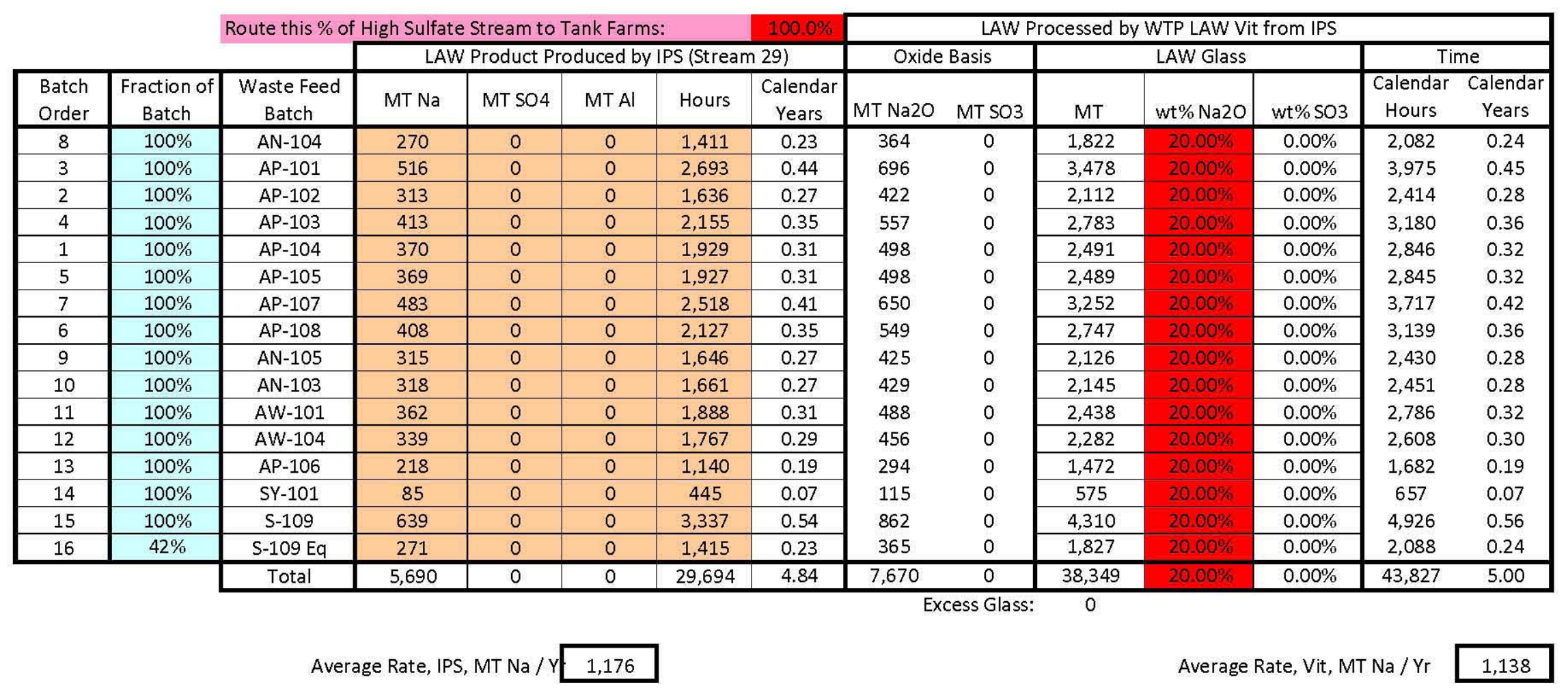

\begin{tabular}{|c|c|c|c|c|c|c|c|c|c|c|c|}
\hline \multirow[b]{2}{*}{$\begin{array}{l}\text { Batch } \\
\text { Order }\end{array}$} & \multirow[b]{2}{*}{\begin{tabular}{|c|}
$\begin{array}{c}\text { Fraction of } \\
\text { Batch }\end{array}$ \\
\end{tabular}} & \multirow[b]{2}{*}{$\begin{array}{c}\text { Waste Feed } \\
\text { Batch }\end{array}$} & \multicolumn{3}{|c|}{ Removed from DSTs (Stream 3) } & \multicolumn{3}{|c|}{ Returned to DSTs (Stream 14) } & \multicolumn{3}{|c|}{ Net Change to DSTs } \\
\hline & & & MT Na & MT SO4 & MT Al & MT Na & MT SO4 & MT Al & MT Na & MT SO4 & MT Al \\
\hline 8 & $100 \%$ & AN-104 & 763 & 24 & 97 & 493 & 24 & 97 & -270 & 0 & 0 \\
\hline 3 & $100 \%$ & AP-101 & 827 & 43 & 48 & 311 & 43 & 48 & -516 & 0 & 0 \\
\hline 2 & $100 \%$ & AP-102 & 740 & 11 & 92 & 427 & 11 & 92 & -313 & 0 & 0 \\
\hline 4 & $100 \%$ & AP-103 & 827 & 24 & 91 & 414 & 24 & 91 & -413 & 0 & 0 \\
\hline 1 & $100 \%$ & AP-104 & 734 & 23 & 62 & 364 & 23 & 62 & -370 & 0 & 0 \\
\hline 5 & $100 \%$ & AP-105 & 807 & 24 & 74 & 437 & 24 & 74 & -369 & 0 & 0 \\
\hline 7 & $100 \%$ & AP-107 & 780 & 65 & 48 & 297 & 65 & 48 & -483 & 0 & 0 \\
\hline 6 & $100 \%$ & AP-108 & 899 & 20 & 103 & 491 & 20 & 103 & -408 & 0 & 0 \\
\hline 9 & $100 \%$ & AN-105 & 826 & 21 & 115 & 510 & 21 & 115 & -315 & 0 & 0 \\
\hline 10 & $100 \%$ & AN-103 & 1,065 & 12 & 233 & 746 & 12 & 233 & -318 & 0 & 0 \\
\hline 11 & $100 \%$ & AW-101 & 1,015 & 11 & 93 & 653 & 11 & 93 & -362 & 0 & 0 \\
\hline 12 & $100 \%$ & AW-104 & 777 & 31 & 101 & 438 & 31 & 101 & -339 & 0 & 0 \\
\hline 13 & $100 \%$ & AP-106 & 445 & 16 & 59 & 227 & 16 & 59 & -218 & 0 & 0 \\
\hline 14 & $100 \%$ & SY-101 & 181 & 7 & 11 & 96 & 7 & 11 & -85 & 0 & 0 \\
\hline 15 & $100 \%$ & S-109 & 760 & 26 & 24 & 121 & 26 & 24 & -639 & 0 & 0 \\
\hline 16 & $42 \%$ & $\mathrm{~S}-109 \mathrm{Eq}$ & 137 & 5 & 4 & 22 & 5 & 4 & -115 & 0 & 0 \\
\hline & & Total & 11,580 & 363 & 1,256 & 6,047 & 363 & 1,256 & $-5,534$ & 0 & 0 \\
\hline
\end{tabular}

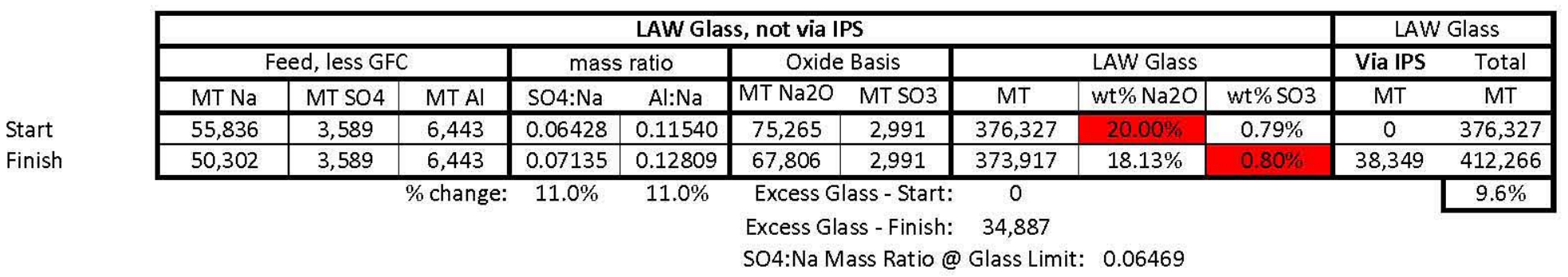




Table B-7 Solvent Extraction 5 Year Mission

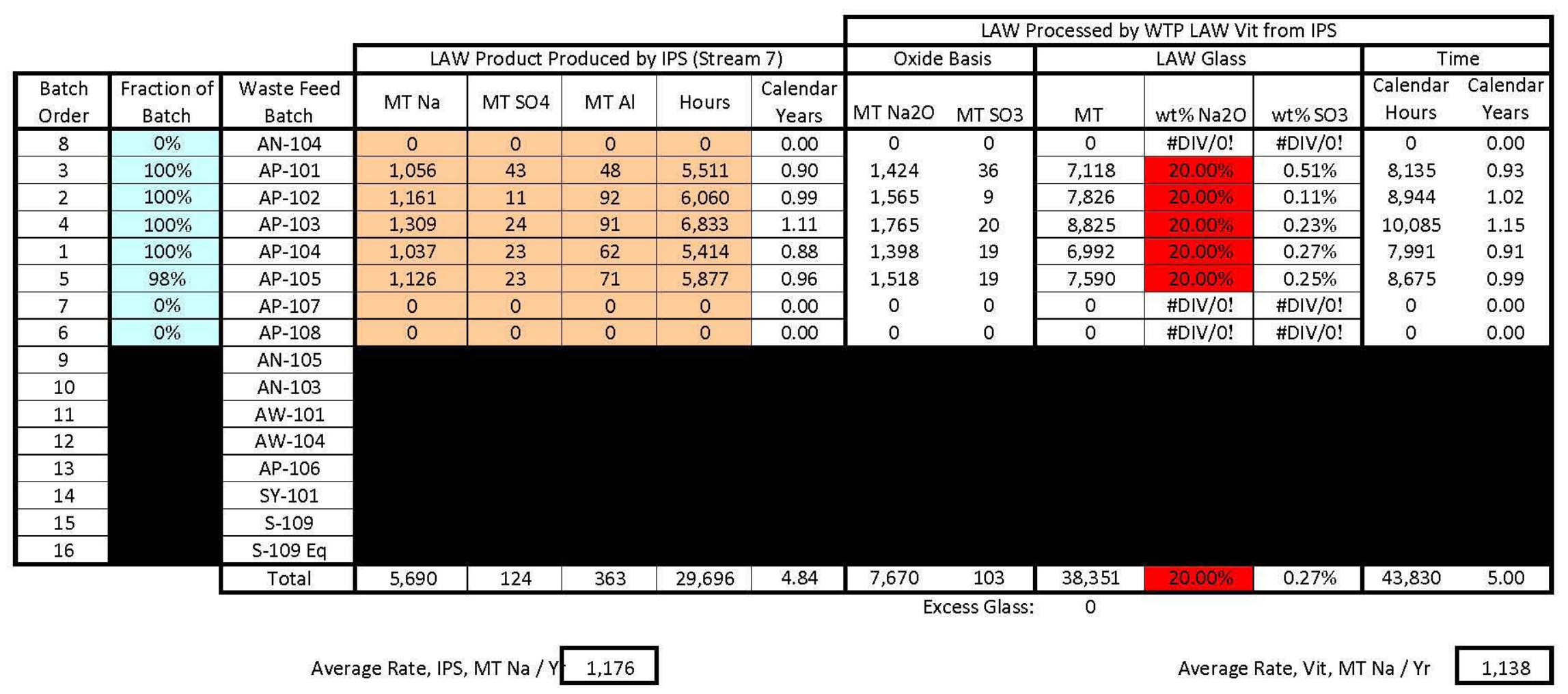

\begin{tabular}{|c|c|c|c|c|c|c|c|c|c|c|c|}
\hline \multirow{2}{*}{$\begin{array}{l}\text { Batch } \\
\text { Order }\end{array}$} & \multirow[b]{2}{*}{$\begin{array}{c}\begin{array}{c}\text { Fraction of } \\
\text { Batch }\end{array} \\
\text { Bats }\end{array}$} & \multirow[b]{2}{*}{$\begin{array}{c}\text { Waste Feed } \\
\text { Batch }\end{array}$} & \multicolumn{3}{|c|}{ Removed from DSTs (Stream 3) } & \multicolumn{3}{|c|}{ Returned to DSTs (Stream 16) } & \multicolumn{3}{|c|}{ Net Change to DSTs } \\
\hline & & & MT Na & MT SO4 & MTAl & MT Na & MT SO4 & MT Al & MT Na & MT SO4 & MT Al \\
\hline 8 & $0 \%$ & AN-104 & 0 & 0 & 0 & 0 & 0 & 0 & $\overline{0}$ & 0 & 0 \\
\hline 3 & $100 \%$ & AP-101 & 827 & 43 & 48 & 3 & 0 & 0 & -824 & -43 & -48 \\
\hline 2 & $100 \%$ & AP-102 & 740 & 11 & 92 & 2 & 0 & 0 & -738 & -11 & -92 \\
\hline 4 & $100 \%$ & AP-103 & 827 & 24 & 91 & 2 & 0 & 0 & -825 & -24 & -91 \\
\hline 1 & $100 \%$ & AP-104 & 734 & 23 & 62 & 2 & 0 & 0 & -732 & -23 & -62 \\
\hline 5 & $98 \%$ & AP-105 & 768 & 23 & 71 & 2 & 0 & 0 & -767 & -23 & -71 \\
\hline 7 & $0 \%$ & AP-107 & 0 & 0 & 0 & 0 & 0 & 0 & 0 & 0 & 0 \\
\hline 6 & $0 \%$ & AP-108 & 0 & 0 & 0 & 0 & 0 & 0 & 0 & 0 & 0 \\
\hline 9 & & AN-105 & & & & & & & & & \\
\hline 10 & & AN-103 & & & & & & & & & \\
\hline 11 & & AW-101 & & & & & & & & & \\
\hline 12 & & AW-104 & & & & & & & & & \\
\hline 13 & & AP-106 & & & & & & & & & \\
\hline 14 & & SY-101 & & & & & & & & & \\
\hline 15 & & S-109 & & & & & & & & & \\
\hline \multirow[t]{2}{*}{16} & & S-109 Eq & & & & & & & & & \\
\hline & & Total & 3,896 & 124 & 363 & 11 & 0 & 0 & $-3,885$ & -124 & -363 \\
\hline
\end{tabular}

\begin{tabular}{|c|c|c|c|c|c|c|c|c|c|c|c|c|}
\hline \multirow{5}{*}{$\begin{array}{l}\text { Start } \\
\text { Finish }\end{array}$} & \multicolumn{10}{|c|}{ LAW Glass, not via IPS } & \multicolumn{2}{|c|}{ LAW Glass } \\
\hline & \multicolumn{3}{|c|}{ Feed, less GFC } & \multicolumn{2}{|c|}{ mass ratio } & \multicolumn{2}{|c|}{ Oxide Basis } & \multicolumn{3}{|c|}{ LAW Glass } & Via IPS & Total \\
\hline & MT Na & MT SO4 & MTAl & SO4:Na & Al: $\mathrm{Na}$ & MT Na2O & MT SO3 & MT & wt $\% \mathrm{Na} 2 \mathrm{O}$ & $\mathrm{wt} \% \mathrm{SO} 3$ & MT & MT \\
\hline & 55,836 & 3,589 & 6,443 & 0.06428 & 0.11540 & 75,265 & 2,991 & 376,327 & $20.00 \%$ & $0.79 \%$ & 0 & 376,327 \\
\hline & 51,951 & 3,465 & 6,080 & 0.06671 & 0.11703 & 70,029 & 2,888 & 361,032 & $19.40 \%$ & $0.80 \%$ & 38,351 & 399,383 \\
\hline & & & $\%$ chang & $3.8 \%$ & $1.4 \%$ & Excess $\mathrm{G}$ & ss - Start & $\overline{0}$ & & & & $6.1 \%$ \\
\hline & & & & & & Excess Gl & - Finis & 10,889 & & & & \\
\hline
\end{tabular}



